\title{
Chapter 6 Material properties and geohazards
}

\author{
M. G. Culshaw ${ }^{1 *}$, D. C. Entwisle ${ }^{2}$, D. P. Giles ${ }^{3}$, T. Berry ${ }^{4}$, A. Collings ${ }^{5}$, V. J. Banks ${ }^{2}$, L. J. \\ Donnelly ${ }^{6}$ \\ 1 British Geological Survey, Keyworth, Nottingham, NG12 1AE, UK and School of Civil \\ Engineering, University of Birmingham, Edgbaston, Birmingham, B15 2TT, UK \\ ${ }^{2}$ British Geological Survey, Keyworth, Nottingham, NG12 1AE, UK \\ 3 School of Earth and Environmental Sciences, University of Portsmouth, Burnaby Building, \\ Burnaby Road, Portsmouth, PO1 3QL, UK \\ ${ }^{4}$ Arup Group Ltd., Lendal Arches, Tanners Moat, York, YO1 6HU, UK \\ ${ }^{5}$ Arup Group Ltd., The Arup Campus, Blythe Gate, Blythe Valley Park, Solihull, Birmingham, B90 \\ 8AE, UK \\ ${ }^{6}$ Arup Group Ltd., 6th Floor, 3 Piccadilly Place, Manchester, M1 3BN, UK \\ * Corresponding author (e-mail: martin.culshaw2@ntlworld.com)
}

\begin{abstract}
In engineering terms, all materials deposited as a result of glacial and periglacial processes are transported soils. Many of these deposits have engineering characteristics that differ from those of water-lain sediments. In the UK, the most extensive glacial and periglacial deposits are tills. Previously, engineering geologists have classified them geotechnically as Lodgement, Melt-out, Flow and Deformation Tills or as variants of these. However, in this book, tills have been reclassified as: subglacial traction till, glacitectonite and supraglacial mass flow diamicton/glaciogenic debris flow deposits (see Chapter 4 Sections 4.1-4.3). Because this classification is new, it is not possible to relate geotechnical properties and characteristics to the subdivisions of the new classification. Consequently, the domain/stratigraphic classification, recently developed by the British Geological Survey and others, has been used and their geotechnical properties and characteristics are discussed on this basis. The geotechnical properties and characteristics of the other main glacial and periglacial deposits are also discussed. For some of these (for example, glaciolacustrine deposits, quick clays and loess), geohazards relating to the lithology and/or fabric of the deposit are discussed along with their properties. Other geohazards that do not relate to lithology and/or fabric are discussed separately as either local geohazards or regional ones.
\end{abstract}

In some cases (for example, glaciofluvial sands and gravels), the geotechnical properties and behaviour are similar to sediments deposited under different climatic conditions. Consequently, these deposits are not discussed at length. Similarly, some of the local geohazards that are found associated with glacial and periglacial deposits relate to current climatic conditions and are not discussed here. Examples include landsliding and highly compressible organic soils (peats).

\subsection{Introduction}

Previous chapters have discussed glacial and periglacial processes and deposits from a geomorphological and geological point of view. Engineering geologists need to understand these aspects of the glacial and periglacial deposits that they may encounter so that they are better able to anticipate the ways in which these deposits are likely to behave, for example, in construction. In this chapter, the focus is on the geotechnical properties and characteristics of materials deposited in glacial and periglacial terrains and on the geohazards created by the environmental conditions, both at the local and the regional scale. However, to do this a new approach to classification of glacial tills, detailed in Chapter 4 Sections 4.1-4.3, is used. It is anticipated that using this approach, it will be possible to obtain a better understanding of the types of deposits that can be expected. The focus is on materials and geohazards that are found in the UK. However, reference is made to examples 
found elsewhere in the world when appropriate and relevant to understanding the UK situation.

The principal materials (soils) in periglacial and glacial terrains discussed are:

Section 6.2. Ice-related terrains - sub-glacial, supra-glacial and glaciated valley materials encompassing tills and kame/esker/braided channel deposits.

Section 6.3. Water-related domains (that is, fluvial, lacustrine, marine) - glaciofluvial; glaciolacustrine and glaciomarine deposits of: sands and gravels; laminated silts and clays; quick clays; ice-rafted debris; and iceberg contact deposits.

Section 6.4. Ice-front-related terrains - glacitectonic and ice marginal materials encompassing deformed/shattered bedrock and the subglacial deformation of soils.

Section 6.5. Upland periglacial terrains - namely, boulder fields, boulder tongues, scree and talus.

Section 6.6. Lowland periglacial terrains - encompassing solifluction deposits and loess/brickearth.

Some of these terrains and the deposits that they contain have been illustrated in 2.5D block models by Fookes et al. (2015), which are reproduced here. These show the relationships between the different deposits in each terrain. Fig. 6.1 shows a glacial valley terrain model and Fig.6.2 a relict periglacial terrain model for southern Britain.

Some of the deposits discussed in this chapter are very similar in composition and engineering behaviour to deposits of similar composition laid down in other environments. For example, many glacial sands and gravels are similar to those deposited by fast-flowing rivers in temperate climate areas. For these deposits, only a brief engineering geological description is given, highlighting any specific characteristics of engineering significance. Peat is not discussed as its composition, properties and behaviour are not specifically related to glacial and periglacial conditions. For others, little geotechnical information is available because the deposits are found in areas where little or no engineering activity has taken place and been reported.

Discussion of geohazards related to glacial and periglacial environments are divided into those that occur locally and those that are more regional in their effects. The geohazards discussed are those that specifically relate to geological/geomorphological processes. However, geohazards that are not specific to glacial or periglacial environments (such as swelling and shrinkage of clay soils, compressible soils, dissolution and most types of landsliding) are not discussed here, though solifluction shears are briefly described in Sections 6.6.1 and 6.7.2. Where the geohazard relates to the properties of a particular material (for example, loessic deposits, quick clays and solifluction deposits) their properties and geohazards are discussed together. The two sections on geohazards cover the following:

Section 6.7. Local geohazards namely: superficial valley disturbances: cambering, gulls and valley bulging; solifluction shears; kettle holes; relict cryogenic mounds; relict scour hollows, infilled periglacial features including pingos and other larger features

Section 6.8. Regional geohazards namely: neotectonics; palaeoseismicity; fault reactivation

These and other geohazards found in the UK are further discussed by Giles \& Griffiths (2017 in prep.). 


\subsection{Ice-related terrains: sub-glacial, supra-glacial and glaciated valley}

\subsubsection{Tills}

\subsubsection{Introduction}

Previously, engineering geologists and geotechnical engineers have tended to sub-divide glacial tills, for the purpose of engineering classification, into two or more of four genetic types (Trenter 1999):

- Lodgement till: debris deposited by plastering from the base of a moving glacier.

- Melt-out till: debris slowly released from melting ice, not subject to deformation.

- Flow till: material deposited by gravitational processes.

- Deformation till: material detached by the glacier at its source and having all its fabric and structure destroyed (and additional material added).

Boulton (1975) referred only to the first three of these in discussing the geotechnical characteristics of tills, while Bell (2000) followed McGowan \& Derbyshire (1977) and identified a range of tills based on:

- Formative processes (comminution till; deformation till).

- Transportation processes (superglacial till; englacial till; basal till).

- Depositional processes (ablation till; meltwater till; lodgement till; flow till; waterlain till).

More recently, Clarke (2012) followed the classification of Trenter (1999). Table 6.1 (from Clarke 2012) provides a useful summary of a range of geological and geotechnical criteria for each of the four till types, together with a large number of references that provide summaries of diagnostic properties. However, recent research into glacial landsystems (see Chapter 3 Section 3.4 .2 and Chapter 4 Section 4.1.2) has resulted in a classification of glacial deposits that is better related to both the glacial environments in which tills were deposited and to the sedimentology, fabric and structure of the deposits themselves. In this book, types of till have been redefined into three classes (see Chapter 4 Section 4.1.1):

- Subglacial Traction Till (which includes lodgement till, deformation till, comminution till and subglacial melt-out till).

- Glacitectonite (which can include supraglacial morainic till, flow till and melt-out till).

- Supraglacial mass flow diamicton/glaciogenic debris flow deposits (that can also include supraglacial morainic till, flow till and melt-out till).

Other types of till (for example, water-lain tills described by McGowan \& Derbyshire 1977) are classified differently.

It is recognised that, for an engineering geologist or geotechnical engineer for whom the only material available is from disturbed or undisturbed borehole samples, applying the new classification is likely to be time-consuming, at least at first, though it is simpler than previous classifications discussed above. Even in trial pit sections, till identification may still be problematical. Further, the current engineering geological literature does not use the new classification and so transferring engineering property information attributed to previous classifications of, for example, Trenter (1999) or Clarke (2012), is likely to be impractical until the literature develops using the new classification. Indeed, it is also not easy to recognise from borehole samples the four till types identified by these authors. However, a large amount of property information is becoming available from the National Geotechnical Properties Database (NGPD) of the British Geological Survey (BGS) (Self et al. 2012). Some of this is summarised here. To overcome the problem of identifying till types, the geotechnical information is subdivided on the basis of a new stratigraphy for superficial deposits (McMillan et al. 2011, McMillan \& Merritt 2012). This new domain approach enables till units to be identified on the basis of 
geographical location and description. This means that some of the data in the literature can be attributed to the new stratigraphical till units. Examples of this are discussed below.

Further, it should be noted that in Chapter 4 Section 4.6 it is demonstrated how the landsystem approach can be reconciled with the domains approach of McMillan et al. (2011) and McMillan \& Merritt (2012). As the geotechnical property information from the NGPD, some of which is summarised here, is classified in terms of domains, it is proposed that, in the longer term, the landsystem/domain approach should supersede the till classifications used by Trenter (1999) and Clarke (2012).

\subsubsection{Glacial till stratigraphy}

\subsection{Glacial tills on the geological map}

During the desk study stage of a site investigation some of the initial geological information comes from the relevant geological map. In the UK, the geological maps used (published by the BGS) are at 1:50,000 or 1:10,000 scale. A broad overview of the national extent of glacial tills in the UK can be obtained from the engineering geology maps produced at a scale of $1: 1,000,000$. In these, the tills are shown on the basis of their lithology - Coarse Till (Layered), Coarse Till, Fine Till (Layered), Fine Till (Bouldery) and Fine Till (Dearman et al. 2011a and b).

The 1:1,000,000 and 1:50,000 scale maps and some 1:10,000 scale maps are available digitally and can be used in Geographical Information Systems (GIS). Also, the 1:50,000 digital map (DigMap50) can be inspected via a web service (the 'Geology of Britain viewer' at http://mapapps.bgs.ac.uk/geologyofbritain/home.html) or via an application (iGeology) on mobile phone or tablet computer. Therefore, it is important to understand the mapping of glacial till on the geological map. On the 1:50,000 scale geological maps, glacial tills (previously called 'Boulder Clay') are generally represented as light blue coloured polygons and presented on the map using terms such as Glacial Till, Glacial Till (undifferentiated), Glacial Till (Devensian), Glacial Till (Anglian) and other more local terms.

In the 1980s, on some 1:50,000 scale geological maps, such as the Warwick sheet (Ambrose et al. 1984), the 'Boulder Clay' comprises two separate till units, in this case, the Oadby Till and the Thrussington Till. The tills are shown in the usual light blue colour but are distinguished by the different ornamentations. More recently, the increased research into, and knowledge of, the formation and deposition of tills in the UK has resulted in many till formations and members being identified, some of which have been used on BGS 1:50,000 and 1:10,000 scale maps. There have been various attempts to rationalize the formation and member names and their meaning over the years, including by Bowen (1999). Since the 1980s, the consistency of mapping of Quaternary deposits, including glacial tills, has improved with greater differentiation between till types. This, with the research required, has culminated in a national database of glacial till domains (Entwisle \& Wildman 2010) and for all Neogene and Quaternary deposits by McMillan et al. (2011) and McMillan \& Merritt (2012). Leading on from these publications, Booth et al. (2015) have described the landscape and geology of the UK in terms of the critical processes responsible for their formation. They have identified three provinces (Glaciated, Non-Glaciated and Coastal, Estuarine and Fluvial Provinces) and these are subdivided into a total of ten domains. For each domain, a figure shows the geographical extent of the domain, the percentages of different types of deposit and provides a schematic cross section showing different elements of the domain. These documents provide a background to the nomenclature and the reasoning behind the classification. There are more till and glaciogenic ${ }^{1}$ units described by McMillan et al. (2011) than are discussed here, as it is

\footnotetext{
${ }^{1}$ There are still discrepancies' over the use of the terms 'glaciogenic' and 'glacigenic'. They are synonymous and the preferred term in Quaternary studies is 'glaciogenic'. However, in the BGS research on till domains, discussed in Section 6.2.1.2, the term 'glacigenic' has been adopted.
} 
intended to discuss only those units found at the ground surface, rather than those that, generally, are found only at depth. However, practitioners should be aware that till units might overlap at investigation depth in some areas, for example in Holderness, East Yorkshire, and North Norfolk.

\subsection{The new stratigraphy as applied to glacigenic deposits}

The new stratigraphy has a framework that utilises the full stratigraphic hierarchy, that is: supergroup, group, sub-group, formation and smaller units (including member). However, some lithogenetically-defined deposits cannot yet be given formational status (McMillan et al. 2011). The Great Britain Superficial Deposits Supergroup is sub-divided into seven groups, two of which relate to glaciogenic deposits:

- Albion Glacigenic Group (Middle Pleistocene, pre-Ipswichian including the major Anglian and 'Wolstonian' glaciations - the glacigenic deposits between the Cromerian and the Ipswichian). Most of the deposits are found south of the Devensian ice-sheet limit in southern Britain. However, some deposits are present locally within the Devensian ice-sheet limits, or are present beneath Caledonia Glacigenic Group deposits.

- Caledonia Glacigenic Group (Late Pleistocene - Devensian). All formations and lithogenetic units of Devensian glacigenic deposits of Scotland, most of Wales, northern England and parts of the English Midlands within the main Devensian ice-sheet limit

Tables 6.2 and 6.3 give the lithostratigraphy, previous name, area of occurrence, thickness and description of Caledonia Glacigenic Group and Albion Glacigenic Group tills respectively, while Appendix 1 provides a summary geological description of each of the formations and members that make up the two Groups. The glacial till subgroups are shown in Fig. 6.3 while the formations are shown in Fig. 6.4. The till units can be identified from their geographical position on the maps and from good lithological descriptions, particularly of colour, matrix lithology $(<2 \mathrm{~mm}$ diameter $)$ and, if present, the lithology and origin of coarser particles.

\subsection{Identification of multiple till units}

One difficulty in identifying till stratigraphy is when more than one till is suspected to be present. For example, Hughes et al. (1998) identified different till units in northern England. There has been considerable debate about whether multiple tills are actually present or whether changes in, for example, colour are the result of weathering. The domain classification agrees with the interpretation of Hughes et al. (1998) that the differences in the tills found in Cumbria, Northumberland and Durham, in northern England, are depositional: the deposits are from different ice streams, and not due to weathering as proposed by Eyles \& Sladen (1981) and Eyles et al. (1982). Table 6.4 lists the tills identified by Hughes et al. (1998) with the new till nomenclature.

In the East Midlands of England, three main tills members have been identified. The upper one, the Oadby Till Member, is grey when fresh and becomes brown upon weathering. In the western part of this area the red or reddish brown Thrussington Till Member crops out at surface but to the east lies beneath the Oadby Till Member. Further east the grey Bozeat Till Member lies beneath the Oadby Till Member. The two grey tills are differentiated primarily on their coarse content (gravel and cobble fraction) as the Oadby Till Member commonly contains chalk and flint gravel, whereas the Bozeat Till Member generally is chalk-free. The tills are described as follows:

- Oadby Till Member (formerly known as the Chalky Boulder Clay): a grey clay, weathering to brown, with chalk and flint gravel and other Cretaceous and Jurassic rock fragments; subordinate lenses of sand and gravel, clay and silt. Present over most of the East Midlands and north to the Devensian limit near Market Weighton, East Yorkshire.

- Thrussington Till Member (formerly known as the Pennine Drift Boulder Clay and Oadby Till [Trias-rich]): a brown to reddish-brown clay with the coarse fraction primarily derived

Therefore this term is used throughout the book when referring to this BGS work. 
from Upper Carboniferous and Triassic rocks; subordinate sand, gravel (glaciofluvial) and clay and silt (glaciolacustrine). Occurs in the west of the area, either at surface (in the west) or beneath the Oadby Till Member elsewhere, usually being exposed in river valleys.

- Bozeat Till Member (formerly the Oadby Till [Lias-rich]): a grey clay, weathering to brown; the gravel content is mostly of Jurassic limestone and ironstone with occasional Triassic mudstone and sandstone and Carboniferous limestone and coal. Chalk and flint are only occasionally present. It occurs beneath the Oadby Till Member in the East Midlands and the west of East Anglia, where, to the east, the facies changes and the Lowestoft Formation replaces it. It is found at surface where the Oadby Till Member has been eroded away in valley sides.

A number of other tills occur one above another; the most notable ones are listed, from north to south in Table 6.5. The colour differences between the till units are given in the final column of the table.

\subsection{Geological unit contents}

The content of each named geological unit depends on the mappable unit, available information and, in part, the detail of the field mapping. Those named 'Glacigenic' as groups, subgroups or formations generally contain deposits from a number of depositional environments primarily glacial till, glaciofluvial deposits and glaciolacustrine deposits. Therefore, they contain a wide variety of material types. Although the term 'Glacigenic' will indicate that a variety of lithologies will be present, there are other formations and members not so named that commonly contain deposits from the various glacial environments, for example, the Brewood Till Formation. The use of genetic terms such as 'glacigenic' is a departure from standard lithostratigraphic practice but this is explained in more detail by McMillan et al. (2011). Other formations comprise a number of members that are identified based on their lithogenic character. Examples from the Albion Glacigenic Group are given below:

Wolston Glacigenic Formation contains:

3 till units (Bozeat, Oadby and Thrussington Members); discussed in more detail by McMillan et al. (2011);

4 glaciofluvial units;

2 glaciolacustrine units.

Happisburgh Glacigenic Formation contains:

4 till units (California, Corton, Happisburgh and Starston Till Members);

2 glaciofluvial units.

Sheringham Cliffs Formation contains:

4 till units (Bacton Green, Hanworth, Runton and Weybourne Town Till Members;

3 glaciofluvial units;

2 glaciolacustrine units.

Within the Caledonia Glacigenic Group, the Gretna Till Formation of the Solway Firth area is made up of one or two till units. Where the sand and gravel of the Plumpe Sand and Gravel Formation separate the two units, the upper leaf is the Gretna Till Formation and the lower leaf is the Chapleknowe Till Member (McMillan et al. 2011), as illustrated in Fig. 6.5. Where they cannot be separated then the formation name takes precedence, as the two tills are difficult to separate based on borehole descriptions. As the Plumpe Sand and Gravel Formation is not part of the Gretna Till Formation the geotechnical data from this formation are not included in the analysis for the Gretna Till Formation.

\subsubsection{Geotechnical properties}

The majority of the geotechnical data discussed in this section was extracted from site investigation 
records for the motorway and trunk road network, underground railway lines, pipelines and housing and industrial developments. In addition, a small number of tests have been carried out at laboratories of the BGS. The site investigation records used are those held at the BGS National Geoscience Data Centre (NGDC), including data in Association of Geotechnical and Geoenvironmental Specialists' (AGS) digital data transfer format provided to the BGS or from the Highways Agency Geotechnical Data Management System (HA GDMS). The use of the digital data format greatly increases the speed of addition to the database and reduces transfer errors. These site investigation records have provided good quality data. Most of the selected reports were for investigations carried out after 1985, although data from earlier site investigations were added where they were considered to be of high quality in areas where there were little or no more recent data.

Wherever possible, the modern lithostratigraphic classification in accordance with the BGS lexicon has been added so that the characteristics of the different units can be analysed. In cases where the identified lithostratigraphy at the surface is carried down the borehole, all the glacial tills within a borehole are from the same unit, unless a different unit can be easily identified. This might not provide an accurate characterisation of a specific unit but does give the characteristics of the till in an area. In some cases, it would be extremely difficult to distinguish between units such as in east Cheshire, where the Stockport Glacigenic Formation might lie above the Brewood Till Formation as both units are derived from Irish Sea Ice and have a similar mixture of glacial till, glaciolacustrine and glaciofluvial deposits.

Summary statistical analyses of the data are given as graphical plots and as 'extended box' plots (Culshaw 2005) that give a graphical representation of the range and distribution of the geotechnical data with respect to area and lithostratigraphy (Groups or Subgroups). Geotechnical properties summarised and discussed by Trenter (1999), Bell (2000) and Clarke (2012) were usually derived from published reports and papers for specific sites. Some of these reports and papers are listed in Table 6.6 together with the new till stratigraphy to which they refer. The geotechnical data presented in this section illustrate different aspects of units that are primarily till or contain till. They also show the differences between till units and why the newly developed stratigraphical units should improve the understanding of the behaviour of glacial till.

\subsection{Lithological variation and its effects}

Commonly, UK glacial tills have a fine-grained matrix with variable quantities of coarser material. However, some tills, such as the Ardverikie and the Mill of Forest Till Formations (see Table 6.2), comprise both fine- and coarse-grained till, whilst the till of the Banchory Till Formation is generally coarse-grained, that is, silty, gravelly sand or sandy gravel. The differences in particle size can be relatively minor between those units described as fine-grained or coarse-grained. Materials with fine-grained behaviour contain enough fine particles to fill the space between the coarse particles whereas, in coarse-grained tills, there are insufficient smaller particles to fill these spaces.

The presence of boulders, particularly if they are composed of strong rock, may impact on ground works, most notably the ground investigation (requiring rotary coring to advance boreholes), foundations (particularly as driven piles may refuse), excavations (in which the boulder may be difficult to remove) and tunnelling (if soft ground methods are employed). They can also be confused with the underlying bedrock, particularly if they are similar to the local rock type, which is commonly the case.

The occurrence, strength, size and shape of a boulder will depend, in part, on the rocks that the glacier has passed over. The survival of larger particles depends, to a great degree, on the resistance to grinding and other physical factors that occur at the base of the glacier. Generally, weaker rocks will not survive as cobbles or boulders but may as gravel. For instance, chalk within the Lowestoft 
Till Member occurs as gravel-sized particles, as well as silt particles in the matrix, whereas flint, which is much stronger and much more resistant to being broken down by the mechanical action of the glacier, is commonly of cobble size. If a particular rock type is more likely to occur as boulders, then they are likely to survive transportation over distances but will become rarer the further from source because of the dilution by other more local material. The lithostratigraphy of cobbles and boulders is often well described in papers and reports about glacial tills, as the origin of these clasts can be used to identify the movement of ice streams. In tills where the source of these clasts is local, then boulders might be relatively common, particularly near the base of the till. Fig. 6.6 shows locations where boulders have been identified within glacial till in borehole logs, plotted on the glacial till subgroups map (Fig. 6.4). Large rafts of weak rock occur in some tills, for instance the chalk rafts in North Norfolk or glaciomarine rafts on the Banffshire coast. In both cases the weaker materials were frozen (that is, permafrost) and 'picked up' and then re-deposited by the glacier.

For engineering projects that include large excavations and tunnels, it is important to have some understanding of the occurrence and nature of very large particles in a glacial till. Excavating boulders during the construction phase slows down progress, adding cost and possibly leading to claims, particularly if boulders had not previously been identified as a potential risk. Finding boulders during the invasive part of a site investigation is a somewhat 'hit and miss' process and depends on the frequency of the boulders and of the boreholes. During tunnelling schemes, where the geology is considered to be relatively simple, the distance between boreholes might be quite wide, typically $50 \mathrm{~m}$, or more, sampling a very small percentage of the total area. If this is the case, then few boulders are likely to be found in many tills. The potential for the likely presence of boulders should be assessed during the early stage of the ground investigation, that is, as a part of development of the conceptual ground model (Parry et al. 2014). A description of the till will be available in most geological memoirs, BGS reports, Quaternary Research Association field guides and from published papers. It is also important to log natural or artificial sections of the relevant till unit, as boulders are far more likely to be seen in larger exposures than identified in boreholes. In natural sections, such as sea or river cliffs, the presence and number of boulders might be assessed from those on the beach or in the river. These exposures may well be located off-site.

The main reasons for lithological variation of named units are of fundamental engineering geological consideration. The engineering characteristics of glacial tills depend on many factors, including the formative processes, mode of sediment transport, depositional environment (see Chapter 4 Section 4.1.1), the original material that makes up the till and the way in which they have been altered by glaciogenic processes, primarily the grinding down of rock to smaller particles. Other important characteristics are the inclusion of sand and gravel beds deposited during periods of melting (glaciofluvial) or laminated clay, silt and, sometimes, sand deposited in lakes during periods of ponding (glaciolacustrine), which depend on changes in climate, the geometric relationship between ice streams and the topography. In some glacial till units, the sand and gravel beds and clay and silt beds occur one above the other. The engineering and hydrogeological behaviour of these two deposit types may contrast markedly from the host glacial till.

The described lithological content of the different subgroups for the Albion and Caledonia Glacigenic Groups are presented in Figs $6.7 \& 6.8$ respectively. In many cases, the described lithology can be used to identify the mode of deposition; for instance, sand and gravel is most likely glaciofluvial, laminated clay and silt is probably glaciolacustrine and unlaminated clay or silt may be glaciomarine. Using the new national lithostratigraphy, site investigation descriptions have been classified as boulders, fines with coarse material (a proxy for most tills), glaciofluvial deposits, which have been separated into sand and sand and gravel as sand may also be glaciolacustrine, and laminated clay and silt (glaciolacustrine deposits) (see Figs. $6.7 \&$ 6.8). Descriptions are used, rather than particle size data, because all material in the particular unit is described, whereas, particle size data relate to specific, relatively small samples. The total number of metres of 
described core for each unit is given above each bar and this can be used as an indicator of the significance of the information presented. The data used are only for those materials that are within the till, that is, either the till or the other deposits that have till above and below ('intratill'). Glaciofluvial and glaciolacustrine deposits above or below till beds are excluded, as are any intervening deposits that have a different unit name, for instance the Plumpe Sand and Gravel Formation mentioned above.

Figs. $6.7 \& 6.8$ show that the units do vary. Most contain glacial till, glaciolacustrine laminated silt/clay and glaciofluvial coarser beds. The representation of boulders is difficult to assess as boreholes might go through different proportions of a boulder, drilling or digging a pit might be halted by the boulder, or a boulder may be described as bedrock. Alternatively, bedrock might be described as a boulder. However, in most cases, if the borehole does not proceed the description is usually "boulder or bedrock".

\subsection{Fine matrix with coarser material ('typical till')}

Most of the 'glacial till units' are made up primarily of 'typical till,' that is a fine matrix (clay or silt) with coarse particles. For example, over $90 \%$ of the Ardverikie and Wilderness Till and Wolston Formations and the North Pennine Glacigenic Subgroup are made up of this fine matrix with coarse particles, whereas, the Irish Sea Coast and Nurseries Formations contain less than 80\% of the 'typical till' lithologies. The Finglack Till Formation comprises only about $66 \%$ of this lithology; however, this till also contains coarse till.

\subsection{Boulders}

In some boreholes boulders are described as a separate layer, with a top and a base, whereas, in most pits and some boreholes they are described along with other lithologies. In light cable percussion boreholes their presence, other than in the description, is identified from the chiselling records. However, this information is not included in this analysis so the values presented here are an underestimate and should be viewed as indicative and for comparison only. Of the units where the thickness of boulders is described they are rare in the Albion Glacigenic Group, making up less than $0.2 \%$ of borehole logs, and none were observed in the Nurseries Formation in more than 1000 $\mathrm{m}$ described; however, an 'occasional' boulder is described in one pit. Their distribution in the Caledonia Glacigenic Group is more variable with similar percentages of about 0.1 to $0.2 \%$ in the Central Cumbrian, Irish Sea Coast and North Sea Coast Glacigenic Subgroups and over 1\% in the Ardverikie Till Formation and the Midland Valley and Wales Glacigenic Subgroups.

\subsection{Laminated silt and clay beds}

Laminated silt and clay beds are associated with glaciogenic deposits. They are most important within the till sequence of the Irish Sea Coast Glacigenic Subgroup (8\%), then the North Sea Coast Glacigenic Subgroup (5\%), the North Pennine Glacigenic Subgroup and the Nurseries Formation (4\%), the Wales Glacigenic Subgroup (3\%), the Wolston Formation and the Lowestoft Till Member $(2 \%)$. They are less common in the Wilderness and Finglack Till Formations of the Midland Valley Glacigenic Subgroup and the Central Cumbria Glacigenic Subgroup (1\%) and absent in the Ardverikie Till Formation. These deposits are discussed in more detail in Section 6.3.2 below.

\subsection{Coarse beds}

The percentage of coarse lithologies is variable in both the Albion and Caledonia Glacigenic Groups. In the former unit, the Lowestoft Till Member and the Nurseries Formation are composed of about $17 \%$ and $22 \%$ respectively while the Wolston Formation contains much less sand and gravel, about 7\%. The highest percentage in the Caledonia Glacigenic Group is over 30\% in the Finglack Till Formation. However, this may include coarse till as well as glaciofluvial deposits. The Central Cumbria, Wales and Central Cumbria Glacigenic Subgroups all have about 12\%, whereas the Ardverikie Formation and North Sea, Midland Valley, North Pennine and North Sea Glacigenic 
Subgroups have about 4 to $7 \%$.

\subsubsection{Geotechnical properties}

\subsection{Particle size distribution}

Particle size distribution tests are of more limited use than the lithological descriptions and, in some cases, site investigation reports contain little or no particle size distribution data and so analysis is limited to fewer units. Some examples are presented here.

The particle size distribution data are presented as distribution graphs for a number of units as percentiles of the data. They illustrate differences between the till units and, for the Brewood Till Formation the different major lithogenic units are presented in separate plots. Typical of most of the Irish Sea Coast Subgroup till units, the Brewood Till Formation contains glacial till, glaciolacustrine and glaciofluvial deposits, as indicated by the particle size distribution (Fig. 6.9). This data set is separated on the basis of the likely depositional origin: glacial till (Fig. 6.10), glaciofluvial sand and gravel (Fig. 6.11), glaciofluvial or glaciolacustrine sand (Fig. 6.12) and glaciolacustrine clay and silt (Fig. 6.13). This method could be followed for most of the units where a reasonable amount of data is available.

The Edenside Till Formation (Fig. 6.14) has a fairly restricted particle size distribution and, typical of the Cumbria Glacigenic Subgroup, it contains few or no clay/silt beds. As discussed earlier, the Gretna Till Formation does not include the main sand/gravel unit, the Plumpe Sand and Gravel Formation, which is associated with the till. Therefore, this unit contains less sand and gravel than other tills that do not contain separate lithostratigraphic units, as shown in Fig. 6.15.

The Finglack Till Formation of the Inverness Glacigenic Subgroup is often described as a silt (Fig. 6.16), whereas many other tills are mostly described as clay, for example, the Gretna Till Formation (Fig. 6.15) but there appears to be little difference in the particle size distribution between these two units. However, small changes in particle size might cause significant differences in engineering behaviour and, therefore, in the description. The differences in description might also be due to the differences in the mineralogy of the clay-size particles and whether they are clay minerals or claysize minerals from ground-up rock ('rock flour').

The tills of the Vale of York Formation contain sandy clay and clayey sand. The particle size distribution graph (Fig. 6.17), when compared with that for the Brewood Till Formation, does contain more sand or sandy material. The clayey sand tills are generally found over the Sherwood Sandstone Group.

\subsection{Other geotechnical plots}

A number of other geotechnical plots for different glacial till formations are presented in Appendix 2. The plots consist of plasticity charts, volume change hazard (based on unmodified plasticity index), particle size distributions, angle of internal friction vs plasticity index, undrained shear strength vs depth, undrained shear strength vs porosity, residual strength vs plasticity, permeability vs depth and extended box and whisker plots for bulk density and undrained shear strength. Most of these plots use data from significant numbers of tests, often in excess of a hundred. Therefore, the information can be considered to be reasonably representative for the particular till units. In general, almost all the tills are of low to intermediate plasticity (with data plotting along the T-line of Boulton (1976) and composed mainly of silt and sand (from the particle size distributions). As a result, the tills have low or very low volume change potential. Median bulk densities range between about 2.0 and $2.3 \mathrm{Mg} \mathrm{m}^{-3}$. Undrained shear strength rarely exceeds about $400 \mathrm{kPa}$, regardless of depth. However, data for individual till units need to be examined carefully to determine local variation from the overall national picture. 
The variation in undrained shear strength for units of the Irish Sea Glacigenic Subgroup is shown in Fig. 6.18. This graph separates the till and glaciolacustrine facies. The tills of the Gretna Till Formation are generally weaker than those of the Stockport Glacigenic Formation and the Brewood Till Formation and the glaciolacustrine deposits have more limited strength than the tills, that is, less than $300 \mathrm{kPa}$. There appears to be little or no relationship between depth and undrained shear strength. Higher values, greater than $300 \mathrm{kPa}$, have a wide geographical distribution, being found in most areas where there is a reasonable amount of data, and may occur at any depth.

Albion Glacigenic Group undrained shear strength data are presented in Fig. 6.19. The Nurseries Formation and the Lowestoft Till and Thrussington Till Members have similar values whereas the Oadby Till Member is more variable and tends to be stronger. There appears to be a limited increase in strength with depth but a very wide scatter. The greater variation may be a function of the number of values. The greater distribution of the higher values, $>300 \mathrm{kPa}$, occurs wherever there is a reasonable amount of data both in the south, in Northampton and Buckinghamshire in site investigations for the M1 to the south of Northampton, for Milton Keynes new town and for the Silverstone Bypass, and further north in Derbyshire for the A546 Derby Southern Bypass.

One of the main conclusions from examination of the large quantities of geotechnical information available is that care is needed when utilising information from published papers based on small or unknown numbers of samples and tests. For example, while Bell (1991) and Bell \& Forster (1991) described in detail the geotechnical properties of tills from the north Norfolk coast and the Holderness coast of Yorkshire, respectively, they did not indicate how many samples were tested and, hence, the size of the datasets. Further, they did not indicate the sample locations. This creates doubt about the representativeness of the datasets described. However, if interpretation of datasets that may be representative of datasets for whole till units needs care, datasets from small areas at the site scale also may be misleading. Denness (1974) looked at the variation in geotechnical index properties (liquid limit, plastic limit, liquidity index, specific gravity and bulk density) on both a 1 $\mathrm{m}$ grid along one wall of a $20 \mathrm{~m}$ long and up to $3.5 \mathrm{~m}$ deep trench and at a sample grid interval of $200 \mathrm{~mm}$ within a $1 \mathrm{~m}$ vertical square in the same trench in the Oadby Till Member (then called Chalky Boulder Clay) of the Wolston Glacigenic Formation near Great Woolston, Milton Keynes in the South Midlands of England. The variations in properties are shown in Table 6.7 together with the results of thousands of tests (except for particle density) from the BGS Geotechnical Properties Database. It is interesting to note that the variations in properties reported by Denness are broadly similar to the variation in properties for the thousands of till samples of the Oadby Till Member contained in the database from across the till's outcrop. This variation in composition and properties of tills over distances of less than $1 \mathrm{~m}$ is significant for engineering as it can affect unpredictably the strength, permeability, settlement and stability of these materials.

\subsection{Summary geotechnical data}

Table $6.8 \& 6.9$ summarise various engineering geological characteristics for most of the glacial till formations/members. The following information is summarised in the tables:

- Unit stratigraphic name. For example: 'Hatton Till,' together with the BGS stratigraphic code, in this case 'HATT.'

- Characteristic lithological description. For example, for the Hatton Till: 'Calcareous, gravelly, sandy clay. Subsidiary: Sand/gravel beds.'

- Matrix composition. The lithology of the matrix of the till. For example, for the Hatton Till it is 'clay.'

- Presence of boulders. A description of the litho-stratigraphy and, sometimes, size range, weathering state and/or strength of any boulders in the unit. For example, for the Hatton Till: 'Occasional strong boulders of Devonian sandstone and Mesozoic limestone.'

- Nature of landsliding (if observed). Frequency, size and location of any mapped landslides. For example, for the Hatton Till: 'Rare, small, mostly coastal.' 
- Other engineering considerations. For example relating to fissuring, stand-up time of excavated slopes, if available.

\subsubsection{Weathering of Glacial tills}

The upper parts of glacial tills are often weathered. Weathering is more likely to be deeper in the tills of the Albion Glacigenic Group than the Caledonia Glacigenic Group. This is because the former, deposited during the Middle Pleistocene, has undergone a longer and more complex weathering cycle than the latter. This includes cycles of temperate climate as well as periods of periglacial conditions during the glacial periods. It is likely that these older tills have undergone both physical and chemical weathering and to a greater depth that the later Devensian tills.

The effects of weathering will depend on the composition of the till and local conditions. Typically, the effects of weathering include closer fissuring, resulting in weakening of the soil mass and increased permeability (Klinck et al. 1997, Marks et al. 2004). This fissuring has implications for sampling, including the effects of sampling on the fissures themselves and the question of upscaling laboratory tests carried out on small samples, to the field condition.

Weathered tills may have higher water contents, although this is controlled largely by the weather conditions. They may be weaker and more compressive than the unweathered till. Recent weather conditions are likely to temporarily affect the near-surface material. The top metre, or so, is commonly softer than below this depth as a result of wet weather. However, it also may be stiffer if desiccated during dry summers. Other effects of weathering include the breakdown of gravel or cobbles to sand and, in the most weathered zone, noticeable reduction of the gravel content and increase of the sand content. In some cases, quite resistant cobbles that have survived the processes associated with glacial deposition are broken down. For instance, the granodiorite gravel and cobbles in the Reay Burn Tills Formation are commonly broken down to sand perhaps with a very weak core. However, the Devonian sandstone gravel, cobbles and boulders are often intact.

In those tills that contain chalk gravel and cobbles, such as the Lowestoft Till and Oadby Till Members of the Albion Glacigenic Group, the top few metres may be decalcified, removing the chalk content. This increases the porosity and reduces density increasing the permeability and potentially increasing the depth of weathering. In both these cases, flints are unaffected and become the most common gravel-sized material. Calcium carbonate concretions, so called 'race,' might be formed near the surface in tills formed primarily of Jurassic and younger clays and mudstones as a result of biological and geological processes.

\subsubsection{Kames, Esker, Kame Terraces}

Eskers, kames and kame terraces have been described and discussed in greater detail in Chapter 3 Sections 3.5.3 \& 3.8.3 and Chapter 4 Section 4.4. In general terms, they are composed of coarsegrained, water-lain, stratified, well-sorted sand and gravel, though interbedded clay and silt may be present, depending upon the sediment contained within the glacier. Cobbles and boulders also may be present. However, lithology may vary over short distances where changes in melt-water velocity occurred. Bedding is likely to be present but may be near horizontal or irregular and cross-bedding is common.

As, locally, sediments show a wide range of grain size, shape and sorting, the geotechnical properties will reflect differences in particle size distribution and shape. Abrupt changes in lithology will result in similar changes in relative density. Relatively few SPT ' $N$ ' values have been published for this group of deposits, though Horvath \& Trochalides (2004) reported medium dense to dense kame sands beneath a site at John F. Kennedy Airport, New York. Kame terrace deposits in the 'Brampton kame belt' (see Chapter 4 Section 4.4.2.1) located to the north east of Carlisle in 
Cumbria, north-west England, consist of sand and gravel, with the sands forming a slightly larger percentage than the gravels (Jackson 1979).

\subsection{Water-related domains (fluvial, lacustrine and marine): glaciofluvial, glaciolacustrine and glaciomarine}

\subsubsection{Sands and gravels}

These deposits originate from water flowing on, within and in front of a glacier. Generally, the rivers are braided (multiple channels). The deposits consist of stratified sands, gravels and some silts; they are usually cross-bedded and coarser nearer to the glacier source. In the U.K. they are often mapped generically as 'glacial sand and gravel.' Density, as determined by Standard Penetration Tests (SPT), varies from medium to very dense and the deposits consist mostly of sand and gravel with the latter often greater in amount. However, because of the nature of the depositional processes, these deposits are usually very variable in composition and properties. Table 6.10 gives engineering geological descriptions and summary geotechnical properties for glacial sand and gravel deposits from a number of locations in England and Wales.

Funnell \& Wilkes (1976) provided an engineering geological description of the Corton Beds of East Anglia (now the Corton Sand Member of the Happisburgh Glacigenic Formation), which are glacial sands of Anglian age (Albion Glacigenic Group). They are compact (dense), occasionally loose, mainly horizontally bedded, yellow sands that can contain layers that are lithified with calcareous cement towards the top and gravelly towards the base, with a maximum thickness of $30 \mathrm{~m}$. They are well-drained, easily excavated, with excellent cut-slope stability, have adequate bearing capacity and no settlement problems. More recently, a series of other sand and gravel beds have been identified in East Anglia by Lee et al. (2004).

The variation in particle size distribution and standard penetration test depth profiles of glaciofluvial sands and gravels by $100 \mathrm{~km}$ square across Britain are shown in Appendix 3.

\subsubsection{Glaciolacustrine Deposits}

\subsubsection{The glacial lake environment}

The glaciolacustrine environment can be considered as encompassing all ice contact or near ice contact deep-water bodies created by the damming of terrestrial drainage basins by glacial ice (Evans 2013). These glacial lakes can be small-scale or extensive, both regional and continental. Fig. 6.20 is an example of the interpreted spatial extent of one such lake, Glacial Lake Bosworth, at its maximum lake level of $125 \mathrm{~m}$ AOD (Murton \& Murton 2012). These lakes can be temporary, dynamic and long-lived.

A variety of sedimentary processes take place in a glaciolacustrine environment. Material can be released directly from glacial ice, deposited from subglacial rivers that enter the lake below water level, settle from suspension, accumulate by gravity flow and be sorted by waves and currents near shorelines. Material can be ice-rafted across the lake and dumped as debris from icebergs. It is also possible for biogenic sedimentation to occur as well as the development of evaporite minerals within the sediment pile. If the lake remains frozen at the surface, the water body can develop a stronger thermal stratification.

Contemporary glacial lakes, such as Lake Vanda in Antarctica, are very warm at depth with temperatures up to $26^{\circ} \mathrm{C}$ with associated strong density stratification within the water body. This water density reflects very high salt concentrations. Subsequently evaporitic minerals such as glauberite and halite can be released under freeze-drying conditions and can be found in the lake 
sediment pile (Nakai et al. [1975], Lyons et al. [1985], Morikawa et al. [1975], Wilson \& Wellman 1962). Typically, the lake will contain deposits of glaciolacustrine rhythmites, which can represent annual cycles of silt/clay couplets (varves) and sediment transported by turbidity currents, which are combined with the settling out of suspended sediment (rhythmites).

\subsubsection{Glaciolacustrine deposits and depositional processes}

Sedimentation in the glaciolacustrine environment is partly controlled by water density differences (as well as waves and currents, slope failures etc.). The water density is dependent on the water temperature, with the density greatest at $+4^{\circ} \mathrm{C}$, the concentration of dissolved solids and the amount of suspended sediment within the water body. Most lakes possess thermally controlled density stratification with an upper epilimnion layer, a middle thermocline or metalimnion layer and a basal hypolimnion layer. This density stratification can vary seasonally and influences sedimentation. In the summer months the lake will have a well-mixed layer of low density (relatively) warmer water that develops at the top of the water column with a sharp temperature decrease at its base. In autumn, the surface waters cool and become denser. They then sink and eventually overturn. Water mixing is enhanced by both wave and wind action on the lake. The role and influence of the inflow of glacial meltwater into the lake on the mixing process depends on the position of the glacial stream with respect to the lake water body and level. If there is a significant difference in water density the sediment laden meltwater may maintain its integrity as a plume (Fig. 6.21). Usually, the sediment plumes are denser and sink to the bottom of the lake as an underflow. This descending sediment-laden water often can behave as a turbidity current giving rise to graded, rhythmically stratified sediments (Fig. 6.22) spread over the entire lake basin floor. If a low density subglacial stream with a small sediment load enters a lake already containing suspended sediment it rises to the surface to become an overflow. If the flow of glacial meltwater entering the lake is the same density as the main water body it will become an interflow.

Deposition in the lake can occur as topsets, steeply dipping foresets and thin bottom sets with the foresets deposits formed by debris flow and, to some extent, by slumping. Overflow and interflow deposits will generate blanket-like drapes that exhibit a proximal to distal fining and thinning. There will be a sediment thickening towards the former shoreline with more massive silts representing shallower water deposition. Deeper water deposits will be typically laminated with fining upward sequences of silt and clay rhythmites. These record fluctuations in both grain size and quantity of incoming sediment. This could be due to daily, meteorological or annual water and sediment discharge cycles (Evans 2013). Short-term surge currents produce thin, normally-graded laminae, which have sharp basal contacts. Annual rhythmic cycles, on the other hand, produce distinctive silt-clay couplets often referred to as varves. This reflects coarse sediment input from overflow and interflow plumes during periods of melting with the finer-grained sediment supply from gradual sediment settling out of suspension during the colder winter periods. More proximal locations to the ice front will be dominated by underflow-driven deposition with turbidite sequences. These can often be interbedded with the rhythmites derived from the interflows and overflows. It is also possible to have subaqueous debris flows generating accumulations of coarser stratified material, which can be interdigitated with the finer-grained units as well as being discontinuous. These debris flows can produce sheet-like or lobate beds and can scour the underlying lake bed (Fig. 6.23).

On very large lakes, shoreline processes are possible with the lake influenced by strong katabatic winds coming off the ice body. This can lead to considerable modification of the shoreline area and can move icebergs and ice rafts with their sediment load out into the lake where further deposition can take place. When developing a conceptual ground model for these relict environments this is an important factor in predicting the variety of sedimentary material (in terms of particle size and spatial distribution) that could be encountered in these former environments. Isolated clasts or dropstones could be present as well as larger coarser sediment accumulations (Fig. 6.24). Care must be taken when interpreting borehole data from this landsystem as what could seem to be relatively 
uniform and homogeneous conditions has the potential to incorporate considerable lateral and vertical variability due to the initial sedimentation conditions. Table 6.11 indicates the sediment range, with suggested nomenclature, that could be encountered in a glaciolacustrine land system.

\subsubsection{Geotechnical properties}

The typical glaciolacustrine rhythmite deposit will be a silt/clay couplet with the silt-rich layer indicative of summer depositional conditions and the clay-rich layer indicating winter conditions. Due to the compound nature of these laminated deposits it is possible that some standard geotechnical tests may give misleading results with regard to their engineering behaviour (Reeves et al. 2006). In many applications, where the engineering characteristics are controlled by a relatively large volume of material, such as indicators of volume change, this does not matter. However, in other applications that might be affected by the behaviour of the laminations or, possibly, a limited number of lower strength laminations, then sampling the appropriate material can be difficult or, in some cases, impossible. When investigating slope stability issues, the use of averaged values may be inappropriate as the material that fails might have a quite different clay content and plasticity than the 'average' value of the larger soil mass. In some situations, effective strength tests might be carried out with the laminations at an angle of, say, $60^{\circ}$ (Bell 1998). Alternatively, shear box tests might be carried out along potentially weaker horizons and the strength envelopes compared with the triaxial tests that are carried out with the axial load perpendicular to the laminations. Unfortunately, there are insufficient shear box data available to compare the results of the two methods.

The plasticity of the Albion and Caledonia Glacigenic Group glaciolacustrine deposits are shown in Figs. $6.25 \& 6.26$ respectively. Typically these deposits will have a liquid limit between 30 and $80 \%$ and associated plastic limits between 15 and 30\% (Culshaw et al. 1991). Lithologically, these deposits are dominantly silt and clay with some sand beds and occasional gravel (Figs. $6.27 \&$ $6.28)$.

The undisturbed behaviour of the glaciolacustrine deposits will depend on the particle size distribution, the structure, (particularly the laminations) and the stress history, which affect density, strength, stiffness and consolidation characteristics. Loading from ice and other materials consolidates the silts and clays, increasing density. It is likely that the greatest loading will come from ice and glacial till. If it is assumed that this is the case, then the denser, stronger glaciolacustrine deposits should be found beneath till units, either at the base, or in between thin till units. Figs. $6.29 \& 6.30$ show the dry density of the Albion and Caledonia Glacigenic Group glaciolacustrine deposits plotted against depth; the data are separated into 'not loaded' (no till indicated above the glaciolacustrine deposit in the borehole) and 'loaded' (occurs below till) deposits. The data for the Albion Glacigenic Group indicate that there is no difference in dry density between 'not loaded' and 'loaded' deposits. However, it appears that the 'not loaded' samples tend to be slightly denser. From the unconsolidated, undrained shear strength from triaxial tests (Figs. $6.31 \& 6.32$ ), it appears that there are differences between the 'not loaded' and 'loaded' glaciolacustrine deposits from both Glacigenic Groups in that the 'not loaded' material tends to be weaker than the 'loaded'. There is also a wider variation in density and strength within a few metres of the ground surface, which is probably due to weather conditions before sampling, with lower density and lower strength occurring after prolonged rainfall and high density and possibly higher strength after dry weather. However, the strength of near-surface samples might be affected by mechanical discontinuities including fissuring.

The effective strength calculated from effective cohesion, $\mathrm{c}^{\prime}$ and effective angle of internal friction,

' are summarised using percentiles for the Albion Glacigenic Group (Fig. 6.33) and the Caledonia Glacigenic Group (Fig 6.34). As a large number of test values are available for the latter Group, these data were subdivided into 'not loaded' and 'loaded' in Figs. $6.35 \&$ 6.36. There appear to be 
differences between the two groups in that over $75 \%$ of the Caledonia Glacigenic Group data have values of effective cohesion, $\mathrm{c}^{\prime}$, of $0 \mathrm{kPa}$ whereas for the Albion Glacigenic Group less than $25 \%$ of samples have $\mathrm{c}^{\prime}$ values of $0 \mathrm{kPa}$. However, there were only ten test values for the Albion Glacigenic Group glaciolacustrine deposits and the plots of 'not loaded' and 'loaded' data show little difference.

The angle of internal friction from the effective strength tests is plotted against plasticity index in Fig. 6.37 and for the angle of residual friction (Fig. 6.38). The former is annotated for the upper bound of the angle of internal residual friction and the latter with the lower bound of the angle in internal friction. The plots show that the angle of residual friction is generally lower, as would be expected, but there is some overlap. This might be due to fissures or other structural controls. However, care should be taken in making any design assumptions because of the varied nature of the laminations and the difficulties in comparing tests carried out on disturbed and undisturbed samples or on larger samples (plasticity index) when compared with smaller ones (for residual strength in the ring shear).

Glaciolacustrine deposits tend to be normally consolidated or lightly overconsolidated and are generally highly compressible (see Chapter 8 Fig. 8.10 for an example). Hydraulic conductivities have been reported in the $10^{-9} \mathrm{~m} / \mathrm{s}$ range (McMillan et al. 2000). Fig. 6.39 shows the typical structure for a varve sequence (Eyles 1983). Investigation of the Tees varved and laminated clays (Bell \& Coulthard 1997) has found that their mineralogical composition is predominantly illite, kaolinite with lesser amounts of chlorite. Included are traces of feldspar and muscovite mica.

Geotechnical properties have been reported from several former UK glacial lake deposits including Glacial Lake Tees (Bell 1998, 2000; Bell \& Coulthard 1991 1997), Glacial Lake Skipton (Threadgold \& Weeks 1975), Glacial Lake Bangor (Waine et al. 1990a) and Glacial Lake Wear (Jackson \& Lawrence 1990). Table 6.12 summarises the range of geotechnical results reported for selected glaciolacustrine deposits in the UK.

\subsubsection{Geohazard behaviour}

Glaciolacustrine deposits are prone to widespread slope instability where over-steepening, stress release and valley rebounds associated with fluvial erosion have taken place (Fletcher et al. 2002). Numerous case studies have been cited of large-scale landslides developing in these materials. Examples from Canada (Bishop et al. 2008, Evans 1982, Fletcher et al. 2002, Geertsema et al. 2006, Ito \& Azam 2009), France (Van Asch 1996, Giroud et al. 1991, Jongmans et al. 2009, Bièvre 2011) and Estonia (Kohv et al. 2009, 2010a, 2010b) illustrate the highly problematic nature of these deposits. In the UK, their distribution is equally widespread and examples of their tendency to failure have been documented in Yorkshire: former Glacial Lake Humber, (Taylor et al. 1976), in Scotland (Rowe 1995, Cochrane \& Carter 1991), in Northern England (Hughes et al. 1998), in Cleveland and Teesside: Glacial Lake Tees (Phipps 2001, Bell 1998), in North Wales (Nichol 2001) and in south west Wales with instability in deposits from Glacial Lake Teifi (Fletcher \& Siddle 1998, Maddison 2000, Gibson et al. 2013). Murton \& Murton (2012) provided a detailed overview of the former glacial lakes of lowland Britain, areas where glaciolacustrine deposits should be expected in predictive ground models.

Fig. 6.40 demonstrates this metastable behaviour within deposits from the former Glacial Lac du Trièves at Sinard in France. Here, an initial rotational mudslide rapidly developed into a translational slide and then, on loss of the soil structure, into a highly mobile mudflow. The potentially rapid nature of the slope failures within these glaciolacustrine soils and subsequent high velocity run-out has caused fatalities in this region (Institut des Risques Majeur no date). The metastable nature of these soils needs to be fully appreciated during any engineering works carried out within them. The rapid loss of soil structure on disturbance can lead to the release of the 
interstitial moisture with subsequent liquefaction of the soil. Fig. 6.41 show glaciolacustrine rhythmites encountered during the construction of a rail track underpass at Voiron, France in 1994. An installation of sheet piling disturbed the soil structure releasing the interstitial water and consequently liquefying the soils.

\subsubsection{UK Lithostratigraphy}

On British Geological Survey 1:10 000 and 1:50 000 scale maps, some glaciolacustrine deposits are given specific names whilst others are classified by their age of deposition, mostly Glaciolacustrine Deposits $=$ Middle Pleistocene $($ GLLMP) or Glaciolacustrine Deposits $=$ Devensian (GLLDD). The named units, with their parent, are listed in Table 6.13.

Other laminated silt and clay deposits can be confused with glaciolacustrine deposits, including Late Pleistocene and Holocene marine silt and clay units that have been raised above sea level by isostatic uplift. They are found around the coast, most notably in Scotland, and some underlie major urban areas, for instance the Paisley Clay Member in Glasgow.

\subsubsection{Quick Clay}

The term 'Quick Clay' designates the behaviour of highly sensitive marine clays that, due to postdepositional processes (see below), have the tendency to change from a relatively stiff condition to a liquid mass when disturbed. On failure, these marine clays can rapidly mobilise into high velocity flow slides and spreads often completely liquefying in the process (Torrance 1983). The physical structure of these clay deposits completely collapses on remoulding, with their shear strength being reduced to near zero (Rankka et al. 2004). Three key factors are required for the formation of these sensitive clays: a flocculated structure with a high void ratio, a dominant low activity mineral content (generally indicated by a low to intermediate plasticity) and the replacement of saline porewater by freshwater due to post-depositional leaching (Hutchinson 1991, 1992).

Potential Quick Clays can be found within former marine areas that have been uplifted through isostatic rebound after Quaternary glaciations. The deposits have been documented in Norway, Sweden, Finland and Russia as well as in Japan, Canada and Alaska. Their distribution in the UK is less clear. Stratigraphical examples include the Leda Clay and the Champlain Sea Clay in Canada. Quick Clays have given rise to some significant landslide events, for example Rissa, Norway in 1978 (Gregersen 1981, L'Heureux et al. 2012), Notre Dame de la Salette, Quebec in 1908 (Ells 1908), Lemieux, Ontario in 1993 (Evans \& Brooks 1994) and Saint-Jude, Quebec in 2010 (Locat et al. 2012). Many of these landslide events have caused fatalities due to the very sudden onset of some of the slope failures and, in the case of the Rissa landslide, by waves produced by the landslide.

Quick Clay behaviour-prone deposits develop from initially marine clays formed from rock flourrich meltwater streams feeding into a near-shore marine environment (Fig. 6.42a). On glacial retreat, crustal rebound (isostatic recovery) uplifts the marine sediments above the current sea level eventually exposing them to temperate weathering (Fig. 6.42b). In Norway, for example, these deposits can be found at elevations up to $220 \mathrm{~m}$ above the present day sea level.

Generally, in freshwater sedimentary environments, clay-sized particles settle even more slowly than silt grains and tend to accumulate in a dispersed structure with a parallel orientation of particles. In more saline conditions silt and clay particles form aggregates (small flocculates) and settle together in a random pattern (Torrance 1983). This random alignment of particles (in effect, a 'house of cards' structure) gives the flocculated material a higher than normal void space and, hence, water content (Fig. 6.43). 
Quick Clays were originally deposited in marine or brackish conditions where these clays initially had a pore water geochemistry of up to $35 \mathrm{~g} / 1 \mathrm{NaCl}$ (sodium chloride). This high cationic strength pore water brought about a flocculation of the clay particles, which then formed links between the silt grains (Torrance 1983). Subsequent uplift of the strata to above sea level exposed them to temperate weathering and soil leaching. This weathering created a top crust of leached material with a subsequent reduction in the strength of the former marine clays. The $\mathrm{NaCl}$ pore waters were progressively leached by rainwater and freshwater streams reducing the salt content to around 1-2 $\mathrm{g} / \mathrm{l}$. This had the effect of generating very sensitive clay-dominated soils that exist in a metastable state. These clays are extremely sensitive and can liquefy and flow if subjected to a relatively small disturbance or change in stress conditions. The mineral composition of Quick Clays is dominated by non-swelling clay particles, such as illite, with a low activity and containing a high proportion of fine quartz; hence they are very poor in clay minerals. They have a very open fabric and high void ratio with a flocculated structure and subsequently have high moisture contents.

Quick Clays can be defined by their geotechnical behaviour, in particular by their sensitivity (St), the ratio of undrained shear strength to remoulded shear strength, (Skempton \& Northey 1952, Skempton 1953). Some typical geotechnical properties of Quick Clays are summarised in Table 6.14. The Norwegian Geotechnical Institute defines a Quick Clay as having a sensitivity greater than 30 and as having a remoulded shear strength of less than $0.5 \mathrm{kPa}$ (Torrance 1983). To exhibit Quick Clay behaviour, the soils would normally have low plasticity indices (between 8 and 12\%), liquid limits of less than $40 \%$, water contents greater than the liquid limit and, so, a liquidity index that normally exceeds 1 . They are usually inactive, with an activity less than 0.5 (Gillott 1979, Geertsema \& Torrance 2005).

Quick Clay failure mechanisms have been described by Gregersen (1981) who observed a Quick Clay failure at Lake Botnen, Rissa in Norway that occurred in April 1978 and was filmed (https://www.youtube.com/watch?v=3q-qfN1EP4A) (Norwegian Geotechnical Institute 2008). The slide contained 5 to 6 million $\mathrm{m}^{3}$ of material and was the biggest slide in Norway in the $20^{\text {th }}$ century but whilst damage to property was significant only one person died. The failure was initiated when a farmer dug a pit on his land and put the extra material on the edge of the lake. This extra weight caused an initial small landslide to start when $80 \mathrm{~m}$ of the lake shoreline collapsed. Over the next forty minutes there was slow retrogression of the landslide as a series of small slides occurred where the debris liquefied and flowed away leaving a $450 \mathrm{~m}$ long scar. Suddenly a flakeslide occurred where the Quick Clay collapsed under a thin coherent crust taking away a block of $150 \mathrm{x}$ $200 \mathrm{~m}$ which then liquefied as it moved over the natural slope. Retrogressive flakesliding continued extending the scar c. $1 \mathrm{~km}$ over the next five minutes, equivalent to a rate of $10+\mathrm{km} / \mathrm{h}$. Not only did the landslide travel backwards from the lake, it also caused great damage to the community of Leira when a $3 \mathrm{~m}$ high seiche reached the opposite bank of the lake.

Gregersen (1981) observed that Quick Clay failures occurred in two ways, either as retrogressive slides, developing relatively slowly, or as 'flake-type' spreading failures that fail very quickly. The state of stress that exists in the Quick Clay prior to instability is a key factor in controlling the failure. When loading of these clays beyond a critical stress level occurs, there is a tendency for a volume decrease to take place, with a resulting pore pressure increase. To obtain an increase in the soil's shear strength the effect of the increased mobilised effective internal angle of friction must be greater than the effective stress reduction due to the increase in pore pressure. If a Quick Clay is loaded undrained beyond this critical stress level the pore pressures will increase dramatically as the metastable 'house of cards' clay particle structure starts to collapse. This will result in a catastrophic decrease in shear strength. As a consequence of this process, failure takes place almost instantaneously, long before the internal angle of friction is fully mobilised. This dramatic failure and change to a liquid state of Quick Clay deposits is what accounts for the frequent loss of life due to these particular landslides. For the 'flake-like' spreading failures to occur, the initial stress levels 
in the Quick Clay deposits must be very close to the critical stress level. Any small increase of stress, due to loading, vibration or erosion, will result in a failure of a large area simultaneously. In many countries affected by potential Quick Clay-prone deposits, geohazard mapping programmes have been initiated to delineate their occurrence.

\subsubsection{Ice-rafted debris (including dropstones) and iceberg contact deposits}

Ice-rafted debris (including 'dropstones') is material carried by icebergs and deposited in seas or lakes as the iceberg melts. Fig. 6.24 shows an example from Glacial Lac du Trièves, Sinard, France. Various methods have been proposed to identify this material (for example, Grobe 1987). However, from a geotechnical point of view, the material has little significance unless, perhaps, coarser material (cobble-size or larger 'dropstones') is encountered in otherwise finer-grained glaciomarine deposits. Their presence may influence methods of excavation.

Iceberg contact deposits are similarly formed by the deposition of material as an iceberg melts. In this case, however, most of the material is deposited in one place when the iceberg is grounded, for example along the coastline. The deposits are likely to be heterogeneous and consisting mainly of coarser material. In borehole samples, without other information, these deposits are likely to be difficult to identify for what they are.

\subsection{Ice-front-related terrains: glaciotectonic and ice marginal}

\subsubsection{Deformed/shattered bedrock}

Several researchers in the UK have identified deformation of the bedrock. For example, Knill (1968) described discontinuities in slates, argillites and greywackes in Wales, Scotland and northern England, which he interpreted as being caused by deep-seated glacial shearing, extending 15-30 m below the ground surface. Infilling of the discontinuities by clay-silt or silt occurred. The discontinuities were planar or curvi-planar in form and orientated sub-parallel to the ground surface. However, Fell et al. (2005) questioned this interpretation, suggesting that the jointing was caused by stress-relief. This possibility had been considered by Knill (1968) but not accepted because of frostshattering in the host rock and the presence of infill material.

Harris (1991) discussed glaciotectonically deformed bedrock at a site at Wylfa Head, Anglesey, and North Wales. The bedrock consists of Early Cambrian low-grade metamorphosed sediments, mainly phyllites, psammites and a mélange. Three types of deformation were identified (Fig. 6.44). Harris attributed the erosion and deformation of the bedrock to higher basal water pressures resulting from varying joint density and the presence or absence of faults. This model assumed pressure melting of the base of the ice as it over-rode the Anglesey coast. However, Phillips et al. (2012) attributed bedrock deformation of similar rocks in northwest Anglesey to the interaction of a potentially extensive layer of permafrost and an overriding ice stream moving down the Irish Sea area that interacted with, and variably reworked, the bedrock. In this situation, the base of the ice would have been dry. However, Harris \& Murton (2005a) stressed the importance of unfrozen water on glaciotectonic deformation both along the base of the permafrost and within it because pore pressures could be high enough to create a zone of negative effective stress.

Harris (1991) highlighted some of the potential engineering problems resulting from glacial deformation of strong, brittle bedrock, including difficulties in identifying rockhead, instability of cutting walls and reduction of bearing capacity above laterally extensive discontinuities and consolidation of silt or clay infilling. Trenching may be necessary to fully understand the nature of this type of bedrock deformation. 


\subsubsection{Subglacial deformation of soils}

Perhaps not surprisingly, deformation of soils (in the engineering geological sense) takes place beneath moving glaciers and ice sheets. It has been recognised for many years that the thermal conditions at the base of the glacier/ice sheet control the nature of deformation (Boulton 1972). However, there has been further discussion about whether basal deformation was limited to areas of 'warm-based' ice (Paterson 1994) or whether deformation also took place when basal temperatures were below freezing (for example, Waller 2001).

Waller et al. (2011) described sand interclasts within highly deformed glaciotectonic mélange facies of the Bacton Green Till Member at West Runton on the north Norfolk coast west of Cromer. They suggested that the inclusion of the sand interclasts in the mélange was caused by glacitectonic deformation of what they called 'warm' permafrost. This demonstrates that deformation beneath glaciers/ice sheets is complex and may be multiphase, making subsequent identification and interpretation of the ground model during the ground investigation difficult. If the nature of the lithological and structural variation is likely to be of importance to engineering activity, it may be necessary to use trial pits to investigate the scale of variability.

\subsection{Upland periglacial terrains (see Chapter 5 Section 5.3)}

\subsubsection{Boulder fields, Boulder tongues}

Block-fields and block tongues, or streams, are found in upland periglacial terrains. The blockfields extend along slopes parallel to the contours while block tongues or streams run at right angles to the contours down slope. They consist of relatively thin accumulations of rock blocks, on bedrock, weathered rock, or transported debris. According to White (1976), they are composed of interlocked blocks without interstitial detritus, but often contain finer material. White suggested that they were formed when interstitial debris, now washed or piped out, permitted movement of the whole deposit. Ballantyne (1998) divided blockfields into three types: openwork clast-supported blockfields, sandy diamicts, with clasts in a coarse sandy matrix and silt-rich diamicts, with clasts in a matrix of frost-susceptible fine sediment. The three types represent end members of a three-way continuum. Further detail is given in Chapter 5 Section 5.3.2.1 and Fig. 5.31.

In geotechnical terms the deposits are extremely coarse, consisting mainly of angular to subrounded boulders, and poorly graded. It is possible to confuse block fields and tongues with rock falls but the latter are likely to be composed of more angular blocks and to include more finergrained material. Investigation needs to determine the thickness of the deposits and their composition.

\subsubsection{Scree and talus}

Scree/talus deposits are found mainly on the mid and lower parts of slopes and result from rock/debris falls from cliffs or steep slopes above. According to Fell et al. (2005) on steeper upper slopes $\left(35-38^{0}\right)$ smaller angular rock fragments occur while lower down larger angular blocks are found. Deposits are usually well sorted, very loose with low bulk densities and hence have high permeability and compressibility. When $>30 \%$ of the deposit consists of fine material, it may be referred to as talus, which can have a poorly developed soil profile, depending upon the rate of deposition of new material. Scree/talus is potentially unstable as it often rests at the angle of repose. Talus deposits can fail as debris flows at times of intense rainfall. Trees and other plant material may be incorporated in the scree/talus, depending on the nature of any vegetation on the slopes above. This organic material can be partly rotted or preserved, depending upon local conditions. 


\subsection{Lowland periglacial terrains (see Chapter 5 Section 5.2)}

\subsubsection{Solifluction deposits, colluvium}

Here, the term solifluction is used to include both frost creep and gelifluction. Both processes are forms of mass movement or wasting downslope in periglacial conditions. Gelifluction involves winter freezing of water within a soil in the 'active' upper soil layer that subsequently melts in the warmer summer conditions. Where the melting water cannot drain away, the soil becomes saturated and the increased pore pressures and disturbed soil structure result in the weakening of soils and slow flow downslopes (Fig. 6.45). However, more rapid slab slides or skin flows along basal shears also occur (Spink 1991). Where the active layer contains coarse-grained material, meltwater saturates the active layer freely, which can result in very rapid movement downhill under the influence of gravity.

The process of creep involves the freezing of soil water in the winter causing an expansion of the soil perpendicular to the slope, followed by the subsequent spring melting of the soil ice and the vertical consolidation of soil. As such, soil creeps slowly down the slope in an annual saw-tooth pattern (Ballantyne \& Harris 1994).

Typically, only the upper 1 to $2 \mathrm{~m}$ of soils are affected by solifluction (gelifluction and creep). However, as the soliflucted material moves downslope, successive lobes of soil can accumulate on top of each other, leading to considerable thicknesses of soliflucted soils (fig. 6.46) often referred to on geological maps using the generic term 'Head'. One key feature within the active layer is the shallow angle at which solifluction occurs. Relict solifluction shears have been observed on slopes as low as $4^{0}$ (Spink 1991, Hutchinson 1991, Waltham 1994). Relict shears are prone to reactivation, often as a result of construction activities, changes in loading regimes (loading a slope or cutting into a slope) or alterations of hydrological or drainage conditions that cause increased porewater pressure. The possibility of unstable slopes in these deposits should be considered on sites with gradients of just a few degrees.

Despite solifluction shearing being described as a geohazard since the 1940s and intensively investigated since the 1960s (Weeks 1969, Early \& Skempton 1972), it still causes issues for modern construction projects and is the dominant major relict periglacial geohazard in the United Kingdom. Cases still regularly occur where failures of embankments, slopes and foundations are attributed to the 'unforeseen' presence of existing slip surfaces (for example, Spink 1991, Gabriel 2008). This is, in part, due to the extensive distribution of soliflucted material. Fig. 6.47 illustrates the distribution of rocks most susceptible to solifluction, for example, clays and extremely weak to weak mudstones, including London Clay, Gault Clay, Oxford Clay, Lias Clay, Fuller's Earth and Weald Clay. Solifluction can affect other rocks, including mudrocks in the Coal Measures Supergroup. As the list of most affected geological formations implies, in lowland Britain, solifluction deposits and processes are mostly found to the south of the various ice limits but particularly the Devensian (Hutchinson 1991).

Other major factors that make reactivation of relict periglacial shears the most important periglacial geohazard in the United Kingdom are the low slope angles at which soliflucted materials can be reactivated, the extent of the shears, the volume of material that can be mobilised and the remediation costs (financial and temporal). The combination of these factors makes solifluction shears a significant risk in ground engineering, especially where the upper deposits are of key importance to stability, for example with earthworks.

When considering the properties of soliflucted material, it is worth remembering the processes that have acted on the soil in the geological past. Firstly, the soil will have been disturbed by 
cryoturbation and frost heave; secondly, the soil will have been saturated and reconsolidated; finally, it will have been transported downslope to its final resting place (Hutchinson 1991). Because of disturbance and movement, the soil will have a lower density and higher water content and be softer, having significantly lower shear strength parameters (cohesion and friction); so, the soils will be more compressible than their in situ undisturbed counterparts. The reduction in shear strength and increase in compressibility will depend on the nature of the soliflucted material. As a general rule, coarser soils are usually less affected than fine-grained plastic soils, which are more sensitive to a reduction in shear strength parameters to those of a residual soil.

When clays move downslope, particles realign. Particles on the slip surface undergo reorientation from the sliding, creating a preferred parallel orientation that produces the lowest possible shear strength, the residual shear strength (Fig. 6.48). Although it may be only the material on the shear surfaces that has a shear strength reduced to the lowest residual friction levels, the remaining soil within the soliflucted mass will also have reduced shear strength to some level below the peak strength of the in situ material (see above).

In summary, soliflucted material will have higher water content, lower density, lower strength parameters, and higher compressibility than in situ unaffected material. The effects of a reduction in shear strength parameters can result in lower bearing capacities, as well as reduced slope stability and increased permeability. A desk study and walkover survey should be sufficient to identify whether there is a potential for reactivation of relict shears. The walkover survey should include geomorphological observations or mapping, particularly indications of slope instability, and observations of fences, posts, telegraph poles etc. that may show signs of movement, and the nearsurface geology. Natural geohazard databases (for example, BGS's National Landslide Database) should be consulted. The best time to observe low-relief solifluction sheets and their characteristic lobes is in the winter months when there is a low sun angle and vegetation growth is at a minimum. The lobes can also be mapped using terrestrial or airborne LIDAR (light detection and ranging) and drone-based stereo-photography. However, ploughing may obliterate the surface expression and examination of land along the strike away from the study site is recommended. The ground investigation can then proceed, in a phased manner as necessary, to identify, classify and sample the features of concern. The desk study, walkover survey and intrusive investigations are of vital importance because reactivation of relict solifluction shears can result in extensive redesign, significant cost increases and considerable time delays on engineering projects.

However, determining parameters with regard to the soliflucted deposits can be challenging due to the inherent difficulties in carrying out tests on material with existing shear surfaces. An appropriate way to sample shear surfaces is to carefully prepare block samples in the field from trial pits (fig. 6.49), making sure the discontinuities are clearly marked so that large shear box tests can be carried out to determine the strength of shear surfaces. Experience indicates that, for planning and budgetary purposes, only one test pit and box sample should be scheduled per day. Trial pits in soliflucted materials should be considered to be unstable unless shown to be otherwise. A health and safety risk assessment is required for all (entered) pits used for logging and collecting samples to assess side stability and the design, construction and maintenance of suitable shoring systems.

Avoidance of soliflucted material might not be possible, as they may be widely distributed. Therefore, preventative designs should be prepared to mitigate the risks posed by soliflucted soils. Remedial strategies and construction works are similar to the preventative measures that can be taken, but remedial works usually cost significantly more and take significantly longer. The mitigation measures for foundations proposed on soliflucted material include methods for lowering the stress imposed by the structure by increasing foundation sizes (strip footing widths and pad dimensions) or by placing the structure on a raft. Whilst such measures may account for the weakness of the foundation soils, a site-wide slope stability assessment is also required to ensure the 
whole structure does not slide down the slope. Alternatively, depending on the nature of the structure, it may be prudent to take the loads through the soliflucted layer and into in situ material using deeper foundations such as piling.

If increasing the foundation areas or founding deeper are not viable, again depending on the nature of the structure, it may be necessary for the soliflucted material to be excavated and replaced with a suitable compacted fill (that could be the excavated material) may be appropriate. However, care may be needed in removing soil because ground upslope of the excavation may be destabilised. Regardless of the mitigation solution selected, it would be prudent to design the structure and services entering and leaving the structure, to be tolerant to greater movements above what would normally be considered acceptable to ensure the long-term serviceability of the structure.

The mitigation measures for earthworks for both the original design and re-design can be divided into three broad categories. The simplest, but not always the most cost effective or practical, method for both cuttings and embankments is flattening the slopes. The basis of the works is to reduce the face gradient of the cutting to a level where the slope angle is less than the residual angle of shearing resistance. Because this angle could be very low this option is unlikely to be viable. The basis of regrading works on an embankment would be to sufficiently spread the load to less than the bearing capacity of the soil. Again this is rarely a viable option due to constraints of available land and material.

The second option, applicable to both embankments and cuttings, is to excavate the soliflucted material underneath and slightly outside of the embankment footprint (a shear key) and within the zone of influence of the cutting, and replace with suitable engineered fill. As mentioned above, care is required on sloping ground to avoid upslope destabilisation. The fill material can be imported granular or lightweight fill or the excavated sheared material. If using the excavated sheared material as fill, care should be taken to ensure that the backfill material has been sufficiently reworked such that the shear planes have been broken and the material has the properties anticipated. When recompacting the previously sheared material back into the excavation, a sheep's foot roller (rather than a smooth drum) should be used to ensure new planes of weakness are not reintroduced.

The third broad mitigation option that might be appropriate uses a 'harder' engineering solution for both cuttings and embankments. Basal reinforcement of embankments can be adopted where other solutions are either impractical or infeasible, for example, where space is limited such that shear keys or regrading solutions cannot be used. The principal purpose of the basal reinforcement is to provide sufficient tensile strength and pull-out resistance at the base of the embankment to prevent global bearing capacity failure mechanisms from mobilising. 'Harder' engineering solutions for cuttings include piling (sheet piles, contiguous or secant) and soil nails that will provide a rigid barrier or element to prevent future movement from taking place.

Whichever mitigation (or remediation) options are considered, careful consideration of the longterm impact of groundwater levels and pressures is needed. Control of groundwater and drainage should be carefully considered to ensure that the most effective solution is adopted for the project. Consideration of the long-term operational effectiveness of the groundwater and drainage controls, plus any maintenance requirements, are an important part of the design and construction.

\subsubsection{Periglaciated rock surfaces}

In areas that were mainly periglaciated, which in the UK can be most clearly identified in areas beyond the Devensian ice limit, Higginbottom \& Fookes (1970) stated that prolonged freezing produced shattering of the frozen layer with the opening up of existing joints and fissures and the 
creation of new ones. This is particularly pronounced in the Chalk of south east England, with shattering extending to depths as much as $30 \mathrm{~m}$. Higginbottom \& Fookes (1970) observed that in the coastal cliff to the east of Brighton, which had been angled back to $70^{\circ}$ during the construction of a sea wall, the only significant falls of material came from the periglacially frost-shattered zone at the top of the cliff. Over long periods of repeated freezing and thawing, chalk tends to lose its macro-structure and turn into a remoulded 'putty'-like material with fragments of unaltered chalk that increase in size with depth. In places, fissures may become infilled with water-carried silt or clay.

Murton (1996) described brecciation of the Chalk in the upper few metres below the ground surface on the Isle of Thanet, Kent. This resulted from ice segregation in continuous permafrost conditions. He suggested that similar repeated ice segregation near the top of permafrost may have had the same effect on other bedrocks in the UK and elsewhere.

In clays of the Palaeogene London Clay Formation and Reading Beds (now the Reading Formation of the Lambeth Group) at Denham, Buckinghamshire in southern England, Spink (1991) observed several types of sheared and unsheared discontinuities, which he suggested were formed under periglacial conditions. The discontinuities consisted of two types of low angle shears above, and truncating, high angle shears. These, in turn overlaid two types of deeper, low angle shears. The two groups of low angle shears were postulated to have formed at the top and bottom, respectively of a permafrost layer. Norbury (1991), in discussion of Spink (1991), suggested that such periglacial shear surfaces would be difficult to find during ground investigation and that detailed logging of trial pits, possibly with pits left open for several weeks, would be required.

However, stronger rocks were also affected by periglaciation. Ealey (2012) described extensive periglacial features in the Palaeozoic bedrock of the Lizard Peninsula (Cornwall, south west England) and the surrounding area. These include brecciation and rock-head deformation involving overturning/terminal curvature. The extent of this suggests probable permafrost conditions. Devensian ground ice and segregated ice were considered to be the main agents.

\subsubsection{Ice wedge pseudomorphs and involutions}

Ice wedge pseudomorphs are thought to have originated by thermal contraction forming fissures infilled with ice and gradually enlarged. Such ice wedges later melted and the space previously filled with ice became filled with sediment, thus forming a pseudomorph of the original ice wedge. The sediment infillings taper downwards and may form a polygonal network in plan (patterned ground). Shotton (1960) identified an ice wedge pseudomorph over $5 \mathrm{~m}$ deep in Worcestershire (UK). Harris \& Murton (2005b) carried out laboratory centrifuge experiments that showed that deformation increased as the host sediment became finer-grained and ice content increased.

Involutions are volumes of highly disturbed material moved upwards by hydrostatic uplift in water below a re-freezing surface layer (Bradshaw \& Ingle Smith 1963). Involutions are described in more detail in Chapter 5 Section 5.2.2.3.

Higginbottom \& Fookes (1970) pointed out the engineering significance of these types of ground disturbance. They suggested that the problem was "... the sudden and usually unexpected replacement of one material by another, often with inferior geotechnical properties." This change in geotechnical properties was particularly relevant to shallow foundations and linear infrastructure such as roads and possibly pipelines (see, for example, Morgan 1971). In formerly periglaciated areas, the rockhead/superficial deposits interface and where interbedded weak rocks of varying lithology (for example, in southern England where Paleogene beds overlie the Chalk) are found close to the surface, need to be carefully investigated to determine whether unpredictable changes in 
lithology caused by periglaciation are present.

\subsubsection{Loessic deposits/brickearth}

Loess is a windblown deposit made up largely of silt-size particles, with varying amounts of clay and/or sand. Windblown loess deposits are characteristically not stratified and have uniform sorting (Bell 2000). However, water re-deposited loess may be stratified. Grabowska-Olszewska (1988) suggested that much of the loess of Poland were deposited in this way, though they were probably originally wind-blown deposits. In Essex and Kent, UK, Northmore et al. (1996) and Bell et al. (2003) identified both types of deposit.

Pye (1995) proposed that there were four fundamental requirements necessary for the formation of loess:

- a dust source;

- an adequate wind energy to transport the dust;

- a suitable depositional area;

- and sufficient time for its accumulation.

These requirements are not specific to any one climatic or vegetational environment. Whilst much loess was formed in glacial/periglacial environments, derived from the floodplains of braided rivers where glacial-ground silts and clays were deposited, windblown deposits can be derived in other environments described by Iriondo \& Krohling (2007) as volcanic, tropical, desert and gypsum loesses and climatically-controlled ones referred to as trade-wind and anticyclonic. However, the large quantities of ice-ground silt created during the Quaternary mean that much of the world's loess is glacially-derived.

In terms of stratigraphic classification, loess is usually referred to as such. However, in the UK the picture is a little confusing as loessic deposits are often referred to by the British Geological Survey on its geological maps as 'brickearth.' The reason for this is that the loess usually had significant clay contents and was very suitable for the manufacture of bricks. However, care is needed when using the term 'brickearth' to identify loess, as some brickearths are not loess at all. For example, in the Norwich area of East Anglia, UK, the 1:50 000 scale geological map (British Geological Survey 1975) and the geological memoir (Cox et al. 1989) incorrectly show the Happisburgh Till Member, described by Rose et al. (1999) as an Anglian sandy glacial till, as the 'Norwich Brickearth.' The terminology used on map legends and summarised in Table 6.15 (see below) is confusing as the BGS does not use the term 'loess' and the term 'aeolian' is used only on map sheets 316 (Fareham), 317/332 (Chichester and Bognor) and 331 (Portsmouth). As well as tills, 'brickearth' may also refer to glaciolacustrine deposits and colluvial deposits. Using the BGS Lexicon of Rock Names, Bell \& Culshaw (2001) described the main brickearth units (see below). All of them should be assumed to be loessic as first deposited, though they may have been reworked, and so potentially collapsible:

- Brickearth - varies from silt to clay, usually yellow-brown and massive.

- River Brickearth - varies from silt to clay, usually yellow-brown and massive; of fluvial origin.

- Head Brickearth - varies from silt to clay, usually yellow-brown and massive. Poorly sorted and poorly stratified, formed mostly by solifluction and/or hillwash and soil creep.

- Head Brickearth, Older -Varies from silt to clay, usually yellow-brown and massive. Poorly sorted and poorly stratified, formed mostly by solifluction and/or hillwash and soil creep. Older than 'Head Brickearth' in the same map area.

- Head Brickearth, Younger - varies from silt to clay, usually yellow-brown and massive. Poorly sorted and poorly stratified, formed mostly by solifluction and/or hillwash and soil creep. Younger than 'Head Brickearth' in the same map area. 
Culshaw et al. (2016) suggested that, to avoid confusion and remain consistent with the long historical useage of the term 'brickearth' on geological maps, the term 'loessic brickearth' should be used for those deposits in the UK that are clearly of aeolian/loessic origin.

\subsubsection{Distribution and identification}

Loessic deposits are extensively distributed around the world (Pye 1994). In the UK relatively thin loessic (brickearth) deposits are found in southern and south eastern England (Fig. 6.50). Fig. 6.50a (i \& ii) shows the distribution of loessic deposits greater than $1 \mathrm{~m}$ thick and between $300 \mathrm{~mm}$ and 1 $\mathrm{m}$ thick, derived from Soil Survey 1:250 000 soil maps. Fig. 6.50b shows brickearth deposits from British Geological Survey 1:50 000 scale geological maps. Table 6.15 lists the British Geological Survey 1:50 000 scale geological maps from which most of Fig. 6.50b was derived and the terminology used on the map keys to define the deposits. The difference between Figs. 6.60a and $6.50 \mathrm{~b}$ is mainly the result of the geological maps showing only deposits thicker than $1 \mathrm{~m}$.

In the UK, loessic deposits comprise a discontinuous blanket deposit of yellowish brown, friable, generally low plasticity, poorly bedded, clayey and/or sandy silt with well-developed vertical jointing. It has a very open, low density, structure. Given that identifying loess deposits from geological maps may be problematical, it is essential to obtain and geotechnically test undisturbed samples suspected of being loessic to determine their index properties and their susceptibility to collapse.

\subsubsection{Composition}

Mineral composition of loessic deposits is variable and will depend on the original materials forming the deposit as well as any mineral formation since deposition (Mildowski et al. 2015) but usually the dominant mineral is quartz (approximately 15-80\%). Feldspars (which can weather to clay) (up to about 20\%), mica and clay minerals (together up to about 30\%) and calcite (up to about $20 \%$ ) may also be present.

\subsubsection{Geotechnical properties}

The most important geotechnical properties of loessic deposits are: index properties, strength and collapsibility. Jefferson \& Rogers (2012, p391) summarised the controls on a soil's susceptibility to collapse. They defined collapsible soils as those "in which the major structural elements are initially arranged in an open metastable packing through a suite of different bonding mechanisms."

Because loess can be deposited by the wind and later re-deposited by water, or altered by solifluction, geotechnical properties can vary. Bell (2000) provided data on the index properties of loessic deposits from a number of locations worldwide which have been summarised in Table 6.16.

The strength of loessic deposits is dependent on the initial porosity and water content, the degree of deterioration of the intergranular bonds and the increase in granular contacts under consolidation, as well as changes in moisture content. When loessic deposits with many macropores and high water content at, or near, saturation, are loaded, the inter-grain bonds are first broken, resulting rapid reductions in volume, a lowering of the cohesion and softening of the soil. With further loading the grains are brought more and more into contact, thereby increasing friction, so giving rise to a hardening effect. The results obtained from undrained triaxial tests on loessic deposits (brickearth) from south Essex (UK) by Northmore et al. (1996) showed that the shear strength was between 10 and $220 \mathrm{kPa}$. Such a range indicates the variability in undrained shear strength. The same authors also carried out consolidated undrained triaxial tests and these showed variable effective shear strengths with peak values of the internal angle of shearing resistance between $19^{\circ}$ and $34^{0}$ and effective cohesions between 10 and $70 \mathrm{kPa}$. Residual values were between $16^{\circ}$ and $25^{\circ}$ and $0 \mathrm{kPa}$, respectively. It is difficult to summarise the overall strength characteristics of loessic deposits 
because of the variability of the mineral content and structure.

Loessic deposits have a much greater vertical than horizontal permeability, which is enhanced by long vertical 'tubes' in the loess structure that are formed by fossil rootholes and vertical fissures. Because of this, loessic deposits are well drained (their permeability ranges from $10^{-5}$ to $10^{-8} \mathrm{~m} \mathrm{~s}^{-1}$ ) compared with non-loessic silts.

Northmore et al. (1996) found that loessic deposits from South Essex in England had a high degree of compressibility $\left(\mathrm{c}_{\mathrm{c}}\right)$ ranging from 0.15 to 0.33 and that the value of the coefficient of volume compressibility $\left(\mathrm{m}_{\mathrm{v}}\right)$ decreases with increasing load. Consolidation was rapid, as shown by high coefficients of consolidation $\left(\mathrm{c}_{\mathrm{v}}\right)$.

\subsubsection{Geohazards associated with loessic deposits}

Loessic deposits may have the potential to collapse when wetted or wetted under loading. This rapid loss of volume ('collapse') is the principle engineering behaviour that distinguishes these soils. Jefferson \& Rogers (2012) suggested that to characterise collapsible soils, four stages of investigation were required:

- Reconnaissance, which requires the obtaining of a good understanding of the geological and geomorphological setting. Collapse potential is related to the origin of the material, to its mode of transportation, its depositional environment, and also weathering. Jefferson \& Rogers (2012) referred to these controls as the PTD sequence of a deposit ( $\mathrm{P}=$ provenance, $\mathrm{T}=$ method of transportation, $\mathrm{D}=$ how the soils were deposited). They pointed out that, during its life, the loess may have experienced several PTD sequences if the soil material is retransported and re-deposited. This can result in a loess deposit having zones of variable collapse potential (both laterally and vertically) depending upon the PTD sequence that different layers have experienced.

- Use of indirect correlations using geotechnical index test data; a number of collapse coefficients have been developed by a number of researchers. Bell et al. (2003) summarised some of these but concluded that they seemed to be site specific in their validity and not reliable when used at other locations. Houston et al. (2001) noted that correlations were sometimes weak and results scattered.

- Laboratory testing: the most effective method uses the double and single oedometer test (Jennings \& Knight 1975, Houston et al. 1988). The collapse strain is measured when the specimen is flooded under load. This gave an indication of susceptibility to collapse. Jennings \& Knight (1975) classified collapse percentage in terms of the severity of the problem:

$0-1 \%$ No problem

$1-5 \%$ Moderate trouble

$5-10 \%$ Trouble

$10-20 \%$ Severe trouble

$>20 \%$ Very severe trouble

- Field testing; methods used include plate loading test, pressuremeter tests, standard penetration tests. Northmore et al. (2008) described how different geophysical methods (such as electromagnetic, resistivity and shear wave profiles) could be used to determine the lateral and vertical extent of collapsible and non-collapsible soils. Calibration by use of laboratory methods is recommended.

There are few recorded instances of building damage due to collapse of loessic deposits in the U.K (Culshaw et al. 2016), although as demonstrated by Case History 4 in Chapter 1 this is a risk in other parts of the world. What is surprising is that these examples are from the Torbay area of southwest England, rather than from southeast England where the brickearth/loessic deposits are thicker and more extensive. While collapsibility is the main geohazard associated with loess, these soils are also susceptible to landsliding, though no loessic landslides have been recorded in the UK. However, they 
are relatively common in China where thick loess mantles areas of higher and steeper relief (for example, Meng \& Derbyshire 1998).

\subsubsection{Engineering treatment}

Jefferson et al. (2005) gave various methods for treating collapsible loessic deposits. Their suggestions are given in Table 6.17 and can be summarised as:

- shallow depths 0-1.5 m: surface compaction, pre-wetting or vibroflotation;

- medium depths 1.5 - $10 \mathrm{~m}$ : vibrocompaction, dynamic compaction, explosives, compaction piles, grouting, pre-wetting, soil mixing with lime/cement, heat treatment, chemical methods;

- depths greater than $10 \mathrm{~m}$ : as for medium depths (though some may be of limited suitability), piling.

Popescu (1992) discussed various design solutions for foundations on loess:

- Very stiff raft foundations and a rigid superstructure to minimise differential settlement. These can be expensive and not always successful.

- Flexibility of the foundation and superstructure to accommodate ground movements.

- Use of piles through the collapsible layer.

- Control/alteration of ground conditions.

A particular problem for linear infrastructure is that non-uniform collapse can cause rough, wavy surfaces over long distances. Railway tracks are particularly sensitive to this kind of differential settlement.

Jefferson \& Rogers (2012) summarised the key tasks with regard to collapsible soils (including loess) as:

- Recognise the existence of these soils by obtaining the key geological and geomorphological information.

- Confirm the potential for collapsibility through direct response to loading/wetting tests in the laboratory and the field.

- Predict the extent and degree of wetting likely.

Once these tasks have been completed, the appropriate improvement technique(s) can be applied (for example, Table 6.17), hence reducing or eliminating the hazard. However, as loessic deposits are highly permeable, wetting the loessic deposit at the correct depth can be time-consuming requiring large quantities of water (Northmore et al. 2008).

\subsection{Local geohazards}

\subsubsection{Superficial valley disturbances: Cambering, gulls and valley bulging}

Hutchinson (1991), in a theme lecture on periglacial and slope processes, brought cambering, gulls and valley bulging together under the general term: 'superficial valley disturbances.' However, each of the names of the three components are frequently used in the UK by engineering geologists and others, so these terms are used here. It should be noted that BGS geological maps do not show cambered ground. However, Hobbs \& Jenkins (2008) described how the term 'Foundered strata' is used on some maps (for example in the Bath, Somerset area) to describe areas where extensive landsliding and cambering have occurred but beneath which the solid geology could not be determined by the mapping geologist. Foundered strata are shown on BGS 1:50 000 scale geological maps as horizontal black hachuring on a pale green background. This is distinct from the normal 'landslide' symbol of vertical hachuring on a white background, with the solid geology shown as dotted lines. As well as Hutchinson's paper, general discussions of superficial valley disturbances have been provided by Parks (1991a and b), Pook (2013), and Chapter 5 Section 5.2.3.3 and are illustrated in 
Superficial valley disturbances are associated with periglacial conditions. Cambering is a geomorphological process involving the large-scale stretching, tilting and rotation of stronger and more brittle rocks on upper valley sides and along plateaux edges. Cambering occurs where valleys have been eroded to expose weaker strata (such as clays, mudstones or shales), which may underlie a stronger cap rock (such as sandstone, limestone or basalt). The erosion, weathering and deformation of the underlying weaker rocks may cause the stronger cap rocks to tilt, rotate or drape along valley crests. As such, cambered blocks tend to be tilted towards the valley axis and, therefore, any bedding planes in the deformed rock mass may appear to dip at a steeper angle into the valley.

Cambering may be associated with extensive and deep fissures, known as gulls, which extend beyond the valley crests. These may align parallel to the valley sides and valley axis and are generated by the lateral extension and spreading of the upper valley slopes and the detachment of cambered blocks. However, gulls may also be aligned perpendicular or obliquely to the valley sides where their orientation is influenced by the geometry and dilation of pre-existing rock mass discontinuities, namely joints and faults, in the strong cap-rock. Gulls may be visible along the ground surface or concealed and bridged by surface vegetation, superficial deposits or rock capping the gull caused by differential extensional movement within the cap-rock. Hawkins \& Privett (1981) identified three main types of extensional movement (Fig. 6.51a) and also four principal classes of gull (infilled, open, mixed and roofed) (Fig. 6.51b). This classification was subsequently modified by Self (1985) as shown in Fig. 6.52. The type of infilling materials may be useful to provide a relative age for the generation of the fissures. Gull width can vary considerably from a few tens of millimetres (for example, Hancock 1969) to many tens of metres (for example, Barron et al. 2002).

Valley bulging may be associated with cambering. This process generates large scale, non-tectonic, broad anticlinal structures, caused by the deformation of weaker rocks that underlie the lower valley slopes and valley floor. Fig. 6.53 shows valley bulging in Namurian rocks (Edale Shales) in Derbyshire. Hutchinson (1991) discussed the processes that cause cambering, gulls and valley bulging based on the work of Vaughan (1976) on the Lias at Empingham, in Central England, and the work of Morgenstern (1981) and McRoberts \& Morgenstern (1974a \& b) on modern periglaciated areas of northern Canada. The sequence of processes involved (based on Empingham) were as follows:

1. "Valley rebound of unfrozen ground ... accompanying valley incision."

2. "Ground freezing ... under periglacial conditions."

3. "Valley-ward creep of the frozen ground and particularly the frozen clay ..." This initiated cambering and gulling of the capping rock and produced growth of the valley bulge caused by slight updoming resulting from valley rebound.

4. Decay (thawing) of permafrost from its top and base. This resulted in solifluction above the permafrost and "excess pore-water pressures in the freshly thawed sub-permafrost ..." “... this led to mobility and incremental extrusion of the (clay) and an intensification of cambering, gulling and valley bulging."

5. The capping stratum was then in tension and pre-existing joints opened to form gulls.

6. Associated with the cambering was multiple toppling of the camber blocks.

Fig. 6.54 is a sketch by Hutchinson (1991) showing partly developed camber, gulls and valley bulging based on the example at Empingham, Central England. The overall process is similar to that described by Parks (1991a) and illustrated in Fig. 6.55. Hutchinson subdivided 'superficial valley disturbances' into three types:

Type 1. Alternating beds of competent rocks and shales. These are characteristic of the Namurian rocks of the Pennines of Northern England. The valleys are often steep-sided and moderately deep.

Type 2. Capping of competent rock over stiff clay or shale. These conditions are typical of Jurassic 
strata (and to some extent Cretaceous strata) of Central and Southern England. Valleys are gentler-sided and shallower than the Carboniferous ones.

Type 3. Mainly well-bedded, ductile stiff clay with thin or no capping rocks. Disturbances are similar to type 2 and valley profiles are also similar. Again, type 3 conditions are found mainly in Jurassic strata and the main differences seem to be the lack of a capping rock (and, hence, an absence of cambering and gulling) and the 'valley bulges' being in the form of multiple folds, sometimes with thrust faults.

Cambered strata, gulls and valley bulges have been observed at several localities throughout upland Britain and in areas of lower relief. Notable examples have been documented in the Namurian strata of the Pennines (Donnelly 2008, Jones \& Weaver 1975, Hill 1949, Lapworth 1911, Miller 1887, Morton 1949, Watts 1905), the Coal Measures of South Wales (Donnelly 2005, 2011, Donnelly et al. 2000) and Yorkshire (Shotton \& Wilcockson 1950), Jurassic strata in North Yorkshire (Cooper 1980), Northamptonshire (Hollingworth et al. 1944, Horswill \& Horton 1976, Vaughan 1976), along the extensive Cotswold escarpment (Ackermann \& Cave 1967, Chandler et al. 1976, Farrant et al. 2014, Self \& Farrant 2013), Worcestershire, the East Midlands (Horswill \& Horton 1976) and Dorset (Arkell 1947) and Cretaceous strata in the Weald of Kent (Bristow \& Bazley 1972).

Fig. 6.56 shows some of the recorded occurrences of cambering in the literature (Donnelly et al. 2002, Hawkins \& Privett 1981, Higginbottom \& Fookes 1970, Hill 1949, Horswill \& Horton 1976, Hutchinson 1991, Kellaway \& Taylor 1968, Lang 1914, Morton 1973, Sandeman 1918, Self 1985), in the British Geological Survey's National Landslide Database and in the PhD thesis of Parks (1991b).

Hutchinson (1991) noted that cambered strata, gulls and valley bulges have not been reported from Scotland and North and Central Wales, partly because of the competence of the older rocks found there and partly because these areas were glaciated for the longest periods and experienced shorter periods of periglaciation than the Midlands and South of England.

Dating the initiation and occurrence of cambering, valley bulging and the generation of gulls may be difficult. Devensian erosion and the formation of gravel terraces in the Cotswolds appear to post-date cambering and valley bulging (Chandler et al. 1976). However, cambering and valley bulging in the East Midlands have been interpreted to pre-date the Anglian glaciation, but in some localities cambering and valley bulging post-dates the retreat of the ice sheets. Hutchinson (1991) argued that the Empingham cambering was of Wolstonian age, or earlier, and did not continue into the Devensian.

The origin of cambers, valley bulges and fissures in parts of the South Wales Coalfield still remains somewhat speculative due to the over-printing of extensive coal mining subsidence and associated fissures (Donnelly 2005). However, coal mining has not taken place in the Namurian of the central Pennines but cambering and fissuring have been also been observed (Donnelly 1998, Donnelly et al. 2005). In both localities, glacially-incised and over-steepened valley slopes contain a strong cap rock and weaker rocks on the valley floor and sides. It is possible that the valley sides may have been initially confined by glacier ice but this may have changed under periglacial conditions when the ice retreated. Processes of gravitational stress relief, weathering of the mudstones and shales, rapid river erosion, stress concentrations in valleys, elevated water-fluid pressures within shales and mudrocks, water take-up by the shales, artesian water pressures and valley notch stress concentrations all may have contributed to cambering, valley bulging and fissure generation. In the case of South Wales, some of the cambered Pennant Sandstone blocks and fissures that were initiated under periglacial conditions may have been exacerbated by mining subsidence in the nineteenth and twentieth centuries (Donnelly 2005, 2011) (Figs. 6.57, 6.58a \& 6.58b).

Gallois (2010) identified another type of disturbance, not associated with cambering, in mudrocks of Lias and Kimmeridgian age in Dorset in southwest England. He termed these structures "creep folds" 
and interpreted them as having been formed under periglacial conditions but not by tectonic processes, valley bulging or landsliding. Rather, he suggested (p.223) that they were caused by "intermittent downhill creep of surface layers up to $20 \mathrm{~m}$ thick when in a partially frozen condition." The folds described by Gallois have all been found in coastal exposures but, presumably, they may exist in other locations where valley sides are composed of weak mudrocks.

\subsubsection{Engineering aspects}

Hawkins \& Privett (1981) described a housing site near Radstock in the Somerset Coalfield, in southwest England. When open gulls were encountered, they recommended that each building needed to be considered individually. If the gulls could not be avoided, the building should be located so that the gull crossed the foundation beneath the centre third of the house. Also, foundations should be reinforced rather than using the usual strip footings.

A series of 'standard' designs were devised:

1. 'Minimum' design: reinforced strips able to span $2 \mathrm{~m}$ with non-suspended reinforced floor slabs.

2. When an open gull was encountered, all the foundations for load-bearing walls were in the form of concrete beams each founded on at least $1.5 \mathrm{~m}$ of good quality rock on each side. Beams were designed to span $4.5 \mathrm{~m}$ or $6 \mathrm{~m}$. Where a gull crossed a corner of a house the beam would be extended up to $5 \mathrm{~m}$ outside the house walls. Floors consisted of $175 \mathrm{~mm}$ thick reinforced suspended floor slabs.

3. For large gulls occurring beneath the corner or load bearing wall a house, plugs were designed consisting of either concrete (with a drainage layer at the base) or coarse grade aggregate.

4. Garages were detached and built on reinforced beamed concrete rafts designed to span $3 \mathrm{~m}$. Garages were not located in 'better' areas where houses could be located.

In some areas, the gulls are wide (ten metres or more). In this situation, careful investigation of the nature of the gulls is required including their width and depth, the presence of any voids and the nature of infilling. It should also be remembered that gulls might occur some distance from the valley slope. Higginbottom \& Fookes (1970) mentioned a site in Northampton for a block of flats on the Northampton Sand Formation that was about $300 \mathrm{~m}$ from a valley side. Consequently, engineering designs in areas of gulling are likely to be site specific.

Cambered strata should be regarded as a particular form of mass movement in which the ground has failed and is likely to be at its residual strength along shear surfaces.

Valley bulging presents particular risks to dam construction, largely due to the extensive fracturing caused. Higginbottom \& Fookes (1970) described the construction of the Ladybower Dam in Derbyshire. Here, valley bulging in Lower Carboniferous shales and sandstones caused such a degree of fracturing that the cut-off trench had to be excavated to an average depth of $52 \mathrm{~m}$ and a maximum of $76 \mathrm{~m}$ with water being pumped out at the rate of 9 million litres per day. Around 16000 tons of cement grout were used to grout the trench and headings in the hillside which also found many open cracks and gulls. Similar valley bulges were also found in the vicinity of the nearby Derwent Dam (Fig. 6.53).

\subsubsection{Solifluction shears}

Solifluction shears are formed under periglacial conditions when saturated material (solifluction debris) is transported downslope by the process of freeze-thaw, fails by shearing. Movement can take place on slopes as low as 3 or $4^{0}$ (for example, in Kent, Skempton \& Weeks [1976]). Shears are found when the slope consists of clayey Head on a clayey sub-base or granular Head on a clayey sub-base (Hutchinson 1991). On the shear surface the strength is reduced to the residual value reducing the factor of safety against failure. The likely presence of such shears can be anticipated if, for example, solifluction lobes 
can be observed as topographic features (see also Section 6.6.1 above).

The failure of the Carsington dam in Derbyshire in 1984 (see Chapter 1 Case History 5) is an example of this type of failure (though failure within the clay core and boot also contributed). The engineering geological conditions were described by Skempton et al. 1991 and the dam failure by Skempton \& Vaughan (1993). Awareness of the failures associated with solifluction shears increased following problems on the Sevenoaks By-pass. Trial pitting found that the shears were at a depth of 2 to $3 \mathrm{~m}$ and the soliflucted material extended some $500 \mathrm{~m}$ out from the foot of the escarpment. From an engineering point of view it is essential to first identify the presence of solifluction shear, usually by trial pitting and then test samples from the pits to determine strength and other parameters. Appropriate engineering designs can then be implemented. Solifluction shears in head deposits are described in more detail in Chapter 5 Section 5.2.3.2

\subsubsection{Kettle holes}

A kettle hole is a hollow left following the melting of blocks of buried glacier ice. Kettle holes may occur individually or in groups and can vary in size from a few metres in diameter to several kilometres. Their depth can vary considerably, too, from a few metres to tens of metres. Often the hollows form obvious lakes. The way in which they are formed and the glacial environments in which they can occur are described in more detail in Chapter 4 Section 4.4.1.

The infill material is likely to have a very high water content and be lithologically very varied but often includes peat. If excavations encounter a kettle hole, rapid outflow of material from the kettle hole is possible. Fig. 6.59 shows a section through a $25 \mathrm{~m}$ deep and $60 \mathrm{~m}$ wide kettle hole near Nefyn on the Lleyn Peninsula in North Wales. Here, coastal erosion has exposed the walls of the kettle hole, the infilling material (mainly silty sediment) having mostly flowed out (Gibson et al. 2002). At the surface, kettle hole infill materials are likely to offer very poor foundation conditions being highly compressible with very high water contents.

\subsubsection{Relict cryogenic mounds}

In current permafrost environments, such as Svalbard (formally known as Spitsbergen) a Norwegian archipelago in the Arctic Ocean, there is a range of conical, cryogenic mounds that are broadly classified (French 2007) as pingos, palsas (developed in peat) or mineral palsas (developed in mineral soils). As described in Chapter 5 (Section 5.2.6.5) they form as a consequence of the freezing of water, which moves under a pressure gradient to the site of the growing ice. Cryogenic mounds also occur in seasonal frost conditions, comprising frost mounds (frost blisters or icing blisters) or hydrolaccoliths (developed in peaty soil). Pingos are the largest of these features comprising approximately circular ice-cored hills, 3-70 $\mathrm{m}$ in height and 30-1000 $\mathrm{m}$ in diameter (Mackay 1988). They may take thousands of years to form. As they grow (at up to $1.5 \mathrm{~m} /$ year initially; Mackay \& Black 1973) they raise the ground, which becomes increasingly unstable. As the core melts and mass wasting transports soil towards the edge of the pingo, the ground settles with the potential for a consequential crater to form. Palsas and mineral palsas are low permafrost mounds with cores of layered segregation ice and peat. They are normally 1-7 m high, $10-30 \mathrm{~m}$ wide and 15 to $150 \mathrm{~m}$ long. They are understood to form when areas of reduced snow cover enables the frost to penetrate more deeply into an unfrozen peat bog. Seasonal cryogenic mounds typically range from 1 to $4 \mathrm{~m}$ in height (French 2007), whilst hydrolaccoliths (Russian bugor) rarely exceed $2 \mathrm{~m}$ in height and 15 to $50 \mathrm{~m}$ in diameter.

\subsubsection{Characteristics of the relict forms}

Relict cryogenic mounds can be difficult to recognise, partly because they may have been subject to subsequent cold climate conditions and therefore further disturbance. In the UK there is the additional complexity of evidence being destroyed by changes in land use (Hutchinson 1991). Additionally, their 
interpretation relies upon cross-sectional analysis and interpretation and this not necessarily visible. They are commonly found in clusters and are associated with lower hill slopes, alluvial fans or valley bottoms (Washburn 1979). Accordingly, Hutchinson (1991) classified them as groundwater discharge features. Ballantyne \& Harris (1994) described the typical morphological evidence of Pleistocene pingos and related cryogenic mounds: circular or oval depressions with dimensions of 25 to $250 \mathrm{~m}$; occurring in a variety of sediments; commonly located on plains, valley floors and lower valley sides where seepage occurs and, where they occur on slopes, they are elongate downslope. De Gans (1988) and Mackay (1988) have summarised key diagnostic features (Table 6.18).

\subsubsection{Occurrence in the UK}

UK examples of pingo scars have been described in Wales, East Anglia, the Thames Basin, Cumbria, the Isle of Man and Ireland (Ballantyne \& Harris 1994, Bryant \& Carpenter 1987). In west and midWales they occur both north and south of the late Devensian ice-sheet.. Ballantyne \& Harris (1994, p. 75) presented a distribution map of ground ice-depressions in Britain; to this, a number of more recently reported occurrences, could be added as shown in Table 6.19. These primarily fall within the Thames catchment, the number and distribution largely reflecting the extent of development in the London area that facilitates their discovery.

\subsubsection{Processes of formation (see Chapter 5 Section 5.2.6.5)}

Cryogenic mounds develop in areas of permafrost or seasonal permafrost through the accumulation of the accumulation of segregation ice or intrusive ice. Once a layer of segregation ice has formed it grows as a consequence of the pore water pressure gradient towards it. Freezing of water under artesian pressure forms intrusive ice. Pingos have two principal genetic forms: hydrostatic and hydraulic. Hydrostatic pingos grow where segregation ice forms in areas of isolated lenses of talik (unfrozen ground) with high water contents, for example, the zone that underlies lakes or channels. Hydraulic pingos are fed by flow paths beneath or within the permafrost being recharged by areas of discontinuous permafrost. Continued growth of pingos results in stretching of the overburden, which is associated with the development of dilation cracks and then slumping of the overlying materials (to form what subsequently becomes the relict pingo rampart). They decay from the top down, as a consequence of ice wasting, which leaves a remnant depression, commonly containing a pond or marshy area (Mackay 1988) that may subsequently be sediment filled.

\subsubsection{Engineering geological characteristics}

In Table 6.20, the key engineering geological characteristics associated with cryogenic mounds have been summarised. It is clear from Table 6.20 that cryogenic mounds are associated with considerable variation in ground conditions due to intra- and inter- formational disturbance (for example see Fig. 6.60) and this has significant implications for surface development because of the increased potential for differential settlement and ground support issues. There are further implications for subsurface engineering, in particular tunnelling. An example is the Blackwall Hollow that was encountered during the construction of the Blackwall Tunnel (Ellison et al. 2004). At this location the infill is a chaotic mix of, primarily, sand and flint and chalk gravel with some clay beds and up to boulder-sized chalk 'rafts'. It comprises the different disturbed units, namely the Chalk, Thanet Formation, Lambeth Group, London Clay Formation and the Kempton Park Gravel Member (Quaternary river terrace deposit). The mixing has resulted in chalk particles occurring at the level of the Kempton Park Gravel Member and gravel from the Kempton Park Gravel Member at the level of the Chalk.

\subsubsection{Mitigation measures}

Mitigation may take a range of forms, but all mitigation work needs to be underpinned by good ground investigation data, including determining if these structures have been documented elsewhere in the area or are likely to occur. If present, the variability in the form of these features necessitates sufficient investigation to characterise them. Investigation may comprise a range of techniques, including both intrusive (probing and boring) and non-intrusive (geophysical techniques, for example, electrical 
resistivity, ground penetrating radar or passive seismic) (for example, Kahout et al. 2014, Raines et al. 2015). The descriptions in Table 6.20 should provide an indication of the necessary depth of investigation. Once the ground conditions are characterised, mitigation for surface developments may incorporate one or more of the following: avoidance, end-bearing piles, contiguous bored piles, buoyancy-designed solutions or, ground improvement. Mitigation for underground engineering includes selection of the appropriate tunnel-boring machine, for example, slurry versus earth pressure balance, and adequate investigation to facilitate appropriate groundwater control.

\subsubsection{Relict scour hollows}

Relict scour hollows comprise localised thickening of the superficial deposits into hollows in the underlying strata (potentially another river terrace or bedrock) (for example, Bejestan \& Hemmati (2008). As with active scour features, they are commonly associated with the outside of meanders or stream confluences (Church 2002). Relict hollows can be determined as such because they are overlain by alluvium associated with the modern course of the river. In the London area they are sometimes associated with the hypothesised location of relict hydraulic pingos. However, the formational processes associated with scour hollows and relict hydraulic pingos are very different (Banks et al. 2015). Furthermore, it should be noted that not all of the scour hollows that have been described by Berry (1979) are associated with disturbance of the bedrock.

\subsubsection{Occurrence}

Scour hollows are associated with most UK river systems (for example, Bridgland et al. 2014), but they are more pronounced in rivers that have been subject to permafrost and periglacial conditions. They have been noted in the rivers that have been subject to the detailed analysis of the succession of river terrace deposits and much of the organic material that has been used for dating terraces has been derived from scour hollows (Lewis et al. 2006).

\subsubsection{Formational processes}

In current permafrost environments the discharge of most streams exhibit seasonal (and even diurnal) patterns, with most of the flow occurring in response to snow melt. During the melt period the enhanced stream energy results in bed erosion or scour. This is particularly focused on the outside of meanders (vortex scour; Mlynarczyk \& Rotnicki 1989) or at the confluence of a tributary of the river with the main channel (junction scour; Ginsberg \& Perillo 1999). The potential for scour is increased when groundwater levels were reduced by a drop in sea-level in response to glaciation, with elevated river flow facilitating river bed erosion.

\subsubsection{Engineering geological characteristics}

The most noticeable characteristics of scour hollows are increased thicknesses of river terrace deposits and alluvium and reduced thicknesses of the underlying strata. The depth of scour can range from metres in present river systems to tens of metres in relict and offshore systems.

\subsubsection{Mitigation measures}

Where a scour hollow is suspected, ground investigation should be undertaken to determine the extent of the anomaly and assess the geotechnical properties to facilitate engineering design. For example, in London the Crossrail project required mitigation for scour features at: i) Liverpool Street/ Moorgate Box at the junction of the Walbrook tributary and main channel, where a thickening of the Taplow Gravel was identified during ground investigation; ii) the Lea/ Thames confluence (at the base of the Kempton Park Terrace), and iii) at the Thames crossing point in the Woolwich Reach, where a scour feature extended into the chalk that underlay a thicker sequence of river terrace deposits (Lenham et al. 2006). Each of these hollows was characterised using a range of techniques that included both intrusive (boreholes) and non-intrusive (geophysical) techniques to facilitate engineering design. 


\subsection{Regional geohazards}

\subsubsection{Neotectonics - differential crustal movements across southeast England during the Holocene following deglaciation}

While the crustal movements discussed here are not a direct consequence of glaciation and periglaciation, they occurred as a result of the rise in temperatures at the end of the last glaciation and the consequent ice melting. This caused a transfer of water from land to ocean and unloading of the landmass.

The elevation of the land in relation to sea level is subject to a variety of processes. In the U.K. this has been considered by many contemporary geoscientists to be associated with an interplay of eustatic variations in sea level due to variations in the volume of the large continental ice sheets at high latitudes and isostatic variations due to the effect of the loading and unloading of the Earth's crust by the waxing and waning of the continental ice sheets. This section reviews the role of neotectonic crustal movements, where a component in the change in elevation reflects a regional tectonic pattern of uplift and subsidence. Here the focus is on southeast England during the Holocene, where the variations in relative sea level over the last 10000 years are recorded in detail in the near-shore sediments and the observed fluctuations in the depositional environment of the sediments cannot be solely related to isostatic and eustatic influences.

These Holocene vertical crustal movements are considered in the context of more general the areas of neotectonic uplift and subsidence across southeast England and the near Continent during the Quaternary.

\subsubsection{The eustatic record}

The eustatic rise in sea level at the end of the last glacial epoch, and the beginning of the Holocene, is well recorded in sea level curves for low latitudes that were not affected by glaciations (Milne 1995) (Fig. 6.61). This shows that the period of rapid eustatic rise was complete by about 7 ka ago, and the curve has subsequently been nearly flat, with no more than 3-4 m rise in this period $(0.5$ $\mathrm{mm} /$ year), with little evidence of high frequency departures, although since the 19th century anthropogenic influences have occurred.

\subsubsection{The isostatic record}

Changes in relative sea level due to glacio-isostatic re-adjustment of the earth's surface, continue to affect the U.K. to the present day, with northwest Scotland rising and southeast England sinking (Bradley 2011, Gehrels 2010, Shennan 2002). The uplift in Scotland reflects a continuing rebound of the earth's surface following the melting of the ice sheet that covered northwest Britain during the last glacial period (Gehrels 2010, Shennan 2002). The sinking of south east England is a little more complex, as outlined by Genrels (2010), with much of the change resulting from a glacioisostatic collapse of a 'fore-bulge' that developed in front of the area of the earth's surface, that was depressed by the adjacent ice sheet. The rates of uplift in Scotland are in the order of 1.0 to 1.6 $\mathrm{mm} /$ year, while the rate of sinking of south and south east England are in the order of 0.5 to 1.0 $\mathrm{mm} /$ year (Fig. 6.62). While this mechanism is a significant factor in the changes in relative sea levels in southeast England, it cannot explain all the observed variations in sea level reflected in the near-shore sediments deposited across southeast England during the Holocene, and neotectonic influences are identified as well.

\subsubsection{Case studies of two areas}

Two areas are considered, the Palaeogene Hampshire Basin and the East Coast, from the Wash to the Thames Estuary. The changes in relative sea-level during the Holocene are mainly inferred from the records of fluvial and near-shore estuarine and marine sediments, with changes in the 
environment of deposition giving a high resolution record of relative sea levels.

\subsection{The Hampshire Basin}

The Hampshire Basin is an area of Palaeocene to Oligocene sedimentation, with a strong zone of deformation along its southern margin (Isle of Wight - Purbeck axis) (Hopson 2011). This zone of deformation has a monoclinal-aspect indicative movement along a pre-existing deep crustal feature. The deformation and in places inversion of Mesozoic and Palaeogene basins of deposition during the Neogene is a regional event that affected much of the United Kingdom and surrounding areas (Gibbard 2003).

During the Quaternary, minor overall uplift of the Palaeogene basin is recorded by the sequence of river terraces deposited by the Test, Avon and Stour, and raised beaches on the Isle of Portland and West Sussex (Bates 2010, Briant 2009) (Fig. 6.63). During the Holocene this uplift has been overprinted by the glacio-isostatic 'fore-bulge' subsidence. However, this overprint is not consistent and appears focused along the synclinal axis of the basin extending from Poole, through Calshot to Portsmouth, as outlined below.

The westernmost tidal harbour (Poole) is reputed to be the largest natural harbour in Europe, covering some $36 \mathrm{~km}^{2}$. It is a good example of a transgressional landscape. This is reflected in the archaeology; data from Watkins (1994) documents a post-Roman subsidence of some $2 \mathrm{~m}$, much of which is indicated to have occurred between 500 and $1500 \mathrm{AD}$ (a rate of $2.0 \mathrm{~mm} /$ year). This is well above the glacio-isostatic rate of $0.5 \mathrm{~mm} /$ year (Fig. 6.62). Other studies (Edwards 2001) give a similar picture, with specific periods of subsidence between 4700 and 1200 years ago, 1200 and 900 years ago and 400 and 200 years ago superimposed on a long-term glacio-isostatic crustal subsidence of $0.5 \mathrm{~mm} /$ year. Edwards, however, considered the higher frequency variations to be eustatic.

Similar findings to those at Poole were reported by Hodson \& West (1972) from the River Test estuary at Fawley. The sequence of sediments indicated about $4.5 \mathrm{~m}$ of glacio-isostatic sea level rise over the last 6500 years, a rate of $0.7 \mathrm{~mm} /$ year. However, this was punctuated by periods of rapid subsidence/transgression at 3600 and 1800 years ago. Some $3 \mathrm{~m}$ of this sea level rise was considered to be eustatic.

Long \& Tooley (1995) noted a considerable discrepancy between the glacio-isostatic model and the data from tide gauge measurements for the Portsmouth area. These data suggested continuing transgression in the area with a subsidence rate of $3.5 \mathrm{~mm} /$ year being recorded, much higher than the combined glacio-isostatic and eustatic effects over the same period ( 1 to $2 \mathrm{~mm} /$ year). However, the dates and details of late Holocene transgression in the Portsmouth - Chichester harbour area vary significantly in the various technical articles on the threat of rising sea levels in the area and the tide gauge data are considered by Haigh et al. (2011) to be less significant. The Scopac report on the Portsmouth, Langstone and Chichester Harbours (University of Portsmouth 2004) suggested that a transgressional phase occurred between 2500 and 1500 years ago with a sea level rise of between 2.7 and $3.0 \mathrm{~m}$. Despite the uncertainty in the literature, the consequences of a late Holocene marine transgression are reflected in the current coastal geomorphology of the region, with extensive tidal harbours and long tidal estuaries being typical.

The Holocene record needs to be seen in the context of regional uplift, documented by Westaway et al. (2006) and Bates (2010). Through studies of river terraces and raised beaches in southern England (Hampshire and Sussex), a chronology of Quaternary uplift is documented, with $70 \mathrm{~m}$ of uplift since the early Pleistocene and $150 \mathrm{~m}$ of uplift since the Middle Pliocene. This uplift is consistent with the regional Quaternary uplift of the Weald - Boulonnais zone (Van Vliet-Lanoe 2002), which has elevated the marine Pliocene Lenham Beds to some $150 \mathrm{~m}$ OD across North Kent. 
The main raised beaches in Sussex reflect the sea level high stands during the pre-Ipswichian Interglacial 200000 years ago (Norton raised beach) and during the pre-Anglian Cromerian Complex 550000 years ago (Boxgrove raised beach) (Westaway 2006) (Fig. 6.63). The Boxgrove raised beach is currently at an elevation of $42 \mathrm{~m} \mathrm{OD}$, implying uplift rates of about $0.08 \mathrm{~mm} /$ year over the last half million years, somewhat less than the current glacio-isostatic subsidence of 0.5 $\mathrm{mm}$ /year. This suggests that in the Hampshire Basin area, the long-term neotectonic elevation has been temporarily reversed by the glacio-isostatic adjustment.

The studies of the marine terraces and river terraces in Hampshire and Sussex revealed significant departures from the regional pattern in the vicinity of the Portsdown anticline, with faster local uplift being observed in this area. This anomaly is explained by middle - late Pleistocene slip on a south dipping blind [Variscan] reverse fault (Westaway 2006).

It is noted that the area just south of the Portsdown anticline is also the focus for departure from the present glacio-isostatic adjustment (Long \& Tooley 1995), raising the possibility that present (Holocene) regional glacio-isostatic adjustment is also interacting with the south dipping reverse fault within a component of normal slip amplifying the glacio-isostatic effects, resulting in the distinct late Holocene coastal geomorphology of the Portsmouth-Chichester Harbour areas. A similar effect could be affecting the Poole Harbour area, with an interaction between the glacioisostatic adjustment and the Purbeck axis.

As outlined below, present day (Holocene) adjustment along deep Variscan age structures can also be demonstrated for the Thames Estuary (Aldiss et al. 2014).

\subsection{The Wash to the Thames Estuary}

The east coast of the United Kingdom from the Wash to the Thames Estuary lies on the western edge of the southern North Sea basin. The records of sea level change as seen in the near-shore Holocene sediments should provide a good record of the regional eustatic and isostatic influences. The glacio-isostatic adjustment results in subsidence at rates of 0.6 to $0.9 \mathrm{~mm} / \mathrm{yr}$ (Shennan 2002), (Fig. 6.62). However, as outlined below, as with the Hampshire Basin, the data contain high frequency departures from the glacio-isostatic adjustment model (Shennan 2002, Gerhals 2010). If this is predominantly a eustatic signal, as suggested by Edwards (2001) for the Poole area, then there should be a consistent pattern in the sea level recorded in the sediments.

The proxy details of the transgressions and minor regressions recorded in the Holocene sediments of this east coast area have been compiled from the details reported by Jones \& Keen (1993) (Fig. $6.64 \mathrm{a}, \mathrm{b}$ ); a summary of the Edwards (2001) observations for the Poole area is included as well for comparison. While the possibility of some eustatic influences cannot be eliminated, the general absence of a consistent pattern in sea level variations from the Wash to the Thames estuary and in the Hampshire Basin over the last 8000 years, leads to the observation that the departures from the glacio-isostatic adjustment model (Shennan 2002, Gerhals 2010) are mainly due to neotectonic influences.

As outlined by Westaway (2009), the area from the Wash to the Thames Estuary is on a (neotectonic) hinge line between Quaternary subsidence of the southern North Sea to the east and uplifting areas to the west. Thus, the variations in the pattern of the near-shore Holocene sediments deposited from the Wash to the Thames Estuary, as outlined in Fig. 6.64a, can be related to the neotectonic processes, with differential movements across basement structures interacting with the glacio-isostatic adjustment. Some of these basement structures with a northeast-southwest trend have been resolved by geophysical studies in Suffolk (Cornwell 1996) and there has been some discussion regarding their role in the deposition and current distribution of the early Pleistocene 
In this context, the observations of Chatwin (1961) for continuing (post-glacial) uplift of parts of Suffolk and northern Essex fall into place, as do the observations of Greensmith \& Tucker (1980), who reported $4.3 \mathrm{~m}$ of differential subsidence, on a northeast-southwest trend, since 5000 years BP between Essex and the Thames Estuary. As this represents a rate of $0.86 \mathrm{~mm} / \mathrm{year}$, it implies that the Thames Estuary is sinking at a faster rate than the glacio-isostaic adjustment model would indicate (Fig. 6.62).

The details of the Thames Estuary sediments as outlined by Devoy $(1977,1979)$ included in the British Regional Geology Memoir for London and the Thames Valley (Sumbler 1996), show a complex record of relative sea level change (Fig. 6.65). An overall subsidence of $2.0 \mathrm{~mm} / \mathrm{year}$ is indicated, well in excess of the glacio-isostatic adjustment model, with a $0.6 \mathrm{~mm} / \mathrm{year}$ neotectonic component indicated, not dissimilar to that reported by Greensmith (1980) for the Maplin Sands area, further east than the Devoy section. Of note are the perturbations from the steady state, suggesting high frequency neotectonic influences, which could reflect episodic movement on the basement structures. This conclusion reflects the absence of any eustatic perturbations in the Jones \& Keen (1993) data.

The interplay between the regional glacio-isostatic and neotectonic influences in the Ipswich/Aldeburgh area were commented on by Pye (2005), who made the following observation: "This part of the Suffolk coast has experienced slow crustal subsidence throughout the mid to late Holocene, partly in response to large-scale tectonic processes involving the whole of the southern North Sea basin, and partly due to the collapse of a 'pro-glacial fore-bulge' following the removal of ice loading in northern Britain at the end of the Pleistocene. The regional distribution of Crag and later deposits provides clear evidence for easterly down-tilting of the region during the last 2-3 million years, probably in response to subsidence of the southern North Sea basin. The rate and timing of onshore neo-tectonic movements may have been affected by localised fault movements, although detailed information is currently lacking."

Further details of the neotectonic influences have come from Aldiss et al. (2014). The results of GPS measurements documented differential movement across the line of the northeast-southwest trending Greenwich Fault and continuing subsidence of the outer Thames Estuary. The GPS measurements indicated subsidence rates of $0.9-1.5 \mathrm{~mm} /$ year on average, in places up to 2.1 $\mathrm{mm} /$ year, well above the glacio-isostatic and eustatic rates, and consistent with that noted by Greensmith (1980). Aldiss et al. (2006) related this differential movement to deep-seated geological structures on the edge of the Midlands Microcraton (The Variscan Front) (Fig. 6.66). It is noted that the GPS measurements across the Greenwich Fault, show a downthrow to the southeast, whereas details from recent boreholes sunk for construction projects show that the Greenwich Fault displaces the Thames River Terraces, with a downthrow to the northwest. This may parallel the observations from the Portsdown structure where uplift on a south-dipping Variscan structure may have been reversed in response to the Holocene glacio-isostatic adjustment.

A more regional review of Neogene to present day crustal movements across southeast England and the near continent was made by Van Vliet-Lanoe et al. (2002). This detailed palaeogeographic review of Neogene to Holocene sediment deposition identified several areas of uplift and subsidence from the Miocene through to the present (Holocene) (fig. 6.66). The boundaries of the domains of uplift and subsidence were related to reactivated Variscan structures, such as the hinge line along the east coast, referenced by Westaway (2009). The northeast-southwest trending Greenwich fault might be linked to basement structures in the Suffolk area. It is possible that there has been reactivation of the Variscan front between the Weald/Boulonnais axis and the southern North Sea basin. From this mosaic of uplift and subsidence, there is continuing uplift of the 
Weald/Boulonnais axis and subsidence of the southern North Sea basin (Fig. 6.67). The subsidence of the southern North Sea basin extends westwards beneath the outer Thames Estuary as far as the Greenwich Fault.

\subsubsection{Summary of eustatic changes in the southeast of England}

Relative sea level changes across southeast England during the Holocene recorded in the sediments deposited, reflect a variety of eustatic, isostatic and neotectonic influences. The role of the forebulge collapse model is important. However, the continuing glacio-isostatic adjustment and eustatic factors cannot explain the differential nature of the crustal movements that can be seen in the Holocene sediments and in the landscape across parts of south east England during the Holocene. As demonstrated by Van Vliet-Lanoe et al. (2002), Aldiss et al. (2006, 2014) and as outlined here, neotectonic movements are occurring as well, and these can be related to the reactivation of deep Variscan structures on the periphery of the subsiding southern North Sea basin, and in the uplifting hinterland to the west.

There is a possibility that the reactivation of some of the Variscan structures across south east England could reflect an interaction between the glacio-isostatic adjustment processes and regional tectonic stresses, as a result of many cycles of fore-bulge uplift and collapse. Blundell (2002) implies this in his discussion on Tertiary landscape evolution across southern Britain.

\subsubsection{Quaternary palaeoseismicity}

Active deglaciation in parts of Europe, Scandinavia and Canada provides a link between fault reactivation and the generation of earthquakes associated with the retreat of glaciers or ice sheets (Mörner 2004, Kujansuu 1964, Lagerback 1979, Lundqvist \& Lagerback 1976). The association between seismicity and deglaciation naturally raises the question as to whether the British Isles may have been susceptible to earthquakes during periglacial times. It may be difficult to find geological evidence for palaeoseismicity having occurred. Any such evidence may, for example, include tsunami deposits, varved sediments, small-scale sedimentary deformation structures, landslides or fault scarps. Most of the geological evidence for periglacial palaeoseismicity in the British Isles appears to be found in Scotland with some more tentative suggestions that palaeoseismicity associated with deglaciation may have occurred in England and Wales.

In Scotland, there is documented evidence for a tsunami event associated with the Storegga submarine landslide, which occurred approximately 7,000 years BP, based on radiocarbon-14 dating. A layer of sand containing microfossils of plankton has been found. However, the details regarding any associated seismicity are unclear (Dawson et al. 1988, Mörner \& Dawson 2011).

In the Scottish Highlands, the small-scale deformation of sediments at Arrat's Mills, Meikleour and Glen Roy have been interpreted as being induced by palaeoseismic events. These glacial sediments were analysed in thin section and were reported to be consistent with a seismically induced origin. Furthermore, the proximity of the deformed sediments to the Highland Boundary and Great Glen Faults has suggested a possible link with the reactivation of these faults (Michael 2005).

Geological evidence for fault reactivation and palaeoseismicity is demonstrated on the Kinloch Hourn Fault and Glen Roy faults. These are located in the western Scottish Highlands and have been interpreted as reactivating to generate large (that is, greater than $\mathrm{M}=6$ ) palaeoseismic earthquakes during deglaciation, approximately 13,000 to $10,000 \mathrm{BP}$. The evidence includes fault scarps up to $2 \mathrm{~m}$ high along mountains slopes, deflected stream channel, landslides, liquefied lacustrine sediments and approximately $160 \mathrm{~mm}$ of sinistral (left lateral) strike slip displacements along a $14 \mathrm{~km}$ section of the Kinloch Hourn fault. This induced the deformation of unconsolidated sediments during a later phase of reactivation about 3,500 to $2,400 \mathrm{BP}$. Other evidence for faulting and, therefore, possible 
palaeoseismicity during glacial and periglacial times may be found on the Southern Uplands Fault and includes, for example, raised shoreline platforms in the Inner Hebrides and at the Firth of Lorne, an ice dammed lake at Glen Roy, buried shorelines in the Upper Forth Valley in Central Scotland and exposed faults at Lismore Island and on the Isles of Mull and Shauna (Stewart et al. 2001, Ringrose 1989, Davenport et al. 1989).

A pattern of extensive and distinct fault scarps, fissures and grabens obliquely cross the interfluves of glacially incised valleys in the South Wales Coalfield. Strong sandstones of the Pennant Sandstone Formation of the Warwickshire Group cap the moorland plateaux, whilst weaker Middle and Lower Coal Measures shales, mudrocks and coals underlie the valley sides and floor. The fault scarps displace streams, may reach at least $4 \mathrm{~m}$ high and can be traced along the ground surface as steep-sided, faultscarp walls for distances of approximately $4 \mathrm{~km}$. The underground mining of coal from around the 1750s (and reaching its peak just before the First World War) and landsliding have made it difficult to determine the mechanisms, which led to the generation of the scarps, fissures and grabens. Past mining and associated subsidence has almost certainly exacerbated or initiated some of the fault scarps. However, these features are unique to the South Wales Coalfield in terms of their scale, magnitude and morphology and do not appear in any other coal mining region of the British Isles, where reactivated faults occur but are generally less extensive. There is little geological evidence available to date the origin of the fault scarps but some research has raised the possibility that the faults may have been initiated during the deglaciation of the South Wales Valleys and later exacerbated by coal mining subsidence, although this is difficult to prove (Donnelly 2005, 2008, 2011). However, there is no evidence that the formation of the South Wales fault scraps was accompanied by palaeoseismicity.

Fault scarps, fissures and grabens have also been observed in similar geomorphological settings in the Pennines. Here, strong Kinderscout Grit (part of the Millstone Grit Group) sandstones overly weaker shales on glacially eroded valley sides. However, mining has not been carried out in this particular part of the Pennines due to the absence of any economic minerals in the Carboniferous (Namurian) sequences. Stress relief of the valley sides and lateral rebound of the slopes may have taken place following deglaciation that may have led to the reactivation of faults and generation of periglacial seismicity. This still remains somewhat speculative due to a lack of geological evidence and further research is required to determine if the reactivated faults in the Pennines and South Wales Coalfield possible generated earthquakes in periglacial times (Donnelly 2008).

\subsection{Summary and Conclusions}

This chapter has considered two aspects of glacial and periglacial engineering geology - the properties of geological materials deposited in glacial and periglacial environments and the geohazards that are caused specifically by glacial and periglacial processes or by the nature of the materials deposited under glacial and periglacial conditions. Consequently, alluvial deposits, for example, which may be deposited during periods of ice melting when periglacial conditions exist, are not considered. Similarly, mass movement geohazards are not considered here except, for example, cambering and solifluction, both of which are primarily periglacial phenomena. Much of the discussion of materials such as loessic deposits/brickearth and quick clays does not provide new insights and approaches; rather, latest research is summarised. However, the discussion of glacial tills is new, reflecting the changed approach to the classification of these deposits and the availability of data.

Previously, engineering geologists and geotechnical engineers considered glacial tills in terms of a classification that related to where and how the tills were deposited; for example, lodgement tills were defined as having been deposited at the sliding base of a moving glacier while melt out tills were deposited from a slow release of glacial debris from ice, neither sliding nor deforming internally. In this book, these definitions are no longer considered to adequately reflect the processes under which the tills were formed. As a result, only three types of till are now recognised - Subglacial Traction 
Till (which includes lodgement till, deformation till, comminution till and subglacial melt-out till), Glacitectonite (which can include supraglacial morainic till, flow till and melt-out till) and Supraglacial mass flow diamicton/glaciogenic debris flow deposits (that can also include supraglacial morainic till, flow till and melt-out till). Because the classification is new and hence engineering geologists and geotechnical engineers have not yet begun identifying tills in terms of the new classification, previously summarised geotechnical property information cannot be allocated to each of the new classes. Consequently, a different approach has been adopted using the BGS's new national lithostratigraphical classification.

Two Glacigenic Groups have been defined - the Albion Glacigenic Group and the Caledonia Glacigenic Group. The former is of Middle Pleistocene, pre-Ipswichian age and includes deposits from the major Anglian glaciation and a possible 'Wolstonian' glaciation. The latter is of Late Pleistocene - Devensian age and includes all formations and lithogenetic units of Devensian glacigenic deposits of Scotland, most of Wales, northern England and parts of the English Midlands within the main Devensian ice-sheet limit. The Albion Glacigenic Group is subdivided into a number of formations and members while the Caledonia Glacigenic Group is subdivided into Subglacigenic Groups, formations and members. From geotechnical data classified in terms of the new stratigraphy and available in BGS databases, it has been possible to summarise the geotechnical properties of many of the new formations and members. Using the new national lithostratigraphy, site investigation descriptions have been classified as boulders, fines with coarse material (a proxy for most tills), glaciofluvial deposits, which have been separated into sand and sand and gravel as sand may also be glaciolacustrine, and laminated clay and silt (glaciolacustrine deposits). Descriptions are used, rather than particle size data, because all materials in the particular unit are described, whereas, particle size data relate to specific, relatively small samples. Of particular interest in the use of this approach is the ability to identify formations where boulders may be present (see Fig. 6.6). Geographically comprehensive information is not yet available but as new data become available from site investigations, the extent of boulders will become more apparent.

In addition to deposits from ice-related terrains consisting of tills and kame/esker/braided channel deposits, deposits from water-related domains (glaciofluvial, glaciolacustrine and glaciomarine), consisting of sands and gravels, laminated silts and clays, quick clays and ice-rafted debris and iceberg contact deposits, ice-front-related terrains: glaciotectonic and ice marginal and deformed/shattered bedrock, upland periglacial terrains including boulder fields, boulder tongues and scree and talus and, finally, lowland periglacial terrains including solifluction deposits and loess/brickearth are discussed and, where available, geotechnical data are summarised.

Glacial and periglacial geohazards have been divided into two types: local and regional. The former includes cambering, gulls and valley bulging, solifluction shears, kettle holes, relict cryogenic mounds, relict scour hollows and infilled periglacial features including pingos and other larger features. Regional geohazards include those caused by neotectonics and the consequent changes in sea level and Quaternary palaeoseismicity, including possible fault reactivation. The intention in discussing these geohazards is to draw engineering geologists' and geotechnical engineers' attention to the nature of these potential geohazards and the environments in which they may occur. In addition, situations that may be problematic in ground investigation and hence present difficulties during construction are discussed in relation to the geological processes and materials that create the potential hazards or uncertainty. An example is the difficulty of identifying rockhead either because of the broken and fractured nature of the rock at rockhead or because of the difficulty in distinguishing between boulders and true rockhead. Problems such as these indicate that there is a need to sustain the development of national databases containing ground investigation data and information and to carry out research to aid practitioners to confidently create more reliable ground models. 


\section{Acknowledgements:}

M.G. Culshaw, D.C. Entwisle and V.J. Banks publish with the permission of the Executive Director of the British Geological Survey (NERC).

\section{References}

Ackermann, K. J. \& Cave, R. 1967. Superficial deposits and structures, including landslip, in the Stroud district, Gloucestershire. Proceedings of the Geologists' Association, 78, 567-586.

Aldiss, D. T., Burke, H. F., Chacksfield, B. C. \& Tragheim, D. G. 2006. Absolute fixing of tide gauge benchmarks and land levels: the BGS contribution to a report on a study of the London and Thames Estuary region. Keyworth, Nottingham: British Geological Survey, Report CR/07/043N. http://nora.nerc.ac.uk/1493/

Aldiss, D. T., Burke, H C., Chacksfield, B. C., Bingley, R. M., Teferle, F .N., Williams, S. D. P., Blackman, D. L., Burren, R. \& Press, N. 2014. Geological interpretation of current subsidence and uplift in the London and Thames estuary area, UK, as shown by high-precision satellitebased surveying. Proceedings of the Geologists' Association, 125, 1-13.

Anderson, W. F. 1974. Factors influencing the measured properties of Glasgow region till. Ground Engineering, 2, February.

Anderson W. F. \& McNichol, R. 1989. The engineering geology of the Kielder Dam. Quarterly Journal of Engineering Geology, 22, 111-130.

Arkell, W.J. 1947. The Geology of the Country around Weymouth, Swanage, Corfe and Lulworth. (Explanation of Sheets 341, 342, 343, with small portions of Sheets 327, 328, 329). With contributions by C. W. Wright and H. J. Osborne White. Memoir of the Geological Survey of Great Britain, Her Majesty's Stationery Office, London, 386p.

Arrowsmith, E. J. 1985. Case histories of slope instability: failure and remedial measures in NW England. In: Forde, M. C. (ed.), Glacial Tills 85, Proceedings of the International Conference on Construction in Glacial Tills and Boulder Clays, Edinburgh. Engineering Technics Press, Edinburgh, 113-120.

Ashton, N., Lewis, S., Parfitt, S., Candy, I., Keen, D., Kemp, R., Penkman, K., Thomas, G., Whittaker, J. \& White, M. J. 2005. Excavations at the Lower Palaeolithic site at Elveden, Suffolk. Proceedings of the Prehistoric Society, 71, 1-61.

Assallay, A. M. 1998. Structure and hydrocollapse behaviour of loess. PhD thesis (unpublished), Loughborough University, UK.

Atkinson, J. H. 1985. Undrained strength and overconsolidation of a clay till. In: Forde, M. C. (ed.), Glacial Tills 85, Proceedings of the International Conference on Construction in Glacial Tills and Boulder Clays. Engineering Technics Press, Edinburgh, 49-54.

Ballantyne, C. K. 1998. Age and significance of mountain-top detritus. Permafrost and Periglacial Processes, 9, 327-345.

Ballantyne, C. K. \& Harris, C. 1994. The periglaciation of Great Britain. Cambridge: Cambridge University Press.

Banks, V. J., Bricker, S. H., Royse, K. R., \& Collins, P. E. F. 2015. Anomalous buried hollows in London: development of a hazard susceptibility map. Quarterly Journal of Engineering Geology and Hydrogeology, 48, 55-70. http://doi:10.1144/qjegh2014-037

Barron, A. J. M., Sumbler, M. G. \& Morigi, A. N. 2002. Geology of the Moreton-in-Marsh District: a brief explanation of the geological map sheet 217 Moreton-in-Marsh. Keyworth, Nottingham, British Geological Survey.

Bates, M. R., Briant, R. M., Rhodes, E. J., Schwenninger, J. L., \& Whittaker, J. E. 2010. A new chronological framework for Middle and Upper Pleistocene landscape evolution in the Sussex/Hampshire Coastal Corridor, UK. Proceedings of the Geologists' Association, 121, 369392.

Bell, F. G. 1991. A survey of the geotechnical properties of some till deposits on the north coast of 
Norfolk. In: Forster, A., Culshaw, M. G., Cripps, J. C., Little, J. A. \& Moon, C. F. (eds), Quaternary Engineering Geology, The Geological Society of London Engineering Geology Special Publication. 7, 103-110.

Bell, F. G. 1998. The geotechnical properties and behaviour of a pro-glacial lake clay and its cementitious stabilization. Geotechnical and Geological Engineering, 16, 167-199.

Bell, F. G. 2000. Engineering Properties of Soils and Rocks. $4^{\text {Th }}$ Edition. Blackwell Science Ltd,. Oxford.

Bell, F. G. 2002. The geotechnical properties of some till deposits occurring along the coastal areas of eastern England. Engineering Geology, 63, 49-68.

Bell, F. G. \& Coultard, J. M. 1991. The Tees laminated clay. In: Forster, A., Culshaw, M. G., Cripps, J. C., Little, J. A. \& Moon, C. F. (eds), Quaternary Engineering Geology, The Geological Society of London Engineering Geology Special Publication, 7, 339-348.

Bell, F. G. \& Coulthard, J. M. 1997. A survey of some geotechnical properties of the Tees Laminated Clay of central Middlesbrough, North East England. Engineering Geology, 48, 117133.

Bell, F. G. \& Culshaw, M. G. 2001. Problem soils: a review from a British perspective. In: Jefferson, I., Murray, E. J., Faragher, E. \& Fleming, P. R. (eds.), Problematic Soils. Thomas Telford Publishing, London. 1-35.

Bell, F. G. \& Forster, A. 1991. The geotechnical characteristics of the till deposits of Holderness. In: Forster, A., Culshaw, M. G., Cripps, J. C., Little, J. A. \& Moon, C. F. (eds), Quaternary Engineering Geology, The Geological Society of London Engineering Geology Special Publication, 7, 111-118. London.

Bell, F. G., Culshaw, M. G. \& Northmore, K. J. 2003. The metastability of some gull fill materials from Allington, Kent, UK. Quarterly Journal of Engineering Geology and Hydrogeology, 36, 217-229.

Bejestan, M. S. \& Hemmati, M. 2008. Scour depth at river confluences of unequal bed level. Journal of Applied Sciences, 8, 1766-1770.

Berry, F. G. 1979. Late Quaternary scour-hollows and related features in central London. Quarterly Journal of Engineering Geology, 12, 9-29.

Bièvre, G., Kniess, U., Jongmans, D., Pathier, E., Schwartz, S., Van Westen, C. J. \& Zumbo, V. 2011. Paleotopographic control of landslides in lacustrine deposits (Trièves plateau, French western Alps). Geomorphology, 125, 214-224.

Bishop, N. F., Evans, S. G., Petley, D. J., \& Unger, A. J. A. 2008. The geotechnics of glaciolacustrine sediments and associated landslides near Ashcroft (British Columbia) and the Grand Coulee dam (Washington). In: Locat, J., Perret, D., Turmel, D., Demers, D. \& Leroueil, S. (eds.), Proceedings of the 4th Canadian Conference on Geohazards: from Causes to Management. Presse de l'Université Laval, Québec, 255-261.

Blundell, D. J. 2002. Cenozoic inversion and uplift of southern Britain. In: Dore, A.G., Cartwright, J.A., Stoker, M.S., Turner, J.P., \& White, N. (eds.) Exhumation of the North Atlantic Margin: Timing, Mechanisms and Implications for Petroleum Exploration. Geological Society of London Special Publication, 196, 85 - 101.

Booth, S. Merritt, J. \& Rose, J. 2015. Quaternary provinces and domains - a quantitative and qualitative description of British landscape types. Proceedings of the Geologists' Association, 126, 163-187. http://dx.doi.org/10.1016/j.pgeola.2014.11.002

Boulton, G. S. 1972. The role of thermal regime in glacial sedimentation. In: Price, R. J. \& Sugden, D. E. (eds), Polar Geomorphology. Institute of British Geographers Special Publication, 4, 119.

Boulton, G. S. 1975. The genesis of glacial tills - a framework for geotechnical interpretation. In: Proceedings of the Symposium on The engineering behaviour of glacial materials, Birmingham, UK. The Midland Soil Mechanics and Foundation Engineering Society, Birmingham, 52-59.

Boulton, G. S. 1976. The development of geotechnical properties in glacial tills. In: Leggett, R. F. 
(ed.) Glacial Till - an Interdisciplinary Study. Royal Society of Canada, Ottawa, Special Publication, 12, 292-303.

Boulton, G. S. 1979. Processes of glacial erosion of different substrata. Journal of Glaciology, 23, 15-38.

Boulton, G. S. \& Deynoux, M. 1981. Sedimentation in glacial environments and the identification of tills and tillites in ancient sedimentary sequences. Precambrian Research, 15, 397-420.

Bowen, D. Q. (Editor). 1999. A Revised Correlation of Quaternary Deposits in the British Isles. Special Report No. 23. The Geological Society of London. 174p.

Bradley, S. L., Milne, G. A., Teferle, F. N., Bingley, R. M. \& Orlliac, E. J. 2009. Glacial isostatic adjustment of the British Isles: new constraints from GPS measurements of crustal motion. Geophysical Journal International, 178, 14-22.

Bradshaw, R. \& Ingle Smith, D. 1963. Permafrost structures on Sully Island, Glamorgan. Geological Magazine, 100, 556-564.

Briant, R. M., Bates, M. R., Hosfield, R. \& Wenban-Smith, F. F. 2009. The Quaternary of the Solent Basin and West Sussex Raised Beaches: Field Guide. Quaternary Research Association, London.

Bridgland, D. R., Howard, A. J., White, M. J. \& White, T. S. \& Westaway, R. 2014. New insight into the Quaternary evolution of the River Trent, UK. Proceedings of the Geologist' Association, 126, 466-479.

Bristow, C. R. 1983. The stratigraphy and structure of the Crag of mid-Suffolk, England. Proceedings of the Geologists' Association, 94, 1-12.

Bristow, C. R. \& Bazley, R. A. 1972. Geology of the country around Royal Tunbridge Wells. Memoir of the Geological Survey of Great Britain, sheet 303 (England and Wales). Her Majesty's Stationery Office, London, 161p.

British Geological Survey. 1975. England and Wales Geological Sheet 161, Norwich. 1:50 000 scale Solid and Drift edition. Keyworth, Nottingham: British Geological Survey.

Bryant, I. D. \& Carpenter, C. P. 1987. Ramparted ground ice depressions in Britain and Ireland. In: Boardman, J. (ed.) Periglacial Processes and Landforms in Britain and Ireland. Cambridge University Press, Cambridge, 183-190.

Butcher, A. P. 1991. The observation and analysis of a failure in a cliff of glacial clay till at Cowden, Holderness. In: Chandler, R. J. (ed) Slope Engineering: Developments and Applications. Institution of Civil Engineers, London, 271-276.

Campion, R. J., Wood, A. M. J., Craig, R. N. \& Runacres, A. J. 1992. The design and construction of the Stansted Airport rail link. Journal of the Permanent Way Institution, 110, 301-322.

Carpenter, C. P. \& Woodcock, M. P. 1981. A detailed investigation of a pingo remnant in western Surrey. Quaternary Studies, 1, 1-26.

Carter, P., Wallace, G. \& Cochrane, G. 1985. Till geology and earthworks - a Scots Quair. In: Forde, M. C. (ed.), Glacial Tills 85, Proceedings of the International Conference on Construction in Glacial Tills and Boulder Clays. Engineering Technics Press, Edinburgh, 67-70.

Catt, J. A. 1985. Soil particle size distribution and mineralogy as indicators of pedogenic and geomorphic history: examples from the loessial soils of England and Wales. In: Richards, K. S., Arnett, R. R. \& Ellis, S. (eds), Geomorphology and Soils. George Allen \& Unwin, London, 202-218

Chandler, R. J., Kellaway, G. A., Skempton, A. W. \& Wyatt, R. J. 1976. Valley slope sections in Jurassic strata near Bath, Somerset. Philosophical Transactions of the Royal Society, A 283, 527-556.

Chatwin, C. P. 1961. East Anglia and adjoining areas (Fourth edition). British Regional Geology. Her Majesty's Stationery Office, London

Church, M. 2002. Geomorphic thresholds in riverine landscapes. Freshwater Biology, 47, 541-557.

Clarke, A. R. \& Guest, S. 1991. The Whitby cliff stabilisation and coast protection scheme. In: Chandler R.J. (ed.) Slope Stability Engineering: Developments and Applications. Institution of Civil Engineers, London, 283-290. 
Clarke, B. G. 2012. Chapter 31: Glacial soils. In: Burland, J., Chapman, T., Skinner, H. \& Brown, M. (eds.) Geotechnical Engineering Principles, Problematic Soils and Site Investigation. ICE manual of geotechnical engineering, Volume 1, ICE Publishing, London, 363-389.

Clarke, B. G. \& Chen, C-C. 1997. Intrinsic properties of permeability. In; Proceedings of the 14th International Conference on Soil Mechanics and Foundation Engineering, Hamburg. A. A. Balkema, Rotterdam, vol.1, 259-262.

Clarke, B. G., Chen, C-C. \& Aflaki, E. 1998. Intrinsic compression and swelling properties of a glacial till. Quarterly Journal of Engineering Geology, 34, 235-246.

Clarke, B. G., Hughes, D. B. \& Hashemi, S. 2008. Physical characteristics of subglacial tills. Géotechnique, 58, 67-76.

Cochrane, G. A. \& Carter, P. G. 1991. Highway embankment construction across the Strathearn buried valley. In: Forster, A., Culshaw, M. G., Cripps, J. C., Little, J. A. \& Moon, C. F. (eds), Quaternary Engineering Geology, The Geological Society of London Engineering Geology Special Publication, 7, 203-209.

Cooper, R. G. 1980. A sequence of landsliding mechanisms in the Hambleton Hills, northern England, illustrated by features at Peak Scar, Hawnby. Geografiska Annaler, 62A, 149-156.

Cox, F. C., Gallois, R. W. \& Wood, C. J. 1989. Geology of the country around Norwich. Memoir for 1:50 000 scale geological sheet 161 (England and Wales). Keywort, Nottingham: British Geological Survey.

Culshaw, M. G. 2005. From concept towards reality: developing the attributed 3D geological model of the shallow subsurface. Quarterly Journal of Engineering Geology and Hydrogeology, 38, 231-284.

Culshaw, M. G. \& Crummy, J. A. 1988. The engineering geology of the Deeside area. Technical Report No. WN/88/7, Keyworth, Nottingham: British Geological Survey. http://nora.nerc.ac.uk/510138/

Culshaw, M. G. \& Crummy, J. A. 1990. S W Essex - M25 Corridor: engineering geology. Technical Report No. WN/90/2, Keyworth, Nottingham: British Geological Survey.

Culshaw, M. G., Cripps, J. C., Bell, F. G., \& Moon, C. F. 1991. Engineering geology of Quaternary soils: I. Processes and properties. In: Forster, A., Culshaw, M. G., Cripps, J. C., Little, J. A. \& Moon, C. F. (eds), Quaternary Engineering Geology, The Geological Society of Engineering Geology Special Publication, 7, 3-38..

Culshaw, M. G., Northmore, K. J., Jefferson, I., Bell, F. G. \& Assadi, A. (in press). Collapsible soils in the UK. In: Giles D. P. \& Griffiths, J. S. (eds). Geological Hazards in the UK: their Occurrence, Monitoring and Mitigation. Geological Society of London Engineering Geology Special Publication.

Davenport, C. A., Ringrose, P. S., Becker, A., Hancock, P., Fenton, C. 1989. Geological investigations of late and post glacial earthquake activity in Scotland. In: Gregersen, S. \& Basham, P. W. (eds.), Earthquakes at North Atlantic Passive Margins: Neotectonics and Postglacial Rebound. Academic Publishers, Kluwer Dordrecht, 175-194.

Dawson, A. G. Long, D. \& Smith, D. E. 1988. The Storegga slides: evidence from eastern Scotland for a possible tsunami. Marine Geology, 82, 271-276.

De Gans, W. 1988. Pingo scars and their identification. In: Clarke, M. J. (Ed.), Advances in Periglacial Geomorphology. John Wiley \& Sons, Chichester, 300-324

Dearman, W. R., Dobbs, M. R., Culshaw, M. G., Northmore, K. J., Entwisle, D. C. \& Reeves, H. J. 2011a. Engineering geology (superficial) map of the United Kingdom. British Geological Survey, Keyworth, Nottingham. http://nora.nerc.ac.uk/19267/

Dearman, W. R., Dobbs, M. R., Culshaw, M. G., Northmore, K. J., Entwisle, D. C. \& Reeves, H. J. 2011b. Extended key for the engineering geology maps of the United Kingdom. British Geological Survey, Keyworth, Nottingham. http://nora.nerc.ac.uk/19268/

Denness, B. 1974. Engineering aspects of the chalky boulder clay at the new town of Milton Keynes in Buckinghamshire. Quarterly Journal of Engineering Geology, 7, 297-309.

Devoy, R. J. N. 1977. Flandrian sea level changes in the Thames estuary. Nature, 270, 712-715. 
Devoy, R. J. N. 1979. Flandrian sea level changes and vegetational history of the lower Thames estuary. Philosophical Transactions of the Royal Society, of London, B 285, 355-410.

Donnelly, L. J. 2005. Fault reactivation in South Wales and the effects of on ground stability. In: Nichol, D., Basssett, M.G. \& Deisler, V. K. (eds.), The Urban Geology of Wales 2. National Museum of Wales Geological Series, 24, Cardiff, 99-117.

Donnelly, L. J. 2008. Subsidence and associated ground movements on the Pennines, northern England. Quarterly Journal of Engineering Geology and Hydrogeology, 41, 315-332.

Donnelly, L. J. 2011. Ground deformation in the vicinity of deep seated landslides in the South Wales Coalfield: mining induced or geological? Field Guide for the Geological Society of London, Engineering Group Field Trip to South Wales, 2nd July 2011.

Donnelly, L. J., Northmore, K. J \& Siddle, H. J. 2000. Lateral Spreading of Moorland in South Wales. In Siddle, H. J., Bromhead, E. N. \& Bassett, M. G. (eds). Landslides and Landslide Management in South Wales. National Museum \& Galleries of Wales, Geological Series, 18, 43-48.

Donnelly, L. J., Northmore, K. J. \& Siddle, H. J. 2002. Block movements in the Pennines and South Wales and their association with landslides. Quarterly Journal of Engineering Geology and Hydrogeology. 35, 33-39.

Dreimanis, A. 1976. Tills, their origin and properties. In: Leggett, R. F. (ed.), Glacial till - an interdisciplinary study. Royal Society of Canada, Ottawa, Special Publication, 12, 11-49.

Drewry, D. J. 1986. Glacial Geological Processes. Edward Arnold, London.

Ealey, P. J. 2012. Periglacial bedrock features of the Lizard Peninsula and surrounding area. Geoscience in South-West England, 13, 52-64.

Early, K.R. and Skempton, A.W., 1972. The landslide at Walton's Wood, Staffordshire. Quarterly Journal of Engineering Geology, 5, 19-41.

Edwards, R. J. 2001. Mid - to Late Holocene relative sea-level change in Poole Harbour. Journal of Quaternary Science, 16, 221-235.

Ellison, R. A., Woods, M. A., Allen, D. J., Forster, A., Pharaoh, T. C. \& King, C. 2004. Geology of London. Special Memoir for 1: 50000 Geological Sheets 256 (North London), 257 (Romford), 270 (South London) and 271 (Dartford) (England and Wales). Keyworth, Nottingham: British Geological Survey.

Ells, R. W. 1908. Report on the landslide at Notre-Dame de la Salette, Lièvre River, Quebec. Geological Survey Branch, Department of Mines, Ottawa, Ontario, 1-15.

Elson, J. A. 1988. Comment on glaciotectonite, deformation till and comminution till. In: Goldthwait, R. P. \& Matsch, C. L. (eds.) Genetic Classification of Glacigenic Deposits. A. A. Balkema, Rotterdam, 85-88.

Entwisle, D. C. \& Wildman, G. 2010. Creation of a Till thematic layer. British Geological Survey Technical Report IR/10/41. British Geological Survey, Keyworth, Nottingham. http://nora.nerc.ac.uk/21121/1/IR10041.pdf

Evans, D. J. A. 2013. Glaciolacustrine. In: Elias, S. A. \& Mock, C. J. (eds.) Encyclopedia of Quaternary Science, vol. 2, 2nd Edition, Elsevier, Amsterdam, 43-51. doi: 10.1016/B978-0444-53643-3.00094-7.

Evans, S. G. 1982. Landslides and surficial deposits in urban areas of British Columbia: a review. Canadian Geotechnical Journal, 19, 269-288.

Evans, S. G. \& Brooks, G. R. 1994. An earthflow in sensitive Champlain Sea sediment at Lemieux, Ontario, June 20, 1993, and its impact on the South Nation River. Canadian Geotechnical Journal, 31, 384-394.

Eyles, N. 1983. Glacial Geology. An Introduction for Engineers and Earth Scientists. Pergamon Press, Oxford.

Eyles, N. \& Sladen, J. A. 1981. Stratigraphy and geotechnical properties of weathered lodgement till in Northumberland, England. Quarterly Journal of Engineering Geology, 14, 129-141.

Eyles, N., Sladen, J. A. \& Gilroy, S. 1982. A depositional model for stratigraphic complexes and facies superimposition in lodgement tills. Boreas, 11, 317-333. 
Farrant, A. R., Noble, S. R., Barron, A. J. M., Self, C. A. \& Grebby, S. R. 2014. Speleothem Useries constraints on scarp retreat rates and landscape evolution: an example from the Severn valley and Cotswold Hills gull-caves, UK. Journal of the Geological Society, 172, 63-76.

Fell, R., MacGregor, P., Stapledon, D. \& Bell, G. 2005. Geotechnical Engineering of Dams. A. A. Balkema Publishers, Leiden.

Fletcher, C. N. \& Siddle, H. J. 1998. Development of glacial Lake Teifi, west Wales: evidence for lake-level fluctuations at the margins of the Irish Sea ice sheet. Journal of the Geological Society, 155, 389-399.

Fletcher, L., Hungr, O. \& Evans, S. G. 2002. Contrasting failure behaviour of two large landslides in clay and silt. Canadian Geotechnical Journal, 39, 46-62.

Fookes, P. G. \& Best, R. 1969. Consolidation characteristics of some Late Pleistocene periglacial metastable soils of east Kent. Quarterly Journal of Engineering Geology, 2, 103-128.

Fookes, P., Pettifer, G. \& Waltham, T. 2015. Geomodels in Engineering Geology: an Introduction. Whittles, Caithness.

Fookes, P. G., Hinch, L. W., Huxley, M. A. \& Simons, N. E. 1975. Some soil properties in glacial terrain - the Taff Valley, South Wales. In: Proceedings of the Symposium on The engineering behaviour of glacial materials" Birmingham, UK. The Midland Soil Mechanics and Foundation Engineering Society, Birmingham, 93-116.

Forster, A. 1991. The engineering geology of Birmingham West (the Black Country). Technical Report No. WN/91/15, Keyworth, Nottingham: British Geological Survey.

Frechen, M. 2011. Loess in Europe. Quaternary Science Journal (EuG), 60, 1: 3-5.

French, H. M. 2007. The Periglacial Environment. 3rd Edition, John Wiley \& Sons, Chichester, 458pp.

Funnell, B. M. \& Wilkes, P. F. 1976. Engineering characteristics of East Anglian Quaternary deposits. Quarterly Journal of Engineering Geology, 9, 145-157.

Gabriel, K. 2008. Soliflucted clay. Ground Engineering, April, 30-32.

Gehrels, W. R. 2010. Late Holocene land- and sea-level changes in the British Isles: implications for future sea-level predictions. Quaternary Science Reviews, 29, 1648-1660.

Gallois, R. W. 2010. Large-scale periglacial creep folds in Jurassic mudstones on the Dorset coast, UK. Geoscience in South-West England, 12, 223-232.

Goldthwait, R. P. 1971. Introduction to till today. In: Goldthwaite, R. P., (ed.) Till: a symposium. Ohio State University, Columbus, 3-26.

Geertsema, M., \& Torrance, J. K. 2005. Quick clay from the Mink Creek landslide near Terrace, British Columbia: geotechnical properties, mineralogy, and geochemistry. Canadian Geotechnical Journal, 42, 907-918.

Geertsema, M., Clague, J. J., Schwab, J. W. \& Evans, S. G. 2006. An overview of recent large catastrophic landslides in northern British Columbia, Canada. Engineering Geology, 83, 120 143.

Gibson, A. D., Humpage, A. J., Culshaw, M. G., Forster, A. \& Waters, R. A. 2002. The Geology and Landslides of Nefyn Bay, Gwynedd. In: Nichol, D., Bassett, M. G. \& Deisler, V. K. (eds), Landslides and landslide management in North Wales. 14-17. National Museum of Wales Geological Series, 22, Cardiff.

Gibson, A. D., Culshaw, M. G., Dashwood, C. \& Pennington, C. V. L. 2013. Landslide management in the UK - the problem of managing hazards in a 'low-risk' environment. Landslides, 10, 599610.

Giles, D. P. \& Griffiths, J. S. (eds) (in prep). Geological hazards in the UK: their occurrence, monitoring and mitigation. Geological Society of London Engineering Geology Special Publication.

Gillott, J. E. 1979. Fabric, composition and properties of sensitive soils from Canada, Alaska and Norway. Engineering Geology, 14, 149-172.

Ginsberg, S. S. \& Perillo, G. M. E. 1999. Deep scour holes at the confluence of tidal channels in the Bahia Blanca Estuary. Argentina. Marine Geology, 160, 171-182. 
Giraud, A., Antoine, P., Van Asch, T. W. \& Nieuwenhuis, J. D. 1991. Geotechnical problems caused by glaciolacustrine clays in the French Alps. Engineering Geology, 31, 185-195.

Grabowska-Olszewska, B. 1988. Engineering-geological problems of loess in Poland. Engineering Geology, 25, 177-199.

Gravenor, C. P., Von Brunn, V. \& Dreimanis, A. 1984. Nature and classification of water lain glacigenic sediments, exemplified by Pleistocene, Late Paleozoic and Late Precamnbrian deposits. Earth Science Reviews, 20, 105-166.

Gray, J. M. 1996. The containment properties of glacial tills: a case study from Hardwick Airfield, Norfolk. In: Bentley, S. P. (ed.),Engineering Geology of Waste Disposal. Geological Society of London Engineering Geology Special Publication, 11, 299-307.

Greensmith, J. T. \& Tucker E. V. 1980. Evidence for differential subsidence on the Essex coast. Proceedings of the Geologists' Association, 91, 170 -175.

Gregersen, O. 1981. The quick clay landslide in Rissa, Norway. The sliding process and discussion of failure modes. In: Proceedings of the $10^{\text {th }}$ International Conference on Soil Mechanics and Foundation Engineering, 3, 421-426. A. A. Balkema, Rotterdam.

Grobe, H. 1987. A simple method for the determination of ice-rafted debris in sediment cores. Polarjorschung, 57, 123-126.

Gurney, S., Astin, T. \& Griffiths, G. 2010. Origin and structure of Devensian depresssions at Letton, Hertfordshire. Mercian Geologist, 17, 181-184.

Haigh, I., Nicholls, R. \& Wells, N. 2011. Rising sea levels in the English Channel 1900 to 2100. Proceedings of the Institution of Civil Engineers - Maritime Engineering, 164, 81-92.

Hancock, P. L. 1969. Jointing in the Jurassic limestones of the Cotsworld Hills. Proceedings of the Geologists' Association, 80, 219-241.

Harris, C. 1991. Glacially deformed bedrock at Wylfa Head, Angelsey, North Wales. In: Forster, A, Culshaw, M. G., Cripps, J. C., Little, J. A. \& Moon, C. F. (eds.) Quaternary Engineering Geology. Geological Society of London Engineering Geology Special Publication, 7, 135-142.

Harris, C. \& Murton, J. B., 2005a. Interactions between glaciers and permafrost: an introduction. In: Harris, C. \& Murton, J. B. (eds.) Cryospheric systems: glaciers and permafrost. Geological Society of London Special Publications, 242, 1-9.

Harris, C. \& Murton, J. B., 2005b. Experimental simulation of ice-wedge casting: processes, products and palaeoenvironmental significance. In: Harris, C. \& Murton, J. B. (eds.), Cryospheric systems: glaciers and permafrost. Geological Society of London Special Publications, 242, 131-143.

Hashemi, S., Hughes, D. B. \& Clarke, B. G. 2006. The characteristics of glacial tills from Northern England derived from a relational database. Geotechnical and Geological Engineering, 24, 973-984.

Hawkins, A. B. \& Privett, K. D. 1981. A building site on cambered ground at Radstock, Avon. Quarterly Journal of Engineering Geology, 14, 151-167.

Hawkins, H. L. 1952. A pinnacle of chalk penetrating the Eocene on the floor of a buried riverchannel at Ashford Hill, near Newbury, Berkshire. Quarterly Journal of the Geological Society, 108, 233-260.

Higginbottom, I. E. \& Fookes, P. G. 1970. Engineering aspects of periglacial features in Britain. Quarterly Journal of Engineering Geology, 3, 85-117.

Hill, H. P. 1949. The Ladybower Reservoir. Journal of the Institution of Water Engineers, 3, 414433.

Hobbs, P. R. N. \& Jenkins, G. O. 2008. Bath's 'foundered strata' - a re-interpretation. British Geological Survey Research Report OR/08/052, Keyworth, Nottingham. 40p. http://nora.nerc.ac.uk/14771/

Hodson, F. \& West, I. M. 1972. Holocene deposits of Fawley Hampshire. Proceedings of the Geologists' Association, 83, 421-441.

Hollingworth, S. E. 1952. Discussion of: Hawkins, H. L. 1952. A pinnacle of Chalk penetrating the Eocene on the floor of a buried channel at Ashford Hill, near Newbury, Berkshire. Quarterly 
Journal of the Geological Society, 108, 233-260.

Hollingworth, S. E., Taylor, J. H. \& Kellaway, G. A. 1944. Large scale superficial structures in the Northampton Ironstone Field. Quarterly Journal of the Geological Society, 100, 1-34 (and discussion 35-44).

Horswill, P. \& Horton, A. 1976. Cambering and valley bulging in the Gwash valley at Empingham, Rutland. Philosophical Transactions of the Royal Society, A 283, 427-451.

Horvath, J. S. \& Trochalides, T. 2004. A half century of tapered-pile usage at the John F. Kennedy International Airport. In: Prakash, S. \& Puri V. K. (eds) Proceedings of the 5th International Conference on Case Histories in Geotechnical Engineering. New York. Paper No. 11.05.

Houston, S. L., Houston, W. N. \& Spadola, D. J. 1988. Predictioon of field collapse of soils due to wetting. Journal of Geotechnical Engineering, 114, 40-58.

Hughes, D. B. \& Clarke, B. G. 1997. The glacial tills of Northern England in relation to the stability of screening and spoil mounds at opencast coal sites. In: Marinos, P. G., Koukis, G. C., Tsiambaos, G. C. \& Stournaras, G. C. (eds), Proceedings of the International Symposium on Engineering Geology and the Environment, Athens, A. A. Balkema, Rotterdam, 2419-2424.

Hughes, D. B., Clarke, B. G. \& Money, M. S. 1998. The glacial succession in lowland Northern England. Quarterly Journal of Engineering Geology, 31, 211-234.

Hutchinson, J. N. 1980. Possible late Quaternary pingo remnants in central London. Nature, 284, 253-255.

Hutchinson, J. N. 1991. Periglacial and slope processes. In: Forster, A., Culshaw, M. G., Cripps, J. C. \& Moon, C. F. (eds.) Quaternary Engineering Geology, Geological Society of London Engineering Geology Special Publication. 7, 283-331. doi:10.1144/GSL.ENG.1991.007.01.27

Hutchinson, J. N. 1992. Engineering in relict periglacial and extraglacial areas in Britain. In: Gray, J. M. (ed.) Applications of Quaternary Research, Quaternary Proceedings No. 2. Quaternary Research Association, Cambridge, 49-65.

Iriondo, M.H. \& Krohling, D. M. 2007. Non-classical types of loess. Sedimentary Geology, 202, 3, 352-368.

Institut des Risques Majeurs (IRMA) (no date). Glissement de terrain dans la commune de Salle en Beumont. http://www.irmagrenoble.com/04risques isere/00commune_evenements_fiche.php?id_evenements $=2184$ (Website visited 1 September 2014).

Ito, M. \& Azam, S. 2009. Engineering characteristics of a glacio-lacustrine clay deposit in a semiarid climate. Bulletin of Engineering Geology and the Environment, 68, 551-557.

Jackson, I. 1979. The sand and gravel resources of the country around Brampton, Cumbria. Description of 1:25,000 resource sheet NY55 and part of NY56. Her Majesty's Stationery Office, London.

Jackson, I. \& Lawrence, D. J. D. 1990. Geology and Land-use Planning. Morpeth-BedlingtonAshington, Technical Report WN/90/14. British Geological Survey, Keyworth, Nottingham. http://nora.nerc.ac.uk/510111/

Jefferson, I. \& Rogers, C. D. F. 2012. Collapsible soils. In: Burland, J., Chapman, T., Skinner, H. \& Brown, M. (eds.), ICE manual of geotechnical engineering, vol 1, 391-411. ICE Publishing, London.

Jefferson, I., Smalley, I. J., Evstatiev, D. \& Karastanev, D. 2005. Treatment of metastable loess soils: lessons from eastern Europe. In: Indraratna, B. \& Chu, J. (eds.), Ground improvement case histories. Elsevier Geo-engineering Book Series, Volume 3. Elsevier, Amsterdam, 723762.

Jennings, J. E. \& Knight, K. 1975. A guide to construction on or with materials exhibiting settlement due to collapse of grain structure. In: Pells, P. J. N., Mac, A. \& Robertson, G. (eds.). Proceedings of the $6^{\text {th }}$ African Conference on Soil Mechanics and Foundation Engineering, Durban, South Africa. Voume 1, A. A. Balkema, Capetown, 99-105

Jones, P. F. \& Weaver, J. D. 1975. Superficial valley folds of Late Pleistocene age in the Breadsall area of South Derbyshire. Mercian Geologist, 5, 279-290. 
Jones, R. L. \& Keen, D. H. 1993. Pleistocene Environments in the British Isles. Chapman \& Hall, London.

Jongmans, D., Bièvre, G., Renalier, F., Schwartz, S., Beaurez, N. \& Orengo, Y. 2009. Geophysical investigation of a large landslide in glaciolacustrine clays in the Trièves area (French Alps). Engineering Geology, 109, 45-56.

Kahout, T., Bućko, M. S., Rasmus, K., Leppäranta, M. \& Matero, I. 2014. Non-invasive geophysical investigation and thermodynamic analysis of a palsa in Lapland, northwest Finland. Permafrost and Periglacial Processes, 25, 45-52.

Kellaway, G. A. \& Taylor, J. H. 1968. The influence of land-slipping on the development of the City of Bath, England. In: Malkovský, M. (ed.), Report of the 23rd Session of the International Geological Congress, Prague. Academia, Prague, Section 12, 65-76.

Kelly, M. R. 1964. The middle Pleistocene of North Birmingham. Philosophical Transactions of the Royal Society of London, B 247, 533-592.

Klinck, B. A., Hopson, P. N., Morigi, A. Q. N., Bloodworth, A. J., Inglethorpe, S. D. J., Entwisle, D. C. \& Wealthall, G. P. 1997. The hydrogeological classification of superficial clay: the hydrogeological characterisation of glacial till in East Anglia. Environment Agency, R\&D Technical Report W28, Bristol: Environment Agency. https://www.gov.uk/government/uploads/system/uploads/attachment data/file/291048/str-w28e-e.pdf

Knill, J. L. 1968. Geotechnical significance of some glacially induced rock discontinuities. Bulletin of the Association of Engineering Geologists, 5, 49-62.

Kohv, M., Talviste, P., Hang, T., Kalm, V. \& Rosentau, A. 2009. Slope stability and landslides in proglacial varved clays of western Estonia. Geomorphology, 106, 315-323.

Kohv, M., Talviste, P., Hang, T. \& Kalm, V. 2010. Retrogressive slope failure in glaciolacustrine clays: Sauga landslide, western Estonia. Geomorphology, 124, 229-237.

Kohv, M., Tiit, H., Peeter, T. \& Volli, K. 2010. Analysis of a retrogressive landslide in glaciolacustrine varved clay. Engineering Geology, 116, 109-116.

Kujansuu, R. 1964. Recent faults in Finnish Lapland. Geologi, 16, 30.

Lagerback, R. 1979. Neotectonic structure in northern Sweden. Geologiska Föreningen i Stockholm Förhandlingar, 100, 263-668.

Lang, W. D. 1914. The geology of the Charmouth cliffs, beach and foreshore. Proceedings of the Geologists' Association, 25, 293-360.

Lapworth, H. 1911. The geology of dam trenches. Transactions of the Institution of Water Engineers, 16, 25-66.

Lawson, D. E. 1979. Sedimentological analysis of the western terminus region of the Matanuska Glacier, Alaska. Cold Region Research and Engineering Laboratory Report 79-9.

Lee, J. R. \& Aldiss, D. T. 2012. Possible Late Pleistocene pingo development within the Lea Valley: evidence from Temple Mills, Stratford, East London. British Geological Survey Open Report $\mathrm{CR} / 11 / 033 \mathrm{~N}$.

Lee, J. R., Booth, S. J., Hamblin, R. J. O., Jarrow, A. M., Kessler, H., Moorlock, B. S. P., Morigi, A. N., Palmer, A., Pawley, S. M., Riding, J. B., Rose, J. 2004. A new stratigraphy for the glacial deposits around Lowestoft, Great Yarmouth, North Walsham and Cromer, East Anglia, UK. Bulletin of the Geological Society of Norfolk, 53, 3-60.

Lenham, J., Meyer, V., Edmonds, H., Harris, D., Mortimore, R., Reynolds, J. \& Black, M. 2006. What lies beneath: surveying the Thames at Woolwich. Proceedings of the Institution of Civil Engineers, 159, 32-41.

Lewis, S. G., Maddy, D., Buckingham, C., Coope, G. R., Field, M. H., Keen, D. H., Pike, A. W. G., Roe, D. A., Scaife, R. G. \& Scott, K. 2006. Pleistocene fluvial sediments, palaeontology and archaeology of the upper River Thames at Latton, Wiltshire, England. Journal of Quaternary Science, 21, 181-205.

L'Heureux, J-S., Eilertsen, R. S., Glimsdal, S., Issler, D., Solberg, I-L. \& Harbitz, C. B. 2012. The 1978 quick clay landslide at Rissa, Mid Norway: subaqueous morphology and tsunami 
simulations. In: Yamada, Y., Kawamura, K., Ikehara, K., Ogawa, Y., Urgeles, R., Mosher, D., Chaytor, J. \& Strasser, M. (eds.), Submarine Mass Movements and Their Consequences. Advances in Natural and Technological Hazards Research, 31, 507-516.

Locat, P., Demers, D., Robitaille, D., Fournier, T., Noël, F., Leroueil, S., Locat, A. \& Lefebvre, G. 2012. The Saint-Jude landslide of May 10, 2010, Québec, Canada. In: Eberhardt, E., Froese, C., Turner, A. K. \& Leroueil, S. (eds.), Landslides and engineered slopes: protecting society through improved understanding. Proceedings of the 11th International and 2nd North American symposium on landslides, CRC Press, Boca Raton, USA, Vol 2, 635-640.

Long, A. J. \& Tooley, M. J. 1995. Holocene sea-level and crustal movements in Hampshire and southeast England, United Kingdom. Journal of Coastal Research, 17, 299-310.

Long, D. 1991. The identification of features due to former permafrost in the North Sea. In: Forster, A., Culshaw, M. G., Cripps, J. C. \& Moon, C. F. (eds.) Quaternary Engineering Geology, Geological Society of London Engineering Geology Special Publication, 7, 369-372. doi:10.1144/GSL.ENG.1991.007.01.27

Lundqvist, J. \& Lagerback, R. 1976. The Parve Fault: a late glacial fault in the Precambrian of Swedish Lapland. Geologiska Föreningen i Stockholm Förhandlingar, 98, 45-51.

Lutenegger, A. J., Kemmis, T. J. \& Hallberg, G. R. 1983. Origin and properties of glacial till and diamictons. In: Young, R. N. (ed.), Geological environment and soil properties. Special Publication of the American Society of Civil Engineers, Geotechnical Engineering Division, 310-331.

Lyons, W. B., Mayewski, P. A., Donahue, P. \& Cassidy, D. 1985. A preliminary study of the sedimentary history of Lake Vanda, Antarctica: climatic implications. New Zealand Journal of Marine and Freshwater Research, 19, 253-260.

Mackay, J. R. 1988. Pingo collapse and paleoclimatic reconstruction. Canadian Journal of Earth Sciences, 25, 495-511.

Mackay, J. R. 1998. Pingo growth and collapse, Tuktoyattuk Peninsula area, Western Arctic Coast, Canada: a long term field study. Géographie Physique et Quaternaire, 52, 271-323.

Mackay, J. R. \& Black, R. F. 1973. Origin, composition and structure of perennially frozen ground and ground ice: a review. In: Proceedings of the $2^{\text {nd }}$ International Conference on Permafrost, Yakutsk, U.S.S.R., North American contribution. National Academy of Sciences, Washington D. C.,185-192.

Maddison, J. D. 2000. St Dogmaels landslide: deep drainage by wells. In: Siddle, H. J., Bromhead, E. N., Bassett, M. G. (eds), Landslide and landslide management in South Wales. Geological Series No. 18, 106-108. National Museum of Wales, Cardiff

Marks, R. J., Lawrence, A. R., Whitehead, E. J., Cobbing, J. E., Mansour, M. M., Darling, W. G. \& Hughes, A. G. 2004. Chalk recharge beneath thick till deposits in East Anglia. BGS Internal report IR/04/179. Keyworth, Nottingham: British Geological Survey. http://nora.nerc.ac.uk/11666/1/IR04179.pdf

Marsland, A. 1976. In-situ and laboratory tests on glacial clays at Redcar. Building Research Establishment Current Paper CP65/76. Her Majesty's Stationery Office, London

Marsland, A. \& Powell, J. J. M. 1991. Field and laboratory investigation of the clay tills at the test bed site at the Building Research Establishment, Garston, Hertfordshire. In: Forster, A., Culshaw, M. G., Cripps, J. C., Little, J. A. \& Moon, C. F. (eds.), Quaternary Engineering Geology, Geological Society of London Engineering Geology Special Publication, 7, 229-238.

McGowan, A. \& Derbyshire, E. 1977. Genetic influences on the properties of tills. Quarterly Journal of Engineering Geology, 10, 389-410.

McKinlay, D. G., Tomlinson, M. J. \& Anderson, W. F. 1974. Observations on the undrained strength of glacial till. Géotechnique, 24, 503-516.

McKinlay, D. G. \& Anderson, W. F. 1975. Determination of the modulus of deformation of a till using a pressuremeter. Ground Engineering. 11, 51-54.

McMillan, A. A. \& Merritt, J. W. 2012. A new Quaternary and Neogene lithostratigraphical framework for Great Britain and the Isle of Man. Proceedings of the Geologists' Association, 
123. 679-691. DOI10.1016/j.pgeola.2012.05.007

McMillan, A. A., \& Powell, J. H. 1999. British Geological Survey rock classification scheme: the classification of artificial (man-made) ground and natural superficial deposits: applications to geological maps and datasets in the UK. British Geological Survey Research Report RR/99/4. British Geological Survey, Keyworth, Nottingham. http://nora.nerc.ac.uk/3228/

McMillan, A. A., Hamblin, R. J. O. \& Merritt, J. W. 2011. A lithostratigraphical framework for onshore Quaternary and Neogene (Tertiary) superficial deposits of Great Britain and the Isle of Man. British Geological Survey Research Report RR 10/03. Keyworth, Nottingham: British Geological Survey. 343p. http://www.bgs.ac.uk/downloads/start.cfm?id=2041

McMillan, A. A., Heathcote, J. A., Klinck, B. A., Shepley, M. G., Jackson, C. P. \& Degnan, P. J. 2000. Hydrogeological characterization of the onshore Quaternary sediments at Sellafield using the concept of domains. Quarterly Journal of Engineering Geology and Hydrogeology, 33, 301-323. doi:10.1144/qjegh.33.4.301

McRoberts, E. C. \& Morgenstern, N. R. 1974a. The stability of thawing slopes. Canadian Geotechnical Journal, 11, 447-469.

McRoberts, E. C. \& Morgenstern, N. R. 1974b. Stability of slopes in frozen soil. MacKenzie Valley, N. W. T. Canadian Geotechnical Journal, 11, 554-573.

Meng, X. M. \& Derbyshire, E. 1998. Landslides and their control in the Chinese Loess Plateau. In: Maund, J. G. \& Eddleston, M. (eds.) Geohazards in Engineering Geology. Geological Society of London Engineering Geology Special Publication, 15, 141-153.

Michael, J. 2005. The micromorphology of palaeoseimic soft sediment deformation structures in glacial deposits form three samples sites in Scotland. Unpublished MSc dissertation, Brock University, Canada.

Miller, H. 1887. The country around Otterburn and Elsdon. Geological Survey of Great Britain (England and Wales). Memoir, Sheet 8. Her Majesty's Stationery Office, London.

Milne, G. A., Long, J. A. \& Bassett, S. E. 2005. Modelling Holocene relative sea-level observations from the Caribbean and South America. Quaternary Science Reviews, 24, 1183-1202.

Milodowski, A. E., Northmore, K. J., Kemp, S. J., Entwisle, D. C., Gunn, D. A., Jackson, P. D., Boardman, D. I., Zourmpakis, A., Rogers, C. D. F., Dixon, N., Jefferson, I., Smalley, I. J. \& Clarke, M. 2015. The mineralogy and fabric of 'Brickearths' in Kent and their relationship to engineering behaviour. Bulletin of Engineering Geology and the Environment, 74, 1187-1211.

Młynarczyk, Z. \& Rotnicki, K. 1989. Flood and vortex scour of the channel bed of the Prosna river, and their depth range. Earth Processes and Landforms, 14, 365-373. doi:10.1002/esp.3290140502

Morgan, A. V. 1971. Engineering problems caused by fossil permafrost features in the English Midlands. Quarterly Journal of Engineering Geology, 4, 111-114.

Morgenstern, N. R. 1981. Geotechnical engineering and frontier resource development. Géotechnique, 31, 305-365.

Morikawa, H., Minato, I., Ossaka, J. \& Hayashi, T. 1975. The distribution of secondary minerals and evaporites at Lake Vanda, Victoria Land, Antarctica. Memoirs of the National Institute of Polar Research, Special Issue 4, 45-59.

Mörner, N. A. 2004. Active faults and palaeoseismicity in Fennoscandia, especially Sweden. Primary structure and secondary effects. Tectonophysics, 380, 139-157.

Mörner, N. A. \& Dawson, S. 2011. Traces of tsunami events in off and on shore environments. Case studies in the Maldives, Scotland and Sweden. Chapter 18 in Mörner, N. A. (ed.), The Tsunami Threat - Research and Technology. Intechopen, Rijeka, 371-388.

Morton, E. 1949. Discussion of: Hill, H. P. 1949. The Ladybower Reservoir. Journal of the Institution of Water Engineers, 3, 414-433.

Morton, E. 1973. A review of the influence of geology on the design and construction of impounding dams. Journal of the Institution of Water Engineers, 27, 243-264 (and discussion, 264-271).

Murton, J. B. 1996. Near-surface brecciation of chalk, Isle of Thanet, south-east England: a 
comparison with ice-rich brecciated bedrocks in Canada and Spitsbergen. Permafrost and Periglacial Processes, 7, 153-164.

Murton, D. K. \& Murton, J. B. 2012. Middle and Late Pleistocene glacial lakes of lowland Britain and the southern North Sea Basin. Quaternary International, 260, 115-142.

Murton, J. B., Bowen, D. Q., Candy, I., Catt, J. A., Currant, A., Evans, J. G., Frogley, M. R., Green, C. P., Keen, D. H., Kerney, M. P., Parish, D., Penkman, K., Schreve, D. C., Taylor, S., Toms, P. S., Worsley, P. \& York, L. L. 2015. Middle and Late Pleistocene environmental history of the Marsworth area, south-central England. Proceedings of the Geologists'Association, 126, 18-49.

Nakai, N., Wada, H., Kiyosu, Y. \& Takimoto, M. 1975. Stable isotope studies on the origin and geological history of water and salts in the Lake Vanda area, Antarctica. Geochemical Journal, 9, 7-24.

Nichol, D. 2001. Geo-engineering along the A55 North Wales Coast Road. Quarterly Journal of Engineering Geology and Hydrogeology, 34, 51-64. doi:10.1144/qjegh.34.1.51

Norbury, D. 1991. Discussion of Spink (1991). In: Forster, A., Culshaw, M. G., Cripps, J. C., Little, J. A. \& Moon, C. F. (eds.) Quaternary Engineering Geology, Geological Society of London Engineering Geology Special Publication, 7, 397.

Northmore, K. J. 1991. The engineering geology of South-Central Leeds. Technical Report No. WN/91/11, Keyworth, Nottingham: British Geological Survey.

Northmore, K. J., Bell, F. G. \& Culshaw, M. G. 1996. The brickearth of South Essex. Quarterly Journal of Engineering Geology, 29, 147-161.

Northmore, K. J., Jefferson, I., Jackson, P. D., Entwisle, D., Milodowski, A., Raines, M., Gunn, D., Boardman, D. I., Zourmpakis, A., Nelder, L. M., Rogers, C. D. F., Dixon, N. \& Smalley, I. J. 2008. On-site characterisation of loessic brickearth deposits at Ospringe, Kent, UK. Proceedings of the Institution of Civil Engineers - Geotechnical Engineering, 161, 3-17.

Norwegian Geotechnical Institute. 2008. The Rissa landslide: Quick clay in Norway. (DVD recording). (24 minutes).

Parks, C. D. 1991a. A review of the mechanisms of cambering and valley bulging. In: Forster, A., Culshaw, M. G., Cripps, J. C., Little, J. A. \& Moon, C. F. (eds.) Quaternary Engineering Geology. Geological Society of London Engineering Geology Special Publication, 7, 373-380.

Parks, C. D. 1991b. Cambering and valley bulging in England. Unpublished Ph.D. thesis, University of Newcastle-upon-Tyne.

Parry, S., Baynes, F. J., Culshaw, M., Eggers, M., Keaton, J. R., Lentfer, K., Novotný, J. \& Paul, D. 2014. Engineering geological models: IAEG Commission 25. In: Lollino, G., Arattano, M., Giardino, M., Oliveira, R. \& Peppoloni, S. (eds.), Education, Professional Ethics and Public Recognition of Engineering Geology. Proceedings of the 12th Congress of the International Association for Engineering Geology and the Environment on "Engineering Geology for Society and Territory", Torino, Italy. Volume 7, Paper 3, 17-19. Springer, Cham (Switzerland).

Paterson, W. S. B. 1994. The Physics of Glaciers. $3^{\text {rd }}$ edition. Pergamon, Oxford.

Phillips, E., Lee, J. R., Riding, J. B., Kendall, R. \& Hughes, L. 2012. Periglacial disruption and subsequent glacitectonic deformation of bedrock: an example from Anglesey, North Wales, UK. Proceedings of the Geologists' Association, 124. 802-817.

Phipps, P. J. 2001. Slope instability within a residential area in Cleveland, UK. In: Griffiths, J.S. (ed.) Land Surface Evaluation for Engineering Practice. Geological Society of London $\begin{array}{lllll}\text { Engineering } \quad \text { Geology } & \text { Special }\end{array}$ doi:10.1144/GSL.ENG.2001.018.01.31

Pissart, A. \& Gangloff, P. 1984. Les palses minerales et organiques de la vallee de l'Aveneau, pres de Kuujjuaq, Quebec subarctique. Geographie Physique et Quaternaire, 38, 217-228.

Ponniah, D. A. \& McAnoy, R. 1985. Pile jacking in glacial till. In: Forde, M. C. (ed.) Glacial Tills 85, Proceedings of the International Conference on Construction in Glacial Tills and Boulder Clays. Engineering Technics Press, Edinburgh. 137-146.

Pook, G. 2013. A spatial analysis of cambering in Jurassic strata of the Cotswolds and Northamptonshire Ironstone Field. Unpublished MSc dissertation (Applied Environmental 
Geology), Cardiff University.

Popescu, M. E. 1992. Engineering problems associated with expansive and collapsible soil behaviour. In: Proceedings of the $7^{\text {th }}$ International Conference on Expansive Soils. Texas Tech University Press, Lubbock, USA, volume 2, 25-46.

Pye, K. 1984. Loess. Progress in Physical Geography, 8, 176-217.

Pye, K. 1995. The nature, origin and accumulation of loess. Quaternary Science Reviews, 14, 653667.

Pye, K. 2005. Alde and Ore Estuary flood management strategy. External Investigation Report EX509. www.aldeandore.org/myfiles/AldeandOreReport2.doc

Raines, M. G., Banks, V. J., Chambers, J. E., Collins, P. E. F., Jones, P. F., Morgan, D. J. R., Riding, J. B. and Royse, K. 2015. The application of passive seismic techniques to the detection of buried hollows. In: Proceedings of the $14^{\text {th }}$ International Sinkholes Conference .Minnesota, USA. October 2015. 423-429.

http://scholarcommons.usf.edu/cgi/viewcontent.cgi?article $=1034 \&$ context $=$ sinkhole 2015

Rankka, K., Andersson-Sköld, Y., Hultén, C., Larsson, R., Leroux, V., \& Dahlin, T. 2004. Quick clay in Sweden. Swedish Geotechnical Institute Report, 65, 145p.

Rappol, M. 1985. Clast fabric strength in tills and debris flows compared for different environments. Geologie en Mijnbouw, 64, 327-332.

Reeves, G. M., Sims, I., \& Cripps, J. C. (eds.) 2006. Clay materials used in construction. Appendix B. Properties data. Geological Society of London Engineering Geology Special Publication,. 21, 461-474, doi:10.1144/GSL.ENG.2006.021.01.17

Ringrose, P. S. 1989. Palaeoseismic (?) liquefaction event in late Quaternary lake sediment at Glen Roy, Scotland. Terra Nova, 1, 57-62.

Rose, J., Lee, J. A., Moorlock, B. S. P. \& Hamblin, R. J. O. 1999. The origin of the Norwich Brickearth: micromorphological evidence for pedological alteration of sandy Anglian Till in northeast Norfolk. Proceedings of the Geologists' Association, 110, 1, 1-8.

Ross, N. 2006. A re-evaluation of the origins of Late Quaternary ramparted depressions in Wales. Unpublished PhD thesis, Cardiff University. 407pp.

Ross, N., Harris, C., Brabham, P. J. \& Sheppard, T. H. 2011. Internal structure and geological context of ramparted deprressions, Llanpumsaint, Wales. Permafrost and Periglacial Processes, 22, 291-305.

Rowe, P. W. 1995. Examples of ground response to various types of structural foundation construction. In Eddleston, M., Walthall, S., Cripps, J.C., \& Culshaw, M.G. (eds.) Engineering Geology of Construction. Geological Society of London Engineering Geology Special Publication, 10, 33-57. doi:10.1144/GSL.ENG.1995.010.01.02

Sandeman, E. 1918. The Derwent Valley Waterworks. Minutes of Proceedings of the Institution of Civil Engineers, 206, 152-189; discussion, 190-220.

Self, C. A. 1985. Two gull caves from the Wiltshire/Avon border. Proceedings of the University of Bristol Spelaeological Society, 17, 153-174.

Self, C. A. \& Farrant, A. R. 2013. Gulls, gull-caves and cambering in the southern Cotswold Hills, England. In: Filippi M. \& Bosak P. (eds.), Proceedings of the 16th International Congress of Speleology, Brno, Czech Republic. Prague, Czech Republic, Czech Speleological Society, volume 3, 132-136.

Self, S. J., Entwisle, D. C. \& Northmore, K. J. 2012. The structure and operation of the BGS National Geotechnical Properties Database Version 2. British Geological Survey Internal Report, IR/12/056. British Geological Survey, Keyworth, Nottingham, 61p. http://nora.nerc.ac.uk/20815/

Shaw, J. 1985. Subglacial and ice marginal environments. In: Ashley, G. M., Shaw, J. \& Smith, H. D. (eds.) Glacial Sedimentary Environments. Society of Economic Paleontologists and Mineralogists, Tulsa, Oklahoma, 7-84.

Shennan, I. 1989. Holocene crustal movements and sea-level changes in in Great Britain. Journal of Quaternary Science, 4, 77-89. 
Shennan, I. \& Horton, B. P. 2002 Holocene land and sea-level changes in Great Britain. Journal of Quaternary Science, 17, 511-526.

Shennan, I., Bradley, S., Milne, G., Brooks, A., Bassett, S. \& Hamiliton, S. 2006. Relative sea-level; changes, glacial isostatic modelling and ice-sheet reconstructions from the British Isles since the Last Glacial Maximum. Journal of Quaternary Science, 21, 585-599.

Shotton, F. W. 1960. Large scale patterned ground in the valley of the Worcestershire Avon. Geological Magazine, 97, 404-408.

Shotton, F. W. \& Osborne, P. J. 1965. The fauna of the Hoxnian interglacial deposits of Nechells, Birmingham. Philosophical Transactions of the Royal Society of London, B 248, 353-378.

Shotton, F. W. \& Wilcockson, W. H. 1950. Superficial valley folds in an opencast working of the Barnsley Coal. Proceedings of the Yorkshire Geological Society, 28, 102-111.

Skempton, A. W. 1953. Soil mechanics in relation to geology. Proceedings of the Yorkshire Geological Society, 29, 33-62.

Skemption, A. W., \& Northey, R. D. 1952. The sensitivity of clays. Géotechnique, 3, 30-53.

Skempton, A. W. \& Vaughan, P. R. 1993. The failure of Carsington Dam. Géotechnique, 43, 151173.

Skempton, A. W. \& Weeks, A. G. 1976. Quaternary history of the Lower Greensand escarpment and Weald Clay vale near Sevenoaks, Kent. Philosophical Transactions of the Royal Society, A283, 493-526.

Skempton, A. W., Norbury, D., Petley, S. J. \& Spink, T. W. 1991. Solifluction shears at Carsington, Derbyshire. In: Forster, A., Culshaw, M. G., Cripps, J. C., Little, J. A. \& Moon, C. F. (eds.) Quaternary Engineering Geolog.y Geological Society of London Engineering Geology Special Publication, 7, 381-387.

Sparks, B. W., Williams, R. B. G. \& Bell, F. G. 1972. Presumed ground-ice depressions in East Anglia. Proceedings of the Royal Society of London, A 327, 329-343.

Spink, T. W. 1991. Periglacial discontinuities in Eocene clays near Denham, Buckinghamshire. In: Forster, A, Culshaw, M. G., Cripps, J. C., Little, J. A. \& Moon, C. F. (eds.) Quaternary Engineering Geology. Geological Society of London Engineering Geology Special Publication, 7, 389-396.

Standing Conference on Problems Associated with the Coastline, Sediment Transport Study 2004. University of Portsmouth. http://www.scopac.org.uk/sediment-transport.html

Stewart, I. S., Frith, C. R., Rust, D. J., Collins, P. E. F. \& Firth, J. A. 2001. Postglacial fault movement and palaeoseismicity in western Scotland: A reappraisal of the Kinloch Hourn fault, Kintail. Journal of Seismology, 5, 307-328.

Strange, P. J., Booth, S. J. \& Ellison, R. A. 1998. Development of 'rockhead' computer-generated geological models to assist geohazard prediction in London. In: Maund, J.G. \& Eddleston, M. (eds.) Geohazards in Engineering Geology. Geological Society of London Engineering Geology Special Publication, 15, 409-414.

Stroud, M. A. \& Butler, F. G. 1975. The standard penetration test and the engineering properties of glacial materials. In: Proceedings of the Symposium on The engineering behaviour of glacial materials. The Midland Soil Mechanics and Foundation Engineering Society, Birmingham, UK, 117-128.

Sumbler, M. G. 1996. British regional geology: London and the Thames Valley (4 ${ }^{\text {th }}$ edition). Her Majesty's Stationery Office, London.

Taylor, R. K., Barton, R., Mitchell, J. E. \& Cobb, A. E. 1976. The engineering geology of Devensian deposits underlying PFA lagoons at Gale Common, Yorkshire. Quarterly Journal of Engineering Geology, 9, 195-216.

Thorburn, S. \& Reid, W. M. 1973. Stability of slopes in lodgement till within the Glasgow District. Civil Engineering and Public Works Review, 68, (issue 801), 321-325.

Threadgold, L. \& Weeks, A. C. 1975. Deep laminated clay deposits in the Skipton area. In: The Engineering Behaviour of Glacial Materials. In: Proceedings of the Symposium on "The engineering behaviour of glacial materials. The Midland Soil Mechanics and Foundation 
Engineering Society, Birmingham, UK, 203-208.

Torrance, J. K. 1983. Towards a general model of quick clay development. Sedimentology, 30, 547555.

Trenter, N. A. 1999. Engineering in Glacial Tills. Construction Industry Research and Information Association (CIRIA) Report C504, CIRIA, London.

Van Asch, T. W., Hendriks, M. R., Hessel, R. \& Rappange, F. E. 1996. Hydrological triggering conditions of landslides in varved clays in the French Alps. Engineering Geology, 42, 239-251.

Van Vliet-Lanoe, B., Vandenberghe, N., Laurent, M., Laignel, B., Lauriat-Rage, A., Louwye, S., Mansy, J-L., Mercier, D., Hallégouët, B., Laga, P., Laquement, F., Meilliez, F., Michel, Y., Moguedet, G. \& Vidier, J-P. 2002. Palaeogeographic evolution of north western Europe during the Upper Cenozoic. Geodiversitas, 24, 511-541.

Vaughan, P. R. 1976. The deformations of the Empingham Valley slope. Appendix to: Horswill, P. \& Horton, A. 1976. Cambering and valley bulging in the Gwash valley at Empingham, Rutland. Philosophical Transactions of the Royal Society, A 283, 451-461.

Waine, P. J., Culshaw, M. G. \& Hallam, J. R. 1990a. Engineering geology of the Wrexham area. Technical Report No. WN/90/10, Keyworth, Nottingham: British Geological Survey. http://nora.nerc.ac.uk/510082/

Waine, P. J., Hallam, J. R. \& Culshaw, M. G. 1990b. Engineering geology of the Stoke-on-Trent area. Technical Report No. WN/90/11, Keyworth, Nottingham: British Geological Survey.

Waller, R. I. 2001. The influence of basal processes on the dynamic behaviour of cold-based glaciers. Quaternary International, 86, 117-128.

Waller, R., Phillips, E., Murton, J., Lee, J. \& Whiteman, C. 2011. Sand interclasts as evidence of subglacial deformation of Middle Pleistocene permafrost, North Norfolk, UK. Quaternary Science Reviews, 30, 3481-3500.

Waltham, A. C. 1994. Foundations of Engineering Geology. Blackie Academic \& Professional, London.

Washburn, A. L. 1979. Geocryology. A Survey of Periglacial Processes and Environments. Edward Arnold, London

Watkins, D. R. 1994. The foundry excavations on Poole waterfront 1986-7. Dorset Natural History \& Archaeological Society Monograph Series No 14.

Watson, E. 1971. Remains of pingos in Wales and the Isle of Man. Geological Journal, 7, 381-392.

Watson, E. 1972. Pingos of Cardiganshire and the latest ice limit. Nature, 236, 343-344.

Watson, E. 1976. Field excursions in the Aberystwyth region, 1-10 July 1975. Biuletyn Peryglacjalny, 26, 79-112.

Watson, E. 1977. The periglacial environment of Great Britain during the Devensian. Philosophical Transactions of the Royal Society of London, B 280, 183-198.

Watson, E. \& Watson, S. 1972. Investigations of some pingo basins near Aberystwyth, Wales. In the Report of The $24^{\text {th }}$ International Geological Congress (Montreal), Section 2, 212-233.

Watson, E. \& Watson, S. 1974. Remains of pingos in the Cletwr Basin, southwest Wales. Geografiska Annaler, Series A: Physical Geography, 56a, 213-225.

Watts, W. 1905. Geological notes on sinking Langsett and Underbank concrete-trenches in the Little Don Valley. Transactions of the Institution of Mining Engineers, 31, 668-687.

Weeks, A. G. 1969. The stability of slopes in south-east England as affected by periglacial activity. Quarterly Journal of Engineering Geology, 5, 223-241.

Weltman, A. J. \& Healy, P. R. 1978. Piling in 'boulder clay' and other glacial tills. Department of the Environment (DoE) and Construction Industry Research and Information Association (CIRIA) Piling Development Group, Report PG5. PSA Civil Engineering Technical Guide 23. London: Construction Industry Research and Information Association.

West, R. G., Dickson, C. A., Catt, J. A., Weir, A. H. \& Sparks, B. W. 1974. Late Pleistocene deposits at Wretton, Norfolk; II, Devensian deposits. Philosophical Transactions of the Royal Society of London, B 267, 337-420.

Westaway, R. 2009. Quaternary vertical crustal motion and drainage evolution in East Anglia and 
adjoining parts of southern England: chronology of the Ingham River terrace deposits. Boreas, 38, 261-284.

Westaway, R., Bridgland, D. \& White, M. 2006. The Quaternary uplift history of central southern England: evidence from the terraces of the Solent River system and nearby raised beaches. Quaternary Science Reviews, 25, 2212-2250.

White, S. E. 1976. Rock glaciers and block fields, review and new data. Quaternary Research, 6, 77-97.

Wilson, A. T. \& Wellman, H. W. 1962. Lake Vanda: an Antarctic Lake: Lake Vanda as a Solar Energy Trap. Nature, 196, 1171 - 1173. doi:10.1038/1961171a0

Wingfield, R. T. R. 1987. Giant sand waves and relict periglacial features on the sea bed west of Anglesey. Proceedings of the Geologists' Association, 98, 400-404.

Zalasiewicz, J. A., Mathers, S. J., Hughes, M. J., Gibbard, P. L., Peglar S. M., Harland, R. A., Nicholson, R. A., Boulton, G.S., Cambridge, P. \& Wealthall, G.P. 1988. Stratigraphy and paleoenvironments of the Red Crag and Norwich Crag Formations between Aldeburgh and Sizewell Suffolk, England. Philosophical Transactions of the Royal Society of London, B 322, 221-272.

Zourmpakis, A., Boardman, D. I., Rogers, C. D. F., Jefferson, I., Gunn, D. A., Jackson, P. D., Northmore, K. J., Entwisle, D. C., Nelder, L. M. \& Dixon, N. 2006. Case study of a loess collapse field trial in Kent, SE England. Quarterly Journal of Engineering Geology and Hydrogeology, 39, 131-150. 


\section{Chapter 6 Figure captions}

Figure 6.1 Block diagram showing glacial environments (after Fookes et al. 2015). (C Fookes, P., Pettifer, G. \& Waltham, T. Published with permission)

Figure 6.2 Relict periglacial terrain model for northern Alaska (after Fookes et al. 2015). (C)

Fookes, P., Pettifer, G. \& Waltham, T. Published with permission)

Figure 6.3 National glacial till subgroups in the UK.

Figure 6.4 National glacial till formations in the UK.

Figure 6.5 Schematic cross-section depicting the inter-relationship between the Gretna Till Formation (Gretna Till Formation and Chapelknowe Till Member) and the intervening

Plumpe Sand and Gravel Formation (Plumpe Farm Sand and Loganhouse Gravel members) near Canonbie [NY 370820 to 392 748], Dumfries and Galloway, south west Scotland (after McMillan et al. 2011).

Figure 6.6 Locations where boulders have been found within glacial till (based on borehole $\operatorname{logs}$ ), plotted on the glacial till subgroups map (Fig. 6-3).

Figure 6.7 The described lithologies of members $(\mathrm{Mb})$ and formations $(\mathrm{Fm})$ of the Albion Glacigenic Group.

Figure 6.8 The described lithologies of formations (Fm) and Subgroups (GS/GL) of the Caledonia Glacigenic Group.

Figure 6.9 Particle size distribution plot for the Brewood Till Formation.

Figure 6.10 Particle size distribution plot for tills of the Brewood Till Formation.

Figure 6.11 Particle size distribution plot of glaciofluvial sand and gravel of the Brewood Till Formation.

Figure 6.12 Particle size distribution plot of glaciofluvial or glaciolacustrine sand of the Brewood Till Formation.

Figure 6.13 Particle size distribution plot of glaciolacustrine clay and silt of the Brewood Till Formation.

Figure 6.14 Particle size distribution plot for the Edenside Till Formation.

Figure 6.15 Particle size distribution plot for the Gretna Till Formation (excluding the Plumpe Sand and Gravel Formation).

Figure 6.16 Particle size distribution plot for the Finglack Till Formation.

Figure 6.17 Particle size distribution plot for the Vale of York Till Formation.

Figure 6.18 Undrained shear strength vs depth for formations $(\mathrm{GF}=$ Glacigenic Formation; $\mathrm{TF}=$ Till Formation) of the Irish Sea Glacigenic Subgroup.

Figure 6.19 Undrained shear strength versus depth below ground level for units of the Albion Glacigenic Group.

Figure 6.20 Glacial Lake Bosworth at its maximum lake level of $125 \mathrm{~m}$ AOD (modified after Murton \& Murton [2012] and references therein). Permission to publish needed from Elsevier?? Dave Giles

Figure 6.21 Glaciolacustrine depositional ground model.

Figure 6.22 Typical glaciolacustrine rhythmite deposits, Glacial Lac du Trièves, Sinard, France. The section is $1 \mathrm{~m}$ high.

Figure 6.23 Scour marks from debris flows into Glacial Lac du Trièves, Sinard, France. The length of the scours is approximately $1.8 \mathrm{~m}$.

Figure 6.24 Dropstone within finer grained glaciolacustrine rhythmites. Glacial Lac du Trièves, Sinard, France. The cobble is approximately $250 \mathrm{~mm}$ along the long axis.

Figure 6.25 Plasticity chart for glaciolacustrine deposits of the Albion Glacigenic Group. Figure 6.26 Plasticity chart for glaciolacustrine deposits of the Caledonia Glacigenic Group. Figure 6.27 Particle size distrubution for glaciolacustrine deposits of the Albion Glacigenic Group. Figure 6.28 Particle size distrubution for glaciolacustrine deposits of the Caledonia Glacigenic Group. 
Figure 6.29 Dry density versus depth for glaciolacustrine deposits of the Albion Glacigenic Group.

Figure 6.30 Dry density versus depth for glaciolacustrine deposits of the Caledonia Glacigenic Group.

Figure 6.31 Undrained shear strength versus depth for glaciolacustrine deposits of the Albion Glacigenic Group.

Figure 6.32 Undrained shear strength versus depth for glaciolacustrine deposits of the Caledonia Glacigenic Group.

Figure 6.33 Effective shear strength envelopes shown as percentiles for glaciolacustrine deposits of the Albion Glacigenic Group.

Figure 6.34 Effective shear strength envelopes shown as percentiles for glaciolacustrine deposits of the Caledonia Glacigenic Group.

Figure 6.35 Effective shear strength envelopes shown as percentiles for 'not loaded' glaciolacustrine deposits of the Caledonia Glacigenic Group.

Figure 6.36 Effective shear strength envelopes shown as percentiles for 'loaded' glaciolacustrine deposits of the Caledonia Glacigenic Group.

Figure 6.37 Angle of internal friction versus plasticity index and showing upper bound for the angle of residual friction for glaciolacustrine deposits of the Albion and Caledonia Glacigenic Groups.

Figure 6.38 Angle of residual friction versus plasticity index and showing lower bound for the angle of internal friction for glaciolacustrine deposits of the Albion and Caledonia Glacigenic Groups.

Figure 6.39 Typical varved clay structure (after Eyles 1983). Permission to publish needed Dave Giles Pergamon Press

Figure 6.40 Mudslide and mudflow at Glacial Lac du Trièves, Sinard, France.

Figure 6.41 Glaciolacustrine rhythmites, Voiron, France.

Figure 6.42a Development of Quick Clays - post-glacial marine clays (modified from Hutchinson 1992). Permission to publish needed Dave Giles Quaternary Research Association

Figure 6.42b Development of Quick Clays - clays leached by fresh water (modified from Hutchinson 1992). Permission to publish needed Dave Giles Quaternary Research Association

Figure 6.43 Failure sequence for quick clays.

Figure 6.44 Styles of glacitectonic deformation at Wylfa, Angelsey, North Wales. a) and b) are associated with a stepped bedrock profile; a) was found immediately downstream of the bedrock steps and b) was found in an upstanding area above the steps; c) relates to areas where the bedrock dips approximately parallel to the eroding surface and ice movement was upslope. (Zone A: undisturbed bedrock; Zone B: weakly deformed bedrock; Zone C: penetratively deformed bedrock; Zone D: sheared glacial till) (after Harris 1991). Permission to publish needed Martin Culshaw Geological Society

Figure 6.45 Relict solifluction lobes between Sevenoaks and Tonbridge, Kent. The rocks forming the escarpment at the top of the image are described on the geological map (British Geological Survey 1:63 360 scale, Solid and Drift map of Sevenoaks, sheet 287, 1971. Reprinted at 1:50 000 scale, 1990) as Lower Cretaceous sandstones and mudstones. The crest of the escarpment is composed of Lower Greensand Hythe Formation and the slopes, which are affected by solifluction shears, are composed of Lower Greensand Atherfield Clay over Wealden Group Weald Clay. (C) Google Earth Pro, Getmapping plc. 2012.)

Figure 6.46 Multiple layers of solifluction shears exposed in a trial pit near Stoke Hammond, north Buckinghamshire, UK. The geology consists of West Walton Formation, Ampthill Clay Formation and Kimmeridge Clay Formation (Undifferentiated) - mudstone, siltstone and sandstone. Compass clinometer for scale (C) Mott MacDonald. Published with permission). Tom Berry has sought permission; awaiting reply

Figure $6.47 \mathrm{a}$ Distribution of some of the rocks susceptible to solifluction in the UK - see http://mapapps.bgs.ac.uk/geologyofbritain/home.html for more details. (Contains British Geological Survey materials (C) NERC 2012. (C) Google Earth Pro, GeoContent, SIO, NOAA, 
US Navy, GEBCO, 2012.)

Figure $6.47 \mathrm{~b}$ Key to the geological formations shown in Fig.47a. (Contains British Geological Survey materials (C) NERC 2012.)

Figure 6.48 Simplified plot showing relationship between peak and residual shear strengths for dense sand/stiff clays (solid) and loose sand/soft clays (dashed).

Figure 6.49 Sampling of undisturbed and oriented soil block in an embankment (near Grazely, Berkshire). (Photographer Tom Berry)

Figure 6.50a Surface distribution of loess/brickearth in the southern UK based on Soil Survey 1:250 000 scale soil map (1983). Loess $>1 \mathrm{~m}$ thick in black; loess $>300 \mathrm{~mm}$ thick (and often partly mixed with subjacent deposits) shown stippled (after Catt 1985). Permission to publish needed Martin Culshaw George Allen and Unwin

Figure 6.50b Distribution of brickearth deposits in south eastern and southern England based on British Geological Survey 1:50,000 scale geological map linework.

Figure 6.51a Three main types of gull extensional movement observed in the Blue Lias at Radstock, Somerset. A-Type results from the opening of a single joint; B-Type involves bed-over-bed movement and produces a larger number of smaller voids; C-Type involves differential movement between beds resulting in an almost intact roof (after Hawkins \& Privett 1981). Permission to publish needed Martin Culshaw Geological Society

Figure 6.51b Classification of extensional gulls based on the type of movement (see Fig. 6-51a) and any infilling as observed in the Blue Lias at Radstock, Somerset. (after Hawkins \& Privett 1981). Permission to publish needed Martin Culshaw Geological Society

Figure 6.52 Morphological classification of gulls based on observations in the Great Oolite Limestone at Box Hill, Wiltshire and Monkton Farleigh, near Bathford, Somerset. A-Type, BType and C-Type are as described by Hawkins and Privett (1981) (see Fig. 6-51a). D-Type movement occurs when secondary gulling occurs above the upper sliding plane. E-type movement is a variant of C-Type when two joints trend in the same direction but are at an angle to one another; this results in subsidence of the block of rock between the two joints. AB-Type movement is a hybrid combining a major near-vertical joint between the surface and the bottom plane of movement and bed-over-bed sliding at all levels. AC-Type movement is also a hybrid where a gull has a roof but the roof is unsupported on the downslope side (after Self 1985). Permission to publish needed Martin Culshaw University of Bristol Spelaeological Society

Figure 6.53 Valley bulging in uppermost Edale Shales at Rowlee Bridge, Ashop Valley, Derbyshire (British Geological Survey Photograph No. P006233. CNERC. Published with permission).

Figure 6.54 Sketch diagram illustrating the development of cambered strata, gulls and valley bulges. Inferred from observations at Empingham, Central England (after Hutchinson 1991). Permission to publish needed Martin Culshaw Geological Society

Figure 6.55 A mechanism for the development of cambering and valley bulging (after Parks 1991a). Permission to publish needed Martin Culshaw Geological Society

Figure 6.56 Recorded occurrences of cambered strata from the literature (30) (purple dots), in the British Geological Survey's National Landslide Database (136) (red dots) and in the PhD thesis of Parks (1991b) (639) (black dots) overlain on a geological map of the UK (derived from the British Geological Survey 1:625,000 scale map).

Figure 6.57 Schematic illustration to demonstrate the possible reactivation of faults caused by a combination of stress relief and the elastic rebound of valleys side associated with valley deglaciation and mining subsidence (after Donnelly 2005, 2011). Permission to publish needed Laurance Donnelly National Museum of Wales

Figure 6.58a Blocks of sandstone which have become detached and translated down slope, along the valley crest to the north of the Darren Ddu landslide. (Note: this photograph was taken in the early 1990s. While the fissure sides were judged to be stable and safe to investigate, now, proper safety equipment would be worn including a hard hat, high visibility jacket and protective footware.)

Figure $6.58 \mathrm{~b}$ Widened fissures, cambered, rotated and detached blocks of sandstone cap rock along 
the valley crests adjacent to the Darren Ddu landslide. (Note: this photograph was taken in the early 1990s. While the slope and fissure were judged to be safe to investigate, now, proper safety equipment would be worn including a hard hat, high visibility jacket and protective footware.)

Figure 6.59 Walls of a kettle hole near Nefyn, Lleyn Penninsula, North Wales, exposed by coastal erosion. The horseshoe-shaped embayment is $60 \mathrm{~m}$ wide at the top of the $40 \mathrm{~m}$ high cliff line. Note the small amount of debris (mainly silt) remaining at the mouth of the failure. (Photographer Adrian Humpage, CNERC. Published with permission).

Figure 6.60 Mélange: irregular 'soft-edged' chalk blocks and chalky smears in clayey fine-grained sand, from a depth of $41 \mathrm{~m}$, Temple Mills, Stratford, East London (from Lee \& Aldiss, 2012. CNERC. Published with permission).

Figure 6.61 The eustatic record for the last 8000 years (after Milne et al. 2005) Permission to publish needed Adrian Collings Quaternary Science Reviews Elsevier

Figure 6.62 The isostatic record. Rates of late Holocene relative sea and land level changes due to the glacio-isostatic adjustment (after Shennan \& Horton 2002). Permission to publish needed Adrian Collings J of Quat Sci Wiley

Figure 6.63 The Palaeogene Hampshire Basin.

Figure 6.64a Changes in relative sea level across south east England over the last 8000 years.

Figure 6.64b Location of Holocene sediment records (after Jones \& Keen 1993). Permission to publish needed Adrian Collings Chapman and Hall

Figure 6.65 Lower Thames sediment record. Neotectonic and GIA component of sea level rise (after Devoy 1977, 1979). Permission to publish needed Adrian Collings Nature/Royal Society

Figure 6-66 Relationship between the Variscan fault-bounded Devonian basin at depth and the Quaternary/Holocene at Greenwich (from Aldiss et al. 2006).

Figure 6.67 The regional Holocene neotectonic influences in south east England and the near Continent (modified after Van Vliet-Lanoe et al. 2002). Permission to publish needed Adrian Collings Geodiversitas Published by Muséum national d'Histoire naturelle, Paris

Appendix 6.2 Figure. 1 Albion Glacigenic Group: consistency for various stratigraphic units (wke = extremely weak; stivwke = very stiff to extremely weak; stiv $=$ very stiff; stistiv $=$ stiff to very stiff; sti = stiff; frmsti = firm to stiff; frm = firm; sftfrm = soft to firm; $\mathrm{sft}=$ soft; $\mathrm{sftvsft}=$ very soft to soft; sftv = very soft). Geological unit codes are explained in Appendix 6.1 Table 1.

Appendix 6.2 Figure 2 Albion Glacigenic Group: density for various stratigraphic units (DENV = very dense; DENDENV = dense to very dense; DEN = dense; DENMDEN = moderately dense to dense; LSDENM = loose to moderately dense; LS = loose; LSVLS = very loose to loose; LSV $=$ very loose). Geological unit codes are explained in Appendix 6.1 Table 1.

Appendix 6.2 Figure 3 Albion Glacigenic Group: lithology for various stratigraphic units $(\mathrm{Mb}=$ Member; Fm = Formation).

Appendix 6.2 Figure 4 Albion Glacigenic Group: volume change for various stratigraphic units (NP = non-plastic). Geological unit codes are explained in Appendix 6-1 Table 1.

Appendix 6.2 Figure 5 Albion Glacigenic Group: angle of internal friction vs plasticity index for various stratigraphic units.

Appendix 6.2 Figure 6 Albion Glacigenic Group: undrained shear strength vs depth for various stratigraphic units.

Appendix 6.2 Figure 7 Albion Glacigenic Group: undrained shear strength extended box and whisker plot for various stratigraphic units. Geological unit codes are explained in Appendix 6.1 Table 1.

Appendix 6.2 Figure 8 Caledonia Glacigenic Group: consistency for various stratigraphic units $($ wke $=$ extremely weak; stivwke $=$ very stiff to extremely weak; stiv = very stiff; stistiv $=$ stiff to very stiff; sti = stiff; frmsti $=$ firm to stiff; frm = firm; sftfrm = soft to firm; sft $=$ soft; sftvsft $=$ very soft to soft; sftv = very soft). Geological unit codes are explained in Appendix 6.1 Table 1. 
Appendix 6.2 Figure 9 Caledonia Glacigenic Group: density for various stratigraphic units (DENV $=$ very dense; DENDENV $=$ dense to very dense; DEN $=$ dense; DENMDEN $=$ moderately dense to dense; LSDENM = loose to moderately dense; LS = loose; LSVLS = very loose to loose; LSV = very loose). Geological unit codes are explained in Appendix 6.1 Table 1.

Appendix 6.2 Figure 10 Caledonia Glacigenic Group: lithology for various stratigraphic units.

Appendix 6.2 Figure 11 Caledonia Glacigenic Group: volume change for various stratigraphic units $(\mathrm{NP}=$ non-plastic). Geological unit codes are explained in Appendix 6.1 Table 1.

Appendix 6.2 Figure 12 Caledonia Glacigenic Group: angle of internal friction vs plasticity index for various stratigraphic units.

Appendix 6.2 Figure 13 Caledonia Glacigenic Group: undrained shear strength vs depth for various stratigraphic units $(\mathrm{Sg}=$ Subgroup).

Appendix 6.2 Figure 14 Caledonia Glacigenic Group: undrained shear strength extended box and whisker plot for various stratigraphic units. Geological unit codes are explained in Appendix 6.1 Table 1.

Appendix 6.2 Figure 15 Albion and Caledonia Glacigenic Groups: undrained shear strength extended box and whisker plot for various stratigraphic units. Geological unit codes are explained in Appendix 6.1 Table 1.

Appendix 6.3 Figure 1 Particle size distribution for glaciofluvial sand and gravel in $100 \mathrm{~km}$ grid square NO.

Appendix 6.3 Figure 2 Particle size distribution for glaciofluvial sand and gravel in $100 \mathrm{~km}$ grid square NT.

Appendix 6.3 Figure 3 Particle size distribution for glaciofluvial sand and gravel in $100 \mathrm{~km}$ grid square NY.

Appendix 6.3 Figure 4 Particle size distribution for glaciofluvial sand and gravel in $100 \mathrm{~km}$ grid square NZ.

Appendix 6.3 Figure 5 Particle size distribution for glaciofluvial sand and gravel in $100 \mathrm{~km}$ grid square SD.

Appendix 6.3 Figure 6 Particle size distribution for glaciofluvial sand and gravel in $100 \mathrm{~km}$ grid square SE.

Appendix 6.3 Figure 7 Particle size distribution for glaciofluvial sand and gravel in $100 \mathrm{~km}$ grid square $\mathrm{SJ}$.

Appendix 6.3 Fig. 8 Particle size distribution for glaciofluvial sand and gravel in $100 \mathrm{~km}$ grid square SK.

Appendix 6.3 Fig. 9 Particle size distribution for glaciofluvial sand and gravel in $100 \mathrm{~km}$ grid square SO.

Appendix 6.3 Fig. 10 Particle size distribution for glaciofluvial sand and gravel in $100 \mathrm{~km}$ grid square SP.

Appendix 6.3 Figure $11 \mathrm{SPT}$ 'N' value for glaciofluvial sand and gravel in $100 \mathrm{~km}$ grid square NH. Appendix 6.3 Figure $12 \mathrm{SPT}$ 'N' value for glaciofluvial sand and gravel in $100 \mathrm{~km}$ grid square NT. Appendix 6.3 Figure 13 SPT 'N' value for glaciofluvial sand and gravel in $100 \mathrm{~km}$ grid square NU. Appendix 6.3 Figure 14 SPT 'N' value for glaciofluvial sand and gravel in $100 \mathrm{~km}$ grid square NY. Appendix 6.3 Figure 15 SPT 'N' value for glaciofluvial sand and gravel in $100 \mathrm{~km}$ grid square NZ. Appendix 6.3 Figure 16 SPT 'N' value for glaciofluvial sand and gravel in $100 \mathrm{~km}$ grid square SD. Appendix 6.3 Figure 17 SPT 'N' value for glaciofluvial sand and gravel in $100 \mathrm{~km}$ grid square SE. Appendix 6.3 Figure $18 \mathrm{SPT}$ 'N' value for glaciofluvial sand and gravel in $100 \mathrm{~km}$ grid square SJ. Appendix 6.3 Figure 19 SPT ' $N$ ' value for glaciofluvial sand and gravel in $100 \mathrm{~km}$ grid square SK. Appendix 6.3 Figure $20 \mathrm{SPT}$ 'N' value for glaciofluvial sand and gravel in $100 \mathrm{~km}$ grid square SO. Appendix 6.3 Figure 21 SPT 'N' value for glaciofluvial sand and gravel in $100 \mathrm{~km}$ grid square SP. Appendix 6.3 Figure 22 SPT ' $N$ ' value for glaciofluvial sand and gravel in $100 \mathrm{~km}$ grid square SS. Appendix 6.3 Figure $23 \mathrm{SPT}$ ' $\mathrm{N}$ ' value for glaciofluvial sand and gravel in $100 \mathrm{~km}$ grid square TL. 


\section{Chapter 6 Table captions}

Table 6.1 Geological and geotechnical characteristics of genetic till types (after Clarke 2012). This classification is not recommended in this book, as explained in Chapter 4 Section 4.1.1.

Table 6.2 Lithostratigraphy, previous name, area of occurrence, thickness and description of Caledonia Glacigenic Group tills.

Table 6.3 Lithostratigraphy, previous name, area of occurrence, thickness and description of Albion Glacigenic Group Tills.

Table 6.4 Multiple till units in northern England (after Hughes et al. 1998).

Table 6.5 Examples of superimposed till units in different regions of Britain.

Table 6.6 Glacial till units and references from the literature.

Table 6.7 Variation in geotechnical index properties in the Oadby Till Member of the Wolston Glacigenic Formation (formerly Chalky Boulder Clay) at Milton Keynes using small scale sampling grids (from Denness 1974) compared with data from the whole of the Oadby Till Member from the BGS Geotechnical Properties Database.

Table 6.8 Some engineering geological characteristics of the Caledonia Glacigenic Group tills.

Table 6.9 Some engineering characteristics of tills of the Albion Glacigenic Group.

Table 6.10 Engineering geological descriptions and summary geotechnical properties for glacial sand and gravel locations in England and Wales.

Table 6.11 Potential deposits to be found in a glaciolacustrine landsystem.

Table 6.12 Some engineering properties of various UK glaciolacustrine deposits (after Reeves et al. 2006). Where three values are given they are the maximum, mean and minimum.

Table 6.13 Glaciolacustrine lithostratigraphic units shown on British Geological Survey 1:10,000 and/or 1:50,000 scale maps (after McMillan et al. [2011]).

Table 6.14 Typical geotechnical properties of clays demonstrating Quick Clay behaviour.

Table 6.15 Legend description of Brickearth and possible Brickearth-like deposits on various editions of British Geological Survey 1:50 000 scale geological maps of South and South East England: Norfolk, Suffolk, Essex, Surrey, Kent, Hampshire, Sussex, Kent and parts of Bedfordshire, Buckinghamshire, Cambridgeshire, Devon, Hertfordshire and Oxfordshire from which Figs $6.15 \mathrm{~b}$ (i) and $6.15 \mathrm{~b}$ (ii) were derived.

Table 6.16 Summarised geotechnical index properties properties of loess from various locations worldwide (from Bell 2000).

Table 6.17 Methods of treating collapsible loess ground (after Jefferson et al. 2005).

Table 6.18 Diagnostic criteria for pingo scars.

Table 6.19 Some British examples of relict cryogenic mounds.

Table 6.20 Engineering geological characteristics of relict cryogenic mounds.

Appendix 6.1 Table 1 Summary list of codes and names of stratigraphic units described in endixendix 6-1. The codes can be used to identify formations and members for which geotechnical data are given in some of the figures. 


\section{Appendix 6.1 Summary Description Of British Till Formations And Members}

\section{A6.1.1 Caledonia Glacigenic Group (CALI)}

\section{A6.1.1.1 Shetland Glacigenic Subgroup (SHETG)}

\section{Burrier Wick Till Formation (BWTI)}

Description: Firm to stiff, sometimes very stiff or hard, sandy CLAY with gravel and cobbles often with a few cobbles and boulders but boulders may be locally common. Gravel is usually fine to medium.

Or: Dense, brown very clayey, sandy GRAVEL with cobbles.

Colour: Pinkish grey, greyish brown, orangish brown, green.

Boulders: Sandstone, felsites, schist, mudstone, granite (local bedrock).

Extent: Shetland

Thickness: Up to $10 \mathrm{~m}$ commonly thin and patchy in some places.

\section{A6.1.1.2 Northwest Highlands Glacigenic Subgroup (NWHG)}

\section{Assynt Glacigenic Formation (ASGL)}

Description: Heterogeneneous, red brown to dark grey, gravelly sandy SILT or CLAY with cobbles and boulders to silty, gravelly SAND with cobbles and boulders. Contains sand and gravel beds.

Clasts locally derived generally strong or very strong of Lewisian Gneiss, Torridon Group sandstone, Eriboll Formation sandstone, Moine Super Group psammite, Durness Group limestone, Canisp Porphory Sill, Loch Borralan Pluton syenite and other minor igneous rocks.

Thickness range: 0.5 to $7.8 \mathrm{~m}$.

Distribution and extent: Patchy and discontinuous extent across Wester Ross and western Sutherland, west of main Highland watershed. Extends offshore.

\section{Reay Burn Till Formation (REBU)}

Description: Firm to very stiff, reddish brown to light yellowish brown gravelly, sandy or very sandy CLAY or SILT or silty, gravelly SAND with some angular to subrounded cobbles and boulders. Sand is fine to coarse and gravel is angular to subrounded, fine to coarse. Boulders are generally medium to very strong of the local country rock, Devonian sandstone, siltstone and mudstone over Devonian rocks, igneous rocks over Caledonia igneous rocks and metamorphic rocks over the Moine Supergroup where overlying Caledonia.

Type area/section: River cliff on the western side of Reay Burn [NC 960 652] about $50 \mathrm{~m}$ upstream of the mouth of Mean High Water Springs, Sanside Beach.

Reference section: Cliff section on the eastern side of Sunside Bay [NC 9686 6576], about $200 \mathrm{~m}$ north of the mouth of the Burn of Isauld.

Thickness: Up to $10 \mathrm{~m}$.

Distribution and extent: Caithness and Sutherland mainly east of a line between Reay and Berridale.

\section{Thormaid Till Member (THTI)}

Description: Firm to stiff, olive grey sometimes mottled reddish brown and light brownish grey, gravelly sometimes very gravelly and sandy SILT, or, sometimes gravelly, sandy, silty CLAY or very silty, gravelly SAND, all with cobbles and boulders. Very coarse material is weak to very strong, sometimes extremely strong, of tabular sandstone, siltstone and red mudstone, rounded granite and psammite. In some situations, boulders and cobbles are weakened during post depositional weathering; mudstone and siltstones become extremely weak to very weak. Thickness: Generally less than $3 \mathrm{~m}$ but up to $5 \mathrm{~m}$.

Distribution and extent: Caithness and Sutherland west of a line between Reay and Berrisdale. 


\section{A6.1.1.3 Western Isles Glacigenic Subgroup (WISG)}

\section{Port Beag Till Formation (PBTI)}

Description: Reddish brown, gravelly sandy CLAY or SILT with a few cobbles and boulders. Boulders of strong to very strong, sometimes extremely strong Torridon Group sandstone. Interbedded and locally glaciotechnically deformed sequence of shelly till, silt, sand and gravel. Distribution: Northern Lewis, north-east of a prominent moraine and eastern part of Eye Peninsula. Type section: Cliff top at Port Beag on the south side of Tosta Head peninsula [NB 557 468], Isle of Lewis.

Thickness: Up to $25 \mathrm{~m}$.

\section{Lewis Till Formation (LEWTI)}

Description: Stiff to very stiff, greyish brown, sandy CLAY or SILT with cobbles and boulders. Cobbles and boulders are very strong to extremely strong, subangular mainly of Lewisian gneiss. Generally containing more coarse material towards the base where boulders up to $2 \mathrm{~m}$ across are common.

Type section: Sea cliff section at the head of Holm Bay, Holm [NB 453 307], $4 \mathrm{~km}$ south east of Stornoway, Isle of Lewis.

Thickness: Up to $6 \mathrm{~m}$.

Distribution and extent: The Western Isles archipelago.

\section{A6.1.1.4 Inverness Glacigenic Subgroup (INVG)}

\section{Finglack Till Formation (FINT)}

Description: Stiff, yellowish brown, gravelly, sandy CLAY, sometimes with cobbles or firm, reddish brown to reddish yellow, gravelly sandy CLAY with many cobbles of Nairn Sandstone Formation sandstone.

Thickness: $8 \mathrm{~m}$ and more.

Distribution and extent: Cromarty and Beauly Firth.

\section{A6.1.1.5 Central Grampian Glacigenic Subgroup (CGDR)}

\section{Beinn An Uain Till Formation (BUTI)}

Description: Very dense, sometimes jointed, dark yellowish brown to olive grey, silty or clayey gravelly SAND, occasionally sandy GRAVEL with cobbles and boulders. Very coarse component typically strong to very strong of angular to subrounded gneissose psammite and semipelite, granite and Devonian sandstone and siltstone. Joints are concavo-convex and commonly sand filled. Thickness: Up to $10 \mathrm{~m}$.

Type area/reference section: River cliffs of the Allt Odhar [NH 798 368], $16 \mathrm{~km}$ south east of Inverness. River cliff section of the Allt Dearg, [NH 815452 to NH 816 454], 6 km south-west of Cordor, Nairnshire.

\section{Ardverikie Till Formation (ARDT)}

Description: Gravelly, sandy CLAY with angular to subrounded cobbles and boulders.

Reference section: River cliff of the confluence of the Allt Coire na Ceardaich and the River Mashie [NN5746 8441]

Thickness: Up to $12 \mathrm{~m}$.

Distribution and extent: Central Highland west of the Caringorms and Gaick Plateau.

\section{Gartocharn Till Formation (GATI)}

Description: Variable. At the reference site stiff to extremely weak, jointed, brown to dark brownish grey occasionally or slightly gravelly CLAY with marine shells with occasional cobbles and 
boulders. Elsewhere it can be gravelly, sandy CLAY with cobbles and boulders. The gravel and very coarse material is locally derived Devonian and Carboniferous from the Midland Valley or from the Highlands including Dalradian metamorphic rocks. Quaternary marine shells may occur locally. Boulders are medium strong to very strong.

Reference section: The BGS Main of Kilmarnock Borehole (BGS borehole NS48NW3) [NS 4483 8829].

Thickness: Up to at least $6 \mathrm{~m}$.

Distibution and extent: Loch Lomond and the Trossachs.

\section{A6.1.1.6 East Grampian Glacigenic Subgroup (EGD)}

\section{Banchory Till Formation (BATI)}

Description: Primarily, very dense, sandy GRAVEL or gravelly SAND or brown, grey or red brown gravelly, slightly sandy or sandy CLAY with occasional cobbles. Gravel is subangular to subrounded fine to coarse, cobbles are subangular of granite and gneiss Sometimes: Medium dense to very dense, pale to yellowish brown, greyish brown and brown clayey or silty sandy GRAVEL or gravelly SAND with cobbles and boulders.

Or: Very coarse and coarse angular to subrounded GRAVEL of pink granite, felsite, fine amphibolite and porphyritic felsite.

Type area: Banchory-Strachan area, Kincardineshire

Reference section: River cliff section of Burn of Granney, $400 \mathrm{~m}$ west of the Mill of Clinter.

Reference section: Small working, $400 \mathrm{~m}$ west-south west of Finzean House (BGS pit reference NO69SW2).

Thickness: Variable, generally 2 to $5 \mathrm{~m}$ but over $8 \mathrm{~m}$ in some places.

Distribution and extent: East Grampian Highlands.

\section{A6.1.1.7 Banffshire Coast And Caithness Glacigenic Subgroup (BCD)}

\section{Essie Till Formation (ESTI)}

Description: Firm to very stiff, dark bluish grey but mottled orange-brown near surface, calcareous, gravelly, sandy CLAY with occasional cobbles and boulders of red granite, quartzite and schistose metasediments with rare red marl, red sandstone and chalk. Rafts of red gravelly clay and black, fossilferous mudstone. Boulders weak to very strong.

Partial type section: BGS-registered borehole NK05SE9, drilled at Kinloch Farm, 4 km north-west of Peterhead [NK 0989 5093].

Thickness: Up to $10 \mathrm{~m}$.

Distribution and extent: Buchan, north-west Scotland, between Peterhead and Fraserburgh.

\section{Reisgill Burn Till Formation (REDR)}

Description: Firm to stiff, calcareous, sometimes shelly, reddish brown, brown or grey, gravelly SILT or CLAY with cobbles and boulders. Coarse fraction Devonian sandstone and siltstone and Mesozoic erratics. Boulders medium strong to very strong.

Type Sections: Stream section at Ellanmore, Reisgill Burn [ND 237 370], Reisgill Burn [ND 230 359] to [ND 220 390], inland of Lybster, Caithness.

Thickness: Up to $25 \mathrm{~m}$.

Extent and distribution: Orkney, Caithness and Sutherland north-east of a line between Reay and Berridale.

\section{Forse Till Member (FOTI)}

Description: Dark grey to olive grey and grey brown, gravelly, sandy SILT or CLAY with cobble and boulders of Devonian sandstone, Jurassic and lower Cretacous mudstone, siltstone and shell fragments, Moine metamorphic and Caledonian igneous rocks. Coarse fraction weak to very strong, 
metamorphic rocks can be extremely strong.

Type section: Stream section at Forse, south of Lybster on the east coast of Caithness [3217 9342].

Reference section: River cliff on the eastern bank of the Forss Water, $300 \mathrm{~m}$ south east of the confluence with the Burn of Brimside, between Reay and Thurso on the north coast of Caithness. Thickness: up to $25 \mathrm{~m}$.

Distribution and extent: Caithness and Sutherland, north east of a line between Reay and Berridale.

\section{A6.1.1.8 Logie-Buchan Glacigenic Subgroup (LBD}

\section{Hatton Till Formation (HATT)}

Description: Firm to very stiff, light brown, brown or red, calcareous, gravelly, sandy CLAY with occasional cobbles and rare boulders, sometimes with shell fragments. Gravel, cobbles and boulders are subangular to subrounded fine to coarse, of mixed weak to strong or very strong, Devonian sandstone, Mesozoic mudstone and limestone.

Type area/Reference section: Abandoned railway cutting of Bellscamphie [NK 0184 3368] and BGS borehole NK03SW11 7 km east-north-east of Ellon [NK 0418 3156].

Thickness: at least $10 \mathrm{~m}$ thick in some places.

Distribution and extent: Coastal lowland north of Aberdeen, east of Ellon and south of Peterhead.

\section{A6.1.1.9 Mearns Glacigenic Subgroup (MDR)}

\section{Mill of Forest Till Formation (MFT)}

Description: Reddish brown, sandy gravel or gravelly SAND or clayey GRAVEL with clayey gravel with cobbles or gravelly, sandy CLAY with cobbles and boulders. Boulders mostly of strong to very strong Old Red Sandstone Supergroup sandstone .

Reference section: BGS trial pit NO77NW12, [NO 7110 7897], about 320 m south-west of Drumelzie Farm, near Auchenblae and trial pit reference number NO77NE11 [NO 7805 7966], 250 m north-east of East Mondynes.

Thickness: Very variable, generally 5 to $8 \mathrm{~m}$.

Distribution and extent: Howe of Mearns area and flanking the coastline between Stonehaven and the mouth of the River Dee, Aberdeenshire.

\section{A6.1.1.10 Midland Valley Glacigenic Subgroup (MVG)}

\section{Wilderness Till Formation (WITI)}

Description: Firm to extremely weak, sometimes jointed, reddish brown (if composed of Devonian and Upper Coal Measures), brownish grey or dark grey (if composed of other Carboniferous rocks), or greenish grey (if composed of Highland metamorphic rocks), gravelly, sandy CLAY or SILT or MUDSTONE with cobbles and boulders. May contain beds of medium sand or laminated clay up to $100 \mathrm{~mm}$ thick. It may be locally graded, either coarsening upwards or downwards with occasional gravel to boulder size. Very occasional firm to stiff, laminated CLAY beds up to $10 \mathrm{~m}$ thick and several 10's of metres in extent near the base of the formation.

Reference section: BGS Belshill Borehole BGS borehole NS 76SW 451 [NS 7304 6161].

Thickness: $30 \mathrm{~m}$ or more particularly in drumlins.

Distribution and extent: Midland Valley of Scotland, north Ayreshire to Stirling, Tayside, the Lothians and Fife.

\section{A6.1.1.11 Southern Uplands Glacigenic Subgroup (SUDR)}

\section{Langholm Till Formation (LHTI)}

Description: Firm to very stiff, light yellowish brown to pale grey yellow, gravelly with cobbles, sandy CLAY with cobbles and boulders or light yellow grey to yellow brown, sandy GRAVEL or 
gravelly SAND (New Abbey Member). Cobbles and boulders are of subangular to subrounded sandstone, siltstone and other rocks form the Southern Uplands.

Type section: River cliff on the southern side of the Hoghill Burn, $1 \mathrm{~km}$ upstream of Hoghill Farm [NY 3820 8905].

Thickness: Up to $15 \mathrm{~m}$.

Distribution and extent: Southern Uplands of Scotland.

New Abbey Till Member (NATI)

Description: Light yellow grey to yellow brown sandy GRAVEL or gravelly SAND with cobbles of granodiorite.

Distribution and extent: Restricted to the South of Scotland plutons of Criffel, Fell of Fleet and Mullwarchar in Dumfries and Galloway.

\section{A6.1.1.12 Cheviot Glacigenic Subgroup (CHVG)}

\section{Kale Water Till Formation (KWTI)}

Description: Stiff to extremely weak, gravelly, sandy CLAY or MUDSTONE with cobbles and boulders. Cobbles and boulders are strong to very strong, sometimes extremely strong, subangular to subrounded and dominated by local andesite, basalt and quartz; sandstones and other sedimentary rocks from the Carboniferous Ballagan Formation.

Type section: East bank of the Kale Water [NT 7694 1561]. South of Swanlaws; at least 3 m of till with boulders.

Thickness: At least $3 \mathrm{~m}$.

Distribution and extent: Valley of the Kale Water, Cheviot Hills.

\section{A6.1.1.13 Borders Glacigenic Subgroup (BDRGL)}

\section{Norham Till Formation (NMTI)}

Description: Firm to very stiff, dark red, gravelly, sandy CLAY with cobbles up to $100 \mathrm{~mm}$ across. The very coarse fraction is of subrounded to subangular of sandstone, quartz and mudstone.

Type section: Top of bank on the north side of the River Tweed [NT 0054 7821], north of Norham, Berwickshire.

Reference section: Pressen Farm [NT 836 359], Northumberland.

Thickness: Up to $4 \mathrm{~m}$.

Distribution and extent: Merse of Berwickshire - the lowlands of the eastern Borders and North Northumberland, west of the coastal strip.

\section{A6.1.1.14 Central Cumbria Glacigenic Subgroup (CCGL)}

\section{Greystoke Till Formation (GYTI)}

Description: Firm to very stiff, grey, gravelly, sandy CLAY with cobbles and boulders. Cobbles and boulders are medium strong to very strong, sometimes extremely strong, of Lake District volcanoclastic rocks and Carboniferous and medium stong to strong Permo-Triassic sandstone also as described in the Edenside Till Member.

Type section: West Bank of Gillcambon Beck [NY 3888 3474], 275 m south east of the Newsham Bridge.

Thickness: Generally up to $10 \mathrm{~m}$.

Distribution and extent: The Vale of Eden and southern Solway lowlands north of the 'Scottish Readvance' limit. 
of Eden, mostly medium strong to strong Permo-Triassic sandstone but also strong to very strong, sometimes extremely strong Carboniferous limestone and sandstone, lake District andesitic lava, welded tuff and rare granodiorite, granite and sandstone from Galloway, Scotland.

Thickness: Up to $20 \mathrm{~m}$.

Distribution and extent: Vale of Eden north-west of Appleby-in Westmorland and south of Carlisle and ground mostly underlain by Permo-Triassic rocks.

\section{Threlkeld Till Formation (TKTI)}

Description: Firm to very stiff, fissured near surface, brown, olive-grey, weathering to yellowish grey or brown gravelly CLAY or SILT with cobbles and boulders Might include beds of dense, silty sand and gravel and sandy, gravelly cobbles and boulders that are medium strong to very strong, sometimes extremely strong mainly Borrowdale Volcanic Group rocks and local slate or Trelkeld microgranite.

Partial Type localities: River cliff sections in the Barrow Beck [NY 370 290], $3 \mathrm{~km}$ northwest of Troutbeck Head, Cumbria. River cliff sections in the banks of the Mosedale Beck [NY 3556 2388], $3 \mathrm{~km}$ south of Wallthaite, Cumbria.

Thickness: Up to $25 \mathrm{~m}$.

Distribution and extent: North east Lake District, Cumbria.

\section{Blengdale Glacigenic Formation (BLGL)}

Description: Interbedded units of: Firm, dark reddish brown CLAY with angular gravel. Occasional cobbles and boulders of Borrowdale Volcanic Group rocks, granite and granophyres from the Lake District and firm, laminated, dark reddish brown CLAY with inter-laminations of silt and reddish brown sand and reddish brown interbedded units of gravelly, sandy CLAY with SAND and GRAVEL, and SILT and CLAY beds.

Partial type sections: Waterfall in deep gulley on eastern side of Blengdale [NY $08600543,120 \mathrm{~m}$ downstream of Bleng Bridge, Lake District. $40 \mathrm{~m}$ high section in side of drumlin on west bank of the River Belah [SD 4945 8080], south of Milnthorpe centre. BGS borehole SD19NW11 (Aikbank Farm Borehole 1) [SD 1008 9988], from 49.2 to $55.1 \mathrm{~m}$ depth.

Thickness: Up to $40 \mathrm{~m}$

Distribution and extent: Western side of the Lake District and at depth beneath Lower Wasdale.

\section{Kendal Till Member (KLTI)}

Description: Stiff, yellowish brown, reddish brown or dark grey, sandy CLAY with cobbles and boulders with a few gravel beds. Coarse material angular to rounded. Very coarse particles, strong to very strong, sometimes extremely strong, locally derived rhyolite, welded tuff, slate, granite, sandstone, siltstone conglomerate and limestone. Large boulders are not uncommon as individuals or as trains. They can be up to $3 \times 2 \times 1 \mathrm{~m}$ commonly consisting of very strong sandstone of the Silurian but also rocks from the Borrowdale Volcanic Group and Shap Granite.

Thickness: Generally $5 \mathrm{~m}$ thick but up to $40 \mathrm{~m}$ thick in drumlins.

Distribution and extent: Southern Lake District east of Duddon, including the Lancashire coast north of Carnforth and east to the foot of the Pennines.

\section{A6.1.1.15 North Pennine Glacigenic Subgroup (NPEG)}

\section{Acklington Till Formation (ANTI)}

Description: Generally stiff to very stiff, dark brown or purplish brown, weathering to reddish brown with vertical prismatic jointing, gravelly sandy CLAY with low cobble and boulder count. The cobbles and boulders are medium strong to very strong, mainly of Carboniferous Fell Sandstone Formation, brown sandstone, pinkish grey siltstone, limestone and dolerite, other Carboniferous rocks of yellow sandstone, black mudstone, coal, seat earth and white sandstone, purple porphyry and andesite from the Cheviots and sandstone and siltstones from the Southern 
Uplands. Contains SAND and GRAVEL, and CLAY and SILT beds or lenses. The fine-grained beds are typically up to $1.5 \mathrm{~m}$ thick but may be up to $12 \mathrm{~m}$ thick, typically fining up and sheared or folded. Up to 7 cyclic sequences have been recorded.

Type section: Burried valley exposure in the former Maiden's Hall opencast coal site [NZ 2370 9845 to NZ 2370 9815], $13 \mathrm{~km}$ north-north east of Morpeth, Northumberland.

Thickness: Up to $25 \mathrm{~m}$

Distribution and extent: The coastal lowlands of Northumberland, north of the River Tyne, but excluding the coastal fringe.

\section{Wear Till Formation (WETI)}

Description: Mixed: Firm to extremely weak, dark greyish brown to dark yellowish brown, gravelly, sandy CLAY SILT or MUDSTONE with cobbles, boulders and sometimes rafts of local rock near the base. Cobbles and boulders are mostly weak to very strong of Carboniferous sandstone, fine gravelly sandstone, limestone, mudstone and coal but also Whin Sill dolerite and rocks from Scotland and the Lake District (sandstone, siltstone, granite and granodiorite).

Beds or lenses of loose to very dense, light brown or grey, silty SAND, SAND and GRAVEL. Beds of dark brown, soft to stiff thinly laminated CLAY.

Type section: River section along the Winch Gill [NZ 3072 4572], a minor tributary of the River Wear, south-south-west of Learnside, Durham City.

Thickness: Generally 3 to $10 \mathrm{~m}$ but locally up to $30 \mathrm{~m}$.

Distribution and extent: Lowlands of County Durham and southern Northumberland west to the Pennines.

\section{Butterby Till Member (BUTTI)}

Description: Firm to very stiff, brown, gravelly sandy CLAY with low cobble and boulder content. The very coarse fraction is composed of weak to very strong, sometimes extremely strong rocks from the Lake District (andesite, tuff and granite), southern Scotland (sandstone and granodiorite) and Triassic to Devonian rocks (sandstone, fine gravelly sandstone, limestone, mudstone and coal). It is commonly intercalated with firm to stiff, laminated dark grey SILT and CLAY beds possibly of the Tyne and Wear Glaciolacustrine Formation and lenses of medium dense to very dense SAND and GRAVEL.

Thickness: Up to $15 \mathrm{~m}$.

Distribution and extent: Coastal Lowlands not including the coastal strip between the River Tyne to a little south of the River Tees.

\section{Stainmore Forest Till Formation (SFTI)}

Description: Firm to extremely weak, bluish grey or reddish brown, gravelly, sandy CLAY or MUDSTONE with cobbles and boulders. The very coarse fraction is of weak to very strong mostly locally derived Carboniferous sandstone, conglomerate, limestone, mudstone, and coal with Whin Sill dolerite and far-travelled rocks from southern Scotland, the Lake District and the Vale of Eden. Minor SAND and GRAVEL beds or lenses.

Type area: The Stainmore Gap west of Barnard Castle and Teesdale [NY 800300 to NY 200 050].

Partial type section: River cliff section in a drumlin on the northern bank of the River Tees immediately downstream from the confluence with the Harwood Beck [NY 861 296].

Thickness: Up to $50 \mathrm{~m}$, may be thicker in buried valleys.

Distribution and extent: Stainmore Gap to the west of Darlington, and Teesdale upstream of Barnard Castle, extending towards the Vale of York.

\section{Yorkshire Dales Formation (YDTI)}

Description: Firm to extremely weak, dark grey to greyish brown, gravelly, sandy CLAY or MUDSTONE with cobbles and boulders. Very coarse material is generally weak to very strong, sometimes extremely strong, of local Carboniferous rocks (limestone, sandstone, fine gravelly 
sandstone and mudstone). Some clasts of sandstone and siltstone from the Howgill Fells occur in till in upper Wensleydale, Yorkshire.

Type area: The Yorkshire Dales south of the Stainmore Gap between Appleby-in-Westmorland and Barnard Castle [NY 790145 to NY 990 130] and north of the Devensian glacial limit.

Partial type section: River cliff section in a drumlin on a northern bank of the Widdale Beck at its confluence with the Snaiseholme Beck [SD 834 886], 4 km south-west of Hawes.

Thickness: Generally less than $10 \mathrm{~m}$.

Distribution and extent: The Yorkshire Dales south of the Stainmore Gap and north of the

Devensian glacial limit.

\section{Vale of York Formation (VYORK)}

Description: Firm to very stiff, gravelly, sandy CLAY with cobbles and boulders or sandy CLAY or loose to dense, occasionally very dense, clayey SAND with interbeds of medium dense to dense SAND and GRAVEL and soft to very soft, laminated CLAY. The sand and gravel and laminated clay lithologies may be thicker in some areas and incorporated in the till sheet and moraines.

Reference section: The Park farm borehole SE46SW52 [SE 4049 6429], 2 km south-south-east of Boroughbridge.

Partial type section: Grafton Gravel Quarry [SE 4200 6310], about 220 m south-east of Grafton village.

Thickness: Generally 10 to $30 \mathrm{~m}$ thick but up to $50 \mathrm{~m}$ in moraines.

Distribution and extent: Vale of York north to Teesside, southwards to the Escrick Moraine.

\section{A6.1.1.16 North Sea Coast Glacigenic Subgroup (NSG)}

\section{Horden Till Formation (HNTI)}

Description: Firm to very stiff, dark brown or purple brown and reddish brown where weathered, gravelly sandy CLAY with cobbles and rare boulders. The very coarse fraction is weak to very strong, mostly of Zechstein Group (limestone and dolostone) Carboniferous sandstone, siltstone, mudstone and limestone and Cheviots (purple porphyry). With minor sand and gravel beds and laminated clay and silt.

Might be inter-digitated with the Tyne and Wear Glaciolacustrine Formation in the west.

Type section: Cliff section near Warren House Gill [NZ 44654250 to NZ 4464 4224], 490 m south of Horden Point.

Thickness: Up to $12 \mathrm{~m}$.

Distribution and extent: Coast of County Durham and southern Northumberland.

\section{Holderness Formation (HOLD)}

Description: Firm to stiff, slightly red or grey, gravelly, sandy CLAY with occasional cobbles and boulders. Medium dense SAND or sandy GRAVEL or firm to stiff SILT beds occurs between the Skipsea and Withernsea Till members and SAND and GRAVEL beds may occur elsewhere. Type section: Dilmington Cliff [TA 376 237]. The cliffs of the Holderness coast and north east Yorkshire coast are commonly affected by landslides, which may obscure the in situ Holderness Formation.

Thickness: From about $10 \mathrm{~m}$ to about $70 \mathrm{~m}$ at Dilmington.

Distribution and extent: The low land of east Yorkshire south of the Tees valley, Linclonshire and north-west Norfolk.

Bridlington Member (no code as does not crop out at surface and, so, does not appear on geological maps)

Description: Stiff to very stiff, grey to dark greyish brown or very dark greyish brown, gravelly, sandy CLAY with low or medium cobble and boulder content. Very coarse particles of chalk, flint, Zechstein Group dolomitic limestone, Carboniferous limestone, occasional Scottish rocks. 
Occasional sand and gravel beds.

Type Section: None. May be seen at the base of the cliff near Dilmington, at Bridlington or north of Whitby depending on the height of the beach and local landslides.

Distribution and extent: East Yorkshire coastal areas including Holderness.

Previous name: Basement Till

\section{Skipsea Member (SKTI)}

Description: Firm to stiff, sometimes banded or sheared, red and darkish red, gravelly, sandy CLAY with a few cobbles and boulders. Boulders of Carboniferous limestone, sandstone and occasional coal and Jurassic sandstone.

Type section: Dilmington Cliff [TA 376 237].

Distribution and extent: The east Yorkshire coast, Holderness and low lying Lincolnshire.

\section{Withernsea Member (WSTI)}

Description: Firm to stiff, purple or reddish purple, sandy or slightly sandy clay with occasional cobbles.

Type section: Dilmington Cliff [TA 376 237].

Distribution and extent: Along the East Yorkshire coast between Filey and Flamborough Head and along the coast from south of Hornsea to south of Easington and inland to Keyingham on the Skipsea Member.

\section{Holkham Till Member (HOTI)}

Description: Firm to stiff or very stiff, reddish brown, gravelly, sandy clay with a low cobble count. Gravel and cobbles are of chalk, flint, and Carboniferous sandstone, siltstone and Triassic sandstone with a variety of igneous and metamorphic rocks.

Type section: Holkham Park Brick Pit, Holkham Estate [TF 8630 4280].

Reference section: Cliffs at Hunstanton [TF 6730 4130].

Thickness: Up to $10 \mathrm{~m}$.

Distribution and extent: Along much of the northern coast of Norfolk from west of Hunstanton to Moston.

Alternative names: Hunstanton Till, Holkham Till.

\section{A6.1.1.17 Irish Sea Coast Glacigenic Subgroup (ISCG)}

\section{Jurby Formation (JURBY)}

Description: Stratigraphically complex sequence includes gravelly, sandy CLAY or SILT, laminated glaciolacustrine CLAY with a little or occasional gravel, interstratified gravelly SAND and SILT and CLAY and gravelly CLAY. The till generally makes up a subsidiary part of the formation. Type section: Coastal cliff section at Jurby Head, about $1 \mathrm{~km}$ west of the village of Jurby West, west Isle of Man [SC 343 980].

Thickness: Probably over $10 \mathrm{~m}$.

Distribution and extent: Northern part of the Isle of Man, the lowland around Stranraer, between Loch Ryan and Luce Bay, and at Drunmore and Mull of Galloway.

\section{Gretna Till Formation (GRET)}

Description: Extremely weak to stiff, reddish brown, or yellowish brown gravelly fine sandy CLAY or MUDSTONE with cobbles and occasional boulders. Gravel content is variable. Cobbles and boulders are weak to very strong, occasionally extremely strong, angular to round most commonly of Southern Upland sandstone and siltstone with lesser proportions of Permo-Triassic red sandstone and red and purple siltstone and occasional south west Scotland pluton granite and granodiorite and Permian and Carboniferous andesite and basalts and dolerite form dykes. Minor sand and gravel beds. 
Partial type section: River cliff section of the Logan Burn [NY 3110 7181], $1.5 \mathrm{~km}$ south of Chapelknowe, Dumfries and Galloway.

Partial type section: Plumpe Farm [NY 3344 6183], 1 km east of Gretna, Dumfries and Galloway. Thickness: Up to $20 \mathrm{~m}$.

Distribution and extent: Solway lowlands.

\section{Gosforth Glacigenic Formation (GOGL)}

Description: Complex and variable.

Firm to very stiff but may be extremely weak, red and grey, greyish brown or dark greyish brown, sometimes calcareous, slightly gravelly to gravelly, sandy CLAY or MUDSTONE, which may contain cobbles and occasional boulders. The gravel, cobbles and boulders are from Scotland, the northern Irish Sea, west Cumbrian coal field and the western Lake District.

Or: Firm thinly interbedded firm to stiff, grey brown CLAY, SILT and SAND with occasional cobbles and sand and gravel lenses.

Or: Greyish brown SAND or SAND and GRAVEL and occasional silt bands.

Type area: The coast between Seascale NY 040010 to SD 090 965], Holmrook and Ravenglass, west Cumbria.

Reference section: BGS Registered borehole SD09NE21 (Carleton Hall) [SD 08098 99036], on

eastern side of River Irt about $1 \mathrm{~km}$ south of Holmrook, west Cumbria.

Thickness: typically 10 to $20 \mathrm{~m}$, till units generally less than $5 \mathrm{~m}$ thick.

Distribution and extent: Lowland western Cumbria, from Whitehaven to Walney Island

Note: This complex sequence has several named members which are described as TILL or SAND or GRAVEL or SAND and GRAVEL or CLAY.

\section{Stockport Glacigenic Formation (STPTG)}

Description: Mixed sequence

Firm to very stiff, red-brown, orange brown, and brown, gravelly, sandy CLAY with cobbles and boulders. Cobbles and boulders are strong to very strong possibly extremely strong of rocks from the Lake District (Borrowdale Volcanic Group, Eskdale Granite and Carboniferous rocks).

Or: Loose to very dense, orange brown, light greyish brown and reddish brown SAND, gravelly SAND and sandy GRAVEL.

Or: Soft to stiff, brown, laminated CLAY and SILT.

Type section: Northern bank of the River Mersey [SJ 908 915], east of Portwood, Greater

Manchester.

Thickness: Highly variable from $3 \mathrm{~m}$ to locally greater than $100 \mathrm{~m}$.

Distribution and extent: Lowlands of Lancashire, Cheshire, Staffordshire south to Wood Lane

Quarry, Ellesmere [SJ 422 328], north to south between Kirkham [SD 430 320] and west along the

North Wales coast to Rhyl, Denbighshire.

\section{Kirkham Till Member (KMGL)}

Description: Soft to extremely weak, sandy, gravelly CLAY or mudstone with cobbles and boulders. The cobbles and boulders are predominantly medium strong to very strong Borrowdale Volcanic Group, Eskdale Granite, Carboniferous rocks and rocks from the bed of the Irish Sea.

And: Firm to stiff, brown or sometime mottled grey, laminated CLAY and SILT.

And: Loose to dense, light brown or brown, SAND, gravelly SAND and sandy GRAVEL.

Type section: Kirkham, Lancashire [SD 343 432].

Thickness: Highly variable, up to $100 \mathrm{~m}$ in deeply incised valleys.

Distribution and extent: Lowlands of north Fylde, north of Blackpool and Kirkham.

\section{Brewood Till Formation (BDTI)}

Description: Firm to very stiff, reddish brown, dark brown or brown, gravelly, sandy CLAY with cobbles. Gravel and cobbles of weak to very strong Sherwood Sandstone Group, Kidderminster 
Formation (conglomerate) and South Uplands (grey granite) and the Lake District volcanic rocks (Eskdale Granite, Ennerdale Granophyre and slates) also limestone and flint.

Beds of: Firm to stiff, brownish grey or brown, laminated or thinly laminated CLAY.

Loose to very dense, orange brown, brown, reddish brown or grey SAND, gravelly SAND and sandy GRAVEL.

Type Section: Former sand and gravel quarry [SJ 916 082] on the north side of Saradon Brook, Four Ashes, Staffordshire.

Partial Section: Ketley Grange opencast site [SJ 690 100], Telford.

Thickness: $3 \mathrm{~m}$ at type section but up to $17 \mathrm{~m}$ at Madeley, Telford.

Distribution and extent: Along the eastern fringe of the Cheshire plain including east Manchester, Stockport, Stoke-on-Trent, Stafford and west to a little south of Market Drayton and Wem, south to the Devensian limit south of Bridgenorth and Wolverhampton.

\section{St. Asaph Glacigenic Formation (SAGL)}

Lleyn Till Member (LLEYN)

Description: Occasionally soft, firm to very stiff, generally calcareous, red, purple, bluish black or green-grey, gravelly, sandy, CLAY or SILT with occasional cobbles and boulders. Cobbles and boulders varied, commonly weak to very strong. The colour generally reflects the local bedrock geology.

Subordinate beds of: Loose to dense, brown clayey or silty SAND and medium dense to very dense, brown, orange brown, grey, clayey or silty gravelly sand or sandy gravel.

Soft to stiff, sometimes deformed or sheared, thickly or thinly laminated, light orangish brown, brown, grey, grey green, greenish grey, sometimes sandy, clay or silt or clay and silt with occasional gravel.

Type Section: Coastal cliff section in Porth Neigwl, Lleyn Peninsula [SH 2408 2838].

Reference section: Coastal cliff section at Traeth y Mwnt, Ceredigion [SN 1937 5192].

Thickness: Highly variable; more than $17 \mathrm{~m}$ in the Cardigan district and more than $30 \mathrm{~m}$ on the Lleyn Peninsula.

Distribution and extent: Coastal lowlands of North Wales west of the River Clwyd to the tip of the Lleyn Peninsula to Llanengan including Anglesey, and the coastal fringe of Ceredigion and Pembrokeshire approximately between Llanrystud and St. Brides Bay. The southern extent is sometimes called the Llangelynin Till Member.

\section{A6.1.1.18 Wales Glacigenic Subgroup (WALES)}

\section{Eryry Glacigenic Formation (ERYG)}

Description: Firm to very stiff, sometimes soft near surface, dark grey to blue-grey, weathering to light brown, greyish brown or orange brown, gravelly CLAY with cobble and boulders. Gravel, cobbles and boulders are typically medium strong to very strong, occasionally very strong, of Snowdonian Ordovician volcanic rock but locally of other Lower Palaeozoic rocks.

Beds of: Medium dense to very dense, dark brown, brown, yellowish brown or grey, clayey or silty gravelly SAND or sandy GRAVEL sometimes with cobbles and occasional boulders. Gravel is usually subangular to subrounded, fine to coarse.

Local beds of: Soft to stiff, laminated or poorly laminated, brown, light brown, mottled brown and grey or grey CLAY, silty CLAY or sometimes sandy CLAY

Type section: Pen-y-brn brickworks [SH 490 615], Caernarfon.

Thickness: Highly variable, may greatly exceed $10 \mathrm{~m}$ in some places.

Distribution and extent: Highlands of Snowdonia, Rhinogs and Cader Idris; eastern and southern Lleyn Peninsula.

\section{Plynlimon Glacigenic Formation (PLYNT)}

Description: Generally, firm to very stiff, blue grey or grey, weathering to yellowish brown, light 
reddish brown and yellow, gravelly sandy CLAY and clayey GRAVEL with cobbles and boulders. Gravel, cobble and boulders, medium to very strong, of Lower Palaeozoic rocks derived from the Cambrian Mountains.

Beds of: Medium dense to very dense sand and gravel.

Type section: Coastal section between Morfa Bychan and Mynachdy'r-graib in Cardigan Bay, Ceredigion [SN 56547749 to SN 5580 to 7482].

Thickness: Highly variable, locally in excess of $30 \mathrm{~m}$.

Distribution and extent: Denbighshire, Mid and west Wales, southwest Wales approximately north of Black Mountain and east of St Clears, Carmarthenshire and Llandysul, Ceredigion.

\section{Merion Till Member (MNTI)}

Description: Firm to very stiff, blue grey weathering to yellow, brown, orangish brown or mottled brown and grey, gravelly or very gravelly, sandy, CLAY and clayey GRAVEL with cobbles and boulders. The coarse fraction comprises medium to very strong, Lower Paleaozoic rocks from the Cambrian Mountains with occasional clasts from Snowdon and the Harlech Dome.

Partial type section: Stream section in a tributary of the River Elwy, midway between Dhol and Tyn'n-y-coed [SH 9994 7245].

Thickness: Highly variable, may exceed $30 \mathrm{~m}$ locally.

Distribution and extent: Mid and north-east Wales, and northern Welsh Borderlands.

\section{Ruabon Till Member (RBNTI)}

Description: Firm to very stiff grey or brown, calcareous, gravelly, sandy CLAY with cobbles and boulders. The cobbles and boulders are weak to very strong, mainly Carboniferous limestone, sandstone and mudstone.

Type Area: Till overlying Silurian (Wenlock) and Carboniferous bedrock west of the River Alyn (Bowen, 1999), [SJ 3050 4360].

Thickness: Variable, but generally less than $5 \mathrm{~m}$; may exceed this locally.

Distribution and extent: At surface, eastern Clwydian Hills, Denbighshire.

\section{Elenid Till Member (ELTI)}

Description: Firm to very stiff, bluish-grey or grey, weathering to brown, yellowish brown, greenish brown, slightly gravelly or gravelly, sandy CLAY or SILT, or gravelly CLAY or SILT with cobbles and boulders more likely near the base of the unit. Coarse fraction weak to very strong of Lower Palaeozoic clasts from the Cambrian Mountains.

Local beds of: Medium dense to very dense light orangish brown, brown, red, or grey, clayey SAND with occasional to some gravel or SAND and GRAVEL or sandy GRAVEL.

Occasional local soft to stiff, laminated, grey weathering to brown, dark brown or mottled brown and grey CLAY or SILT.

Partial type section: Coastal section between Morfa Bychan and Mynachdy'r-graib in Cardigan Bay, Ceredigion [SN 56547749 to SN 5580 to 7482].

Thickness: Highly variable, locally in excess of $30 \mathrm{~m}$.

Distribution and extent: Mid and west Wales, south west Wales approximately west of Swansea and including the Gower.

\section{Shrewsbury Glacigenic Formation (SHREW)}

Description: Firm to very stiff, gravelly sandy CLAY with cobbles and boulders. Cobbles and boulders are medium to very strong, consisting of Lower Palaeozoic rocks derived from the Welsh Massif.

Beds of: Loose to very dense greenish grey or grey weathering to light brown, reddish brown, orangish brown, slightly clayey or silty SAND, gravelly SAND or sandy GRAVEL.

Soft to very stiff, laminated, grey, dark grey, greenish grey, brown, dark brown, reddish brown CLAY or SILT, 
Type section: Mousecroft Lane Quarry [SJ 476 109], south west suburbs of Shrewsbury (Worsley, 2005).

Thickness: Up to about $6 \mathrm{~m}$.

Distribution and extent: Shropshire lowlands to the west of Shrewsbury and Dorrington and north to Four Cross and west of Wrexham.

\section{Brecknockshire Glacigenic Formation (BNOCK)}

Distribution and extent: Usk Valley west of Talybont, Swansea Bay, Cardiff, Newport, Fforest Fawr and Breacon Beacons.

\section{Hereford Till Member (HDTI)}

Description: Soft to very stiff, reddish brown, red, brown, light yellow, slightly gravelly or gravelly, slightly sandy or sandy SILT or CLAY with cobbles and occasional boulders. The coarse material is weak to very strong, from the Black Mountains, Fforest Fawr and Brecon Beacon sandstones of the Old Red Sandstone Supergroup and a few Lower Palaeozoic clasts.

Beds of: Loose to very dense, brown or reddish brown slightly gravelly or gravelly, clayey SAND. Gravel usually of sandstone.

Partial type section: 100 m north of Knapp Farm, Bishopstone, north of Garnon's Hill Brandon [SO 4132 4265].

Thickness: Generally less than $4 \mathrm{~m}$.

Distribution and extent: Herefordshire and the Brecon Beacons west of the River Lugg.

\section{Langland Till Member (LDTI)}

Description: Firm to very stiff, grey, greenish grey, dark grey, light brown, orangish brown, brown, slightly sandy or sandy CLAY or SILT with occasional to some gravel, cobbles and occasional boulders. The coarse material is of often strong or very strong sandstone of the Old Red Sandstone Supergroup from the Black Mountains, Fforest Fawr and Brecon Beacon with a few Lower Palaeozoic clasts. Sand and gravel beds occur locally.

Type section: Coastal section at Rotherslade in Langland Bay [SS 6130 8720], West Glamorgan. Thickness: Highly variable, locally up to $25 \mathrm{~m}$.

Distribution and extent: Brecon Beacons to Swansea Bay north and west of the South Wales Coalfield.

\section{Glamorgan Glacigenic Formation (GLGL)}

Description: Soft to very stiff, grey, pale grey, bluish grey, greenish grey, greyish brown, orange brown or brown, slightly gravelly to gravelly, slightly sandy to very sandy CLAY or SILT with some cobbles and boulders. The coarse material is weak to very strong Carboniferous sandstone; siltstone and mudstone from the South Wales Coalfield.

Beds of: Loose to very dense, brown or grey or greyish brown silty gravelly SAND and sandy GRAVEL

Local beds of: Firm to stiff, slightly gravelly, purplish red clay, silt and sand.

Type area: The valley of the Rhondda Fawt [SN 900200 to ST 100 900], Mid Glamorgan.

Thickness: May be up to $30 \mathrm{~m}$.

Distribution and extent: The South Wales Coalfield.

\section{A6.1.2 Albion Glacigenic Group (ALBI)}

\section{Happisburgh Glacigenic Formation (HPGL)}

Description: Variable sequence of glacial tills (Corton, Happisburgh and California Till Members), glaciofluvial sand and gravel (Happisburgh Sand and Leet Hill Sand and Gravel Members) and glaciolacustrine deposits (Banham Member). The Starston Till Member is beneath the Lowestoft Formation in the Diss and Harleston districts, south Norfolk. 
Firm to very stiff sometimes extremely weak, yellowish grey or grey, sandy CLAY, or clayey SAND. Firm to very stiff sandy CLAY.

Or: Soft to very stiff or extremely weak, thickly laminated brown CLAY or dense clayey SAND.

Or: Loose to dense SAND or SAND and GRAVEL.

Type section: Coastal cliff sections beneath Happisburgh lighthouse [TG 3900 3050] about $1 \mathrm{~km}$ south east of Happisburgh.

Thickness: Up to about $20 \mathrm{~m}$.

Distribution and extent: Between Great Yarmouth, North Walsham and Mundsley, west to Norwich and Diss areas and south to the Lowestoft district, east Norfolk and north Suffolk. Can be observed in cliffs between Pakefield [TG 950 905] (south Lowestoft) Suffolk to Overstrand, [TG 260 405] in north-east Norfolk.

\section{Happisburgh Till Member (HPTI)}

Description: Firm to stiff, sometimes very stiff, light, yellowish grey to grey, sandy CLAY with occasional subangular to rounded gravel $(<1 \%)$ with occasional pockets of clayey fine to coarse sand. Gravel composed predominantly of weak to very strong flint, quartz, quartzite with minor Carboniferous limestone, Carboniferous coal, Devonian Red Sandstone, Permian Red Sandstone, Permian 'Magnesian' limestone, felsic and basaltic porphyry, Dalradian metasediments.

Location: North east Norfolk, between Happisburgh and Overstand on the coast and inland to Norwich.

Thickness: Generally between 2 and $7 \mathrm{~m}$.

Previous names: Part of the first Cromer Till; Happisburgh Diamicton.

\section{Corton Till Member (COTI)}

Description: Firm to very stiff, thickly laminated, light olive-brown to olive-brown dark brown CLAY, very sandy CLAY or clayey SAND. Contains shell fragments and a little gravel chalk and of rounded flint.

Beds of: Sand, thin.

Sections: Cliff sections at Corton [TM 543 979], California Gap [TG 518 148] and Happisburgh [TG 390 305].

Distribution and extent: Lowestoft, Great Yarmouth and North Walsham districts. Along the east coast of Norfolk and Suffolk between Corton and Happisburgh.

Previous or other name: Norwich Diamicton

\section{Sheringham Cliffs Glacigenic Formation (SMCL)}

Description: Variable unit comprising till units (Becton Green, Hanworth, Runton and Weybourne Town Till members), glaciofluvial sand or sand and gravel units (Runton Sand and Gravel and Trimingham Sand Members) and glaciolacustrine, laminated silt and clay units (Ivy Farm Laminated Silt and Trimingham Clay Members).

Type locality: Coastal section between West Runton and Sheringham, north east Norfolk. Thickness: Up to $40 \mathrm{~m}$.

Distribution and extent: Northern Norfolk.

\section{Bacton Green Till Member (BGTI)}

Description: A stratified sequence of firm to extremely weak, slightly gravelly CLAY, MUDSTONE or clayey SAND. With reconstituted chalk incorporated into the till from stringers a few tens of millimetres wide to masses hundreds of metres across of the Weybourne Town Till Member. Rafts of upper part of the Chalk Group, many tens of metres wide and several metres thick occur, for instance a West Runton. It is highly tectonised with isoclinal folds, a few centimetres thick interbedded into the till.

Beds of: Loose to dense SAND, gravelly SAND or sandy GRAVEL. Firm to stiff laminated CLAY and SILT beds or laminae of sand, silt or clay. 
Thickness: Up to $15 \mathrm{~m}$.

Type section: Coastal cliff section about 800 m northwest of Bacton Green beneath the Bacton Gas terminal [TG 3340 3470], north east Norfolk.

Distribution and extent: Northeast Norfolk coast between Bacton Green and Sheringham.

Previous names: Cromer Diamicton, Third Cromer Till.

\section{Runton Till Member (RUTI)}

Description: Stiff to very stiff dark grey to greyish brown, slightly gravelly CLAY with thin beds of gravel, lenses and laminations of sand, chalk and older, more chalk-rich till of the Walcott Member. Type section: Coastal section between West Runton (east) and Sheringham (west) near Beeston Hill, north Norfolk.

Thickness: Up to $9 \mathrm{~m}$.

Distribution and extent: Outcrops between East Runton and Sheringham on the north Norfolk coast.

\section{Weybourne Town Till Member (WTTI)}

Description: Very stiff to very weak, white or light grey, very calcareous, chalk-rich SILT or SILTSTONE comprised primarily of chalk but may have stratified inclusions of Bacton Green Till Member.

Thickness: Up to $6 \mathrm{~m}$.

Type section: Weybourne Town Pit, east Weybourne, north Norfolk [TG 1140 4310].

Distribution and extent: Weybourne, Hanworth and Trimingham, north Norfolk.

Previous name: Marly Drift.

\section{Lowestoft Glacigenic Formation (LOFT)}

Comprises glacial till units (Lowestoft and Walcott Till Members), glaciofluvial sand and gravel units (Aldeby and Haddiscoe Sand and Gravel and High Lodge Gravel Members) and glaciolacustrine laminated clay and silt members (Oulton Clay Member and Woolpit Beds). Description: Firm to very stiff, gravelly sandy CLAY with cobbles.

Beds of: Loose to very dense SAND, gravelly SAND and sandy GRAVEL. Firm to very stiff, laminated, pale grey or grey, sandy SILT and CLAY or silty fine SAND with occasional grey sand lenses.

Thickness: Extremely variable; thickest in buried valleys where locally up to $60 \mathrm{~m}$. Thick accumulations are also more generally present beneath much of northern Essex and south Suffolk. Type section: Cliff section at Corton [TM 5400, 96800].

Distribution and extent: Extensive over central and southern East Anglia as far south as Romford in Essex, north London and north of Luton.

Prevous names: Lowestoft Boulder Clay, Cromer Till, Lowestoft Till Formation, Lowestoft Tiil Group.

\section{Lowestoft Till Member (LTTI)}

Description: Firm to very stiff, fissured near surface, olive-grey, weathering to yellowish orange, light orangish brown, gravelly, sandy or sandy, gravelly clay with cobbles. Cobbles are usually chalk or flint but may also include Mesozoic limestone and sandstone, quartz and quartzite. Chalk might be leached out in the upper few metres. Beds of medium dense to dense SAND and GRAVEL and firm to stiff CLAY and SILT.

Type Section: Cliff section at Corton [TM 54000, 96800].

Location: Extensive over central and southern East Anglia as far south as Romford in Essex, north London and west to north of Luton.

Walcott Till Member (WATI)

Description: Lower part greenish grey to greenish brown, gravelly, sandy SILT. Gravel is of chalk, black flint, quartz and quartzite, magnesium limestone and Carboniferous limestone. 
Thickness: Maximum $2.2 \mathrm{~m}$.

Type section: Ostend cliffs, north Norfolk [TM 3910 3040].

Distribution and extent: North Walsingham and Cromer and along the coast between Happisburgh and Overstrand, North Norfolk.

Previous name: Second Cromer Till, Walcott Diamicton.

\section{Nurseries Formation (NURS)}

Description: Firm to very stiff, brown or reddish brown, gravelly, sand CLAY with cobbles and boulders. Gravel, cobbles and boulders are of local Coal Measures rocks, primarily sandstone, and from the west, including North Wales rhyolite. Beds of loose to very dense sand and gravel beds and firm to stiff, laminated silt and clay beds.

Type locality: Quinton [SO 992 847] near Birmingham.

Type section: Site investigation borehole along the motorway cutting at Quinton, Birmingham. Reference section: At Nechells, [40800, 288200] (Kelly 1964, Shotton and Osborne 1965).

Thickness: Up to 20 to $25 \mathrm{~m}$ may be thicker locally.

Distribution or extent: South of the Devensian limit, most of the West Midlands (includes most of Birmingham), Worcestershire, south west Staffordshire, southern part of Staffordshire, west Warwickshire. May underlie the Brewood Till Formation.

Previous names: Lower Glacial Series and late Glacial Series, Western Drift.

\section{Wolston Glacigenic Formation (WOLS)}

Comprises glacial till units (Bozeat Till, Oadby Till, Thrussington Till and Moreton Members), glaciofluvial sand and gravel units (Dunsmore Gravel, Hillmorton Sand, Kirkby Moor Sand, Knightlow Sand, Paxford Gravel, Shawell Sand, Woolridge Sand and Gravel, Wigston Sand and Gravel, Wolford Heath Sand and Gravel and Woolridge Sand and Gravel Members), glaciolacustrine laminated clay, silt, and sometimes with sand units (Bosworth Clay, [formerly Glen Parva and Rothbery Clays], Skellingthorpe Clay and Snitterfield Sand, Wolston Clay Members), and glacigenic unit (Moreton Member).

Description: Predominantly gravelly sandy CLAY, SAND and GRAVEL and laminated SILT and CLAY beds.

Distribution and extent: English Midlands east of Birmingham and south to Moreton-in-Marsh and the Tewkesbury area. The eastern limit is probably north-west of the Chilterns and Norfolk and west of the Fens and west of the Lincolnshire scarp.

\section{Bozeat Till Member (BOZE)}

Description: Firm to stiff or very stiff, dark bluish grey, weathering to orangish brown, brown, mottled brown and grey, gravelly, sandy CLAY. Gravel is of Jurassic limestone and rare chalk. Thickness: Up to $5 \mathrm{~m}$.

Distribution and extent: Eastern East Midlands.

Generally underlies the Oadby Till Member.

Previous name: Oadby Till Member (Lias-rich).

\section{Thrussington Member (THT)}

Description: Firm to very stiff, brown or reddish brown or red, sometimes grey, variably gravelly, variably sandy CLAY with occasional cobbles. Cobbles mostly derived from Coal Measures and Triassic rocks.

Beds or lenses of: Loose to very dense, orangish brown, yellowish brown, reddish brown, light brown or brown, silty fine to coarse SAND or silty, gravelly SAND or sandy GRAVEL, occasionally GRAVEL.

Local beds of: Mostly firm to stiff, laminated, orangish brown, reddish brown or brown, CLAY, sometimes with silt partings, CLAY and SILT or sandy SILT.

Thickness: Typically 1 to $7 \mathrm{~m}$ but can be up to $20 \mathrm{~m}$. 
Distribution and extent: Primarily the East Midlands west to east Staffordshire and south to east Warwickshire. Well exposed in the west part but sporadically exposed in much of Leicestershire, south Derbyshire and south Nottinghamshire as it is beneath the Oadby Till Member.

Previous names: Pennine Drift and Thrussington Till.

\section{Oadby Till Member (ODT)}

Description: Firm to very stiff, grey to dark grey, weathering to orangish brown or brown, variously gravelly slightly sandy CLAY with a few cobbles. Gravel and cobbles are mostly composed of chalk and flint with some Jurassic limestone sandstone and quartzite.

Beds or lenses of: Loose to very dense, grey, orangish brown or brown, slightly silty or silty SAND, gravelly SAND, sandy, sometimes clayey GRAVEL. Soft to very stiff, thinly or thickly laminated, grey, blue grey, brown, orangish brown or yellowish brown, CLAY or SILT with occasional fine SAND.

Thickness: Typically 1 to $7 \mathrm{~m}$ but up to $20 \mathrm{~m}$.

Distribution and extent: East Midlands west to east Warwickshire. East to west East Anglia and north to Market Weighton, Yorkshire.

Previous names: Chalky Boulder Clay, Oadby Till.

\section{Moreton Member (MTON)}

Description: Heterogeneous, partly glacial till (mapped). Stiff to very stiff, reddish brown, gravelly, sand CLAY with occasional cobbles or red brown, slightly laminated CLAY, SILT or SAND with occasional flint or chalk.

Thickness: Proved to $21 \mathrm{~m}$ but might be thicker in places.

Distribution: In the Moreton-in-Marsh area, Gloucestershire.

\section{Penfro Till Formation (POTI)}

Description: Firm to very stiff, sometimes extremely weak, red and purple, light brown, orangish brown, sandy, gravelly CLAY or MUDSTONE with cobbles and boulders. The cobbles and boulders are generally of igneous rock, tuff and quartz felsite.

Beds or lenses of: Loose to very dense gravelly SAND or sandy GRAVEL.

Partial type section: Llandre Gravel Quarry [SN 093 203], Pembrokeshire.

Partial type section: West Angle Bay [SM853 031], Milford Haven.

Thickness: generally 2 to $5 \mathrm{~m}$ but locally up to $9.5 \mathrm{~m}$.

Distribution and extent: Dissected in northern Pembrokeshire and western Carmarthenshire.

Widespread in south Pembrokeshire.

\section{Llanddewi Glacigenic Formation (LITI)}

Description: Firm to very stiff, red, reddish brown and grey brown, slightly gravelly, sandy or gravelly CLAY or sandy CLAY with cobbles and boulders. Cobbles and boulders of Carboniferous Millstone Grit Group and of Irish Sea provenance.

Beds of: SAND and GRAVEL.

Reference section: Hill Farm Borehole [SS 4525 8615], Port Eynon, Gower Peninsula.

Reference section: Hangman's Cross Borehole [SS 483 867], Oxwich, Gower Peninsula.

Thickness: Up to $23 \mathrm{~m}$

Location: South and west Gower Peninsula.

Description. Gravelly sandy CLAY or Gravelly sand/sandy gravel.

\section{Bakewell Formation (BAKW)}

Description: Firm to very stiff gravelly, sandy CLAY. Coarser rocks are from the Lake District and Scotland.

And: Interbedded laminated clay and silt and sand.

Type section: Shining Bank Quarry [SK 230 632], near Alport, Derbyshire. 
Thickness: Greater than $15 \mathrm{~m}$ at the type section.

Distribution and extent: Highly dissected in the southern Pennines from Hebden Bridge and Huddersfield, Yorkshire, south to Belper, Derbyshire and Cheadle, north Staffordshire.

\section{Harrogate Till Formation (HRT)}

Description: Soft to very stiff, brown yellowish brown, grey brown or grey, gravelly, slightly sandy to sandy CLAY with cobbles and boulders. Coarse and very coarse fraction is usually of limestone and sandstone.

Local beds of: Firm, laminated, grey CLAY may include layers of yellow brown fine sand. Type section: Site investigation boreholes in the west of the Harrogate Stray area typified by [SE 2989 5421].

Thickness: Up to $8 \mathrm{~m}$.

Distribution and extent: Harrogate area south to Doncaster, west of the Vale of York and east of Bradford and the Pennines to the south. Also, capping the plateaux in the Leeds area.

Previous name: Older Drift. 


\section{Appendix 6.2 Additional Geotechnical Plots}

Additional geotechnical plots for the Albion and Caledonia Glacigenic Groups are presented here. The plots show consistency, lithology, density, volume change hazard (based on unmodified plasticity index), angle of internal friction vs plasticity index, undrained shear strength vs depth and extended box and whisker plots for undrained shear strength. A combined extended box and whisker plot for undrained shear strength for both Glacigenic Groups is also included. 
Appendix 6.3 Particle Size Distribution And Spt 'N' Value Depth Plots By 100 Km Grid Square

The variation in particle size distribution and standard penetration test (SPT) ' $\mathrm{N}$ ' value depth profiles for glaciofluvial sand and gravel by $100 \mathrm{~km}$ grid square across Britain are presented here. Each plot covers a $100 \mathrm{~km}$ grid square: NO, NT, NY, NZ, SD, SE, SJ, SK, SO and SP for particle size distribution and NH, NT, NU, NY, NZ, SD, SE, SJ, SK, SO, SP, SS and TL for SPT 'N' values. 


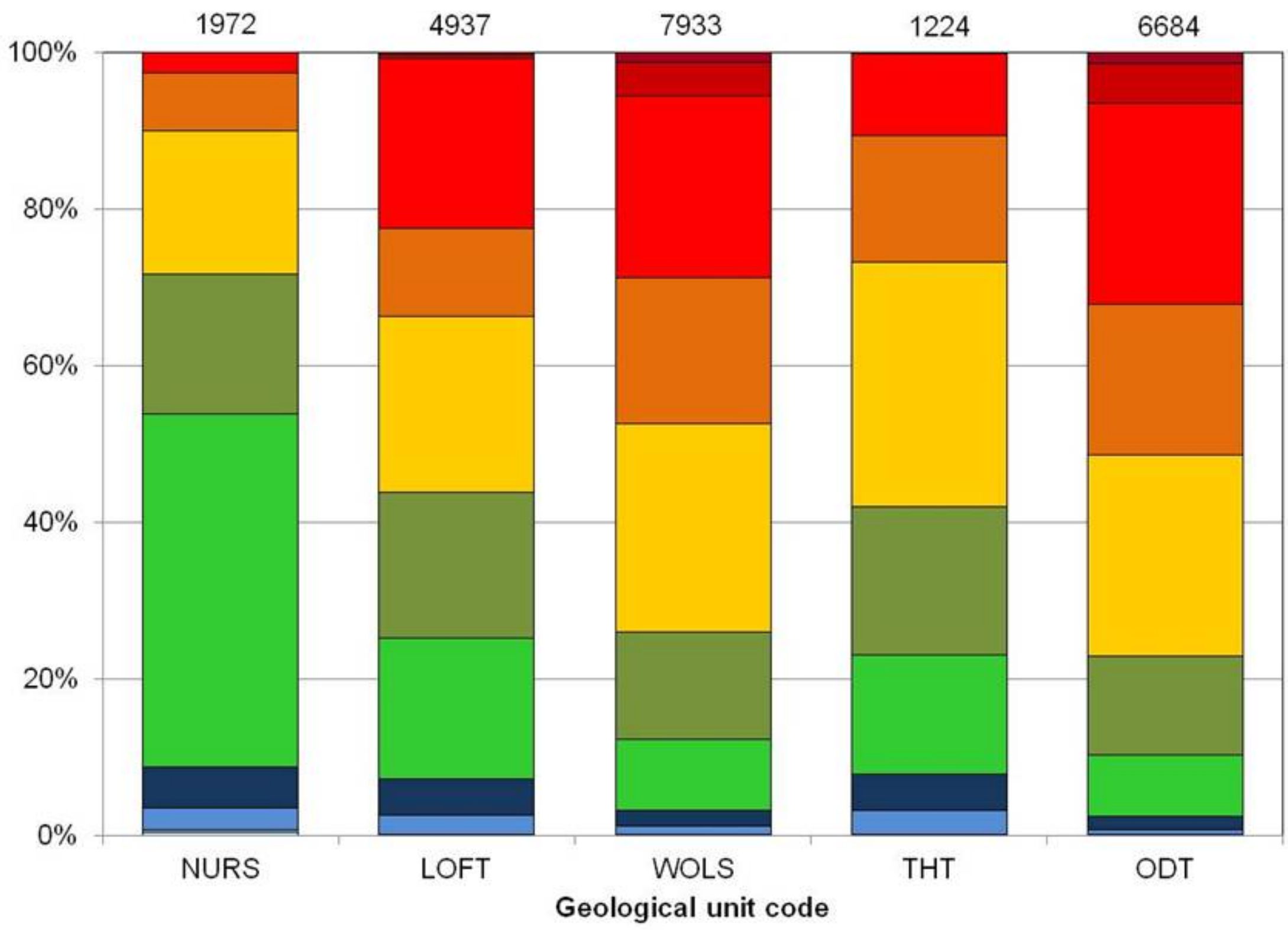

aWKE

aSTIWWKE

aSTIV

口STISTIV

口STI

口FRMSTI

aFRM

-SFTFRM

$\square S F T$

口SFTVSFT

口SFTV

\section{Geological unit code}




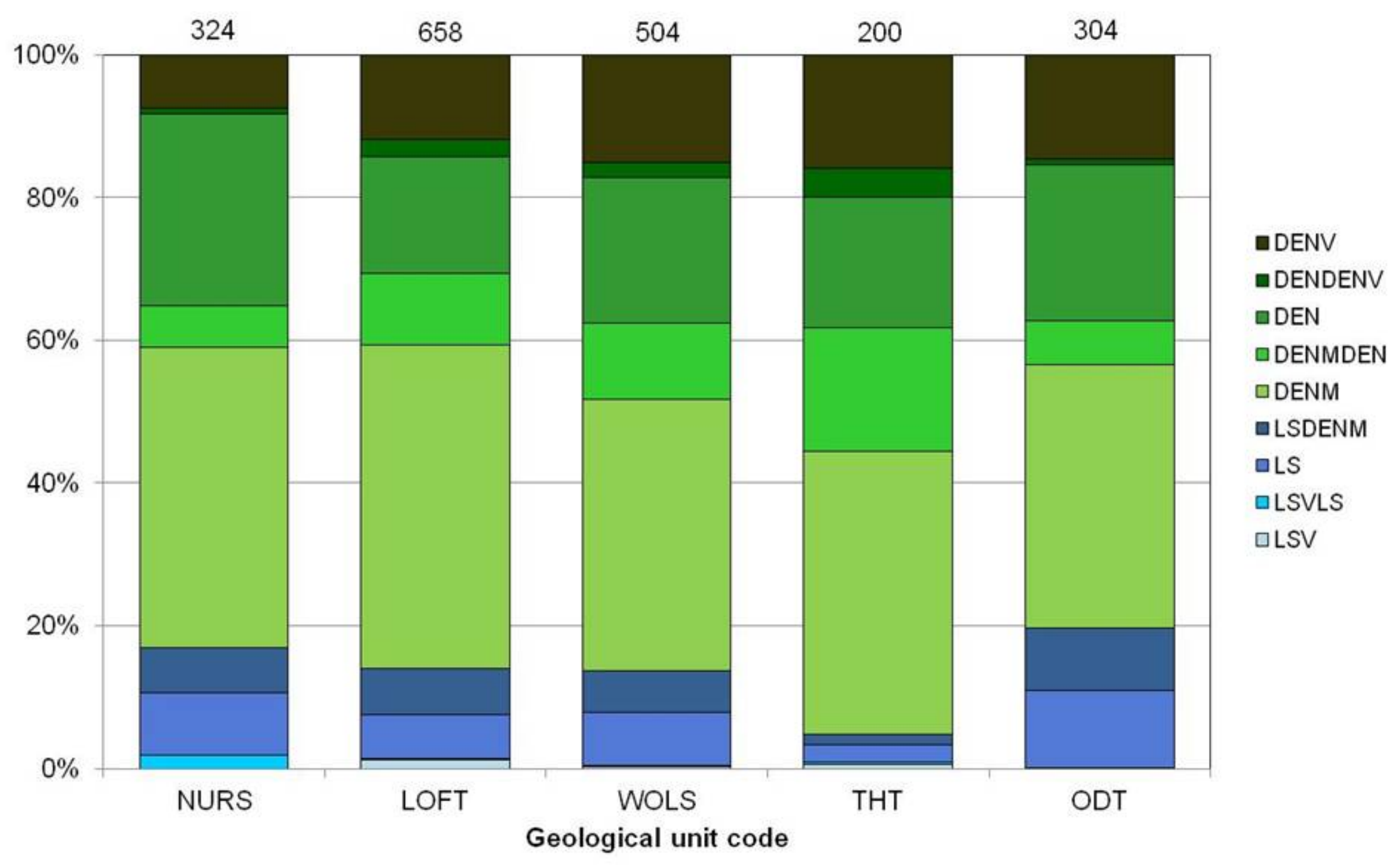




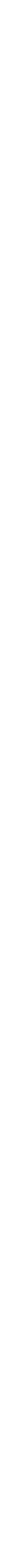




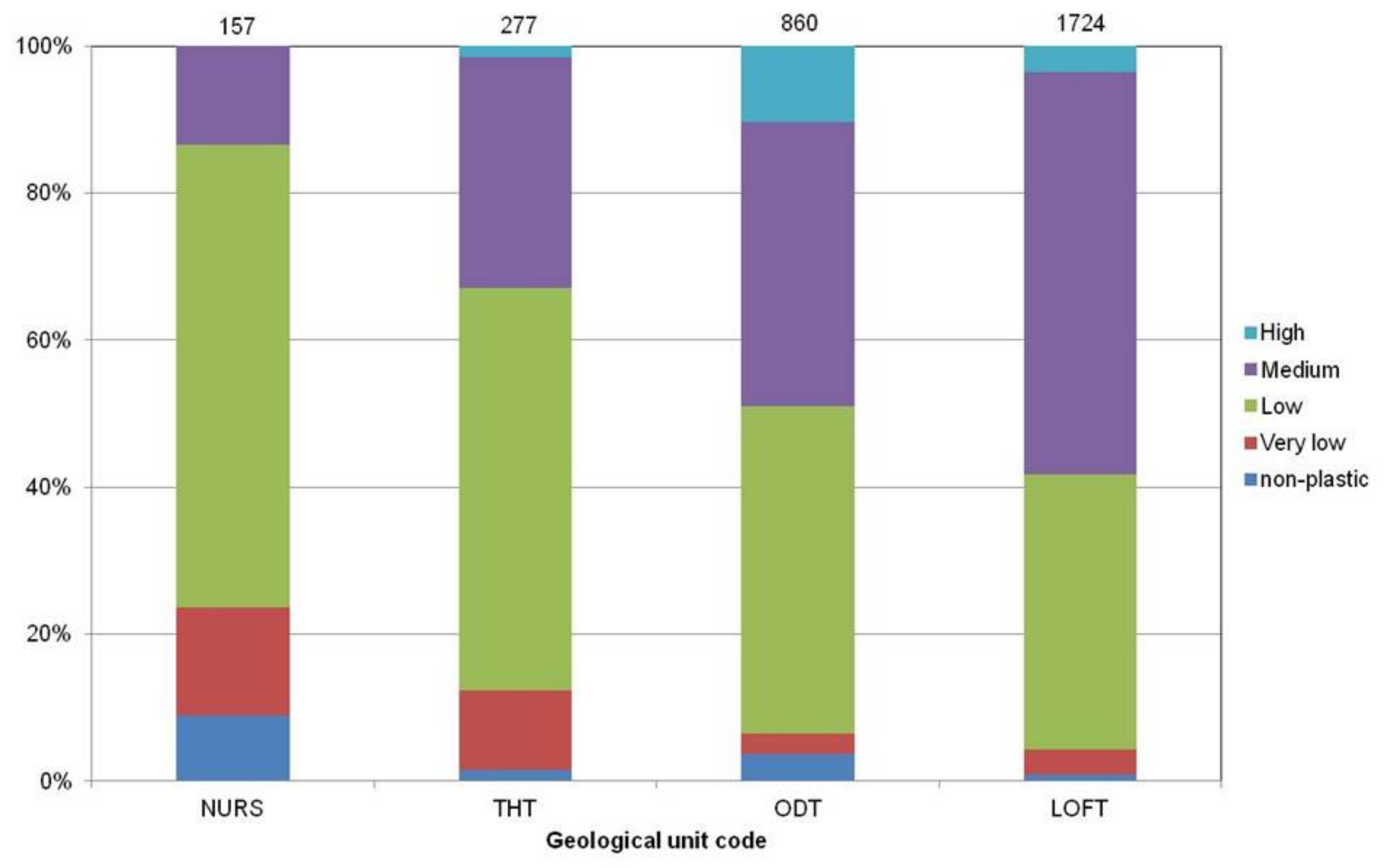




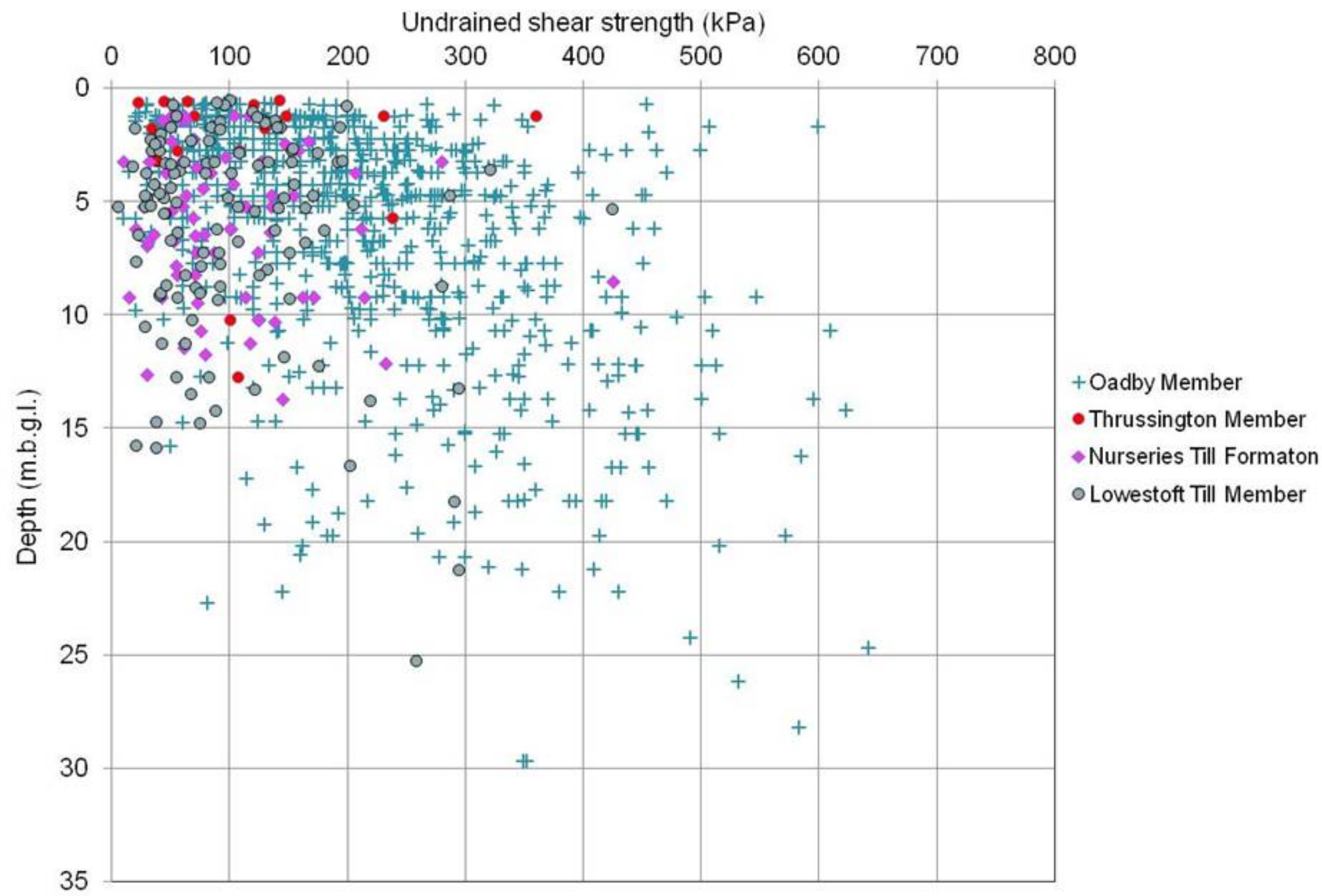


$\begin{array}{llll}124 & 77 & 818 & 17\end{array}$

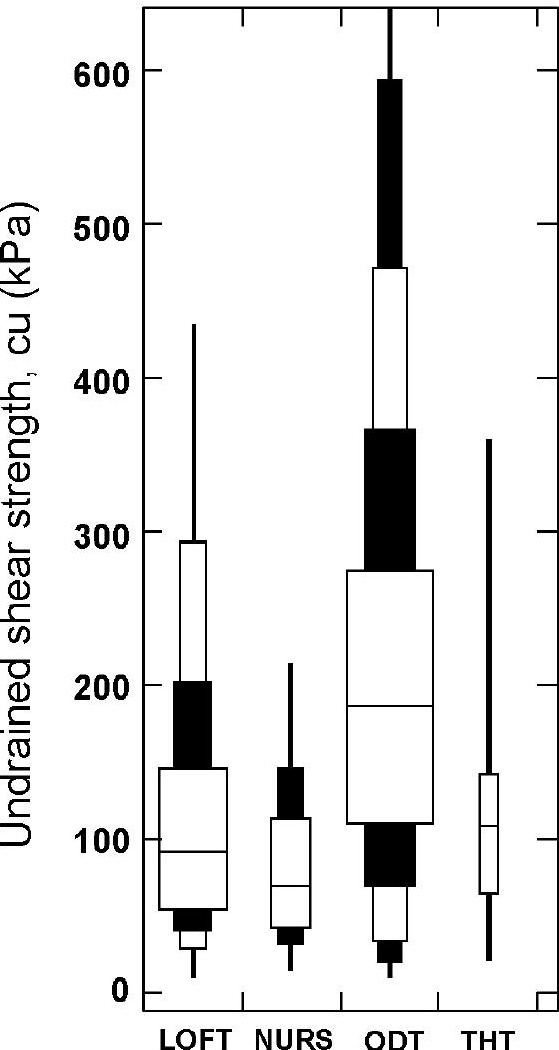




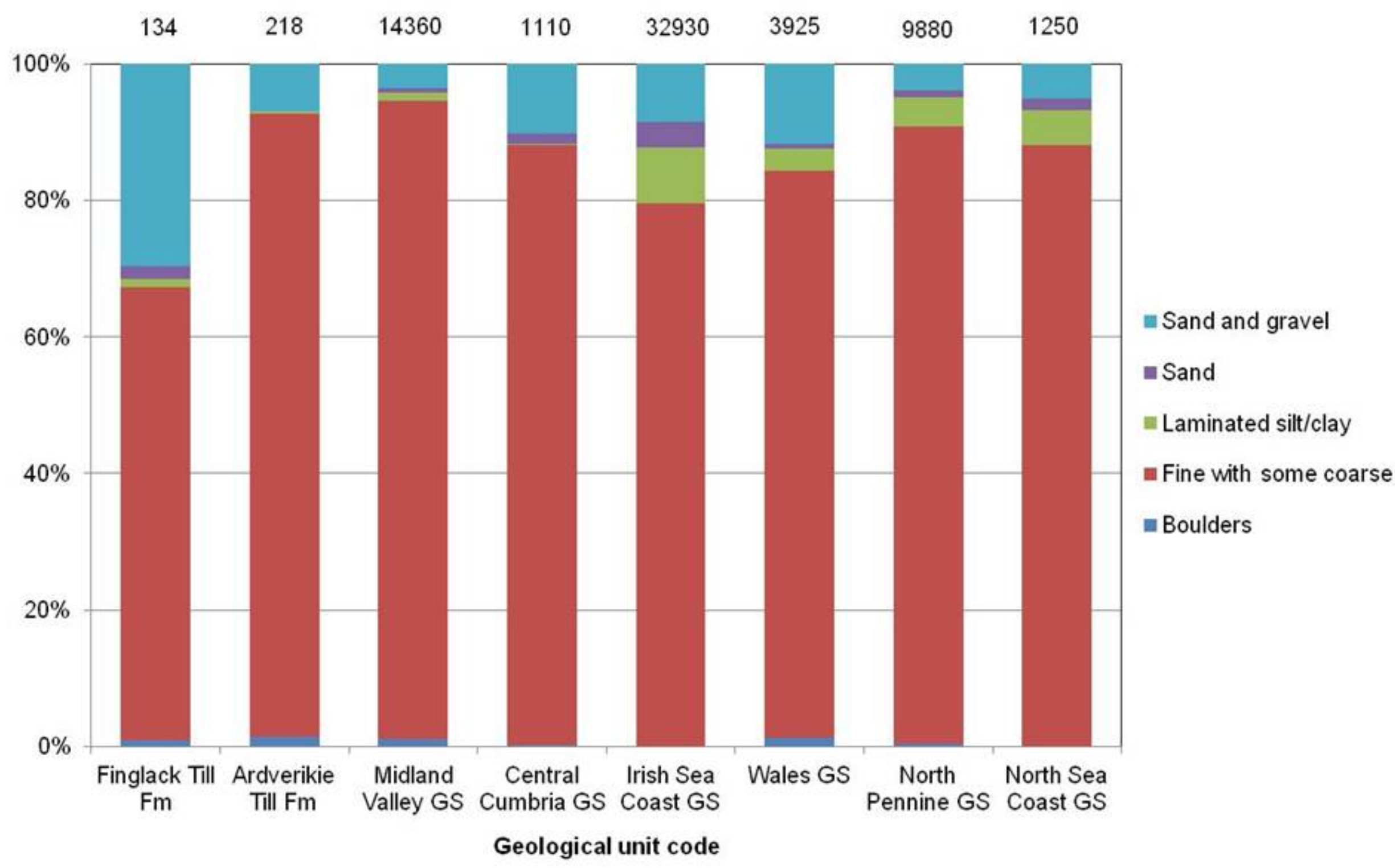




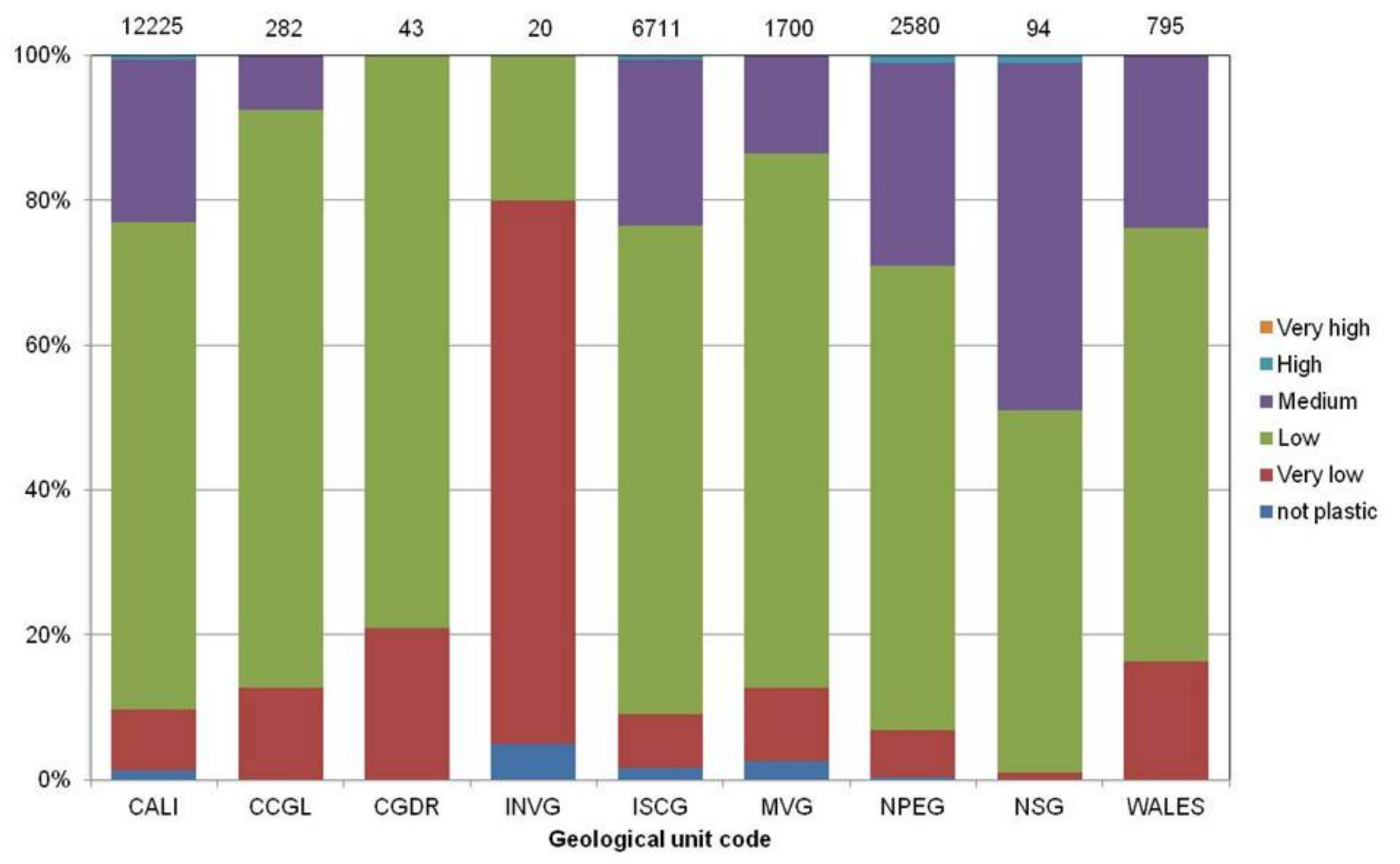




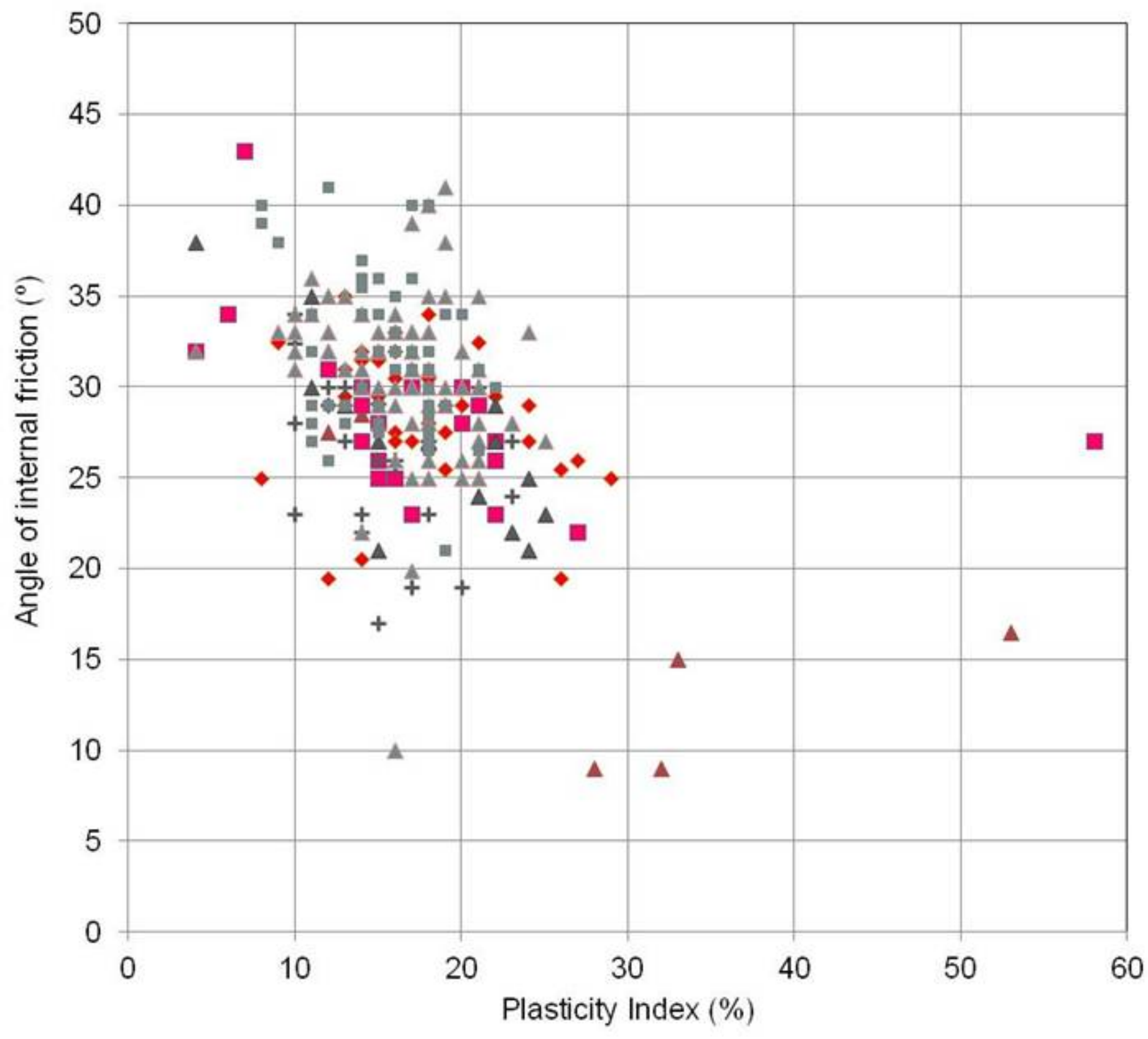

$\Delta$ Lleyn Till Member

- Brewood Till Formation

-Stockport Glacigenic Formation

+Wilderness Till Formation

$\Delta$ Acklington Till Formation

$\Delta$ Vale of York Formation

=Wear Till Formation 


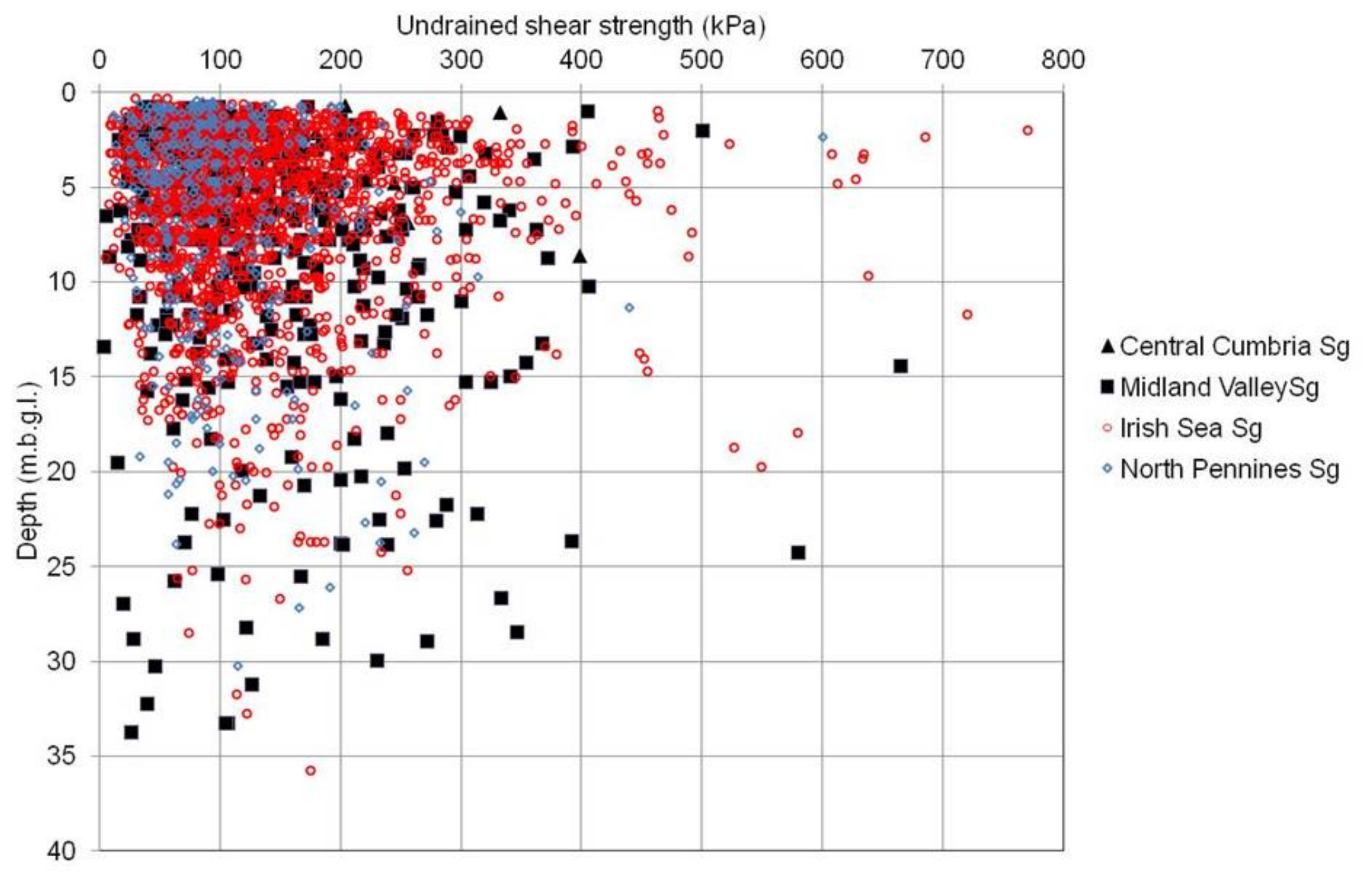




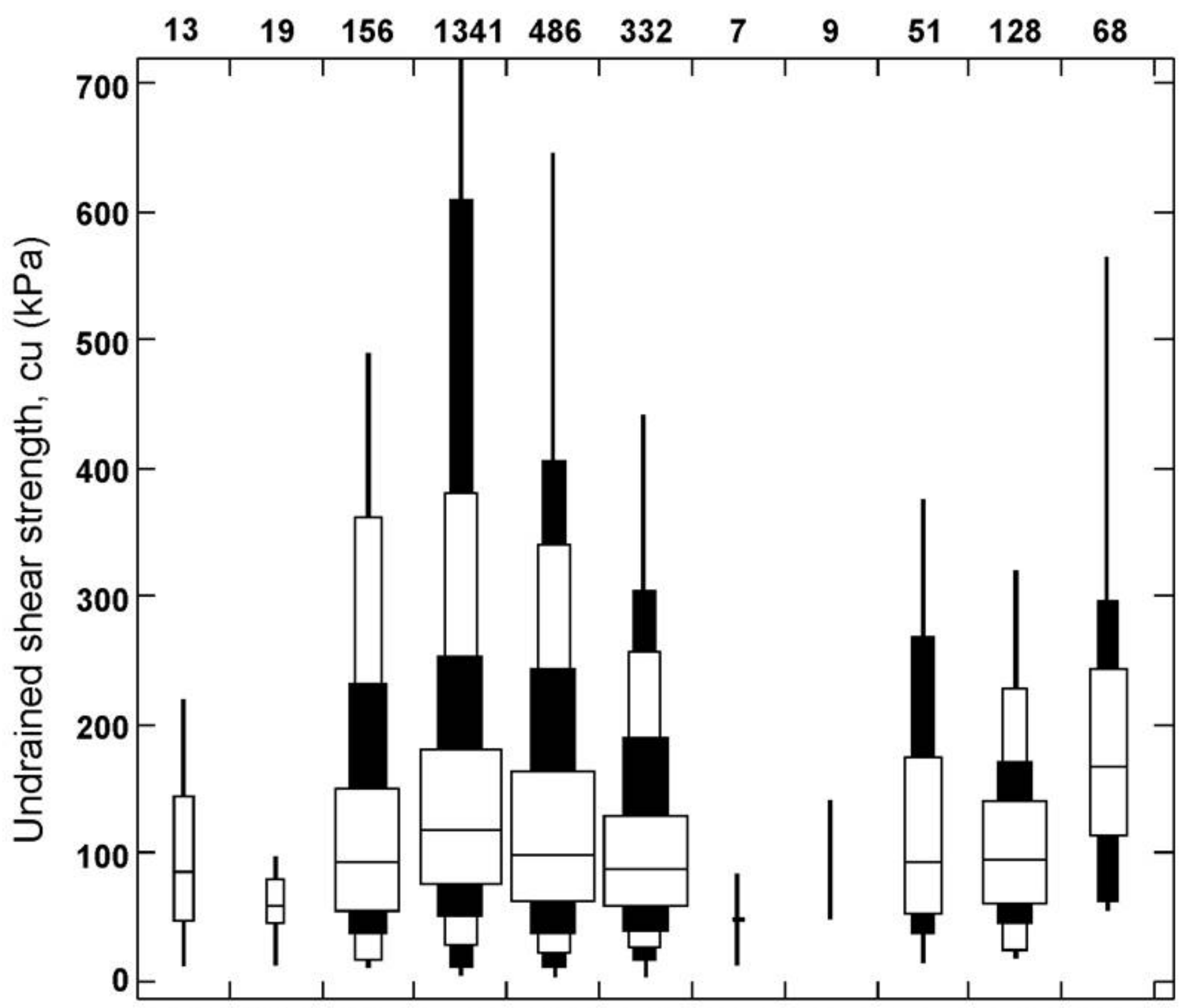

EDTI GRET BDTI STPTG WITI ANTI WETI YDTI HNTI SKTISHREW 


\section{5 samples}

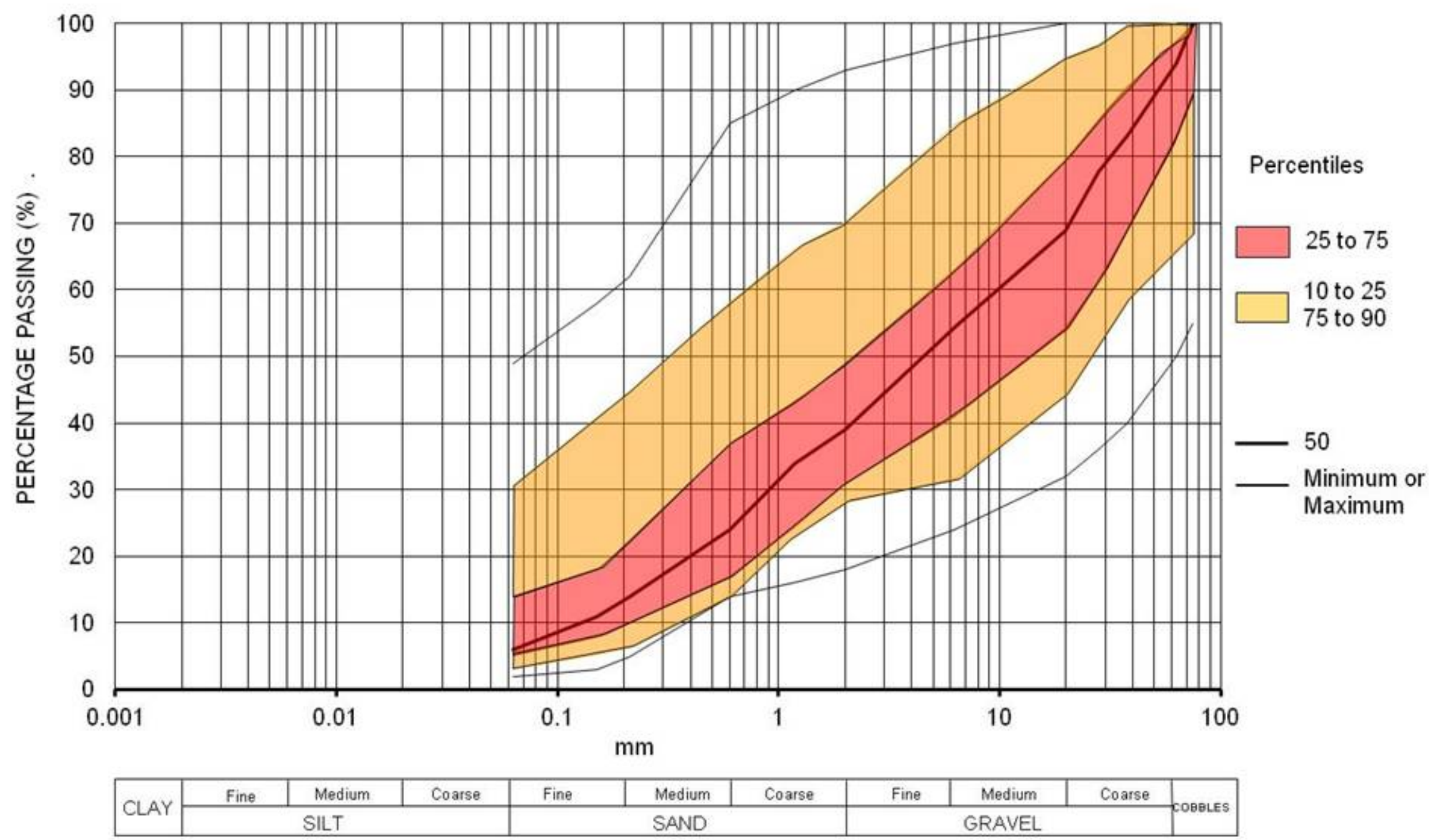




\section{8 samples}

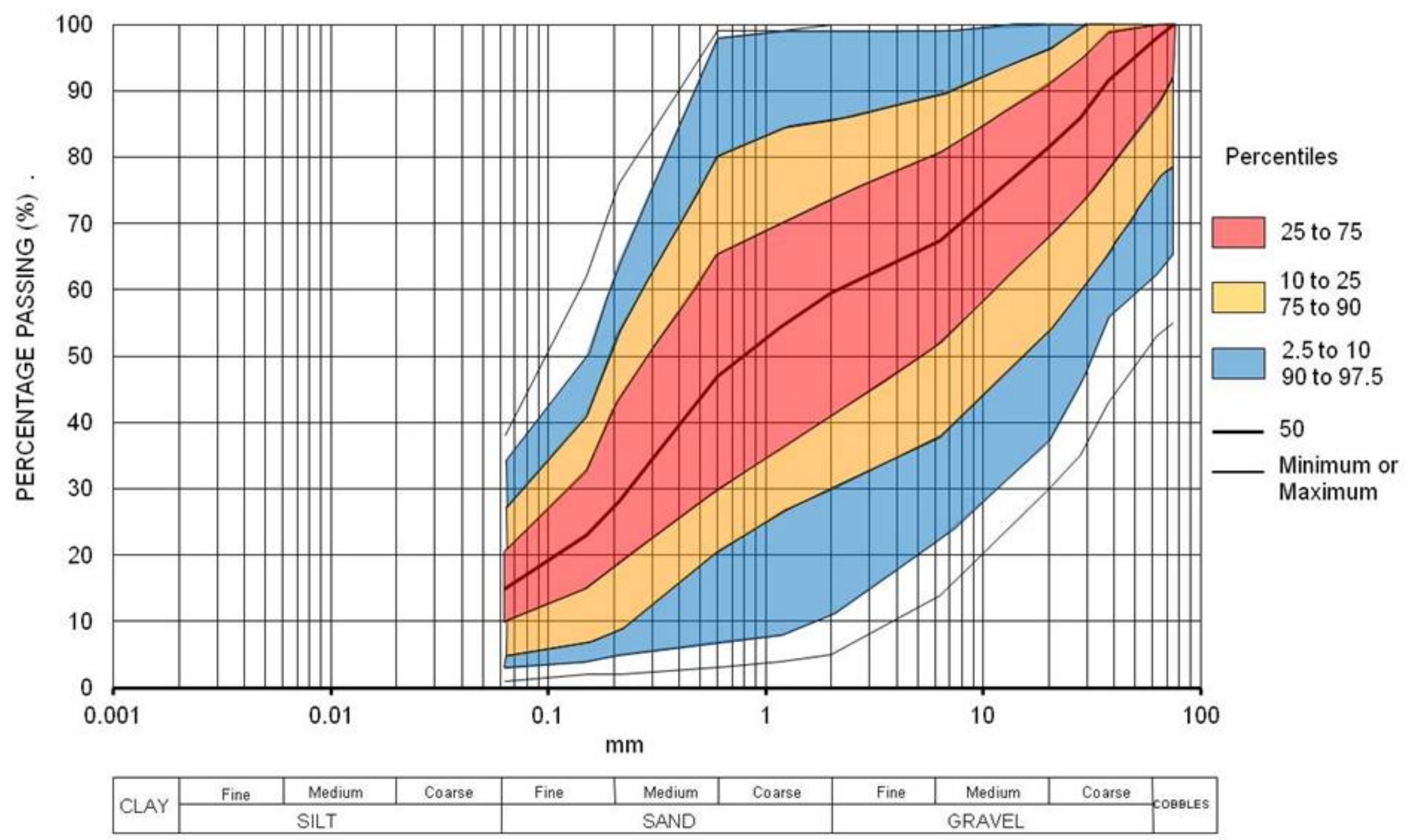


31 samples

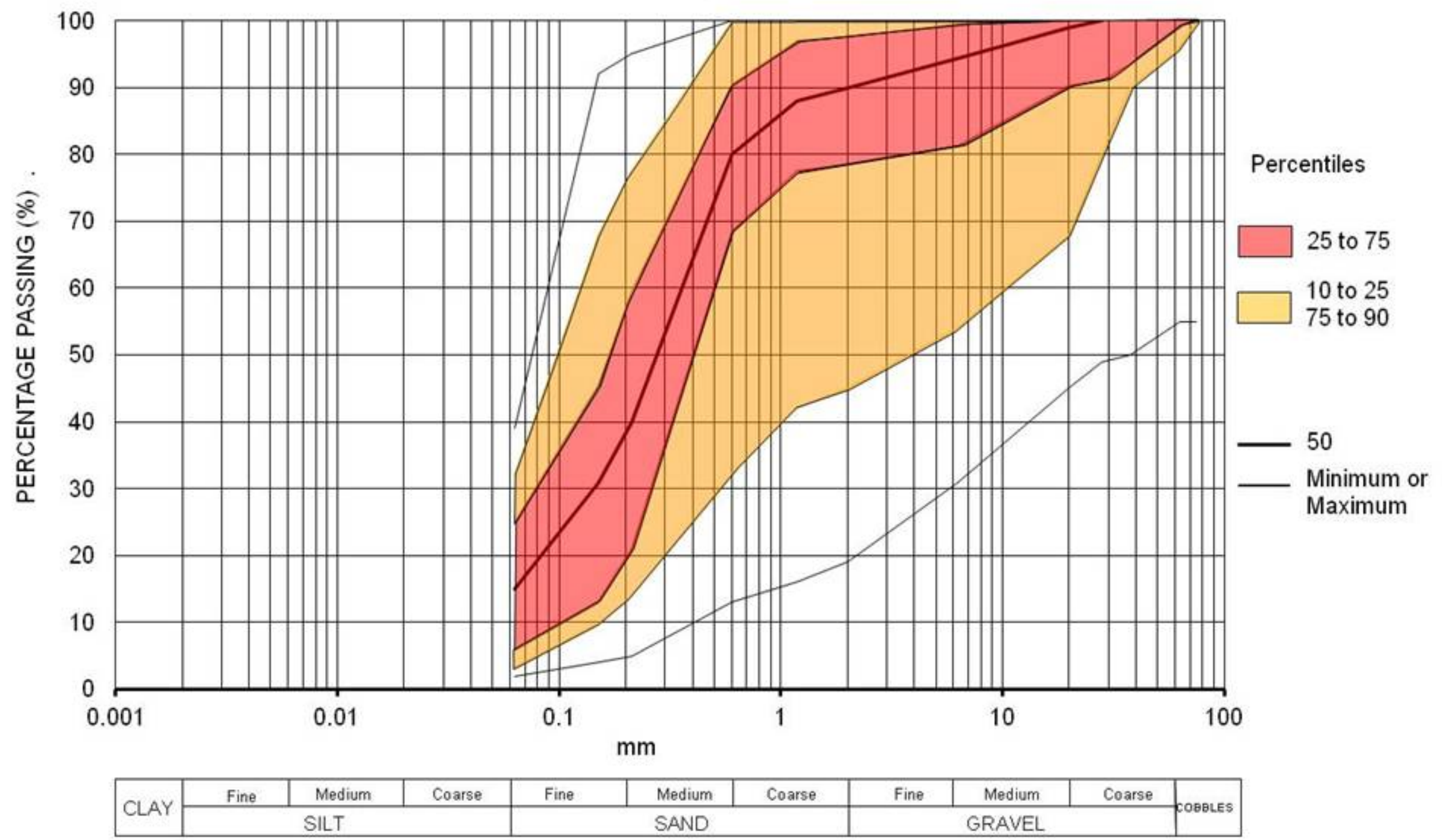




\section{8 samples}

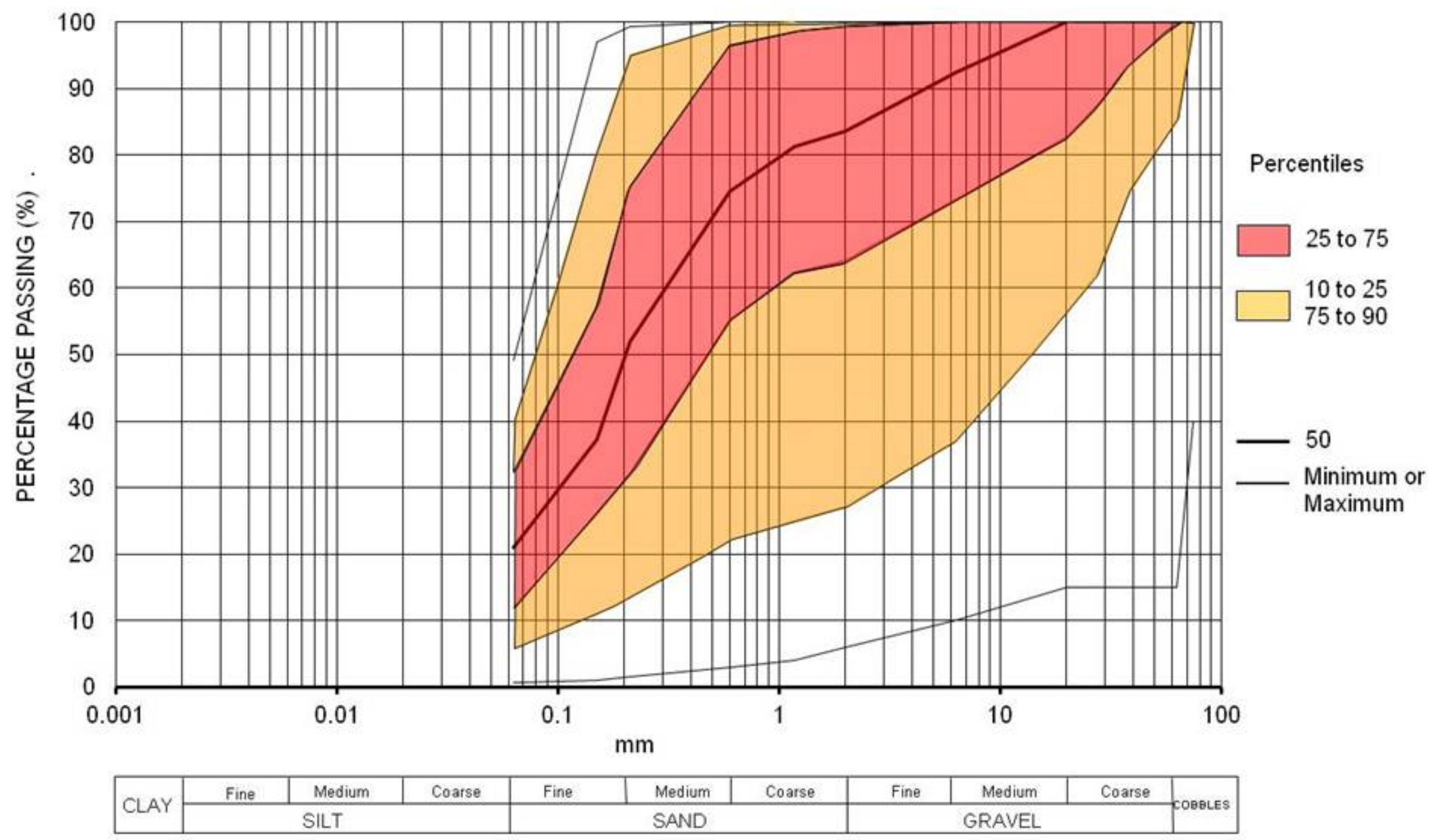




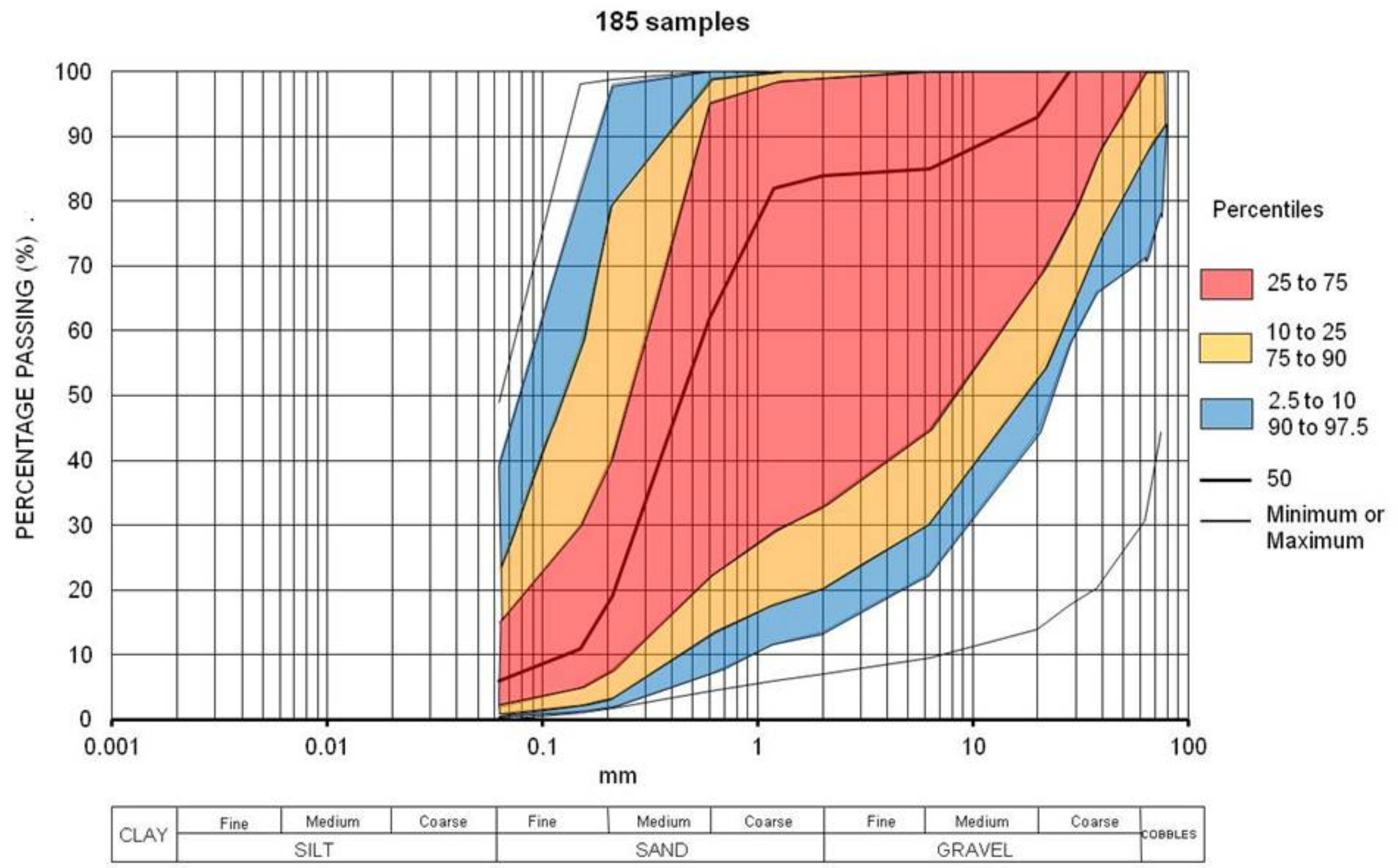




\section{1 samples}

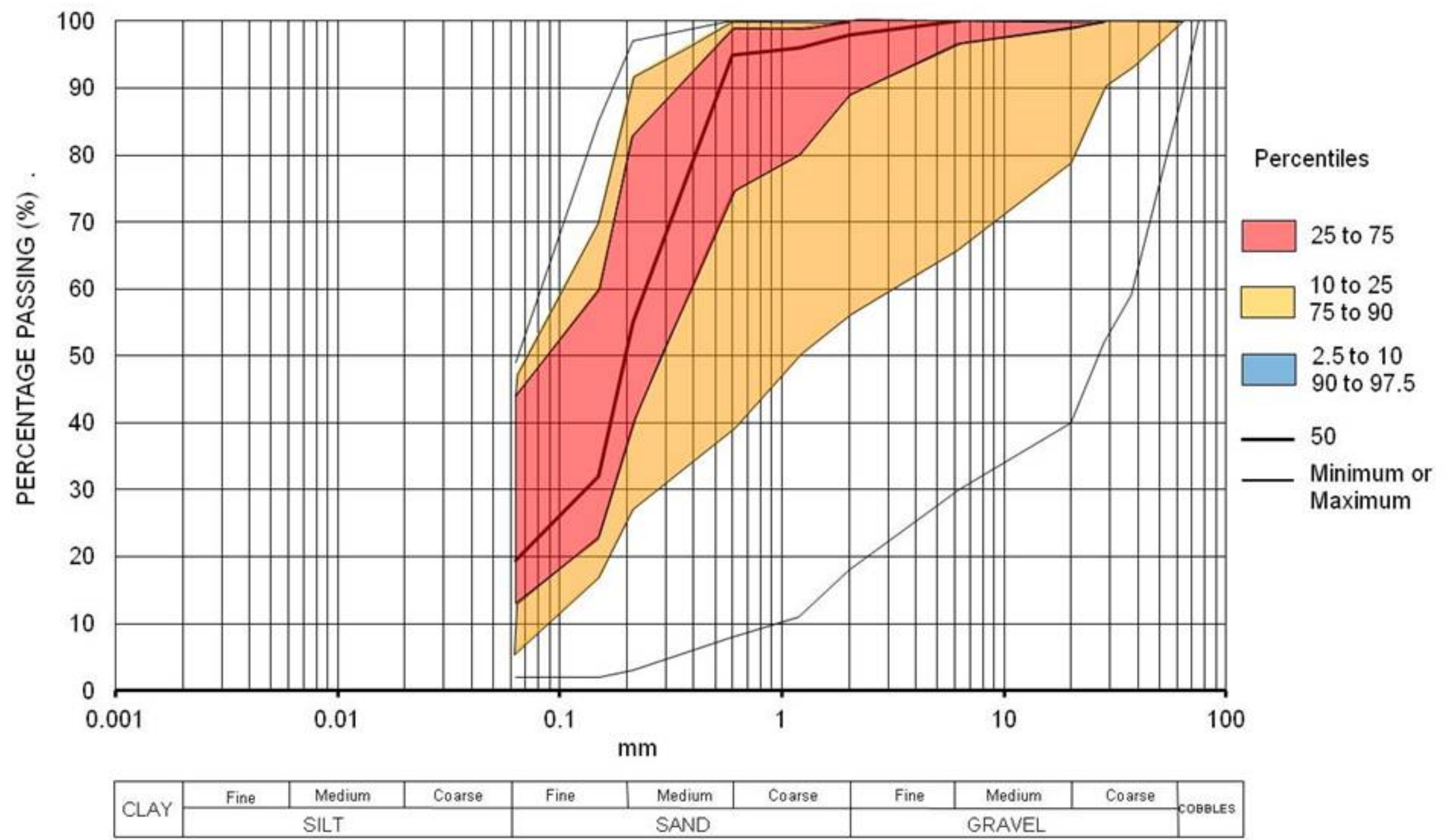


1147 samples

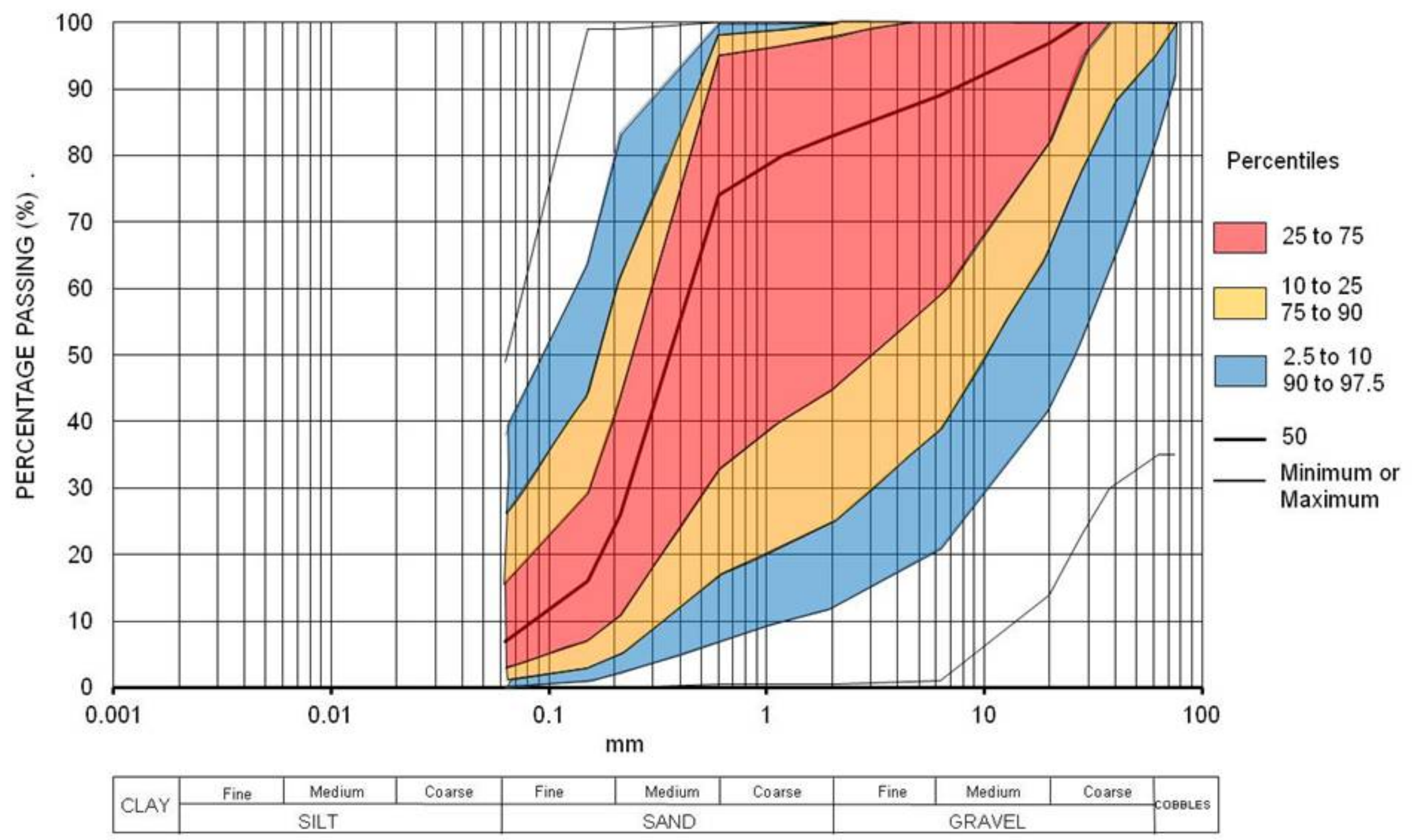




\section{7 samples}

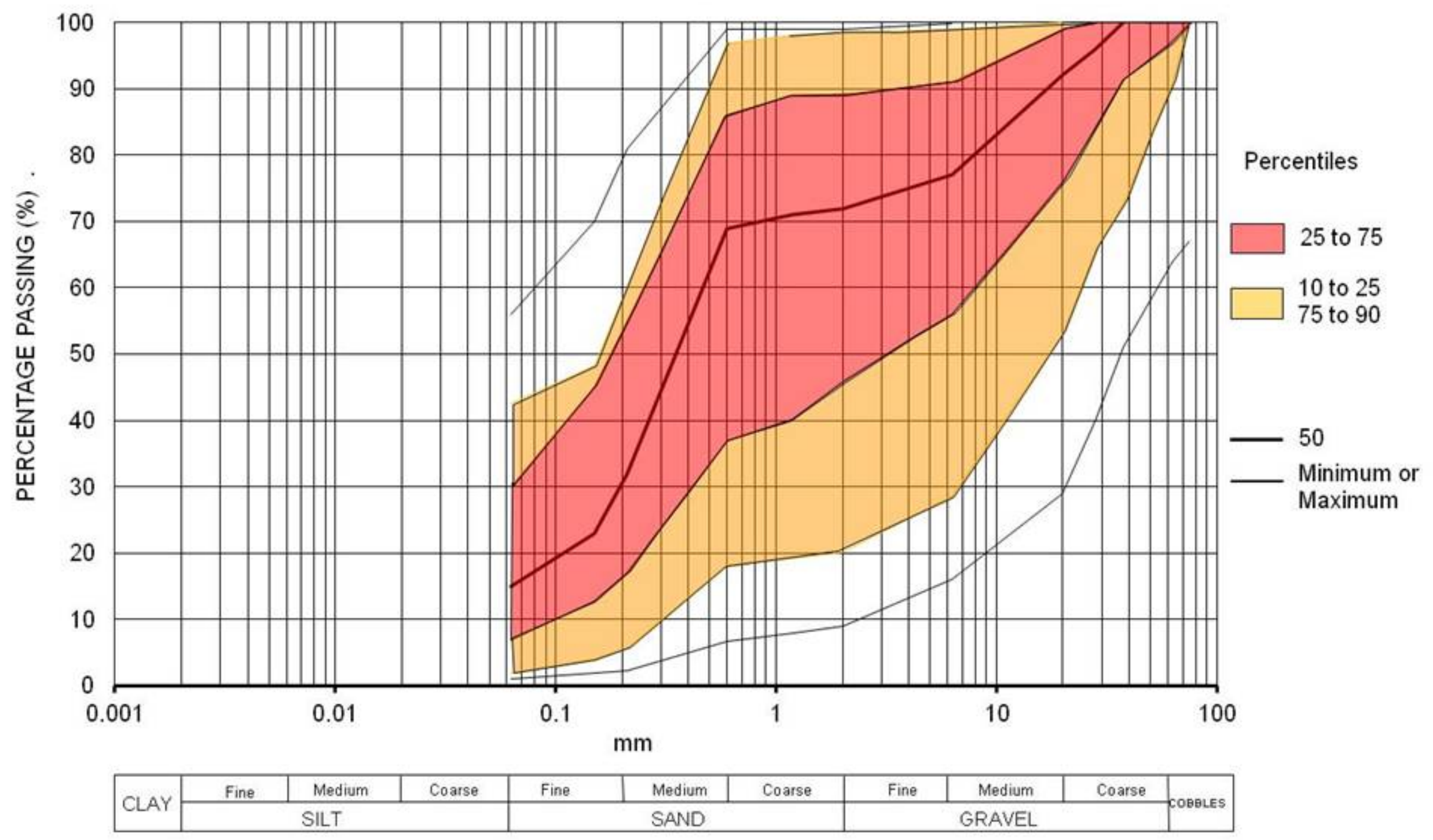




\section{2 samples}

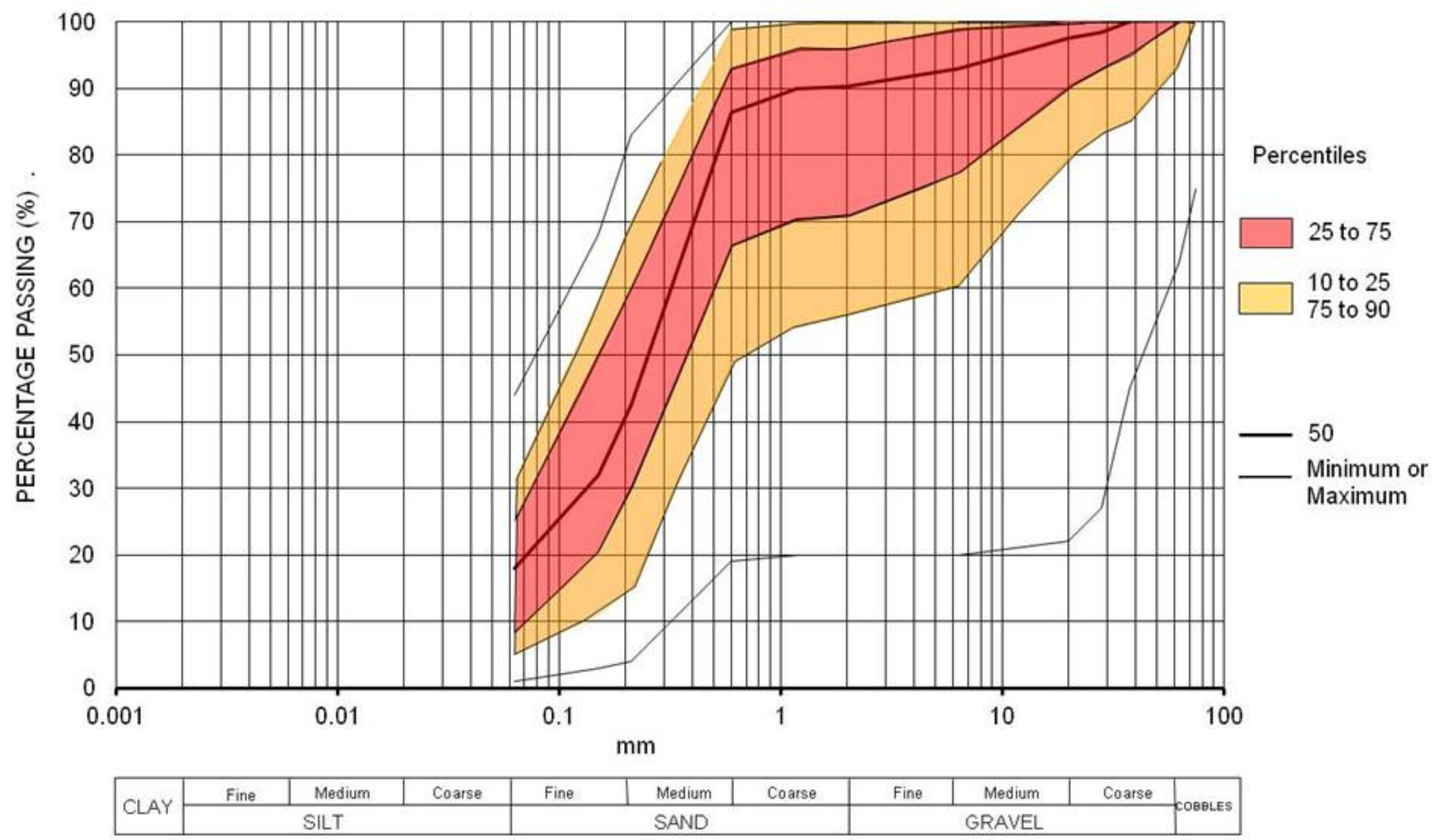




\section{6 samples}

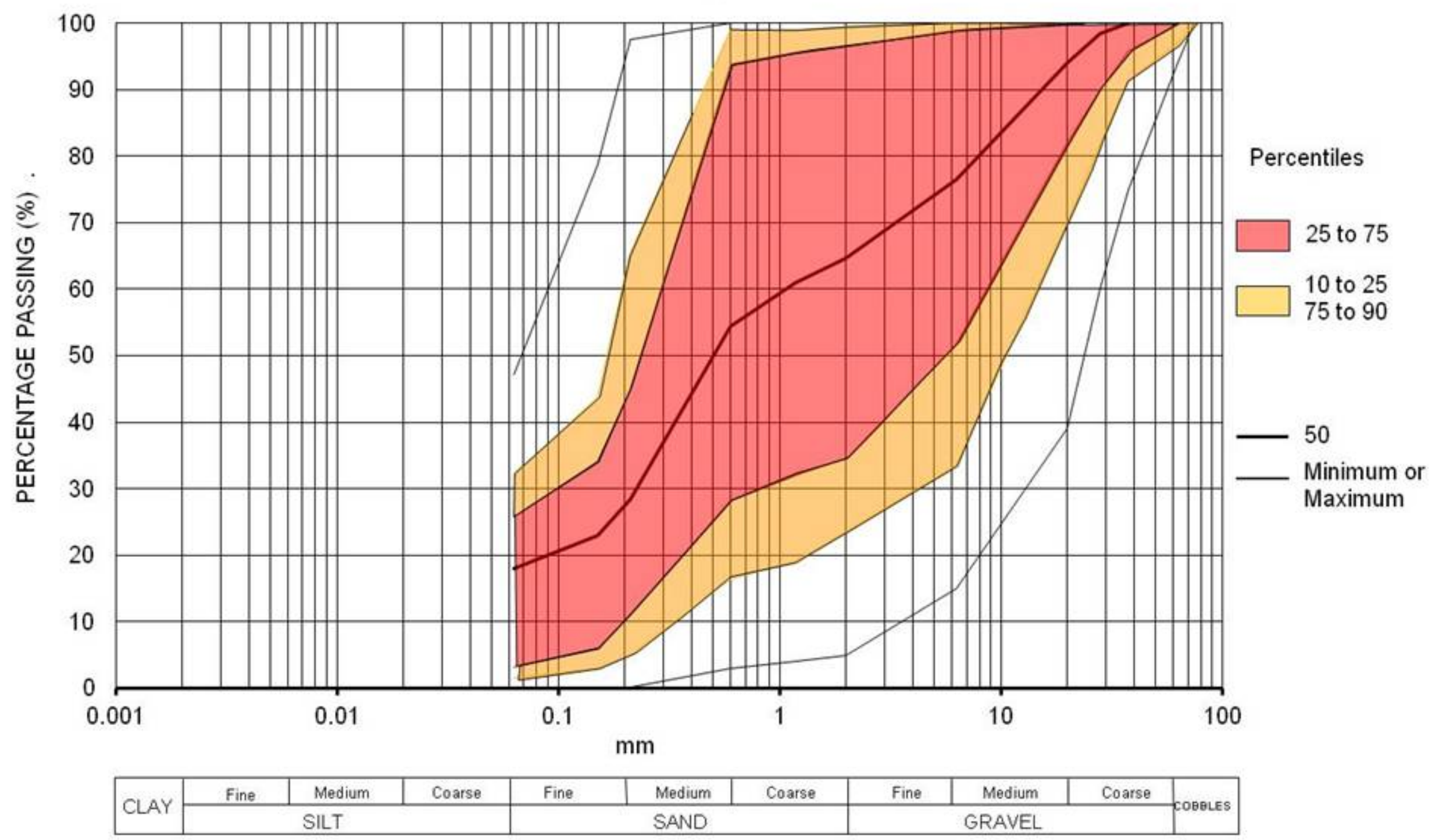




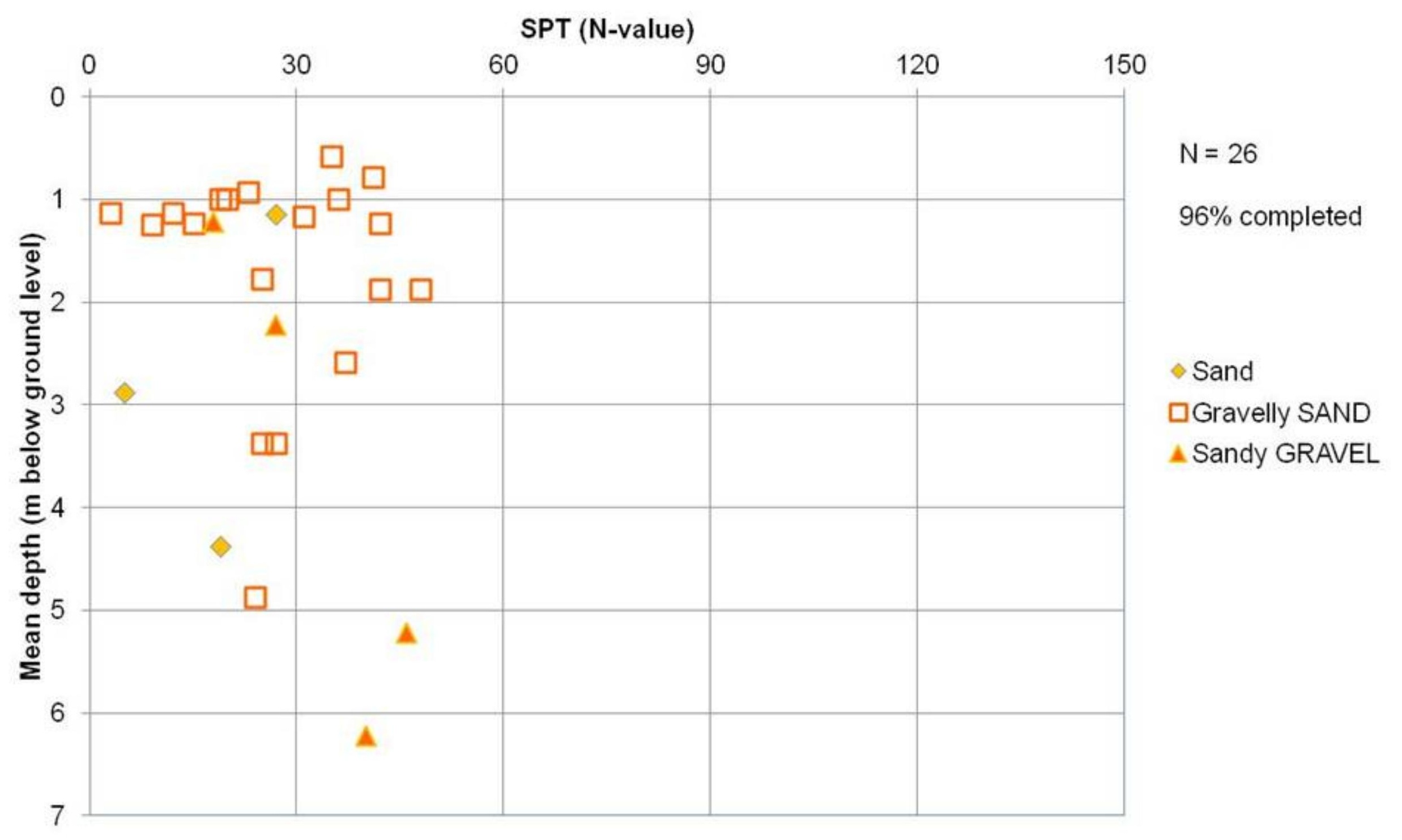




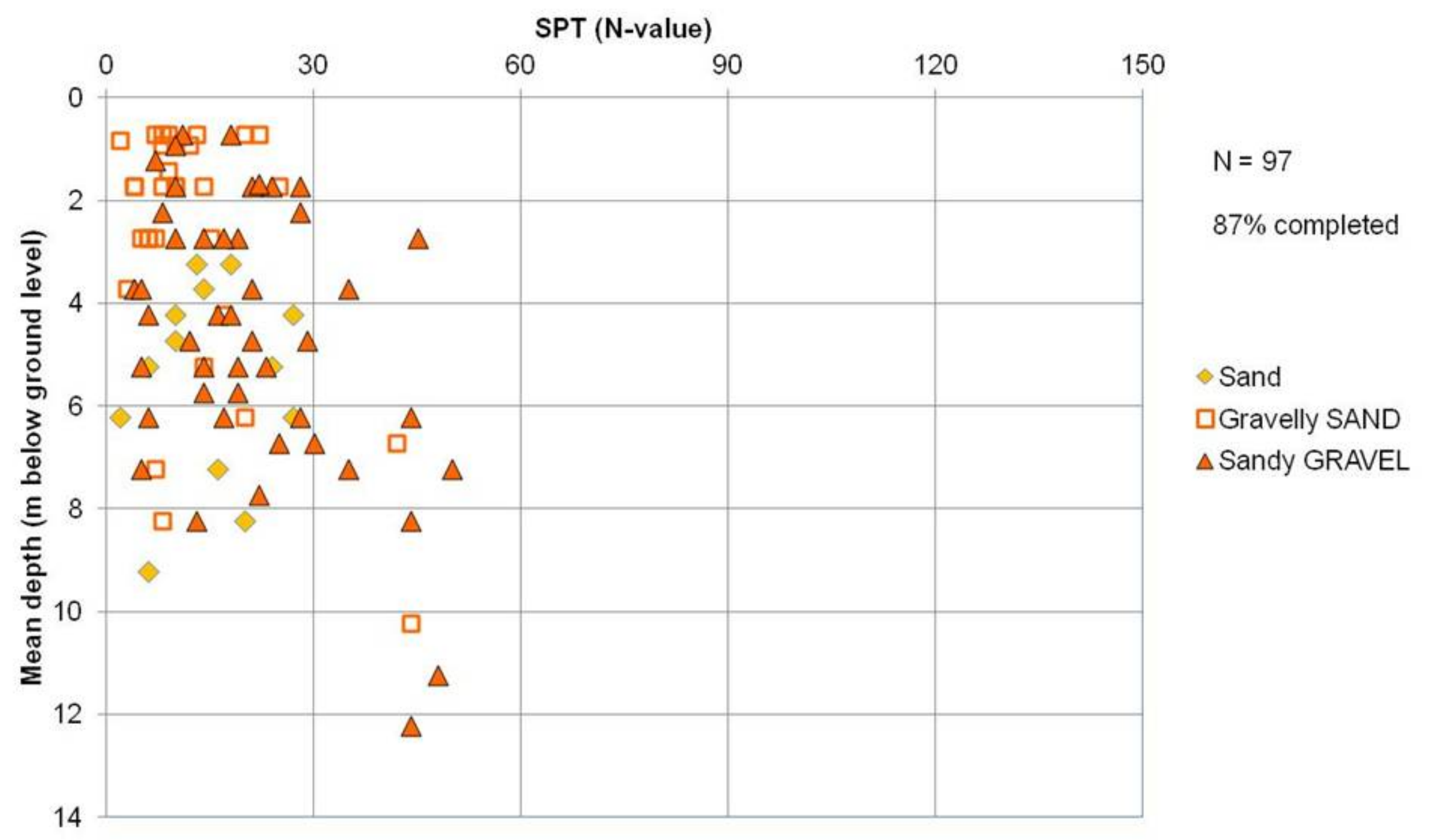




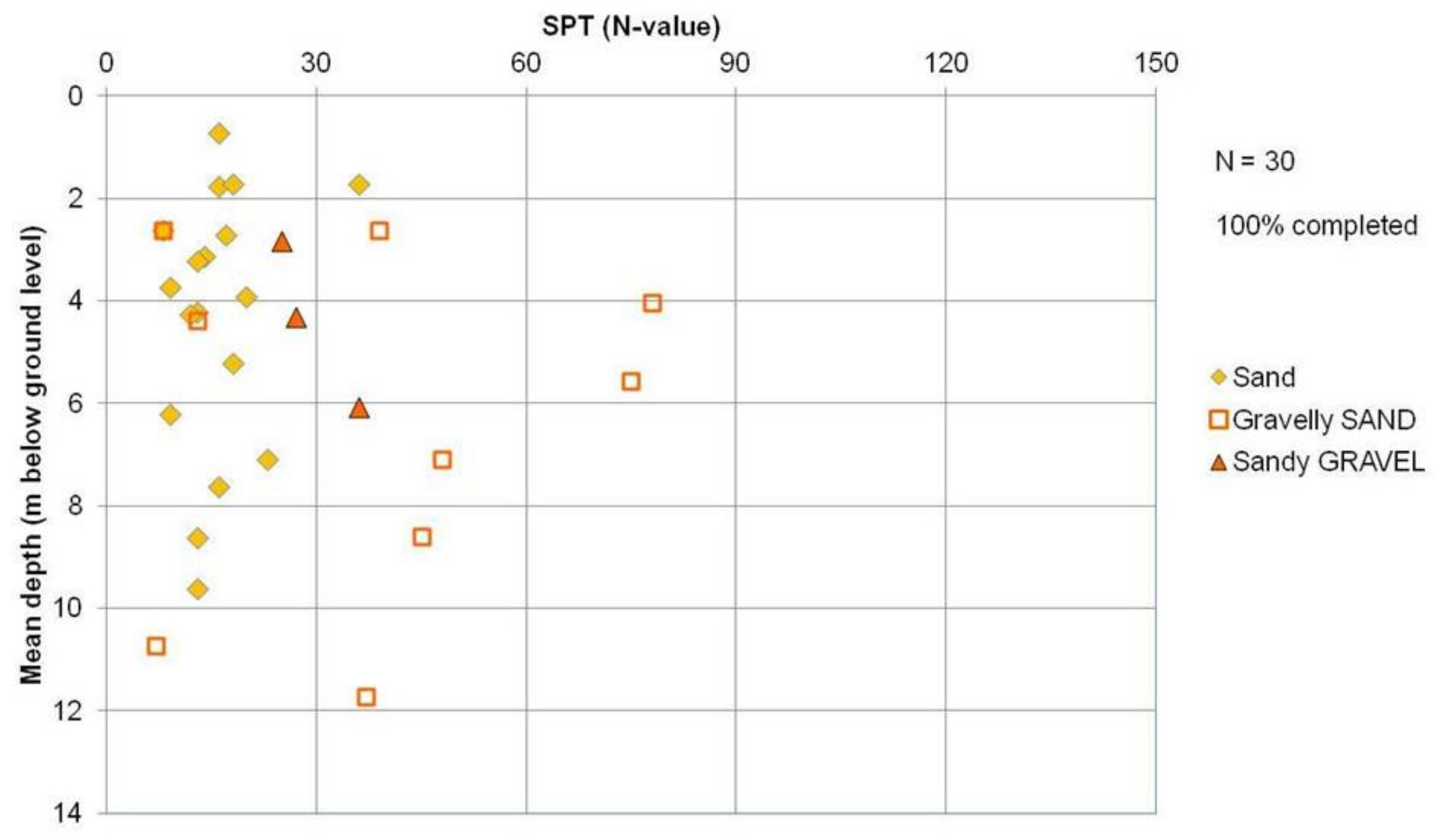




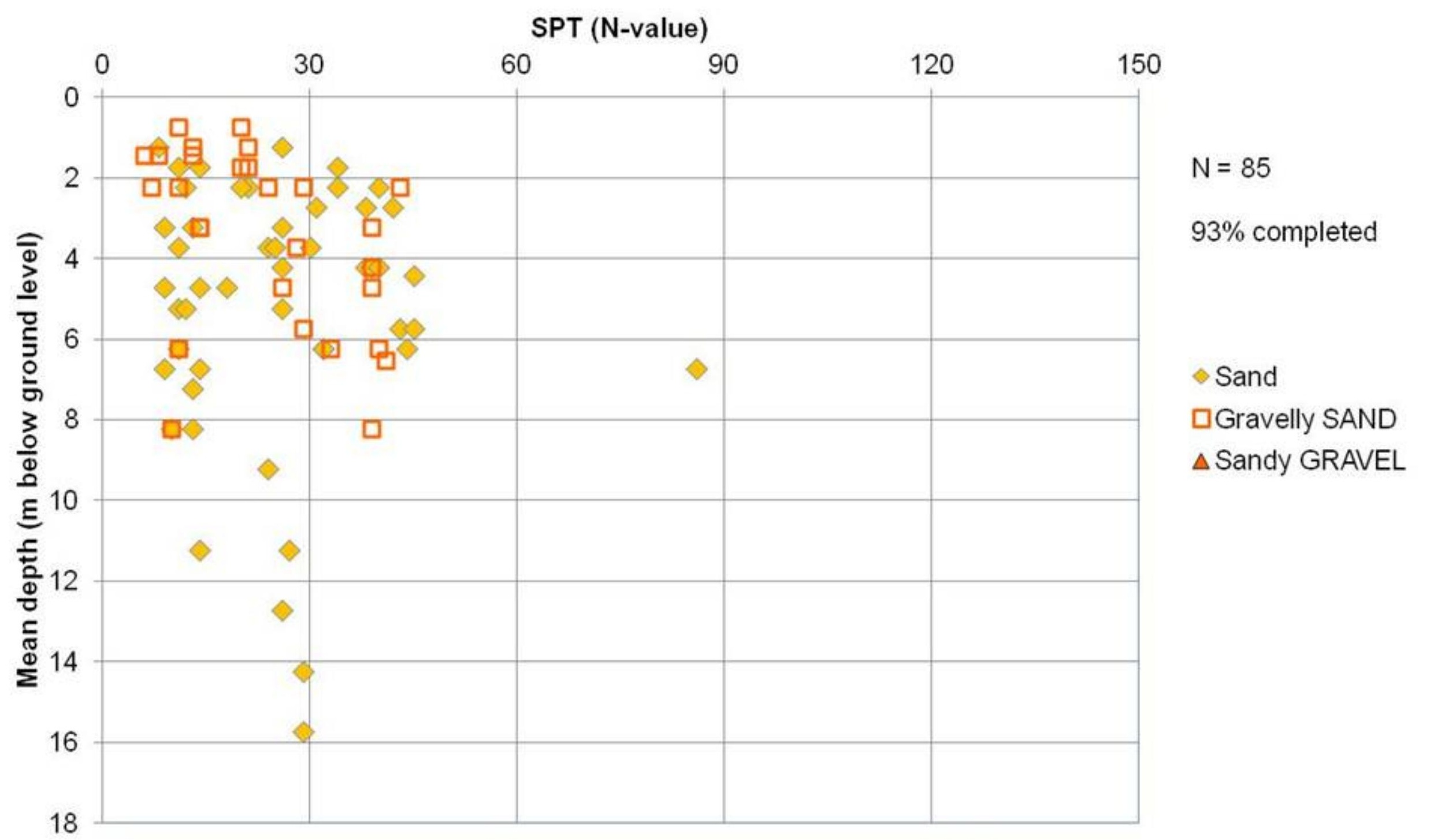




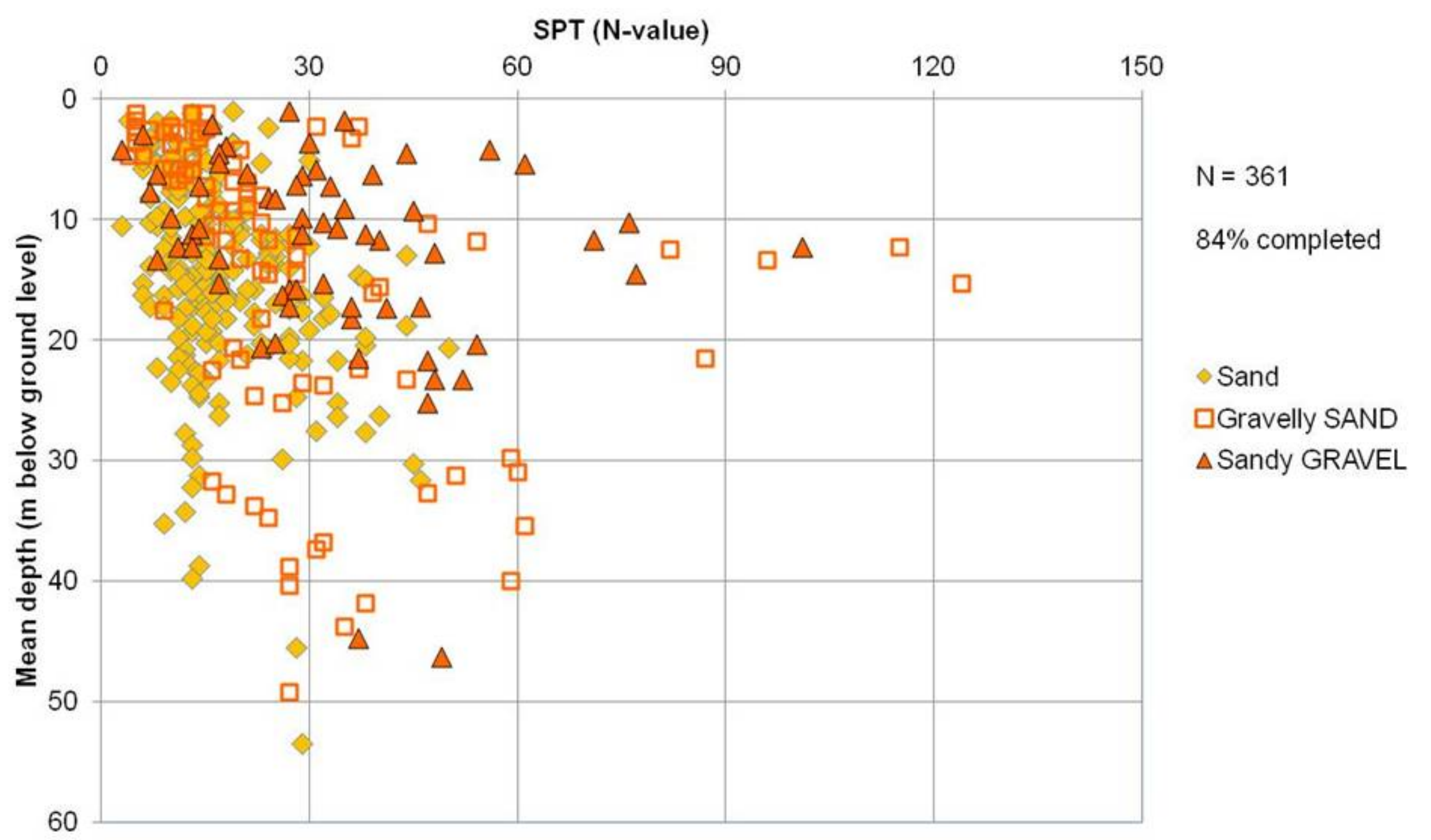




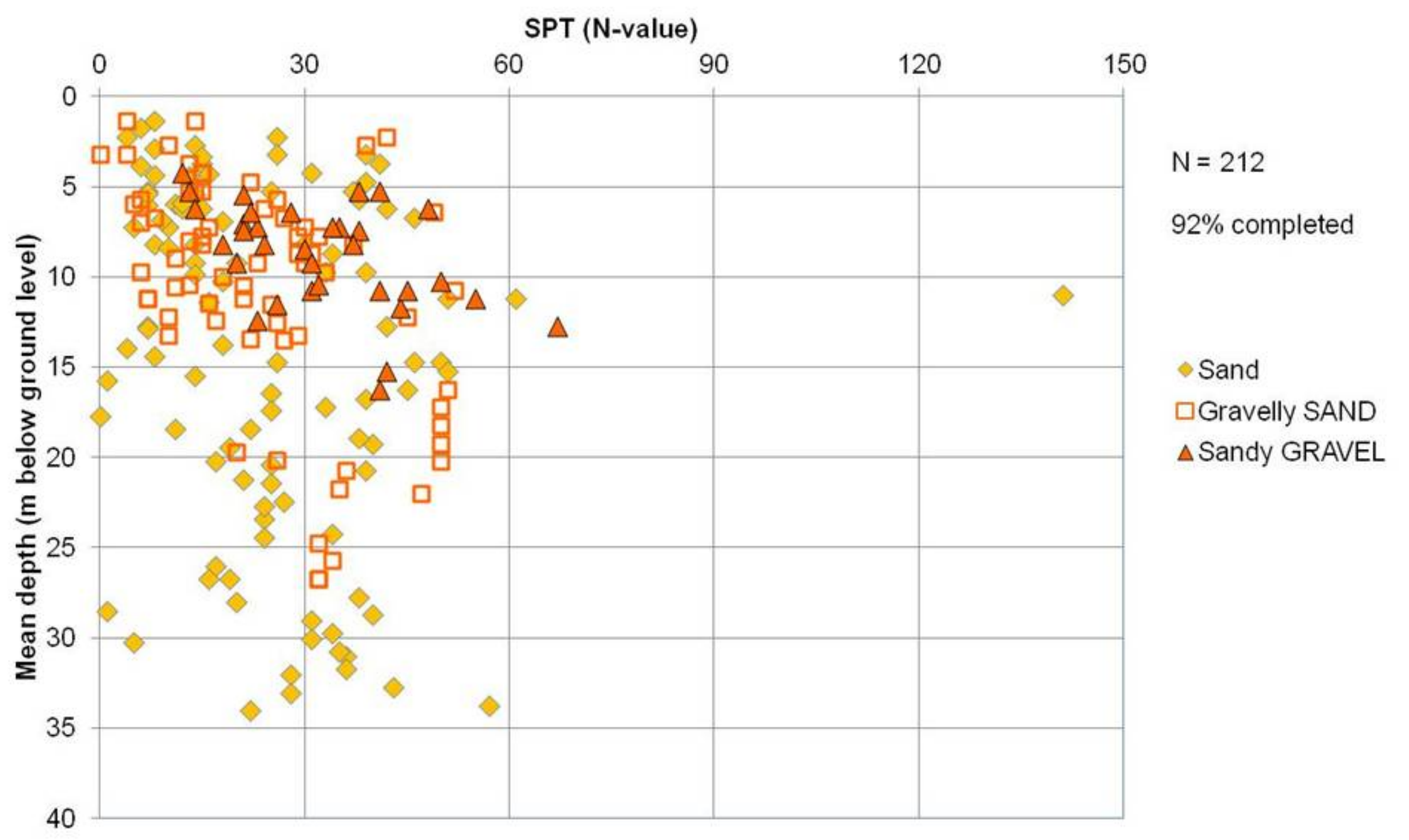




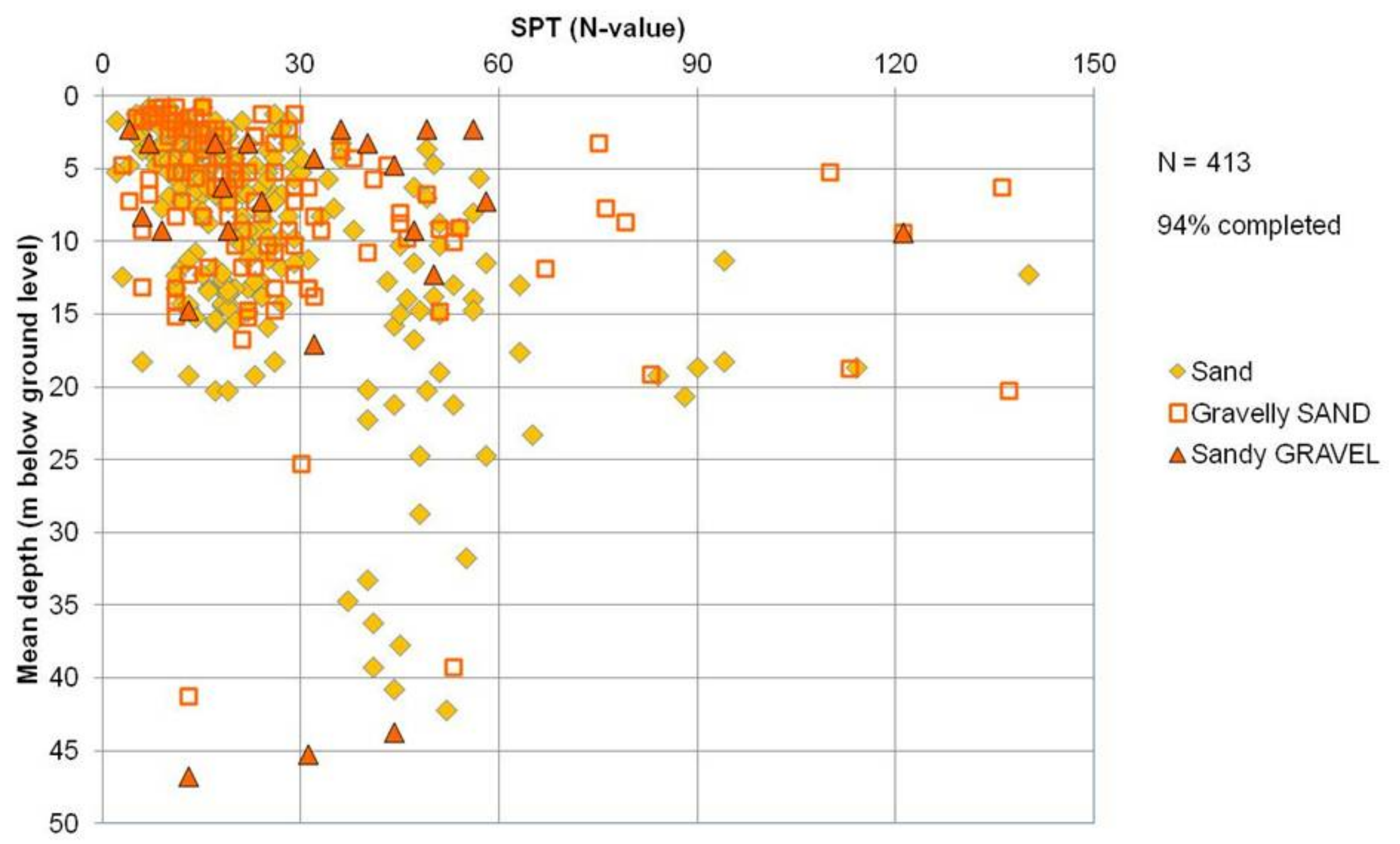


SJ 100 km square SPT (N-value) vs Depth

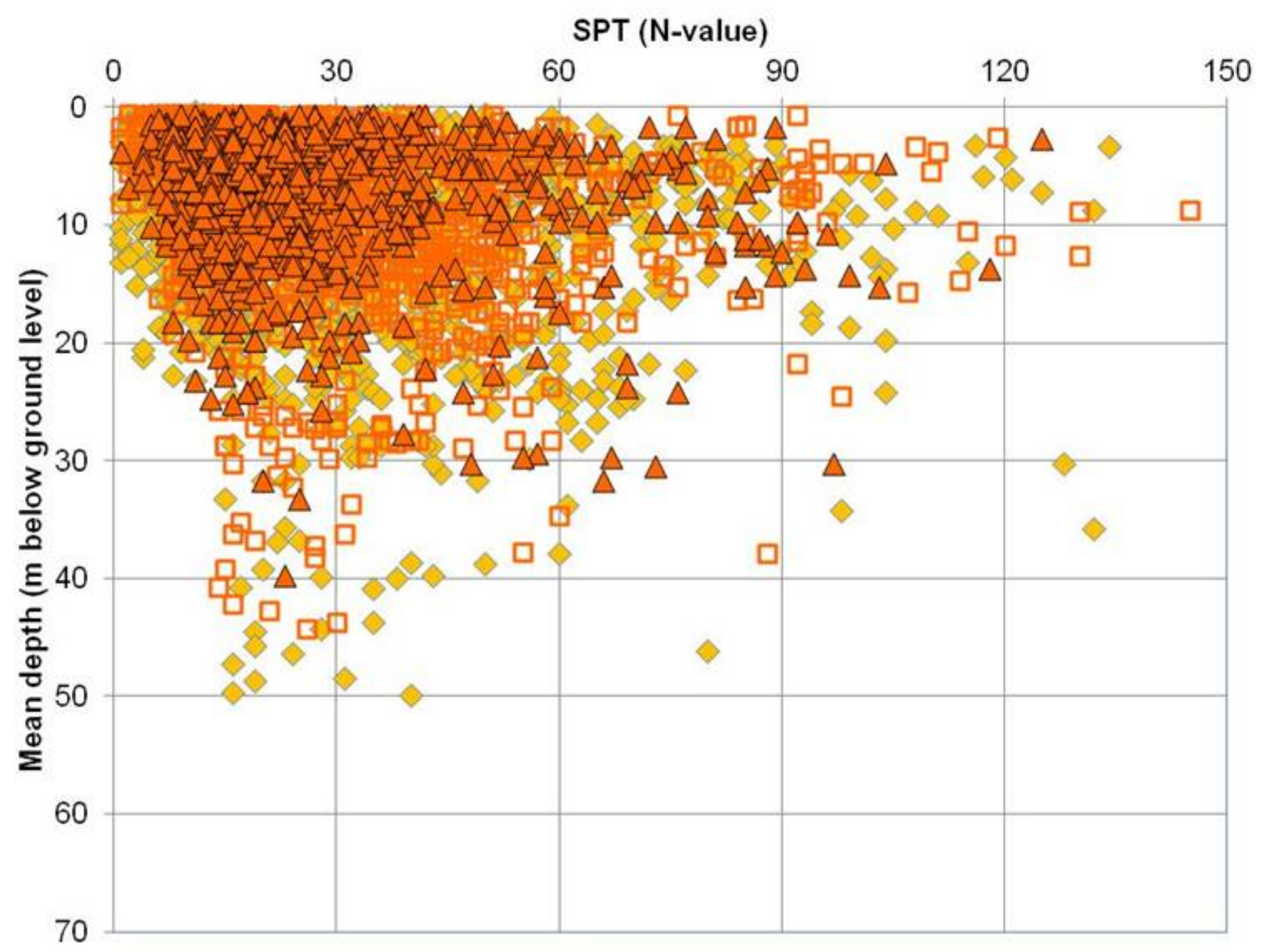

$N=5310$

$93 \%$ completed

$\diamond$ Sand

$\square$ Gravelly SAND $\triangle$ Sandy GRAVEL 


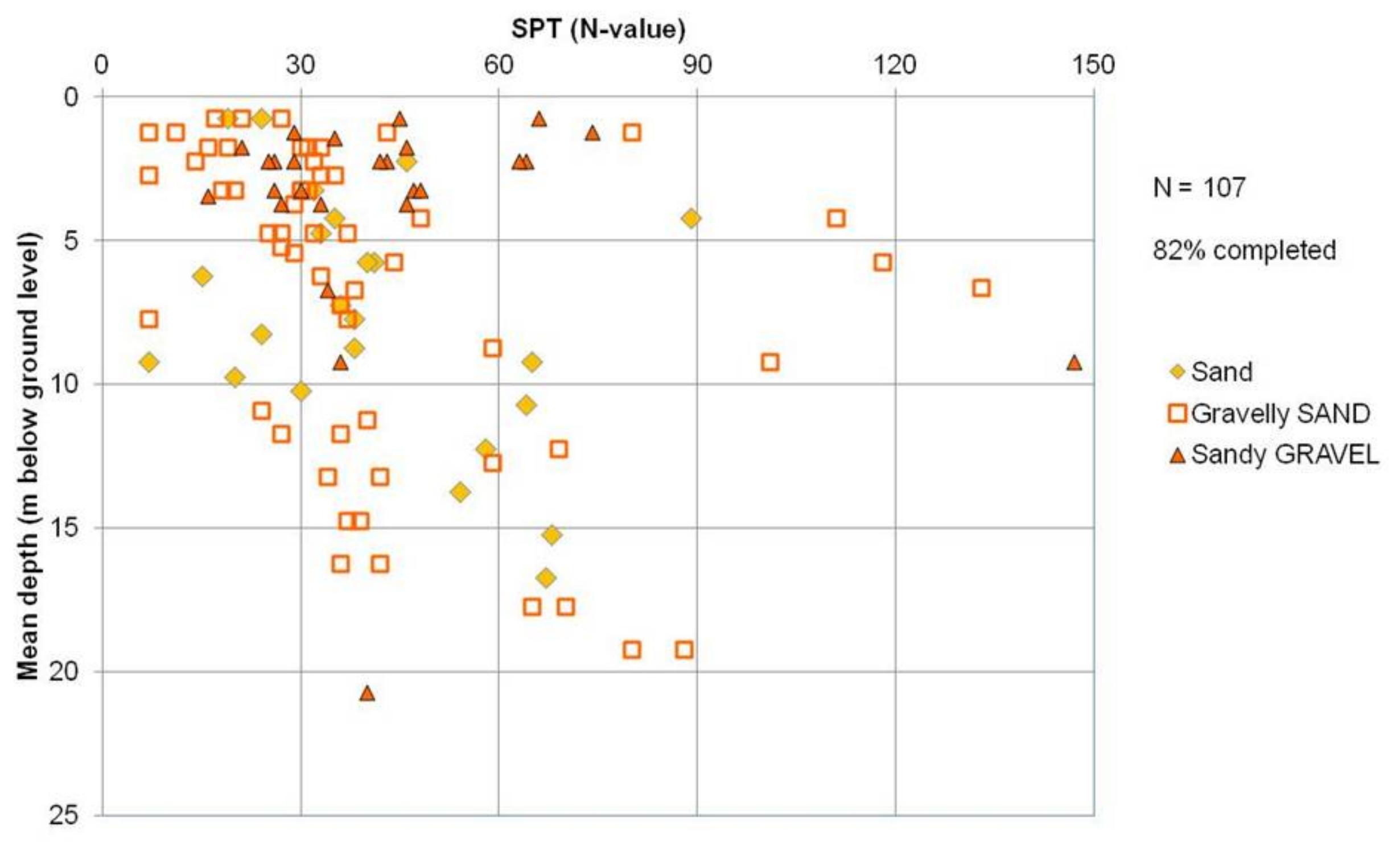




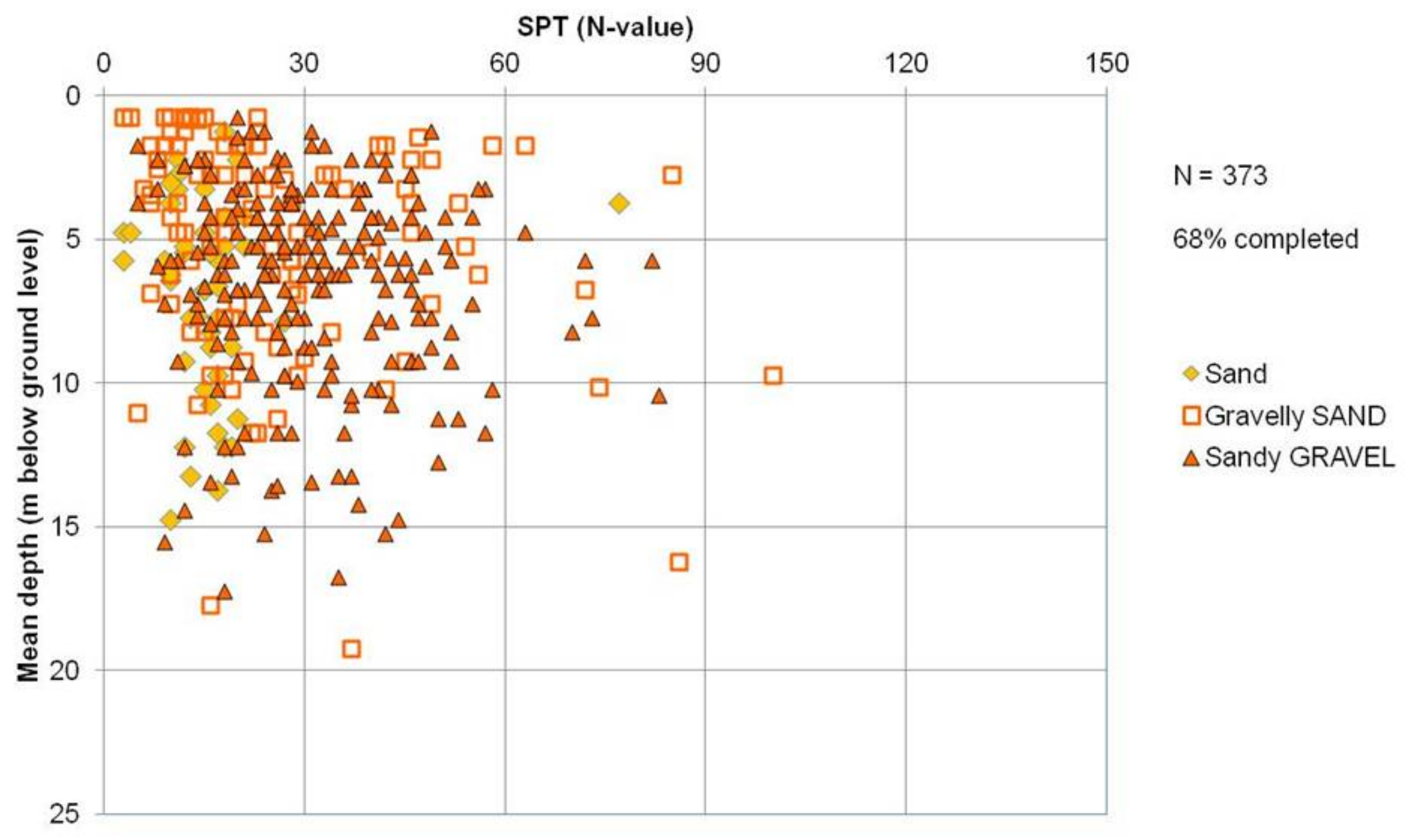




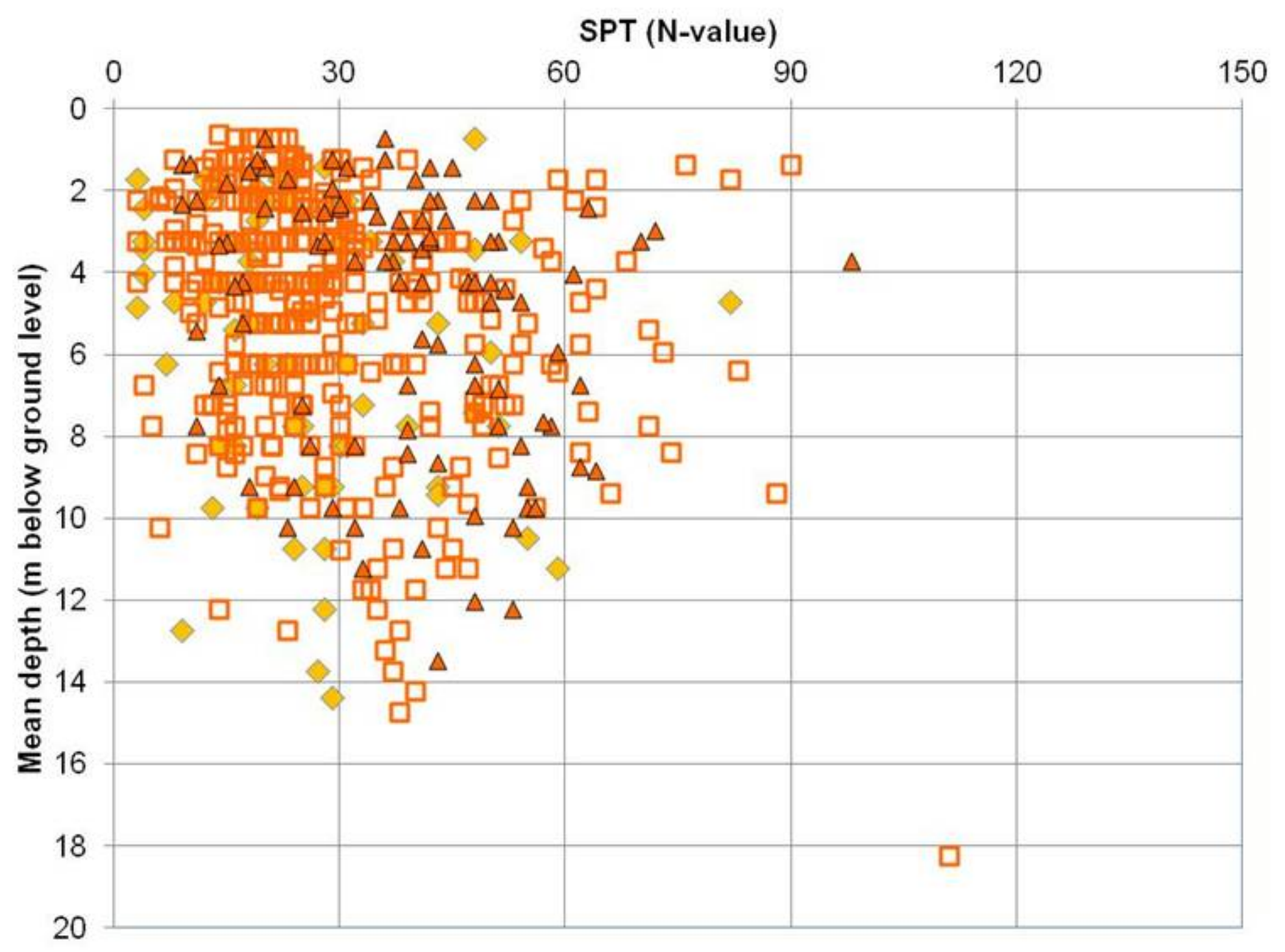

$N=619$

$97 \%$ completed

$\diamond$ Sand

$\square$ Gravelly SAND

$\triangle$ Sandy GRAVEL 


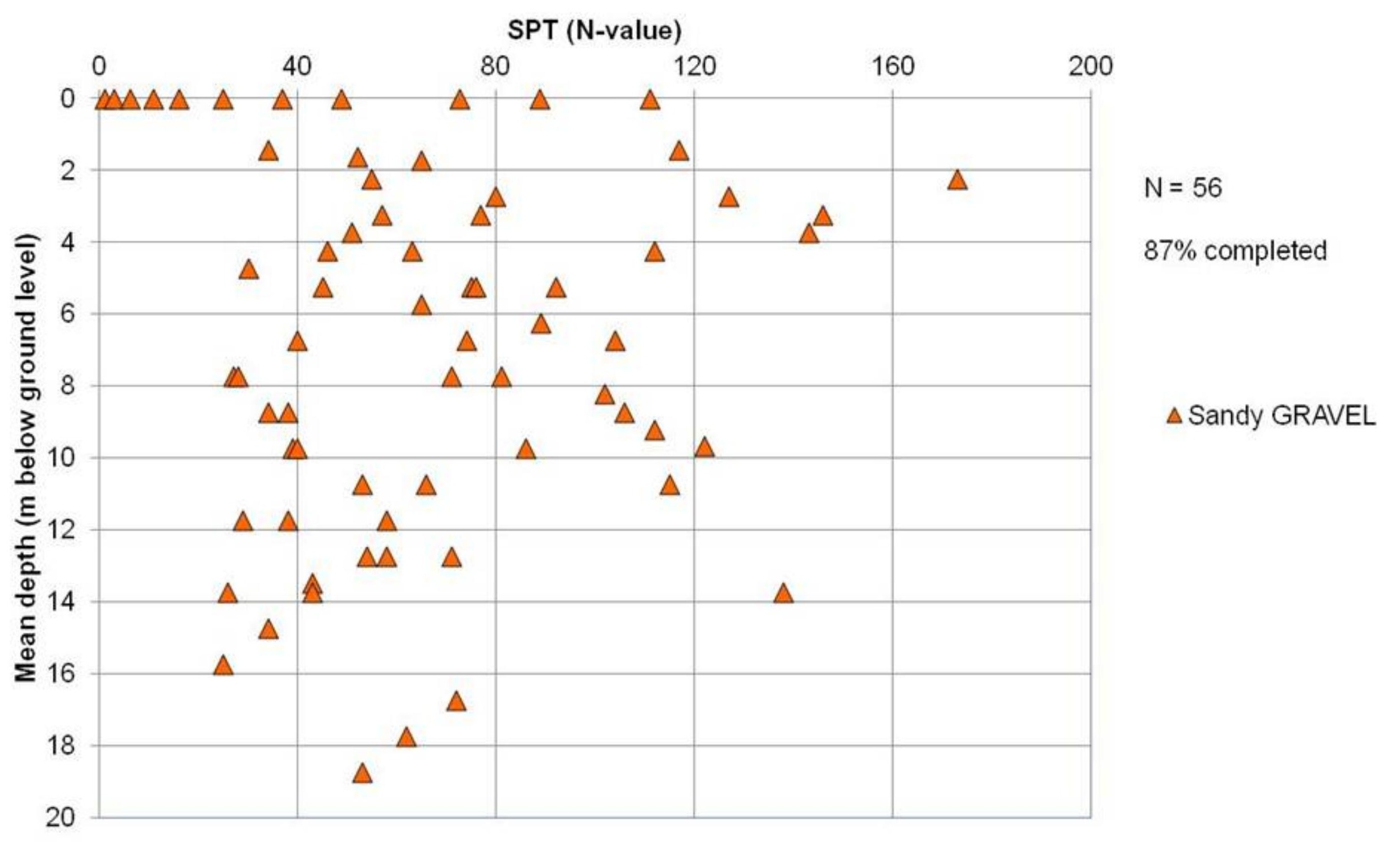




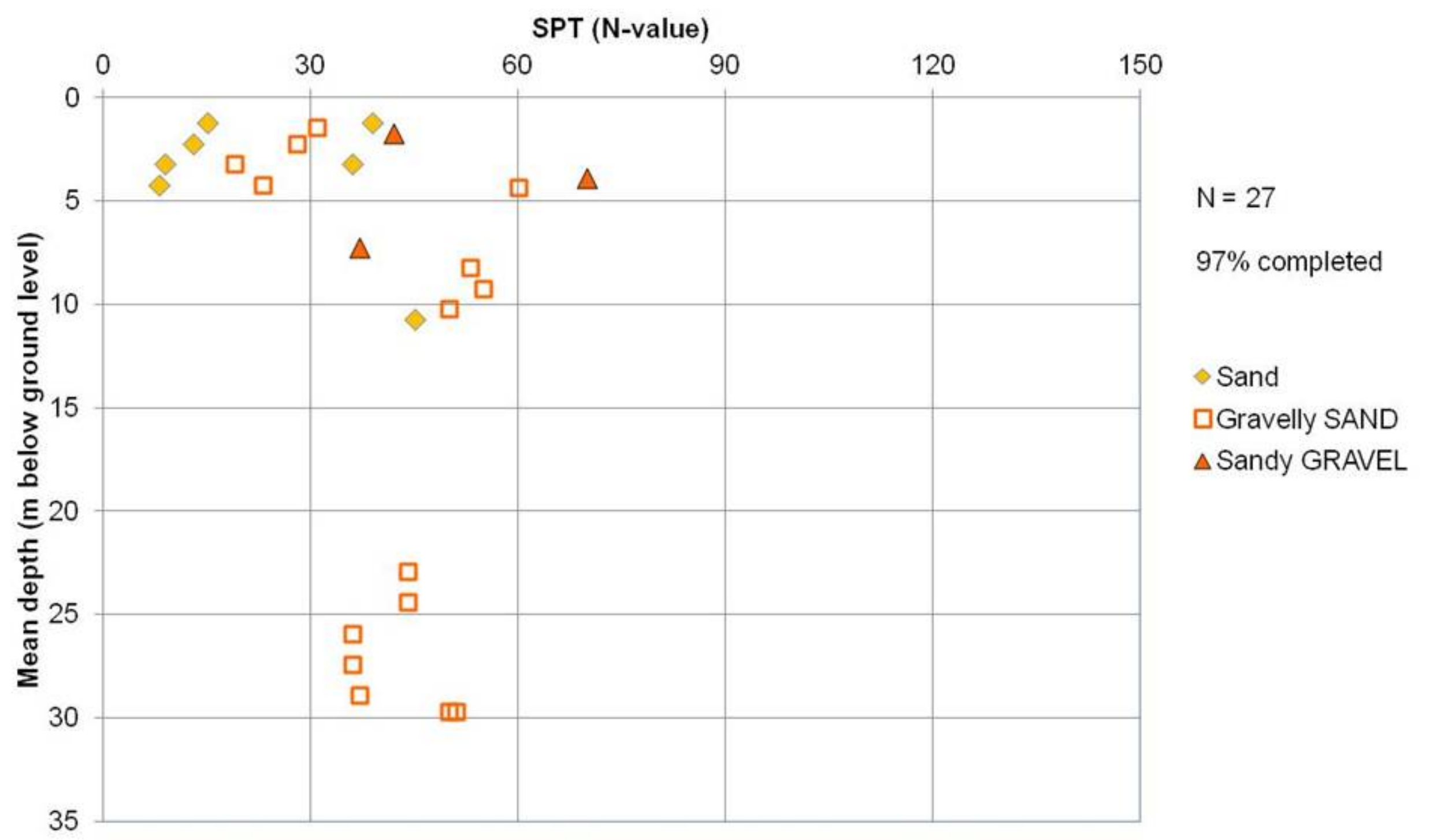


APPENDIX 6-1 TABLE 1. Summary list of codes and names of stratigraphic units described in Appendix 6-1. The codes can be used to identify formations and members for which geotechnical data are given in some of the figures.

\begin{tabular}{|c|c|}
\hline CODE & STRATIGRAPHIC NAME \\
\hline ALBI & Albion Glacigenic Group \\
\hline ANTI & Acklington Till Formation \\
\hline ARDT & Ardverikie Till Formation \\
\hline ASGL & Assynt Glacigenic Formation \\
\hline BAKW & Bakewell Formation \\
\hline BATI & Banchory Till Formation \\
\hline BCD & Banffshire Coast and Caithness Glacigenic Subgroup \\
\hline BDRGL & Borders Glacigenic Subgroup \\
\hline BDTI & Brewood Till Formation \\
\hline BGTI & Bacton Green Till Member \\
\hline BLGL & Blengdale Glacigenic Formation \\
\hline BNOCK & Brecknockshire Glacigenic Formation \\
\hline BOZE & Bozeat Till Member \\
\hline BUTI & Beinn An Uain Till Formation \\
\hline BUTTI & Butterby Till Member \\
\hline BWTI & Burrier Wick Till Formation \\
\hline CALI & Caledonia Glacigenic Group \\
\hline CCGL & Central Cumbria Glacigenic Subgroup \\
\hline CGDR & Central Grampian Glacigenic Subgroup \\
\hline CHVG & Cheviot Glacigenic Subgroup \\
\hline COTI & Corton Till Member \\
\hline EDTI & Edenside Till Member \\
\hline EGD & East Grampian Glacigenic Subgroup \\
\hline ELTI & Elenid Till Member \\
\hline ERYG & Eryry Glacigenic Formation \\
\hline ESTI & Essie Till Formation \\
\hline FINT & Finglack Till Formation \\
\hline FOTI & Forse Till Member \\
\hline GATI & Gartocharn Till Formation \\
\hline GLGL & Glamorgan Glacigenic Formation \\
\hline GOGL & Gosforth Glacigenic Formation \\
\hline GRET & Gretna Till Formation \\
\hline GYTI & Greystoke Till Formation \\
\hline HATT & Hatton Till Formation \\
\hline HDTI & Hereford Till Member \\
\hline HNTI & Horden Till Formation \\
\hline HOLD & Holderness Formation \\
\hline HOTI & Holkham Till Member \\
\hline HPGL & Happisburgh Glacigenic Formation \\
\hline HPTI & Happisburgh Till Member \\
\hline HRT & Harrogate Till Formation \\
\hline INVG & Inverness Glacigenic Subgroup \\
\hline ISCG & Irish Sea Coast Glacigenic Subgroup \\
\hline
\end{tabular}




\begin{tabular}{|l|l|}
\hline JURBY & Juby Formation \\
\hline KLTI & Kendal Till Member \\
\hline KMGL & Kirkham Till Member \\
\hline KWTI & Kale Water Till Formation \\
\hline LBD & Logie-Buchan Glacigenic Subgroup \\
\hline LDTI & Langland Till Member \\
\hline LEWTI & Lewis Till Formation \\
\hline LHTI & Langholm Till Formation \\
\hline LITI & Llanddewi Glacigenic Formation \\
\hline LLEYN & Lleyn Till Member \\
\hline LOFT & Lowestoft Glacigenic Formation \\
\hline LTTI & Lowestoft Till Member \\
\hline MDR & Mearns Glacigenic Subgroup \\
\hline MFT & Mill of Forest Till Formation \\
\hline MNTI & Merion Till Member \\
\hline MTON & Moreton Member \\
\hline MVG & Midland Valley Glacigenic Subgroup \\
\hline NATI & New Abbey Till Member \\
\hline NMTI & Norham Till Formation \\
\hline NPEG & North Pennine Glacigenic Subgroup \\
\hline NSG & North Sea Coast Glacigenic Subgroup \\
\hline NURS & Nurseries Formation \\
\hline NWHG & Northwest Highlands Glacigenic Subgroup \\
\hline ODT & Oadby Till Member \\
\hline PBTI & Port Beag Till Formation \\
\hline PLYNT & Plynlimon Glacigenic Formation \\
\hline POTI & Penfro Till Formation \\
\hline RBNTI & Ruabon Till Member \\
\hline REBU & Reay Burn Till Formation \\
\hline REDR & Reisgill Burn Till Formation \\
\hline RUTI & Runton Till Member \\
\hline SAGL & St. Asaph Glacigenic Formation \\
\hline SFTI & Stainmore Forest Till Formation \\
\hline SHETG & Shetland Glacigenic Subgroup \\
\hline SHREW & Shrewsbury Glacigenic Formation \\
\hline SKTI & Skipsea Member \\
\hline SMCL & Sheringham Cliffs Glacigenic Formation \\
\hline STPTG & Stockport Glacigenic Formation \\
\hline SUDR & Southern Uplands Glacigenic Subgroup \\
\hline THT & Thrussington Member \\
\hline THTI & Thormaid Till Member \\
\hline TKTI & Threlkeld Till Formation \\
\hline VYORK & Vale of York Formation \\
\hline WALES & Wales Glacigenic Subgroup \\
\hline WATI & Walcott Till Member \\
\hline WETI & Wilderness Tsill Formation \\
\hline WISG & \\
\hline WITI & \\
\hline & STacigenic Subgroup \\
\hline
\end{tabular}




\begin{tabular}{|l|l|}
\hline WOLS & Wolston Glacigenic Formation \\
\hline WSTI & Withernsea Member \\
\hline WTTI & Weybourne Town Till Member \\
\hline YDTI & Yorkshire Dales Formation \\
\hline
\end{tabular}


Table 6.1. Geological and geotechnical characteristics of genetic till types (after Clarke 2012). ). This classification is not recommended in this volume, as explained in Chapter 4 Sections 4.1-4.3.

\begin{tabular}{|c|c|c|c|c|}
\hline Criterion & Lodgement till & Melt-out till & Flow till & Deformation till \\
\hline Deposition & $\begin{array}{l}\text { Deposited by } \\
\text { plastering of glacial } \\
\text { debris from the } \\
\text { sliding base of a } \\
\text { moving glacier, by } \\
\text { pressure melting } \\
\text { and/or other } \\
\text { mechanical } \\
\text { processes (Hambrey, } \\
\text { 1994). }\end{array}$ & $\begin{array}{l}\text { Deposited from a } \\
\text { slow release of } \\
\text { glacial debris from } \\
\text { ise, neither sliding } \\
\text { nor deforming } \\
\text { internally } \\
\text { (Dreimanis, } \\
\text { 1988). }\end{array}$ & \begin{tabular}{|l|} 
Deposition \\
accomplished by \\
gravitational slope \\
processes and may \\
occur \\
supraglacially, \\
sub-glacially or at \\
the ice margin \\
(Dreimanis, \\
1988).
\end{tabular} & $\begin{array}{l}\text { Comprises rock or } \\
\text { unconsolidated } \\
\text { sediment detached } \\
\text { by the glacier } \\
\text { from its source; } \\
\text { primary } \\
\text { sedimentary } \\
\text { structures } \\
\text { distorted or } \\
\text { destroyed and } \\
\text { some foreign } \\
\text { material admixed } \\
\text { (Elson, 1988). }\end{array}$ \\
\hline $\begin{array}{l}\text { Position and } \\
\text { sequence }\end{array}$ & $\begin{array}{l}\text { Lodged over older } \\
\text { glacial sediments or } \\
\text { on bedrock. }\end{array}$ & $\begin{array}{l}\text { Usually deposited } \\
\text { during glacial } \\
\text { retreat. }\end{array}$ & $\begin{array}{l}\text { Most commonly } \\
\text { the uppermost } \\
\text { glacigenic deposit. }\end{array}$ & $\begin{array}{l}\text { Formed and } \\
\text { deposited sub- } \\
\text { glacially, often } \\
\text { where the glacier } \\
\text { moves upslope. }\end{array}$ \\
\hline Basal contact & \multicolumn{2}{|c|}{$\begin{array}{l}\text { Lodgement and melt-out tills formed and } \\
\text { deposited at glacial base. Contact with } \\
\text { the substratum (bedrock and } \\
\text { unconsolidated sediments) generally } \\
\text { erosional and sharp. Glacial erosion- } \\
\text { marks and clast alignment have same } \\
\text { orientation. Supraglacial melt-out tills } \\
\text { may have variable basal contact. }\end{array}$} & \begin{tabular}{|l|} 
Variable basal \\
contact but seldom \\
conformable over \\
longer distances. \\
Tills may fill \\
shallow channels \\
or depressions.
\end{tabular} & $\begin{array}{l}\text { Variable basal } \\
\text { contact. }\end{array}$ \\
\hline Landforms & $\begin{array}{l}\text { Mainly ground } \\
\text { moraines, drumlins, } \\
\text { flutes and other sub- } \\
\text { glacial landforms. }\end{array}$ & $\begin{array}{l}\text { Those ice- } \\
\text { marginal } \\
\text { landforms where } \\
\text { glacial ice } \\
\text { stagnated. }\end{array}$ & $\begin{array}{l}\text { Associated with } \\
\text { most ice marginal } \\
\text { landforms. }\end{array}$ & $\begin{array}{l}\text { Landform rarely } \\
\text { diagnostic. }\end{array}$ \\
\hline Thickness & $\begin{array}{l}\text { Typically one to a } \\
\text { few metres thick but } \\
\text { may attain } \\
\text { substantial thickness } \\
\text { in the English } \\
\text { lowlands; relative } \\
\text { lateral consistency. }\end{array}$ & $\begin{array}{l}\text { Single units } \\
\text { usually a few } \\
\text { centimetres to a } \\
\text { few metres thick. } \\
\text { Units may stack to } \\
\text { much greater } \\
\text { accumulated } \\
\text { thickness. }\end{array}$ & \begin{tabular}{|l|} 
Very variable. \\
Individual flow \\
usually a few tens \\
of centimetres to \\
metres thick. \\
Units may stack to \\
accumulated \\
thicknesses of \\
many metres.
\end{tabular} & $\begin{array}{l}\text { Varies up to many } \\
\text { metres depending } \\
\text { upon nature of } \\
\text { glacial bed. }\end{array}$ \\
\hline Structure & $\begin{array}{l}\text { Usually massive but } \\
\text { may contain various } \\
\text { consistently } \\
\text { orientated macro- } \\
\text { and micro-structures. }\end{array}$ & $\begin{array}{l}\text { Either massive, or } \\
\text { with faint } \\
\text { structures partially } \\
\text { preserved from } \\
\text { debris }\end{array}$ & $\begin{array}{l}\text { Either massive or } \\
\text { displaying various } \\
\text { flow structures } \\
\text { depending on type } \\
\text { of flow and water }\end{array}$ & $\begin{array}{l}\text { Primary structures } \\
\text { may be preserved } \\
\text { but usually } \\
\text { deformed, } \\
\text { especially in upper }\end{array}$ \\
\hline
\end{tabular}




\begin{tabular}{|c|c|c|c|c|}
\hline & $\begin{array}{l}\text { Sub-horizontal } \\
\text { jointing common } \\
\text { and vertical and } \\
\text { transverse joints may } \\
\text { also be present. } \\
\text { Orientation of } \\
\text { deformation } \\
\text { structures related to } \\
\text { stress applied by } \\
\text { moving glacier and } \\
\text { may be laterally } \\
\text { consistent. }\end{array}$ & $\begin{array}{l}\text { stratification in } \\
\text { basal debris-rich } \\
\text { ice. Loss of } \\
\text { volume with } \\
\text { melting leads to } \\
\text { draping of sorted } \\
\text { sediments over } \\
\text { large clasts. }\end{array}$ & content. & $\begin{array}{l}\text { part of the } \\
\text { sequence which } \\
\text { may blend into } \\
\text { other massive tills. }\end{array}$ \\
\hline $\begin{array}{l}\text { Grain size } \\
\text { composition }\end{array}$ & $\begin{array}{l}\text { Abrasion in traction } \\
\text { zone during } \\
\text { lodgement produces } \\
\text { silt-size particles } \\
\text { typical of lodgement } \\
\text { tills. Most have } \\
\text { relatively consistent } \\
\text { grain-size } \\
\text { composition except } \\
\text { for the basal part } \\
\text { which may contain } \\
\text { boulders of local } \\
\text { glacier bed. }\end{array}$ & $\begin{array}{l}\text { Winnowing of silt- } \\
\text { and clay-size } \\
\text { particles occurs } \\
\text { during melt-out. } \\
\text { Some particle size } \\
\text { variability } \\
\text { inherited from } \\
\text { debris bands in } \\
\text { ice. Supraglacial } \\
\text { melt-out tills of } \\
\text { valley glaciers } \\
\text { contain } \\
\text { characteristic } \\
\text { coarse-grained } \\
\text { debris. }\end{array}$ & $\begin{array}{l}\text { Usually diamicton } \\
\text { with polymodal } \\
\text { particle size } \\
\text { distribution. Some } \\
\text { particle size } \\
\text { redistribution and } \\
\text { sorting may occur } \\
\text { during flow. } \\
\text { Inverse or normal } \\
\text { grading may } \\
\text { develop. }\end{array}$ & $\begin{array}{l}\text { When derived } \\
\text { from weak rocks } \\
\text { contain clasts } \\
\text { separated by } \\
\text { minor amounts of } \\
\text { finer matrix. Clast } \\
\text { size reflects } \\
\text { bedding thickness } \\
\text { of original } \\
\text { material. }\end{array}$ \\
\hline $\begin{array}{l}\text { Lithology of } \\
\text { clasts and } \\
\text { matrix }\end{array}$ & $\begin{array}{l}\text { Lithological } \\
\text { composition often } \\
\text { more consistent than } \\
\text { other tills. } \\
\text { Composition of } \\
\text { matrix particularly } \\
\text { uniform. Materials } \\
\text { of local derivation } \\
\text { increase in } \\
\text { abundance towards } \\
\text { basal contact. }\end{array}$ & $\begin{array}{l}\text { Supraglacial melt- } \\
\text { out till more } \\
\text { variable in } \\
\text { composition with } \\
\text { increased } \\
\text { possibility of } \\
\text { exotic material. }\end{array}$ & $\begin{array}{l}\text { Lithological } \\
\text { composition } \\
\text { generally same as } \\
\text { source material. } \\
\text { May include } \\
\text { incorporated } \\
\text { glacier bed or } \\
\text { exotic materials } \\
\text { depending on } \\
\text { debris source, } \\
\text { transport and } \\
\text { deposition. }\end{array}$ & $\begin{array}{l}\text { Generally have } \\
\text { same lithological } \\
\text { composition as } \\
\text { underlying } \\
\text { sediments. } \\
\text { Occasional } \\
\text { erratics present } \\
\text { particularly in } \\
\text { upper part of the } \\
\text { sequence. }\end{array}$ \\
\hline $\begin{array}{l}\text { Clast shapes } \\
\text { and their } \\
\text { surface marks }\end{array}$ & $\begin{array}{l}\text { Sub-angular to sub- } \\
\text { rounded clasts. } \\
\text { Bullet-shaped, } \\
\text { faceted, crushed, } \\
\text { sheared and } \\
\text { streaked-out clasts } \\
\text { more common in } \\
\text { lodgement than other } \\
\text { tills. Lodged clasts } \\
\text { striated parallel to } \\
\text { direction of the } \\
\text { lodging movement. }\end{array}$ & $\begin{array}{l}\text { Variable degree of } \\
\text { roundness but } \\
\text { angular clasts } \\
\text { occur where } \\
\text { supraglacial melt- } \\
\text { out debris is } \\
\text { englacially or } \\
\text { supraglacially } \\
\text { derived. }\end{array}$ & $\begin{array}{l}\text { If present, soft } \\
\text { sediment clasts } \\
\text { may be rounded or } \\
\text { deformed by } \\
\text { shear. More } \\
\text { resistant rock } \\
\text { clasts will retain } \\
\text { their original } \\
\text { shape. }\end{array}$ & $\begin{array}{l}\text { Clast shape and } \\
\text { surface marks } \\
\text { generally inherited } \\
\text { from original } \\
\text { material and not } \\
\text { diagnostic. Clasts } \\
\text { generally } \\
\text { transported } \\
\text { passively and not } \\
\text { significantly } \\
\text { modified. }\end{array}$ \\
\hline
\end{tabular}




\begin{tabular}{|c|c|c|c|c|}
\hline Fabric & $\begin{array}{l}\text { Strong macro fabric } \\
\text { with clast long axes } \\
\text { parallel to local } \\
\text { direction of } \\
\text { movement. } \\
\text { Transverse } \\
\text { orientation possible, } \\
\text { associated with } \\
\text { folding and shearing. }\end{array}$ & $\begin{array}{l}\text { Fabric inherited } \\
\text { from glacier } \\
\text { transport. Melt-out } \\
\text { process may } \\
\text { weaken fabric, } \\
\text { particularly micro- } \\
\text { fabric. }\end{array}$ & $\begin{array}{l}\text { Fabric may be } \\
\text { random or } \\
\text { strongly } \\
\text { developed and } \\
\text { parallel or } \\
\text { transverse to flow } \\
\text { direction. Fabric } \\
\text { may vary laterally } \\
\text { over short } \\
\text { distances. }\end{array}$ & $\begin{array}{l}\text { Preferred } \\
\text { orientation rare } \\
\text { and generally } \\
\text { reflects shearing } \\
\text { deformation. }\end{array}$ \\
\hline Consolidation & $\begin{array}{l}\text { Consolidation } \\
\text { process depends on } \\
\text { pore pressure } \\
\text { regime, temperature } \\
\text { profile and } \\
\text { permeability of } \\
\text { glacier bed. Tills can } \\
\text { be 'lightly } \\
\text { overconsolidated' to } \\
\text { 'heavily } \\
\text { overconsolidated.' }\end{array}$ & $\begin{array}{l}\text { Lightly } \\
\text { overconsolidated. }\end{array}$ & $\begin{array}{l}\text { Usually normally } \\
\text { consolidated. }\end{array}$ & $\begin{array}{l}\text { Variably } \\
\text { consolidated. }\end{array}$ \\
\hline Density & $\begin{array}{l}\text { Very dense, often in } \\
\text { excess of } \\
\text { gravitationally } \\
\text { compacted stiff clays } \\
\text { due to combination } \\
\text { of normal and shear } \\
\text { stress during } \\
\text { deposition. }\end{array}$ & $\begin{array}{l}\text { Bulk density } \\
\text { lower and more } \\
\text { variable than } \\
\text { lodgement till. } \\
\end{array}$ & $\begin{array}{l}\text { Density lower } \\
\text { than lodgement } \\
\text { tills and typical of } \\
\text { normally } \\
\text { consolidated } \\
\text { deposits. }\end{array}$ & $\begin{array}{l}\text { Spatially variable } \\
\text { densities due to } \\
\text { presence of lower } \\
\text { density pockets of } \\
\text { material and } \\
\text { dilatency during } \\
\text { deformation. }\end{array}$ \\
\hline Strength & $\begin{array}{l}\text { Very strong due to } \\
\text { high densities. } \\
\text { Strengths can } \\
\text { approach those of } \\
\text { weak rock in some } \\
\text { cases. }\end{array}$ & $\begin{array}{l}\text { Strength lower } \\
\text { and more variable } \\
\text { than lodgement } \\
\text { till. }\end{array}$ & $\begin{array}{l}\text { Strengths typical } \\
\text { of normally } \\
\text { consolidated } \\
\text { deposits. }\end{array}$ & $\begin{array}{l}\text { Spatially variable } \\
\text { strength due to } \\
\text { presence of lower } \\
\text { density pockets of } \\
\text { material and } \\
\text { dilatency during } \\
\text { deformation. }\end{array}$ \\
\hline Permeability & $\begin{array}{l}\text { Highly impermeable } \\
\text { if a clay matrix } \\
\text { dominated till. }\end{array}$ & $\begin{array}{l}\text { Variable due to } \\
\text { mix of particle } \\
\text { sizes. }\end{array}$ & $\begin{array}{l}\text { Relatively } \\
\text { permeable } \\
\text { compared to clay } \\
\text { matrix-dominated } \\
\text { lodgement tills. }\end{array}$ & $\begin{array}{l}\text { Spatially variable } \\
\text { permeability due } \\
\text { to presence of } \\
\text { lower density } \\
\text { pockets of } \\
\text { material and } \\
\text { dilatency during } \\
\text { deformation. }\end{array}$ \\
\hline $\begin{array}{l}\text { References for } \\
\text { summaries of } \\
\text { diagnostic } \\
\text { properties }\end{array}$ & $\begin{array}{l}\text { Goldthwait (1971), } \\
\text { Boulton (1976), } \\
\text { Dreimanis (1976), } \\
\text { Boulton \& Deynoux } \\
\text { (1981), McGown \& } \\
\text { Derbyshire (1977), }\end{array}$ & $\begin{array}{l}\text { Boulton (1976), } \\
\text { Dreimanis (1976), } \\
\text { McGown \& } \\
\text { Derbyshire } \\
\text { (1977), Lawson } \\
\text { (1979), Boulton }\end{array}$ & $\begin{array}{l}\text { Boulton (1976), } \\
\text { Lawson (1979), } \\
\text { Boulton \& } \\
\text { Deynoux (1981), } \\
\text { Lutenegger et al. } \\
\text { (1983), Gravenor }\end{array}$ & $\begin{array}{l}\text { Elson (1988), } \\
\text { Boulton (1979), } \\
\text { Clarke et al. } \\
\text { (2008) }\end{array}$ \\
\hline
\end{tabular}


Eyles et al. (1982), | \& Deynoux | et al. (1984),

Clarke \& Chen $\quad$ (1981), Shaw $\quad$ Rappol (1985),

(1997), Clarke et al. (1985) Drewry (1986)

(1998, 2008) 
Table 6.2. Lithostratigraphy, previous name, area of occurrence, thickness and description of Caledonia Glacigenic Group tills.

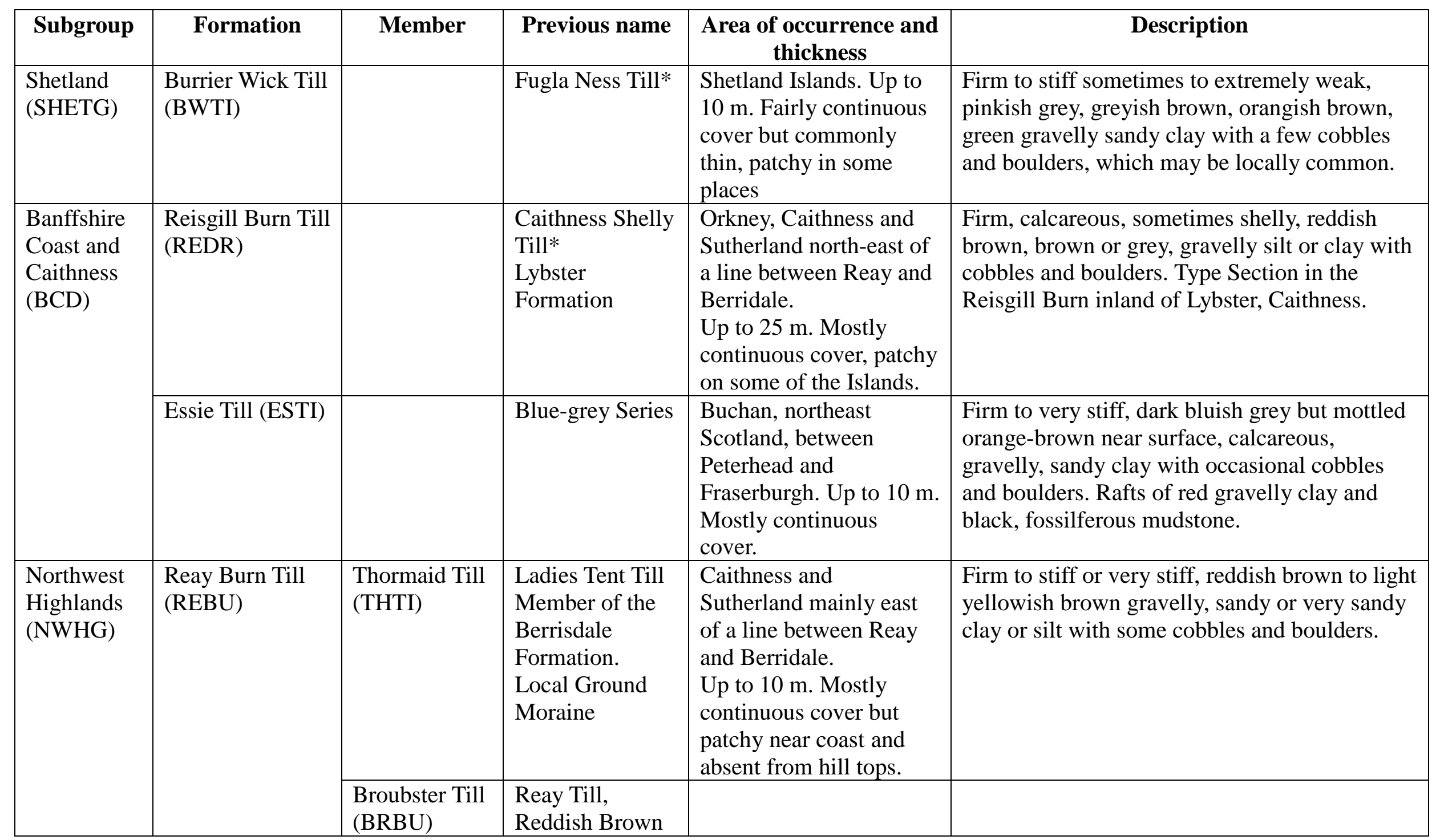




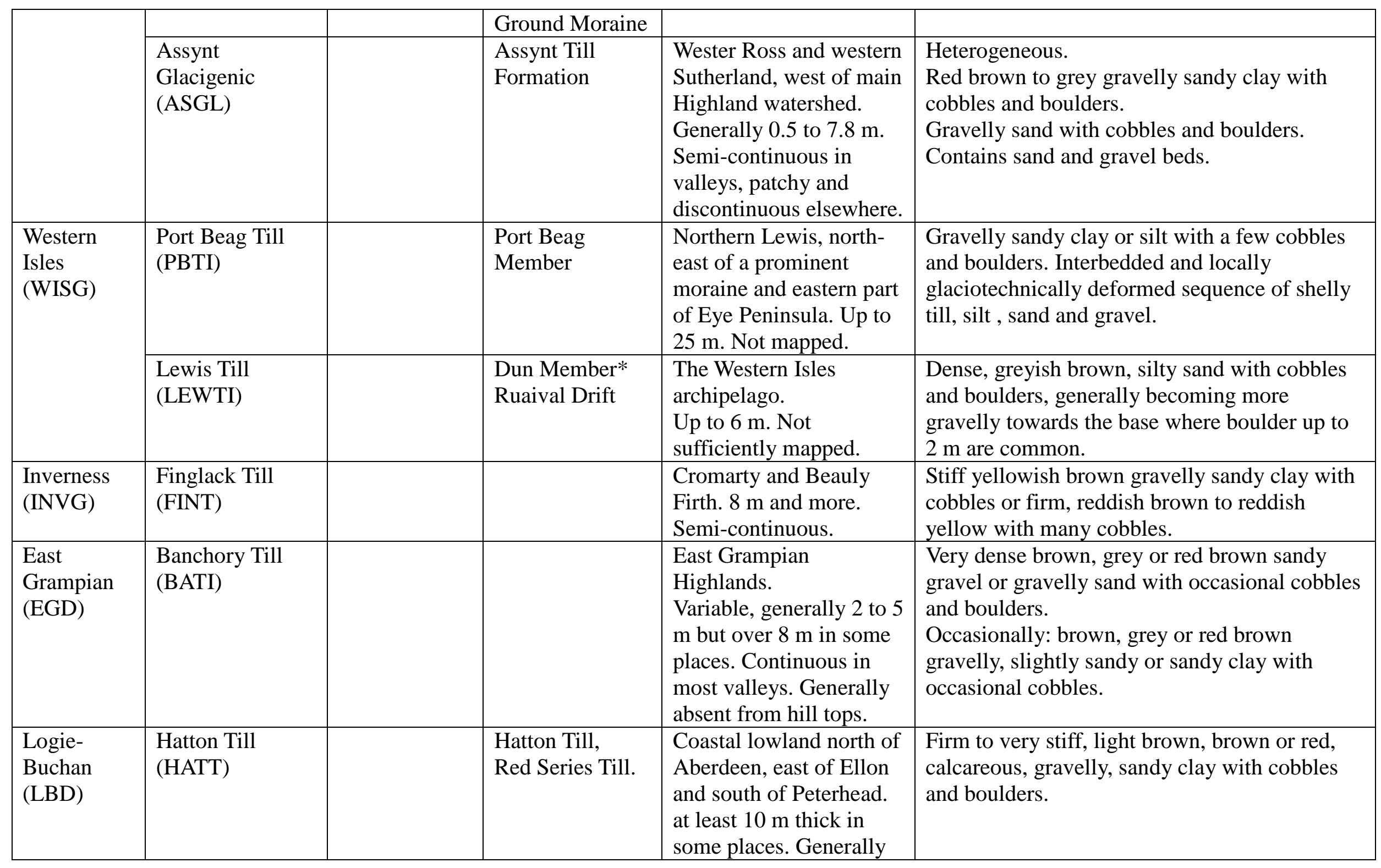




\begin{tabular}{|c|c|c|c|c|}
\hline & & & continuous. & \\
\hline \multirow{2}{*}{$\begin{array}{l}\text { Central } \\
\text { Grampian } \\
\text { (CGDR) }\end{array}$} & $\begin{array}{l}\text { Ardverikie Till } \\
\text { (ARDT) }\end{array}$ & & $\begin{array}{l}\text { Central Highland west of } \\
\text { the Caringorms and } \\
\text { Gaick Plateau. } \\
\text { Up to } 12 \text { m. In most } \\
\text { valley and missing from } \\
\text { hill tops and mountain. } \\
\text { More dissected in the } \\
\text { south west. }\end{array}$ & Gravelly, sandy clay with cobbles and boulders. \\
\hline & $\begin{array}{l}\text { Gartocharn Till } \\
\text { (GATI) }\end{array}$ & & $\begin{array}{l}\text { Loch Lomond and the } \\
\text { Trossachs. } \\
\text { At least up to } 6 \mathrm{~m} \text {. } \\
\text { Mostly in the valleys } \\
\text { particularly in the south } \\
\text { east, but generally } \\
\text { patchy. }\end{array}$ & $\begin{array}{l}\text { Variable lithology. } \\
\text { Stiff to extremely weak jointed, brown to dark } \\
\text { brownish grey occasional or slightly gravelly } \\
\text { clay with marine shells with occasional cobbles } \\
\text { and boulders. } \\
\text { Elsewhere it can be gravelly sandy clay with } \\
\text { cobbles and boulders. Quaternary marine shells } \\
\text { may occur locally. }\end{array}$ \\
\hline $\begin{array}{l}\text { Mearns } \\
\text { (MDR) }\end{array}$ & $\begin{array}{l}\text { Mill of Forest } \\
\text { Till (MFT) }\end{array}$ & & $\begin{array}{l}\text { South east } \\
\text { Aberdeenshire and the } \\
\text { coastline between } \\
\text { Stonehaven and the } \\
\text { mouth of the River Dee. } \\
\text { Very variable, generally } \\
5 \text { to } 9 \text { m. Fairly } \\
\text { continuous but patchy or } \\
\text { missing from hills. }\end{array}$ & $\begin{array}{l}\text { Sandy gravel or gravelly sand and reddish } \\
\text { brown, very clayey gravel or gravel with clayey } \\
\text { gravel with cobbles and gravelly sandy clay } \\
\text { with cobbles and boulders. }\end{array}$ \\
\hline Midland & Wilderness Till & Wilderness & Midland Valley of & Firm to extremely weak, sometimes with joint \\
\hline
\end{tabular}




\begin{tabular}{|c|c|c|c|c|c|}
\hline $\begin{array}{l}\text { Valley } \\
\text { (MVG) }\end{array}$ & $\begin{array}{l}\text { Formation } \\
\text { (WITI) }\end{array}$ & & $\begin{array}{l}\text { Member } \\
\text { Lowland Tills }\end{array}$ & $\begin{array}{l}\text { Scotland, north } \\
\text { Ayreshire to Stirling, } \\
\text { Tayside, the Lothians } \\
\text { and Fife. } \\
\text { Up to } 30 \text { m in drumlins. } \\
\text { Fairly continuous, } \\
\text { mostly in valleys and on } \\
\text { coast. }\end{array}$ & $\begin{array}{l}\text { sets, reddish brown, brownish grey or dark } \\
\text { grey, or greenish grey, gravelly, sandy clay or } \\
\text { silt or mudstone with cobbles and occasional } \\
\text { boulders. } \\
\text { May contain lenses or beds of medium sand or } \\
\text { laminated clay up to } 10 \mathrm{~cm} \text { thick. }\end{array}$ \\
\hline $\begin{array}{l}\text { Borders } \\
\text { (BDRGL) }\end{array}$ & $\begin{array}{l}\text { Norham Till } \\
\text { Formation } \\
\text { (NMTI) }\end{array}$ & & & $\begin{array}{l}\text { The low country } \\
\text { between the } \\
\text { Lammermuirs and the } \\
\text { River Tweed and east of } \\
\text { Boondreigh and Leader } \\
\text { Waters. } \\
\text { Up to } 4 \text { m. } \\
\text { Continuous in valleys, } \\
\text { patchy in higher areas. }\end{array}$ & $\begin{array}{l}\text { Dark red gravelly, sandy clay with cobbles and } \\
\text { small boulders. }\end{array}$ \\
\hline $\begin{array}{l}\text { Southern } \\
\text { Uplands } \\
\text { (SUDR) }\end{array}$ & $\begin{array}{l}\text { Langholm Till } \\
\text { (LHTI) }\end{array}$ & $\begin{array}{l}\text { New Abbey } \\
\text { Till }\end{array}$ & & $\begin{array}{l}\text { South west Scotland } \\
\text { plutons. } \\
\text { Patchy, mostly in } \\
\text { valleys. }\end{array}$ & $\begin{array}{l}\text { Light yellow grey to yellow brown sandy } \\
\text { gravel or gravelly sand with cobbles. }\end{array}$ \\
\hline $\begin{array}{l}\text { Irish Sea } \\
\text { Coast } \\
\text { (ISCG) } \\
\text { (Irish Sea } \\
\text { Till) }\end{array}$ & $\begin{array}{l}\text { Jurby Till } \\
\text { (JURBY) }\end{array}$ & & & $\begin{array}{l}\text { Northern part of the Isle } \\
\text { of Man, the low land } \\
\text { around Stranraer, } \\
\text { between Loch Ryan and } \\
\text { Luce Bay, and at } \\
\text { Drunmore and Mull of }\end{array}$ & $\begin{array}{l}\text { Statigraphical complex sequence include } \\
\text { glaciolacustrine clays and laminated clay with a } \\
\text { little or occasional gravel, interstratified } \\
\text { gravelly sand and silt and clay and gravelly } \\
\text { clay. The till generally makes up a subsidiary } \\
\text { part of the formation. }\end{array}$ \\
\hline
\end{tabular}




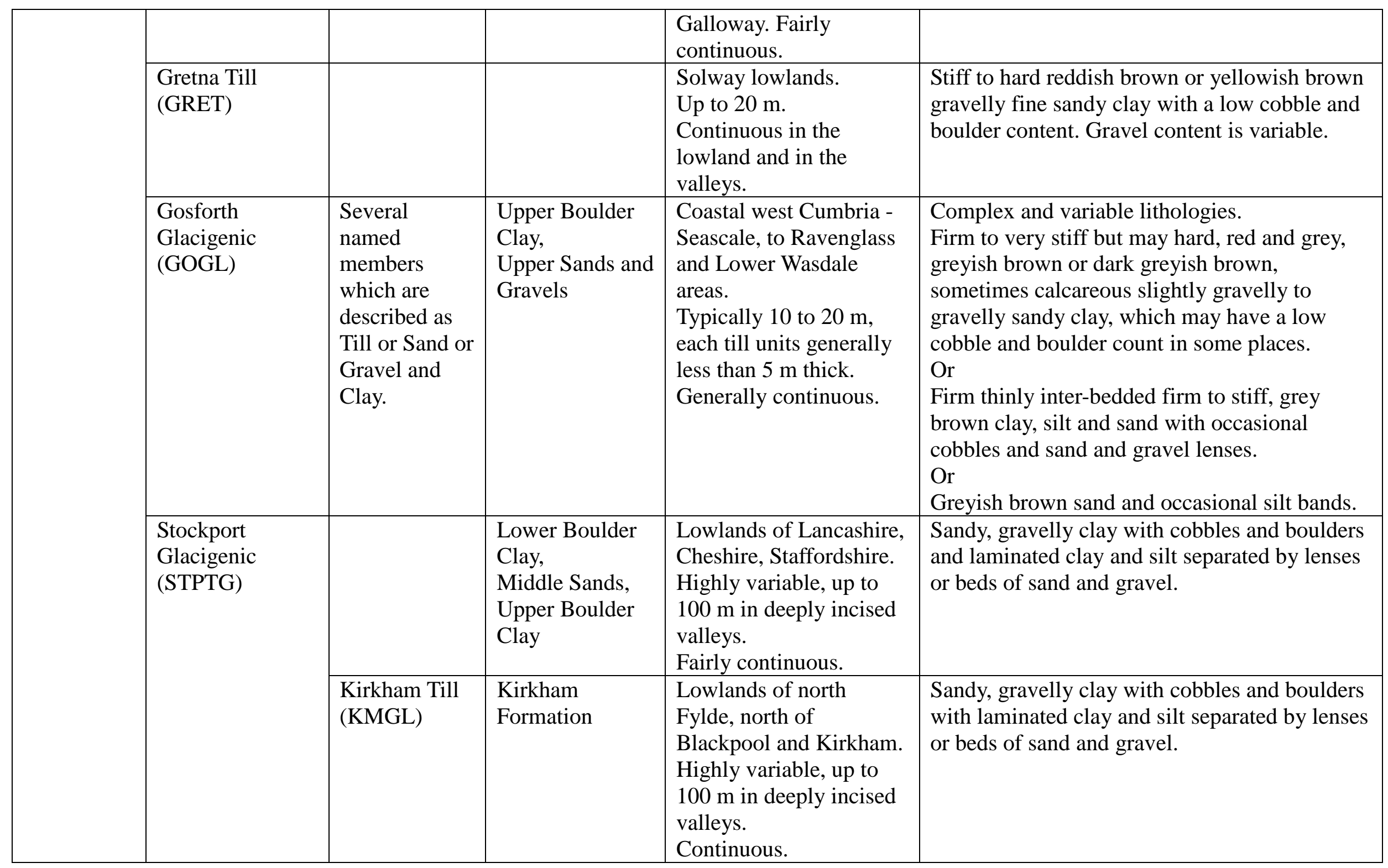




\begin{tabular}{|c|c|c|c|c|c|}
\hline & $\begin{array}{l}\text { Brewood Till } \\
\text { (BDTI) }\end{array}$ & & $\begin{array}{l}\text { Un-Named Till } \\
\text { of Irish Sea } \\
\text { Provenance at } \\
\text { Four Ashes. }\end{array}$ & $\begin{array}{l}\text { East Manchester, } \\
\text { Stockport, Stoke-on- } \\
\text { Trent, Stafford and west } \\
\text { to south to the } \\
\text { Devensian limit. } \\
3 \text { m at type section but } \\
\text { up to } 17 \text { m at Madeley, } \\
\text { Telford. } \\
\text { Fairly continuous to } \\
\text { patchy. }\end{array}$ & $\begin{array}{l}\text { Reddish brown, gravelly, sandy clay with } \\
\text { cobbles and boulders. }\end{array}$ \\
\hline & $\begin{array}{l}\text { St Asaph } \\
\text { Glacigenic } \\
\text { (SAGL) }\end{array}$ & $\begin{array}{l}\text { Lleyn Till } \\
\text { (LLEYN) }\end{array}$ & $\begin{array}{l}\text { Irish Sea Till, } \\
\text { St Asaph } \\
\text { Formation. }\end{array}$ & $\begin{array}{l}\text { Anglesey, north coast } \\
\text { and western tip of the } \\
\text { Lleyn Peninsula as far } \\
\text { east as Llanddulas, } \\
\text { coastal fringe of } \\
\text { Ceredigion and } \\
\text { Pembrokeshire } \\
\text { between Llanrystud and } \\
\text { St. Brides Bay. } \\
\text { Highly variable, more } \\
\text { than } 17 \text { m in the } \\
\text { Cardigan district and } \\
\text { more than } 30 \text { m on the } \\
\text { Lleyn Peninsula. } \\
\text { Semi continuous. }\end{array}$ & $\begin{array}{l}\text { Stiff, generally calcareous, red, purple, bluish } \\
\text { black or green-grey, gravelly, sandy, clay. } \\
\text { Includes sand and gravel beds and clayey } \\
\text { gravel. }\end{array}$ \\
\hline & & $\begin{array}{l}\text { Llangelynin } \\
\text { Till Member* } \\
\text { (LNTI) }\end{array}$ & & $\begin{array}{l}\text { Along the coast south of } \\
\text { Barmouth Bay and north } \\
\text { of River Dovey, } \\
\text { Gwynedd. }\end{array}$ & \\
\hline $\begin{array}{l}\text { Central } \\
\text { Cumbria } \\
\text { (ISCG) }\end{array}$ & $\begin{array}{l}\text { Greystoke Till } \\
\text { (GYTI) }\end{array}$ & & $\begin{array}{l}\text { Main Late } \\
\text { Devensian Till } \\
\text { of the Vale of }\end{array}$ & $\begin{array}{l}\text { The Vale of Eden and } \\
\text { southern Solway } \\
\text { lowlands north of the }\end{array}$ & $\begin{array}{l}\text { Grey gravelly sandy clay with cobbles and } \\
\text { boulders. }\end{array}$ \\
\hline
\end{tabular}




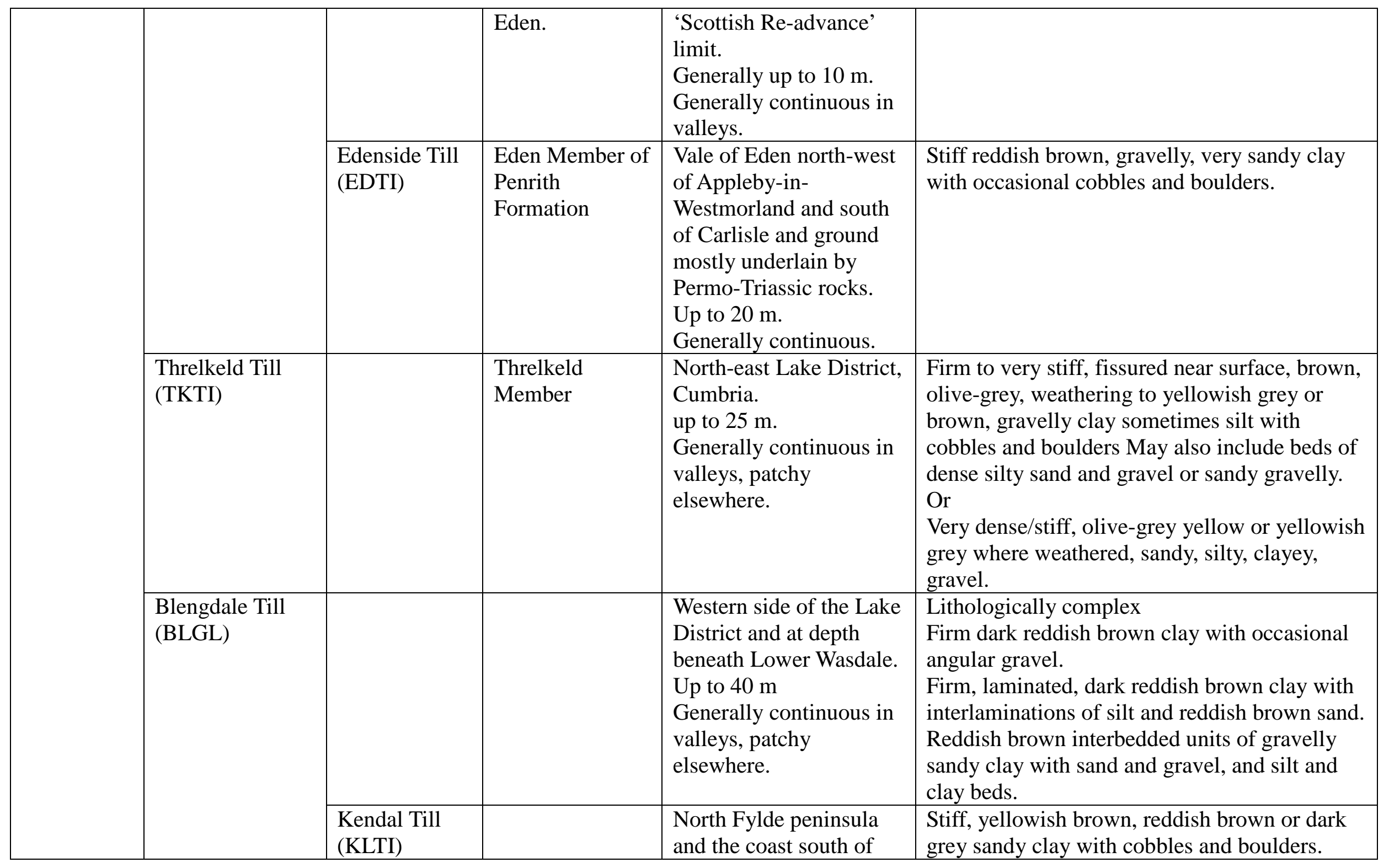




\begin{tabular}{|c|c|c|c|c|c|}
\hline & & & & $\begin{array}{l}\text { Haysham to the foot of } \\
\text { the Pennines. } \\
\text { Generally } 5 \text { m thick but } \\
\text { up to } 40 \mathrm{~m} \text { thick in } \\
\text { drumlins. } \\
\text { Generally continuous in } \\
\text { valleys, patchy } \\
\text { elsewhere. }\end{array}$ & $\begin{array}{l}\text { Boulders are not uncommon as individuals or } \\
\text { as trains. They can be up to } 3 \text { by } 2 \text { by } 1 \mathrm{~m} \text {. }\end{array}$ \\
\hline Cheviot & $\begin{array}{l}\text { Kale Water Till } \\
\text { (KWTI) }\end{array}$ & & & $\begin{array}{l}\text { Valley of the Kale Water, } \\
\text { Cheviot Hills. At least } 3 \\
\text { m. } \\
\text { Continuous in valleys, } \\
\text { patchy on higher areas. }\end{array}$ & Gravelly, sandy clay with cobbles and boulders. \\
\hline \multirow[t]{3}{*}{$\begin{array}{l}\text { North } \\
\text { Pennine } \\
\text { (NPEG) }\end{array}$} & $\begin{array}{l}\text { Acklinton Till } \\
\text { (ANTI) }\end{array}$ & & $\begin{array}{l}\text { Acklinton } \\
\text { Formation* }\end{array}$ & $\begin{array}{l}\text { The coastal lowlands of } \\
\text { Northumberland, north } \\
\text { of the River Tyne, but } \\
\text { excluding the coastal } \\
\text { fringe. } \\
\text { Up to } 25 \mathrm{~m} \text {. } \\
\text { Generally continuous in } \\
\text { valleys, patchy } \\
\text { elsewhere. }\end{array}$ & $\begin{array}{l}\text { Dark brown or purplish brown, weathering to } \\
\text { reddish brown Generally stiff to very stiff, with } \\
\text { vertical prismatic jointing, gravelly sandy clay } \\
\text { with low cobble and boulder count. } \\
\text { Lenses of sand and gravel and laminated silt } \\
\text { and clay typically up to } 1.5 \text { m but may be up to } \\
12 \text { m thick. Up to } 7 \text { cyclic sequences have been } \\
\text { recorded. }\end{array}$ \\
\hline & \multirow[t]{2}{*}{$\begin{array}{l}\text { Wear Till } \\
\text { (WETI) }\end{array}$} & & $\begin{array}{l}\text { Winch Gill } \\
\text { Member+, } \\
\text { Durham Lower } \\
\text { Till (Boulder } \\
\text { Clay) }\end{array}$ & $\begin{array}{l}\text { Lowlands of County } \\
\text { Durham and southern } \\
\text { Northumberland west to } \\
\text { the Pennines. } \\
\text { Generally } 3 \text { to } 10 \text { m but } \\
\text { locally up to } 30 \mathrm{~m} \text {. } \\
\text { Generally continuous in } \\
\text { valleys and lower land } \\
\text { patchy elsewhere. }\end{array}$ & $\begin{array}{l}\text { Dark greyish brown to dark yellowish brown, } \\
\text { gravelly sandy clay with cobbles, boulder and } \\
\text { sometimes rafts of local rock near the base. }\end{array}$ \\
\hline & & Butterby Till & Butterby & Coastal Lowlands, not & Firm to very stiff, brown, gravelly sandy clay \\
\hline
\end{tabular}




\begin{tabular}{|c|c|c|c|c|c|}
\hline & & (BUTTI) & $\begin{array}{l}\text { Member, Upper } \\
\text { Stony Clays }\end{array}$ & $\begin{array}{l}\text { including the coastal } \\
\text { strip, between the River } \\
\text { Tyne to a little south of } \\
\text { the River Tees. } \\
\text { Up to } 10 \text { m. } \\
\text { Mostly continuous. }\end{array}$ & $\begin{array}{l}\text { with low cobble and boulder content. } \\
\text { Commonly intercalated with firm to stiff } \\
\text { laminated dark grey silt and clay beds possibly } \\
\text { of the Tyne and Wear Glaciolacustrine } \\
\text { Formation and lenses of medium to very dense } \\
\text { sand and gravel. }\end{array}$ \\
\hline & $\begin{array}{l}\text { Vale of York } \\
\text { (VYORK) }\end{array}$ & & $\begin{array}{l}\text { Vale of York } \\
\text { Glacigenic } \\
\text { Formation } \\
\text { Vale of York Till } \\
\text { Formation }\end{array}$ & $\begin{array}{l}\text { Vale of York: Teesside } \\
\text { to Escrick. Generally } 10 \\
\text { to } 30 \mathrm{~m} \text { thick but up to } \\
50 \mathrm{~m} \text { in moraines. } \\
\text { Continuous, often } \\
\text { beneath other superficial } \\
\text { deposits. }\end{array}$ & $\begin{array}{l}\text { Firm to very stiff gravelly sandy clay with } \\
\text { cobbles and boulders or sandy clay or clayey } \\
\text { sand with interbeds of sand and gravel and } \\
\text { laminated clay. The sand and gravel and } \\
\text { laminated clay lithologies may be thicker in } \\
\text { some area incorporated in the till sheet and } \\
\text { moraines. }\end{array}$ \\
\hline & $\begin{array}{l}\text { Stainmore Forest } \\
\text { Till } \\
\text { (SFTI) }\end{array}$ & & $\begin{array}{l}\text { Stainmore Ice } \\
\text { Tills }\end{array}$ & $\begin{array}{l}\text { Stainmore Gap to the } \\
\text { west of Darlington, and } \\
\text { Teesdale upstream of } \\
\text { Barnard Castle, } \\
\text { extending towards the } \\
\text { Vale of York. } \\
\text { Up to } 50 \mathrm{~m} \text {, may be } \\
\text { thicker in buried valleys. } \\
\text { Generally continuous on } \\
\text { the lower land. }\end{array}$ & $\begin{array}{l}\text { Firm to hard bluish grey or reddish brown } \\
\text { gravelly sandy clay with cobbles and boulders. }\end{array}$ \\
\hline & $\begin{array}{l}\text { Yorkshire Dales } \\
\text { Till (YDTI) }\end{array}$ & & & $\begin{array}{l}\text { The Yorkshire Dales } \\
\text { south of the Stainmore } \\
\text { Gap and north of the } \\
\text { Devensian glacial limit. } \\
\text { Generally less than } 10 \\
\text { m. } \\
\text { Mostly continuous in } \\
\text { valleys. }\end{array}$ & $\begin{array}{l}\text { Firm to extremely weak, dark grey to greyish } \\
\text { brown, gravelly sandy clay with cobbles and } \\
\text { boulders. }\end{array}$ \\
\hline North Sea & Horden Till & & Horden Member, & Coast of County Durham & Firm to very stiff dark brown or purple brown \\
\hline
\end{tabular}




\begin{tabular}{|c|c|c|c|c|c|}
\hline \multirow[t]{6}{*}{$\begin{array}{l}\text { Coast } \\
\text { (NSG) }\end{array}$} & (HNTI) & & $\begin{array}{l}\text { Durham Upper } \\
\text { Till, } \\
\text { Warren House* } \\
\text { Wear and } \\
\text { Blackheath } \\
\text { Tills* }\end{array}$ & $\begin{array}{l}\text { and southern } \\
\text { Northumberland. } \\
\text { Up to } 12 \mathrm{~m} \text {. } \\
\text { Generally continuous. }\end{array}$ & $\begin{array}{l}\text { and reddish brown where weathered, gravelly } \\
\text { sandy clay with a low to medium cobble and } \\
\text { low boulder count. }\end{array}$ \\
\hline & \multirow[t]{5}{*}{$\begin{array}{l}\text { Holderness Till } \\
\text { (HOLD) }\end{array}$} & & & $\begin{array}{l}\text { The east Yorkshire coast, } \\
\text { Holderness low lying } \\
\text { Lincolnshire and east } \\
\text { and north Norfolk coast. } \\
\text { From about } 10 \text { m to } \\
\text { about } 70 \text { m at } \\
\text { Dilmington. } \\
\text { Mostly continuous. }\end{array}$ & $\begin{array}{l}\text { Firm to stiff, slightly red or grey, gravelly } \\
\text { sandy clay with a low cobble and boulder count } \\
\text { in the upper part (Skipsea and Withernsea } \\
\text { members. Sand and gravel or silt bed occurs } \\
\text { between the Skipsea and Withernsea Till } \\
\text { members and sand and gravel beds may occur } \\
\text { elsewhere. }\end{array}$ \\
\hline & & $\begin{array}{l}\text { Withernsea } \\
\text { Till (WSTI) }\end{array}$ & Purple & $\begin{array}{l}\text { Along the East Yorkshire } \\
\text { coast: Filey to } \\
\text { Flamborough Head and } \\
\text { south of Hornsea to } \\
\text { south of Easington; } \\
\text { inland to Keyingham. } \\
5 \text { to } 15 \text { m. } \\
\text { Mostly continuous. }\end{array}$ & $\begin{array}{l}\text { Firm to stiff, purple or reddish purple, sandy or } \\
\text { slightly sandy clay with occasional cobbles. }\end{array}$ \\
\hline & & $\begin{array}{l}\text { Skipsea Till } \\
\text { (SKTI) }\end{array}$ & Drab & $\begin{array}{l}\text { The east Yorkshire coast, } \\
\text { Holderness and low } \\
\text { lying Lincolnshire. } \\
\text { Generally less than } 30 \mathrm{~m} \\
\text { but up to } 60 \text { m. } \\
\text { Mostly continuous. }\end{array}$ & $\begin{array}{l}\text { Firm to stiff, sometimes banded or sheared, red } \\
\text { are darkish red, gravelly sandy clay with a low } \\
\text { cobble and boulder count. }\end{array}$ \\
\hline & & Bridlington & Basement Till & & \\
\hline & & $\begin{array}{l}\text { Holkham } \\
\text { (HOTI) }\end{array}$ & $\begin{array}{l}\text { Hunstanton Till, } \\
\text { Holkham Till. }\end{array}$ & $\begin{array}{l}\text { Along much of the } \\
\text { northern coast of } \\
\text { Norfolk from west of }\end{array}$ & $\begin{array}{l}\text { Firm to stiff or very stiff, reddish brown } \\
\text { gravelly sandy clay with a low cobble count. }\end{array}$ \\
\hline
\end{tabular}




\begin{tabular}{|c|c|c|c|c|}
\hline & & & $\begin{array}{l}\text { Hunstanton to Moston. } \\
\text { Up to } 10 \mathrm{~m} \text {. } \\
\text { Fairly continuous along } \\
\text { the coast. }\end{array}$ & \\
\hline \multirow[t]{2}{*}{$\begin{array}{l}\text { Wales } \\
\text { (WALES) }\end{array}$} & $\begin{array}{l}\text { Eryri Glacigenic } \\
\text { (ERYG) }\end{array}$ & $\begin{array}{l}\text { North Welsh } \\
\text { Boulder Clay } \\
\text { Wales } \\
\text { Glacigenic } \\
\text { Subgroup }\end{array}$ & $\begin{array}{l}\text { Mountains of } \\
\text { Snowdonia, Rhinogs and } \\
\text { Cader Idris; eastern and } \\
\text { southern Lleyn } \\
\text { Peninsula. } \\
\text { Highly variable may } \\
\text { greatly exceed } 10 \text { m in } \\
\text { some places. } \\
\text { Variable coverage, } \\
\text { dissected to semi- } \\
\text { continuous. }\end{array}$ & $\begin{array}{l}\text { Stiff, dark grey to blue-grey gravelly clay with } \\
\text { cobble and boulders(?). Also contains sand and } \\
\text { gravel beds. }\end{array}$ \\
\hline & $\begin{array}{l}\text { Plynlimon } \\
\text { Glacigenic } \\
\text { (PLYNT) }\end{array}$ & $\begin{array}{l}\text { Central Wales } \\
\text { Drift } \\
\text { Welsh Till }\end{array}$ & $\begin{array}{l}\text { Denbighshire, Mid and } \\
\text { west Wales, southwest } \\
\text { Wales approximately } \\
\text { north of Black Mountain } \\
\text { and east of St Clears and } \\
\text { Llandysul. Highly } \\
\text { variable, locally in } \\
\text { excess of } 30 \mathrm{~m} \text {. } \\
\text { Variable coverage, } \\
\text { dissected to semi- }\end{array}$ & $\begin{array}{l}\text { Generally, stiff, blue grey or grey, gravelly } \\
\text { sandy clay and clayey gravel with low cobble } \\
\text { and boulder count. Sand and gravel beds occur } \\
\text { locally. }\end{array}$ \\
\hline
\end{tabular}




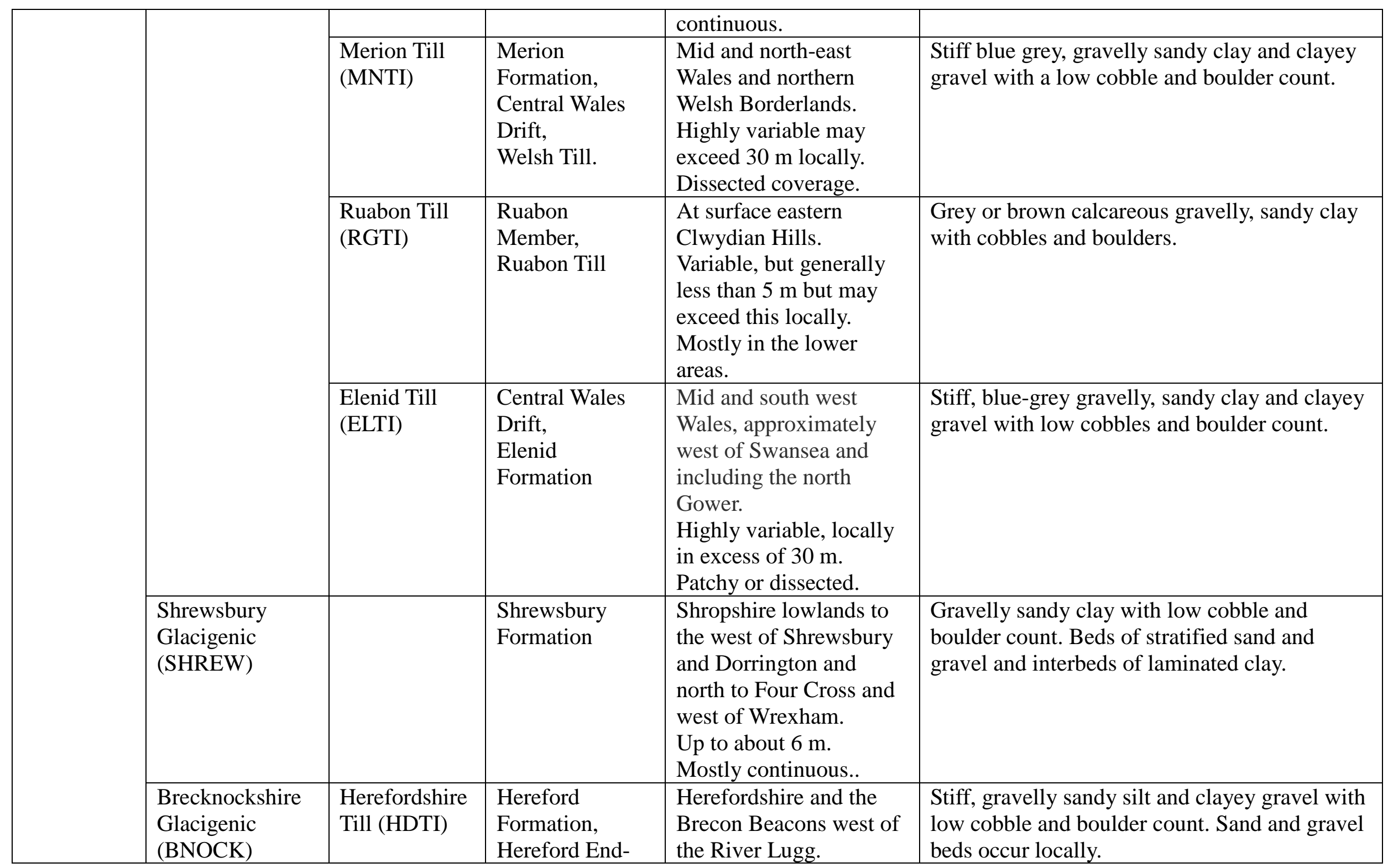




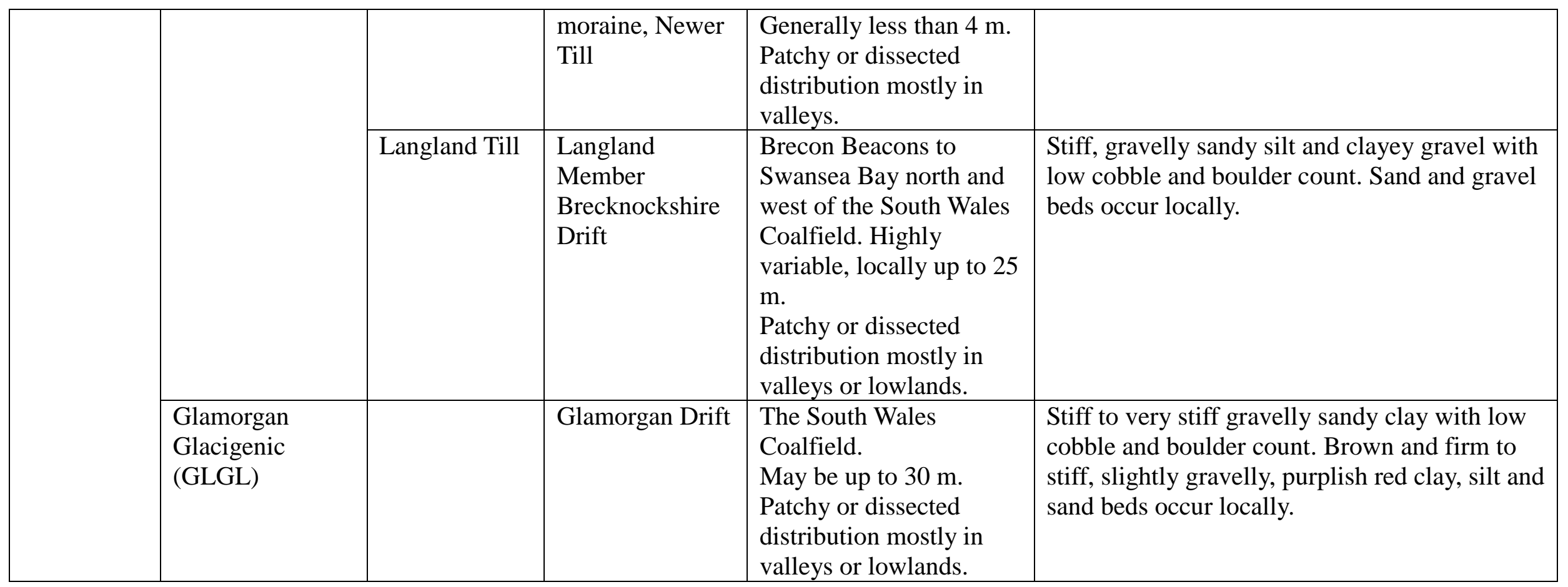


Table 6.3. Lithostratigraphy, previous name, area of occurrence, thickness and description of Albion Glacigenic Group Tills.

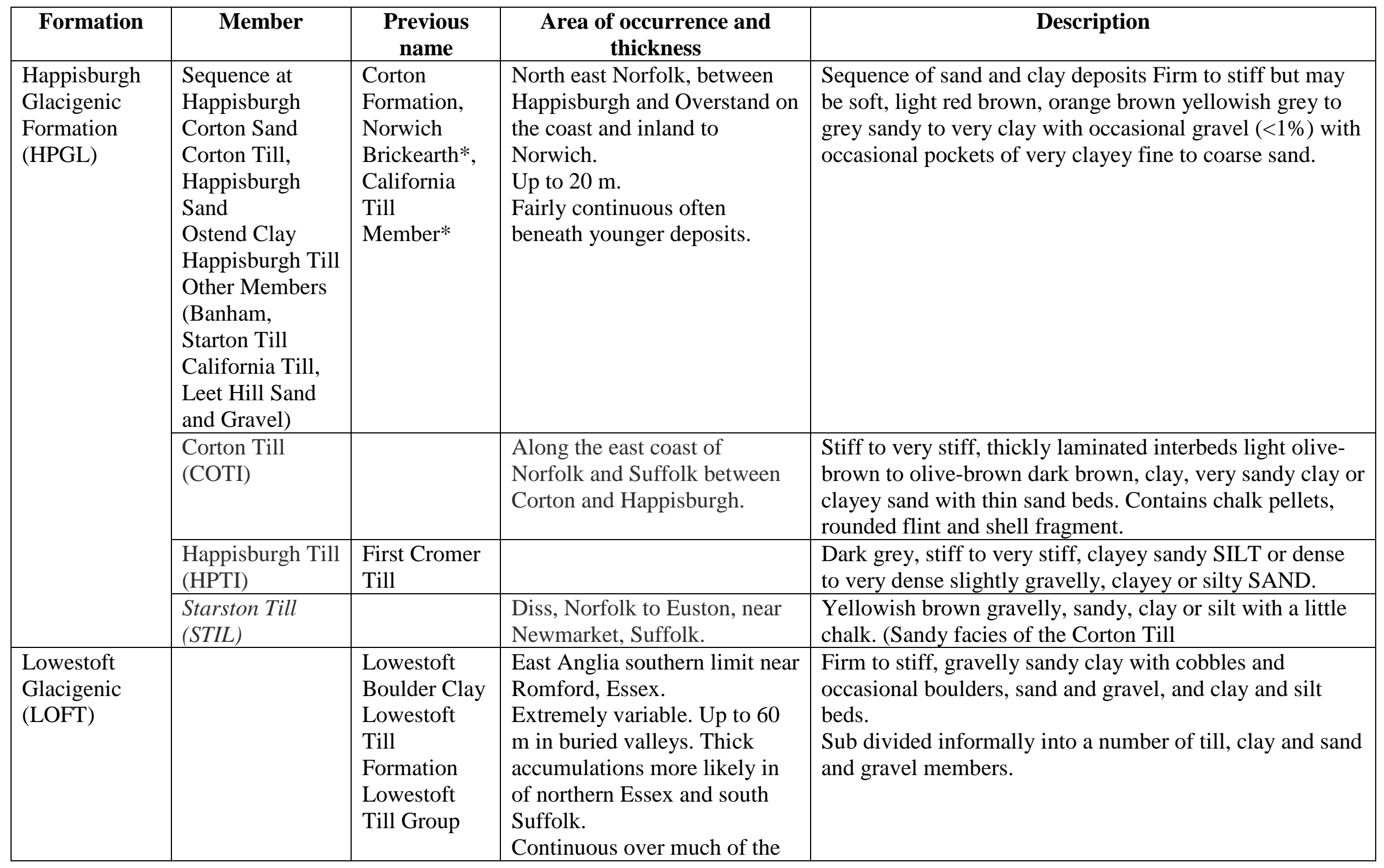




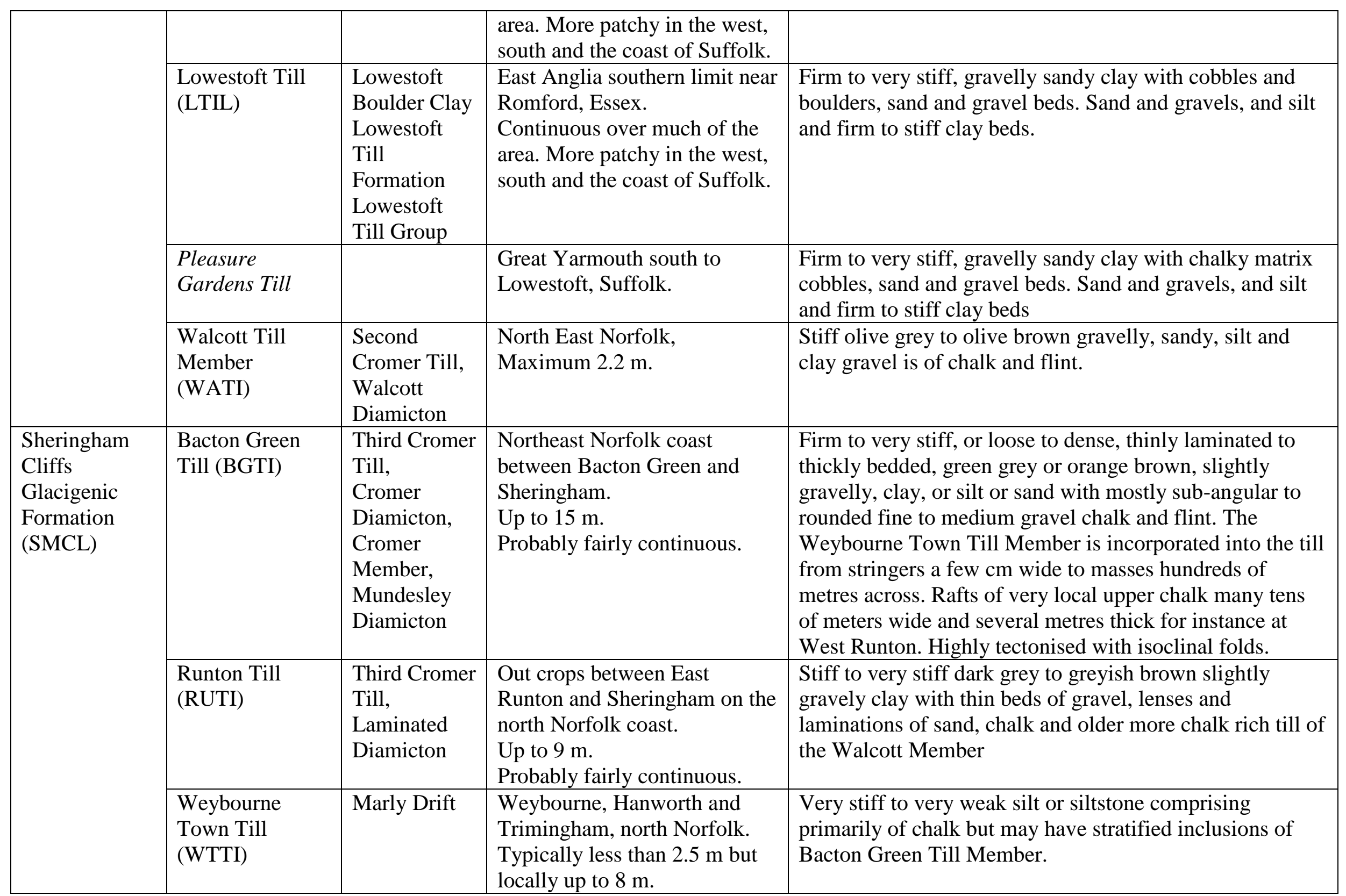




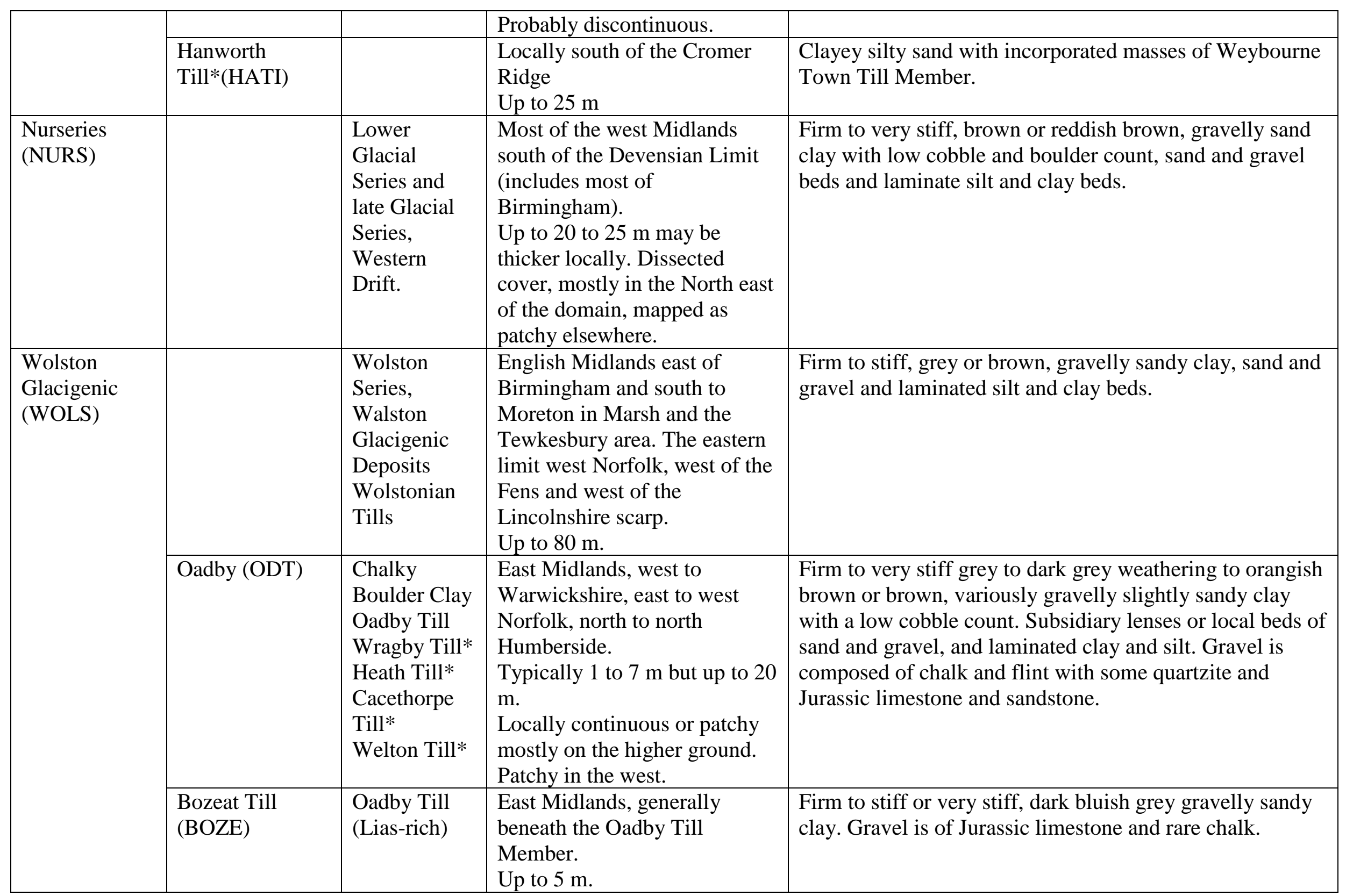




\begin{tabular}{|c|c|c|c|c|}
\hline & $\begin{array}{l}\text { Thrussington } \\
\text { (THT) }\end{array}$ & $\begin{array}{l}\text { Pennine } \\
\text { Drift, } \\
\text { Oadby Till } \\
\text { (Trias -rich), } \\
\text { Triassic Till, } \\
\text { Thrussington } \\
\text { Till. }\end{array}$ & $\begin{array}{l}\text { Primarily the East Midlands to } \\
\text { the western East Anglia and to } \\
\text { the west Midlands. Often } \\
\text { beneath the Oadby Till } \\
\text { Member. } \\
\text { Typically } 1 \text { to } 7 \mathrm{~m} \text { but may be } \\
\text { up to } 20 \mathrm{~m} \text {. Patchy. }\end{array}$ & $\begin{array}{l}\text { Firm to very stiff, brown or reddish brown or red, variably } \\
\text { gravelly, variably sandy clay with occasional cobbles. } \\
\text { Beds or lenses of sand and or gravel and laminated silt and } \\
\text { clay. }\end{array}$ \\
\hline $\begin{array}{l}\text { Bakewell } \\
\text { Formation } \\
\text { (BWTI) }\end{array}$ & & & $\begin{array}{l}\text { Southern Pennines from } \\
\text { Hebden Bridge and } \\
\text { Huddersfield, Yorkshire, south } \\
\text { to Belper, Derbyshire and } \\
\text { Cheadle, north Staffordshire. } \\
\text { Highly variable greater than } 15 \\
\text { m at the type section. } \\
\text { Very patchy absent over large } \\
\text { parts of the area. }\end{array}$ & $\begin{array}{l}\text { Firm to very stiff gravelly sandy clay with interbedded } \\
\text { laminated clay and silt and sand. }\end{array}$ \\
\hline $\begin{array}{l}\text { Pickering Till } \\
\text { Formation } \\
\text { (PKTI) }\end{array}$ & & & $\begin{array}{l}\text { The Vale of Pickering and } \\
\text { southern Cleveland Hills. } \\
\text { Very patchy in the Vale, not } \\
\text { mapped elsewhere. }\end{array}$ & Firm to very stiff, grey or brown, gravelly sandy clay. \\
\hline $\begin{array}{l}\text { Penfro Till } \\
\text { Formation } \\
\text { (POTI) }\end{array}$ & & $\begin{array}{l}\text { Penfro } \\
\text { Formation }\end{array}$ & $\begin{array}{l}\text { South Pembrokeshire and } \\
\text { western Carmarthenshire, } \\
\text { south west Wales. } \\
\text { Generally up to } 5 \mathrm{~m} \text { but locally } \\
\text { up to } 9.5 \mathrm{~m} \text {. Mostly highly } \\
\text { dissected. }\end{array}$ & $\begin{array}{l}\text { Stiff red and purple, gravelly, sandy clay with and low } \\
\text { cobble count and occasional boulders, and sand and gravel } \\
\text { beds. }\end{array}$ \\
\hline
\end{tabular}


Table 6.4. Multiple till units in northern England (after Hughes et al. 1998).

\begin{tabular}{|c|c|c|c|c|}
\hline Area & Site & $\begin{array}{l}\text { Previous name } \\
\text { (Hughes et al. } \\
\text { 1998) }\end{array}$ & $\begin{array}{l}\text { Description } \\
\text { (mainly } \\
\text { colour) }\end{array}$ & Till unit \\
\hline \multirow{5}{*}{ 㗊 } & Sellafield & $\begin{array}{l}\text { Sellafield Till } \\
\text { Lowca Till }\end{array}$ & $\begin{array}{l}\text { Red } \\
\text { Red or brown }\end{array}$ & $\begin{array}{l}\text { Irish Sea Glacigenic } \\
\text { Formation, } \\
\text { Gosforth Till Formation }\end{array}$ \\
\hline & $\begin{array}{l}\text { Outerside } \\
\text { NY } 126400\end{array}$ & & $\begin{array}{l}\text { Dark reddish } \\
\text { brown }\end{array}$ & $\begin{array}{l}\text { Irish Sea Glacigenic } \\
\text { Formation, } \\
\text { Gosforth Till Formation }\end{array}$ \\
\hline & \multirow[t]{2}{*}{$\begin{array}{l}\text { Lowca } \\
\text { (NX } 986 \text { 235) }\end{array}$} & Upper Till & Red or Brown & $\begin{array}{l}\text { Irish Sea Glacigenic } \\
\text { Formation, } \\
\text { Gosforth Till Formation }\end{array}$ \\
\hline & & Lower Till & Dark grey & $\begin{array}{l}\text { Central Cumbria } \\
\text { Glacigenic Subgroup } \\
\text { Blengdale Till Formation } \\
\end{array}$ \\
\hline & $\begin{array}{l}\text { Moresby and Keekle } \\
\text { NX } 00018\end{array}$ & & $\begin{array}{l}\text { Red and very } \\
\text { sandy }\end{array}$ & $\begin{array}{l}\text { Irish Sea Glacigenic } \\
\text { Formation, Gosforth Till } \\
\text { Formation }\end{array}$ \\
\hline \multirow{5}{*}{ 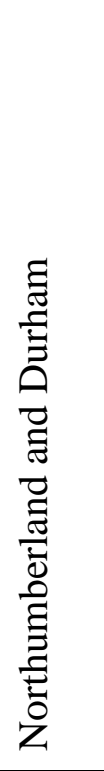 } & \multirow[t]{2}{*}{$\begin{array}{l}\text { Butterwell and East } \\
\text { Chevington } \\
\text { NZ } 210900 \text { and NZ } \\
210900\end{array}$} & Upper till & Red & $\begin{array}{l}\text { Horden Till Formation, } \\
\text { North Sea Coast } \\
\text { Glacigenic Subgroup }\end{array}$ \\
\hline & & Lower Till & Grey & $\begin{array}{l}\text { North Pennine Glacigenic } \\
\text { Formation } \\
\text { Acklinton Till Formation }\end{array}$ \\
\hline & $\begin{array}{l}\text { Acklinton Extension } \\
\text { NU } 240010\end{array}$ & & Grey & $\begin{array}{l}\text { North Pennine Glacigenic } \\
\text { Formation } \\
\text { Acklinton Till Formation }\end{array}$ \\
\hline & $\begin{array}{l}\text { Herrington } \\
\text { NZ } 335540\end{array}$ & & $\begin{array}{l}\text { Grey and } \\
\text { brown }\end{array}$ & $\begin{array}{l}\text { North Pennine Glacigenic } \\
\text { Formation } \\
\text { Wear Till Formation }\end{array}$ \\
\hline & $\begin{array}{l}\text { Deborah } \\
\text { NZ } 175273\end{array}$ & & & $\begin{array}{l}\text { North Pennine Glacigenic } \\
\text { Formation } \\
\text { Wear Till Formation }\end{array}$ \\
\hline
\end{tabular}


Table 6.5. Examples of superimposed till units in different regions of Britain.

\begin{tabular}{|c|c|c|c|}
\hline Geographical area & Upper Unit & Lower Unit & Colour \\
\hline \multicolumn{4}{|c|}{ Caledonia Glacigenic Group } \\
\hline Caithness & $\begin{array}{l}\text { Banffshire and } \\
\text { Caithness Glacigenic } \\
\text { Subgroup - Reisgill } \\
\text { Burn Till Formation }\end{array}$ & $\begin{array}{l}\text { Northwest Highland } \\
\text { Glacigenic Subgroup } \\
\text { - Assynt Glacigenic } \\
\text { Formation. }\end{array}$ & $\begin{array}{l}\text { Calcareous, reddish } \\
\text { brown on light brown }\end{array}$ \\
\hline $\begin{array}{l}\text { North East } \\
\text { Banffshire }\end{array}$ & $\begin{array}{l}\text { Banffshire and } \\
\text { Caithness Glacigenic } \\
\text { Subgroup - Essie } \\
\text { Till Formation }\end{array}$ & $\begin{array}{l}\text { Logie-Buchan } \\
\text { Glacigenic Subgroup } \\
\text { - Hatton Till } \\
\text { Formation }\end{array}$ & $\begin{array}{l}\text { Dark bluish grey on } \\
\text { red }\end{array}$ \\
\hline $\begin{array}{l}\text { North East } \\
\text { Banffshire }\end{array}$ & $\begin{array}{l}\text { Logie-Buchan } \\
\text { Glacigenic Subgroup } \\
\text { - Hatton Till } \\
\text { Formation }\end{array}$ & Pre-Devensian Till & Red on dark blue grey \\
\hline $\begin{array}{l}\text { Western extent of } \\
\text { Beinn an Uain Till } \\
\text { Formation }\end{array}$ & $\begin{array}{l}\text { Central Grampian } \\
\text { Glacigenic Subgroup } \\
\text { - Beinn an Uain Till } \\
\text { Formation }\end{array}$ & $\begin{array}{l}\text { Inverness Glacigenic } \\
\text { Subgroup - Athais } \\
\text { Till Formation }\end{array}$ & $\begin{array}{l}\text { Dark greenish grey on } \\
\text { brown or yellowish } \\
\text { brown }\end{array}$ \\
\hline $\begin{array}{l}\text { North east of the } \\
\text { Midland Valley, } \\
\text { Scotland. }\end{array}$ & $\begin{array}{l}\text { Central Grampian } \\
\text { Glacigenic Subgroup } \\
\text { - Gartocharn Till } \\
\text { Formation }\end{array}$ & $\begin{array}{l}\text { Midland Valley } \\
\text { Glacigenic Subgroup } \\
\text { - Wilderness Till } \\
\text { Formation }\end{array}$ & $\begin{array}{l}\text { Brown or dark } \\
\text { brownish grey on } \\
\text { reddish brown or grey }\end{array}$ \\
\hline $\begin{array}{l}\text { Midland valley of } \\
\text { Scotland - along the } \\
\text { Clyde Valley eastern } \\
\text { Glasgow }\end{array}$ & $\begin{array}{l}\text { Midland Valley } \\
\text { Glacigenic Subgroup } \\
\text { - Wilderness Till } \\
\text { Formation }\end{array}$ & $\begin{array}{l}\text { Midland Valley } \\
\text { Glacigenic Subgroup } \\
\text { - Baillieston Till } \\
\text { Formation }\end{array}$ & $\begin{array}{l}\text { Reddish brown or } \\
\text { grey on } \\
\text { Reddish brown or } \\
\text { brownish grey }\end{array}$ \\
\hline $\begin{array}{l}\text { Eden Valley, } \\
\text { Cumbria }\end{array}$ & $\begin{array}{l}\text { Central Cumbria } \\
\text { Glacigenic Subgroup } \\
\text { - Greystoke Till } \\
\text { Formation }\end{array}$ & $\begin{array}{l}\text { Irish Sea Coast } \\
\text { Glacigenic Subgroup } \\
\text { - Gillcambon Till } \\
\text { Formation }\end{array}$ & $\begin{array}{l}\text { Grey on red or } \\
\text { reddish brown }\end{array}$ \\
\hline West Cumbria & $\begin{array}{l}\text { Irish Sea Glacigenic } \\
\text { Subgroup } \\
\text { - Gosforth Till } \\
\text { Formation }\end{array}$ & $\begin{array}{l}\text { Central Cumbria } \\
\text { Glacigenic Subgroup } \\
\text {-Blengdale Till } \\
\text { Formation }\end{array}$ & $\begin{array}{l}\text { Red or reddish brown } \\
\text { on reddish brown }\end{array}$ \\
\hline $\begin{array}{l}\text { Durham and } \\
\text { Northumberland near } \\
\text { the coast }\end{array}$ & $\begin{array}{l}\text { North Sea Coast } \\
\text { Glacigenic Subgroup } \\
\text { - Horden Till } \\
\text { Formation }\end{array}$ & $\begin{array}{l}\text { North Pennine } \\
\text { Glacigenic Subgroup } \\
\text { - Acklinton Till } \\
\text { Formation including } \\
\text { the Butterby Till } \\
\text { Member }\end{array}$ & $\begin{array}{l}\text { Red or reddish brown } \\
\text { on grey }\end{array}$ \\
\hline \multirow[t]{2}{*}{$\begin{array}{l}\text { South of } \\
\text { Aberystwyth and } \\
\text { possibly North Wales } \\
\text { Coast. }\end{array}$} & $\begin{array}{l}\text { Wales Glacigenic } \\
\text { Subgroup - Eryri } \\
\text { Glacigenic } \\
\text { Formation }\end{array}$ & $\begin{array}{l}\text { Irish Sea Coast } \\
\text { Glacigenic Subgroup } \\
\text { - St Asaph’s } \\
\text { Glacigenic } \\
\text { Formation - Lleyn } \\
\text { Till Member }\end{array}$ & $\begin{array}{l}\text { Grey on red or } \\
\text { reddish brown }\end{array}$ \\
\hline & $\begin{array}{l}\text { Irish Sea Coast } \\
\text { Glacigenic Subgroup }\end{array}$ & $\begin{array}{l}\text { Wales Glacigenic } \\
\text { Subgroup }\end{array}$ & $\begin{array}{l}\text { Reddish brown or red } \\
\text { on blueish grey }\end{array}$ \\
\hline
\end{tabular}




\begin{tabular}{|c|c|c|c|}
\hline & $\begin{array}{l}\text { - St Asaph’s } \\
\text { Glacigenic } \\
\text { Formation - Lleyn } \\
\text { Till Member }\end{array}$ & $\begin{array}{l}\text { - Plynlimon Till } \\
\text { Formation }\end{array}$ & \\
\hline Shropshire lowlands & $\begin{array}{l}\text { Wales Glacigenic } \\
\text { Subgroup } \\
\text { - Shrewsbury } \\
\text { Glacigenic } \\
\text { Formation }\end{array}$ & $\begin{array}{l}\text { Wales Glacigenic } \\
\text { Subgroup } \\
\text { - Plynlimon Till } \\
\text { Formation - Merion } \\
\text { Till Member, } \\
\text { Ruabon Till Member }\end{array}$ & $\begin{array}{l}\text { Greyish brown or } \\
\text { grey on bluish grey }\end{array}$ \\
\hline Shropshire & $\begin{array}{l}\text { Wales Glacigenic } \\
\text { Subgroup } \\
\text { - Shrewsbury } \\
\text { Glacigenic } \\
\text { Formation }\end{array}$ & $\begin{array}{l}\text { Irish Sea Coast } \\
\text { Glacigenic Subgroup } \\
\text { - Stockport } \\
\text { Glacigenic } \\
\text { Formation }\end{array}$ & $\begin{array}{l}\text { Grey or brown on red } \\
\text { or reddish brown }\end{array}$ \\
\hline Yorkshire coast & $\begin{array}{l}\text { North Sea Coast } \\
\text { Glacigenic Subgroup } \\
\text { - Holderness Till } \\
\text { Formation - Skipsea } \\
\text { Till member }\end{array}$ & $\begin{array}{l}\text { North Sea Coast } \\
\text { Glacigenic Subgroup } \\
\text { - Holderness Till } \\
\text { Formation - } \\
\text { Bridlington Till } \\
\text { Member }\end{array}$ & $\begin{array}{l}\text { Reddish brown on } \\
\text { Light grey or grey }\end{array}$ \\
\hline Yorkshire coast & $\begin{array}{l}\text { North Sea Coast } \\
\text { Glacigenic Subgroup } \\
\text { - Holderness Till } \\
\text { Formation - } \\
\text { Withernsea Till } \\
\text { Member }\end{array}$ & $\begin{array}{l}\text { North Sea Coast } \\
\text { Glacigenic Subgroup } \\
\text { - Holderness Till } \\
\text { Formation - Skipsea } \\
\text { Till Member }\end{array}$ & $\begin{array}{l}\text { Purplish red on } \\
\text { reddish brown }\end{array}$ \\
\hline \multicolumn{4}{|c|}{ Albion Glacigenic Group } \\
\hline $\begin{array}{l}\text { English East } \\
\text { Midlands - area } \\
\text { covered by an } \\
\text { approximate triangle } \\
\text { Uttoxeter - } \\
\text { Nottingham - Market } \\
\text { Harborough } \\
\end{array}$ & $\begin{array}{l}\text { Wolston Glacigenic } \\
\text { Formation } \\
\text { - Oadby Till Member }\end{array}$ & $\begin{array}{l}\text { Wolston Glacigenic } \\
\text { Formation - } \\
\text { Thrussington Till } \\
\text { Member }\end{array}$ & $\begin{array}{l}\text { Grey on reddish } \\
\text { brown or red }\end{array}$ \\
\hline $\begin{array}{l}\text { English East } \\
\text { Midlands - western } \\
\text { East Anglia to } \\
\text { Loghborough and } \\
\text { Leicester }\end{array}$ & $\begin{array}{l}\text { Wolston Glacigenic } \\
\text { Formation } \\
\text { - Oadby Till Member }\end{array}$ & $\begin{array}{l}\text { Wolston Glacigenic } \\
\text { Formation } \\
\text { - Bozeat Till } \\
\text { Member }\end{array}$ & $\begin{array}{l}\text { Both grey, chalk and } \\
\text { flint rare in Bozeat } \\
\text { Till Member }\end{array}$ \\
\hline $\begin{array}{l}\text { English East } \\
\text { Midlands - A thin } \\
\text { strip in the Leicester } \\
\text { and Loughborough } \\
\text { areas }\end{array}$ & $\begin{array}{l}\text { Wolston Glacigenic } \\
\text { Formation } \\
\text { - Bozeat Till } \\
\text { Member }\end{array}$ & $\begin{array}{l}\text { Wolston Glacigenic } \\
\text { Formation } \\
\text { - Thrussington Till } \\
\text { Member }\end{array}$ & $\begin{array}{l}\text { Grey on reddish } \\
\text { brown or red }\end{array}$ \\
\hline East Anglia & $\begin{array}{l}\text { Happisburgh } \\
\text { Glacigenic } \\
\text { Formation } \\
\text { - Corton Till } \\
\text { Member }\end{array}$ & $\begin{array}{l}\text { Happisburgh } \\
\text { Glacigenic } \\
\text { Formation } \\
\text { - Happisburgh Till } \\
\text { Member }\end{array}$ & $\begin{array}{l}\text { Dark brown on dark } \\
\text { grey }\end{array}$ \\
\hline
\end{tabular}




\begin{tabular}{|l|l|l|l|}
\hline & $\begin{array}{l}\text { Lowestoft Glacigenic } \\
\text { Formation } \\
\text { - Lowestoft Till } \\
\text { Member }\end{array}$ & $\begin{array}{l}\text { Happisburgh } \\
\text { Glacigenic } \\
\text { Formation } \\
\text { - Corton Till } \\
\text { Member }\end{array}$ & $\begin{array}{l}\text { Dark greenish grey on } \\
\text { dark brown }\end{array}$ \\
\hline $\begin{array}{l}\text { East Anglia - north } \\
\text { east coast and inland }\end{array}$ & $\begin{array}{l}\text { Lowestoft Glacigenic } \\
\text { Formation } \\
- \text { Walcott Till } \\
\text { Member }\end{array}$ & $\begin{array}{l}\text { Happisburgh } \\
\text { Glacigenic } \\
\text { Formation } \\
- \text { Happisburgh Till } \\
\text { Member }\end{array}$ & $\begin{array}{l}\text { Dark greenish grey or } \\
\text { greenish brown on } \\
\text { dark grey }\end{array}$ \\
\hline $\begin{array}{l}\text { East Anglia - north } \\
\text { east coast and inland }\end{array}$ & $\begin{array}{l}\text { Sherringham Cliffs } \\
\text { Formation } \\
- \text { Bacton Green Till } \\
\text { Member }\end{array}$ & $\begin{array}{l}\text { Lowestoft Glacigenic } \\
\text { Formation } \\
- \text { Walcott Till } \\
\text { Member }\end{array}$ & $\begin{array}{l}\text { Brown or dark green } \\
\text { on dark greenish grey } \\
\text { or greenish brown }\end{array}$ \\
\hline $\begin{array}{l}\text { East Anglia - } \\
\text { northern }\end{array}$ & $\begin{array}{l}\text { Sherringham Cliffs } \\
\text { Formation } \\
- \text { Weybourne Town } \\
\text { Till Member }\end{array}$ & $\begin{array}{l}\text { Sherringham Cliffs } \\
\text { Formation } \\
- \text { Bacton Green Till } \\
\text { Member }\end{array}$ & $\begin{array}{l}\text { Greyish white or } \\
\text { brown streaks on } \\
\text { brown or dark green }\end{array}$ \\
\hline
\end{tabular}


Table 6.6 Glacial till units and references from the literature.

\begin{tabular}{|c|c|c|c|}
\hline Current name & Site or Area & References & Subject \\
\hline Acklinton Till Formation & Acklinton & Eyles \& Sladen (1981) & Properties of tills \\
\hline \multirow[t]{2}{*}{ Ardverikie Till Formation } & $\begin{array}{l}\text { A } 83 \text { Sandhole } \\
\text { Bridge }\end{array}$ & $\begin{array}{l}\text { Weltman \& Healy } \\
\text { (1978) }\end{array}$ & Piling \\
\hline & A 82 Loch Lomond & Carter et al. (1985) & $\begin{array}{l}\text { Earthworks } \\
\text { suitability }\end{array}$ \\
\hline Brewood Till Formation & $\begin{array}{l}\text { Boggart Pit, North } \\
\text { Manchester }\end{array}$ & $\begin{array}{l}\text { Weltman \& Healy } \\
\text { (1978) }\end{array}$ & Piling \\
\hline $\begin{array}{l}\text { Glamorgan Glacigenic } \\
\text { Formation }\end{array}$ & $\begin{array}{l}\text { M4, Miskin Viaduct, } \\
\text { J 34, Mid Glamorgan. }\end{array}$ & $\begin{array}{l}\text { Weltman \& Healy } \\
\text { (1978) }\end{array}$ & Piling \\
\hline Gretna Till Formation & $\begin{array}{l}\text { A75, Annan, A7 } \\
\text { Canonbie }\end{array}$ & Carter et al. (1985) & $\begin{array}{l}\text { Road embankment } \\
\text { suitability }\end{array}$ \\
\hline $\begin{array}{l}\text { Happisburgh Glacigenic } \\
\text { Formation }\end{array}$ & Happisburgh & Bell (1991) & Laboratory tests \\
\hline \multirow{8}{*}{$\begin{array}{l}\text { Holderness Till } \\
\text { Formation (Skipsea, } \\
\text { Withernsea and Holkham } \\
\text { Till members) }\end{array}$} & $\begin{array}{l}\text { Holderness Coast, } \\
\text { East Yorkshire }\end{array}$ & Bell \& Forster (1991) & $\begin{array}{l}\text { Mineralogy, } \\
\text { plasticity and } \\
\text { laboratory strength }\end{array}$ \\
\hline & $\begin{array}{l}\text { Holkham, Norfolk, } \\
\text { East Anglia }\end{array}$ & Bell (1991) & Laboratory tests \\
\hline & $\begin{array}{l}\text { Whitby, North } \\
\text { Yorkshire }\end{array}$ & Clarke \& Guest (1991) & $\begin{array}{l}\text { Cliff stability and } \\
\text { coastal protection }\end{array}$ \\
\hline & $\begin{array}{l}\text { Imingham, } \\
\text { Humberside }\end{array}$ & $\begin{array}{l}\text { Weltman \& Healy } \\
\text { (1978) }\end{array}$ & Piling \\
\hline & $\begin{array}{l}\text { Recketts Chimney, } \\
\text { Kingston-upon-Hull }\end{array}$ & $\begin{array}{l}\text { Weltman \& Healy } \\
\text { (1978) }\end{array}$ & Piling \\
\hline & \multirow[t]{3}{*}{$\begin{array}{l}\text { BRE till test bed site } \\
\text { at Crowden, East } \\
\text { Yorkshire }\end{array}$} & $\begin{array}{l}\text { Ponniah \& McAnoy } \\
\text { (1985) }\end{array}$ & Pile jacking \\
\hline & & Atkinson (1985) & $\begin{array}{l}\text { Strength and } \\
\text { consolidation }\end{array}$ \\
\hline & & Butcher (1991) & Cliff stability \\
\hline \multirow[t]{3}{*}{ Horden Till Formation } & $\begin{array}{l}\text { Hartlepool, } \\
\text { Cleveland. }\end{array}$ & $\begin{array}{l}\text { Weltman \& Healy } \\
\text { (1978) }\end{array}$ & Piling \\
\hline & Northumberland & Eyles \& Sladen (1981) & $\begin{array}{l}\text { Geotechnical } \\
\text { properties of } \\
\text { weathered till } \\
\end{array}$ \\
\hline & Redcar, Yorkshire & *Marsland (1976) & $\begin{array}{l}\text { Field and } \\
\text { laboratory } \\
\text { investigation }\end{array}$ \\
\hline Langholm Till Formation & $\begin{array}{l}\text { A75 Gatehouse of } \\
\text { Fleet, Dumfries and } \\
\text { Galloway }\end{array}$ & Carter et al. (1985) & $\begin{array}{l}\text { Earthworks } \\
\text { suitability }\end{array}$ \\
\hline $\begin{array}{l}\text { Langland Till Member, } \\
\text { Breckonshire Glacigenic } \\
\text { Formation }\end{array}$ & $\begin{array}{l}\text { M4, Stormy Down to } \\
\text { Groes; Kenfig } \\
\text { Viaduct, Mid } \\
\text { Glamorgan }\end{array}$ & $\begin{array}{l}\text { Weltman \& Healy } \\
\text { (1978) }\end{array}$ & Piling \\
\hline
\end{tabular}




\begin{tabular}{|c|c|c|c|}
\hline \multirow[t]{3}{*}{ Lowestoft Formation } & $\begin{array}{l}\text { BRE test site Garston, } \\
\text { Hertfordshire }\end{array}$ & $\begin{array}{l}\text { Marsland \& Powell, } \\
\text { (1991) }\end{array}$ & $\begin{array}{l}\text { Field and } \\
\text { laboratory } \\
\text { investigation }\end{array}$ \\
\hline & Norfolk Coast & Bell (1991) & Laboratory tests \\
\hline & $\begin{array}{l}\text { Stansted Airport, } \\
\text { Essex }\end{array}$ & Campion et al. (1992) & $\begin{array}{l}\text { Design and } \\
\text { construction }\end{array}$ \\
\hline $\begin{array}{l}\text { Mill of the Forest Till } \\
\text { Formation }\end{array}$ & A9 Perth, M90 Perth & Carter et al. (1985) & \\
\hline Oadby Till Member & $\begin{array}{l}\text { Milton Keynes, } \\
\text { Buckinghamshire }\end{array}$ & Denness (1974) & $\begin{array}{l}\text { Engineering } \\
\text { aspects }\end{array}$ \\
\hline \multirow[t]{2}{*}{ Wear Till Formation } & $\begin{array}{l}\text { Kielder Dam, } \\
\text { Northumberland }\end{array}$ & $\begin{array}{l}\text { Anderson \& McNichol } \\
\text { (1989) }\end{array}$ & \\
\hline & $\begin{array}{l}\text { Felton, } \\
\text { Northumberland }\end{array}$ & Eyles \& Sladen (1981) & $\begin{array}{l}\text { Properties of } \\
\text { weathered Till }\end{array}$ \\
\hline \multirow[t]{6}{*}{$\begin{array}{l}\text { Wilderness Till } \\
\text { Formation }\end{array}$} & $\begin{array}{l}\text { M73, Baillieston, } \\
\text { Glasgow }\end{array}$ & Carter et al. (1985) & $\begin{array}{l}\text { Road embankment } \\
\text { suitability }\end{array}$ \\
\hline & \multirow[t]{3}{*}{ Glasgow } & $\begin{array}{l}\text { Weltman \& Healy } \\
\text { (1978) }\end{array}$ & \multirow[t]{3}{*}{ Piling } \\
\hline & & $\begin{array}{l}\text { *Thornburn \& Reid } \\
\text { (1973) }\end{array}$ & \\
\hline & & *McKinlay et al. (1974) & \\
\hline & Knockenden Dam & Banks (1952) & $\begin{array}{l}\text { Dam design and } \\
\text { construction }\end{array}$ \\
\hline & $\begin{array}{l}\text { Edinburgh, Glasgow, } \\
\text { Irvine bypass } \\
\text { Motherwell, Renfrew }\end{array}$ & $\begin{array}{l}\text { Weltman \& Healy } \\
\text { (1978) }\end{array}$ & Piling \\
\hline $\begin{array}{l}\text { Stockport Glacigenic } \\
\text { Formation }\end{array}$ & $\begin{array}{l}\text { M6, Wardley Hall } \\
\text { Bridge, near Swinton, } \\
\text { Greater Manchester, } \\
\text { Heaton’s Canal } \\
\text { Bridge, West } \\
\text { Lancashire, } \\
\text { Leeds Liverpool } \\
\text { Canal, } \\
\text { Ring O’Bells Canal } \\
\text { Bridge, Near Hoscar, } \\
\text { Lancashire. } \\
\text { M61, Blacow Bridge } \\
\text { (between J32 and } \\
\text { J33), Lancashire. } \\
\text { Haslington slip road, }\end{array}$ & $\begin{array}{l}\text { Weltman \& Healy } \\
\text { (1978) }\end{array}$ & Piling \\
\hline $\begin{array}{l}\text { Weybourne Town Till } \\
\text { Member, Sheringham } \\
\text { Cliffs Formation }\end{array}$ & $\begin{array}{l}\text { Weybourne, North } \\
\text { Norfolk. }\end{array}$ & Bell (1991) & Laboratory tests \\
\hline $\begin{array}{l}\text { Yorkshire Dales Till } \\
\text { Formation }\end{array}$ & $\begin{array}{l}\text { M62, Buersil Head } \\
\text { Bridge, (between J20 } \\
\text { and J21). Greater } \\
\text { Manchester. }\end{array}$ & $\begin{array}{l}\text { Weltman \& Healy } \\
\text { (1978) }\end{array}$ & Piling \\
\hline
\end{tabular}




\begin{tabular}{|l|l|l|l|}
\hline & $\begin{array}{l}\text { M62, Trub Bridge } \\
\text { (between J19 and 20), }\end{array}$ & & \\
Greater Manchester. & & \\
M66, Simister, North & & \\
and South Bridges, & & \\
Greater Manchester & & \\
\cline { 1 - 3 } & A56 Rawtenstall to & Arrowsmith (1985) & Slope stability \\
& Edenfield bypass, & & \\
Lancashire & & \\
\hline
\end{tabular}


Table 6.7. Variation in geotechnical index properties in the Oadby Member of the Wolston Glacigenic Formation (formerly Chalky Boulder Clay) at Milton Keynes using small scale sampling grids (from Denness 1974) compared with data from the whole of the Oadby Member from the BGS Geotechnical Properties Database.

\begin{tabular}{|l|c|c|c|c|c|c|c|}
\hline $\begin{array}{c}\text { Geotechnical } \\
\text { property }\end{array}$ & \multicolumn{2}{|c|}{$\begin{array}{c}\text { Trench side (1 m } \\
\text { sample grid) }\end{array}$} & \multicolumn{2}{c|}{$\begin{array}{c}\text { 1 m square face (200 } \\
\text { mm sample grid) }\end{array}$} & \multicolumn{2}{c|}{$\begin{array}{c}\text { BGS Geotechnical Properties } \\
\text { Database information 2014 } \\
\text { (number of test results) }\end{array}$} \\
\hline & Minimum & Maximum & Minimum & Maximum & $\begin{array}{c}10^{\text {th }} \\
\text { percentile }\end{array}$ & Median & $\begin{array}{c}90^{\text {th }} \\
\text { percentile }\end{array}$ \\
\hline Liquid Limit \% & $<30$ & $>50$ & $<35$ & $>50$ & $32(2042)$ & $42(2042)$ & $53(2042)$ \\
\hline Plastic Limit \% & $<14$ & $>20$ & $<16$ & $>22$ & $14(2010)$ & $17(2010)$ & $23(2010)$ \\
\hline Liquidity Index & $<-0.1$ & $>0.2$ & $<-0.1$ & $>0.2$ & - & - & - \\
\hline $\begin{array}{l}\text { Particle density } \\
\text { Mg m }\end{array}$ & $<2.50$ & $>2.65$ & $<2.55$ & $>2.65$ & $2.6(152)$ & $2.65(152)$ & $2.7(152)$ \\
\hline $\begin{array}{l}\text { Bulk density } \\
\text { Mg m }^{-3}\end{array}$ & $<1.9$ & $>2.2$ & $<2.0$ & $>2.3$ & $\begin{array}{c}1.98 \\
(2008)\end{array}$ & $\begin{array}{c}\text { (2.11 } \\
(2008)\end{array}$ & $2.21(2008)$ \\
\hline
\end{tabular}


Table 6.8. Some engineering geological characteristics of the Caledonia Glacigenic Group tills.

\begin{tabular}{|c|c|c|c|c|c|}
\hline Unit & $\begin{array}{c}\text { Characteristic } \\
\text { lithological } \\
\text { description }\end{array}$ & $\begin{array}{c}\text { Matrix } \\
\text { composition }\end{array}$ & Presence of boulders & Landslides & $\begin{array}{c}\text { Other engineering } \\
\text { considerations }\end{array}$ \\
\hline $\begin{array}{l}\text { Burrier Wick } \\
\text { Till (BWTI) }\end{array}$ & Gravelly, sandy clay, & Clay & $\begin{array}{l}\text { Generally occasional } \\
\text { boulders but locally some } \\
\text { boulders. } \\
\text { Generally strong or stronger } \\
\text { locally derived. }\end{array}$ & $\begin{array}{l}\text { Rare, on steep slopes or } \\
\text { coastal. }\end{array}$ & \\
\hline $\begin{array}{l}\text { Essie Till } \\
\text { (ESTI) }\end{array}$ & $\begin{array}{l}\text { Calcareous, gravelly, } \\
\text { sandy clay }\end{array}$ & Clay & $\begin{array}{l}\text { Occasional strong or } \\
\text { stronger boulders and rafts } \\
\text { of clay or mudstone. } \\
\text { Boulders of red granite, } \\
\text { quartzite, schist. }\end{array}$ & $\begin{array}{l}\text { Occasional, coastal and } \\
\text { river valley slopes }>\sim 15^{\circ} \\
\text { in north west. }\end{array}$ & \\
\hline $\begin{array}{l}\text { Broubster Till } \\
\text { (BRBU) }\end{array}$ & $\begin{array}{l}\text { Gravelly sandy clay } \\
\text { or silt }\end{array}$ & Clay or silt & $\begin{array}{l}\text { Occasional strong or } \\
\text { stronger boulders of } \\
\text { Devonian Caithness } \\
\text { Flagstone Group and some } \\
\text { Caledonian igneous and } \\
\text { Moine metamorphic rocks. }\end{array}$ & & \\
\hline Assynt & Heterogeneous, & Clay or sandy & Some strong or stronger & Rare, steep slopes & \\
\hline
\end{tabular}




\begin{tabular}{|c|c|c|c|c|c|}
\hline $\begin{array}{l}\text { Glacigenic } \\
\text { (ASGL) }\end{array}$ & $\begin{array}{l}\text { gravelly sand } \\
\text { sometimes gravelly } \\
\text { sandy clay } \\
\text { Subsidiary beds of: } \\
\text { Gravelly sand } \\
\text { sometimes with } \\
\text { cobbles and boulders. }\end{array}$ & $\begin{array}{l}\text { gravel/gravelly } \\
\text { sand. }\end{array}$ & $\begin{array}{l}\text { boulders of Lewisian gneiss, } \\
\text { Torridon Group and Eriboll } \\
\text { sandstone and quartzite, } \\
\text { Moine Supergroup } \\
\text { psammite, Durness Group } \\
\text { Limestone and other } \\
\text { metamorphic and igneous } \\
\text { rocks. }\end{array}$ & & \\
\hline $\begin{array}{l}\text { Port Beag Till } \\
\text { (PBTI) }\end{array}$ & $\begin{array}{l}\text { Gravelly sandy clay } \\
\text { or silt } \\
\text { Subsidiary: } \\
\text { Interbeds of shelly } \\
\text { clay, silt, sand and } \\
\text { gravel. }\end{array}$ & Clay or silt & $\begin{array}{l}\text { Occasional to some strong } \\
\text { or stronger boulders of } \\
\text { Torridonian sandstone. }\end{array}$ & Rare, coastal only & \\
\hline $\begin{array}{l}\text { Lewis Till } \\
\text { Formation } \\
\text { (LEWTI) }\end{array}$ & $\begin{array}{l}\text { Silt sand, gravel } \\
\text { towards the base with } \\
\text { cobble to boulders. }\end{array}$ & $\begin{array}{l}\text { Silty sand } \\
\text { Gravel toward the } \\
\text { base. }\end{array}$ & $\begin{array}{l}\text { Occasional to some strong } \\
\text { or stronger boulders of } \\
\text { Lewisian gneiss, which are } \\
\text { may be large (up to } 2 \mathrm{~m} \text { ) } \\
\text { particularly towards the } \\
\text { base. }\end{array}$ & Not mapped & \\
\hline $\begin{array}{l}\text { Banchory Till } \\
\text { Formation } \\
\text { (BATI) }\end{array}$ & $\begin{array}{l}\text { Gravelly, slightly } \\
\text { sandy or sandy clay } \\
\text { And } \\
\text { Sandy gravel or } \\
\text { gravelly sand. }\end{array}$ & $\begin{array}{l}\text { Clay or sand and } \\
\text { gravel. Clay } \\
\text { generally occurs } \\
\text { above sand and } \\
\text { gravel where both } \\
\text { are present. }\end{array}$ & $\begin{array}{l}\text { Low boulder count strong or } \\
\text { stronger Caledonian. Some } \\
\text { metamorphic boulders are } \\
\text { decomposed. }\end{array}$ & $\begin{array}{l}\text { Coastal and steeper river } \\
\text { valleys slopes (generally } \\
>\sim 14^{\circ} \text { occasionally lower) } \\
\text { in north, occasionally in } \\
\text { the south margin }\end{array}$ & \\
\hline $\begin{array}{l}\text { Hatton Till } \\
\text { (HATT) }\end{array}$ & $\begin{array}{l}\text { Calcareous, gravelly, } \\
\text { sandy clay } \\
\text { Subsidiary: }\end{array}$ & Clay & $\begin{array}{l}\text { Occasional strong or } \\
\text { stronger boulders of } \\
\text { Devonian sandstone and }\end{array}$ & $\begin{array}{l}\text { Rare, small, mostly } \\
\text { coastal. }\end{array}$ & \\
\hline
\end{tabular}




\begin{tabular}{|c|c|c|c|c|c|}
\hline & Sand/gravel beds & & Mesozoic limestone. & & \\
\hline $\begin{array}{l}\text { Beinn an Uain } \\
\text { Till } \\
\text { (BUTI) }\end{array}$ & $\begin{array}{l}\text { Gravelly sandy clay } \\
\text { with cobbles }\end{array}$ & Clay/mudstone & $\begin{array}{l}\text { Occasional boulders } \\
\text { psammite, semipelite, } \\
\text { granite, Devonian sandstone } \\
\text { and siltstone. }\end{array}$ & $\begin{array}{l}\text { Rare, small, steep river } \\
\text { valleys }\left(>\sim 20^{\circ}\right) \text {. }\end{array}$ & \\
\hline $\begin{array}{l}\text { Ardverikie Till } \\
\text { (ARDT) }\end{array}$ & $\begin{array}{l}\text { Gravelly, sandy clay } \\
\text { Subsidiary: } \\
\text { Sand/gravel }\end{array}$ & $\begin{array}{l}\text { Clay or } \\
\text { sand/gravel. }\end{array}$ & $\begin{array}{l}\text { Occasional strong or } \\
\text { stronger boulders of various } \\
\text { metamorphic and igneous } \\
\text { rocks. }\end{array}$ & $\begin{array}{l}\text { Small, on steep slopes } \\
\left(>\sim 20^{\circ}\right) .\end{array}$ & \\
\hline $\begin{array}{l}\text { Mill of Forest } \\
\text { Till (MFT) }\end{array}$ & $\begin{array}{l}\text { Variable lithology: } \\
\text { gravelly sandy clay or } \\
\text { silt. } \\
\text { Subsidiary: } \\
\text { Sandy gravel or } \\
\text { gravelly sand, } \\
\text { Very, clayey gravel. }\end{array}$ & $\begin{array}{l}\text { Clay or } \\
\text { Sand or gravel }\end{array}$ & $\begin{array}{l}\text { Occasional strong and } \\
\text { stronger boulders of } \\
\text { Devonian sedimentary } \\
\text { rocks. }\end{array}$ & $\begin{array}{l}\text { Occur in steep river } \\
\text { valleys and coast, } \\
\text { generally small (less than } \\
100 \mathrm{~m} \text { ) but may be over } \\
200 \mathrm{~m} \text {. }\end{array}$ & \\
\hline $\begin{array}{l}\text { Wilderness Till } \\
\text { Formation } \\
\text { (WITI) }\end{array}$ & $\begin{array}{l}\text { Slightly gravelly to } \\
\text { gravelly sandy clay or } \\
\text { silt. } \\
\text { Subsidiary local: } \\
\text { Lenses or beds of } \\
\text { sand or laminated } \\
\text { clay. }\end{array}$ & Clay or silt & $\begin{array}{l}\text { Isolated to occasional strong } \\
\text { and stronger boulders of } \\
\text { Devonian, Carboniferous } \\
\text { and metamorphic rocks. }\end{array}$ & $\begin{array}{l}\text { Generally small to } \\
\text { medium sized landslides } \\
\text { on moderate slopes, rivers } \\
\text { and coastal (generally } \\
>\sim 11 \text { to } 25^{\circ} \text { ). }\end{array}$ & \\
\hline $\begin{array}{l}\text { Norham Till } \\
\text { Formation } \\
\text { (NMTI) }\end{array}$ & Gravelly, sandy clay & Clay & Rare small boulders. & $\begin{array}{l}\text { Rare, small river valley } \\
\text { slope. }\end{array}$ & \\
\hline
\end{tabular}




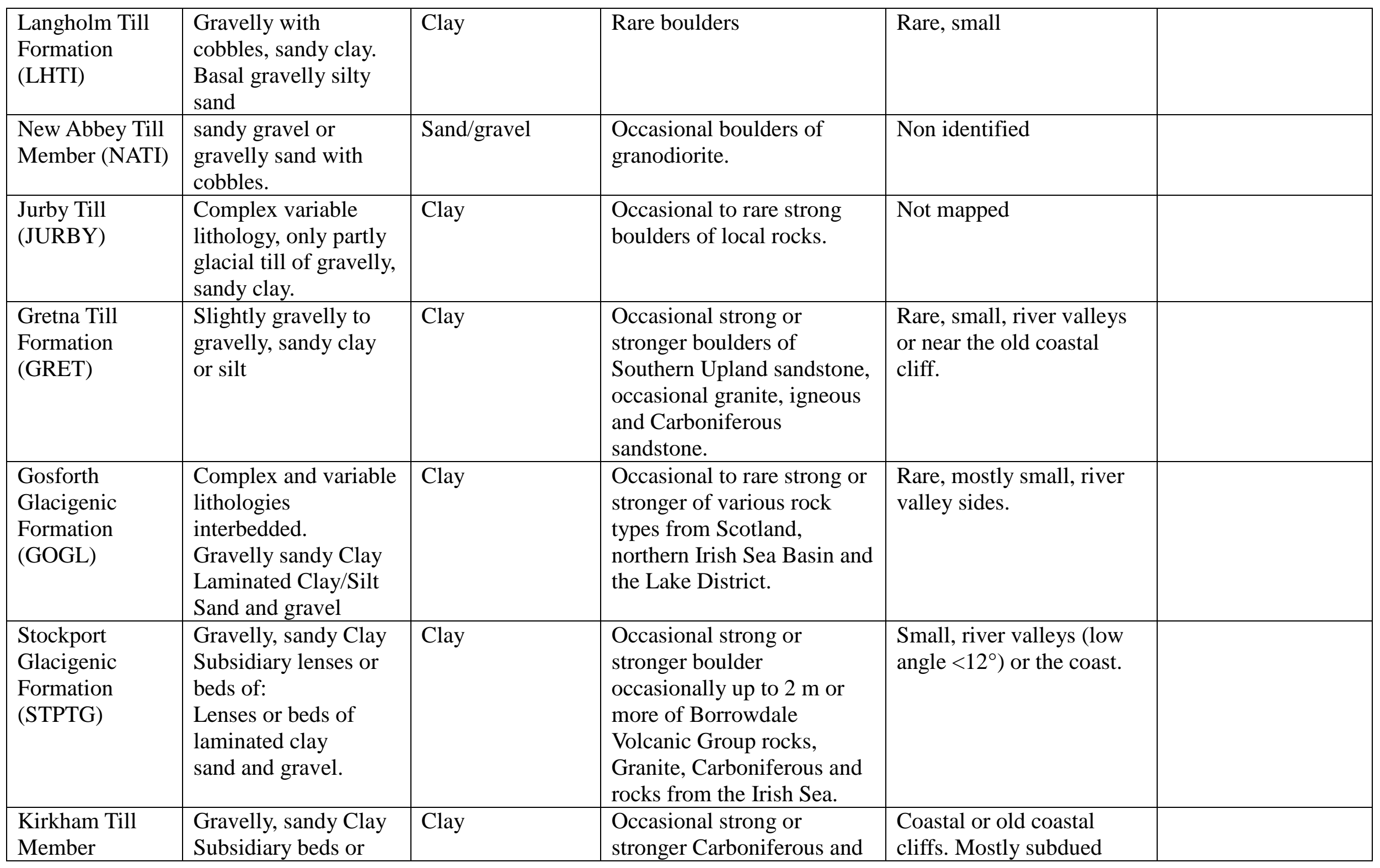




\begin{tabular}{|c|c|c|c|c|c|}
\hline (KMGL) & $\begin{array}{l}\text { lenses of: } \\
\text { Laminated clay/silt } \\
\text { and Sand and gravel. }\end{array}$ & & $\begin{array}{l}\text { Lake District rocks and Irish } \\
\text { Sea-derived bedrock. }\end{array}$ & topography. & \\
\hline $\begin{array}{l}\text { Brewood Till } \\
\text { Formation } \\
\text { (BDTI) }\end{array}$ & $\begin{array}{l}\text { Slightly Gravelly to } \\
\text { gravelly, usually } \\
\text { sandy Clay. } \\
\text { Sand and gravel } \\
\text { layers } \\
\text { Laminated clay in } \\
\text { places. }\end{array}$ & Clay & $\begin{array}{l}\text { Occasional strong or } \\
\text { stronger boulders of granite, } \\
\text { granophyres, limestone. }\end{array}$ & $\begin{array}{l}\text { Landslides in river valleys } \\
\text { often next to alluvium. } \\
\text { Generally }<15^{\circ} \text {. }\end{array}$ & \\
\hline $\begin{array}{l}\text { Lleyn Till } \\
\text { Member } \\
\text { (LLEYN) }\end{array}$ & $\begin{array}{l}\text { Slightly Gravelly to } \\
\text { gravelly, usually } \\
\text { sandy Clay or Silt } \\
\text { Subsidiary local: } \\
\text { Sand and gravel, } \\
\text { Laminated clay/silt in } \\
\text { places. }\end{array}$ & Clay & Boulders rare. & $\begin{array}{l}\text { Coastal landslides and in } \\
\text { steep and moderate } \\
\text { valleys. }\end{array}$ & \\
\hline $\begin{array}{l}\text { Edenside Till } \\
\text { Member (EDTI) }\end{array}$ & $\begin{array}{l}\text { gravelly, very sandy } \\
\text { clay }\end{array}$ & Clay & $\begin{array}{l}\text { Occasional strong or } \\
\text { stronger boulders of } \\
\text { Carboniferous sandstone } \\
\text { and limestone, Lake } \\
\text { District, igneous rocks and } \\
\text { North of England sandstone. }\end{array}$ & $\begin{array}{l}\text { Generally small, landslides } \\
\text { near rivers, (slope angles } \\
\sim<14 \text { ) or coastal. }\end{array}$ & \\
\hline $\begin{array}{l}\text { Threlkeld Till } \\
\text { Formation } \\
\text { (TKTI) }\end{array}$ & $\begin{array}{l}\text { Gravelly Clay } \\
\text { Subsidiary } \\
\text { Gravel }\end{array}$ & Clay & $\begin{array}{l}\text { Occasional strong or } \\
\text { stronger boulders of } \\
\text { Borrowdale Volcanic Group } \\
\text { and microgranite. }\end{array}$ & $\begin{array}{l}\text { Generally small next to } \\
\text { rivers or alluvial track } \\
\text { (slope angles } \sim 20^{\circ} \text { ). }\end{array}$ & \\
\hline
\end{tabular}




\begin{tabular}{|c|c|c|c|c|}
\hline $\begin{array}{l}\text { Blengdale Till } \\
\text { Formation } \\
\text { (BLGL) }\end{array}$ & $\begin{array}{l}\text { Lithologically } \\
\text { complex. } \\
\text { Gravelly Clay. } \\
\text { Subsidiary: } \\
\text { Sand and gravel. } \\
\text { Laminated clay, silt, } \\
\text { sand. }\end{array}$ & Clay & $\begin{array}{l}\text { Occasional to locally some } \\
\text { strong and stronger boulders } \\
\text { Borrowdale Volcanic Group } \\
\text { igneous rocks, granite and } \\
\text { granophyres. }\end{array}$ & $\begin{array}{l}\text { Generally small next to } \\
\text { rivers (slope angles } \sim 13^{\circ} \\
\text { to } 20^{\circ} \text { ) }\end{array}$ \\
\hline $\begin{array}{l}\text { Kendal Till } \\
\text { Member (KLTI) }\end{array}$ & Gravelly, sandy Clay & Clay & $\begin{array}{l}\text { Occasional to locally some } \\
\text { large, strong to stronger } \\
\text { boulders of Borrowdale } \\
\text { Volcanic Group igneous } \\
\text { rocks Lake District granite } \\
\text { and sandstone. }\end{array}$ & $\begin{array}{l}\text { Generally small to } \\
\text { moderate size next to } \\
\text { rivers most notably in the } \\
\text { southern part (slope angles } \\
\left.\sim 10^{\circ} \text { to } 17^{\circ}\right) .\end{array}$ \\
\hline $\begin{array}{l}\text { Kale Water Till } \\
\text { Formation } \\
\text { (KWTI) }\end{array}$ & Gravelly sandy Clay & Clay & $\begin{array}{l}\text { Occasional to some strong } \\
\text { or stronger boulders of } \\
\text { andesite and sandstone. }\end{array}$ & $\begin{array}{l}\text { Few mapped, River valley } \\
\text { slopes (slope angles } \sim 14^{\circ} \\
\text { to } 18^{\circ} \text { ). }\end{array}$ \\
\hline $\begin{array}{l}\text { Acklinton Till } \\
\text { Formation } \\
\text { (ANTI) }\end{array}$ & $\begin{array}{l}\text { Gravelly sandy Clay, } \\
\text { Subsidiary lenses or } \\
\text { beds of: } \\
\text { Sand/gravel } \\
\text { Laminated clay/silt. }\end{array}$ & Clay & $\begin{array}{l}\text { Occasional to some strong } \\
\text { or stronger boulders of } \\
\text { sandstone, limestone, } \\
\text { porphyry and andesite. }\end{array}$ & $\begin{array}{l}\text { Few small but also larger } \\
\text { (to over } 1 \mathrm{~km} \text { to } 150 \mathrm{~m} \\
\text { deep) long and landslides } \\
\text { mapped generally along } \\
\text { river valleys generally } \\
\text { next to the alluvial tract } \\
\text { (slope angles } 8^{\circ} \text { to } 14^{\circ} \text { ). }\end{array}$ \\
\hline $\begin{array}{l}\text { Wear Till } \\
\text { Formation } \\
\text { (WETI) }\end{array}$ & $\begin{array}{l}\text { Gravelly, sandy Clay, } \\
\text { Sand/gravel beds } \\
\text { Local beds of } \\
\text { laminated clay/silt. }\end{array}$ & Clay & $\begin{array}{l}\text { Occasional to some strong } \\
\text { or stronger boulders of } \\
\text { sandstone, limestone, } \\
\text { dolerite and granite. } \\
\text { Rafts of local rock towards } \\
\text { the base.. }\end{array}$ & $\begin{array}{l}\text { Small to medium, } \\
\text { occasionally larger (to } 3 \\
\text { km wide and } 300 \text { m long) } \\
\text { landslides generally next } \\
\text { to or near the alluvial tract } \\
\text { but some away from rivers } \\
\text { (slope angle } 8^{\circ} \text { to } 16^{\circ} \text { ). } \\
\text { Common along some } \\
\text { rivers (e.g. North Tyne }\end{array}$ \\
\hline
\end{tabular}




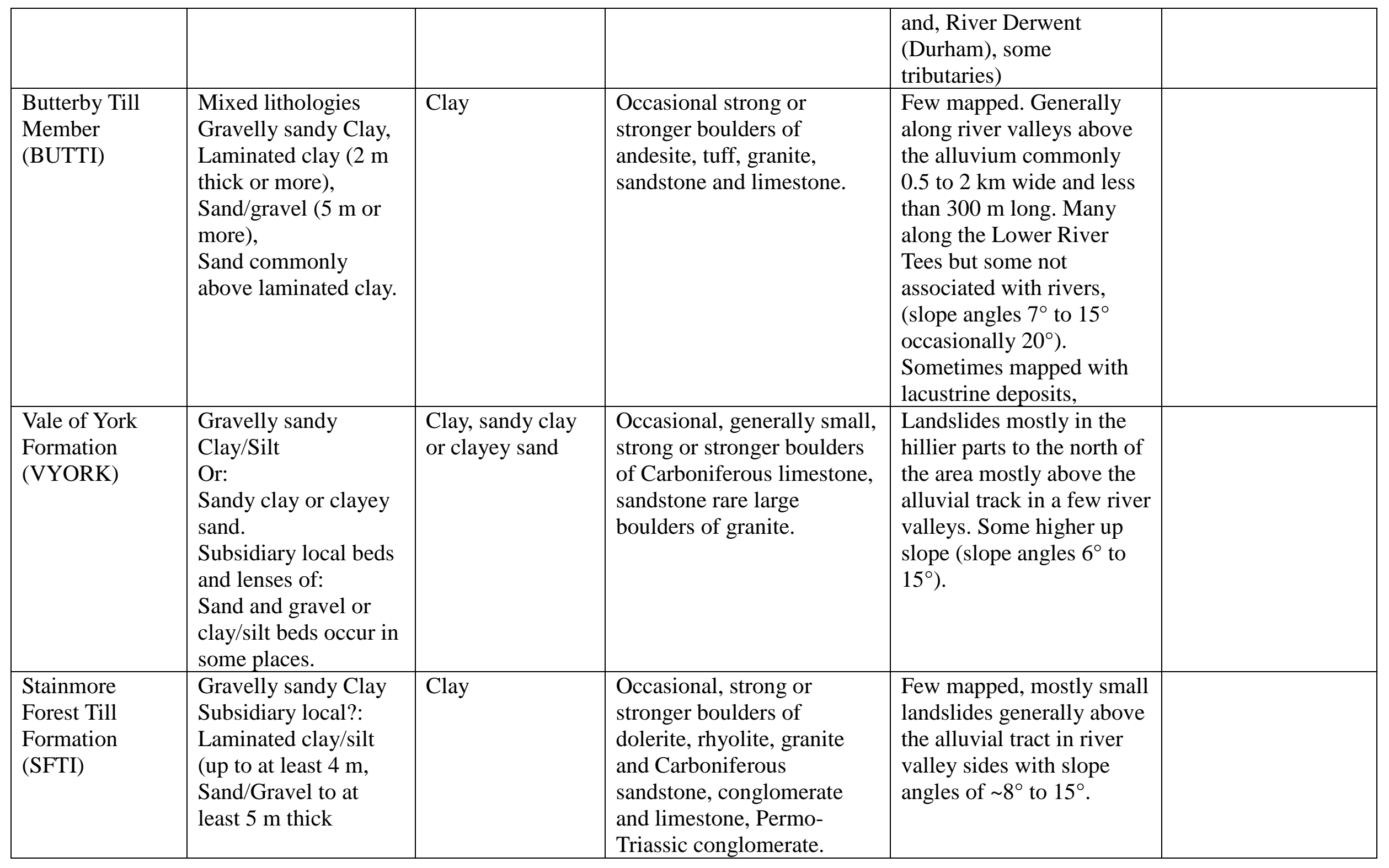




\begin{tabular}{|c|c|c|c|c|}
\hline $\begin{array}{l}\text { Yorkshire Dales } \\
\text { Till Formation } \\
\text { (YDTI) }\end{array}$ & $\begin{array}{l}\text { Gravelly sand clay } \\
\text { Subsidiary beds or } \\
\text { lenses } \\
\text { Laminated clay/silt } \\
\text { (near base in some } \\
\text { cases) } \\
\text { Sand and gravel }\end{array}$ & Clay & $\begin{array}{l}\text { Occasional, strong or } \\
\text { stronger boulders of } \\
\text { Carboniferous Limestone, } \\
\text { sandstone, and } \\
\text { conglomerate. }\end{array}$ & $\begin{array}{l}\text { Landslides, generally } \\
\text { small, above alluvial tract } \\
\text { and on valley sides (slopes } \\
11^{\circ} \text { to } 18^{\circ} \text { ). }\end{array}$ \\
\hline $\begin{array}{l}\text { Horden Till } \\
\text { (HNTI) }\end{array}$ & $\begin{array}{l}\text { Gravelly sandy clay. } \\
\text { Subsidiary beds or } \\
\text { lenses of: } \\
\text { Sand and gravel } \\
\text { Silt } \\
\text { Laminated clay/silt. }\end{array}$ & Clay & $\begin{array}{l}\text { Occasional, strong or } \\
\text { stronger boulders of } \\
\text { limestone, dolostones, and } \\
\text { porphyry. }\end{array}$ & $\begin{array}{l}\text { A few coastal landslides } \\
\text { and steep sided river } \\
\text { valleys e.g. Castle Eden } \\
\text { Burn and the wider } \\
\text { landslides along the } \\
\text { outside of bends Slope } \\
\text { angles } \sim 8^{\circ} \text { to } 15^{\circ} \text {. }\end{array}$ \\
\hline $\begin{array}{l}\text { Holderness Till } \\
\text { (HOLD) }\end{array}$ & $\begin{array}{l}\text { Slightly gravelly, } \\
\text { sandy clay } \\
\text { Subsidiary beds or } \\
\text { lenses of: } \\
\text { sand and gravel beds } \\
\text { Laminated clay/silt. }\end{array}$ & Clay & $\begin{array}{l}\text { Generally rare some in } \\
\text { Bridlington unit boulders of } \\
\text { limestone, sandstone, } \\
\text { Scottish rocks. }\end{array}$ & $\begin{array}{l}\text { Primarily coastal and some } \\
\text { river valley, e.g. River Esk } \\
\text { and tributaries. Slopes } \\
\text { angles of } 10^{\circ} \text { to } 17^{\circ} \text {. }\end{array}$ \\
\hline $\begin{array}{l}\text { Skipsea Till } \\
\text { Member }\end{array}$ & $\begin{array}{l}\text { Slightly gravelly, } \\
\text { sandy clay. }\end{array}$ & Clay & $\begin{array}{l}\text { Occasional strong or } \\
\text { stronger boulders of } \\
\text { limestone and sandstone, } \\
\text { Scottish rocks. }\end{array}$ & Coastal. \\
\hline Bridlington & $\begin{array}{l}\text { Gravelly sandy Clay } \\
\text { with cobbles }\end{array}$ & Clay & $\begin{array}{l}\text { Occasional strong or } \\
\text { stronger boulders of } \\
\text { limestone, sandstone and } \\
\text { various rocks from } \\
\text { Scotland. }\end{array}$ & $\begin{array}{l}\text { Non, only seen below the } \\
\text { Skipsea Till Member. }\end{array}$ \\
\hline
\end{tabular}




\begin{tabular}{|c|c|c|c|c|}
\hline $\begin{array}{l}\text { Holkham Till } \\
\text { Member (HOTI) }\end{array}$ & $\begin{array}{l}\text { Slightly gravelly, } \\
\text { sandy clay }\end{array}$ & Clay & $\begin{array}{l}\text { Rare boulders of igneous } \\
\text { and metamorphic rocks }\end{array}$ & Coastal. \\
\hline $\begin{array}{l}\text { Eryri Glacigenic } \\
\text { (ERYG) }\end{array}$ & $\begin{array}{l}\text { Gravelly clay } \\
\text { Subsidiary beds of: } \\
\text { Sand/gravel }\end{array}$ & Clay & $\begin{array}{l}\text { Occasional strong or } \\
\text { stronger boulders of } \\
\text { volcanic and Lower } \\
\text { Palaeozoic rocks. } \\
\end{array}$ & $\begin{array}{l}\text { Few landslides, above } \\
\text { alluvial tract or coastal } \\
\text { (slope } 10^{\circ} \text { to } 18^{\circ} \text { ) }\end{array}$ \\
\hline $\begin{array}{l}\text { Merion Till } \\
\text { Member } \\
\text { (MNTI) }\end{array}$ & $\begin{array}{l}\text { Gravelly sandy clay } \\
\text { Subsidiary to } \\
\text { occasional: } \\
\text { Sand and gravel beds } \\
\text { Silt }\end{array}$ & Clay & $\begin{array}{l}\text { Occasional strong or } \\
\text { stronger boulders of mostly } \\
\text { Lower Palaeozoic rocks. }\end{array}$ & $\begin{array}{l}\text { Many landslides; on hill } \\
\text { sides and above alluvial } \\
\text { tract (slope of } \sim 8^{\circ} \text { to } 14^{\circ} \text { ) } \\
\text { especially in the north and } \\
\text { south of the area. }\end{array}$ \\
\hline $\begin{array}{l}\text { Elenid Till } \\
\text { Member }\end{array}$ & Gravelly sandy clay & Clay & $\begin{array}{l}\text { Occasional strong or } \\
\text { stronger boulders of mostly } \\
\text { Lower Palaeozoic rocks. }\end{array}$ & $\begin{array}{l}\text { Landslides mostly above } \\
\text { the alluvial tract (slope } \\
\text { angle } \sim 9^{\circ} \text { to } 14^{\circ} \text { ). }\end{array}$ \\
\hline $\begin{array}{l}\text { Shrewsbury } \\
\text { Glacigenic } \\
\text { Formation }\end{array}$ & $\begin{array}{l}\text { Gravelly Sandy clay } \\
\text { Subsidiary beds of: } \\
\text { Sand/gravel } \\
\text { Laminated clay/silt. }\end{array}$ & Clay & $\begin{array}{l}\text { Occasional strong or } \\
\text { stronger boulders mostly } \\
\text { Lower Palaeozoic rocks. }\end{array}$ & $\begin{array}{l}\text { A few, small landslides } \\
\text { (slope angle of } \sim 8^{\circ} \text { to } \\
12^{\circ} \text { ). }\end{array}$ \\
\hline $\begin{array}{l}\text { Herefordshire } \\
\text { Till Member }\end{array}$ & $\begin{array}{l}\text { Gravelly, sandy silt or } \\
\text { clay, } \\
\text { And clayey gravel }\end{array}$ & $\begin{array}{l}\text { Clay/Silt } \\
\text { Or } \\
\text { Gravel }\end{array}$ & $\begin{array}{l}\text { Occasional strong or } \\
\text { stronger boulders of } \\
\text { sandstone and occasional }\end{array}$ & $\begin{array}{l}\text { A few landslides, generally } \\
\text { small but up to } 0.5 \mathrm{~km} \\
\text { wide by } 0.25 \mathrm{~km} \text { long, }\end{array}$ \\
\hline
\end{tabular}




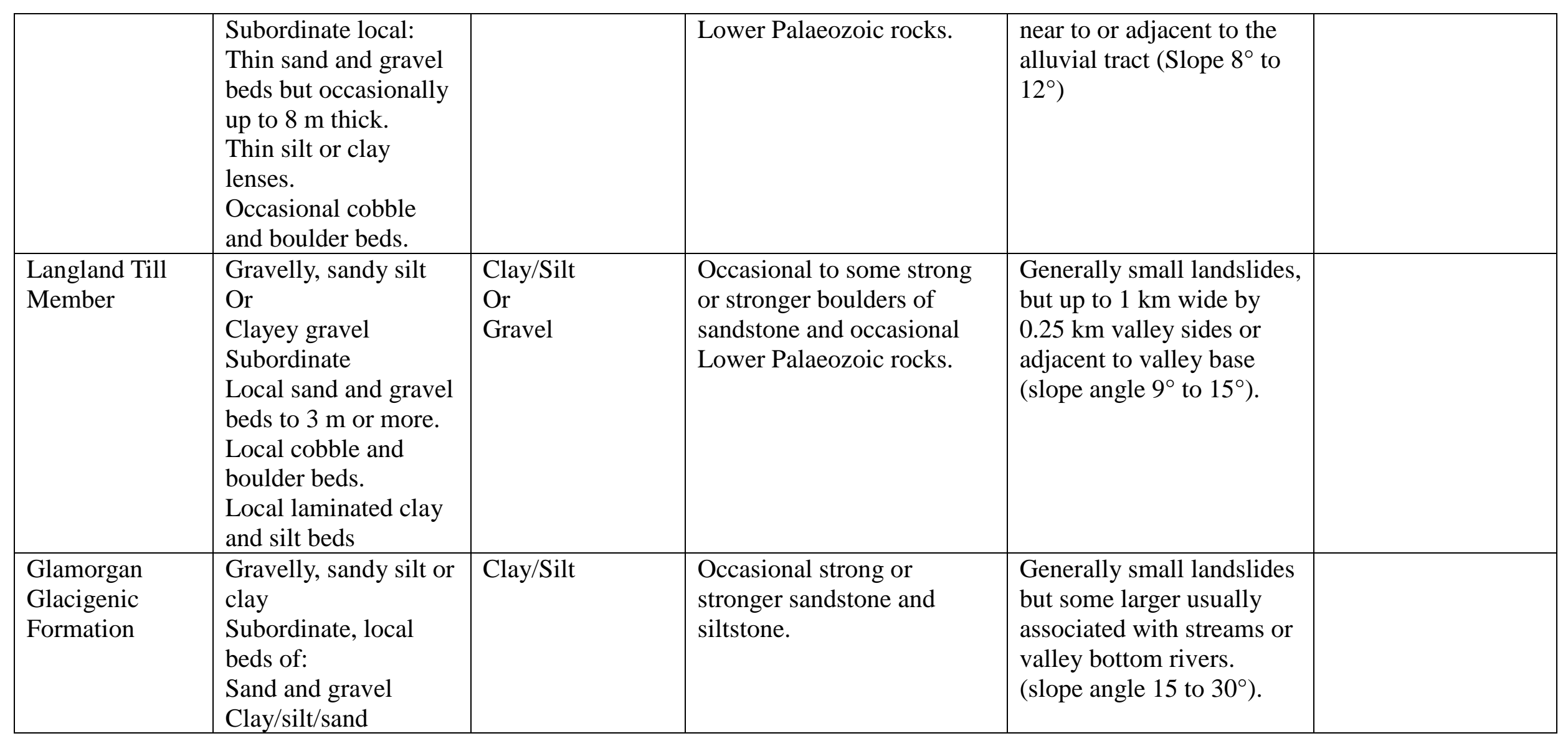


Table 6.9. Some engineering characteristics of tills of the Albion Glacigenic Group.

\begin{tabular}{|c|c|c|c|c|c|}
\hline Unit & $\begin{array}{c}\text { Characteristic } \\
\text { lithological } \\
\text { description }\end{array}$ & $\begin{array}{c}\text { Matrix } \\
\text { composition }\end{array}$ & Presence of boulders & Landslides & Other engineering considerations \\
\hline $\begin{array}{l}\text { Happisburgh } \\
\text { Till Member } \\
\text { (HPTI) }\end{array}$ & $\begin{array}{l}\text { Occasionally gravelly, } \\
\text { sandy clay or silt } \\
\text { Or } \\
\text { Clayey or silty sand }\end{array}$ & $\begin{array}{l}\text { Sand, silt or } \\
\text { clay }\end{array}$ & $\begin{array}{l}\text { Local chalk rafts, } \\
\text { chalk boulders from } \\
\text { break up of raft near } \\
\text { base. }\end{array}$ & Coastal landslides & \\
\hline $\begin{array}{l}\text { Corton Till } \\
\text { Member } \\
\text { (COTI) }\end{array}$ & $\begin{array}{l}\text { clay, very sandy clay } \\
\text { or clayey sand } \\
\text { Subsidiary } \\
\text { Thin sand beds. }\end{array}$ & Clay/sand & None & Coastal landslides & \\
\hline $\begin{array}{l}\text { Starston Till } \\
\text { Member (STIL) }\end{array}$ & $\begin{array}{l}\text { gravelly, sandy, clay } \\
\text { or silt }\end{array}$ & Clay or Silt & None & None mapped & \\
\hline $\begin{array}{l}\text { Bacton Green } \\
\text { Till Member } \\
\text { (BGTI) }\end{array}$ & $\begin{array}{l}\text { slightly gravelly sandy } \\
\text { clay/mudstone } \\
\text { Subsidiary beds or } \\
\text { lenses of: } \\
\text { clayey sand and beds } \\
\text { or laminae of sand, } \\
\text { silt } \\
\text { or clay } \\
\text { Rafts of local Chalk }\end{array}$ & $\begin{array}{l}\text { Clay or } \\
\text { mudstone }\end{array}$ & $\begin{array}{l}\text { Chalk rafts sometime } \\
\text { present }\end{array}$ & None mapped & \\
\hline $\begin{array}{l}\text { Runton Till } \\
\text { Member } \\
\text { (RUTI) }\end{array}$ & $\begin{array}{l}\text { slightly gravely clay } \\
\text { Subsidiary; } \\
\text { Thin beds of sand and } \\
\text { gravel }\end{array}$ & Clay & None & Coastal landslides & \\
\hline $\begin{array}{l}\text { Weybourne } \\
\text { Town Till } \\
\text { Formation } \\
\text { (WTTI) }\end{array}$ & $\begin{array}{l}\text { Very calcareous, } \\
\text { slightly gravelly, } \\
\text { slightly sandy silt } \\
\text { Subsidiary } \\
\text { Slightly gravelly, } \\
\text { slightly sandy clay }\end{array}$ & Silt & None & $\begin{array}{l}\text { Small coastal } \\
\text { landslides? }\end{array}$ & $\begin{array}{l}\text { May be decalcified and have an } \\
\text { undulating, karstic, upper surface. }\end{array}$ \\
\hline
\end{tabular}




\begin{tabular}{|c|c|c|c|c|c|}
\hline $\begin{array}{l}\text { Hanworth Till* } \\
\text { Member (HATI) }\end{array}$ & $\begin{array}{l}\text { Clayey silty Sand } \\
\text { Subsidiary: } \\
\text { Highly calcareous silt. }\end{array}$ & Sand. & $\begin{array}{l}\text { ‘Rafts' of Weybourne } \\
\text { Town Till Formation. }\end{array}$ & $\begin{array}{l}\text { Member not } \\
\text { included on } \\
\text { geological maps }\end{array}$ & \\
\hline $\begin{array}{l}\text { Lowestoft } \\
\text { Glacigenic } \\
\text { Formation } \\
\text { (LOFT) }\end{array}$ & $\begin{array}{l}\text { Gravelly sandy clay } \\
\text { Subsidiary: } \\
\text { Sand and gravel } \\
\text { Local: } \\
\text { Laminated clay/silt }\end{array}$ & Clay & $\begin{array}{l}\text { Rare strong or } \\
\text { stronger boulders of } \\
\text { flint. }\end{array}$ & $\begin{array}{l}\text { Occasional small to } \\
\text { moderate sized } \\
\text { landslides } \\
\text { generally adjacent } \\
\text { to alluvial tract or } \\
\text { tract of head in } \\
\text { valleys, most likely } \\
\text { in the south of the } \\
\text { domain }\end{array}$ & $\begin{array}{l}\text { Upper few metres often decalcified } \\
\text { and fissured. }\end{array}$ \\
\hline $\begin{array}{l}\text { Lowestoft Till } \\
\text { Member (LTIL) }\end{array}$ & $\begin{array}{l}\text { Gravelly sandy clay } \\
\text { Subsidiary: } \\
\text { Sand and gravel } \\
\text { Laminated clay/silt }\end{array}$ & Clay & Rare boulders & $\begin{array}{l}\text { Occasional small to } \\
\text { moderate sized } \\
\text { landslides } \\
\text { generally adjacent } \\
\text { to alluvial tract }\end{array}$ & $\begin{array}{l}\text { Upper few metres often decalcified } \\
\text { and fissured. }\end{array}$ \\
\hline $\begin{array}{l}\text { Walcott Till } \\
\text { Member } \\
\text { (WATI) }\end{array}$ & $\begin{array}{l}\text { Calcareous, gravelly, } \\
\text { sandy, silt or clay, } \\
\text { Subsidiary } \\
\text { Laminated clay/silt } \\
\text { and sand }\end{array}$ & Silt or Clay & None & None mapped & \\
\hline $\begin{array}{l}\text { Nurseries } \\
\text { (NURS) }\end{array}$ & $\begin{array}{l}\text { Gravelly, sandy, clay } \\
\text { Subsidiary, local: } \\
\text { Sand and gravel } \\
\text { Laminated clay and } \\
\text { silt beds }\end{array}$ & Clay & $\begin{array}{l}\text { Occasional strong or } \\
\text { stronger boulders of } \\
\text { sandstone, North } \\
\text { Wales rocks including } \\
\text { rhyolite. }\end{array}$ & None mapped & \\
\hline $\begin{array}{l}\text { Wolston } \\
\text { Glacigenic } \\
\text { Formation }\end{array}$ & $\begin{array}{l}\text { Gravelly sandy clay, } \\
\text { Subsidiary, local, } \\
\text { sand and gravel beds }\end{array}$ & Clay & $\begin{array}{l}\text { Rare or strong or } \\
\text { stronger boulders }\end{array}$ & $\begin{array}{l}\text { Occasional, small } \\
\text { landslides } \\
\text { generally adjacent }\end{array}$ & \\
\hline
\end{tabular}




\begin{tabular}{|c|c|c|c|c|c|}
\hline (WOLS) & $\begin{array}{l}\text { laminated silt and clay } \\
\text { beds }\end{array}$ & & & to alluvial tract & \\
\hline $\begin{array}{l}\text { Thrussington } \\
\text { Member (THT) }\end{array}$ & $\begin{array}{l}\text { Variably gravelly, } \\
\text { variably sandy clay } \\
\text { Subsidiary and local } \\
\text { beds or lenses of } \\
\text { sand/gravel } \\
\text { Laminated clay/silt. }\end{array}$ & Clay & $\begin{array}{l}\text { Rare strong or } \\
\text { stronger boulders. }\end{array}$ & $\begin{array}{l}\text { Occasional, small } \\
\text { landslides } \\
\text { generally adjacent } \\
\text { to alluvial tract }\end{array}$ & \\
\hline $\begin{array}{l}\text { Harrogate Till } \\
\text { Formation } \\
(\mathrm{HRT})\end{array}$ & $\begin{array}{l}\text { Slightly gravelly, } \\
\text { slightly sandy to } \\
\text { sandy clay with } \\
\text { cobbles and boulders } \\
\text { Subsidiary (local) } \\
\text { sand and gravel beds } \\
\text { Laminated clay/silt } \\
\text { ( } 2 \text { m thick) }\end{array}$ & Clay & $\begin{array}{l}\text { Occasional strong or } \\
\text { stronger sandstone } \\
\text { boulders. }\end{array}$ & $\begin{array}{l}\text { A few, small } \\
\text { landslides }\end{array}$ & \\
\hline $\begin{array}{l}\text { Pickering Till } \\
\text { Formation } \\
\text { (PKTI) }\end{array}$ & Gravelly sandy clay. & Clay & $\begin{array}{l}\text { Rare strong or } \\
\text { stronger }\end{array}$ & None mapped & \\
\hline
\end{tabular}




\begin{tabular}{|l|l|l|l|l|l|}
\hline $\begin{array}{l}\text { Formation } \\
\text { (POTI) }\end{array}$ & $\begin{array}{l}\text { Local sand and gravel } \\
\text { beds. }\end{array}$ & & $\begin{array}{l}\text { stronger include tuff, } \\
\text { felsite boulders and } \\
\text { rocks from north } \\
\text { Pembrokeshire. }\end{array}$ & & \\
\hline $\begin{array}{l}\text { Llanddewi } \\
\begin{array}{l}\text { Glacigenic } \\
\text { Formation } \\
\text { (LITI) }\end{array}\end{array}$ & Gravelly sandy Clay & Clay & $\begin{array}{l}\text { Occasional strong or } \\
\text { stronger boulders } \\
\text { mostly of sandstone }\end{array}$ & Non mapped & \\
\hline
\end{tabular}


Table 6.10. Engineering geological descriptions and summary geotechnical properties for glacial sand and gravel locations in England and Wales.

\begin{tabular}{|c|c|c|c|c|c|c|}
\hline $\begin{array}{l}\text { Location } \\
\text { and } \\
\text { informatio } \\
\text { n source }\end{array}$ & $\begin{array}{c}\text { Engineering } \\
\text { geological } \\
\text { description }\end{array}$ & $\begin{array}{c}\text { SPT 'N' } \\
\text { value - } \\
\text { median ( } 25 \\
\text { and } 50 \% \\
\text { percentiles } \\
\text { ) }\end{array}$ & $\begin{array}{c}\text { Silt \% - } \\
\text { median } \\
(25 \text { and } \\
50 \% \\
\text { percentiles } \\
\text { ) }\end{array}$ & $\begin{array}{c}\text { Sand \% - } \\
\text { median } \\
(25 \text { and } \\
50 \% \\
\text { percentiles } \\
\text { ) }\end{array}$ & \begin{tabular}{|} 
Gravel \% \\
- median \\
$(25$ and \\
$50 \%$ \\
percentiles \\
)
\end{tabular} & Comments \\
\hline $\begin{array}{l}\text { South- } \\
\text { Central } \\
\text { Leeds } \\
\text { (Northmore } \\
\text { 1991) }\end{array}$ & $\begin{array}{l}\text { Range from } \\
\text { slightly cohesive, } \\
\text { clayey, silty SAND } \\
\text { to highly } \\
\text { permeable, } \\
\text { medium dense to } \\
\text { very dense sandy } \\
\text { GRAVEL with } \\
\text { local layers and } \\
\text { lenses of silt and } \\
\text { clay }\end{array}$ & $44(32-54)$ & $10(4-22)$ & $37(21-53)$ & $51(30-73)$ & $\begin{array}{l}\text { Few } \\
\text { foundation } \\
\text { problems } \\
\text { provided } \\
\text { lithological } \\
\text { variation } \\
\text { determined. } \\
\text { Excavations } \\
\text { will require } \\
\text { immediate } \\
\text { support and } \\
\text { where } \\
\text { water- } \\
\text { bearing, } \\
\text { water } \\
\text { inflow will } \\
\text { need } \\
\text { control }\end{array}$ \\
\hline $\begin{array}{l}\text { West and } \\
\text { North West } \\
\text { Birmingha } \\
\text { m and the } \\
\text { Black } \\
\text { Country } \\
\text { (Forster } \\
\text { 1991) }\end{array}$ & $\begin{array}{l}\text { Mainly sandy } \\
\text { GRAVEL or } \\
\text { gravelly SAND. } \\
\text { Some silty, sandy } \\
\text { or gravelly CLAY } \\
\text { may be present }\end{array}$ & 22 (14-33) & $4(2-11)$ & 33 (19-55) & $58(29-76)$ & $\begin{array}{l}\text { Good } \\
\text { bearing } \\
\text { capacity but } \\
\text { SPT results } \\
\text { may be } \\
\text { unreliable; } \\
\text { density } \\
\text { variable. } \\
\text { Settlement } \\
\text { low and } \\
\text { rapid. } \\
\text { Excavations } \\
\text { require } \\
\text { support. } \\
\text { Running } \\
\text { sand and } \\
\text { water } \\
\text { inflow } \\
\text { possible. }\end{array}$ \\
\hline $\begin{array}{l}\text { South West } \\
\text { Essex } \\
\text { (Culshaw \& }\end{array}$ & $\begin{array}{l}\text { Clayey, angular to } \\
\text { rounded, fine to } \\
\text { coarse GRAVEL }\end{array}$ & $29(26-36)$ & - & $69(---)$ & $5(1-57)$ & \\
\hline
\end{tabular}




\begin{tabular}{|c|c|c|c|c|c|c|}
\hline $\begin{array}{l}\text { Crummy } \\
1990)\end{array}$ & $\begin{array}{l}\text { and SAND. Occurs } \\
\text { above, below or as } \\
\text { lenses within the } \\
\text { till }\end{array}$ & & & & & \\
\hline $\begin{array}{l}\text { Deeside, } \\
\text { North } \\
\text { Wales } \\
\text { (Culshaw \& } \\
\text { Crummy } \\
\text { 1988) }\end{array}$ & $\begin{array}{l}\text { Widely occurring, } \\
\text { generally thick, } \\
\text { irregular spreads } \\
\text { and SAND and } \\
\text { GRAVEL. Very } \\
\text { variable, medium } \\
\text { dense, well sorted. } \\
\text { Clay can occur as a } \\
\text { soft to firm matrix } \\
\text { or as thin, very } \\
\text { weak to very stiff } \\
\text { bands }\end{array}$ & $\begin{array}{l}\text { Mean } \\
\text { (range) } \\
37(0-140)\end{array}$ & $\begin{array}{l}\text { Mean } \\
12\end{array}$ & $\begin{array}{l}\text { Mean } \\
\text { (range) } \\
23(2-87)\end{array}$ & $\begin{array}{l}\text { Mean } \\
\text { (range) } \\
50(0-97)\end{array}$ & $\begin{array}{l}\text { Excavations } \\
\text { require } \\
\text { support. } \\
\text { Running } \\
\text { sand and } \\
\text { water } \\
\text { inflow } \\
\text { possible. } \\
\text { Groundwate } \\
\text { r control } \\
\text { may be } \\
\text { necessary. }\end{array}$ \\
\hline $\begin{array}{l}\text { Wrexham, } \\
\text { North } \\
\text { Wales } \\
\text { (Waine et } \\
\text { al. 1990a) }\end{array}$ & $\begin{array}{l}\text { Medium dense to } \\
\text { dense, well sorted, } \\
\text { grey-brown SAND } \\
\text { and GRAVEL with } \\
\text { occasional cobbles, } \\
\text { and layers of clean } \\
\text { SAND and silty, } \\
\text { clayey SAND. Up } \\
\text { to } 38 \text { m thick }\end{array}$ & $29(17-46)$ & $5(3-10)$ & $50(25-87)$ & $45(8-68)$ & $\begin{array}{l}\text { Heterogene } \\
\text { ous, with } \\
\text { varying } \\
\text { properties. } \\
\text { Often } \\
\text { water- } \\
\text { bearing; } \\
\text { excavations } \\
\text { require } \\
\text { support and } \\
\text { groundwate } \\
\text { r control. }\end{array}$ \\
\hline $\begin{array}{l}\text { Stoke-on- } \\
\text { Trent } \\
\text { (Waine et } \\
\text { al. 1990b) }\end{array}$ & $\begin{array}{l}\text { Very loose to very } \\
\text { dense, well sorted, } \\
\text { light brown, coarse } \\
\text { SAND and } \\
\text { subangular to } \\
\text { subrounded } \\
\text { GRAVEL with } \\
\text { occasional } \\
\text { subrounded } \\
\text { cobbles }\end{array}$ & $20(11-33)$ & $7(---)$ & $22(14-40)$ & $68(46-84)$ & $\begin{array}{l}\text { Generally } \\
\text { water- } \\
\text { bearing; } \\
\text { excavations } \\
\text { require } \\
\text { support and } \\
\text { groundwate } \\
\text { r control. }\end{array}$ \\
\hline
\end{tabular}


Table 6.11. Potential deposits to be found in a glaciolacustrine landsystem

\begin{tabular}{|c|c|}
\hline $\begin{array}{l}\text { Glaciolacustrine } \\
\text { Deposit }\end{array}$ & Description and comments \\
\hline $\begin{array}{l}\text { Rhythmites } \\
\text { (Non-genetic) }\end{array}$ & $\begin{array}{l}\text { Stratified sediments that display rhythmic or cyclic repetition of beds, related } \\
\text { specifically to alternations between dominant grain size distributions. The term } \\
\text { rhythmite is a non-genetic term used to refer to a range of deposits that display } \\
\text { cyclic alternations in bedding, but is often replaced when the exact origins of the } \\
\text { rhythms are known }\end{array}$ \\
\hline $\begin{array}{l}\text { Varves } \\
\text { (Seasonal rhythmites) }\end{array}$ & $\begin{array}{l}\text { Varves are rhythmites produced on the bottoms of deep water bodies by } \\
\text { interflows and overflows on a seasonal or annual basis in glaciated catchments. } \\
\text { Each season produces a coarse and fine grained couplet in response to the high } \\
\text { and low discharges of the summer and winter seasons respectively. }\end{array}$ \\
\hline $\begin{array}{l}\text { Cyclopels and } \\
\text { cyclopsams (Tidally } \\
\text { influenced rhythmites) }\end{array}$ & $\begin{array}{l}\text { Rhythmites deposited as couplets from overflow and interflow plumes in } \\
\text { glaciomarine environments. Silt and mud couplets are called cyclopels and sand } \\
\text { and mud couplets are called cyclopsams. }\end{array}$ \\
\hline Turbidites & $\begin{array}{l}\text { An individual turbidite can be identified as a graded vertical sequence of } \\
\text { horizontally bedded/laminated sediments created by the passage and slowing of } \\
\text { turbidity currents. They also display proximal-to-distal fining, reflecting the } \\
\text { rapid deposition of coarse material and the transport of finer material into deeper } \\
\text { parts of the basin. The characteristic vertical "Bouma" sequence comprises: (A) } \\
\text { massive or normally graded sand or gravel; (B) planar-laminated sand; (C) } \\
\text { ripple cross-laminated sand and silt; (D) interlaminated silt and/or clay; (E) } \\
\text { massive clay or silt. }\end{array}$ \\
\hline Palimpsest lags & $\begin{array}{l}\text { Concentrations of clasts occurring in discrete horizons in stratified sediment } \\
\text { sequences. }\end{array}$ \\
\hline $\begin{array}{l}\text { Dropstone mud and } \\
\text { plumites / silt \& mud } \\
\text { drapes } \\
\text { (Ice-rafted debris) }\end{array}$ & $\begin{array}{l}\text { Dropstone muds are matrix-supported diamictons with strongly bimodal } \\
\text { particle-size distributions, reflecting dominant suspension sedimentation and } \\
\text { minor quantities of dropstones. Dropstone muds and drapes form extensive, } \\
\text { blanket-like sheets covering pre-existing topography, and can be massive or } \\
\text { weakly stratified. Laminations within such deposits are interpreted as the } \\
\text { product of the cyclicity of suspension sedimentation from turbid meltwater } \\
\text { plumes and are hence called plumites. Dropstone muds can be differentiated } \\
\text { from dropstone diamictons by their clast content, which should be less than } 10 \% \\
\text { clasts per unit area. }\end{array}$ \\
\hline $\begin{array}{l}\text { Dropstone diamicton } \\
\text { and glaciomarine } \\
\text { varves } \\
\text { (Ice-rafted debris) }\end{array}$ & $\begin{array}{l}\text { Dropstone diamictons are matrix-supported diamictons with relatively large } \\
\text { concentrations of clasts derived from iceberg rafting and fine-grained matrices } \\
\text { produced by background suspension sedimentation from plumes. They can form } \\
\text { extensive, blanket-like sheets covering pre-existing topography, and can be } \\
\text { massive or weakly stratified. Dropstone diamictons can be differentiated from } \\
\text { dropstone muds by their clast content, which should be greater than } 10 \% \text { clasts } \\
\text { per unit area. Where stratified and displaying rhythmic sequences, dropstone } \\
\text { diamictons have been termed glaciomarine varves. This reflects the alternations } \\
\text { between IRD-poor, fine-grained muds and stratified, matrix-supported } \\
\text { diamictons. The laminated muds in such sequences are interpreted as the } \\
\text { products of suspension sedimentation from turbid meltwater plumes (see } \\
\text { plumites), whereas the stratified diamictons reflect rain-out of IRD combined } \\
\text { with suspension settling when iceberg melting is dominant. The diamictons are } \\
\text { regarded as winter layers, introduced by iceberg sedimentation, when plumes are } \\
\text { suppressed due to reduced meltwater production. }\end{array}$ \\
\hline $\begin{array}{l}\text { Debris flow (debrites) } \\
\text { /sub aqueous slide \& }\end{array}$ & $\begin{array}{l}\text { Debris flow deposits are created by sediment gravity flows, which result from } \\
\text { the flowage of concentrated sediment-water mixtures. Subaqueous slides and }\end{array}$ \\
\hline
\end{tabular}




\begin{tabular}{|c|c|}
\hline $\begin{array}{l}\text { slump deposits } \\
\text { (including cohesive \& } \\
\text { cohesionless) }\end{array}$ & $\begin{array}{l}\text { slumps occur whenever slopes fail along internal shear planes and undergo } \\
\text { downslope transport. Debris flows, slides and slumps can undergo } \\
\text { transformations during transport depending on whether or not they lose or gain } \\
\text { fluid, resulting in lateral and vertical changes in sedimentary characteristics. For } \\
\text { example, a cohesive debris flow can become liquefied if it enters a water body } \\
\text { and hence becomes disaggregated or fluidal flows (see turbidite). Indeed, } \\
\text { sediment gravity flows lie on a process-form continuum, with cohesive debris } \\
\text { flows at the relatively better-drained end (see supraglacial mass flow diamicton) } \\
\text { and turbidites at the saturated end of the continuum. Subaqueous debris flows } \\
\text { are traditionally subdivided into cohesive and cohesionless varieties based upon } \\
\text { the presence or absence of matrix cohesion. Cohesive flows contain some clay } \\
\text { matrix so that they act as a fluid with cohesive strength within which large } \\
\text { clasts, boulders and blocks of pre-existing sediment can be rafted. The upper } \\
\text { part of the flow commonly consists of a semi-rigid 'plug' riding passively on a } \\
\text { thin basal shear zone, but the flow top can become diluted due to turbulent } \\
\text { mixing with the overlying water column, thereby causing a transformation into a } \\
\text { turbulent underflow. Cohesionless debris flows are high-concentration, non- } \\
\text { turbulent flows which tend to occur in sandy and gravelly materials, with grains } \\
\text { being supported during transport by a variety of dispersive pressure, buoyancy } \\
\text { effects, liquefaction and fluidization. At the liquefied end of the cohesionless } \\
\text { debris flow continuum are grain flows, fluidized flows and liquefied flows, } \\
\text { overlapping with fall deposits created on steeper slopes (see subaqueous debris } \\
\text { fall deposits). Deposition from a cohesionless flow will occur when grain } \\
\text { suspension ceases and grains begin to settle out and regain contact with each } \\
\text { other, displacing pore water upwards. This causes flows to shut down or 'freeze' } \\
\text { from the bottom upwards and to develop water escape and loading structures. }\end{array}$ \\
\hline $\begin{array}{l}\text { Subaqueous debris fall } \\
\text { deposits } \\
\text { (including } \\
\text { olistostromes) }\end{array}$ & $\begin{array}{l}\text { In debris falls (often also referred to as "grain falls", although this term also } \\
\text { implies suspension sedimentation) clasts move individually or as masses of } \\
\text { strongly dispersed particles. Each particle is driven in a downslope direction by } \\
\text { its own momentum, and will bounce, slide or roll when impacting the bottom. } \\
\text { This gives rise to downslope coarsening and a fining-upward or normally graded } \\
\text { sequence due to the tendency for larger particles to be deposited first and then to } \\
\text { be overrun by the finer-grained tail of the avalanche. The term "olistostrome" is } \\
\text { used for very large scale debris falls in the geological record in which a range of } \\
\text { materials are liberated from pre-existing sediment piles to produce melanges, a } \\
\text { scale of failure that is possible in large glacially influenced marine basins for } \\
\text { example. }\end{array}$ \\
\hline Undermelt diamicton & $\begin{array}{l}\text { Stratified diamictons containing numerous dropstones, winnowed lags and } \\
\text { poorly sorted gravelly lenses. }\end{array}$ \\
\hline $\begin{array}{l}\text { Iceberg contact deposits } \\
\text { (ice keel turbate, } \\
\text { iceberg dump structures } \\
\text { \& mounds) }\end{array}$ & $\begin{array}{l}\text { Diamictons and clusters of clasts deposited directly from icebergs without } \\
\text { intervening gravitational transport where bergs lodge on the sea or lake bed and } \\
\text { debris melts out in situ. Iceberg scouring can also modify pre-existing } \\
\text { depositional structures, creating a massive, structureless diamicton called ice- } \\
\text { keel turbate. }\end{array}$ \\
\hline
\end{tabular}


Table 6.12. Some engineering properties of various UK glaciolacustrine deposits (after Reeves et al. 2006). Where three values are given they are the minimum, mean and maximum.

\begin{tabular}{|c|c|c|c|c|c|c|c|c|c|c|c|}
\hline Location & Source & $\begin{array}{c}\text { Moisture } \\
\text { Content } \\
\%\end{array}$ & $\begin{array}{c}\text { Liquid } \\
\text { Limit } \\
\%\end{array}$ & $\begin{array}{c}\text { Plastic } \\
\text { Limit } \\
\%\end{array}$ & $\begin{array}{c}\text { Plasticity } \\
\text { Index } \\
\%\end{array}$ & $\begin{array}{c}\text { Bulk } \\
\text { Density } \\
\text { Mg/m³ }\end{array}$ & $\begin{array}{c}\text { Dry } \\
\text { Density } \\
\text { Mg/m } \mathbf{m}^{3}\end{array}$ & $\begin{array}{c}\text { Undrained } \\
\text { Cohesion } \\
\text { kPa }\end{array}$ & $\begin{array}{c}\text { Undrained } \\
\text { Angle of } \\
\text { Friction } \\
\circ\end{array}$ & $\begin{array}{c}\text { Effective } \\
\text { Cohesion } \\
\text { kPa }\end{array}$ & $\begin{array}{c}\text { Effective } \\
\text { Angle of } \\
\text { Friction } \\
\circ\end{array}$ \\
\hline $\begin{array}{l}\text { N. } \\
\text { England - } \\
\text { Skipton } \\
\end{array}$ & $\begin{array}{l}\text { Threadgold } \\
\& \text { Weeks } \\
1975 \\
\end{array}$ & $\begin{array}{l}26 \\
27 \\
28 \\
\end{array}$ & $\begin{array}{l}40 \\
45 \\
50 \\
\end{array}$ & $\begin{array}{l}17 \\
20 \\
25 \\
\end{array}$ & $\begin{array}{l}20 \\
22 \\
28 \\
\end{array}$ & & & $\begin{array}{c}40 \\
- \\
100 \\
\end{array}$ & & & \\
\hline $\begin{array}{l}\text { NE } \\
\text { England }\end{array}$ & $\begin{array}{l}\text { Jackson \& } \\
\text { Lawrence } \\
1990\end{array}$ & $\begin{array}{l}14 \\
26 \\
37\end{array}$ & $\begin{array}{l}28 \\
48 \\
72\end{array}$ & $\begin{array}{l}15 \\
20 \\
27\end{array}$ & $\begin{array}{l}10 \\
28 \\
45\end{array}$ & $\begin{array}{l}1.77 \\
1.98 \\
2.21\end{array}$ & $\begin{array}{l}1.58 \\
1.59 \\
1.61\end{array}$ & $\begin{array}{c}20 \\
71 \\
134\end{array}$ & $\begin{array}{c}0 \\
1.5 \\
32\end{array}$ & & \\
\hline $\begin{array}{l}\text { N. Wales - } \\
\text { Wrexham }\end{array}$ & $\begin{array}{l}\text { Waine et al. } \\
1990\end{array}$ & $\begin{array}{l}20 \\
23 \\
26 \\
\end{array}$ & $\begin{array}{l}39 \\
44 \\
49 \\
\end{array}$ & $\begin{array}{l}19 \\
22 \\
24 \\
\end{array}$ & $\begin{array}{l}19 \\
22 \\
25 \\
\end{array}$ & $\begin{array}{l}1.99 \\
2.06 \\
2.10 \\
\end{array}$ & $\begin{array}{l}1.56 \\
1.68 \\
1.75 \\
\end{array}$ & $\begin{array}{c}50 \\
80 \\
120 \\
\end{array}$ & $\begin{array}{l}- \\
0 \\
-\end{array}$ & & $\begin{array}{l}20 \\
22 \\
23\end{array}$ \\
\hline $\begin{array}{l}\mathrm{NE} \\
\text { England - } \\
\text { Teeside }\end{array}$ & $\begin{array}{l}\text { Bell } \\
2000\end{array}$ & $\begin{array}{c}22 \\
- \\
35\end{array}$ & $\begin{array}{c}29 \\
- \\
78\end{array}$ & $\begin{array}{c}18 \\
- \\
31\end{array}$ & $\begin{array}{c}16 \\
- \\
49\end{array}$ & $\begin{array}{c}- \\
1.19 \\
-\end{array}$ & $\begin{array}{c}- \\
1.45 \\
-\end{array}$ & $\begin{array}{c}27 \\
60 \\
102\end{array}$ & & $\begin{array}{l}- \\
0\end{array}$ & $\begin{array}{l}- \\
14 \\
-\end{array}$ \\
\hline
\end{tabular}


Table 6.13. Glaciolacustrine lithostratigraphic units shown on British Geological Survey 1:10,000 and/or 1:50,000 scale maps (after McMillan et al. [2011])

\begin{tabular}{|c|c|c|c|}
\hline Group & Subgroup & Formation & Member \\
\hline \multirow{6}{*}{$\begin{array}{l}\text { Albion } \\
\text { Glacigenic } \\
\text { Group }\end{array}$} & & \multirow[t]{2}{*}{ Lowestoft Formation } & $\begin{array}{l}\text { Oulton Clay Member } \\
\text { (OULT) }\end{array}$ \\
\hline & & & $\begin{array}{l}\text { Woolpit Beds } \text { Member } \\
\text { (WPIT) }\end{array}$ \\
\hline & & \multirow[t]{2}{*}{ Sheringham Cliffs Formation } & $\begin{array}{l}\text { Ivy Farm Laminated Silt } \\
\text { (IFLS) }\end{array}$ \\
\hline & & & $\begin{array}{l}\text { Trimingham } \\
\text { (TRICS) }\end{array}$ \\
\hline & & \multirow[t]{2}{*}{ Wolston Formation } & Bosworth Clay (BOSW) \\
\hline & & & Wolston Clay (WOC) \\
\hline \multirow[t]{24}{*}{$\begin{array}{l}\text { Caledonia } \\
\text { Glacigenic } \\
\text { Group }\end{array}$} & $\begin{array}{lr}\text { Banffshire } & \text { Coast and } \\
\text { Caithness } & \text { Glacigenic } \\
\text { Subgroup } & \\
\end{array}$ & $\begin{array}{l}\text { Kirk Burn Silt } \\
\text { (KBSI) }\end{array}$ & \\
\hline & $\begin{array}{l}\text { Central Cumbria } \\
\text { Glacigenic Subgroup }\end{array}$ & $\begin{array}{ll}\text { Blengdale } & \text { Glacigenic } \\
\text { Formation } & \end{array}$ & $\begin{array}{l}\text { Bark Butts Silts Member } \\
\text { (BBSI) }\end{array}$ \\
\hline & $\begin{array}{l}\text { Central Grampian } \\
\text { Glacigenic Subgroup }\end{array}$ & $\begin{array}{l}\text { Linn of Patrick Silt Formation } \\
\text { (LPSI) }\end{array}$ & \\
\hline & $\begin{array}{l}\text { East Grampian } \\
\text { Glacigenic Subgroup }\end{array}$ & Glan Dye Silts (GDSI) & \\
\hline & Inverness Glacigenic & Kincurdy Silts (KSI) & \\
\hline & \multirow[t]{10}{*}{$\begin{array}{l}\text { Irish Sea Coastal } \\
\text { Glacigenic Subgroup }\end{array}$} & $\begin{array}{l}\text { Aikbank Farm Glacigenic } \\
\text { Formation (AIK) (mostly) }\end{array}$ & \\
\hline & & \multirow{2}{*}{$\begin{array}{lll}\text { Aikbank } & \text { Farm } & \text { Glacigenic } \\
\text { Formation (AIK) } & \end{array}$} & Holmeside Clay \\
\hline & & & $\begin{array}{l}\text { Whinneyhill Coppice } \\
\text { Clay }\end{array}$ \\
\hline & & Carleton Silts (CNSI) & \\
\hline & & Culliviat Silts (CUS) & \\
\hline & & Great Easby Clay (GECL) & \\
\hline & & \multirow[t]{2}{*}{$\begin{array}{ll}\text { Gosforth } & \text { Glacigenic } \\
\text { Formation } & \end{array}$} & $\begin{array}{l}\text { Drigg Moorside Silt } \\
\text { (DGMS) }\end{array}$ \\
\hline & & & $\begin{array}{lll}\text { Meadow } & \text { House } & \text { Clay } \\
(\mathrm{MWHO}) & & \end{array}$ \\
\hline & & $\begin{array}{ll}\text { Seascale } & \text { Glacigenic } \\
\text { Formation } & \\
\end{array}$ & Ehen Valley Silt (EVSI) \\
\hline & & Teifi Clay (TFICL) & \\
\hline & \multirow{2}{*}{$\begin{array}{l}\text { Logie-Buchan } \\
\text { Glacigenic }\end{array}$} & \multirow[t]{2}{*}{ Ugie Clay (UGCL) } & \\
\hline & & & Tullos Clay (TSCL) \\
\hline & Mearns Glacigenic & Ury Silt (USI) & \\
\hline & \multirow[t]{3}{*}{$\begin{array}{ll}\text { Midland } & \text { Valley } \\
\text { Glacigenic } & \end{array}$} & $\begin{array}{l}\text { Broomhouse Sand and Gravel } \\
\text { (BHSE) }\end{array}$ & Bellshill Clay (BILL) \\
\hline & & Blane Water Silt (BLAW) & \\
\hline & & Broomhill Clay (BRLL) & \\
\hline & \multirow[t]{3}{*}{$\begin{array}{ll}\text { North } & \text { Pennine } \\
\text { Glacigenic } & \end{array}$} & $\begin{array}{l}\text { Alne } \quad \text { Glaciolacustrine } \\
\text { Formation (ALNE) }\end{array}$ & \\
\hline & & $\begin{array}{l}\text { Elvington } \text { Glaciolacustrine } \\
\text { Formation }\end{array}$ & \\
\hline & & Hemingborough & \\
\hline
\end{tabular}




\begin{tabular}{|l|l|l|l|}
\hline \multirow{2}{*}{} & $\begin{array}{l}\text { Glaciolacustrine Formation } \\
\text { (HEM) }\end{array}$ & $\begin{array}{l}\text { Park Farm Clay (PAF) } \\
\text { Thornganby Clay } \\
\text { (THOR) }\end{array}$ \\
\cline { 3 - 4 } & $\begin{array}{l}\text { Tyne and Wear Glacigenic } \\
\text { Formation (TYWE) }\end{array}$ & \\
\cline { 2 - 4 } $\begin{array}{l}\text { North Sea Coast } \\
\text { Glacigenic }\end{array}$ & Teesside Clay (TSDC) & \\
\hline
\end{tabular}


Table 6.14. Typical geotechnical properties of clays demonstrating Quick Clay behaviour.

\begin{tabular}{|l|l|}
\hline \multicolumn{1}{|c|}{ Geotechnical Parameter } & \multicolumn{1}{c|}{ Data Range } \\
\hline Moisture content & Natural Moisture Content $>$ Liquid Limit \\
\hline Plasticity index & $8-12 \%$ \\
\hline Liquidity index & $>1$ \\
\hline Liquid limit & $<40 \%$ \\
\hline Undisturbed shear strength & $10-25 \mathrm{kPa}$ \\
\hline Remoulded shear strength & $<0.5 \mathrm{kPa}$ \\
\hline Sensitivity & $>30$ \\
\hline Activity & $<0.5$ \\
\hline
\end{tabular}


Table 6.15. Legend description of Brickearth and possible Brickearth-like deposits on various editions of British Geological Survey 1:50 000 scale geological maps of South and South East England: Norfolk, Suffolk, Essex, Surrey, Kent, Hampshire, Sussex, Kent and parts of Bedfordshire, Buckinghamshire, Cambridgeshire, Devon, Hertfordshire and Oxfordshire from which Figs 15b(i) and 15b(ii) were derived.

\begin{tabular}{|c|c|c|}
\hline $\begin{array}{l}\text { 1:50 } 000 \text { scale geological map } \\
\text { sheet name and number }\end{array}$ & $\begin{array}{c}\text { Publication } \\
\text { Date }\end{array}$ & Description \\
\hline \multicolumn{3}{|c|}{ Norfolk and parts of Cambridgeshire, Befordshire and Buckinghamshire } \\
\hline Wells-Next-The-Sea, 130 & 2008 & No Brickearth or similar deposits mapped \\
\hline Cromer, 131 & 2002 & No Brickearth or similar deposits mapped \\
\hline $\begin{array}{l}\text { Mundesley and North } \\
\text { Walsham, } 132 / 148\end{array}$ & 1999 & No Brickearth or similar deposits mapped \\
\hline $\begin{array}{l}\text { Kings Lynn and The Wash, } \\
145 / 129\end{array}$ & 1978 & No Brickearth or similar deposits mapped \\
\hline Fakenham, 146 & 1999 & $\begin{array}{l}\text { "Brickearth": silt and clay. Anglian Lowestoft } \\
\text { Till Formation }\end{array}$ \\
\hline Aylesham, 147 & 2014 & No Brickearth or similar deposits mapped \\
\hline Peterborough, 158 & 1984 & No Brickearth or similar deposits mapped \\
\hline Wisbech, 159 & 1995 & No Brickearth or similar deposits mapped \\
\hline Swaffham, 160 & 1999 & $\begin{array}{l}\text { "Brickearth”: silt and clay. Anglian Lowestoft } \\
\text { Till Formation }\end{array}$ \\
\hline Norwich, 161 & 1975 & $\begin{array}{l}\text { Norwich Brickearth. This deposit is a glacial till } \\
\text { not a loess }\end{array}$ \\
\hline Great Yarmouth, 162 & 1996 & Silt. Anglian Lowestoft Till Formation \\
\hline Ramsey, 172 & 1995 & No Brickearth or similar deposits mapped \\
\hline Ely, 173 & 1980 & No Brickearth or similar deposits mapped \\
\hline Thetford, 174 & 2010 & $\begin{array}{l}\text { Coversand - non-dune formed sand sheets and } \\
\text { dune fields. } \\
\text { Hoxnian Barnham Silt and Clay Member } \\
\text { (probably colluvial in origin, not aeolian - } \\
\text { see Ashton et al. 2005) }\end{array}$ \\
\hline Diss, 175 & 1986 & $\begin{array}{l}\text { Glacial Silt and Clay: silt and clay, commonly } \\
\text { laminated }\end{array}$ \\
\hline Lowestoft, 176 & 1996 & Silt. Anglian Lowestoft Till Formation \\
\hline Huntingdon, 187 & 1975 & No Brickearth or similar deposits mapped \\
\hline Cambridge, 188 & 1981 & Glacial Silt \\
\hline Bury St Edmunds, 189 & 1982 & $\begin{array}{l}\text { Coversand } \\
\text { Glacial Silt }\end{array}$ \\
\hline Eye, 190 & 1995 & No Brickearth or similar deposits mapped \\
\hline Bedford, 203 & 2010 & No Brickearth or similar deposits mapped \\
\hline Biggleswade, 204 & 2001 & No Brickearth or similar deposits mapped \\
\hline Buckingham, 219 & 2002 & No Brickearth or similar deposits mapped \\
\hline Leighton Buzzard, 220 & 1992 & No Brickearth or similar deposits mapped \\
\hline \multicolumn{3}{|c|}{ Suffolk, Essex and parts of Hertfordshire and Oxfordshire } \\
\hline Saxmundham, 191 & 1996 & Silt. Anglian Lowestoft Till Formation \\
\hline Saffron Walden, 205 & 2002 & No Brickearth or similar deposits mapped \\
\hline
\end{tabular}




\begin{tabular}{|c|c|c|}
\hline Sudbury, 206 & 1991 & Glacial Silt \\
\hline Ipswich, 207 & 2006 & Glacial Silt and Clay: silt and clay \\
\hline $\begin{array}{l}\text { Woodbridge \& Felixstowe, } \\
208 / 225\end{array}$ & 2001 & No Brickearth or similar deposits mapped \\
\hline Hitchen, 221 & 1995 & Brickearth - silt and clay \\
\hline Great Dunmow, 222 & 1990 & Glacial SIlt \\
\hline Braintree, 223 & 1982 & Glacial Silt - glacial deposits \\
\hline $\begin{array}{l}\text { Colchester and Brightlingsea, } \\
224 / 242\end{array}$ & 2010 & Head Silt - Post Anglian to Devensian \\
\hline Witney, 236 & 1982 & No Brickearth or similar deposits mapped \\
\hline Thame, 237 & 1994 & No Brickearth or similar deposits mapped \\
\hline Ayelsbury, 238 & $\begin{array}{l}1990 \\
\text { (reprint of } \\
1946 \\
\text { edition) }\end{array}$ & No Brickearth or similar deposits mapped \\
\hline Hertford, 239 & 1978 & $\begin{array}{l}\text { Laminated clay (Brickearth) } \\
\text { Brickearth }\end{array}$ \\
\hline Epping, 240 & 1981 & No Brickearth or similar deposits mapped \\
\hline Chelmsford, 241 & 1975 & $\begin{array}{l}1^{\text {st }} \text { and } 2^{\text {nd }} \text { Terrace Loam } \\
\text { Head Brickearth }\end{array}$ \\
\hline Abingdon, 253 & 1971 & No Brickearth or similar deposits mapped \\
\hline Henley-on-Thames, 254 & 1980 & No Brickearth or similar deposits mapped \\
\hline Beaconsfield, 255 & 2005 & $\begin{array}{l}\text { Langley Silt - 'Brickearth': sandy clay and silt } \\
\text { Enfield Silt - 'Brickearth': sandy clay and silt }\end{array}$ \\
\hline North London, 256 & 2006 & Langley Silt - 'Brickearth': sandy clay and silt \\
\hline Romford, 257 & 1996 & $\begin{array}{l}\text { Roding Silt - 'Brickearth': sandy clay and silt } \\
\text { Ilford Silt - 'Brickearth': sandy clay and silt }\end{array}$ \\
\hline $\begin{array}{l}\text { Southend \& Foulness, } 258 \text { \& } \\
259\end{array}$ & 1976 & $\begin{array}{l}\text { Loam/River Brickeath }-1^{\text {st }} \text { Terrace } \\
\text { Loam/River Brickeath }-2^{\text {nd }} \text { Terrace } \\
\text { Loam/River Brickeath }-3^{\text {rd }} \text { Terrace } \\
\text { Brickearth including Head Brickearth (see } \\
\text { Northmore et al. 1996) }\end{array}$ \\
\hline Newbury, 267 & 2006 & No Brickearth or similar deposits mapped \\
\hline Reading, 268 & 2000 & $\begin{array}{l}\text { Langley Silt - 'Brickearth': sandy clay and silt } \\
\text { Brickearth: clayey and sandy silt }\end{array}$ \\
\hline \multicolumn{3}{|l|}{ Surrey and Kent } \\
\hline Windsor, 269 & 1999 & Langley Silt - 'Brickearth': sandy clay and silt \\
\hline South London, 270 & 1998 & Langley Silt: sandy clay and silt ('Brickearth') \\
\hline Dartford, 271 & 1998 & $\begin{array}{l}\text { Ilford Silt - 'Brickearth': sandy clay and silt } \\
\text { Crayford Silt - 'Brickearth': sandy clay and silt } \\
\text { Dartford Silt - 'Brickearth': sandy clay and silt }\end{array}$ \\
\hline Chatham, 272 & 1977 & $\begin{array}{l}\text { River Brickearth } \\
\text { Head Brickearth }\end{array}$ \\
\hline Faversham, 273 & 1974 & Head Brickearth (see Zourmpakis et al. 2006) \\
\hline Ramsgate, 274 & 1980 & $\begin{array}{l}\text { Head Brickearth (younger) (see Fookes \& Best } \\
\text { 1969) } \\
\text { Head Brickearth (older) }\end{array}$ \\
\hline Guildford, 285 & 2001 & No Brickearth or similar deposits mapped \\
\hline Reigate, 286 & 1978 & Brickearth \\
\hline
\end{tabular}




\begin{tabular}{|c|c|c|}
\hline Sevenoaks, 287 & $\begin{array}{l}1990 \text { (reprint } \\
\text { of } 1971 \\
\text { edition) }\end{array}$ & Brickearth \\
\hline Maidstone, 288 & 1976 & $\begin{array}{l}\text { River Brickearth } \\
\text { Head Brickearth }\end{array}$ \\
\hline Canterbury, 289 & 1982 & Head Brickearth \\
\hline Dover, 290 & 1977 & Head Brickearth \\
\hline Arlesford, 300 & $\begin{array}{l}1975 \\
1999\end{array}$ & No Brickearth or similar deposits mapped \\
\hline Haslemere, 301 & 1981 & No Brickearth or similar deposits mapped \\
\hline Horsham, 302 & 1972 & No Brickearth or similar deposits mapped \\
\hline Tunbridge Wells, 303 & 1971 & No Brickearth or similar deposits mapped \\
\hline Tenterden, 304 & 1981 & River Brickearth \\
\hline $\begin{array}{l}\text { Folkestone and Dover A, } 305 \\
\& 306\end{array}$ & 1974 & Head Brickearth \\
\hline \multicolumn{3}{|c|}{ Hampshire, Sussex and parts of Dorset } \\
\hline Andover, 283 & 2012 & No Brickearth or similar deposits mapped \\
\hline Basingstoke, 284 & 1980 & Loam (River Brickearth) \\
\hline Winchester, 299 & 2002 & No Brickearth or similar deposits mapped \\
\hline Ringwood, 314 & $\begin{array}{l}1976 \text { (reprint } \\
\text { of } 1902 \\
\text { edition) }\end{array}$ & Brickearth \\
\hline Southampton, 315 & 1948 & Brickearth \\
\hline Southampton, 315 & 1987 & $\begin{array}{l}\text { River terrace deposits (mainly loam and clay) } \\
\text { resting on River Terrace Gravels }\end{array}$ \\
\hline Fareham, 316 & 1958 & Brickearth \\
\hline Fareham, 316 & 1998 & $\begin{array}{l}\text { Aeolian deposits ('Brickearth'): mainly fine } \\
\text { sandy silt, locally contaminated with gravel }\end{array}$ \\
\hline Chichester, 317 & 1957 & Brickearth \\
\hline $\begin{array}{l}\text { Chichester and Bognor, } \\
317 / 332\end{array}$ & 1996 & $\begin{array}{l}\text { Aeolian deposits ('Brickearth'): mainly silts, in } \\
\text { part contaminated with gravel }\end{array}$ \\
\hline Brighton, 318 & 1938 & Brickearth \\
\hline $\begin{array}{l}\text { Brighton and Worthing, } \\
318 / 333\end{array}$ & 1984 & Brickearth \\
\hline $\begin{array}{l}\text { Lewes and Eastbourne, } \\
\text { 319/334 }\end{array}$ & 2006 & No Brickearth or similar deposits mapped \\
\hline $\begin{array}{l}\text { Hastings and Dungeness, } \\
320 / 321\end{array}$ & 1980 & No Brickearth or similar deposits mapped \\
\hline Bournmouth, 329 & 1895 & Brickearth \\
\hline Bournmouth, 329 & 1991 & $\begin{array}{l}\text { River terrace deposits (mainly loam and clay) } \\
\text { resting on River Terrace Gravels }\end{array}$ \\
\hline Lymington, 330 & 1975 & Brickearth \\
\hline Portsmouth, 331 & 1964 & Brickearth \\
\hline Portsmouth, 331 & 1994 & $\begin{array}{l}\text { River terrace and aeolian deposits ('Brickearth'): } \\
\text { mainly sandy silt, locally contaminated with } \\
\text { gravel }\end{array}$ \\
\hline Isle of Wight Special Sheet & 1976 & Brickearth of the Plateau \\
\hline Isle of Wight Special Sheet & 2013 & No Brickearth or similar deposits mapped \\
\hline
\end{tabular}




\section{Devon}

Newton Abbot, 339

Torquay, 350

1976

Loam

\begin{tabular}{l|l}
2004 & No Brickearth or similar deposits mapped
\end{tabular} 
Table 6.16. Summarised geotechnical index properties of loess from various locations worldwide (from Bell 2000).

\begin{tabular}{|l|l|}
\hline \multicolumn{1}{|c|}{ Geotechnical Index Property } & \multicolumn{1}{c|}{ Range of Values } \\
\hline Particle size & \\
\hline Sand & $3-38 \%$ \\
\hline Silt & $50-90 \%$ \\
\hline Clay & $8-24 \%$ \\
\hline Moisture content & $12-26 \%$ \\
\hline Plastic limit* & $10-23 \%$ \\
\hline Liquid limit* & $26-46 \%$ \\
\hline Plasticity index* & $8-28 \%$ \\
\hline Specific gravity & $2.57-2.79$ \\
\hline Dry density & $1.15-1.75 \mathrm{Mg} \mathrm{m}^{-3}$ \\
\hline Bulk density & $1.4-2.1 \mathrm{Mg} \mathrm{m}^{-3}$ \\
\hline Void ratio & $0.55-1.11$ \\
\hline Porosity & $35-50 \%$ \\
\hline
\end{tabular}

*includes additional data from Assallay (1998) 
Table 6.17. Methods of treating collapsible loess ground (after Jefferson et al. 2005).

\begin{tabular}{|c|c|c|}
\hline Depth (m) & Treatment method & Comments \\
\hline \multirow[t]{3}{*}{$0-1.5$} & $\begin{array}{l}\text { Surface compaction with } \\
\text { vibratory rollers, light tampers }\end{array}$ & $\begin{array}{l}\text { Economical but requires careful } \\
\text { site control, for example, limits } \\
\text { on water content. }\end{array}$ \\
\hline & Pre-wetting (inundation) & $\begin{array}{l}\text { Can effectively treat thicker } \\
\text { deposits but needs large } \\
\text { volumes of water and time. }\end{array}$ \\
\hline & Vibrofloatation & Needs careful site control. \\
\hline \multirow[t]{9}{*}{$1.5-10$} & $\begin{array}{l}\text { Vibrocompaction (stone } \\
\text { columns, concrete columns, } \\
\text { encased stone columns). }\end{array}$ & $\begin{array}{l}\text { Cheaper than conventional piles } \\
\text { but requires careful site control } \\
\text { and assessment. If uncased, } \\
\text { stone columns may fail with } \\
\text { loss of lateral support on } \\
\text { collapse. }\end{array}$ \\
\hline & $\begin{array}{l}\text { Dynamic compaction; } \\
\text { rapid impact compaction }\end{array}$ & $\begin{array}{l}\text { Simple and easily understood } \\
\text { but requires care with water } \\
\text { content and vibrations } \\
\text { produced. }\end{array}$ \\
\hline & Explosions & $\begin{array}{l}\text { Safety issues need to be } \\
\text { addressed. }\end{array}$ \\
\hline & Compaction pile & Need careful site control. \\
\hline & Grouting & $\begin{array}{l}\text { Flexible but may adversely } \\
\text { affect the environment. }\end{array}$ \\
\hline & Ponding/inundation/pre-wetting & $\begin{array}{llr}\text { Difficult } & \text { to } & \text { control } \\
\text { effectiveness } & \text { of } & \text { compression } \\
\text { produced. } & & \end{array}$ \\
\hline & Soil mixing lime/cement & $\begin{array}{l}\text { Convenient and gains strength } \\
\text { with time. } \\
\text { environmental and safety } \\
\text { aspects; the chemical controls } \\
\text { on reactions need to be } \\
\text { assessed. }\end{array}$ \\
\hline & Heat treatment & Expensive. \\
\hline & Chemical methods & Flexible; relatively expensive. \\
\hline \multirow[t]{2}{*}{$>10$} & $\begin{array}{l}\text { As for } 1.5-10 \mathrm{~m} \text {, some } \\
\text { techniques may have a limited } \\
\text { effect. }\end{array}$ & (see above) \\
\hline & Pile foundations & $\begin{array}{l}\text { High bearing capacity but } \\
\text { expensive. }\end{array}$ \\
\hline
\end{tabular}


Table 6.18. Diagnostic criteria for pingo scars.

\begin{tabular}{|l|l|}
\hline \multicolumn{1}{|c|}{ De Gans (1988) } & \multicolumn{1}{c|}{ Mackay (1988) } \\
\hline $\begin{array}{l}\text { Minimum depth of depression } 1.5 \mathrm{~m} \text { and } \\
\text { diameter } 25 \mathrm{~m} \text {. }\end{array}$ & $\begin{array}{l}\text { The volume of the rampart should approximate } \\
\text { to that of the depression. }\end{array}$ \\
\hline $\begin{array}{l}\text { Base of the depression lies below the } \\
\text { level of the surrounding ground and is } \\
\text { floored by sediment of sufficient } \\
\text { permeability to allow migration of } \\
\text { groundwater. }\end{array}$ & $\begin{array}{l}\text { Presence of peripheral deposits associated with } \\
\text { mass wasting, stream deposition and debris } \\
\text { flow. }\end{array}$ \\
\hline $\begin{array}{l}\text { At least part of the rampart is present, and } \\
\text { contains sediment derived from the } \\
\text { depression often as outward dipping } \\
\text { strata. }\end{array}$ & Casts of dilation crack ice across the ramparts. \\
\hline $\begin{array}{l}\text { Pingo scars on flat ground or slopes up to } \\
5^{0} \text {. }\end{array}$ & $\begin{array}{l}\text { The presence of peripheral normal faults in } \\
\text { ramparts. }\end{array}$ \\
\hline $\begin{array}{l}\text { Accompanied by other permafrost } \\
\text { phenomena. }\end{array}$ & \\
\hline
\end{tabular}


Table 6.19. Some British examples of relict cryogenic mounds.

\begin{tabular}{|c|c|c|c|}
\hline Locality & Description & Interpretation & References \\
\hline $\begin{array}{l}\text { West of London: } \\
\text { Thorney }\end{array}$ & $\begin{array}{l}32 \mathrm{~m} \text { of London } \\
\text { Clay pinched out by } \\
\text { a palaeochannel. }\end{array}$ & Artesian dome & $\begin{array}{l}\text { Ballantyne \& Harris } \\
\text { (1994) }\end{array}$ \\
\hline $\begin{array}{l}\text { Newbury, } \\
\text { Berkshire }\end{array}$ & $\begin{array}{l}\text { Alluvium filled } \\
\text { hollow. }\end{array}$ & Valley bulging & Hawkins (1952) \\
\hline $\begin{array}{l}\text { River Wey, } \\
\text { southern valley } \\
\text { side, near } \\
\text { Elstead, Surrey }\end{array}$ & $\begin{array}{l}100 \text { m long, } 60 \mathrm{~m} \\
\text { wide, } 3.5 \mathrm{~m} \text { deep. } \\
\text { Uncemented, well- } \\
\text { sorted Cretaceous } \\
\text { Greensands. }\end{array}$ & $\begin{array}{l}\text { Dimlington (26-13 ka } \\
\text { BP), spring line, open, } \\
\text { hydraulic }\end{array}$ & $\begin{array}{l}\text { Carpenter \& Woodcock } \\
\text { (1981) }\end{array}$ \\
\hline $\begin{array}{l}\text { Walton } \\
\text { Common, } \\
\text { Cambridgeshire }\end{array}$ & $\begin{array}{l}10-120 \mathrm{~m} \\
\text { diameter, } 3 \text { m deep, } \\
\text { in clusters. Driftless } \\
\text { areas of low-lying } \\
\text { chalk. }\end{array}$ & $\begin{array}{l}\text { Older Dimlington and } \\
\text { fresher Loch Lomond } \\
\text { Stadial (11-10 ka BP). } \\
\text { Foot slope, chalk } \\
\text { groundwater seepage. } \\
\text { Shallow discontinuous } \\
\text { permafrost. }\end{array}$ & Sparks et al. (1972) \\
\hline $\begin{array}{l}\text { River Wissey } \\
\text { valley, Wretton, } \\
\text { Norfolk }\end{array}$ & $\begin{array}{l}\text { Peat filled } \\
\text { depressions, 5-10 m } \\
\text { wide and } 3 \mathrm{~m} \text { deep. }\end{array}$ & $\begin{array}{l}\text { Devensian sands and } \\
\text { gravels. Seasonal/ } \\
\text { short-lived ground ice } \\
\text { mounds formed by } \\
\text { segregation ice in the } \\
\text { finer grained channel } \\
\text { fill deposits. }\end{array}$ & West et al. (1974) \\
\hline $\begin{array}{l}\text { Whicham Valley, } \\
\text { Cumbria }\end{array}$ & $\begin{array}{l}\text { Infill gyttja, overlain } \\
\text { by peat, dumped } \\
\text { material and mineral } \\
\text { soil. }\end{array}$ & $\begin{array}{l}\text { Sand and gravel domed } \\
\text { up within lake } \\
\text { lacustrine clays. } \\
\text { Hydraulic pingo scars. }\end{array}$ & Bryant et al. (1987) \\
\hline $\begin{array}{l}\text { Brent Tor, } \\
\text { Dartmoor }\end{array}$ & $\begin{array}{l}\text { Circular rims up to } \\
43 \mathrm{~m} \text { (one elongate } \\
\text { basin up to } 60 \mathrm{~m} \text { ), } \\
\text { up to } 1 \mathrm{~m} \text { deep. }\end{array}$ & $\begin{array}{l}\text { Hollows infilled with } \\
\text { basal clay overlain by } \\
\text { clay and silt. Suspected } \\
\text { mineral palsas. }\end{array}$ & $\begin{array}{l}\text { Ballantyne \& Harris } \\
\text { (1994) }\end{array}$ \\
\hline $\begin{array}{l}\text { Southwest Wales, } \\
\text { valleys of the } \\
\text { Rivers Cledlyn } \\
\text { and Cletwr. }\end{array}$ & $\begin{array}{l}\text { Cledlyn Valley } \\
\text { external diameter } 60 \\
-180 \mathrm{~m} \text {, long axis } \\
\text { of elongate features } \\
\text { up to } 250 \mathrm{~m} \text {. } \\
\text { Ramparts up to } 5 \mathrm{~m} \\
\text { high. Infill } 3.35 \mathrm{~m} \\
\text { peat on > } 6.9 \mathrm{~m} \\
\text { clayey silt. Cletwr } \\
\text { Valley; more marked } \\
\text { elongation. } \\
\text { Superimposition. }\end{array}$ & $\begin{array}{l}\text { On gentle slopes near } \\
\text { circular, on steeper } \\
\text { ground horseshoe } \\
\text { shape with upper part } \\
\text { of rampart missing. On } \\
\text { poorly sorted } \\
\text { diamicton. Hydraulic } \\
\text { pingos? Pissart and } \\
\text { Gangloff suggest } \\
\text { mineral palsas, because } \\
\text { high permeability soil. } \\
\text { Discontinuous } \\
\text { permafrost Late } \\
\text { Devensian - Loch } \\
\text { Lomond Stadial. } \\
\text { Ross (2006) suggests } \\
\text { meltout of stagnating }\end{array}$ & $\begin{array}{l}\text { Watson (1971, 1972, 1976, } \\
\text { 1977); Watson \& Watson } \\
\text { (1972, 1974); Pissart \& } \\
\text { Gangloff (1984); Ross } \\
\text { (2006) }\end{array}$ \\
\hline
\end{tabular}




\begin{tabular}{|c|c|c|c|}
\hline & & glacier ice. & \\
\hline $\begin{array}{l}\text { South Wales, } \\
\text { Gwili Valley }\end{array}$ & $\begin{array}{l}\text { Six circular } \\
\text { ramparted } \\
\text { depressions (up to } 2 \\
\text { m) at } 125-140 \mathrm{~m} \\
\text { OD. Peat/clay filled } \\
\text { and up to } 45 \mathrm{~m} \text { in } \\
\text { diameter. Some are } \\
\text { interlocking. }\end{array}$ & $\begin{array}{l}\text { Glaciolacustrine } \\
\text { sediments providing } \\
\text { the context for either } \\
\text { ground-ice mounds or } \\
\text { in-situ meltout of } \\
\text { blocks of glacier ice } \\
\text { ground in the } \\
\text { sediments. The } \\
\text { lithology and } \\
\text { geomorphology } \\
\text { favours the former }\end{array}$ & Ross et al. (2011) \\
\hline $\begin{array}{l}\text { River, Wye, } \\
\text { Hertfordshire } \\
\text { (Letton) }\end{array}$ & $\begin{array}{l}\text { Thirty-two } \\
\text { depresssions of } 10 \\
\text { to } 55 \mathrm{~m} \text { diameter } \\
\text { and } 0.2 \text { to } 0.8 \mathrm{~m} \\
\text { depth; some are } \\
\text { occupied by } \\
\text { perennial ponds. No } \\
\text { ramparts. }\end{array}$ & $\begin{array}{l}\text { Above the floodplain } \\
\text { of the river, underlain } \\
\text { by glaciolacustrine } \\
\text { deposits. Geophysical } \\
\text { evidence supports the } \\
\text { hypothesis that these } \\
\text { are kettle holes } \\
\text { (melting of ice blocks, } \\
\text { which had been } \\
\text { discharged into shallow } \\
\text { lakes) }\end{array}$ & Gurney et al. (2010) \\
\hline $\begin{array}{l}\text { Ballaugh, Isle of } \\
\text { Man }\end{array}$ & $\begin{array}{l}\text { Up to } 140 \mathrm{~m} \\
\text { diameter }\end{array}$ & $\begin{array}{l}\text { Overlie gravels, gently } \\
\text { sloping surface of an } \\
\text { alluvial fan. }\end{array}$ & Watson (1971) \\
\hline $\begin{array}{l}\text { West of } \\
\text { Anglesey, } \\
\text { offshore. }\end{array}$ & Large scale & Possibly hydrostatic & Wingfield (1987) \\
\hline $\begin{array}{l}\text { Northern North } \\
\text { Sea }\end{array}$ & Large scale & Possibly hydrostatic & Long (1991) \\
\hline
\end{tabular}


Table 6.20. Engineering geological characteristics of cryogenic mounds.

\begin{tabular}{|c|c|}
\hline $\begin{array}{l}\text { Engineering geological } \\
\text { characteristics }\end{array}$ & Implications for geotechnical characterisation \\
\hline $\begin{array}{l}\text { Unconsolidated, organic } \\
\text { sediments in the core of } \\
\text { depression }\end{array}$ & $\begin{array}{l}\text { These sediments have a low strength and high consolidation } \\
\text { characteristics. Their extent needs defining to facilitate } \\
\text { engineering design. These sediments may be of sedimentological } \\
\text { value (for dating). Underlying soils are likely to be softened as a } \\
\text { consequence of the poor drainage of these features. }\end{array}$ \\
\hline Bedrock disturbance & $\begin{array}{l}\text { Ground disturbance associated with the formational processes } \\
\text { results in: intraformational loss of structure and associated } \\
\text { variation in density; shear surfaces; changes (usually an increase) } \\
\text { in material permeability due to the loss of structure; change } \\
\text { (decrease) in strength; increased compressibility, and increased } \\
\text { variability in geotechnical properties. In addition to the } \\
\text { intraformational disturbance there is evidence of diapirism and } \\
\text { downward movement of sediment in the features that have been } \\
\text { interpreted as hydraulic; this results in considerable variation in } \\
\text { the geotechnical properties within the "root" of the feature. }\end{array}$ \\
\hline $\begin{array}{l}\text { Complexities in the } \\
\text { hydrogeology }\end{array}$ & $\begin{array}{l}\text { Hydrogeological responses vary with the type of cryogenic } \\
\text { mound. Alluvial soils are associated with high standing water } \\
\text { levels, which may be perched above the regional groundwater } \\
\text { table. Hydraulic pingos may be associated both with perched } \\
\text { water tables and preferential flow paths for groundwater. } \\
\text { Consequently, they may form contaminant pathways. The } \\
\text { potential for significant changes in moisture content resulting } \\
\text { from the development of zones of enhanced permeability } \\
\text { (drainage flow paths) has significant implications for shrink-swell } \\
\text { behaviour. }\end{array}$ \\
\hline Rampart fractures & $\begin{array}{l}\text { By virtue of the mode of their formation rampart materials are } \\
\text { also likely to comprise materials that have undergone disturbance } \\
\text { of their depositional structure, which may be associated with } \\
\text { shear surfaces and enhanced variability of geotechnical } \\
\text { properties. }\end{array}$ \\
\hline
\end{tabular}




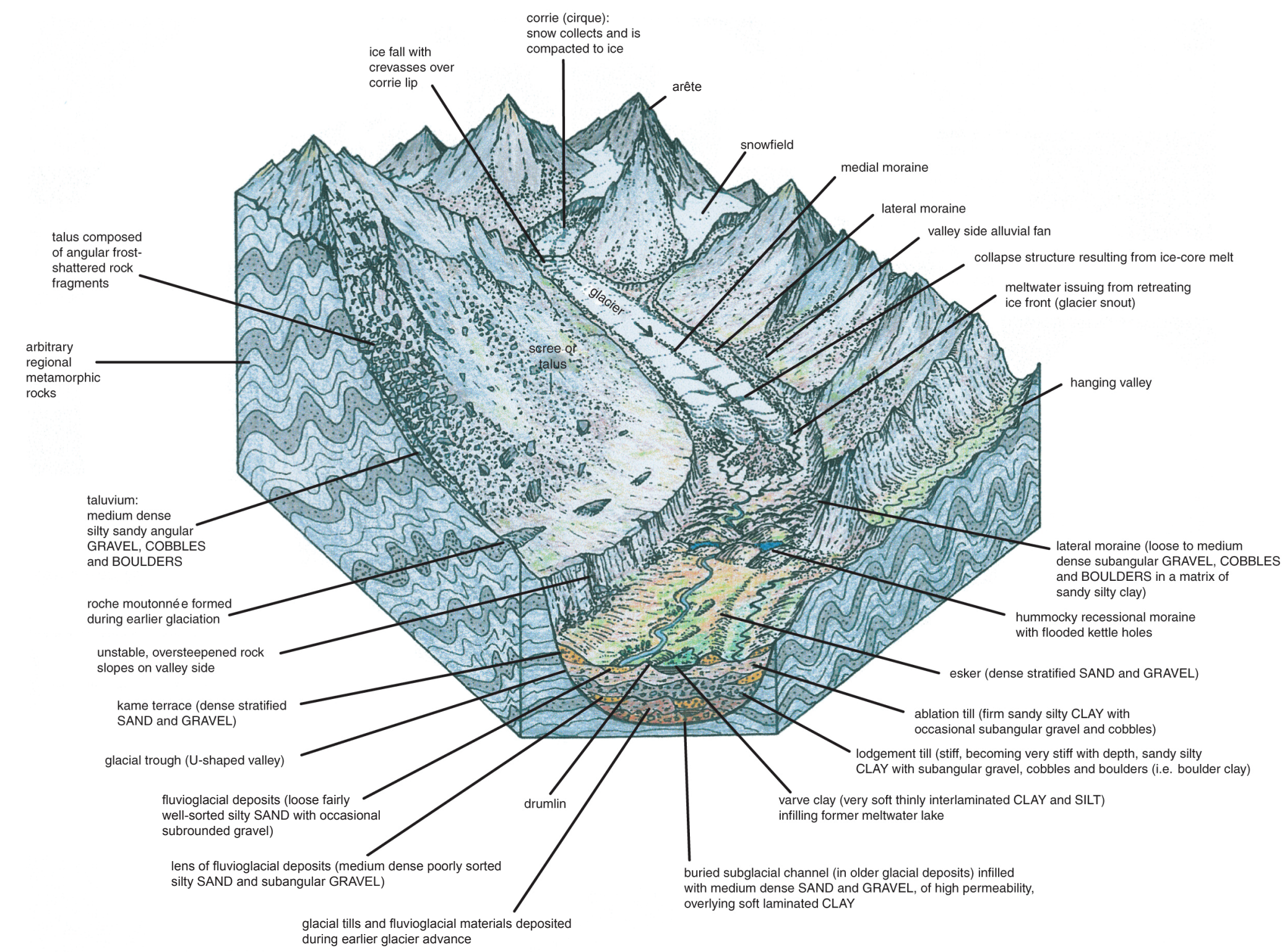




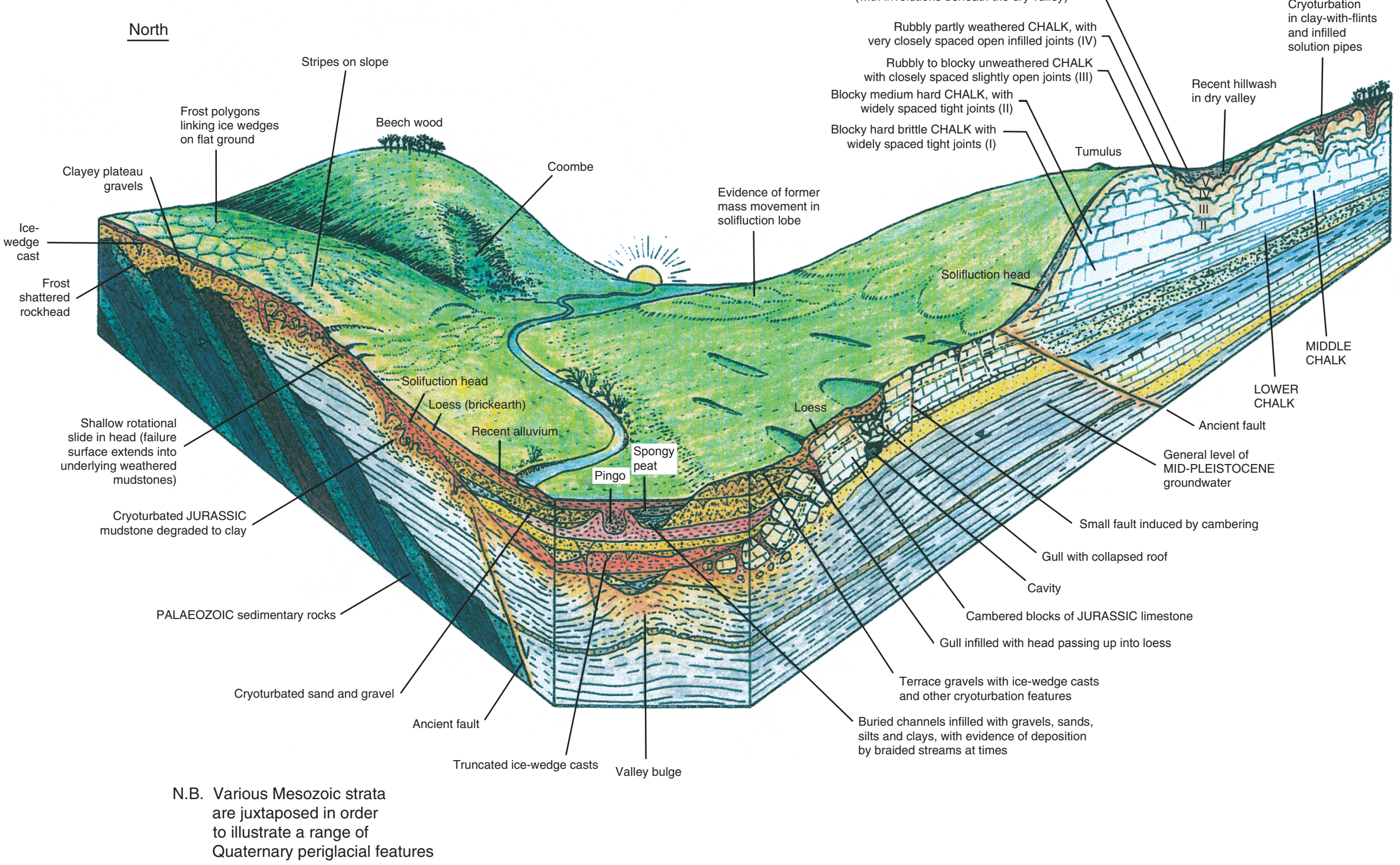



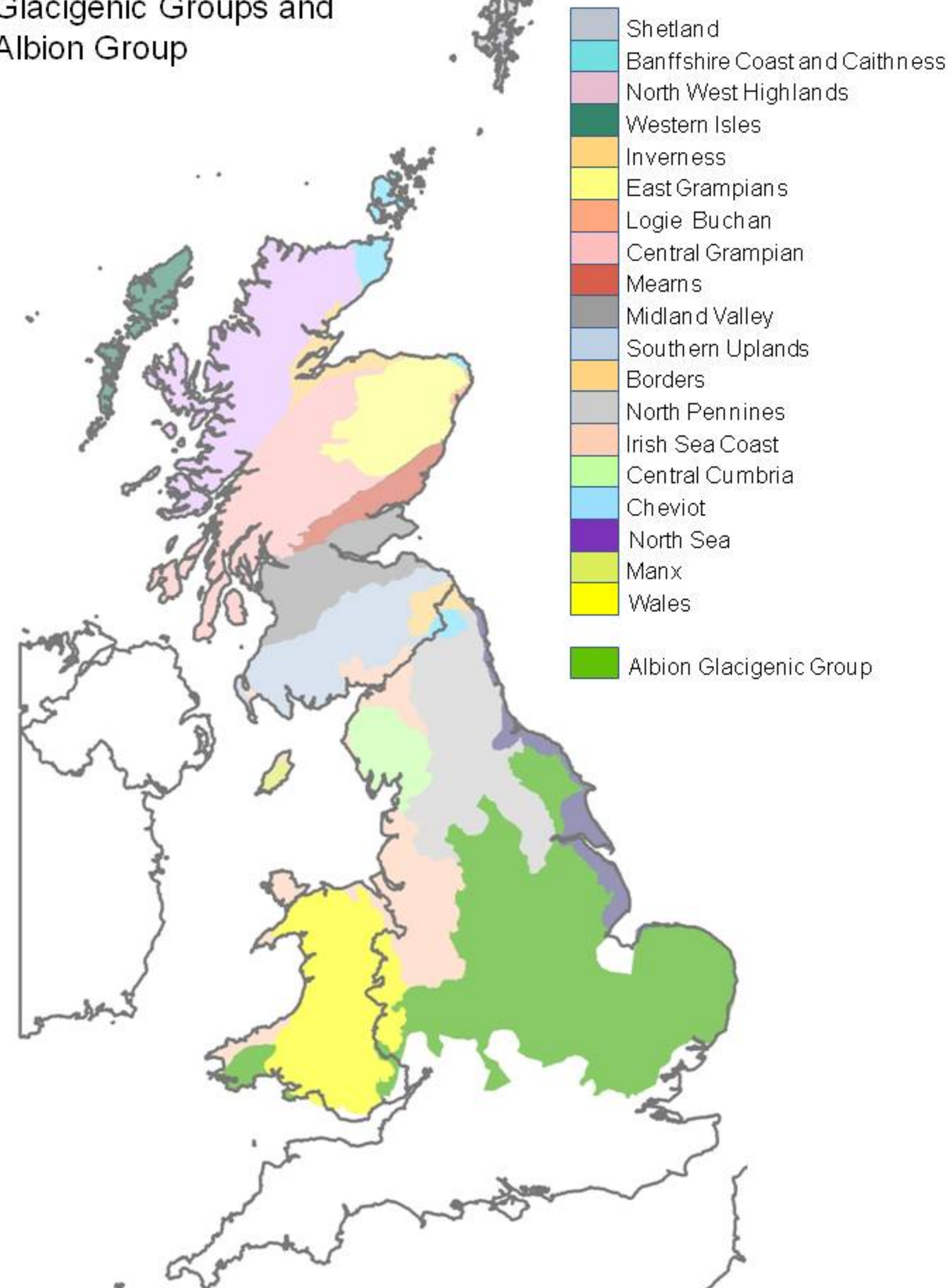
Shetland

Banffshire Coast and Caithness

Northwest Highland

Western Isles

Inverness

East Grampian

Logie Buchan

Central Grampian

Mearns

Midland Valley

Southern Uplands

Borders

North Pennine

Irish Sea Coast

Central Cumbria

Cheviot

North Sea Coast

Manx

Wales

Albion Group

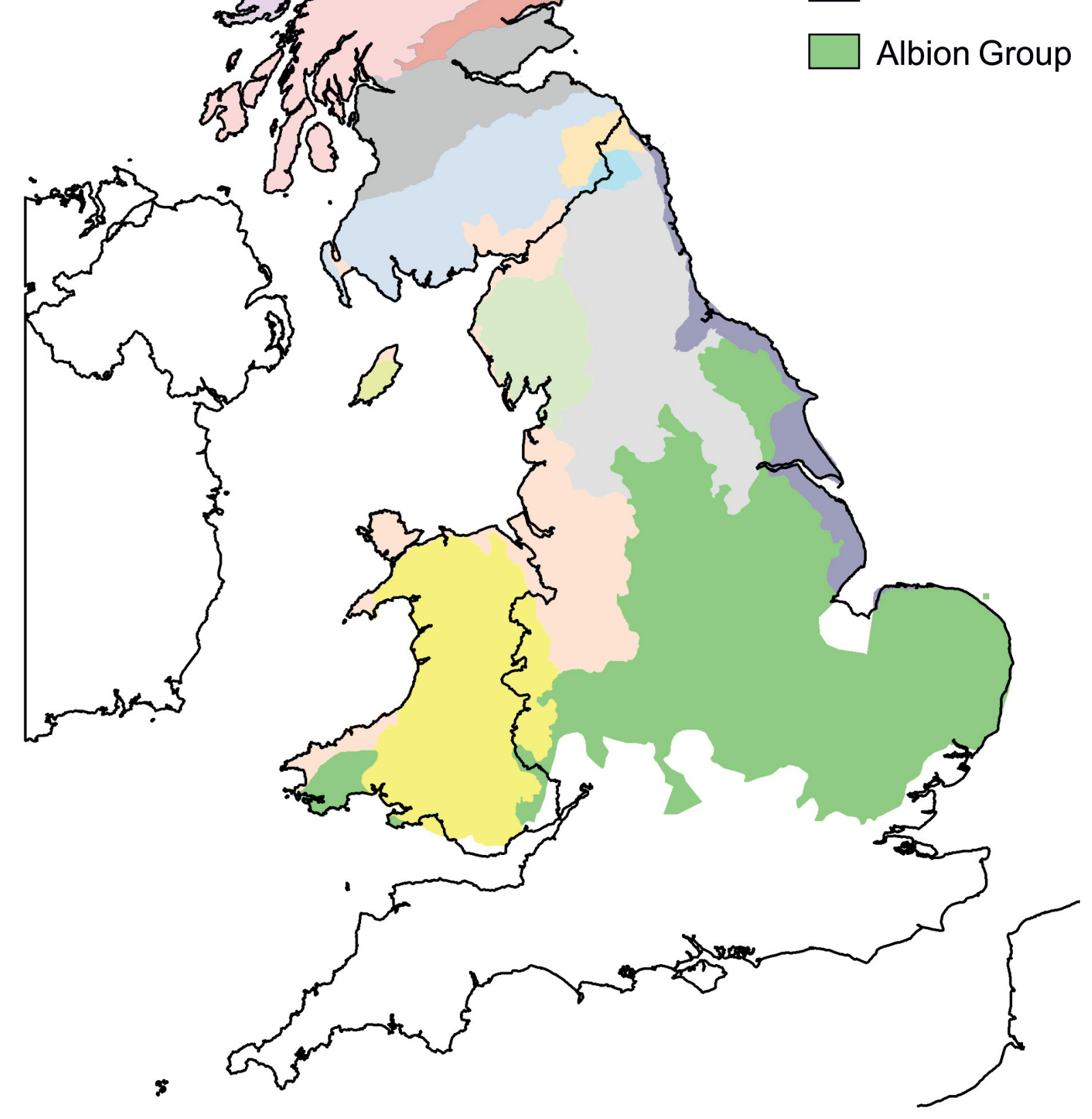


SHETLAND

1 Burrier Wick Mb BANFFSHIRE COAST AND CAITHNESS

2 Reisgill Burn Till Fm

3 Essie Till Formation

NORTHWEST HIGHLANDS

4 Thormaid Till Mb

5 Assynt Till Fm

WESTERN ISLES

6 Port Beag Till Fm

7 Lewis Till Fm
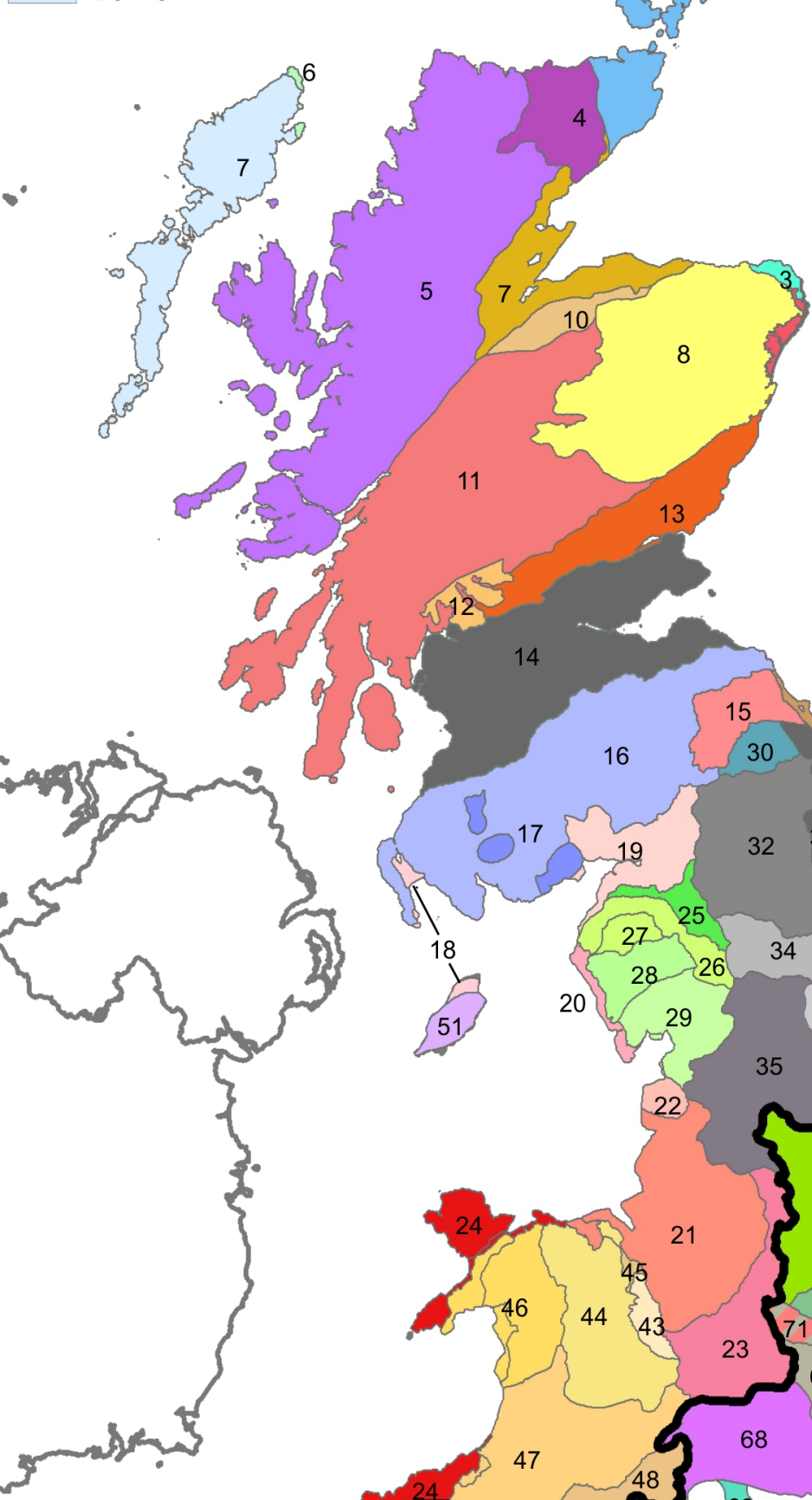

18

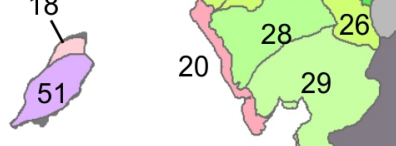

20

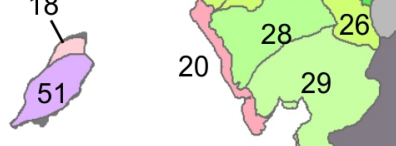

INVER

7 Finglack Till Fm

EAST GRAMPIAN

。

1 . 8 Banchory Till Fm

LOGIE-BUCHAN

9 Hatton Till Fm

CENTRAL GRAMPIAN

10 Beinn an Uain Till Fm

11 Ardverikie Till Fm

12 Gartocharn Till Fm MEARNS

13 Mill of Forest Till Fm

MIDLAND VALLEY

14 Wilderness Till Fm

BORDERS

15 Norham Till Fm

SOUTHERN UPLANDS

16 Langholm Till Fm

17 New Abbey Till Mb

IRISH SEA

18 Jurby Fm

19 Gretna Till Fm

20 Gosforth Glacigenic Fm

21 Stockport Glacigenic Fm

22 Kirkham Till Member

23 Brewood Till Fm

24 Lleyn Till Mb

CENTRAL CUMBRIA

25 Edenside Till Mb

26 Greystoke Till Fm

27 Threlkeld Till Fm

28 Blengdale Glacigenic Fm

29 Kendal Till Mb

CHEVIOT

30 Kale Water Till Fm
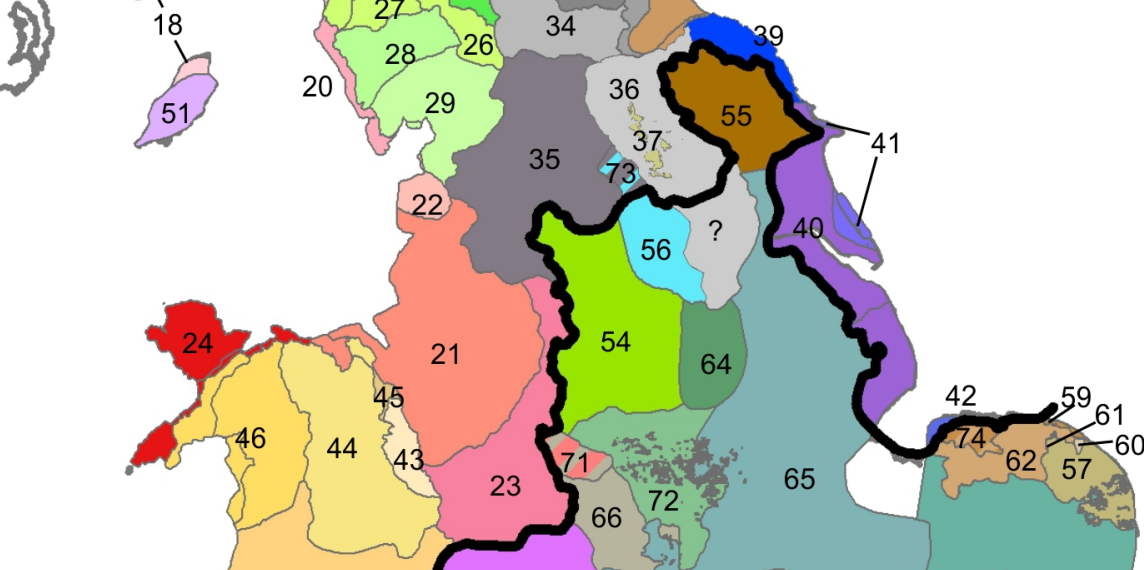

58

NORTH PENNINE

31 Acklinton Till Fm

32 Wear Till Fm

33 Butterby Till Mb

34 Stainmore Forest Till Fm

35 Yorkshire Dales Till Fm

36 Vale of York Fm

37 Vale of York Fm

(sandy facies)

NORTH SEA

38 Horden Till Fm

39 Holderness Fm

40 Skipsea Till Mb

41 Withernsea Till Mb

42 Holkham Till Mb

WALES GLACIGENIC

SUBGROUP

43 Shrewsbury Glacigenic Fm

44 Merion Till Mb

45 Ruabon Till Mb

46 Eryri Glacigenic Fm

47 Elenid Till Mb

48 Hereford Till Mb

49 Langland Till Mb

50 Glamorgan Glacigenic Fm

MANX

51 Snaefell Formation

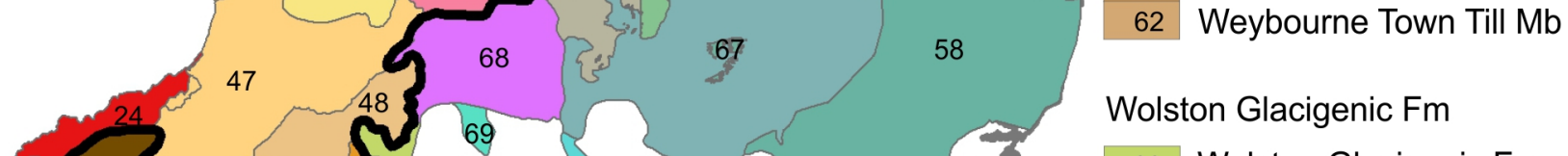

63 Wolston Glacigenic Fm

64 Wolston Glacigenic Fm (sand)

65 Oadby Till Mb

66 Thrussington Till Mb

67 Bozeat Till Mb

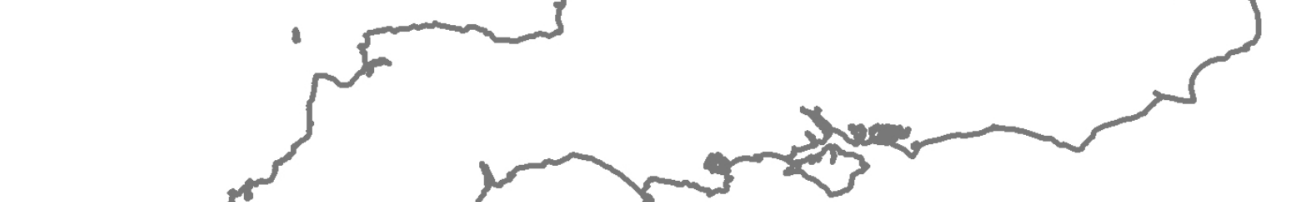

68 Nurseries Glacigenic Fm

69 Coddington Till Fm

70 Moreton Mb

\section{Mixed domains}

71 Brewood Till Fm or Thrussington Till Mb

72 Oadby Till $\mathrm{Mb}$ and Thrussington Till Mb

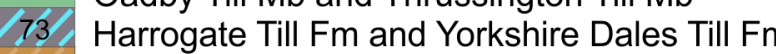

74. Runton Till Mb and Weybourne Town Till Mb 

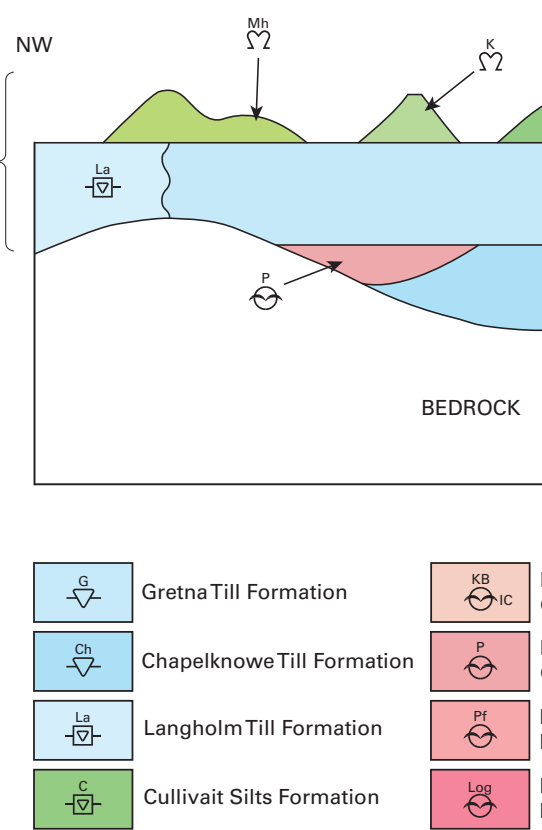

Kilbane Sand and

Gravel Formation

Plumpe Sand and

Gravel Formation

Plumpe Farm Sand

Member

Loganhouse Gravel

Member

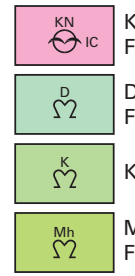

Kirkbean Sand and Gravel

Formation

Dalswinton Moraine

Formation

The Gretna Till Formation $(\overbrace{}^{\mathrm{G}}$ ) is generally undivided from the Chapelknowe Till Formation ( $(-\nabla^{\mathrm{Ch}}$ ) except where deposits of the Plumpe Sand and Gravel Formation ( $\overbrace{}^{\mathrm{P}}$ ) are identified. The Plumpe Sand and Gravel Formation may be subdivided locally into the Plumpe Farm Sand Member ( $\overbrace{}^{\text {pf }})$ and Loganhouse Gravel Member ( $\overbrace{}^{\text {Log }})$. 


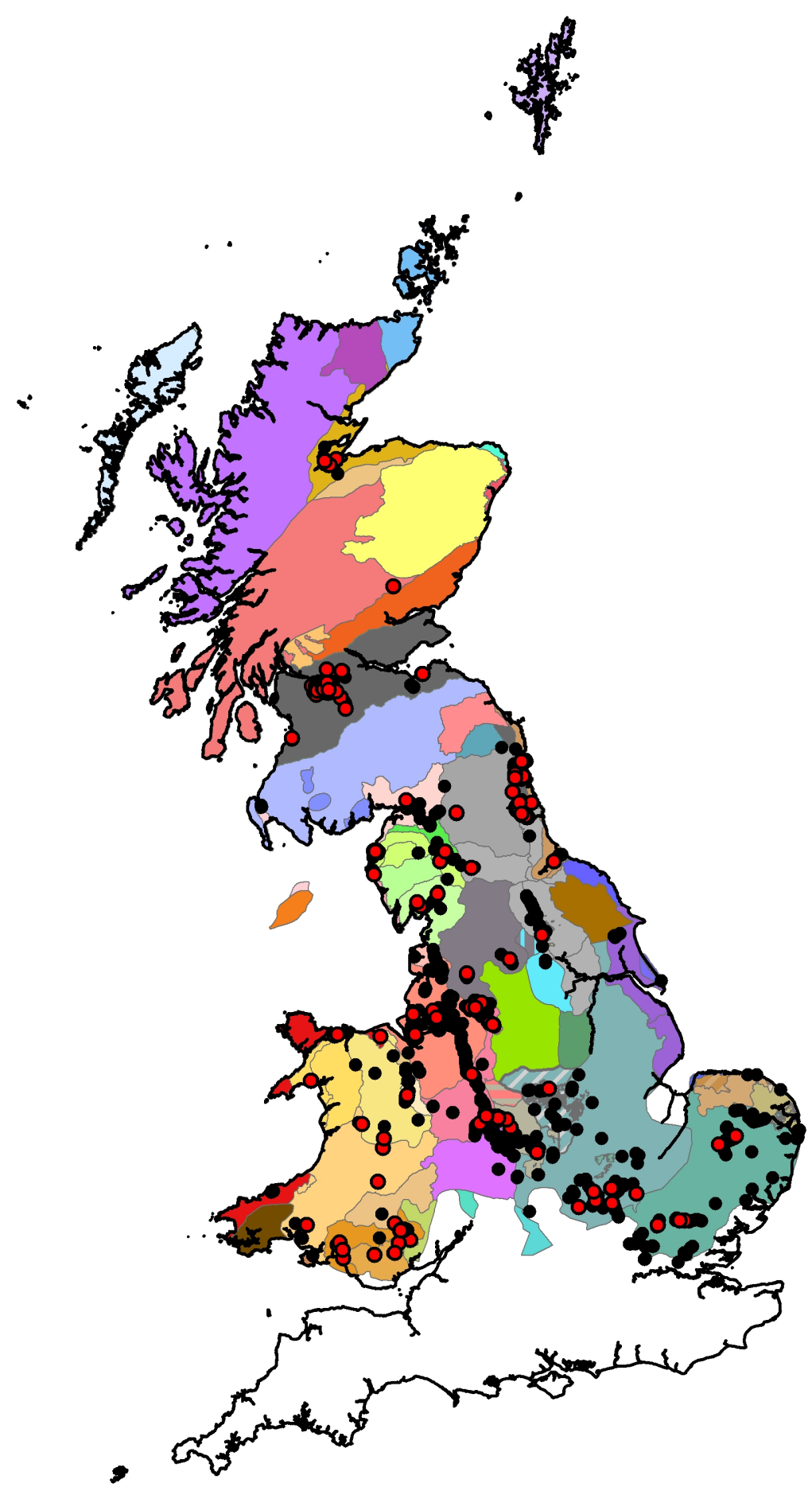




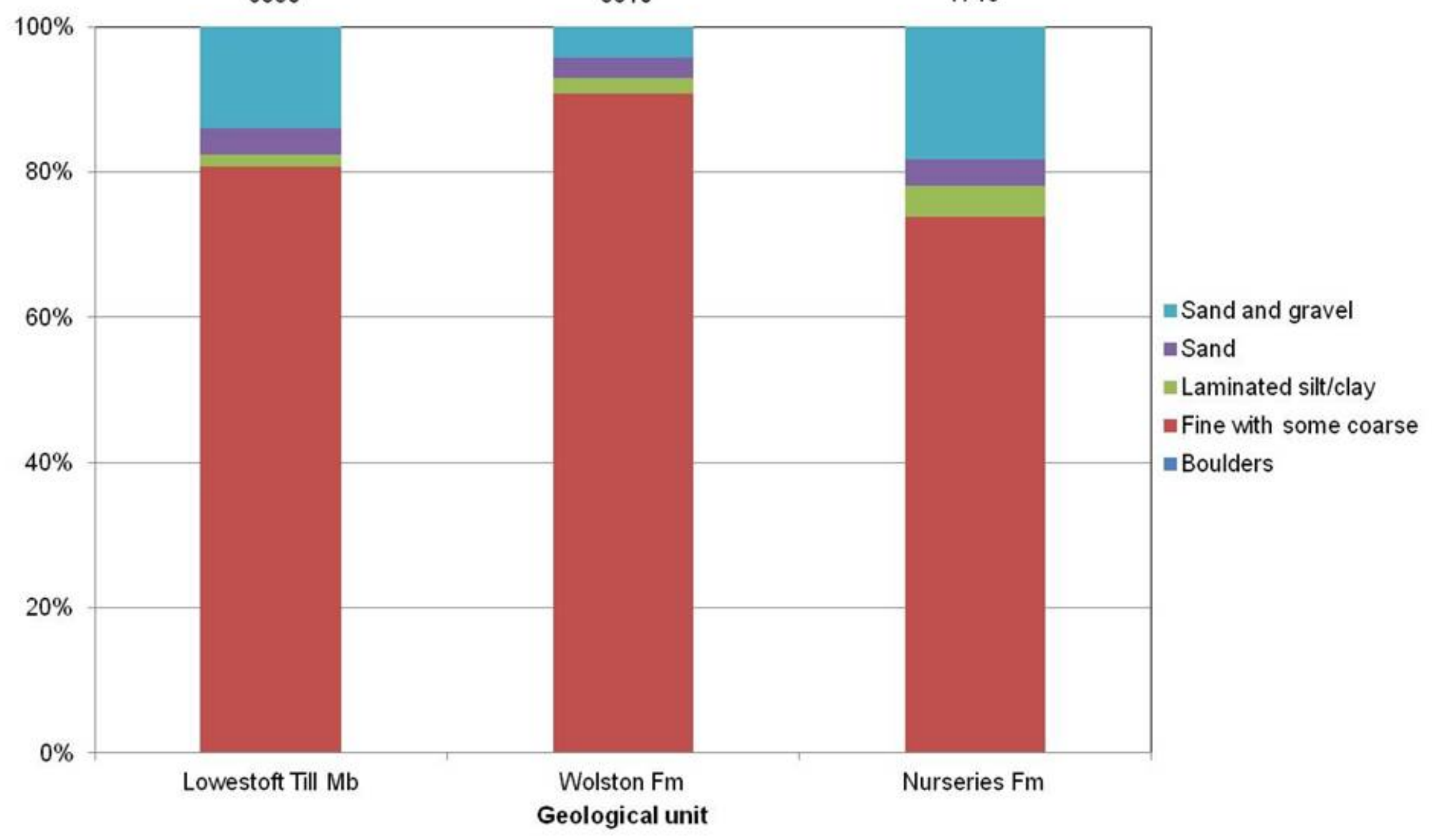




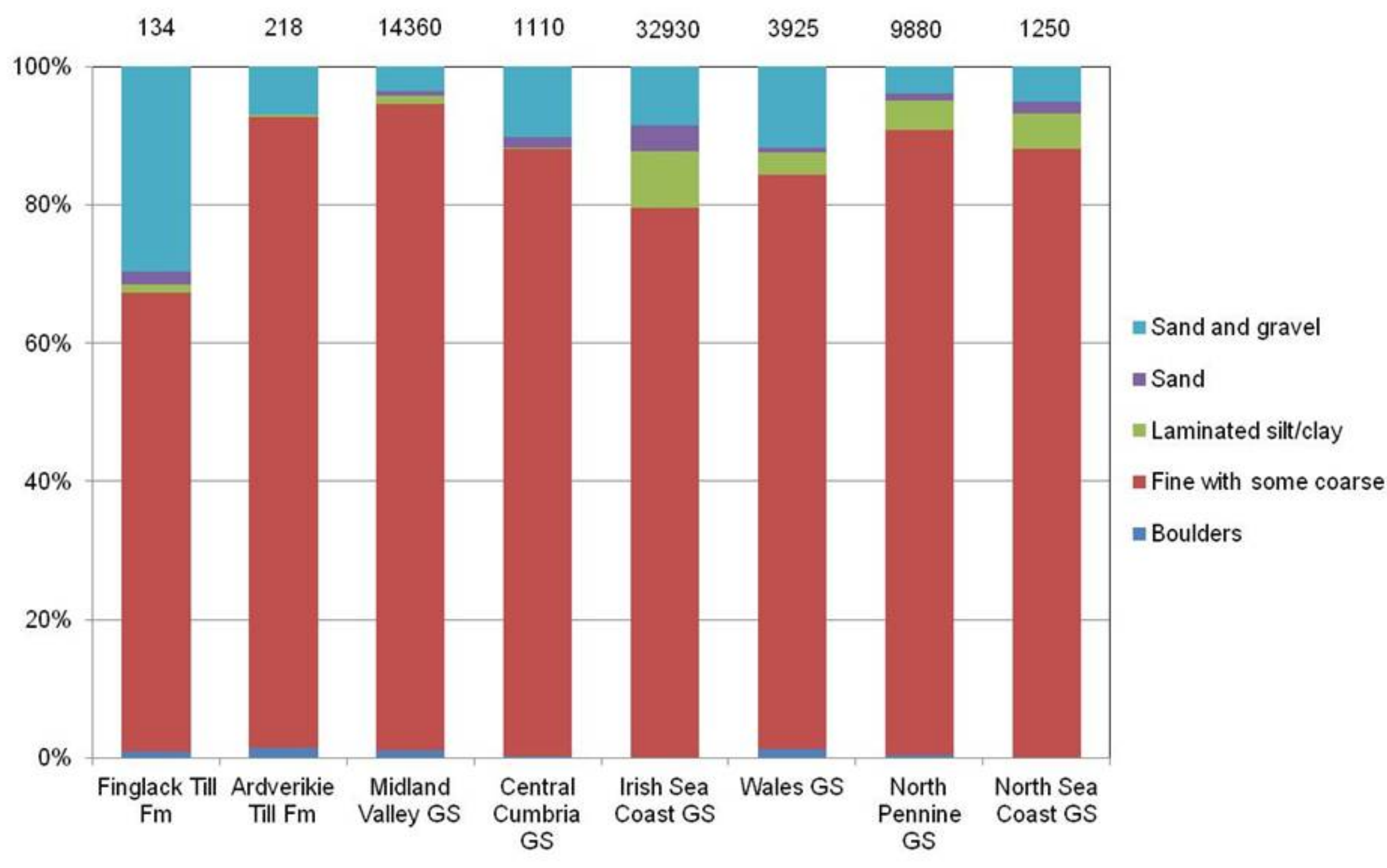




\section{1 samples}

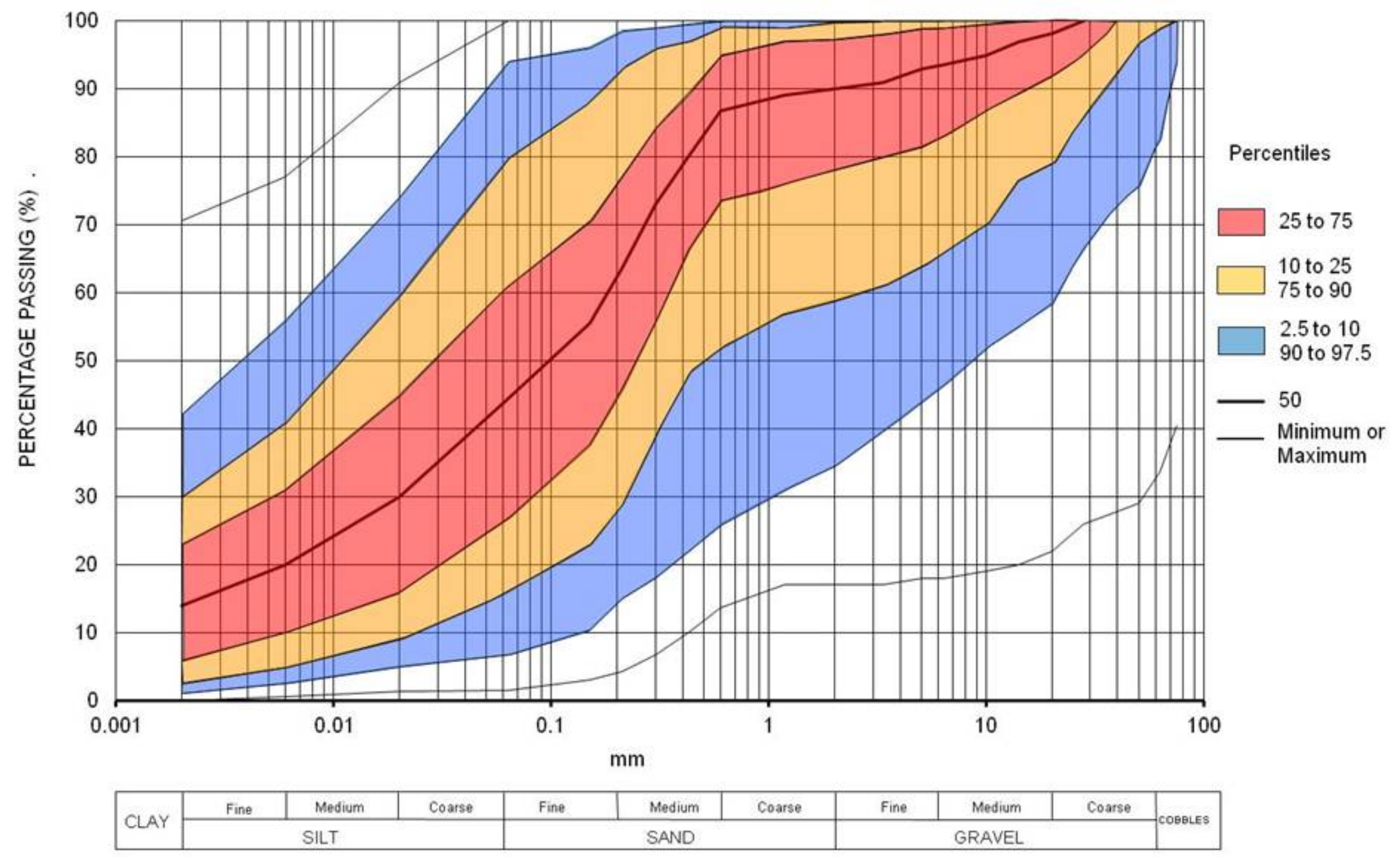




\section{3 samples}

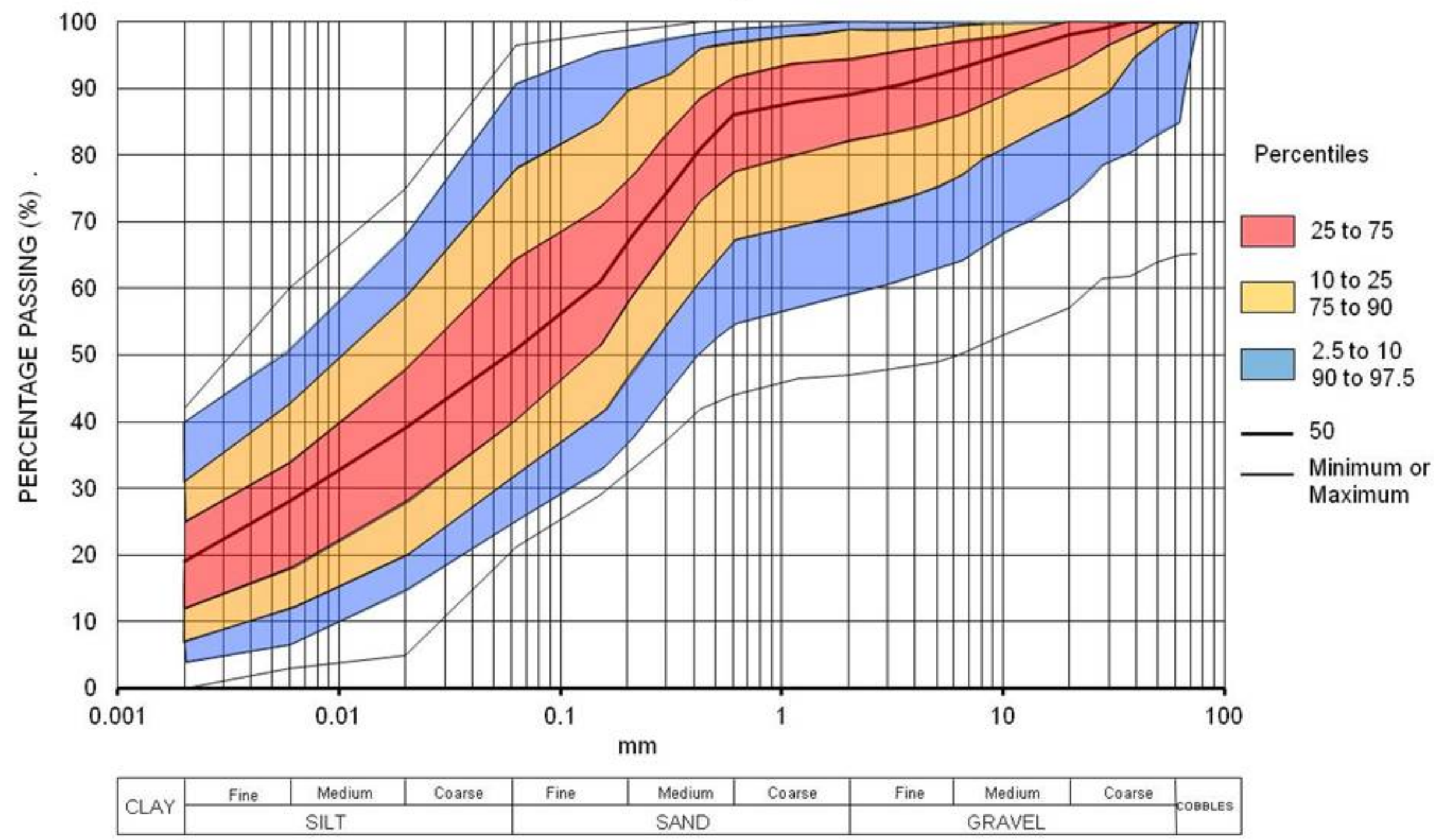




\section{2 samples}

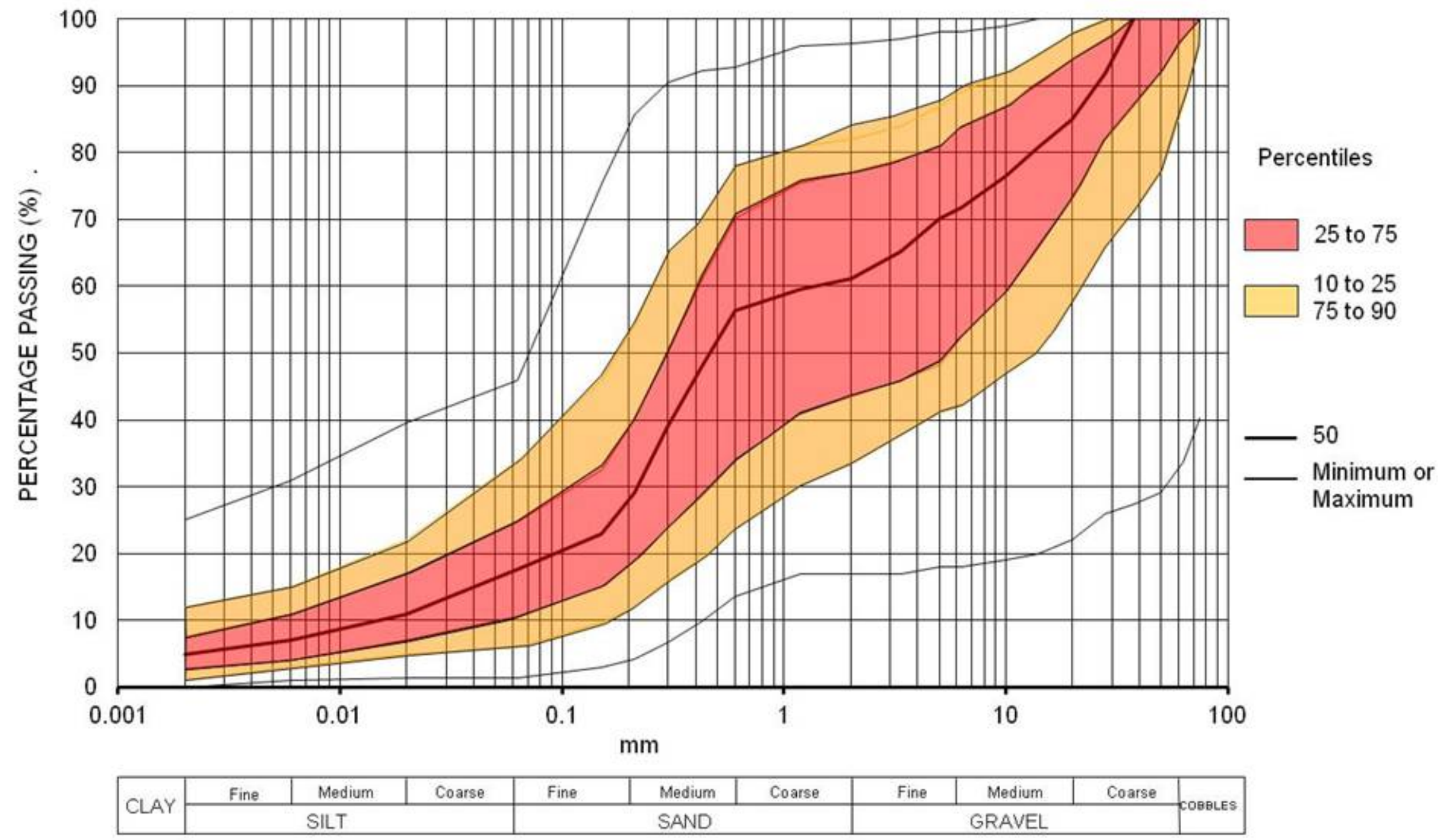




\section{0 samples}

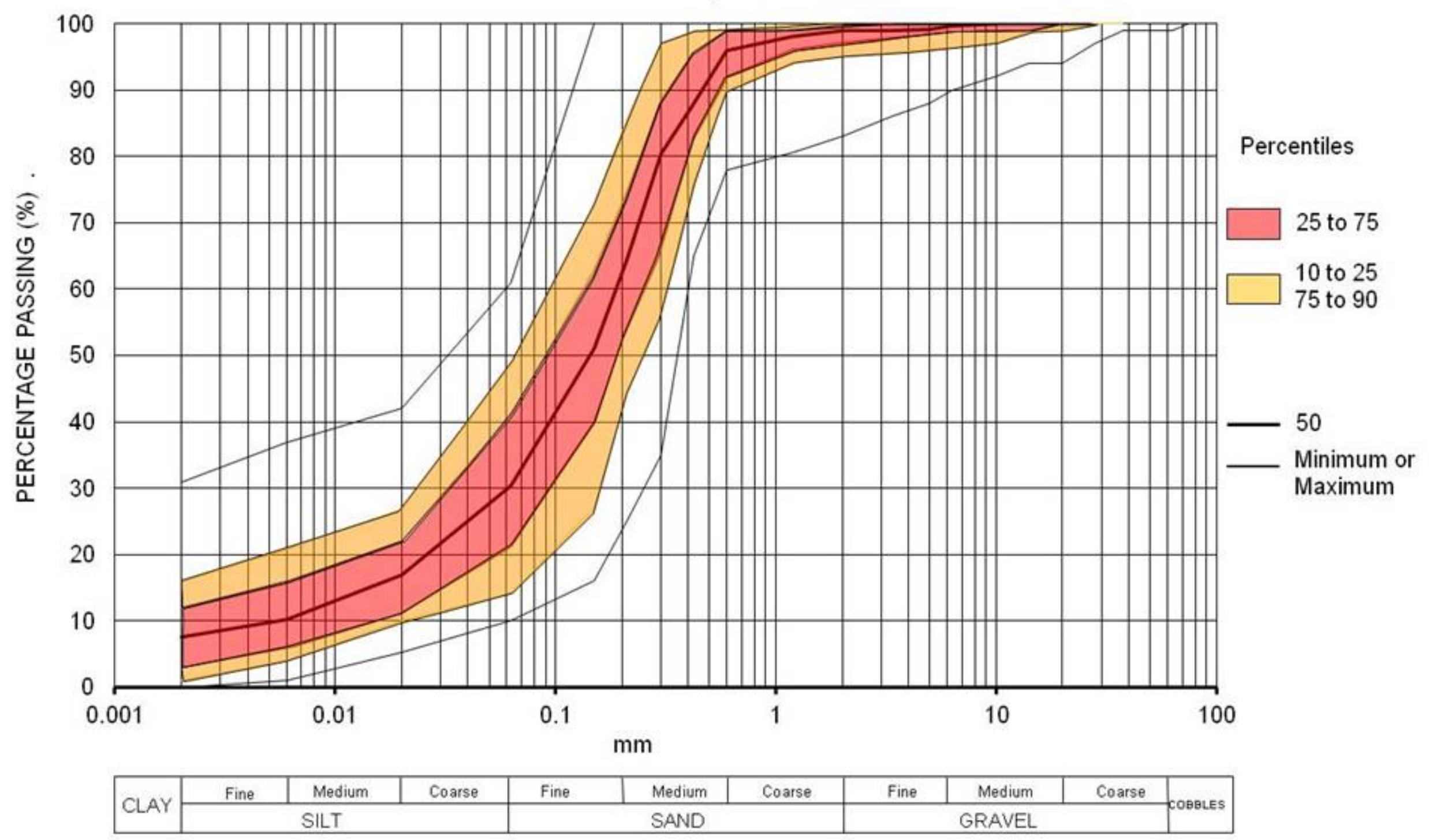




\section{3 samples}

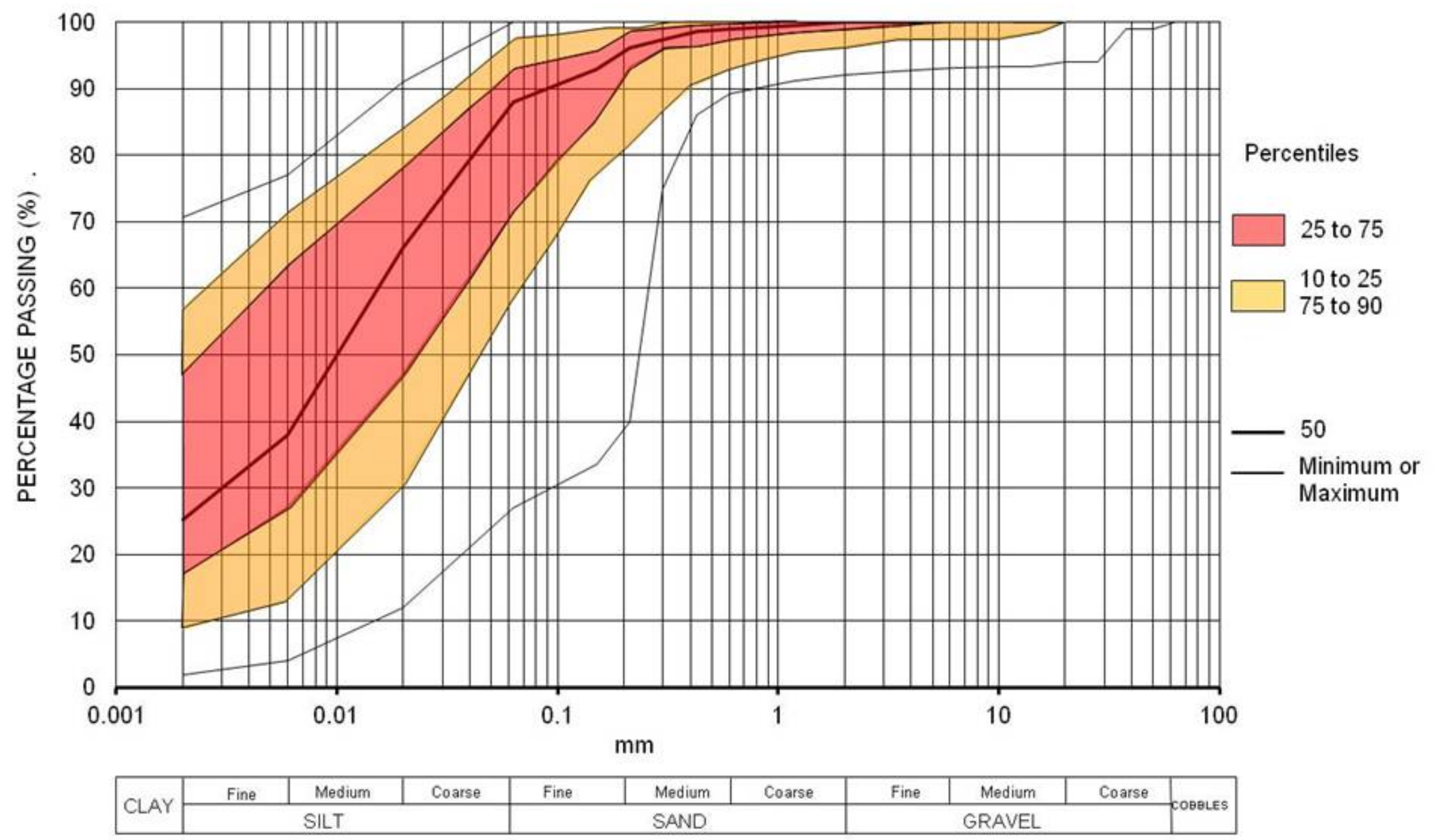




\section{2 samples}

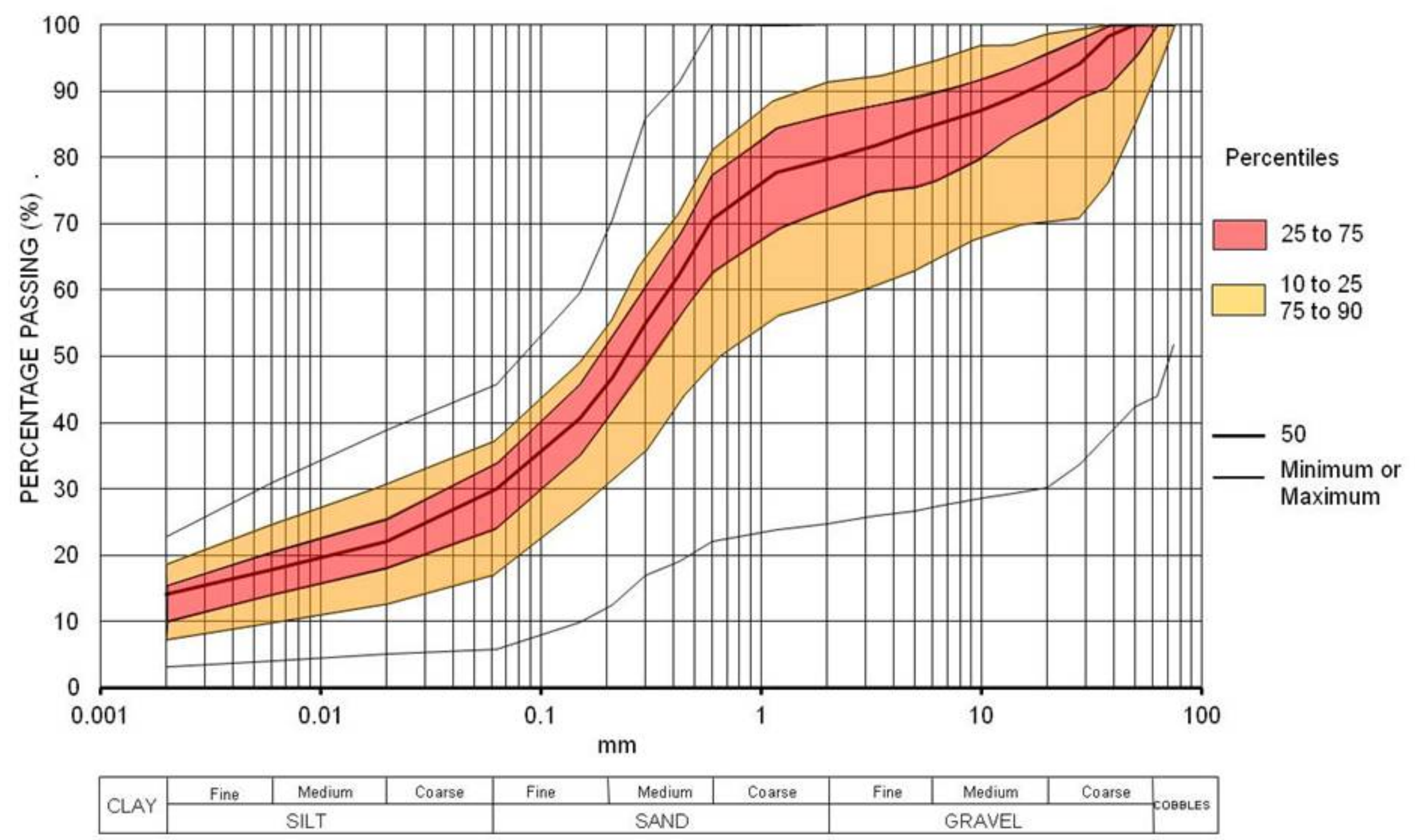


13 samples

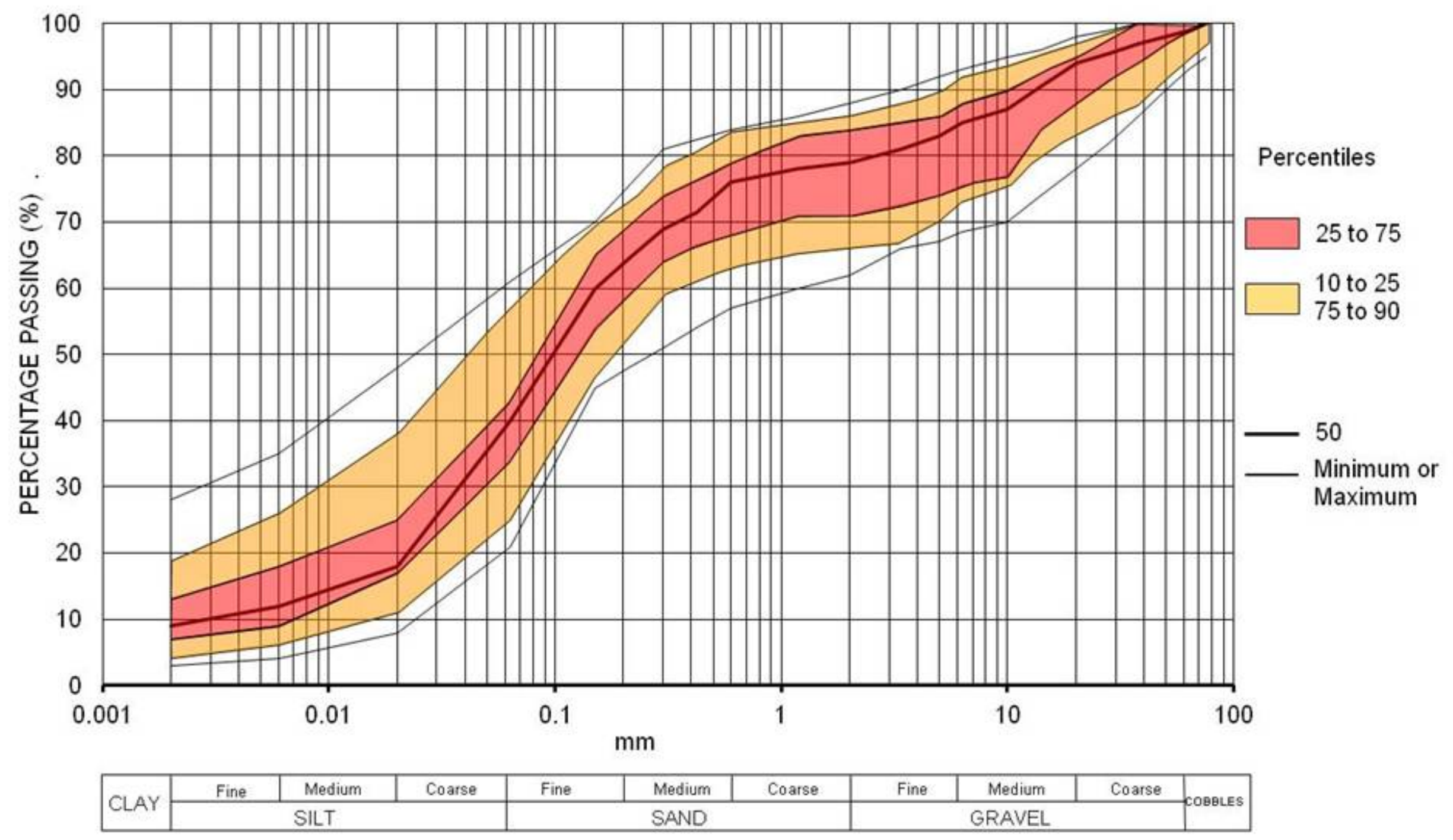




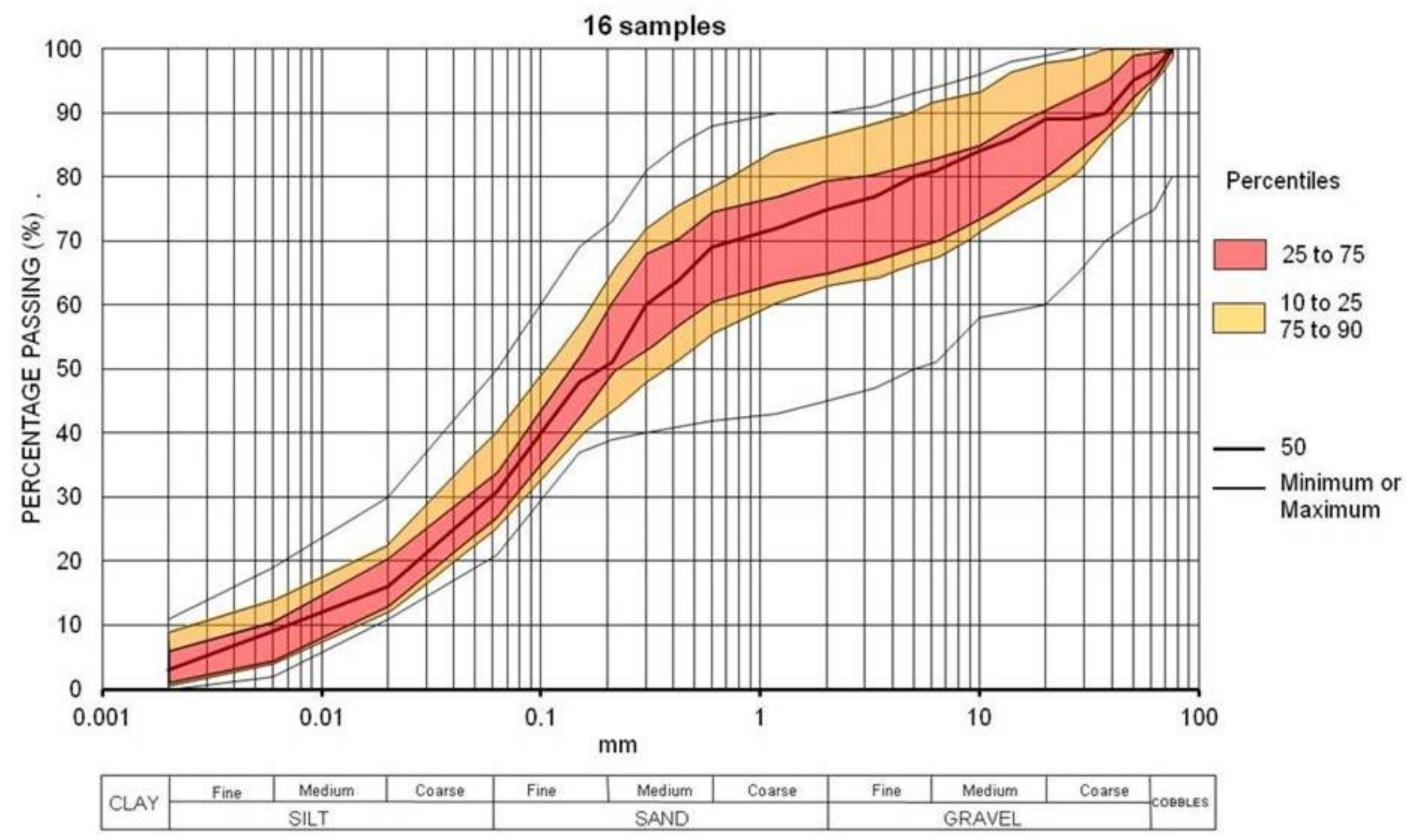




\section{9 samples}

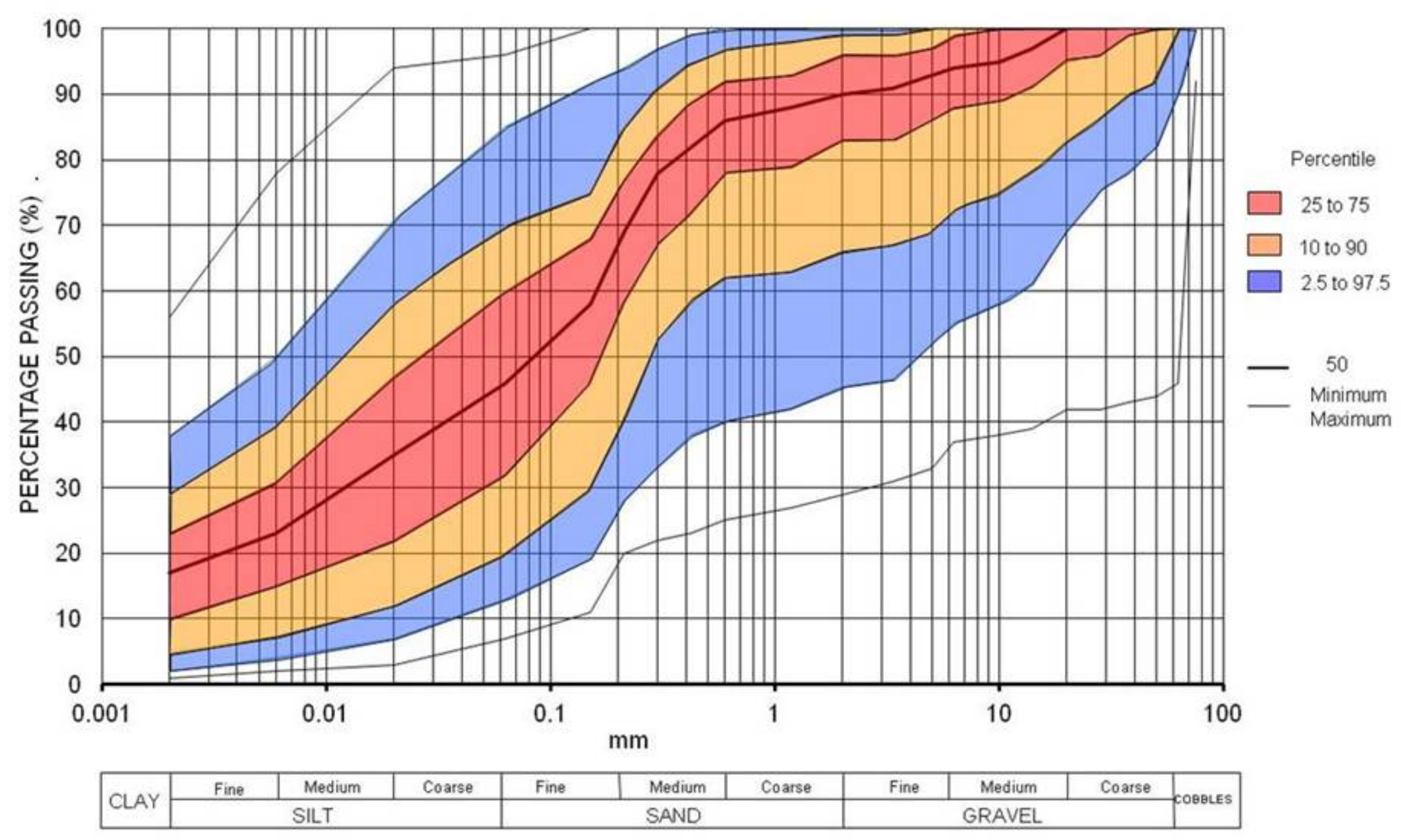




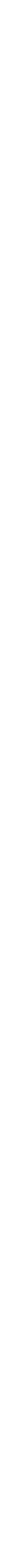




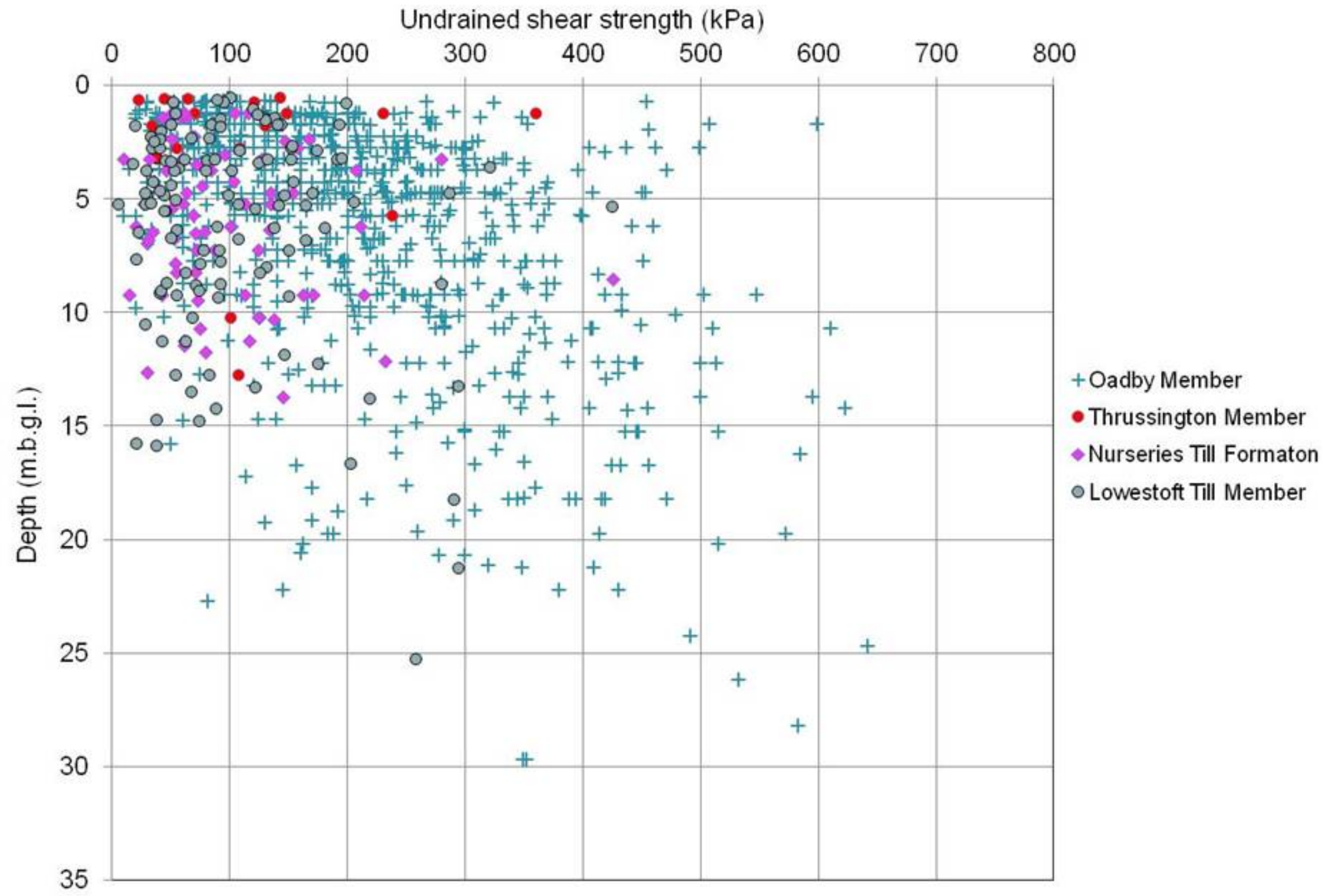




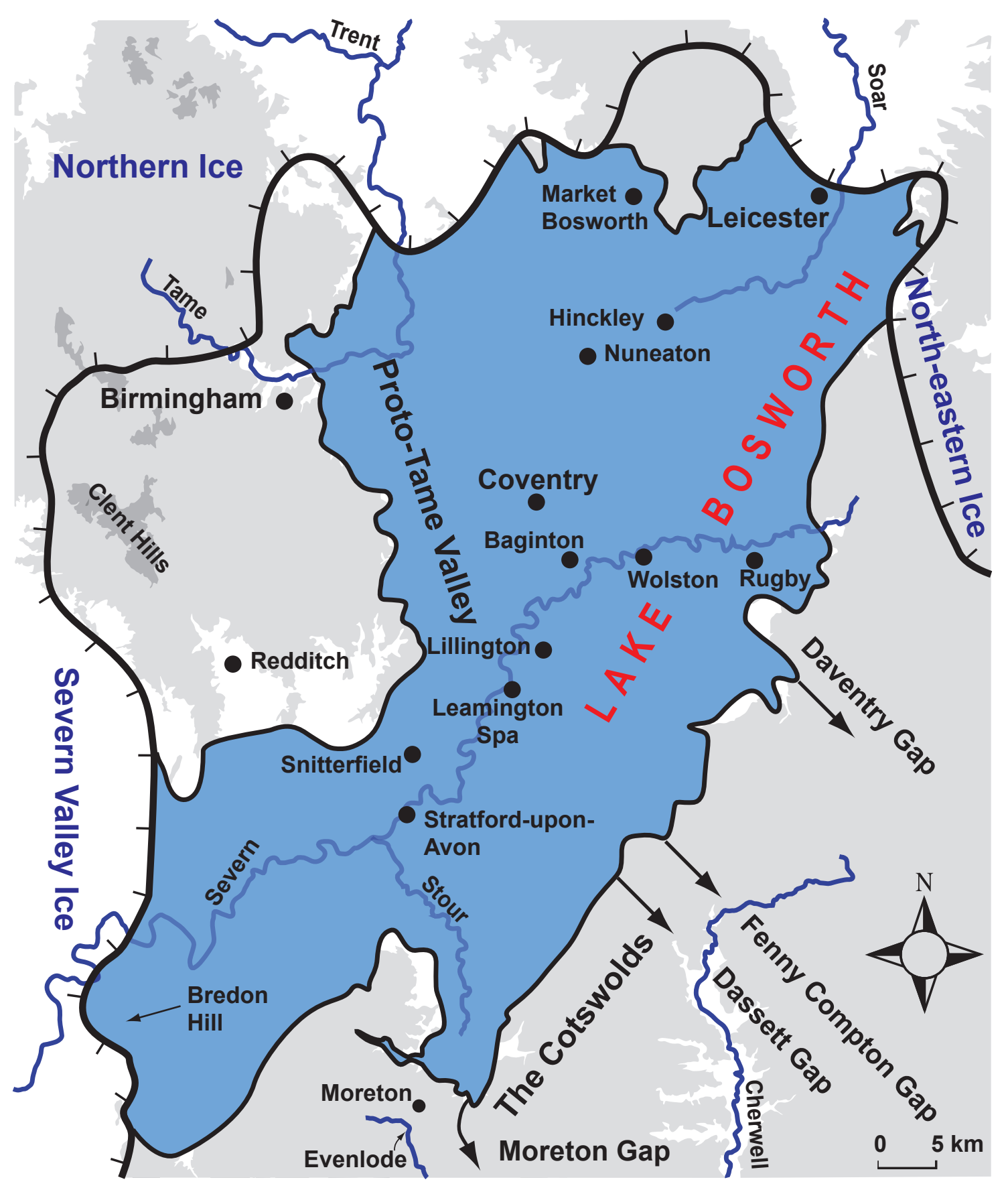




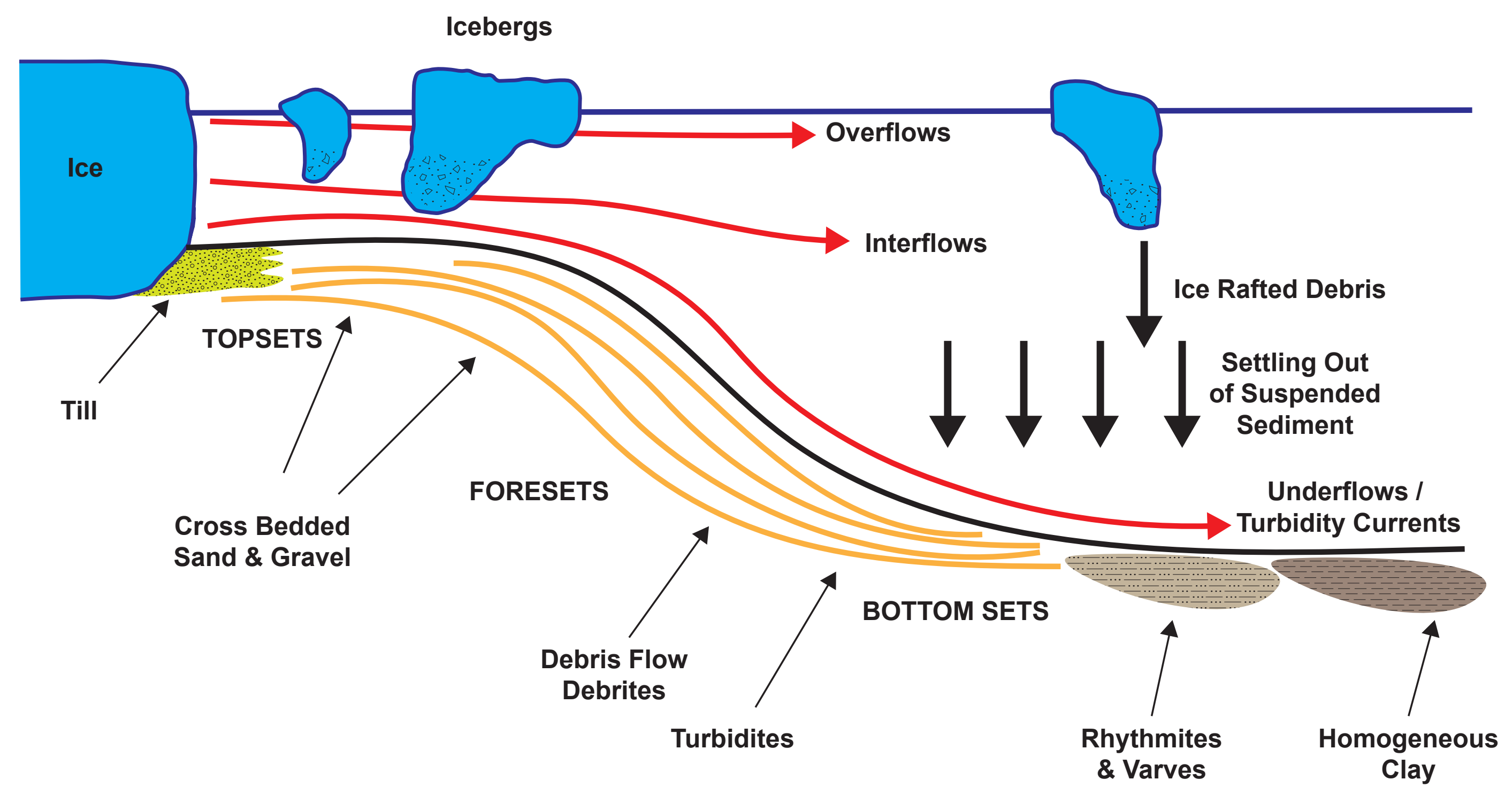




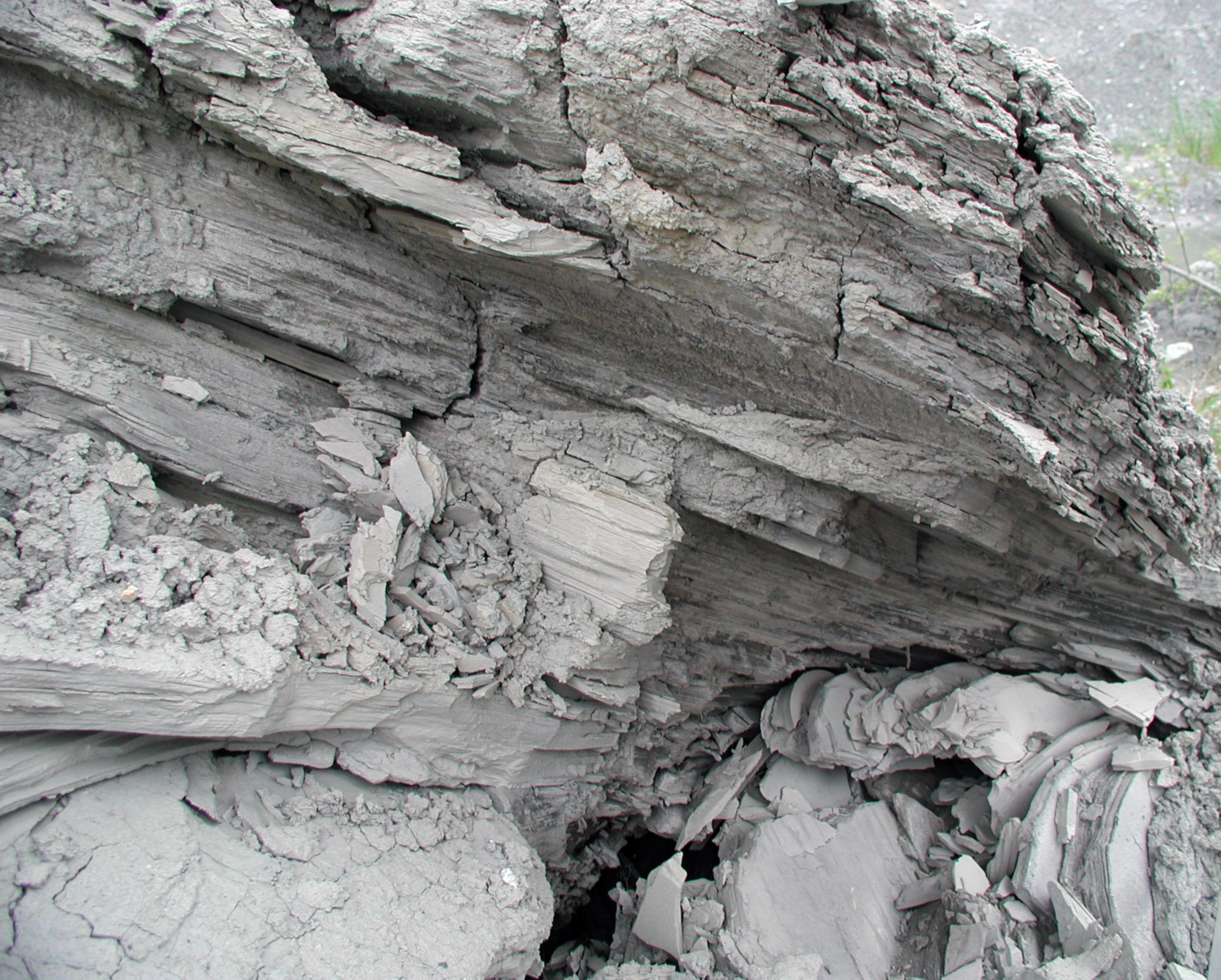




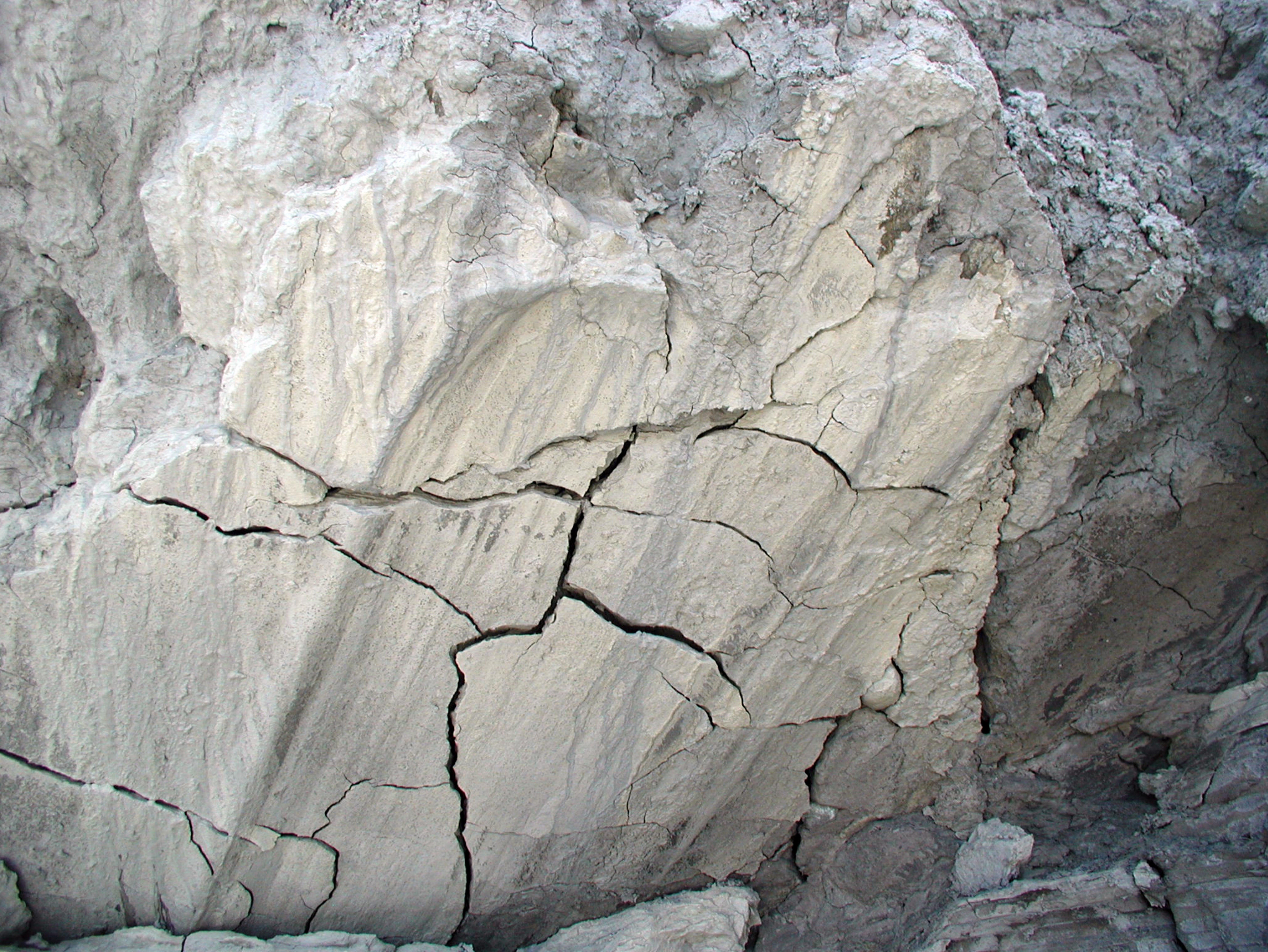




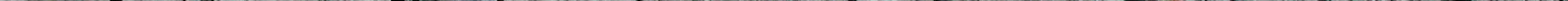




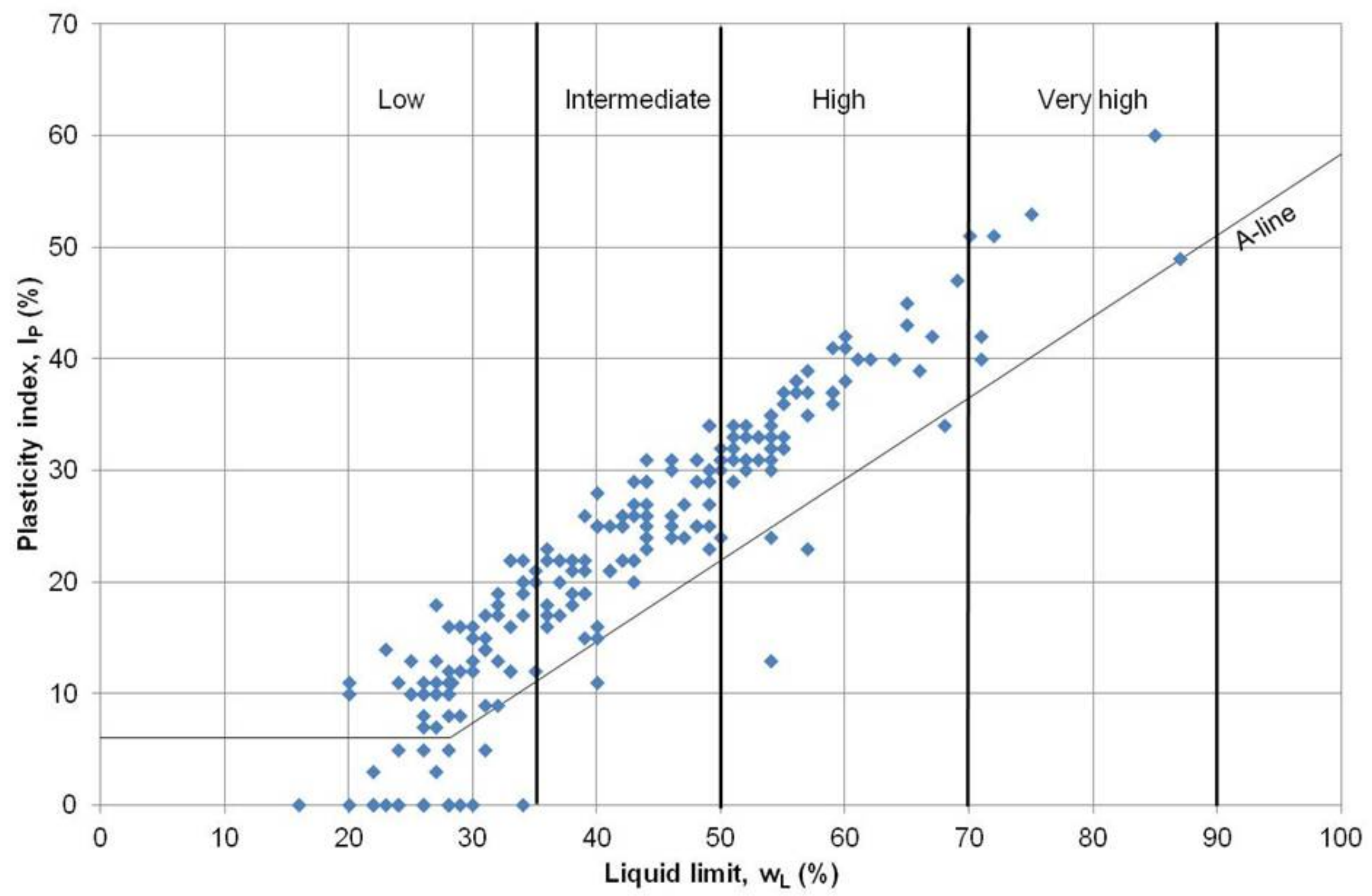




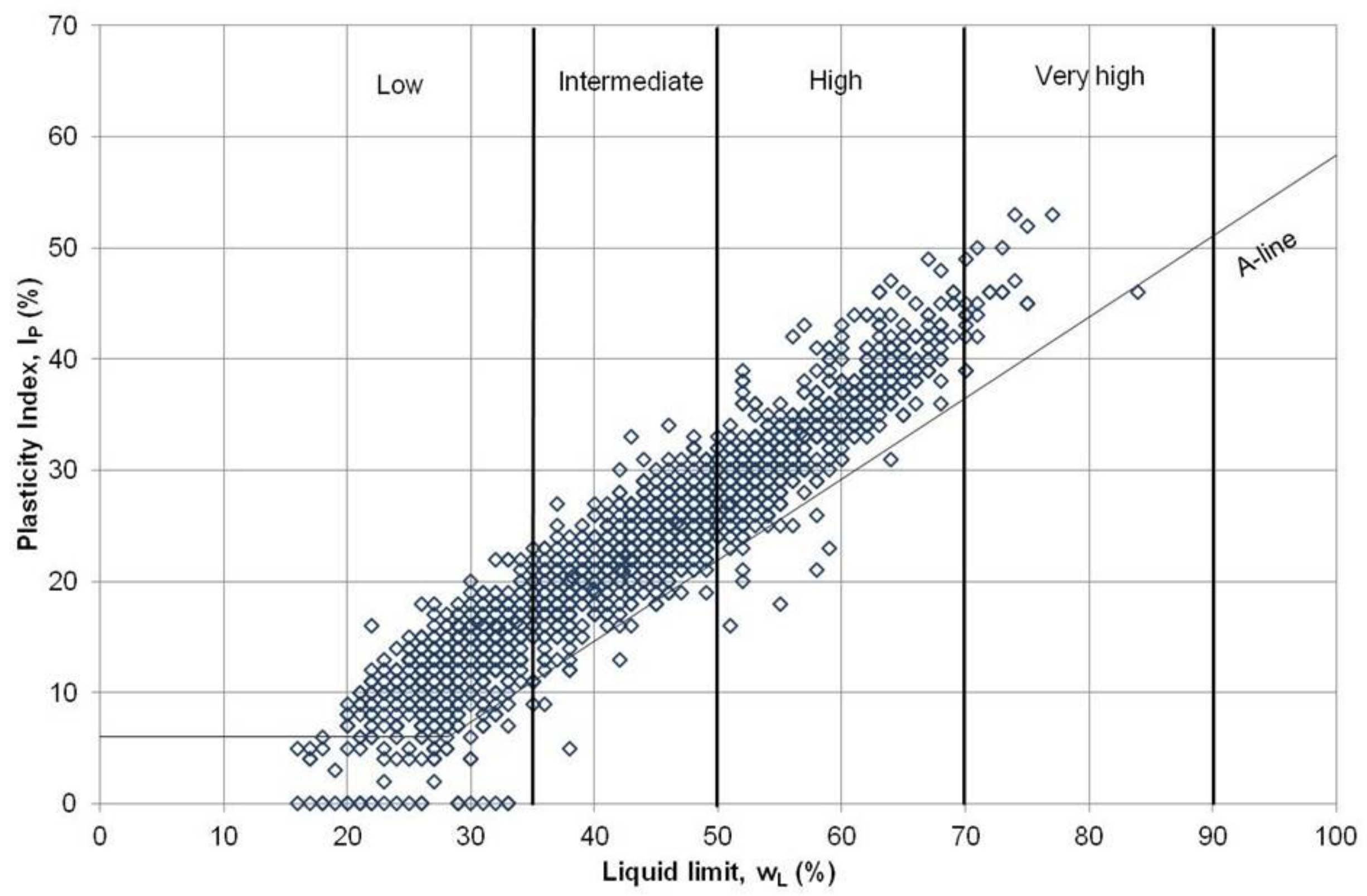


56 samples

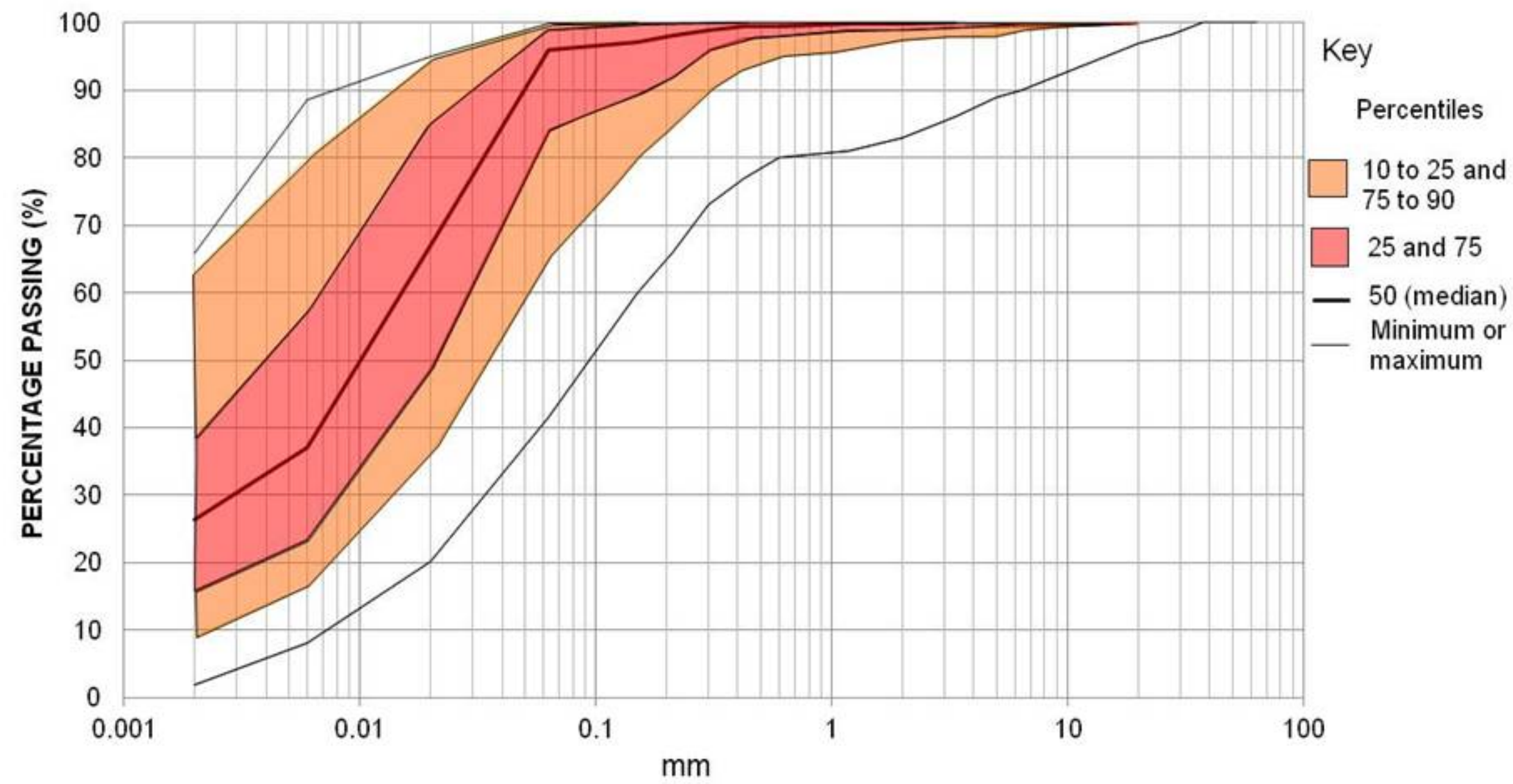

\begin{tabular}{|c|c|c|c|c|c|c|c|c|c|c|}
\hline \multirow{2}{*}{ CLAY } & Fine & Medium & Coarse & Fine & Medium & Coarse & Fine & Medium & Coarse & \multirow{2}{*}{ COBBLES } \\
\hline & \multicolumn{3}{|c|}{ SILT } & \multicolumn{3}{|c|}{ SAND } & \multicolumn{3}{|c|}{ GRAVEL } & \\
\hline
\end{tabular}




\section{8 samples}

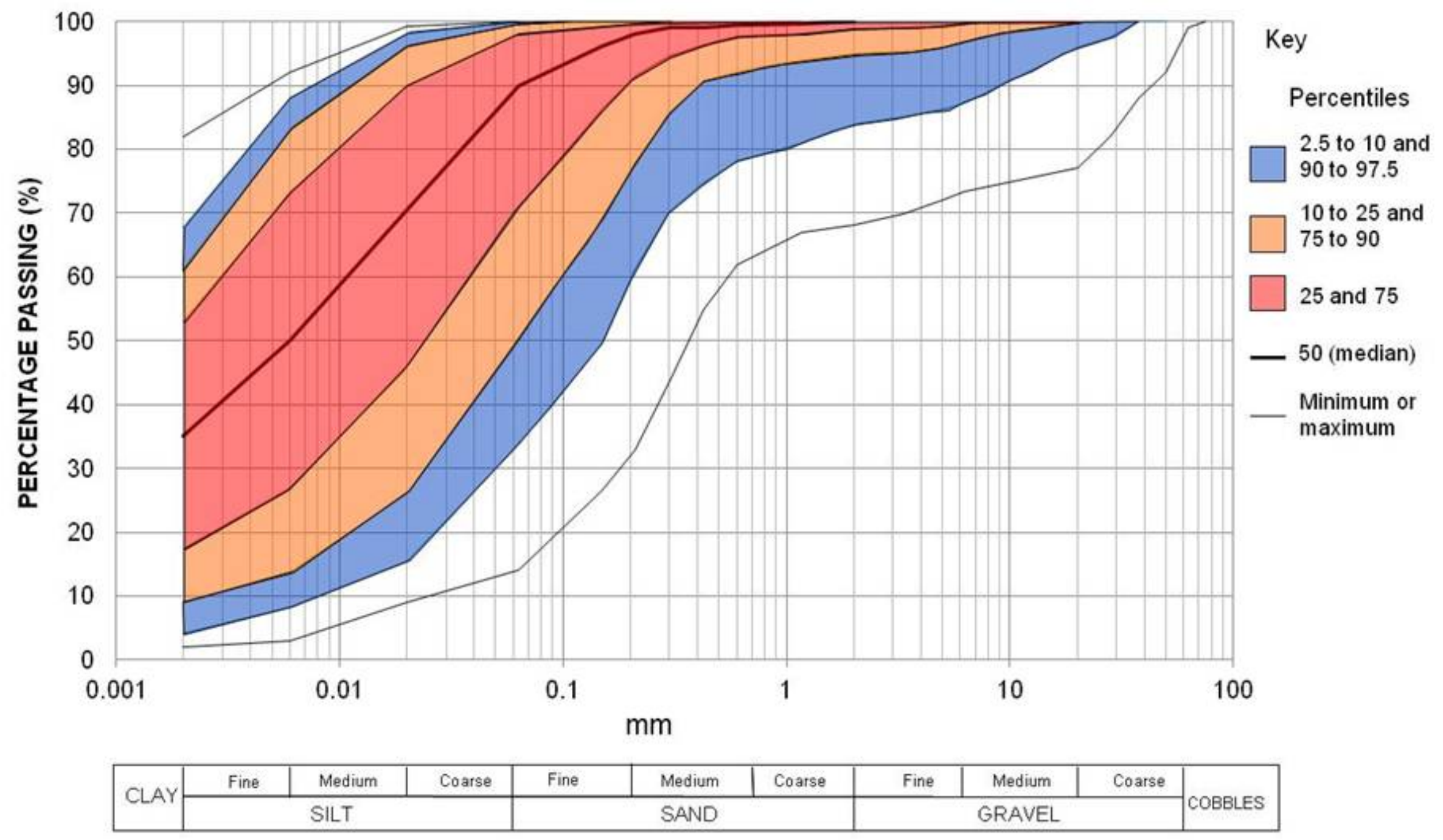




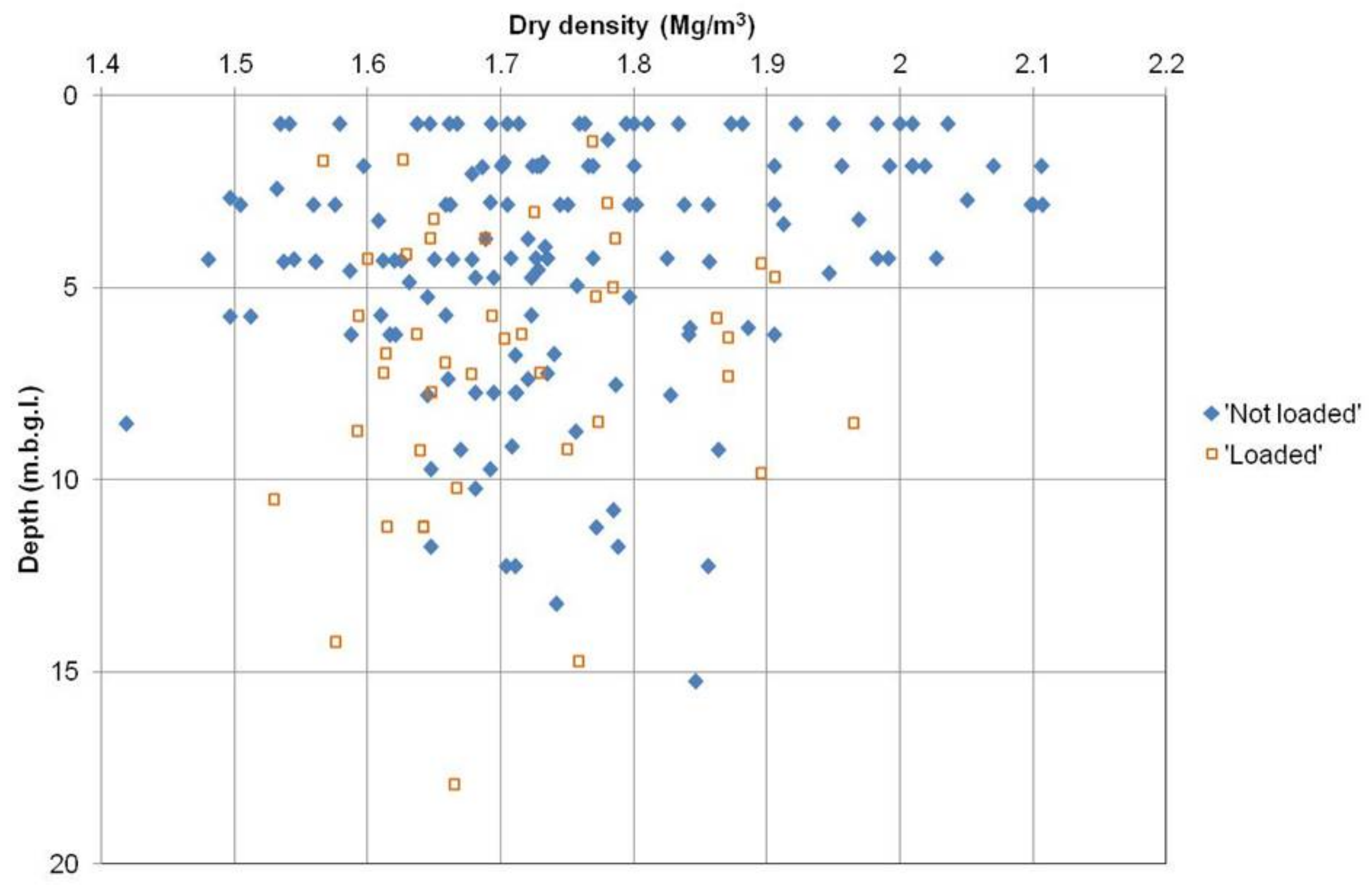




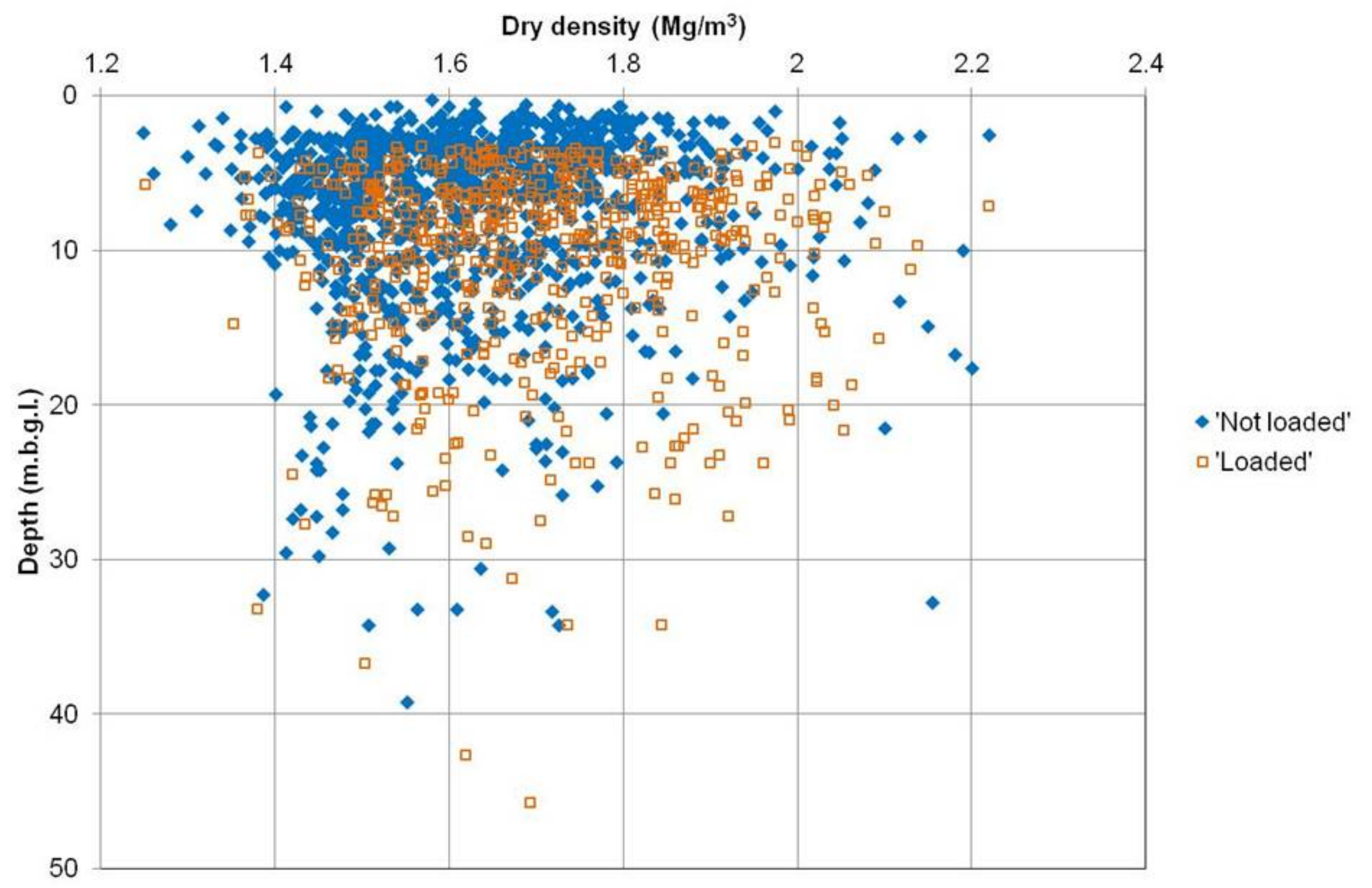




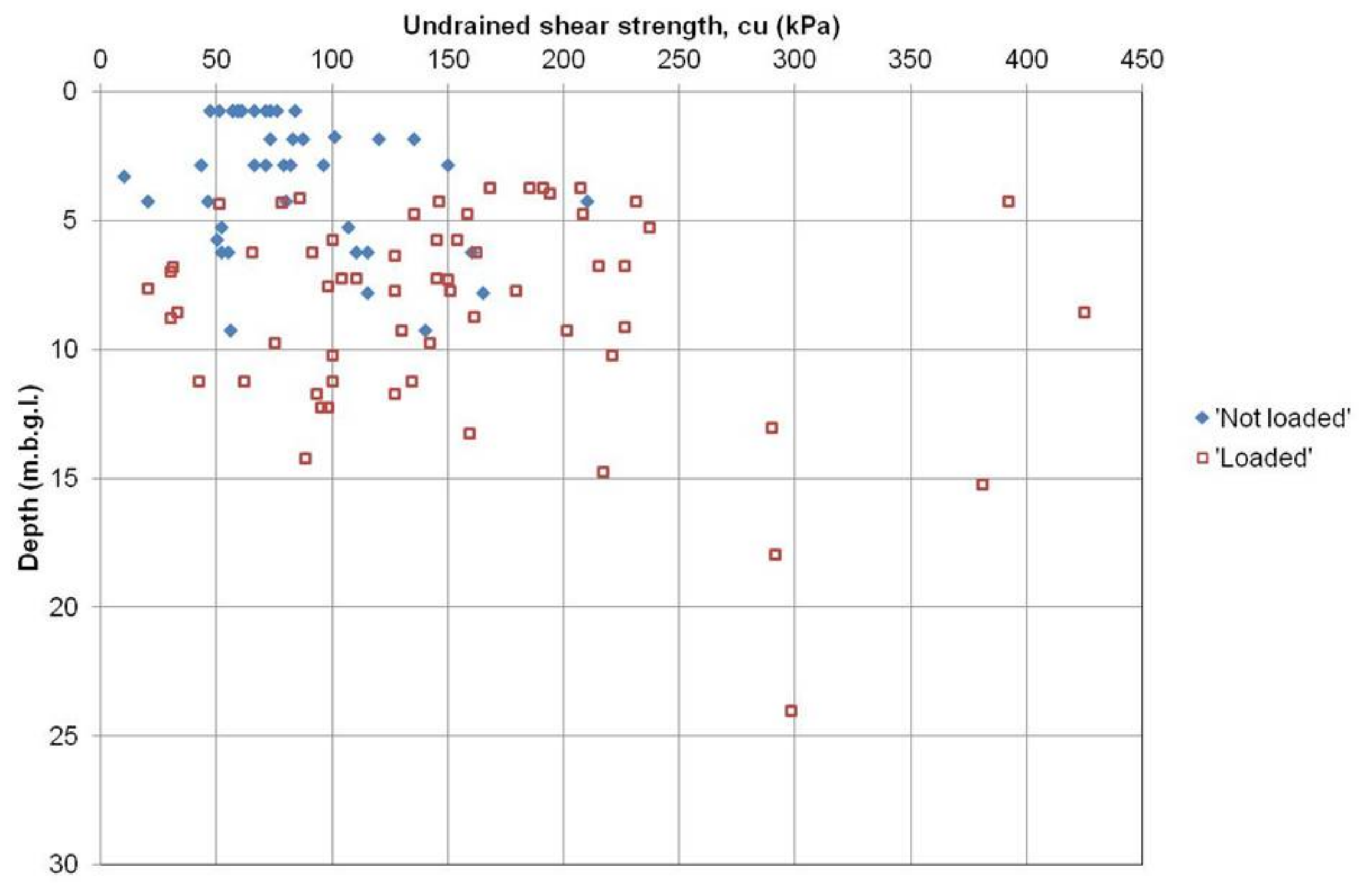




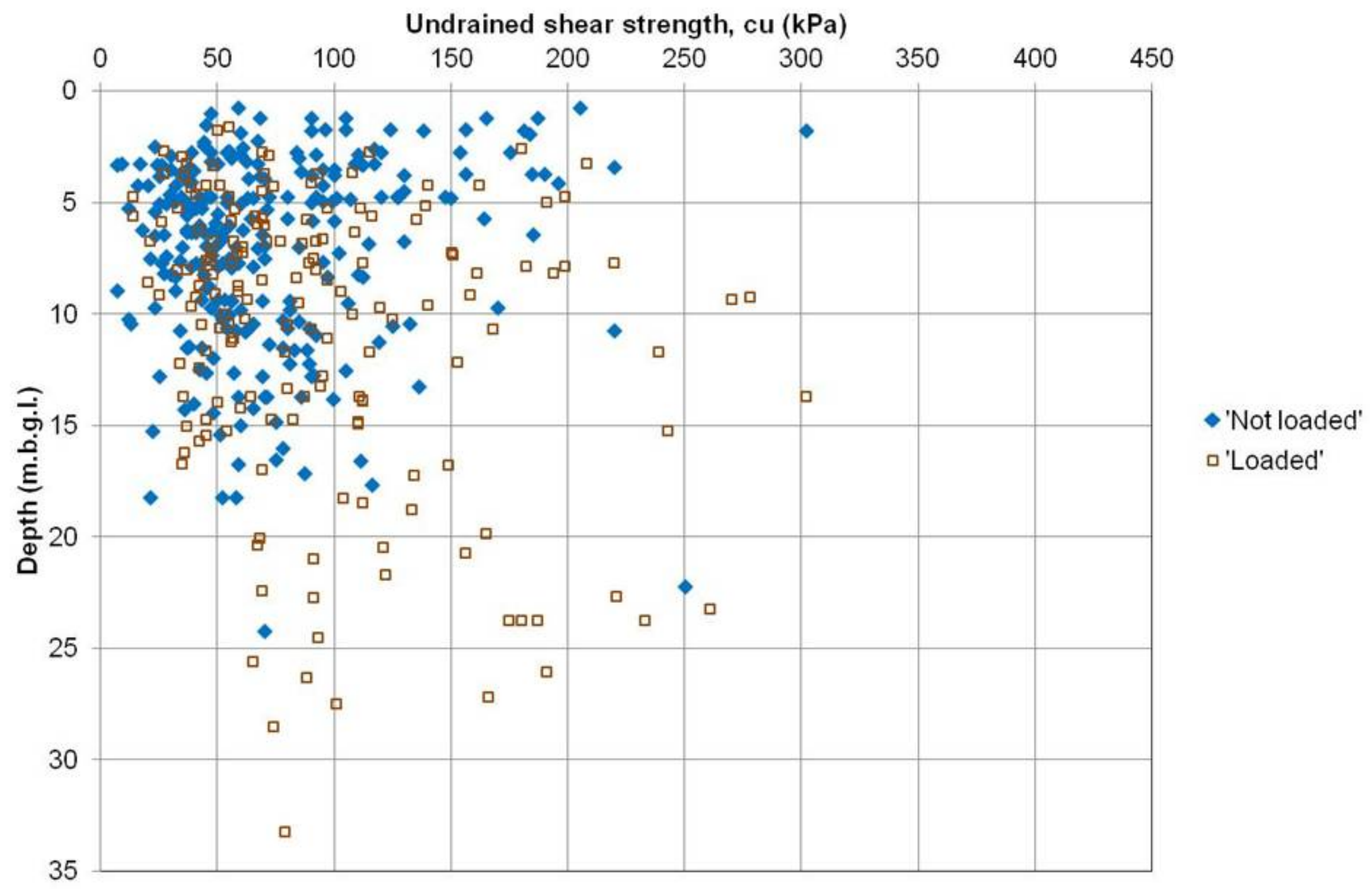


10 samples

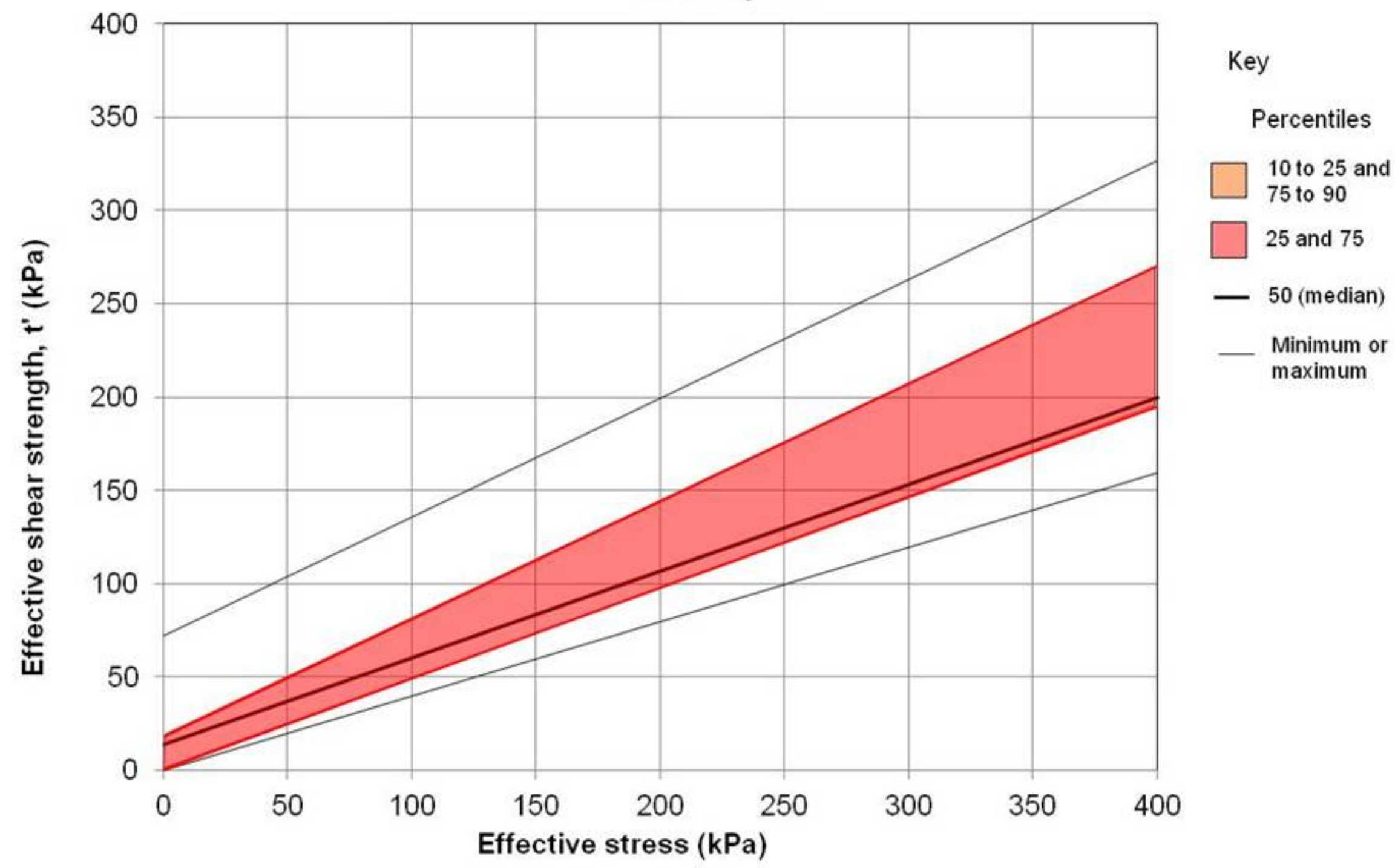




\section{5 samples}

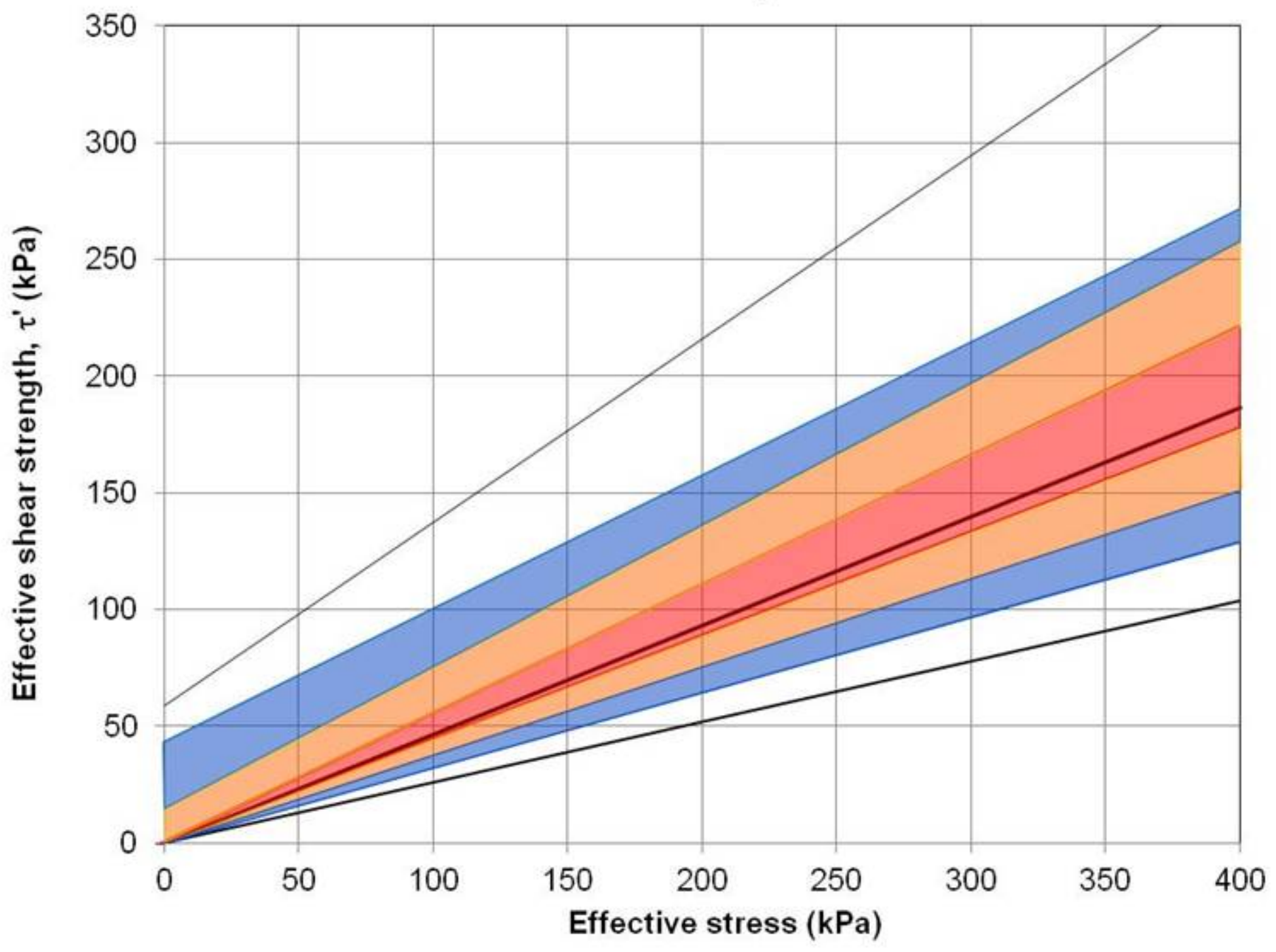

Percentiles

2.5 to 10 and 90 to 97.5

10 to 25 and 75 to 90

25 and 75

— 50 (median)

Minimum or maximum 


\section{2 samples}

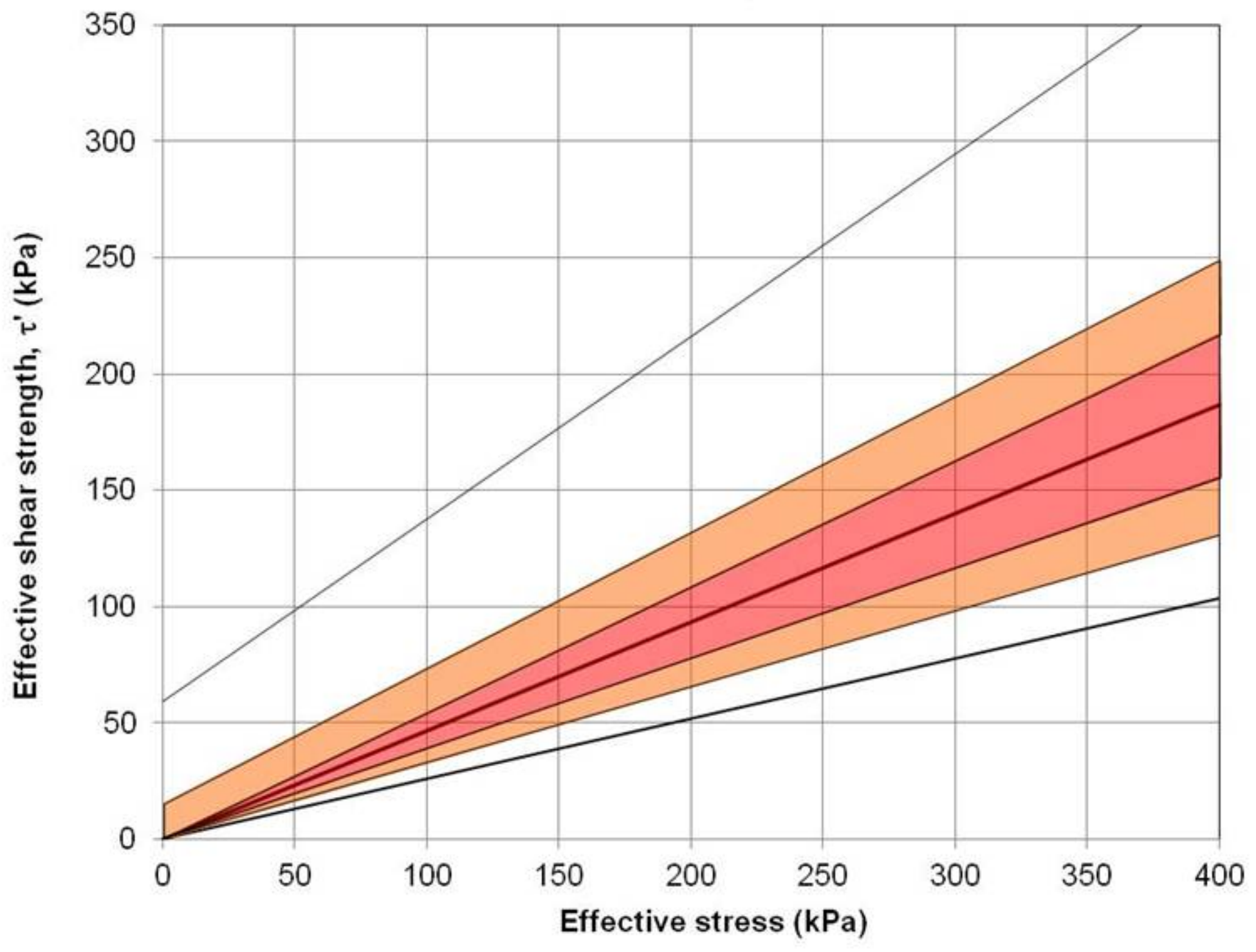

Key

\section{Percentiles}

10 to 25 and

75 to 90

25 and 75

- 50 (median)

_ Minimum or maximum 


\section{3 samples}

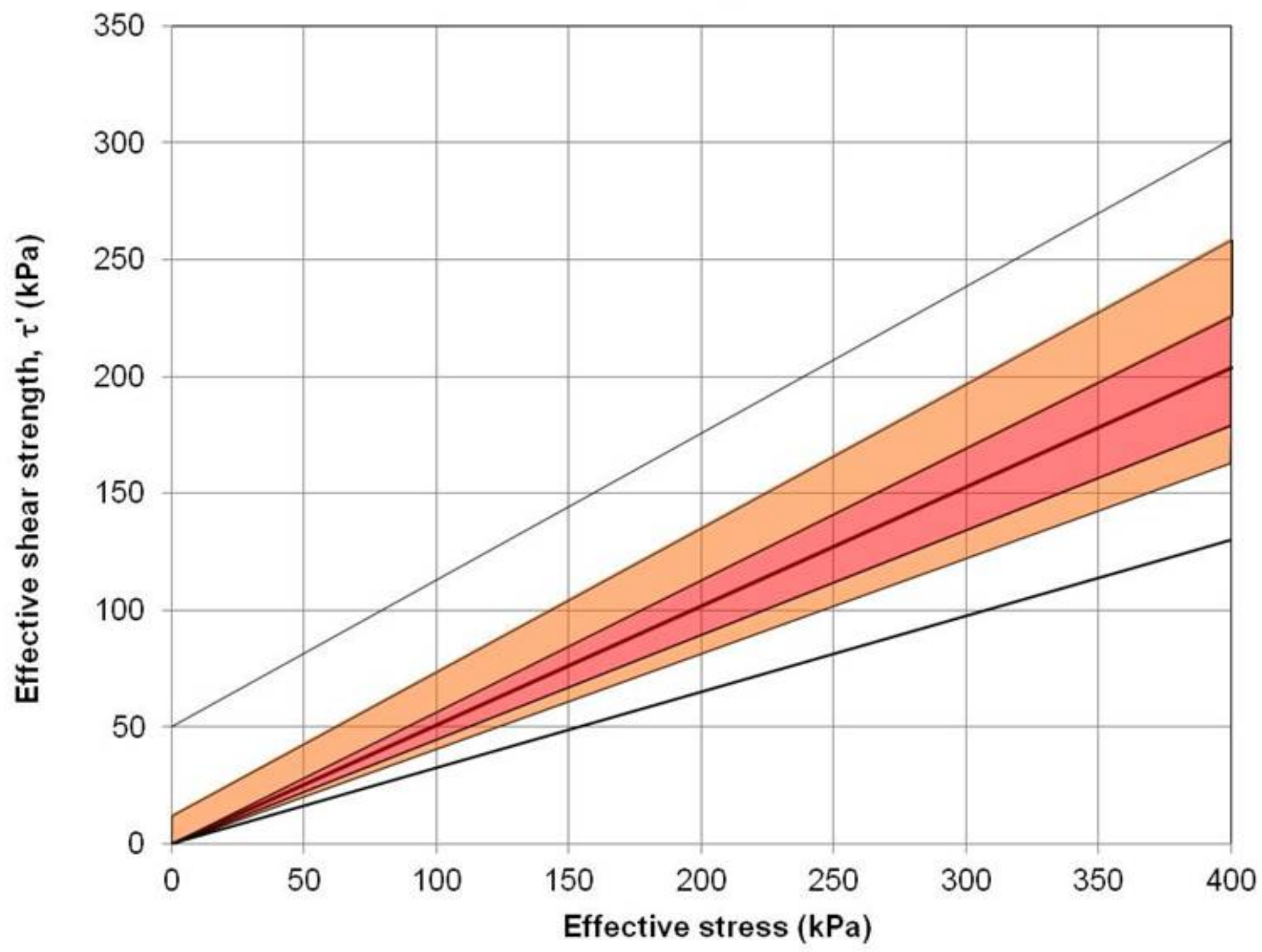

Key

Percentiles

10 to 25 and 75 to 90

25 and 75

- 50 (median)

_ Minimum or maximum 


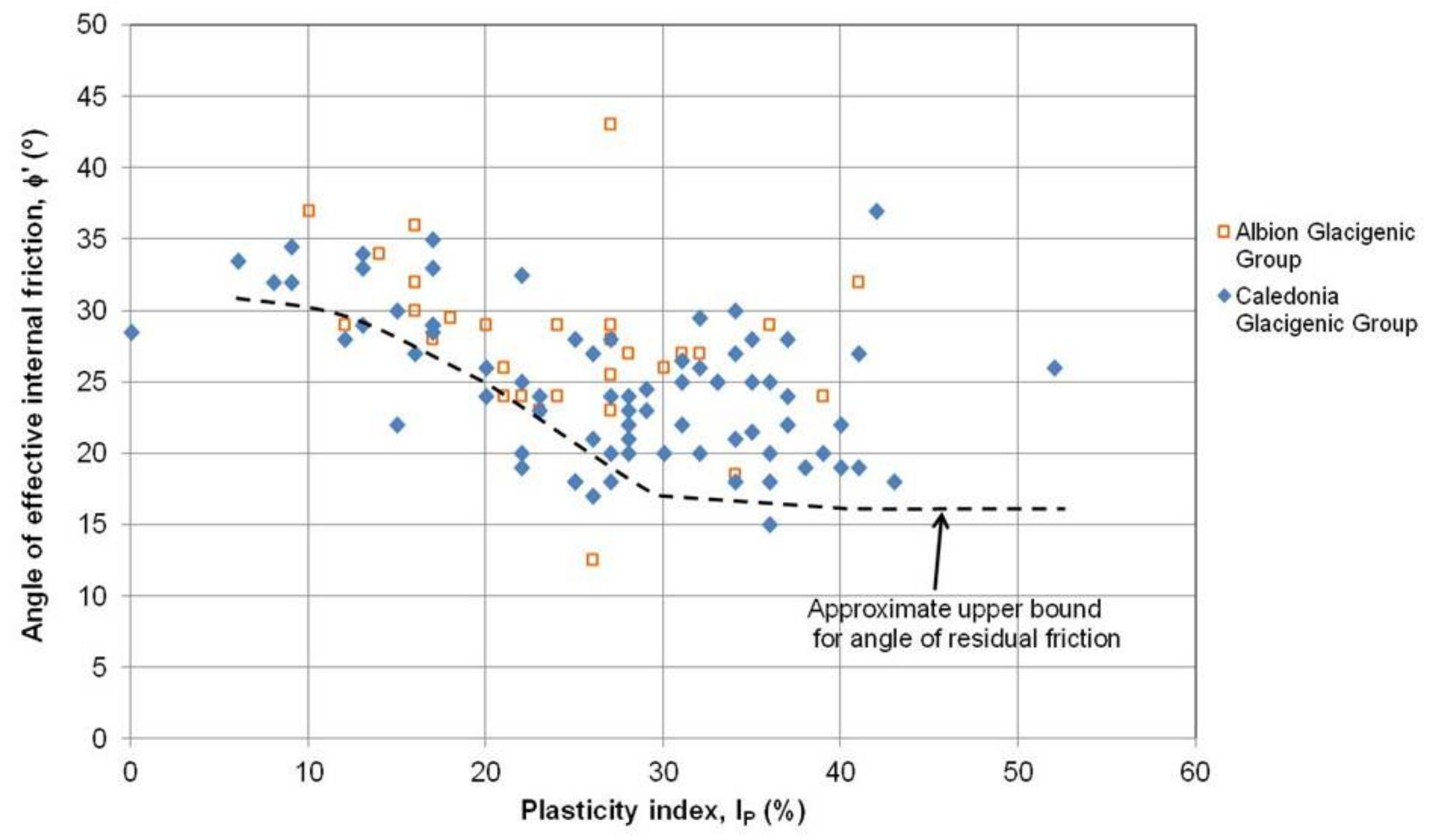




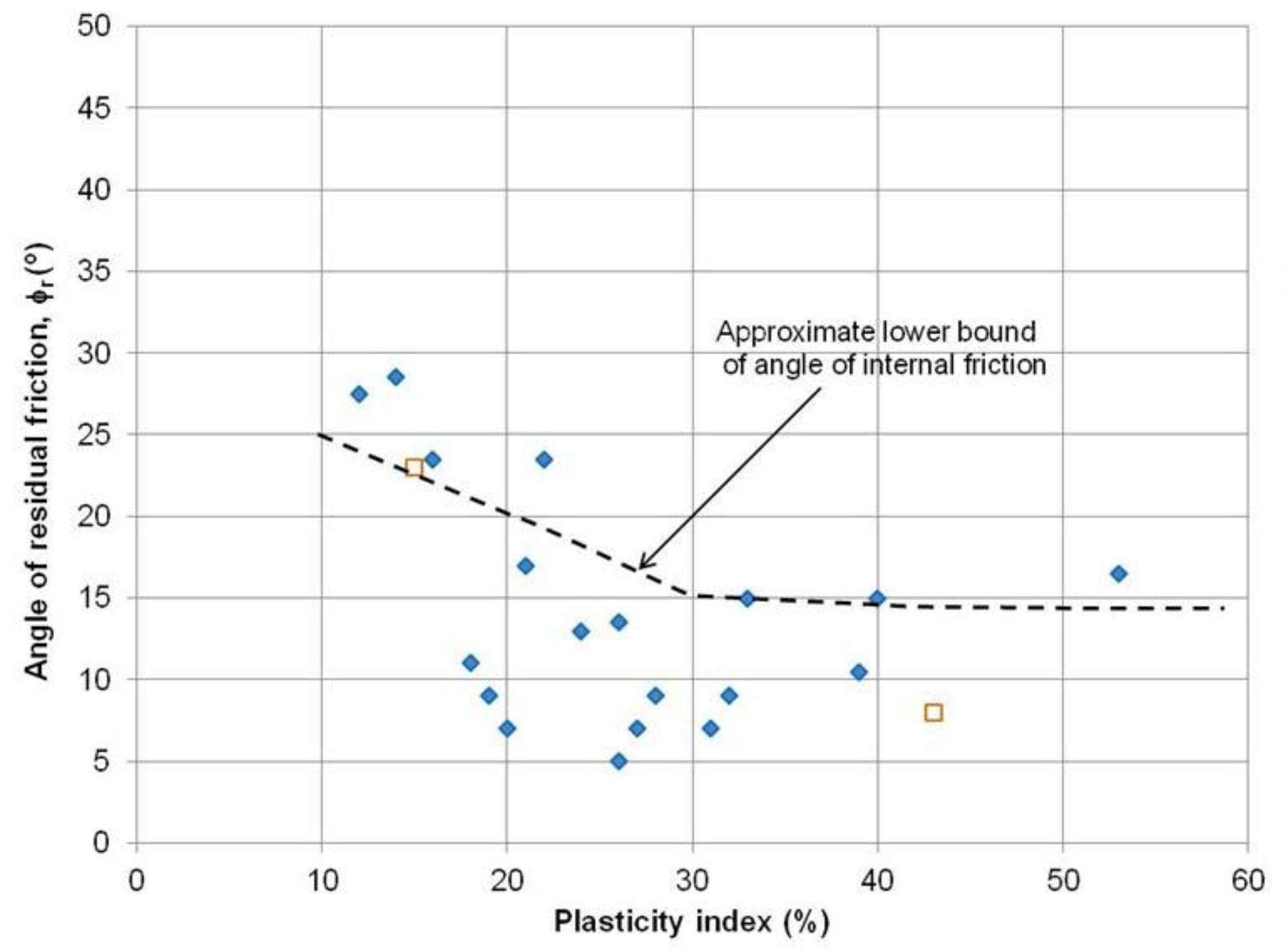

$\square$ Albion Glacigenic Group

- Caledonia Glacigenic Group 
WATER CONTENT VARIATION

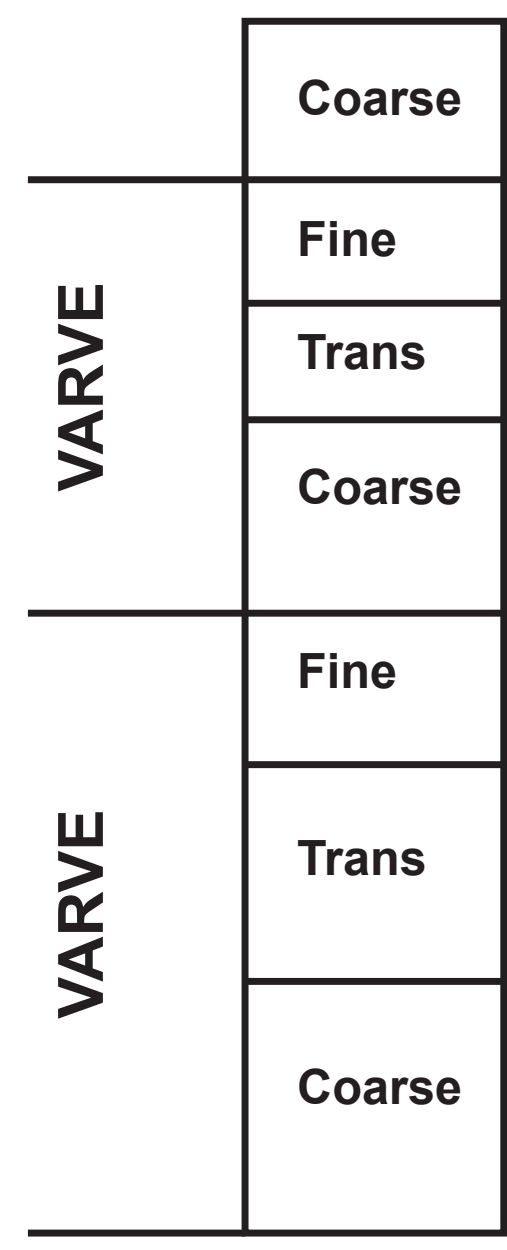

GRAIN SIZE VARIATION

FABRIC
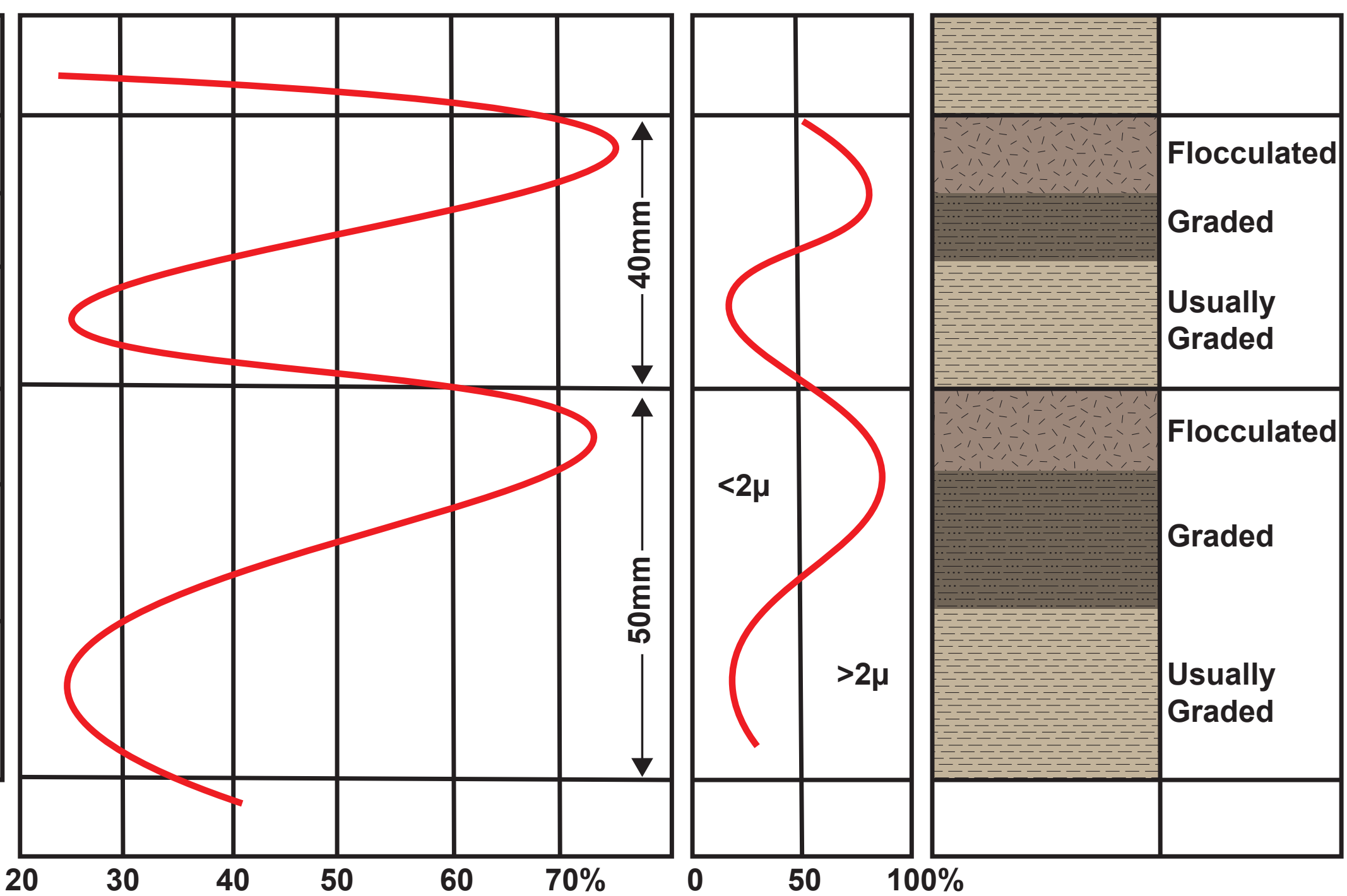


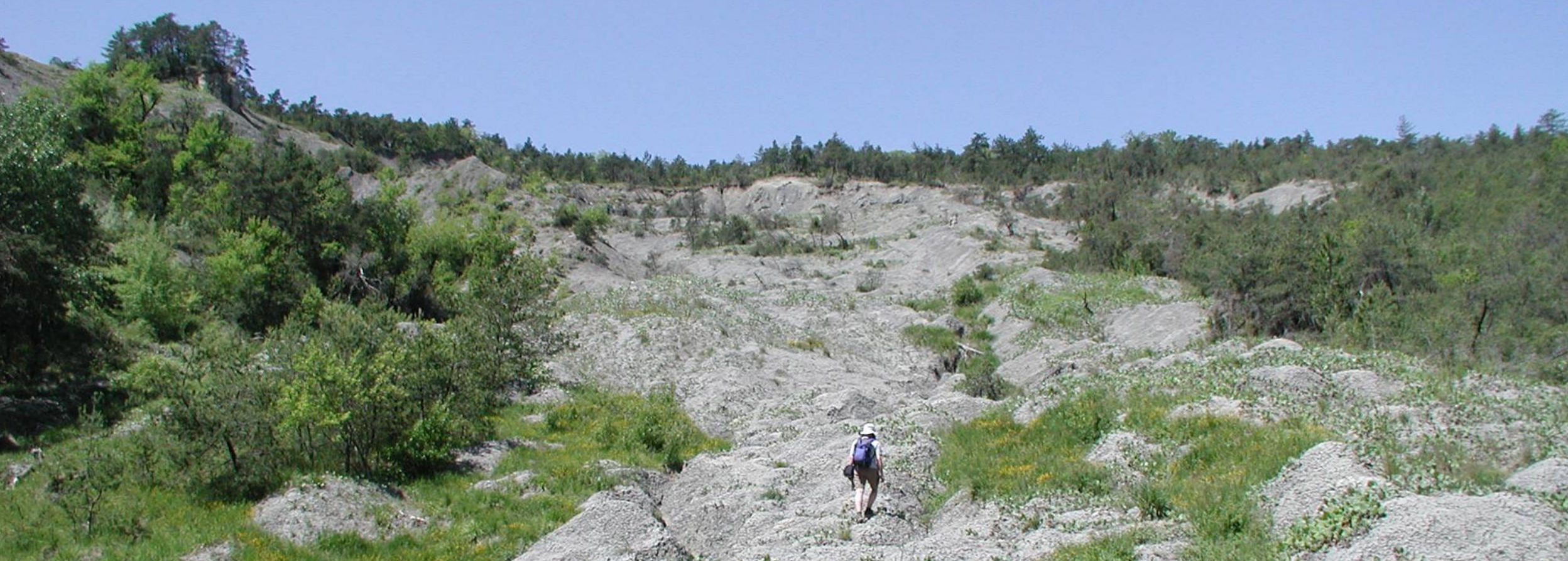

6.

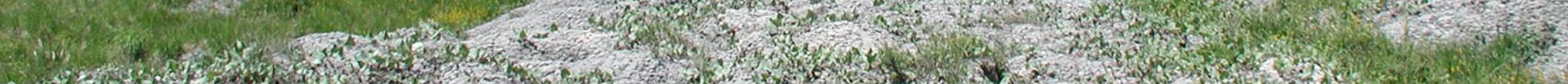

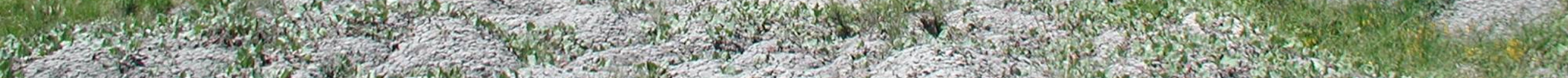

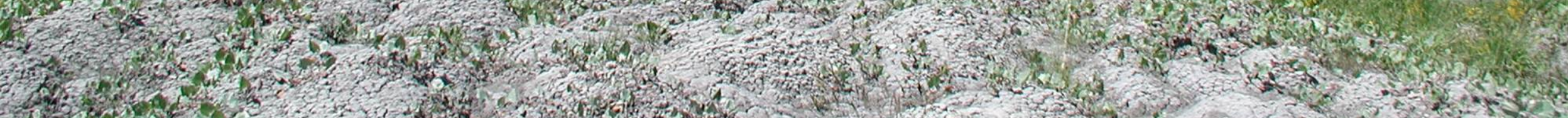

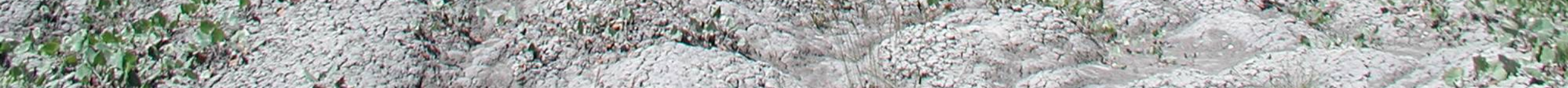

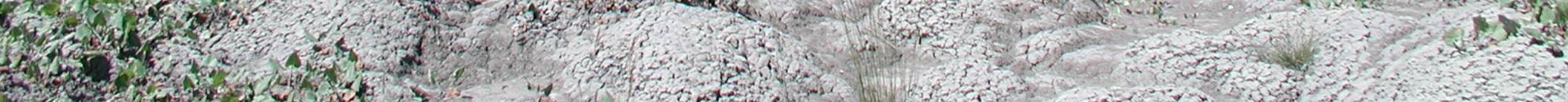

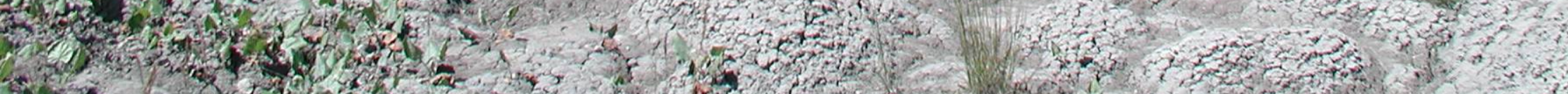

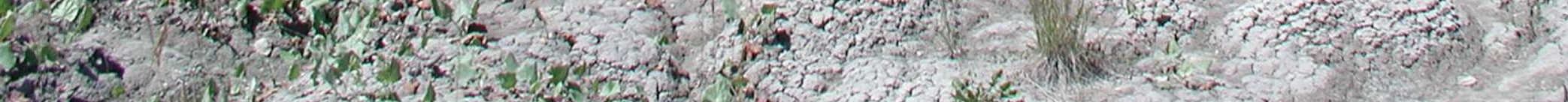

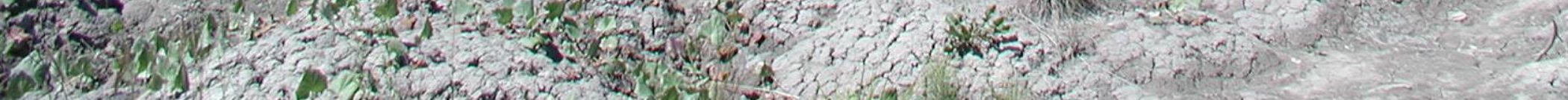




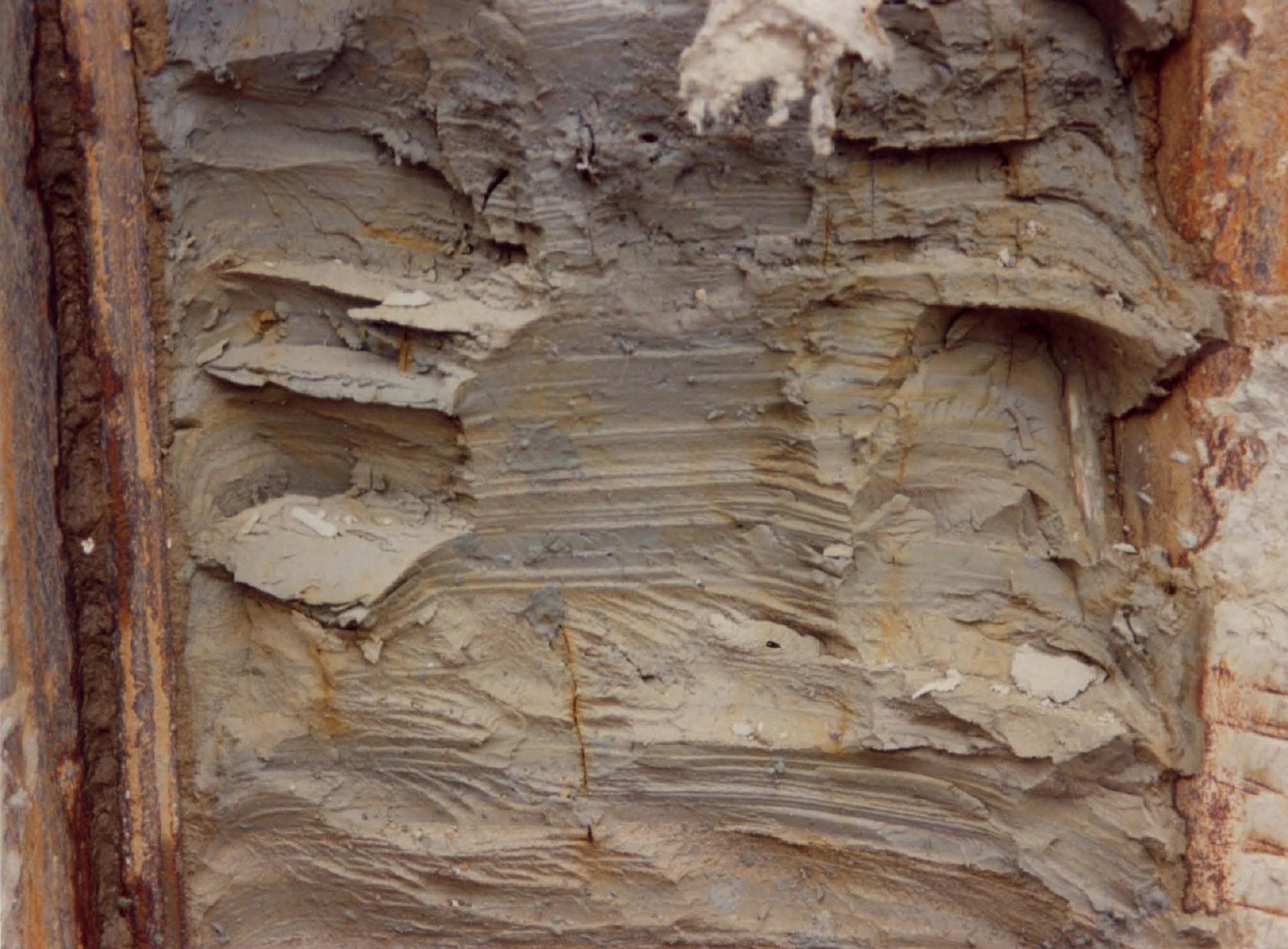


Post glacial marine clays

$$
\mathrm{NaCl}=35 \mathrm{~g} / \mathrm{l}
$$

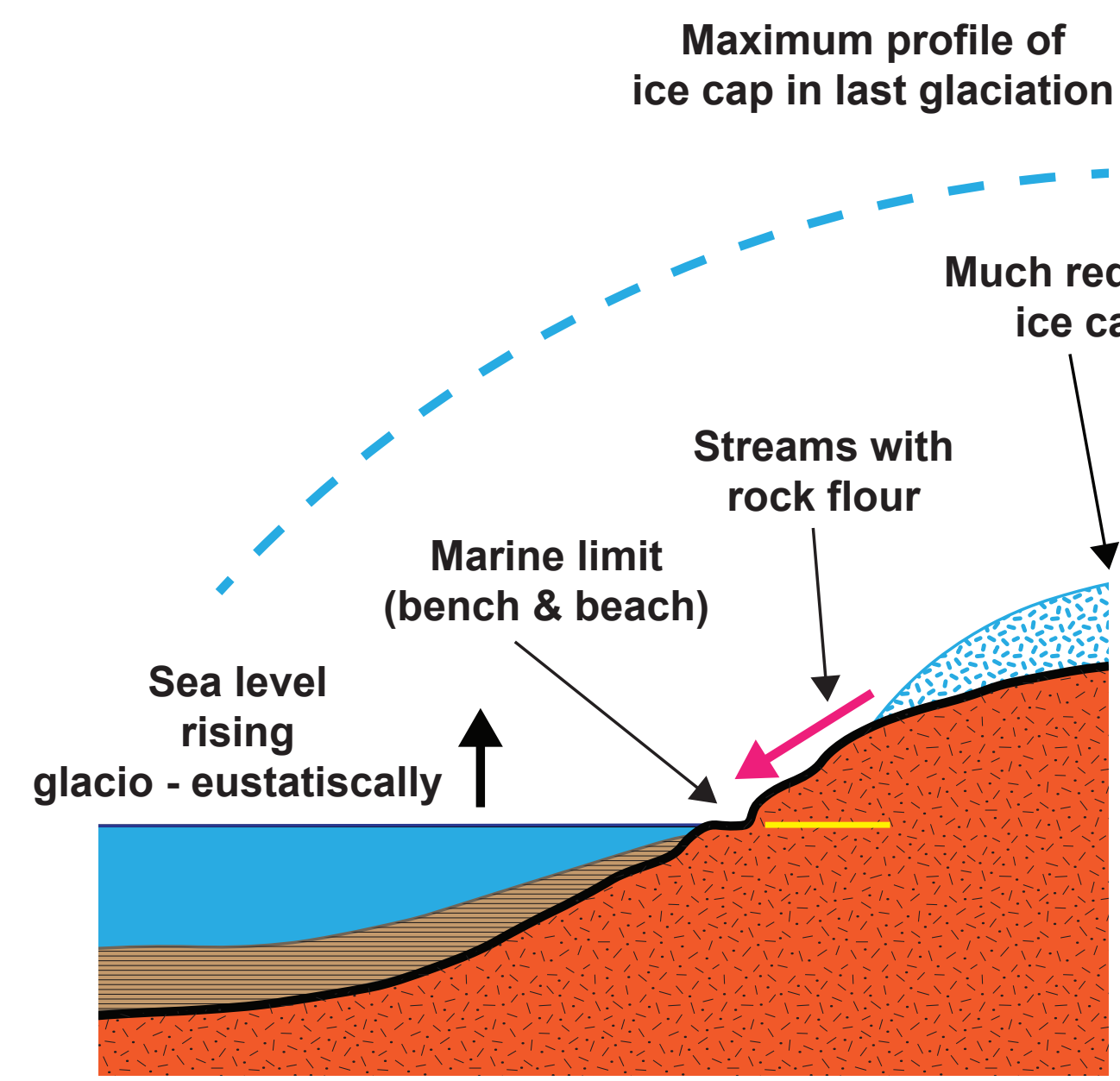

Maximum profile of ice cap in last glaciation (bench \& beach)

ea level rising glacio - eustatiscally

PL__ _LL \& W $\mathrm{S}_{\mathrm{t}}$ Low

8300 BC$$
23 \%
$$

$43 \%$
Clays leached by freshwater

$\mathrm{NaCl} \sim 1-2 \mathrm{~g} / \mathrm{l}$

Small, relict ice masses to north
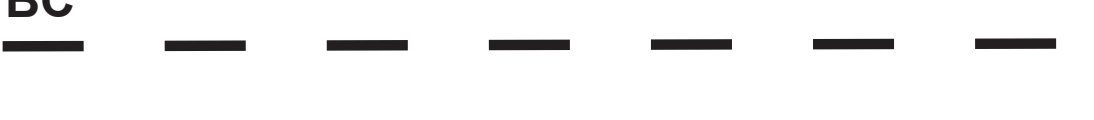

Bedrock

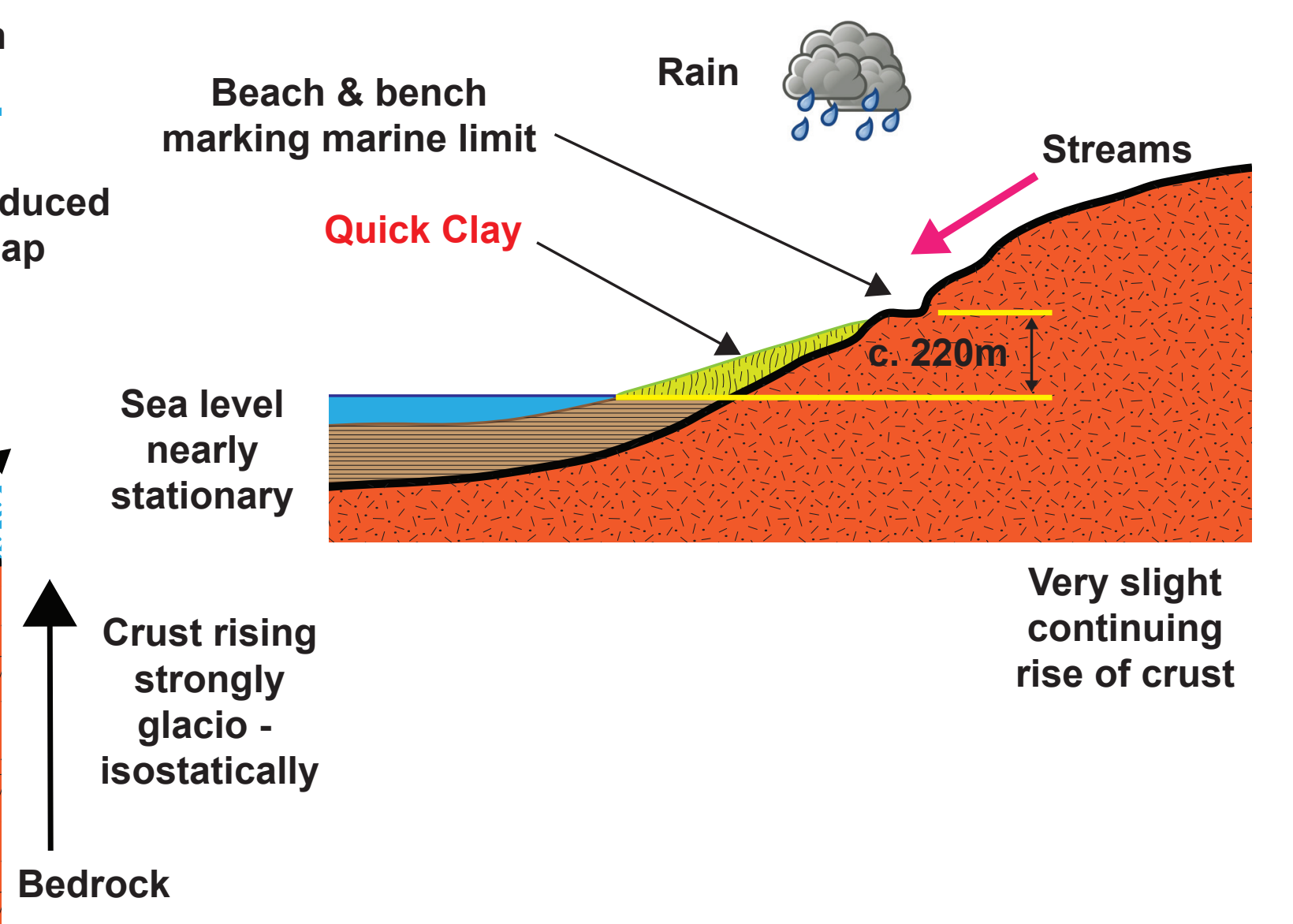

Present Day 
No bonds - Unflocculated
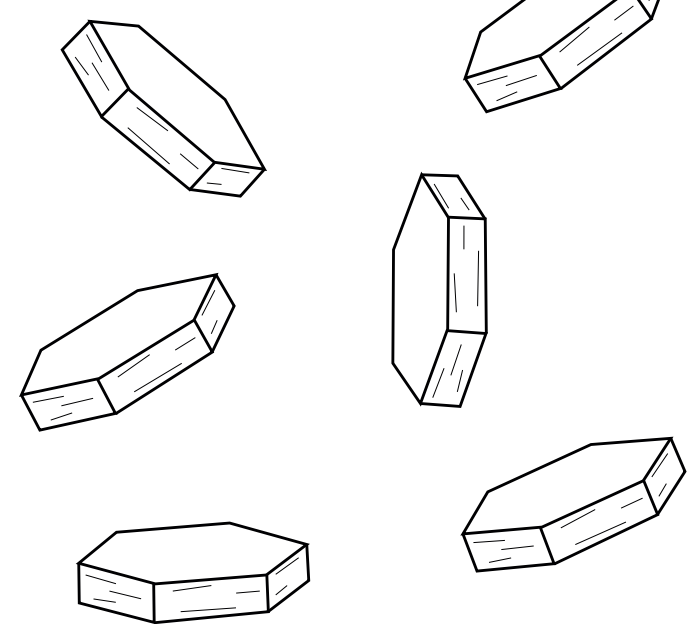

\section{Edge to edge - Flocculated}

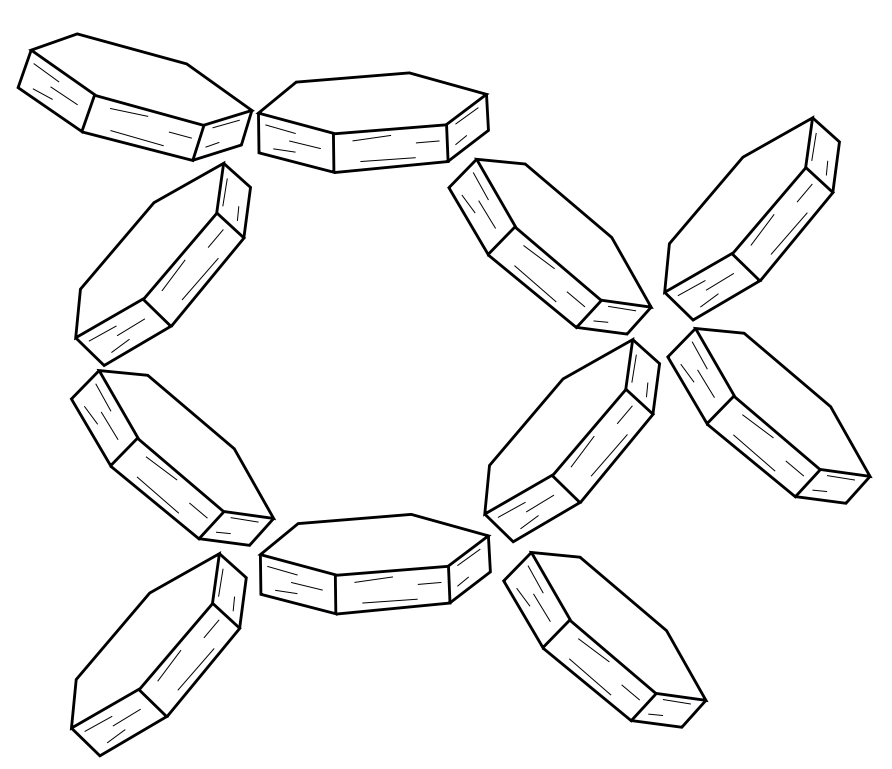

Plane to plane - Unflocculated

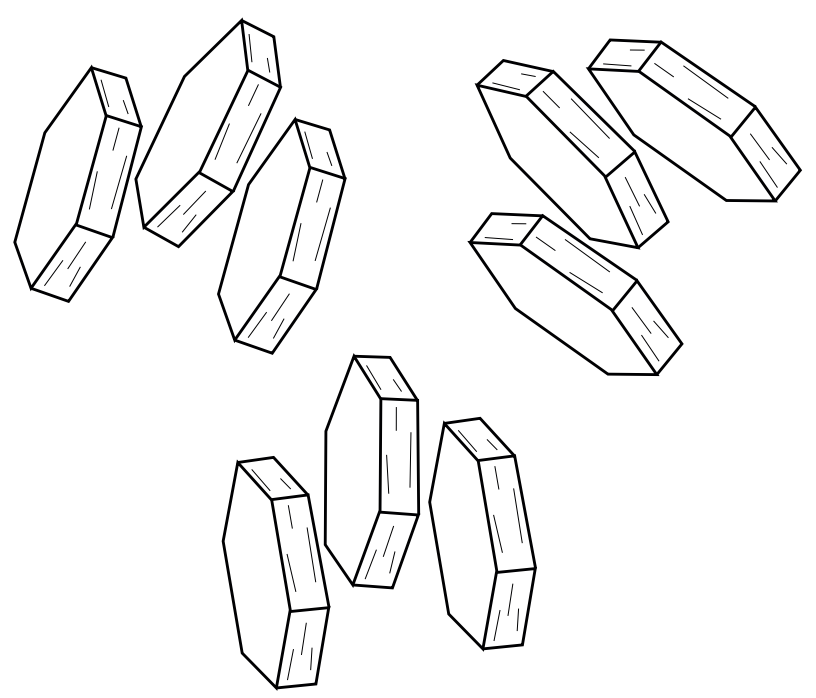

Plane to plane and plane to edgeFlocculated

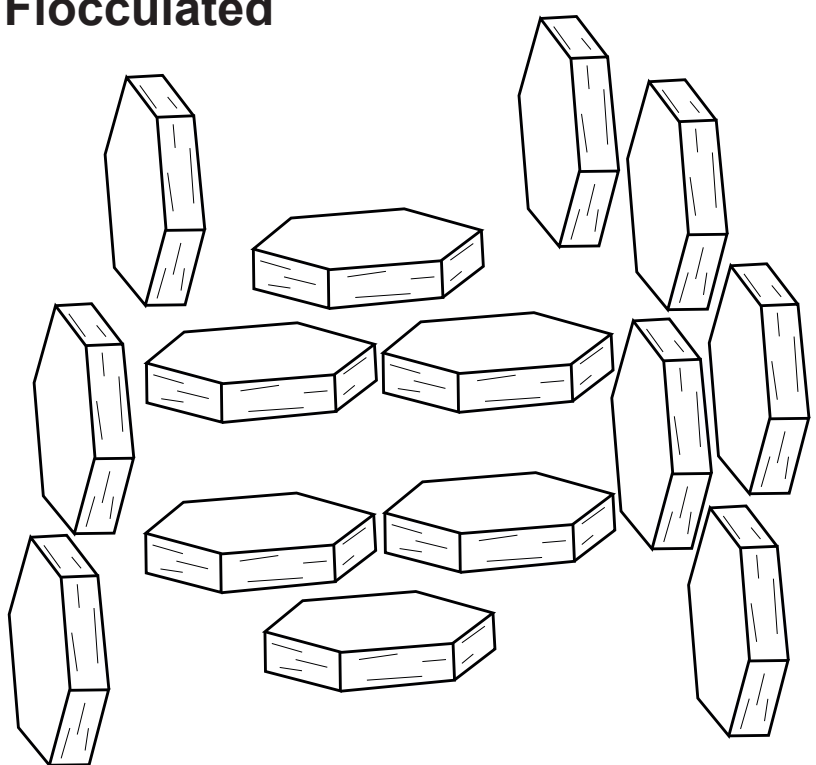

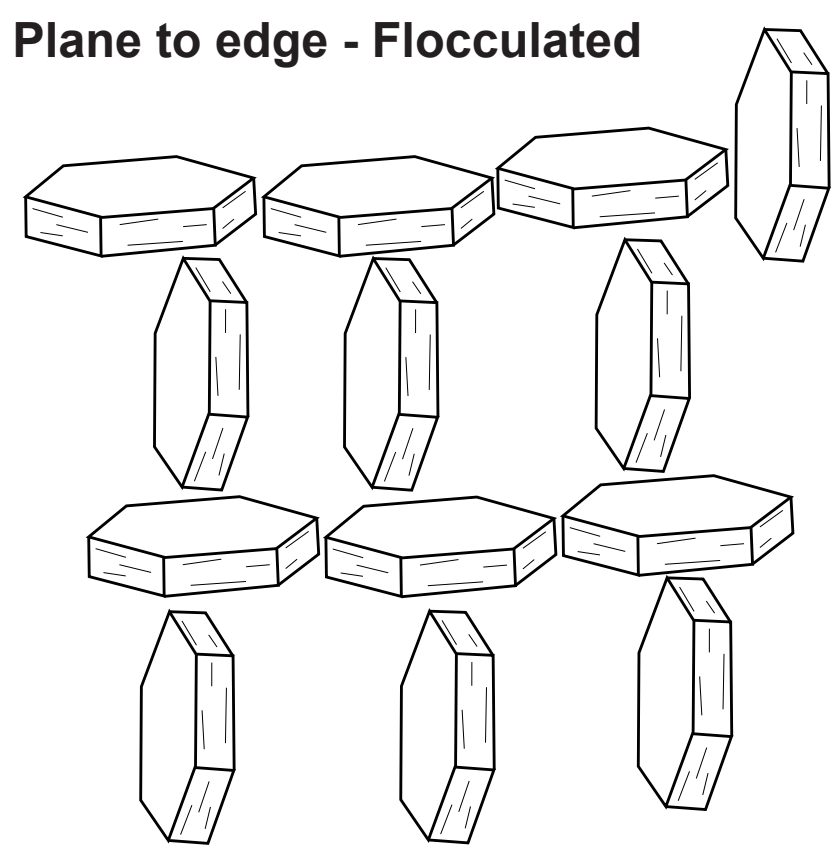




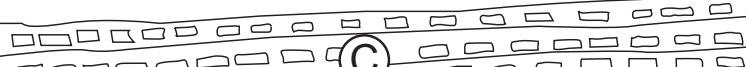

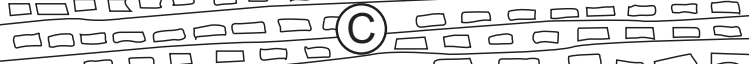
$\square \curvearrowleft \square \square \square \square \square \square \square \square \square \square \square \square \square \square$ (n)

b

(D)

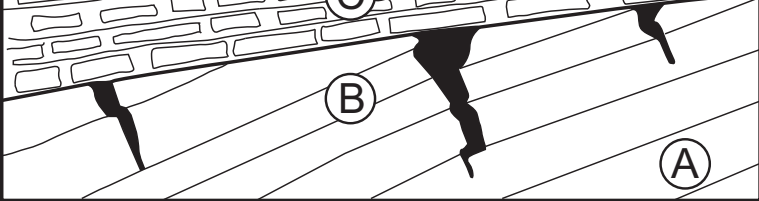

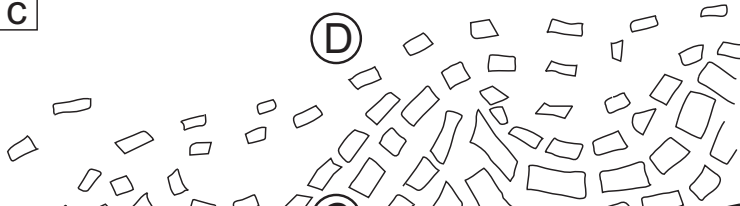
00000

C

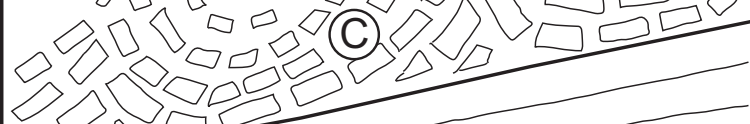

400

(A) 


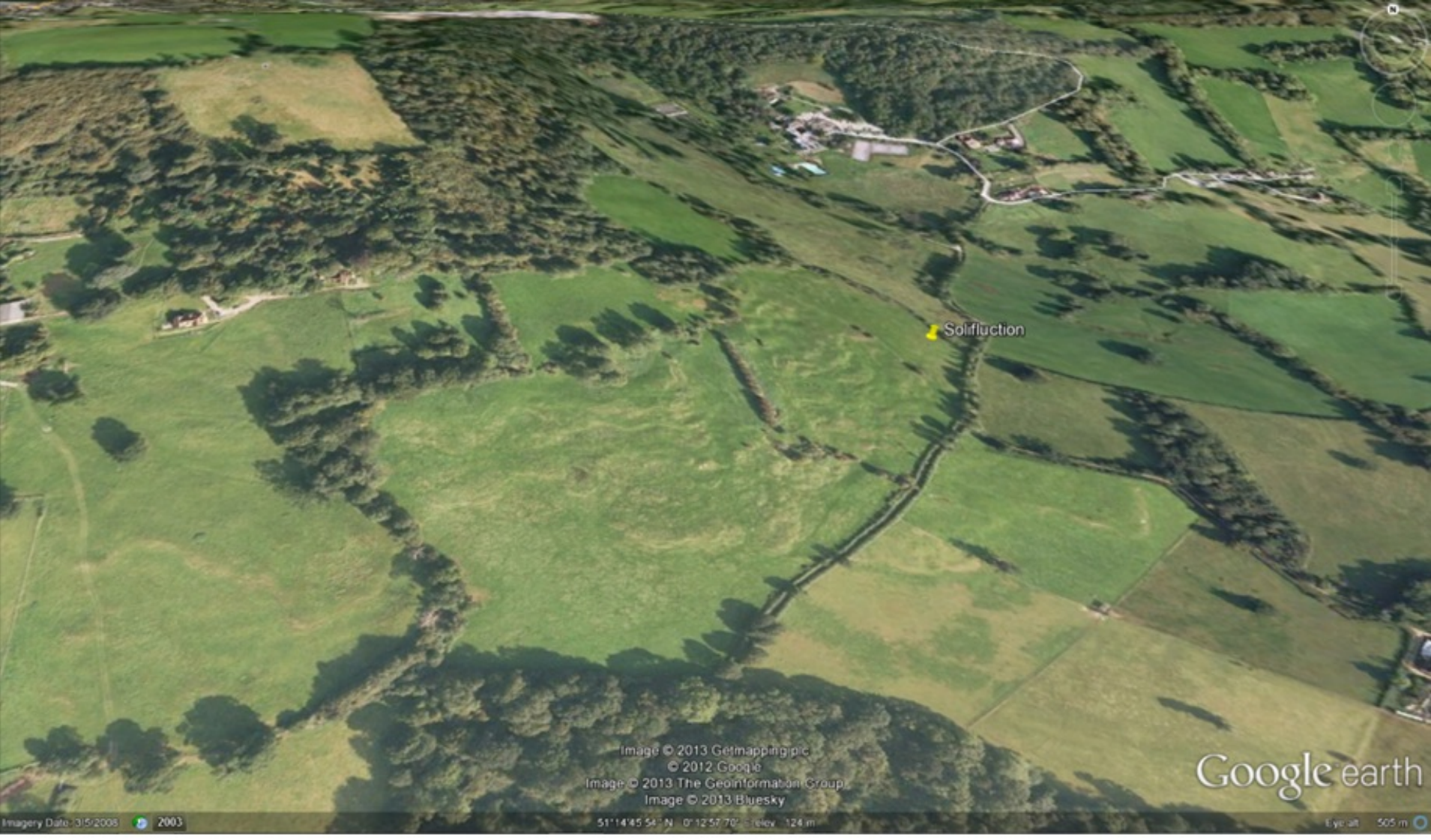




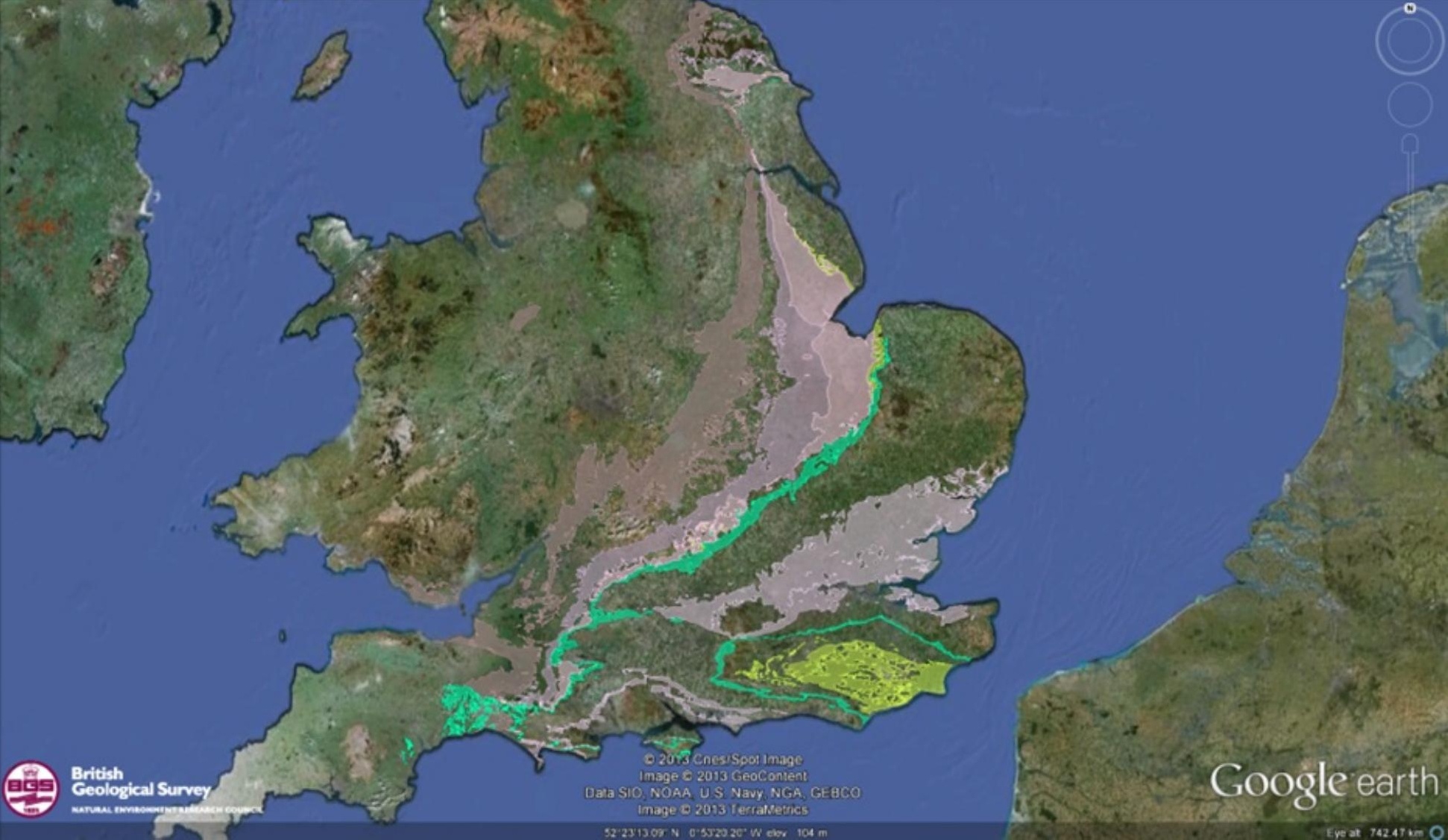




\begin{tabular}{|c|l|}
\hline Key & \multicolumn{1}{|c|}{ Stratigraphy } \\
\hline & $\begin{array}{l}\text { LIAS GROUP } \\
\text { KELLAWAYS FORMATION AND OXFORD } \\
\text { CLAY FORMATION }\end{array}$ \\
\hline & $\begin{array}{l}\text { WEST WALTON FORMATION, AMPTHILL } \\
\text { CLAY FORMATION AND KIMMERIDGE CLAY } \\
\text { FORMATION }\end{array}$ \\
\hline & $\begin{array}{l}\text { GAULT FORMATION AND UPPER } \\
\text { GREENSAND FORMATION } \\
\text { (UNDIFFERENTIATED) }\end{array}$ \\
\hline WEALDEN GROUP \\
\hline \\
\hline
\end{tabular}

Fig. 47b Key to the geological formations shown in Fig. 47a. 


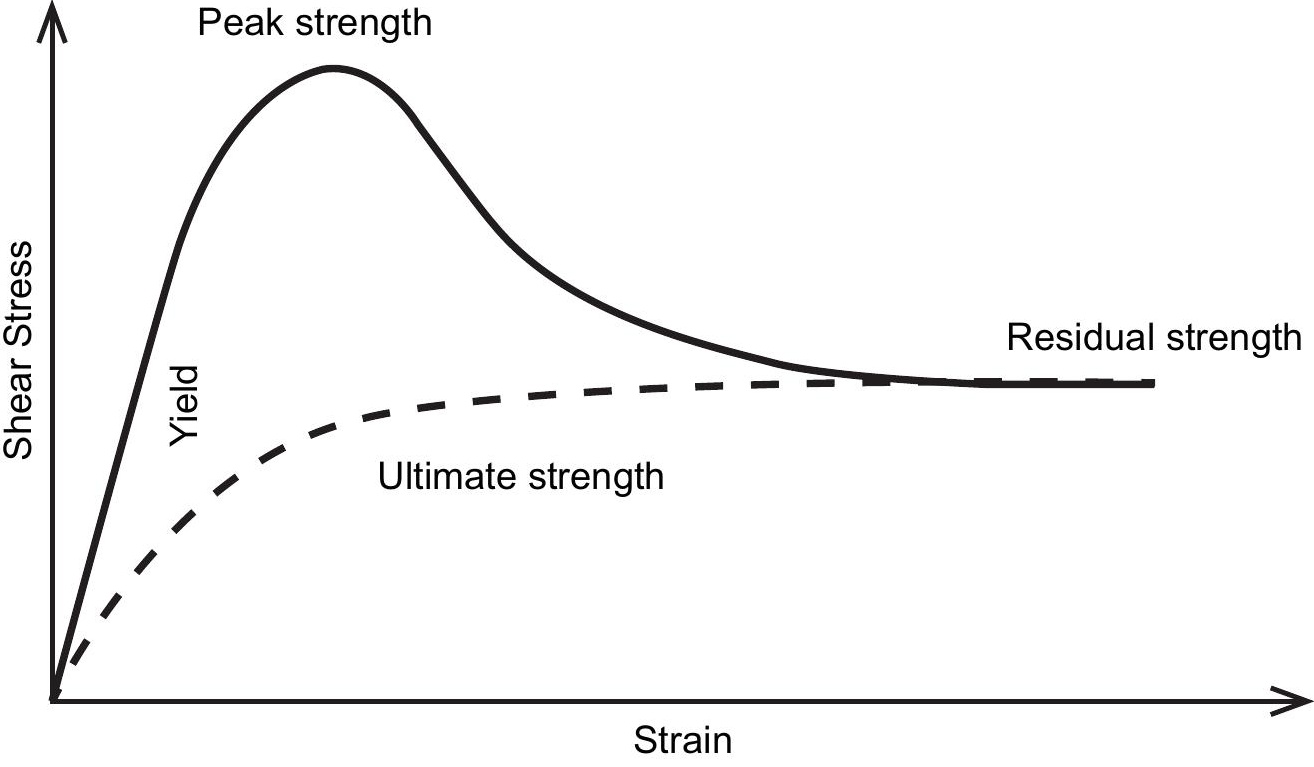




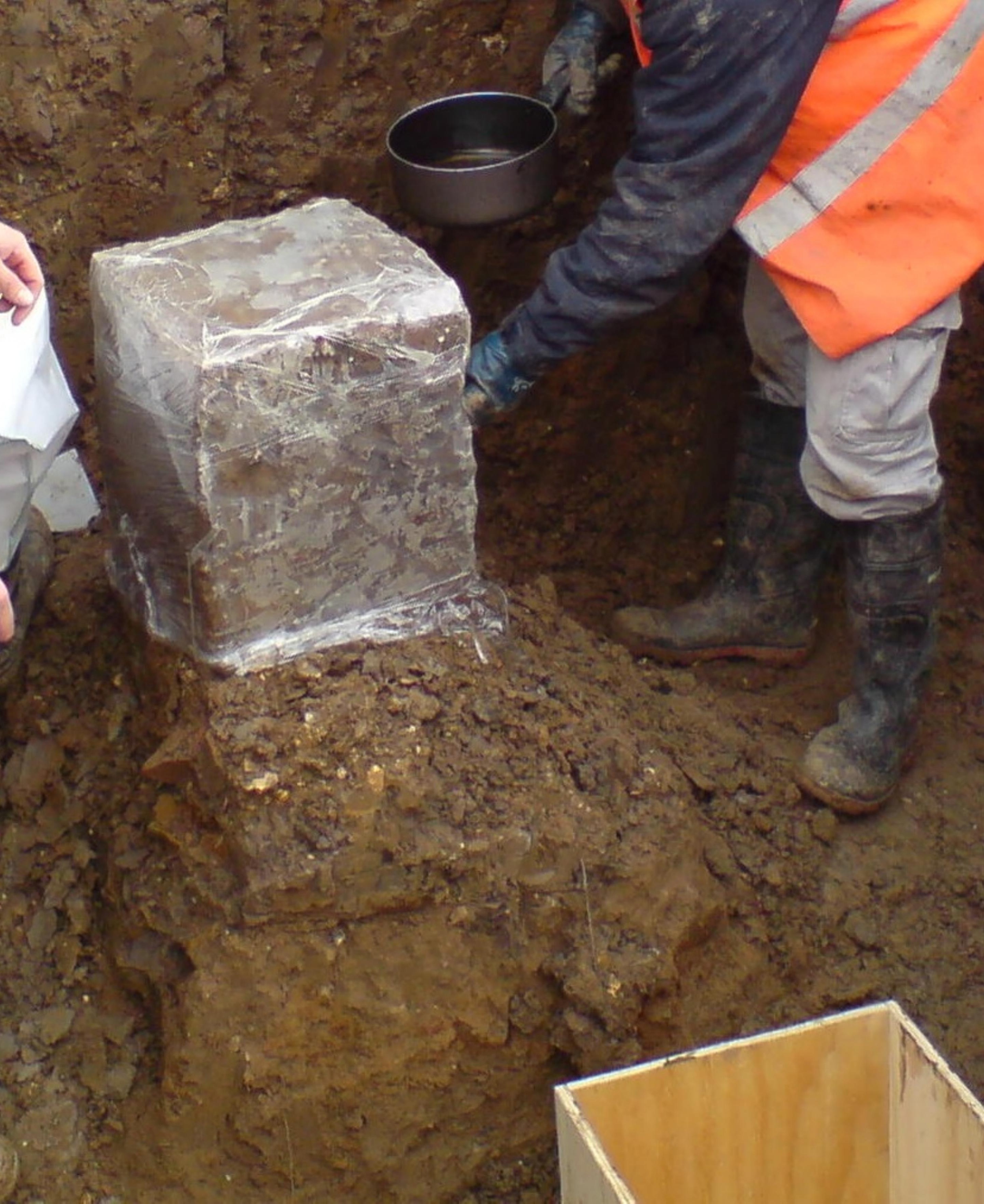


(a)

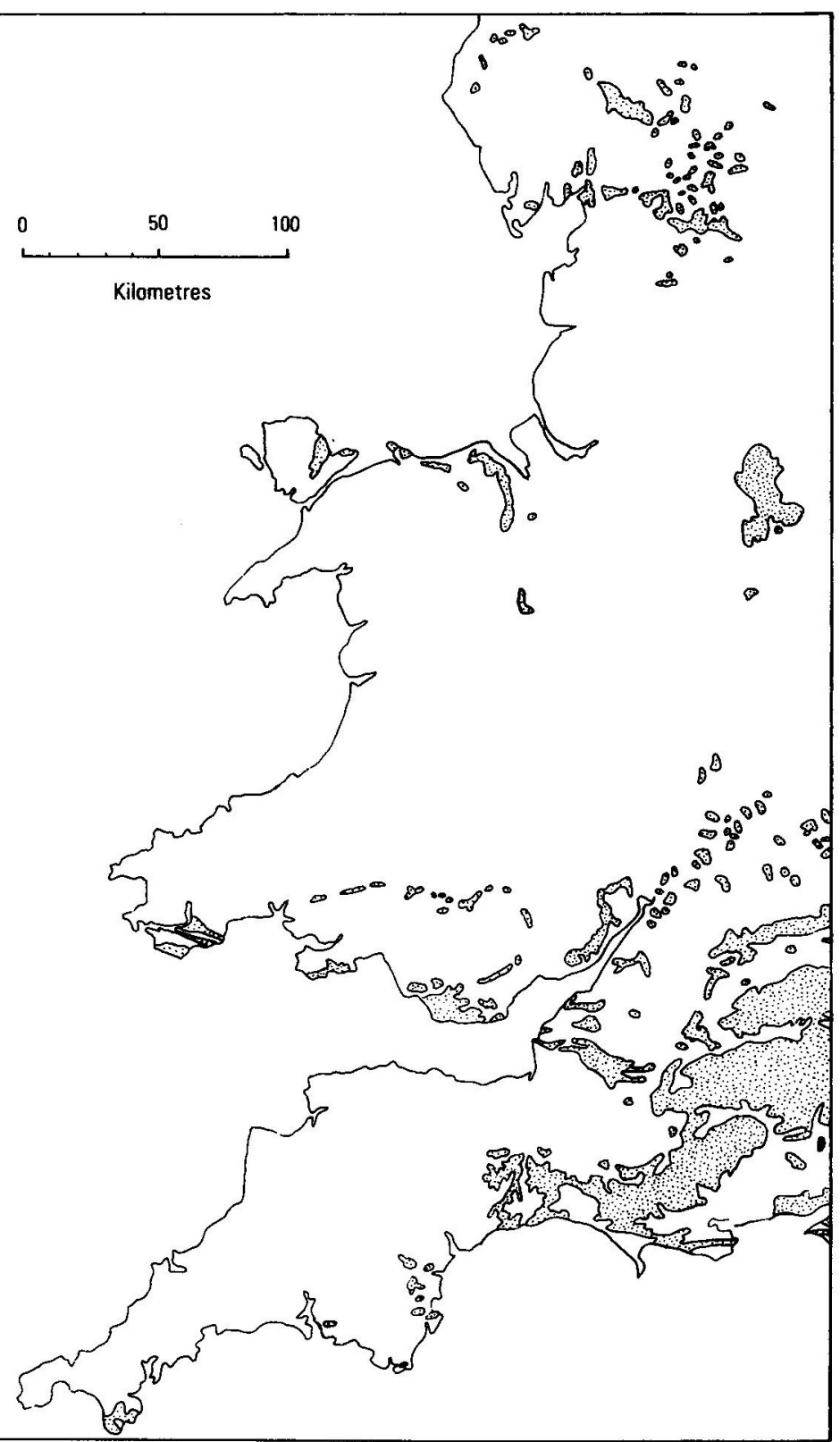




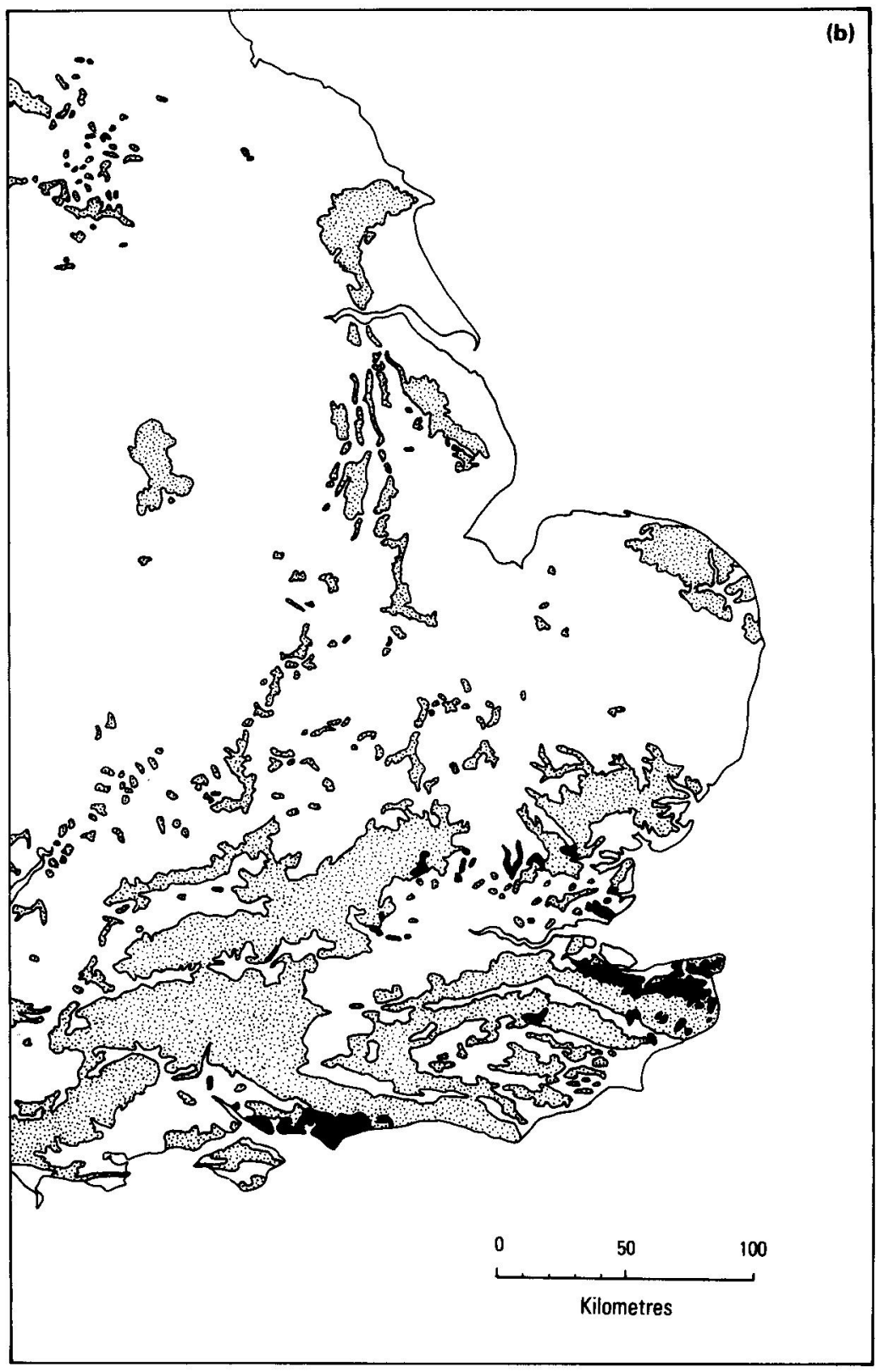




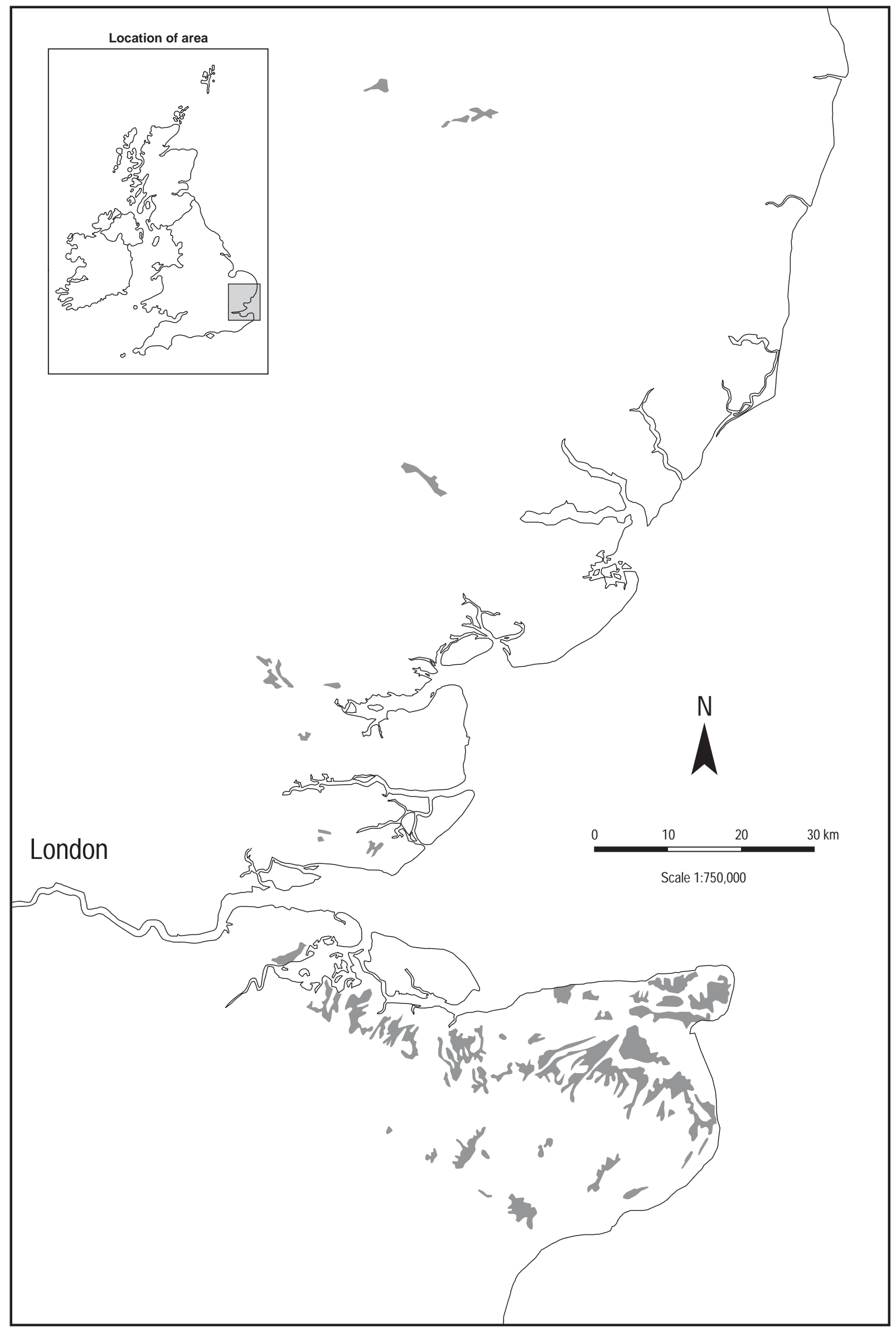




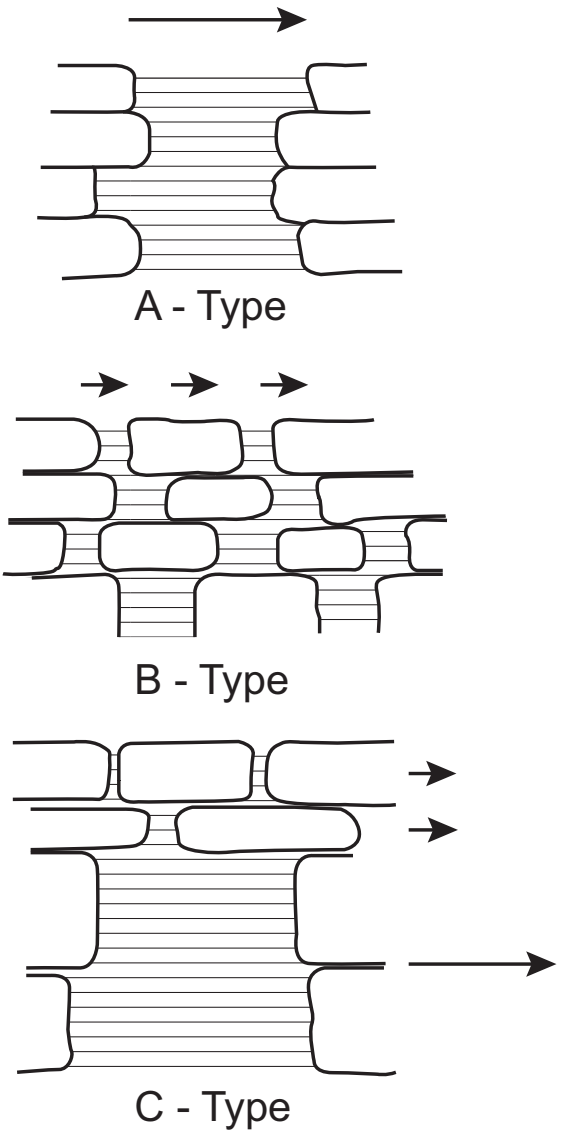




\begin{tabular}{|c|c|c|c|c|}
\hline CLASS & NAME & $\begin{array}{c}\text { TYPE, } \\
\text { MOVEMENT }\end{array}$ & CHARACTERISTICS & SKETCH \\
\hline I & Infilled & $\begin{array}{l}\text { A-Type movement, } \\
\text { small to large } \\
\text { displacement }\end{array}$ & Head sags into gull & 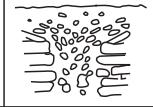 \\
\hline $\mathrm{Il}_{\mathrm{a}}$ & Open & $\begin{array}{l}\text { B-Type movement, } \\
\text { small } \\
\text { displacement }\end{array}$ & $\begin{array}{l}\text { Head not affected. Medium to } \\
\text { large voids at depth }\end{array}$ & 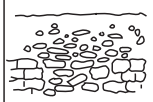 \\
\hline $\mathrm{Il}_{\mathrm{b}}$ & Open & $\begin{array}{l}\text { B-Type movement, } \\
\text { large displacement }\end{array}$ & $\begin{array}{l}\text { No Head. Many tilted blocks } \\
\text { Large voids at depth }\end{array}$ & \\
\hline III & Mixed & $\begin{array}{l}\text { B-Type movement, } \\
\text { large displacement }\end{array}$ & $\begin{array}{l}\text { Head sags into gull. } \\
\text { Large voids at depth }\end{array}$ & 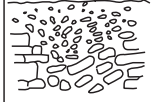 \\
\hline $\mathrm{IVa}$ & $\begin{array}{l}\text { Intact } \\
\text { Roofed }\end{array}$ & $\begin{array}{l}\text { C-Type movement, } \\
\text { medium to large } \\
\text { displacement }\end{array}$ & $\begin{array}{l}\text { Level limestone roof. If present, } \\
\text { Head is undisturbed. Large } \\
\text { voids and cavity at depth }\end{array}$ & 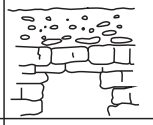 \\
\hline $\mathrm{IVb}$ & $\begin{array}{l}\text { Collapsed } \\
\text { Roofed }\end{array}$ & $\begin{array}{l}\text { C-Type movement, } \\
\text { (+ B- Type at top), } \\
\text { large displacement }\end{array}$ & $\begin{array}{l}\text { Roof of fallen blocks wedged in } \\
\text { the top of a large cavity. If present, } \\
\text { Head may sag a little }\end{array}$ & 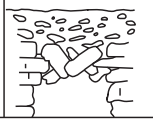 \\
\hline
\end{tabular}



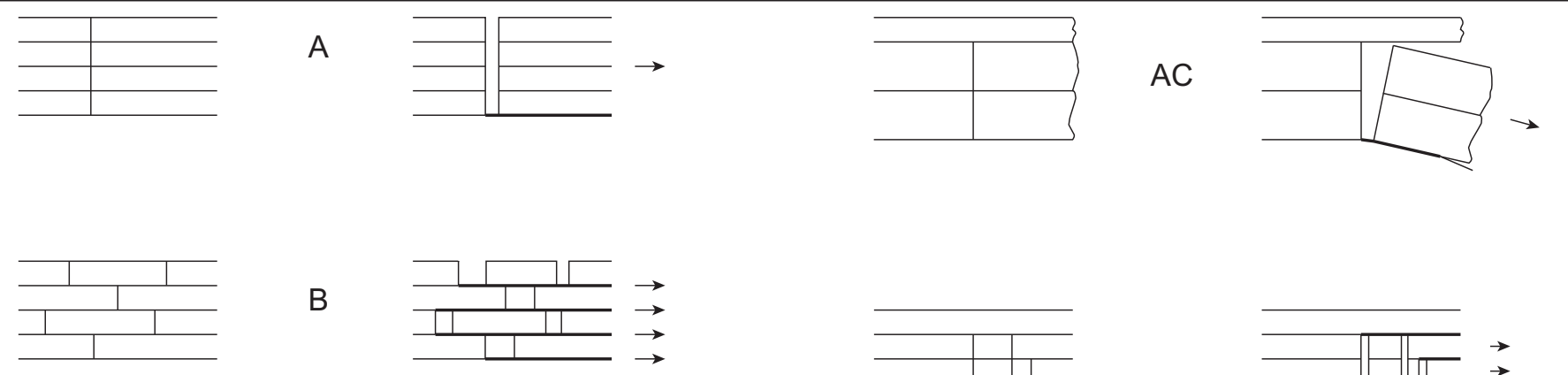

$$
\mathrm{AB} \quad \stackrel{\square+\square}{\square} \underset{\square}{\longrightarrow}
$$

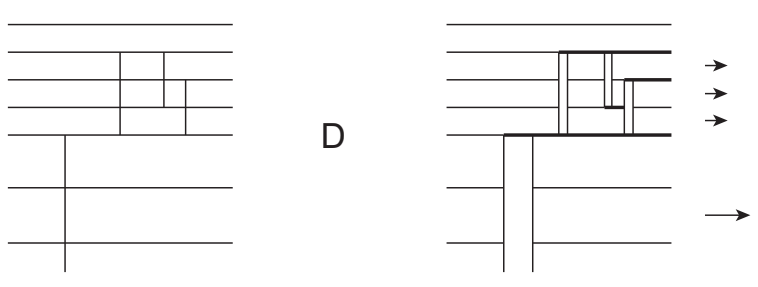

E

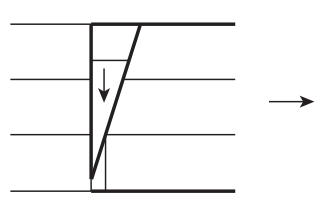




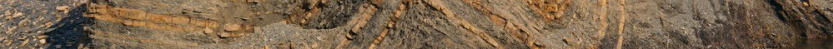

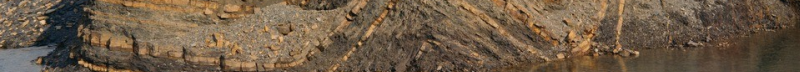

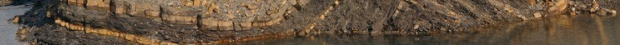




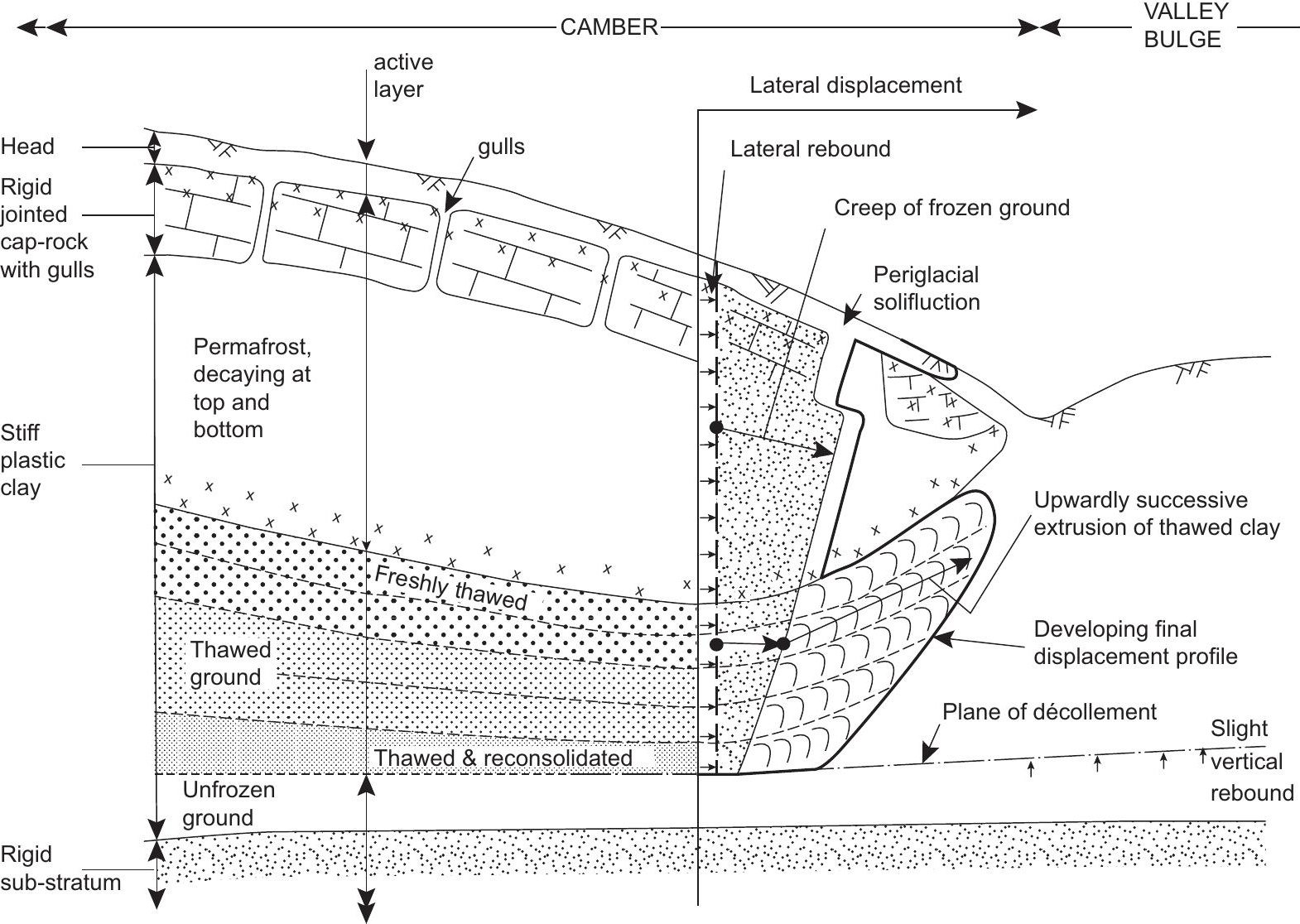




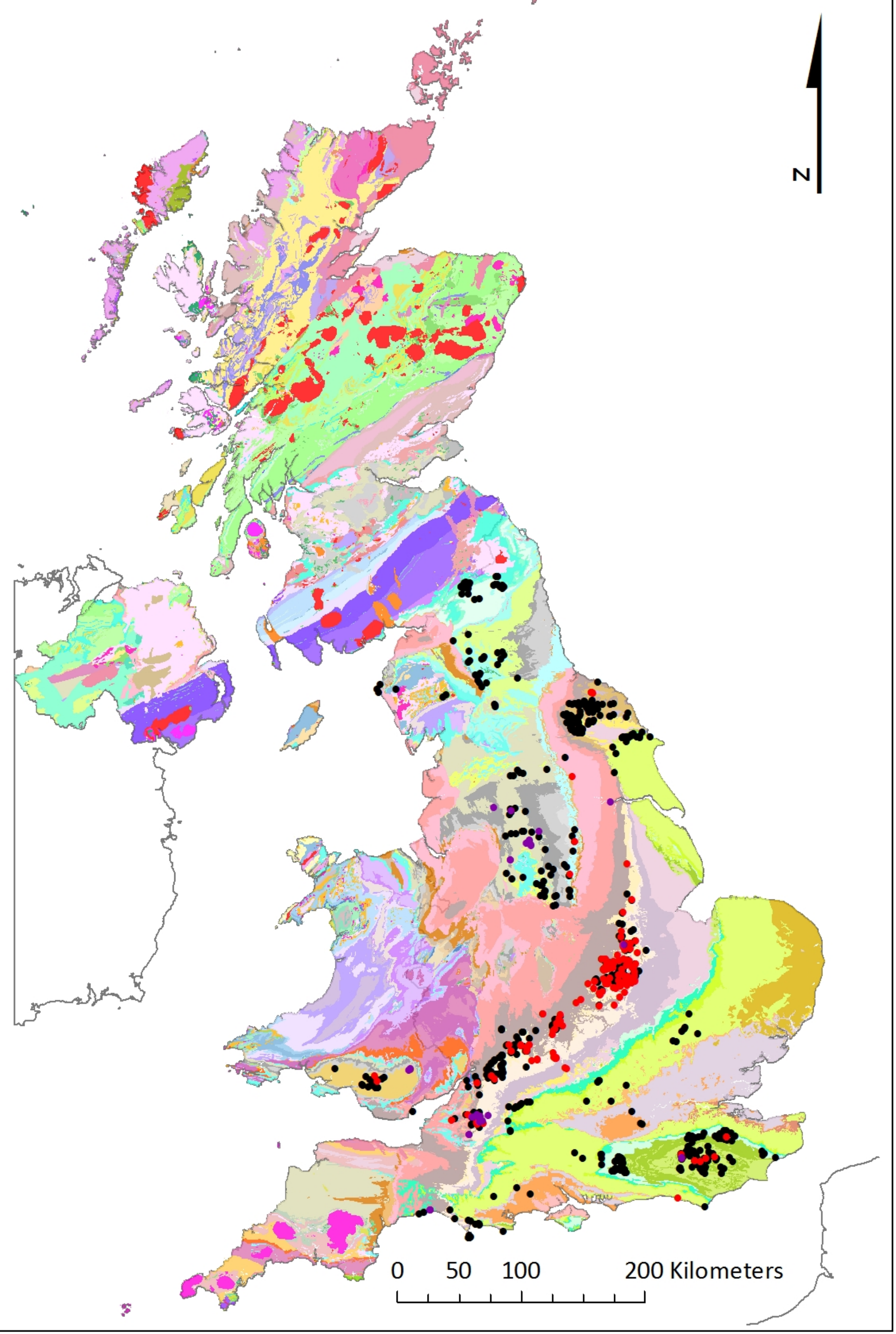


Fistisentest

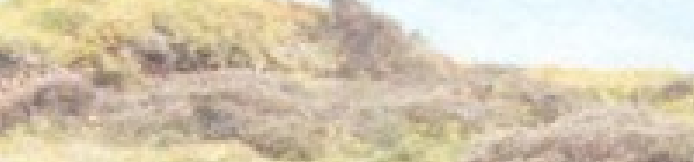

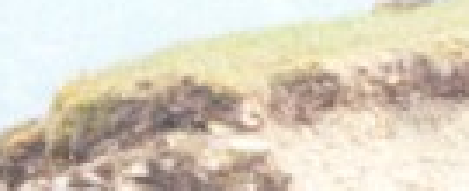

. sitos

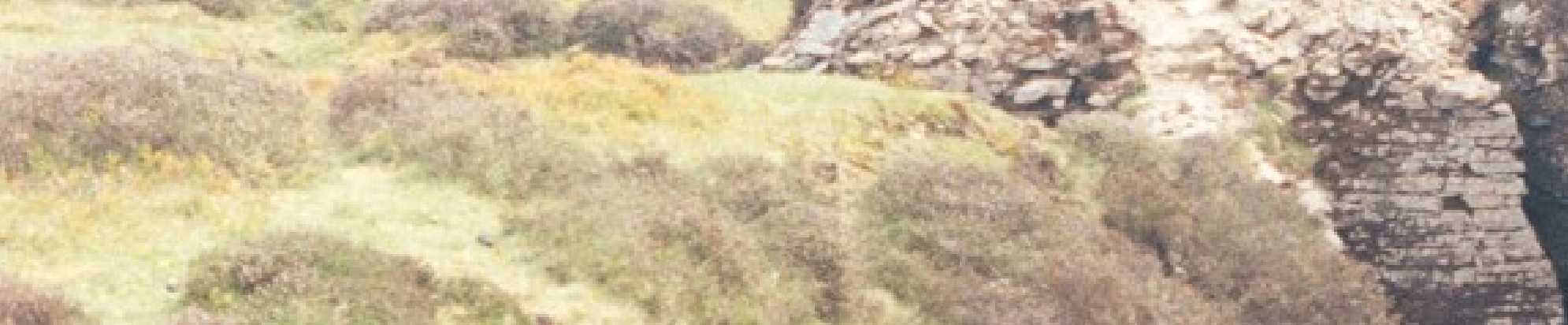

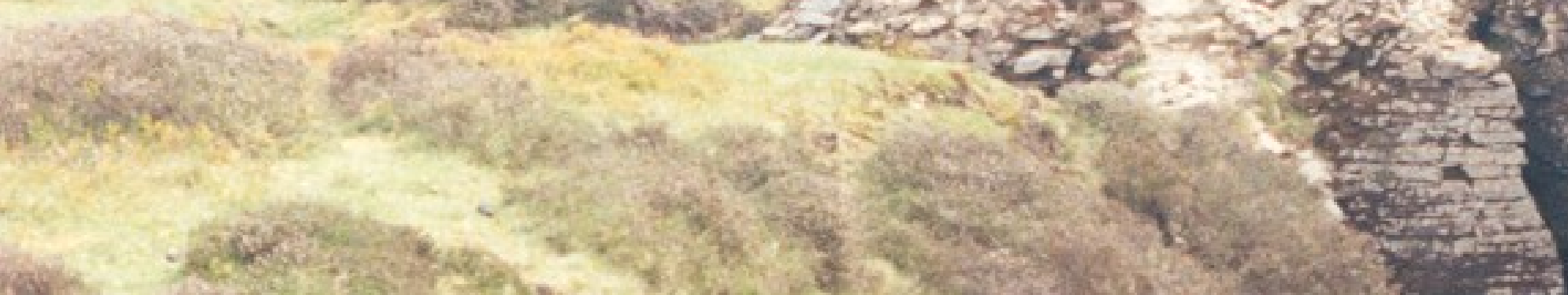

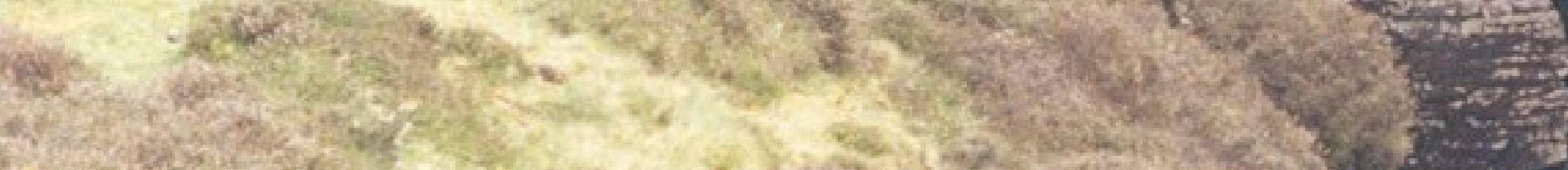

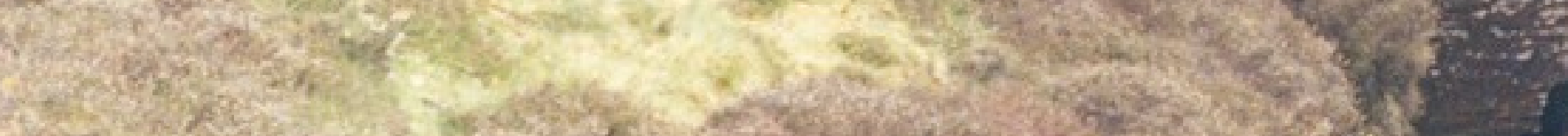

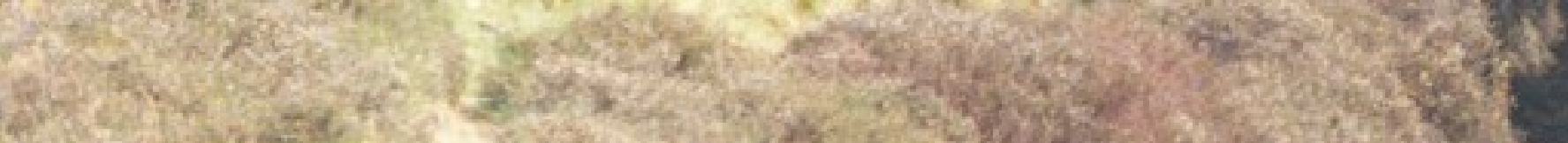
a

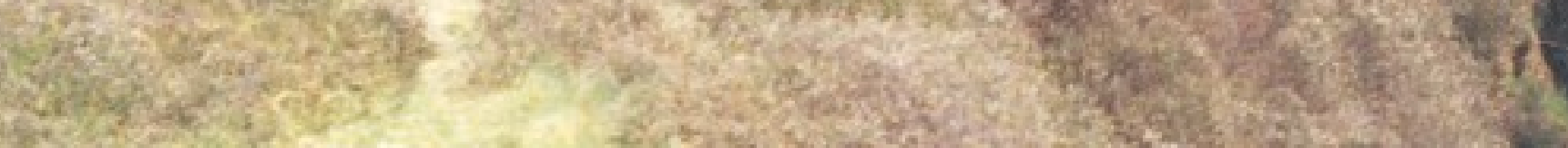

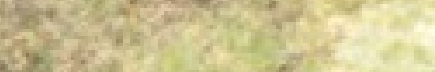
sects 25.

\section{the}

\section{(4)}

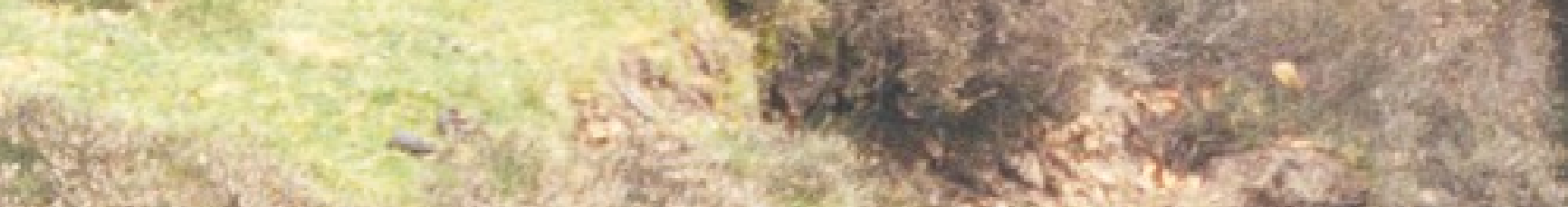

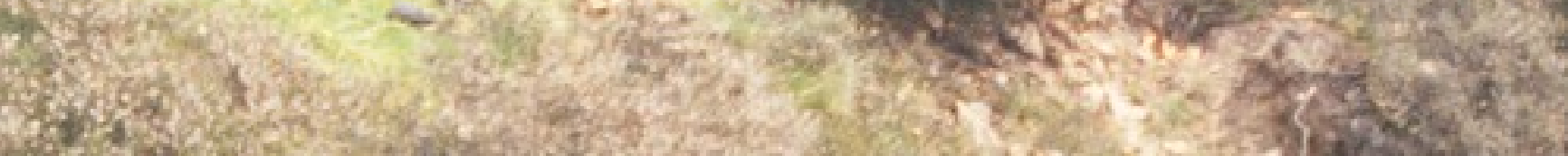

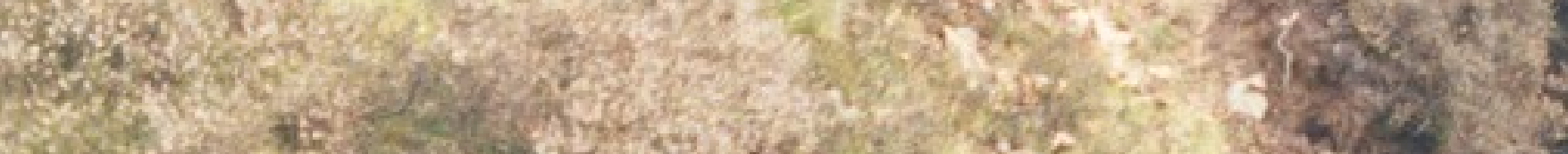

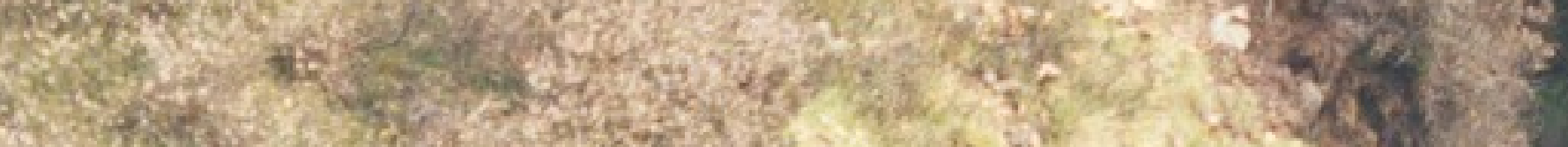

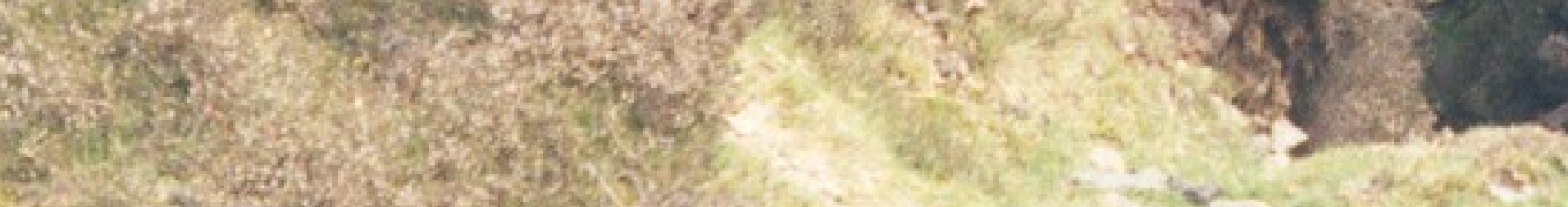

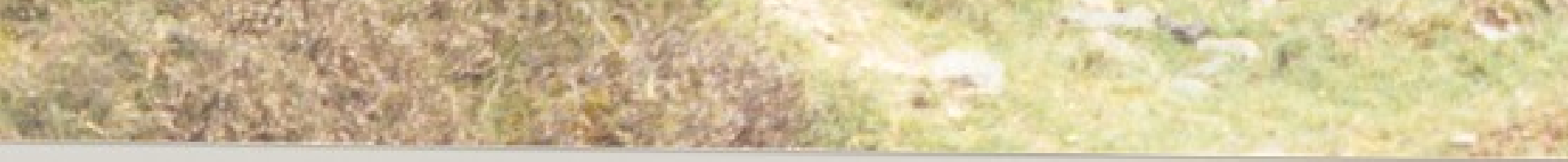

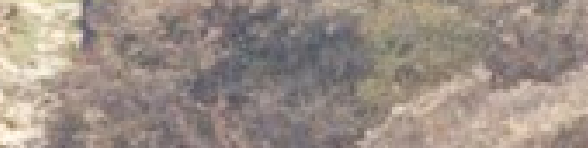

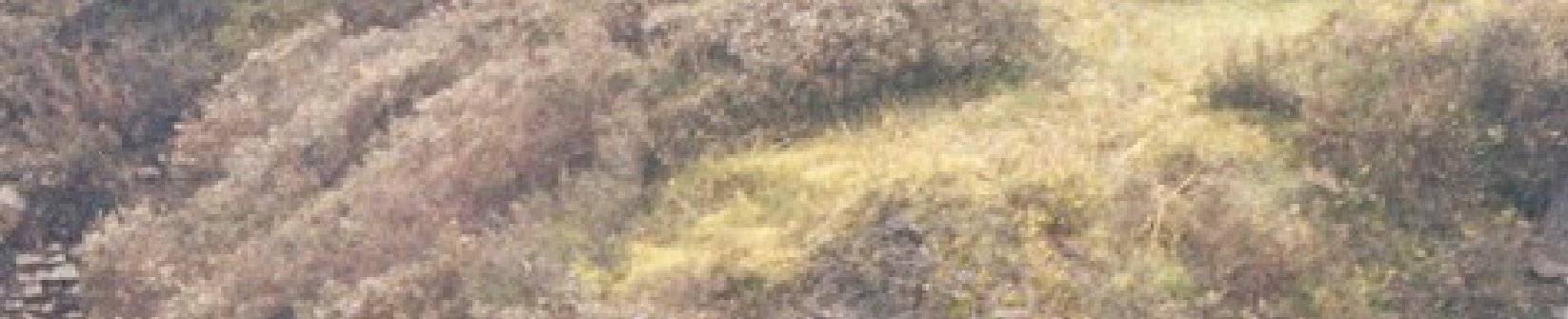

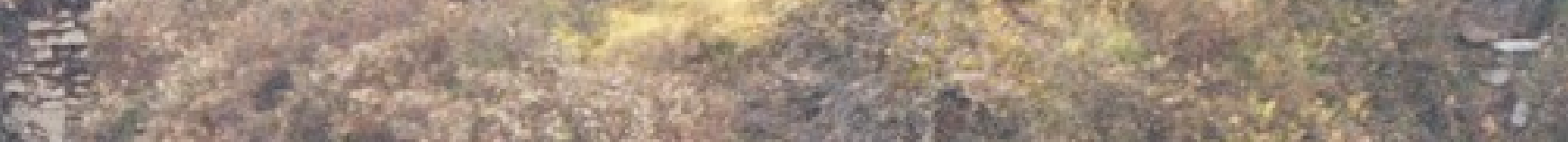

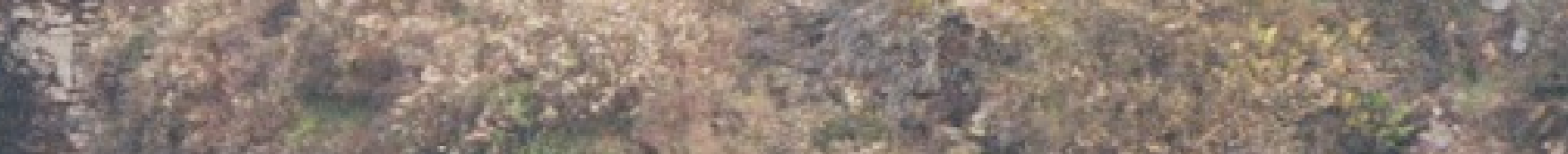
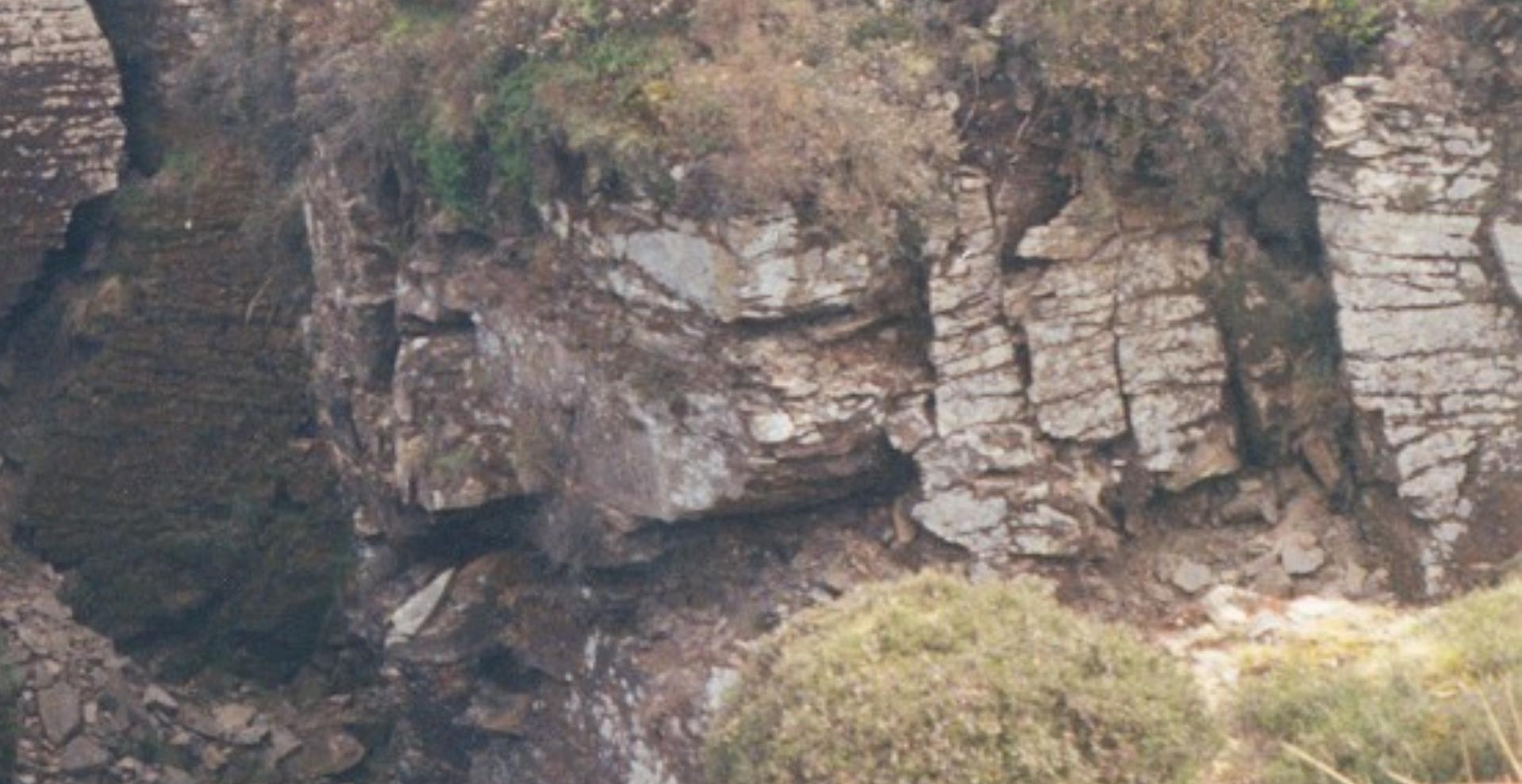
Q 4. Simis. 3 . $3 x^{2}-x^{2}+1$ 


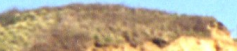

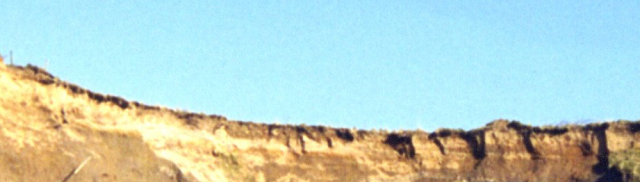

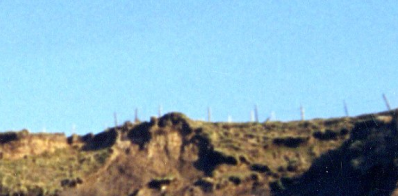

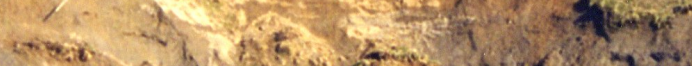

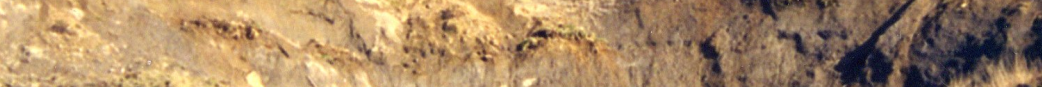

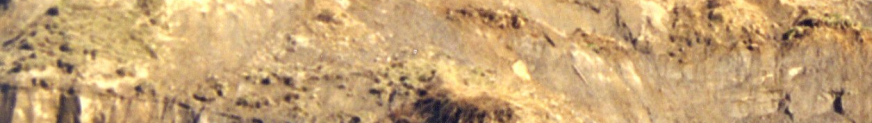

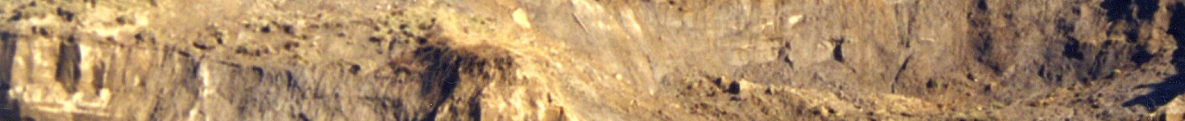

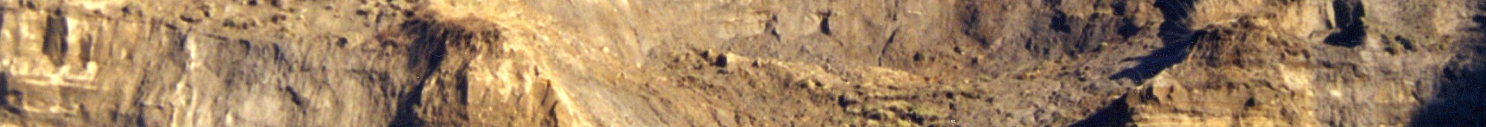

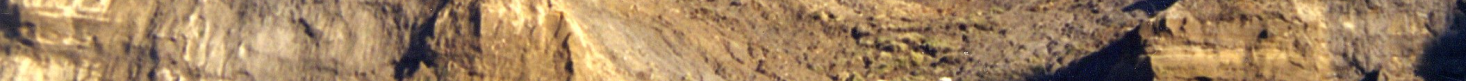
S.

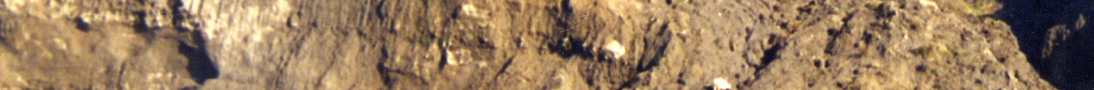

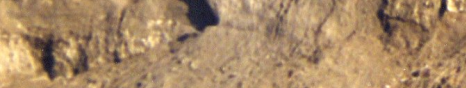

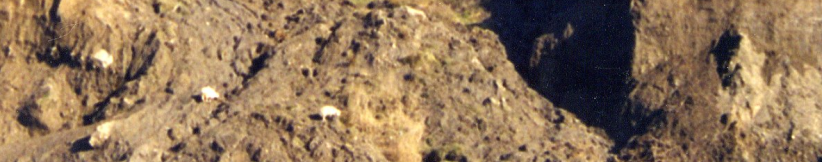

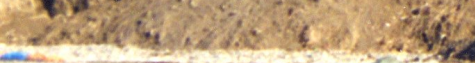

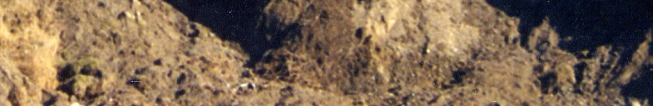

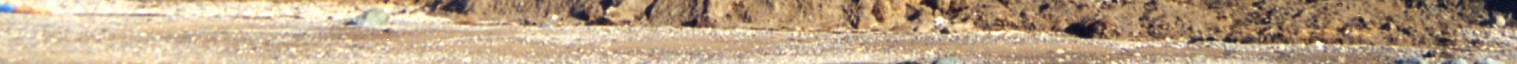

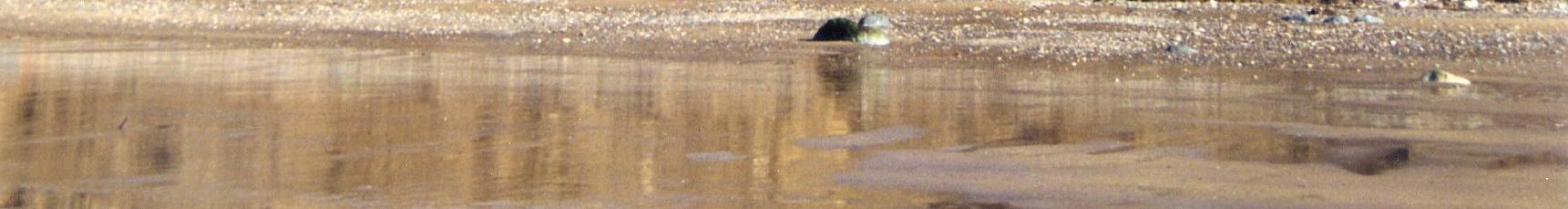




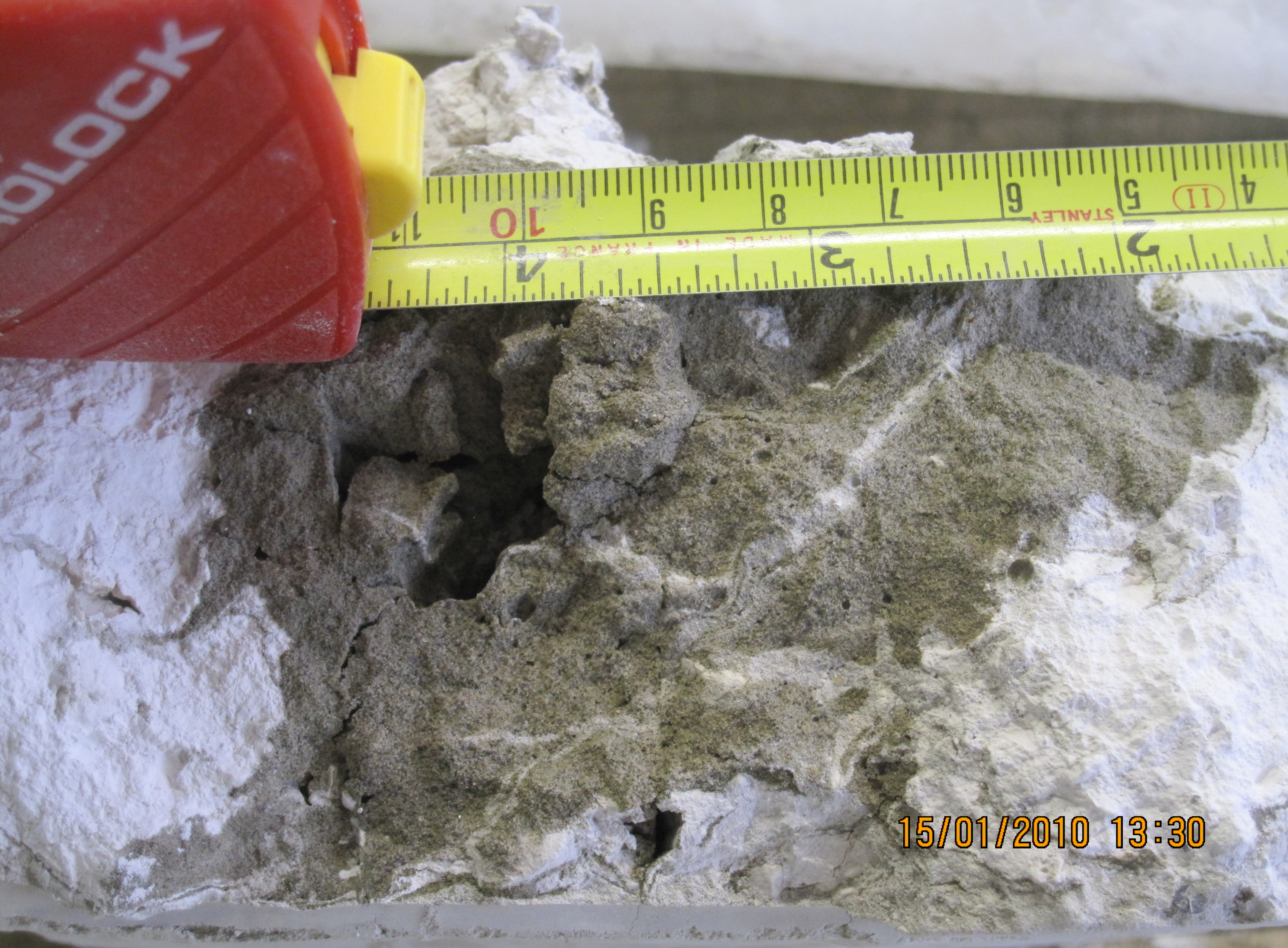




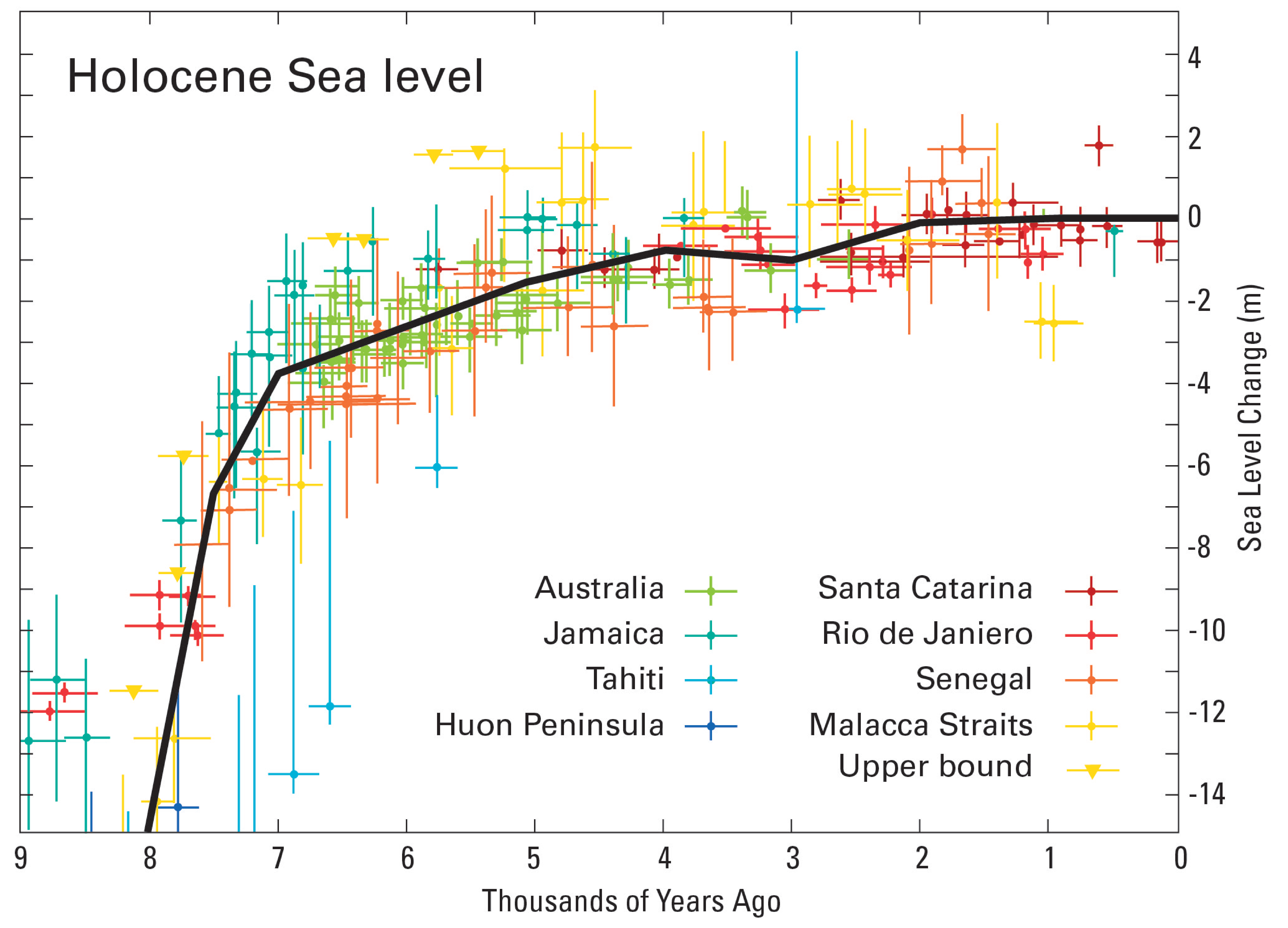





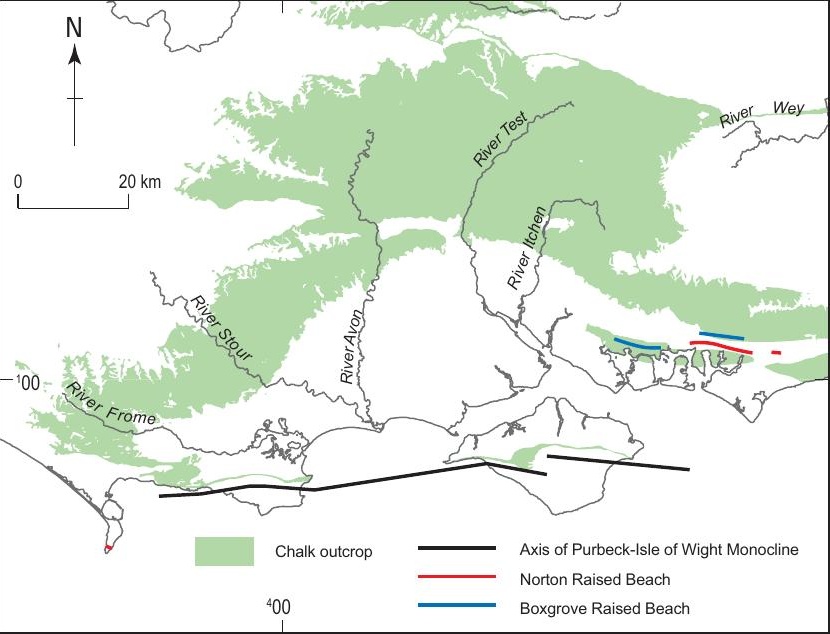


Fenland/Cambridgeshire

\section{Subsidence/ \\ Elevation/}

Transgression

Regression

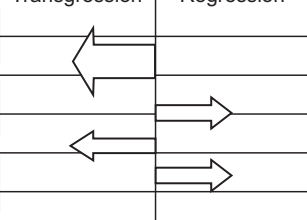

2000BP

\begin{tabular}{|c|c|c|}
\hline $1000 \mathrm{BP}$ & & \\
\hline $2000 \mathrm{BP}$ & & $\Rightarrow$ \\
\hline $3000 \mathrm{BP}$ & & \multirow{4}{*}{$\begin{array}{c}\text { Alternation of } \\
\text { freshwater and } \\
\text { marine } \\
\text { sedimentation. } \\
\text { Seven } \\
\text { transgressions } \\
\text { and six } \\
\text { regressions }\end{array}$} \\
\hline $4000 \mathrm{BP}$ & & \\
\hline $5000 \mathrm{BP}$ & & \\
\hline $6000 \mathrm{BP}$ & & \\
\hline $7000 \mathrm{BP}$ & Initial & \\
\hline & & \\
\hline & & \\
\hline & & \\
\hline
\end{tabular}

OBP

\section{Norfolk Broads}

Aldeburgh Marshes
Maplin Sands Essex

Poole Harbour

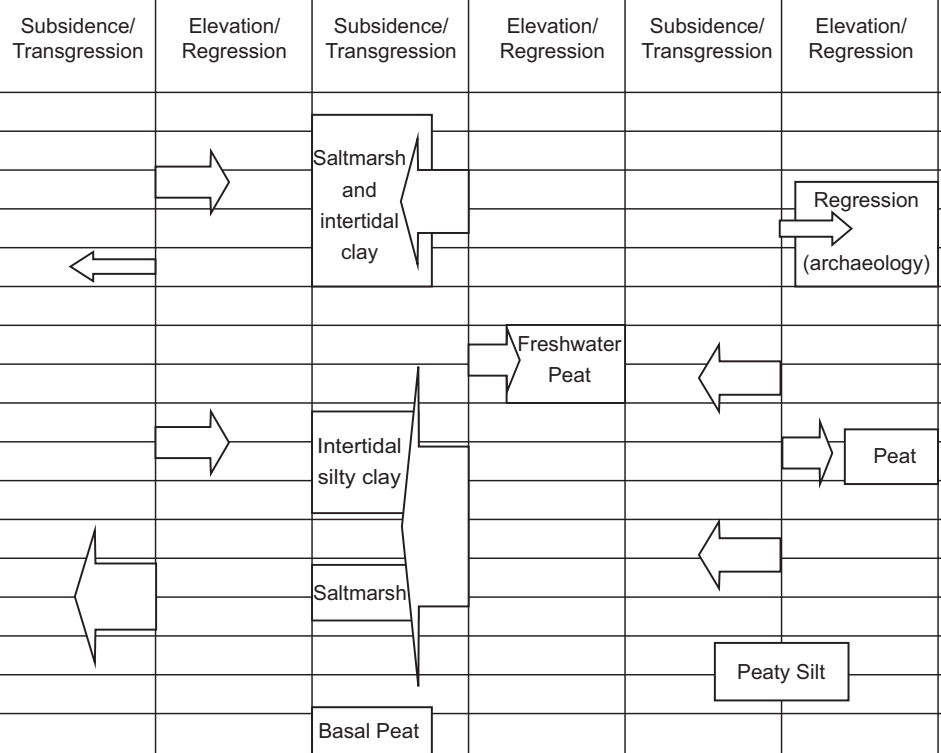

Subsidence/

Transgression

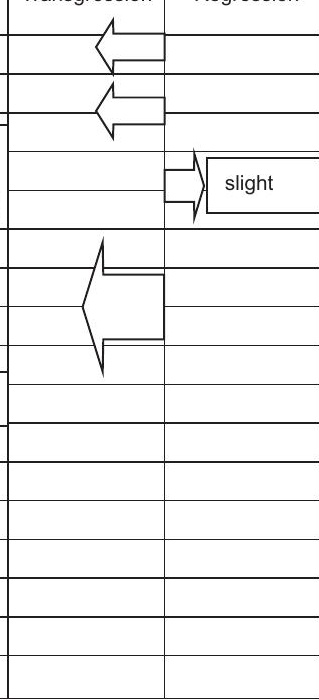

Elevation/

Regression 

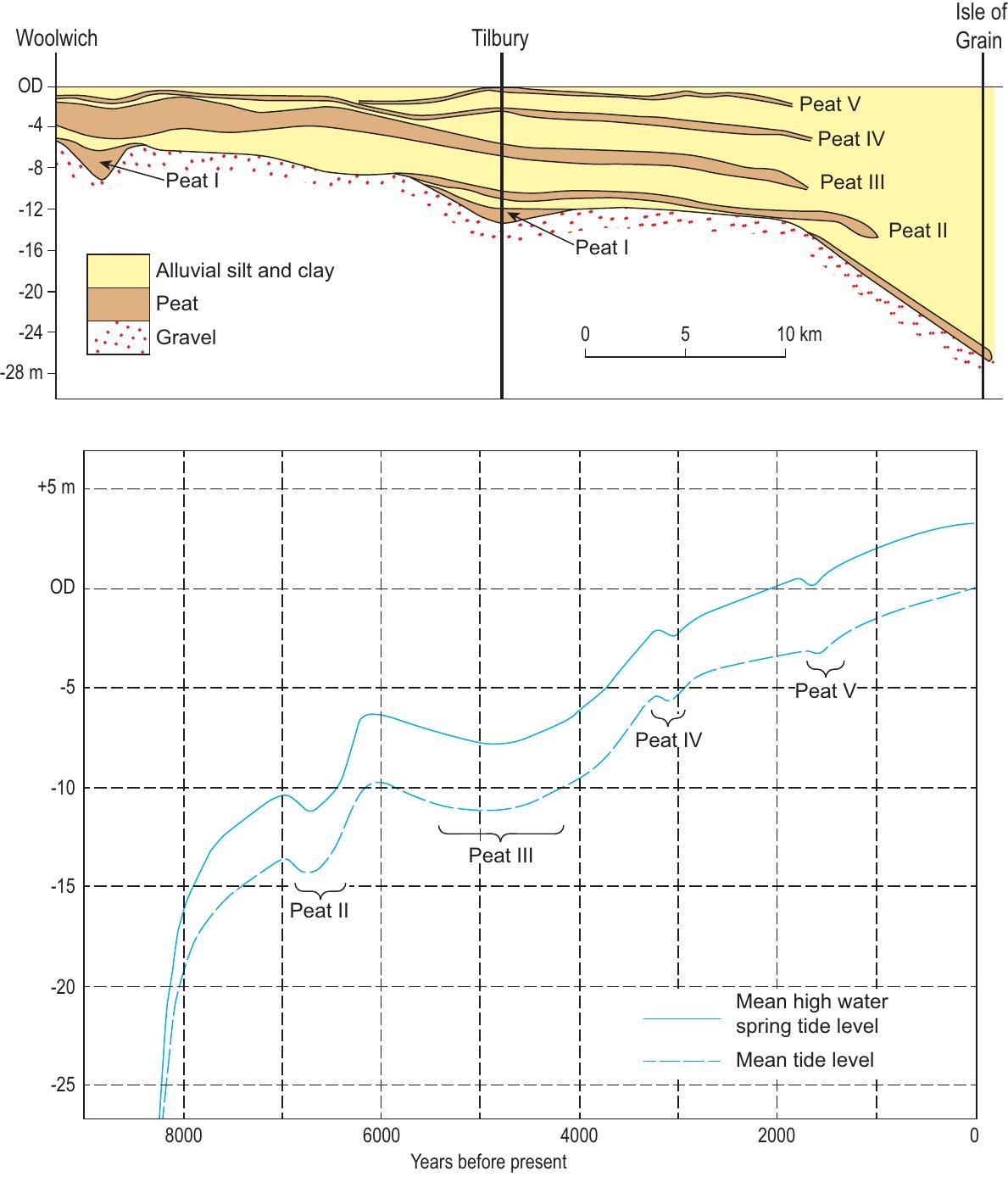


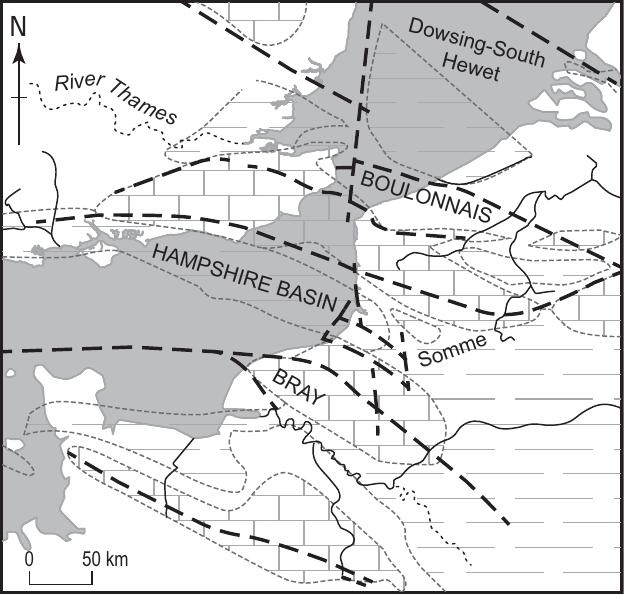

